
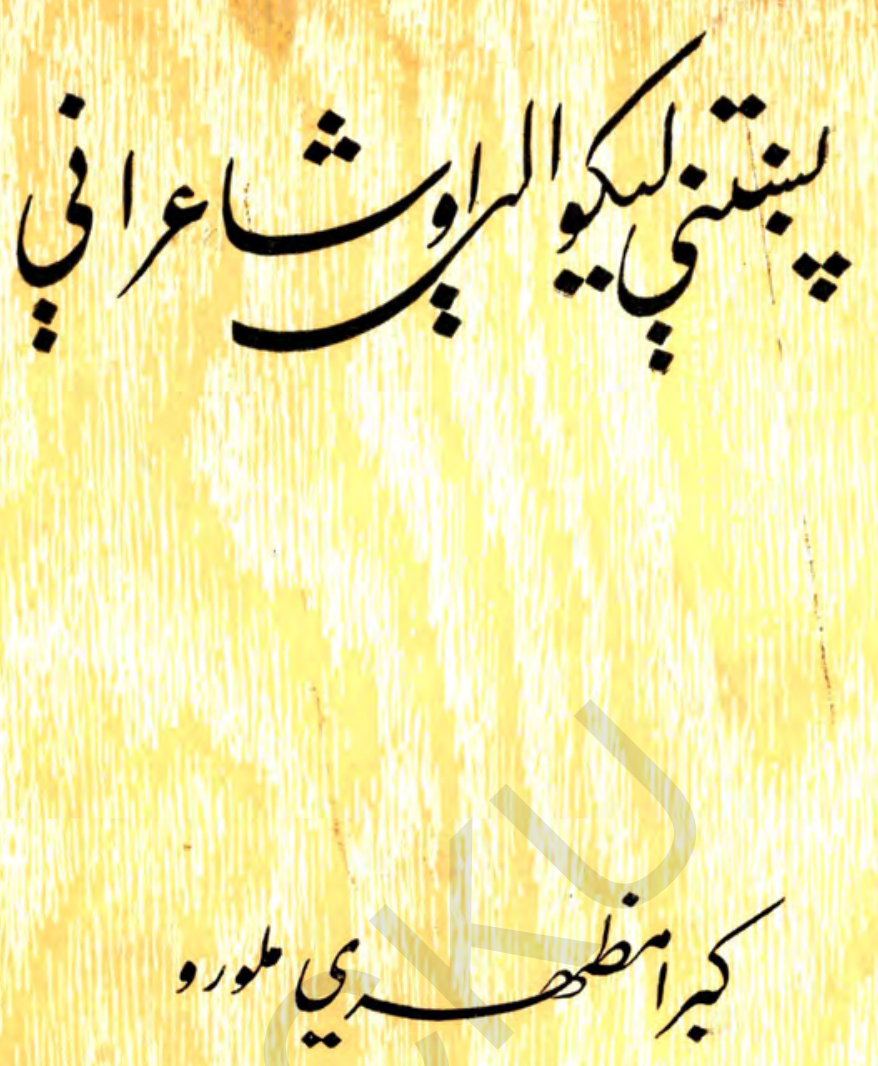

'6.

JKIrT 


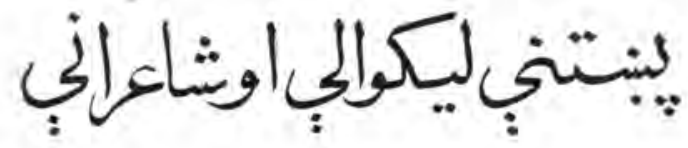

\author{
لومريتول \\ كبالمظهريملقوح

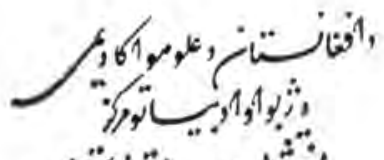

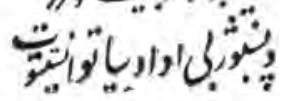

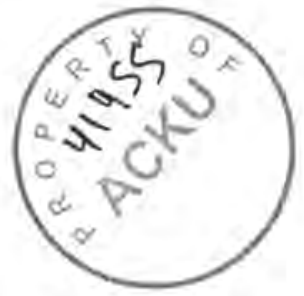




\section{تهون:}

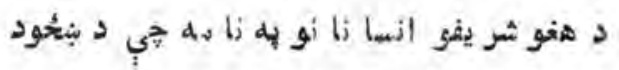

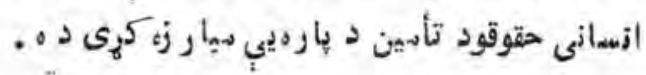
كبر ا ملو رو تلو

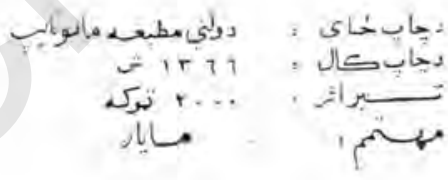




\section{دا نيمكَى هisi}

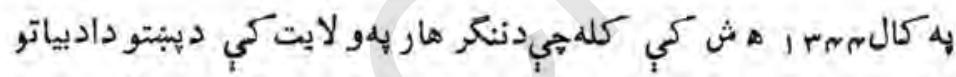

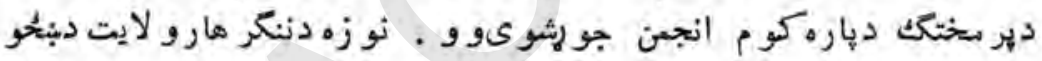

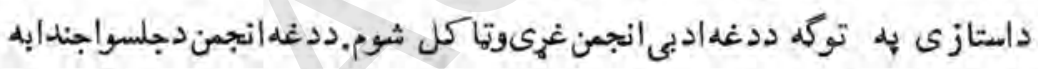

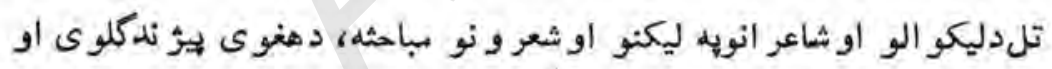

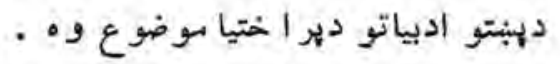

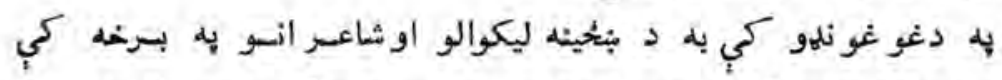

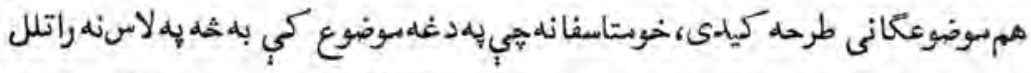

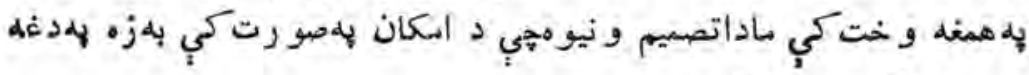

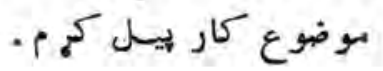




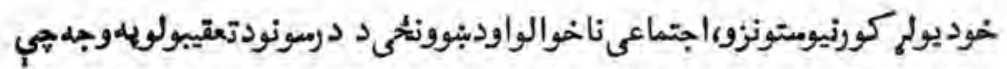

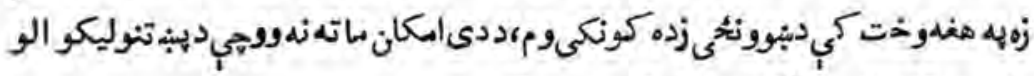

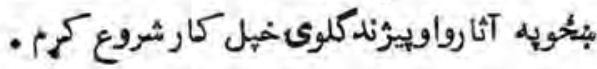

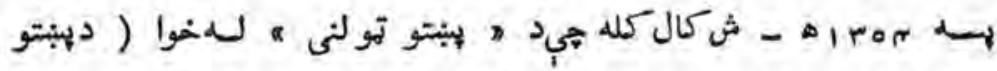

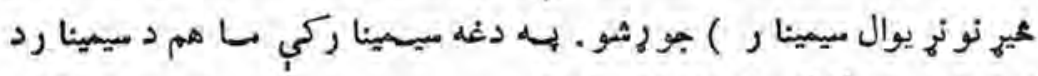

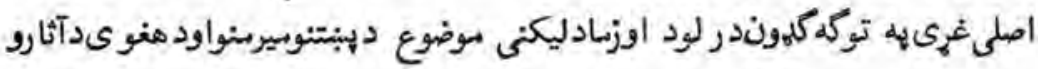

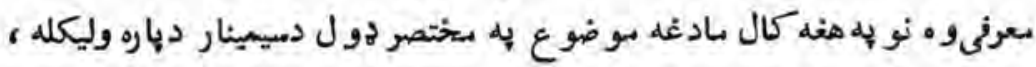

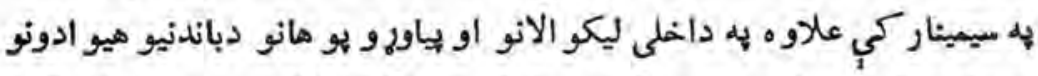

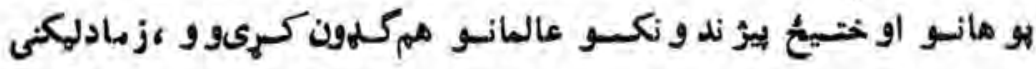

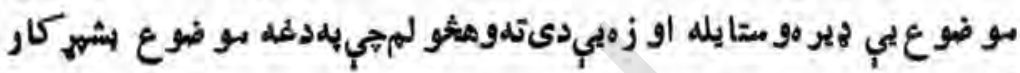
-

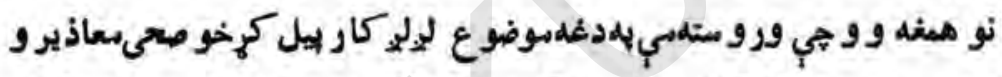

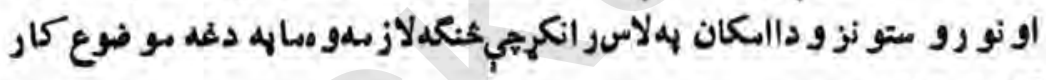
كرى و ایى.

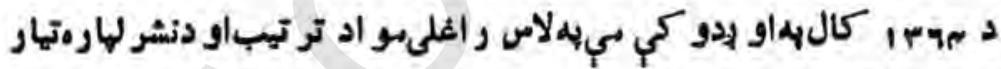

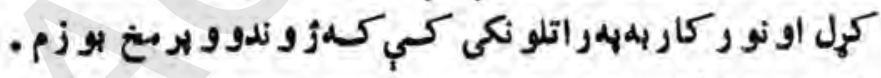

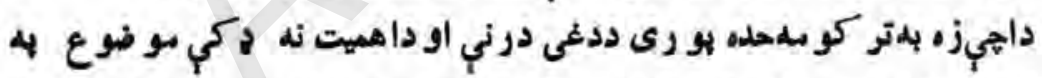

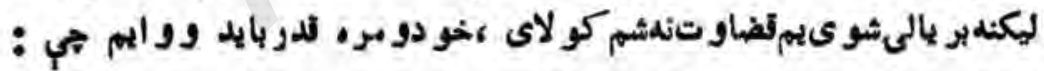

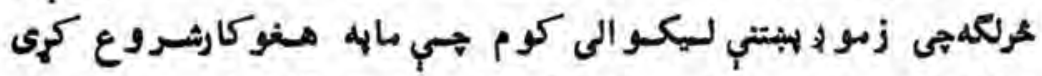

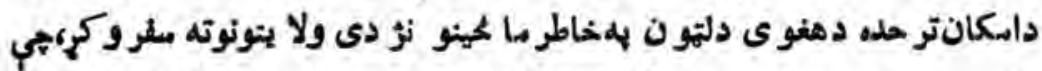

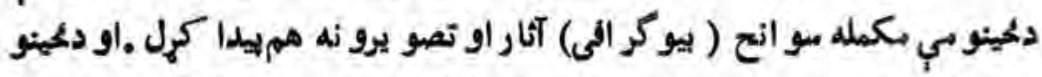

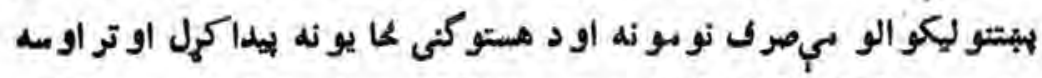

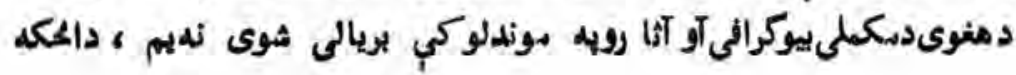




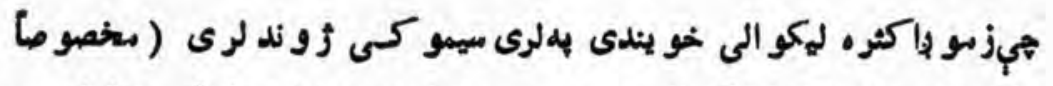

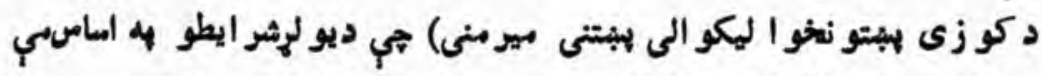

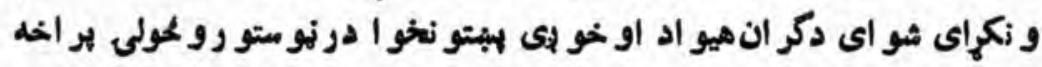

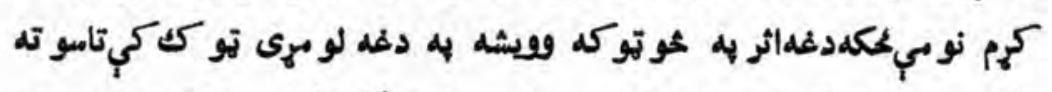

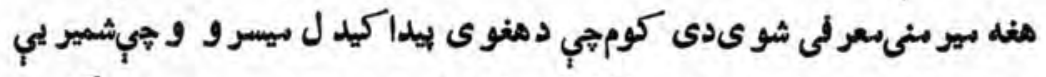

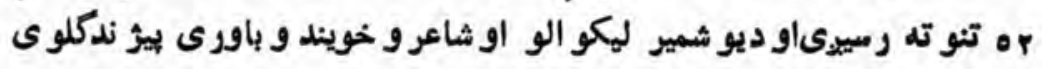

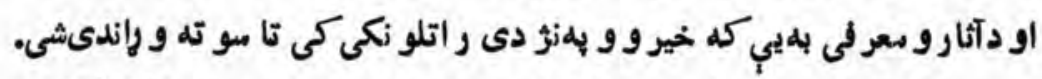

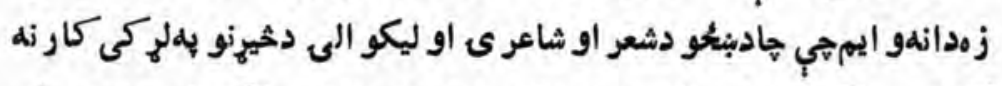

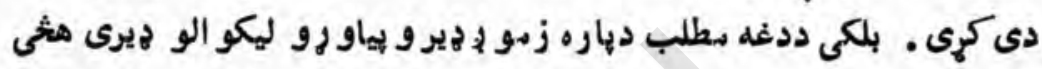

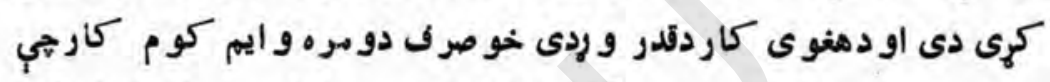

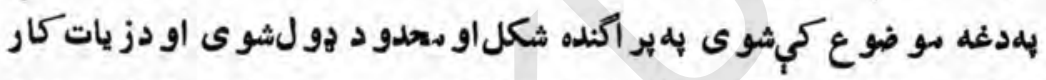

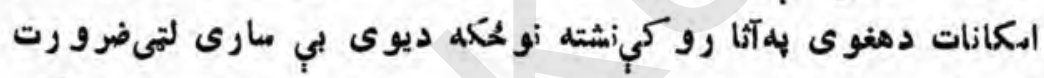

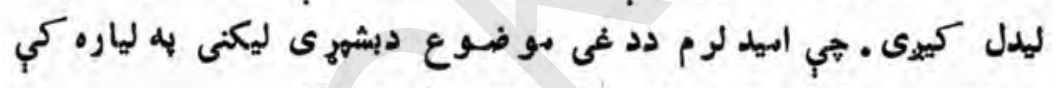
بهز ماسرودسو ول او صلاحيتلرو نكى اشخاص من سته و كوى .

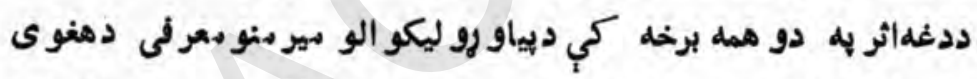

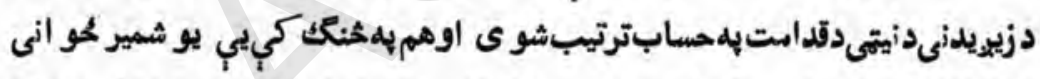

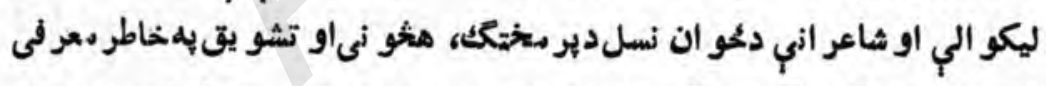

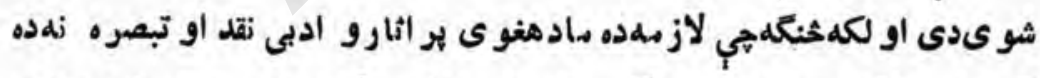

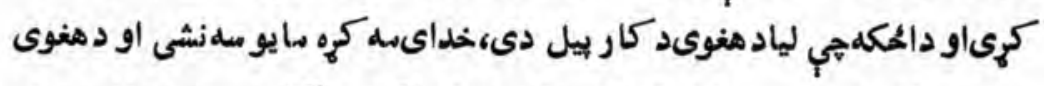

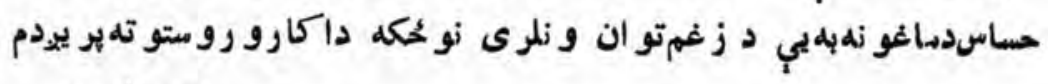
بلهدرناو

كبر انظهرى ملو رو 


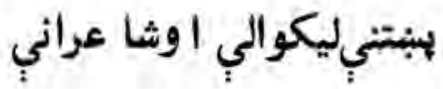

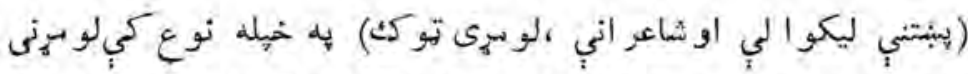

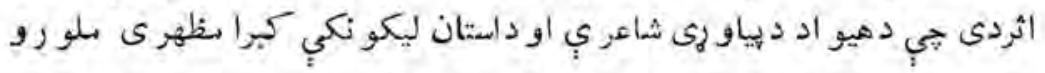

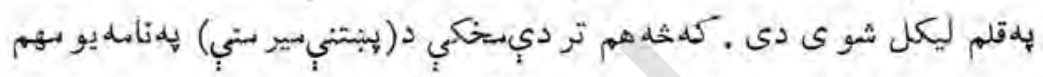

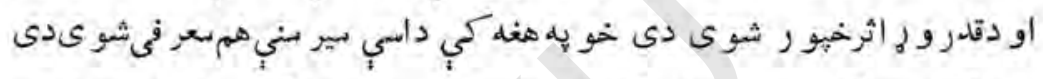

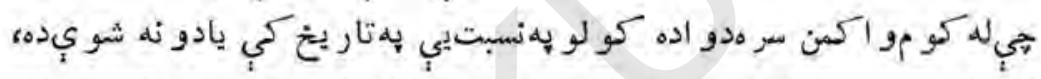

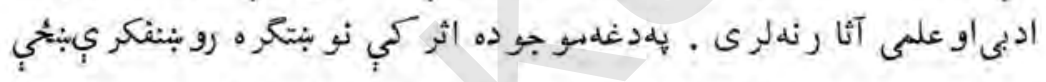

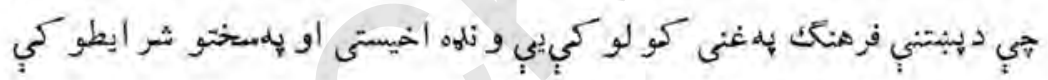

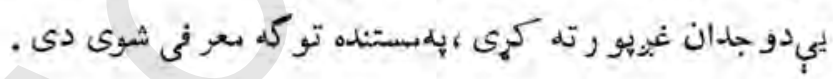

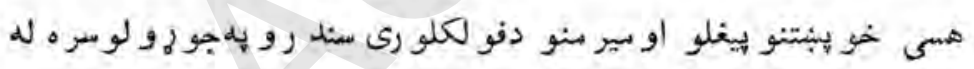

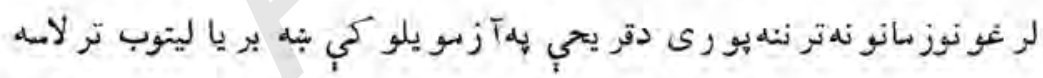

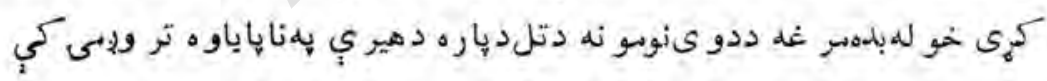

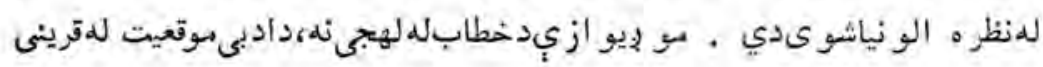

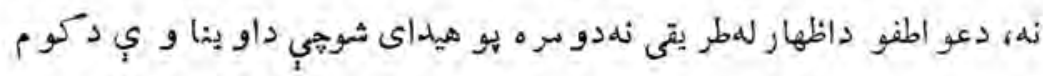

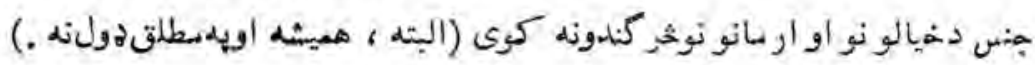




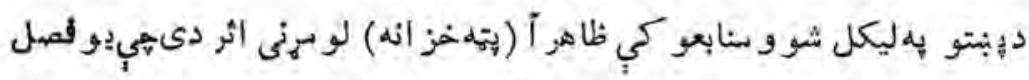

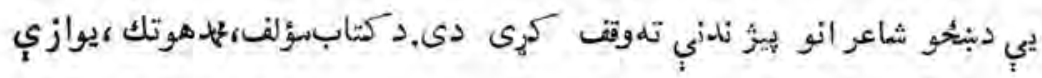

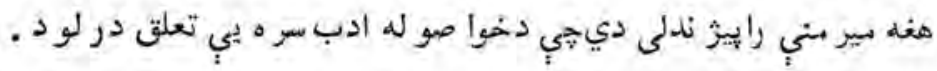

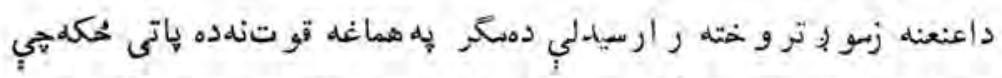

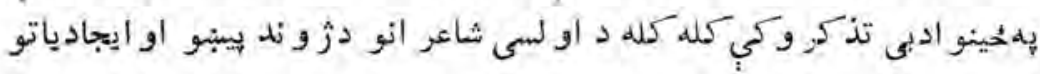

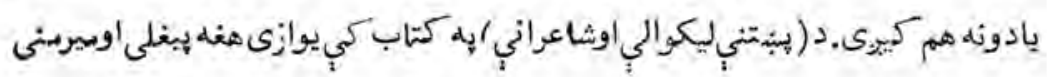

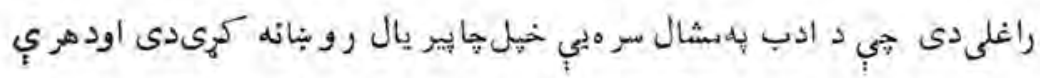

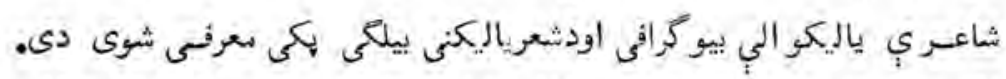

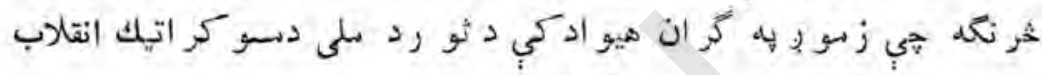

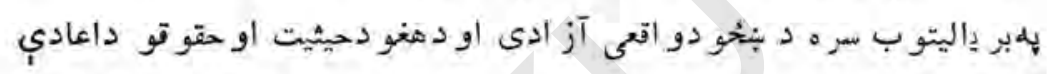

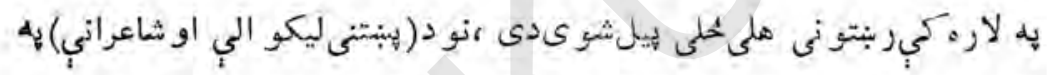

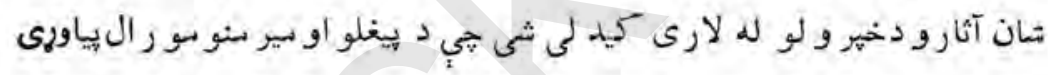

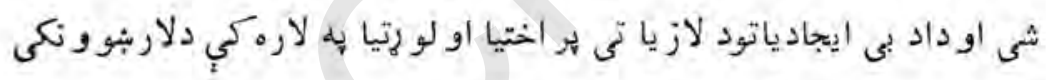

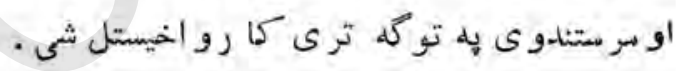
زمدسختر بى كبر ابظهرى نلو رو كار او ز يار تههي ددغه اثر به تهيه كو لو

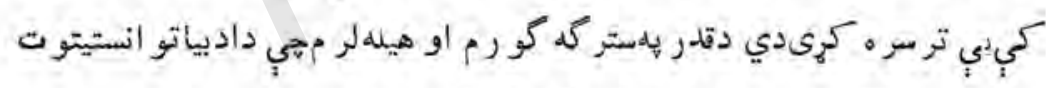

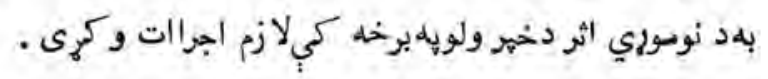
يلهدرناوى

داكاهميسين كانديلسر محقى ثط حديق روهى

$$
\text { ب }
$$




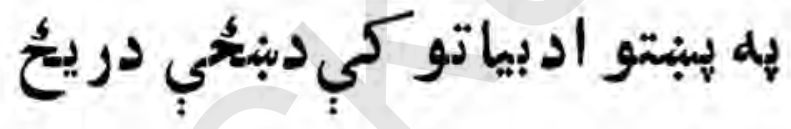

$$
\begin{aligned}
& \text { او } \\
& \text { برخه }
\end{aligned}
$$

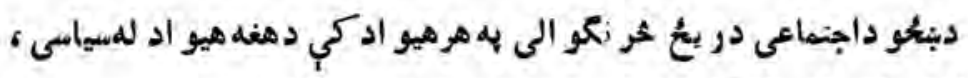

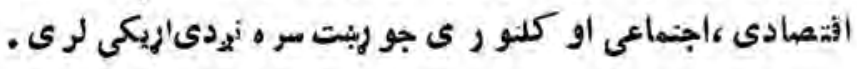

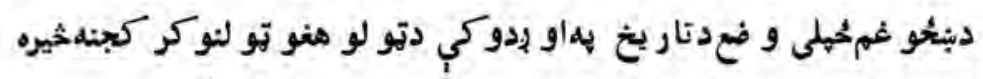

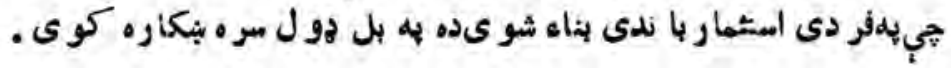




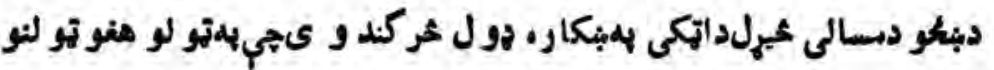

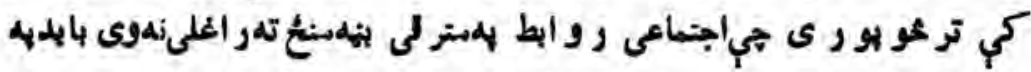
تو له هاناداجنساعى عدالت هيلهو نه شى ت

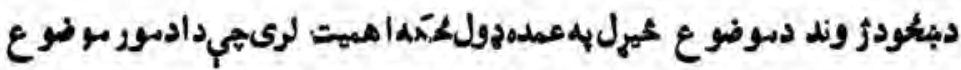

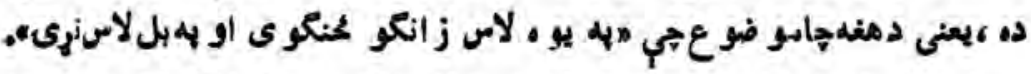

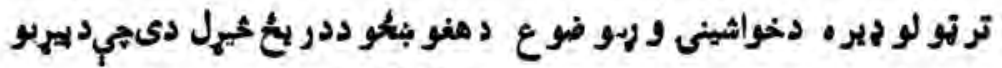

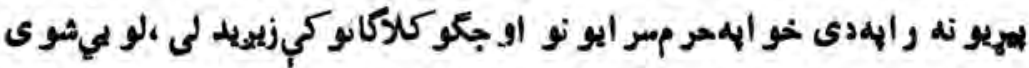

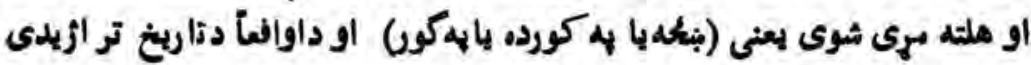

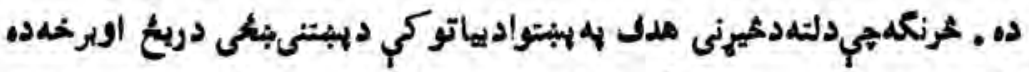

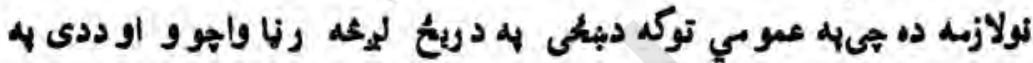

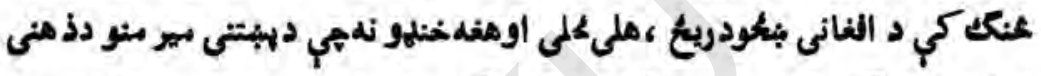

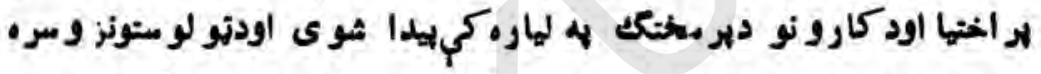

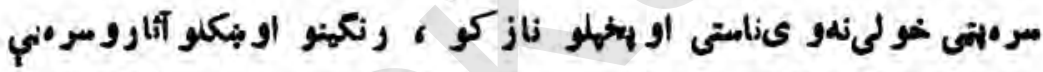

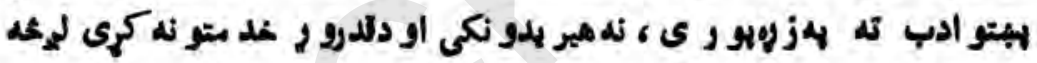

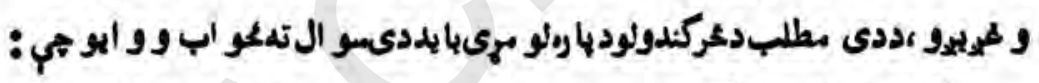

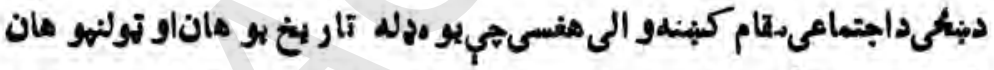

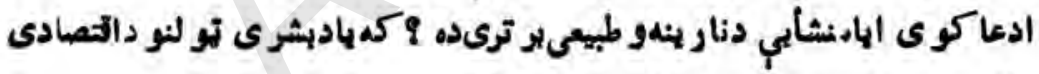
نتلام دجر بان د و دى نتيجه

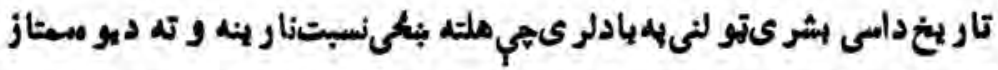

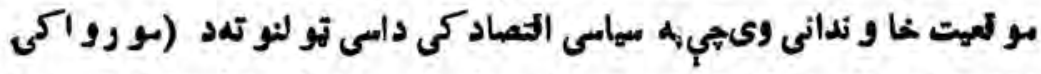

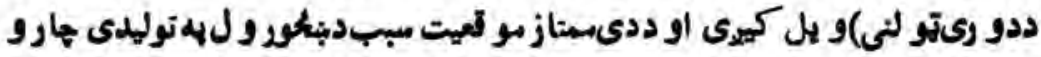

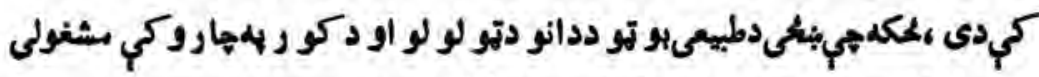

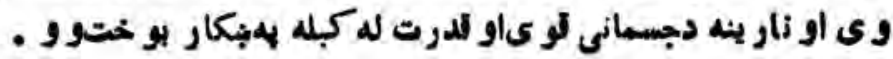




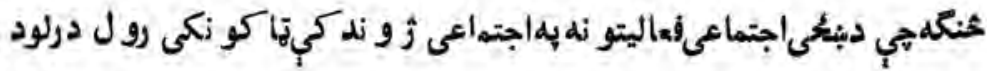

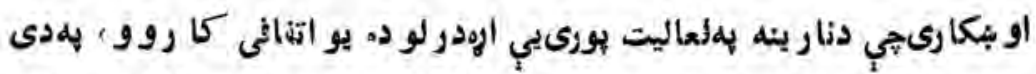

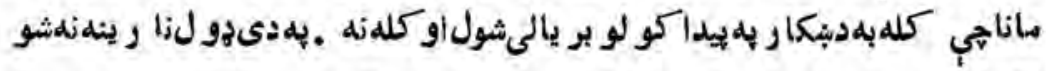

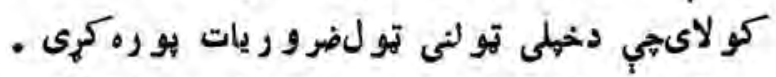

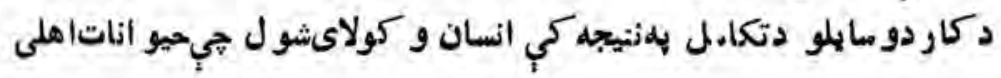

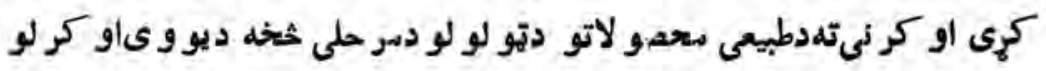

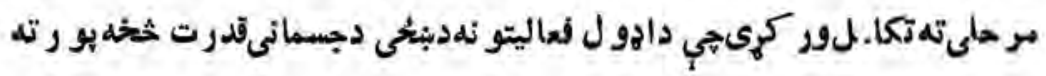
9

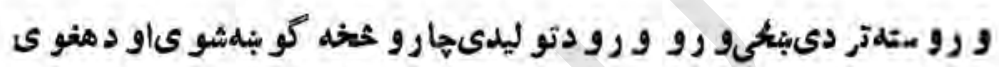
فعاليتو نه يو ازى او بو ا:ى بهكو رنيو ها رو بو رى مو بوط شول .

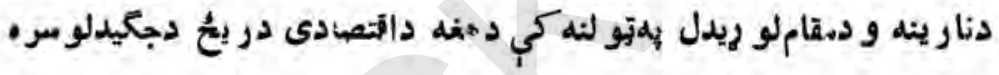

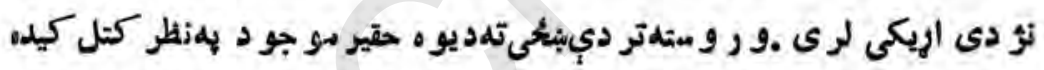

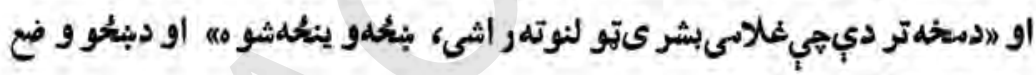

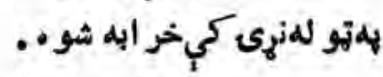

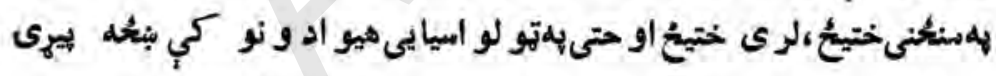
بيرى دانهراطو رانو او دحلىادير انو ددر باردلو بوكو هآكى وكرحيده او يو

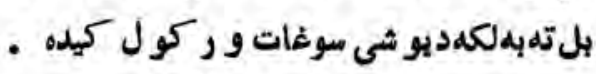

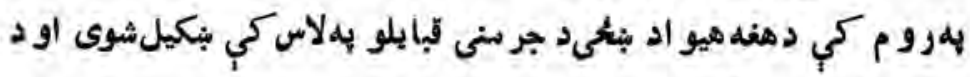
و ينثلىتوب ز و نديبي كاوه .

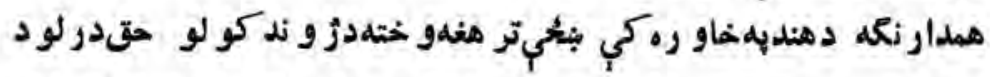

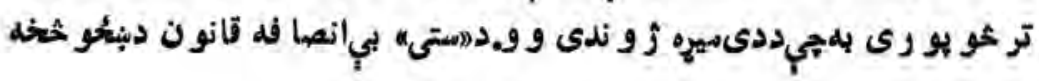




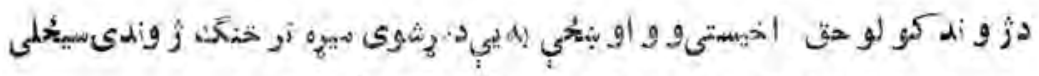

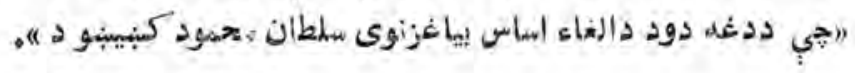

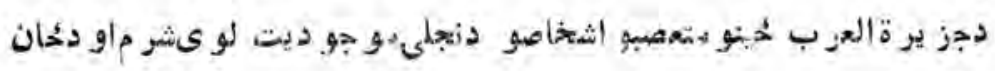

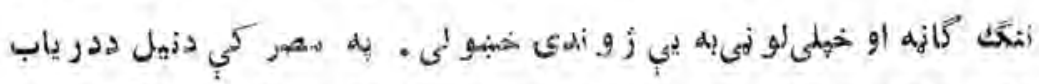

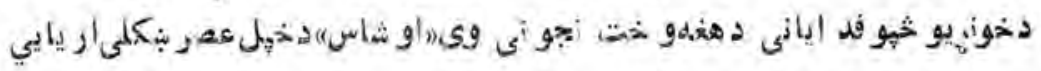

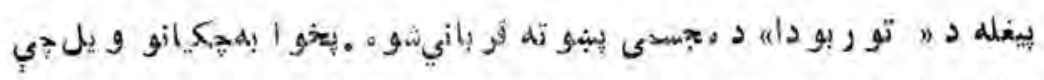

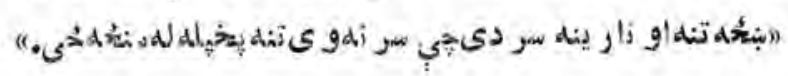

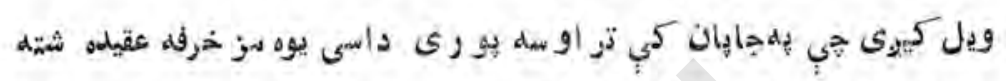

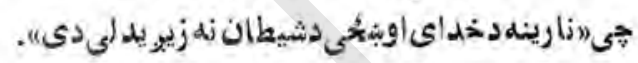

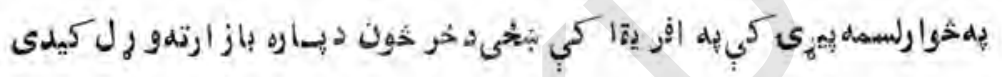

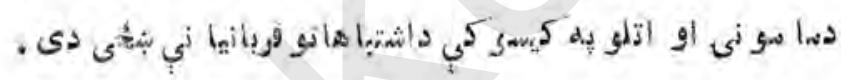

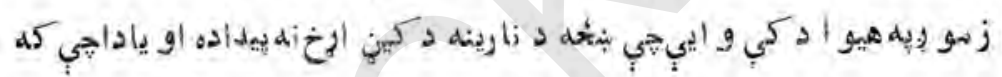

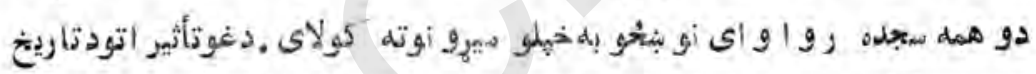

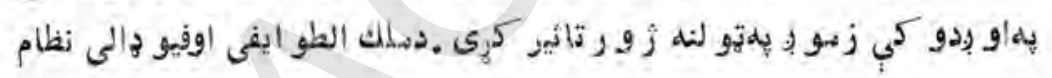

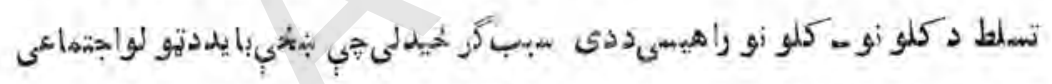

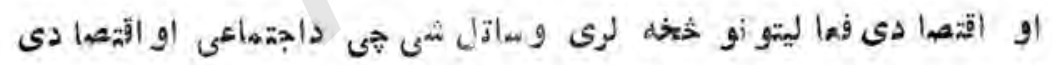

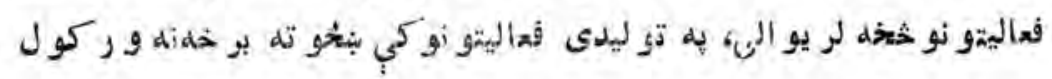

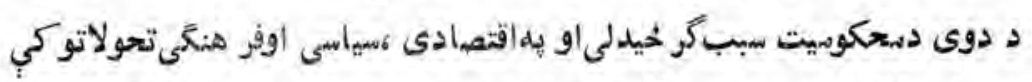

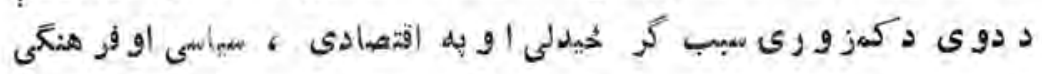

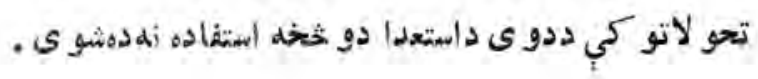




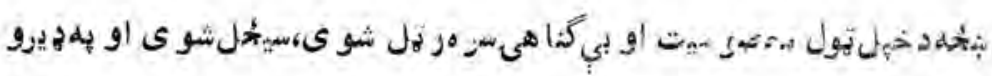

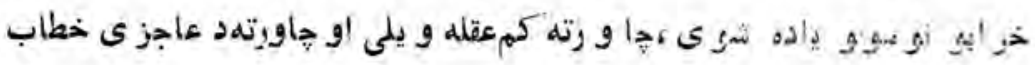

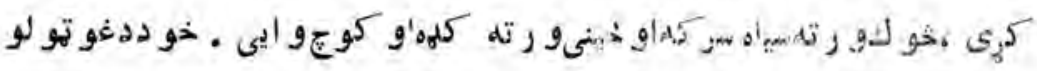

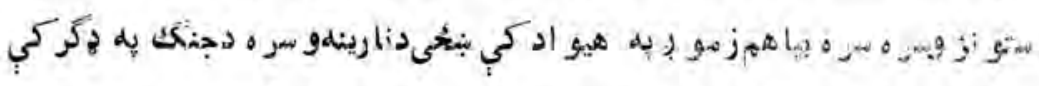

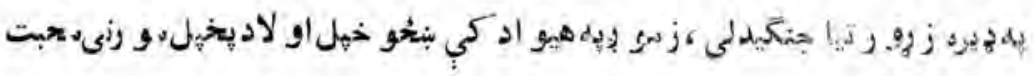

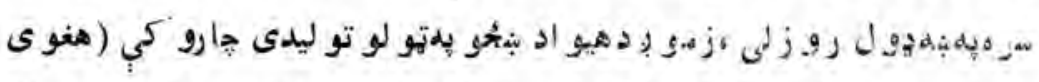

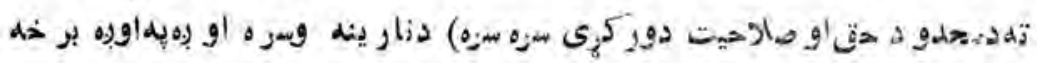

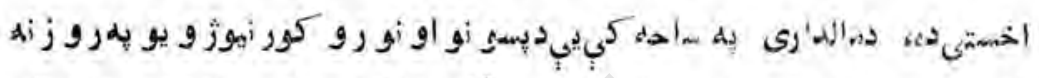

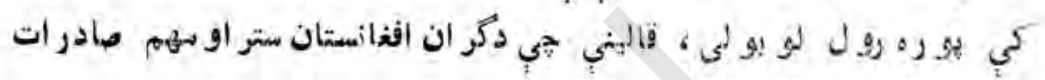

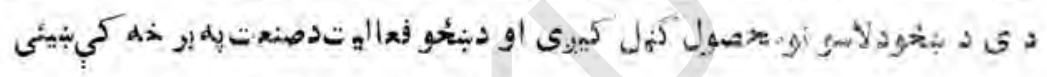

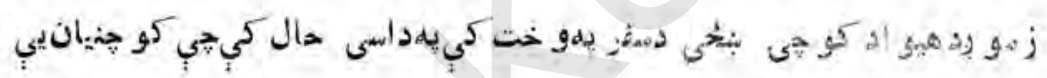

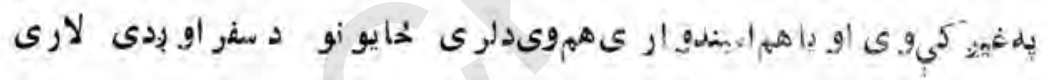

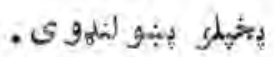

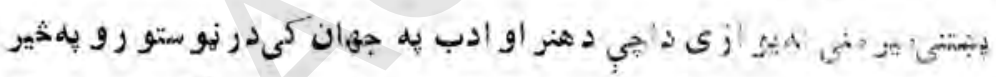

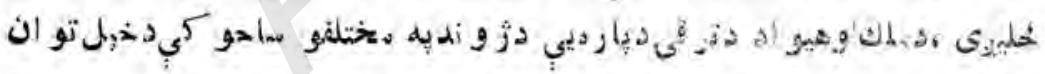

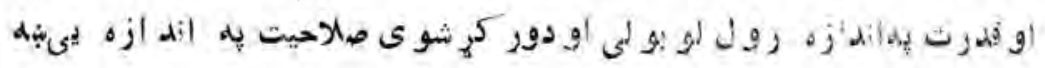

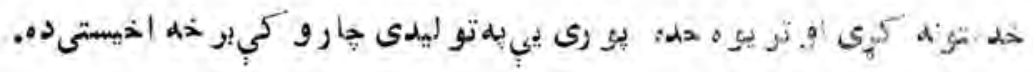

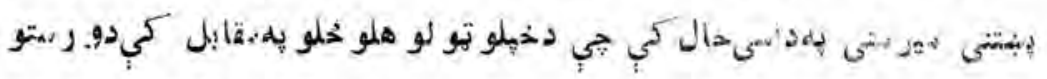

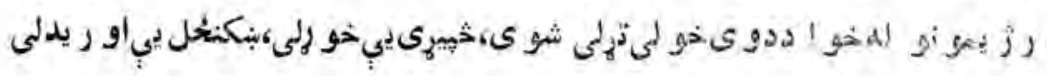

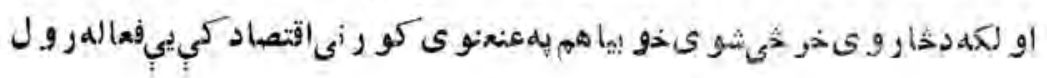
بنغخ 


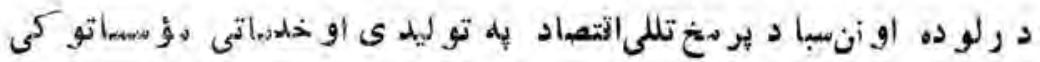

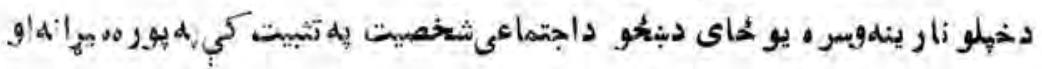
براخه حو صله كاركوى .

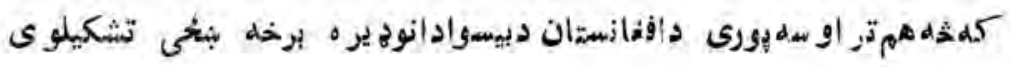

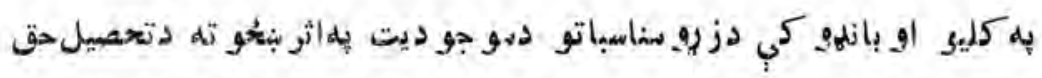

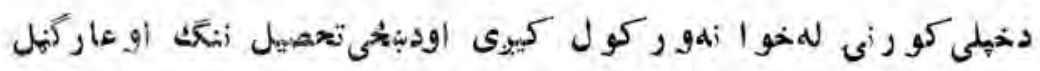

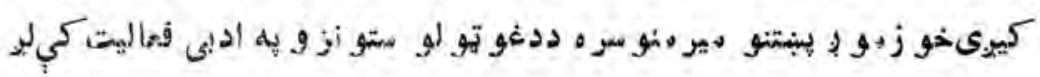

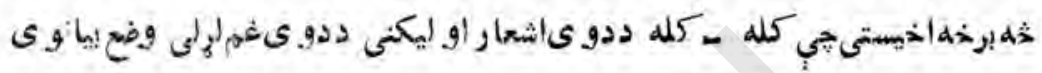

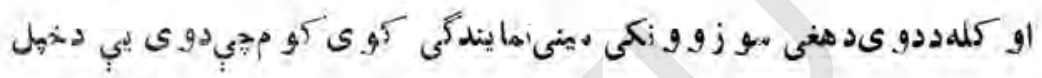

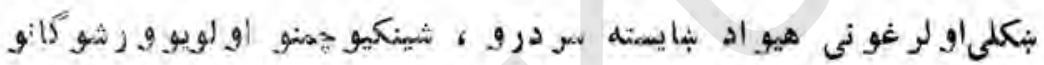
.

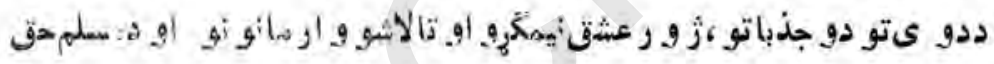

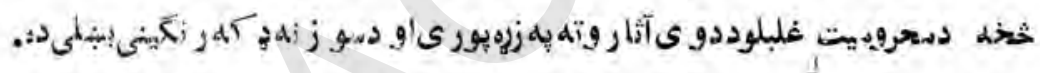

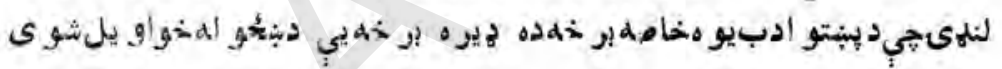

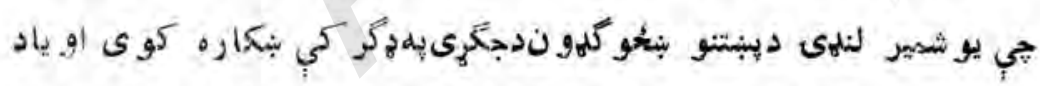

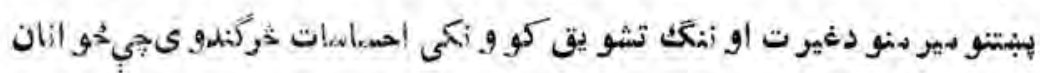

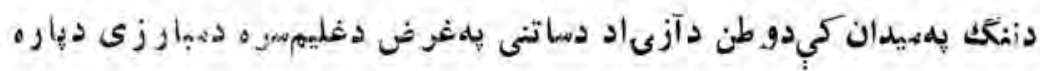

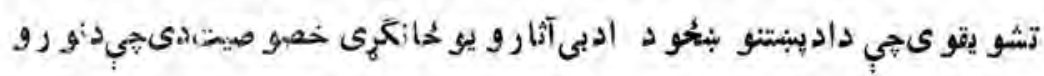

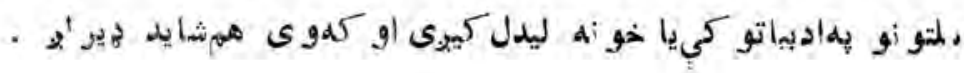

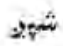




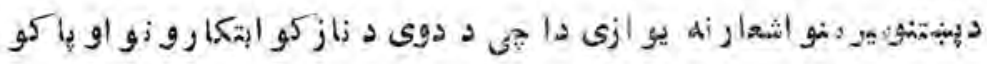

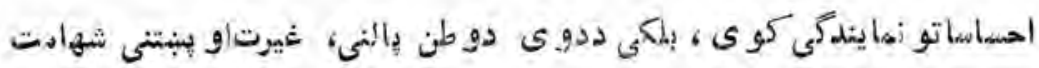

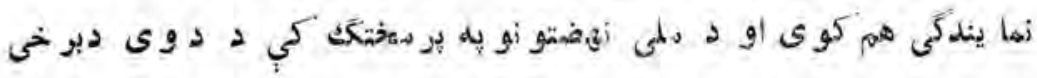

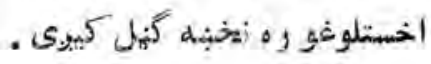

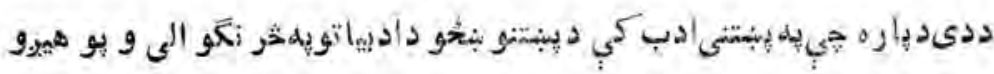

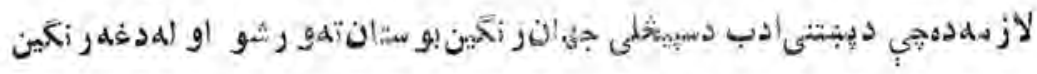

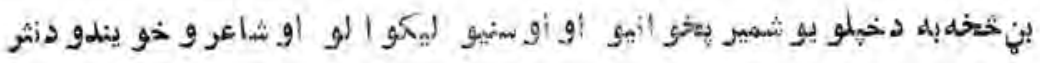

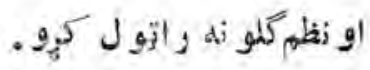

كيبر أنظوندى هلمو رو 


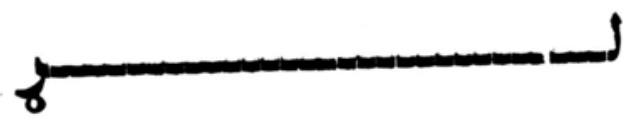

مخ

$$
\text { مركهن }
$$

مير بن أيك بلهته

دير من مليهمانلة

$r$

ميرمن زازوا زا

-

ميرمن ز رغونه كاك

$\wedge$

بى بى زينب

1.

مهودن نازو

ir

I, Ind

IP

بى بى تاج

10

رايهاخرونى

iv

بله زشته

19

مهينه

1

مير من صاهبو عاجزه

P 
ใै

معرلكم

IVY

كر يمه رسولى

IN

بلقيم.جبوبى حقيت

199

كلالق رحهى

$+.9$

يرو بن مل

$\$ 19$

و إنكانه هالقى

$r p r$

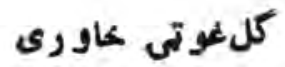

YNP

صفيهصديقى

P०I

نوثيا هله ثهمد

ที

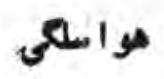

V.

لهلم لها

rvo

ز زلهته مليطا

TAI

$$
\text { نقهسه لبى }
$$




\section{لو مرى}

بوخه

بخغوانى شاعراني 


\section{مير من نيككبربخته (1)}

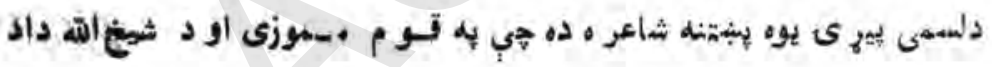

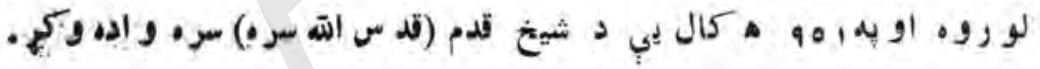

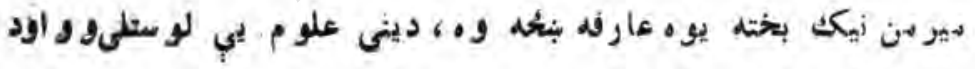

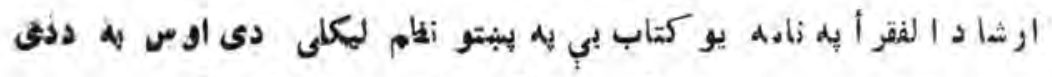

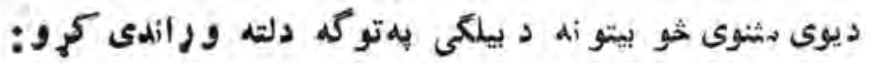

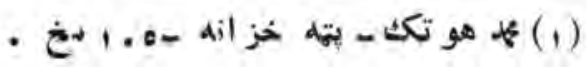




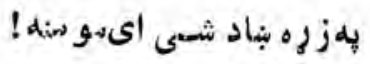

بهله ظـاه هر به باطن سيبنسه

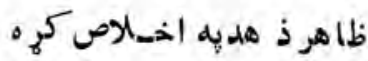

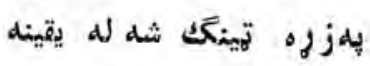

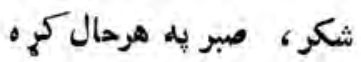

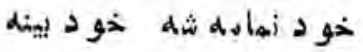

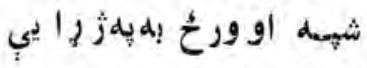

dinxwd d

سبتحين حاى د خو د دمايه

د إسى أهاز و أو و إبى دينه

له هـنه خأى الهان راكي

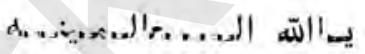

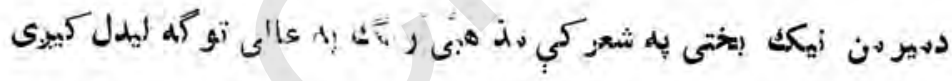

او خاخهلو اشمارو كمي خلكك تقوى اود يندارى تلمرا بو أى . 


\section{مير من حليمه حافظ (1)}

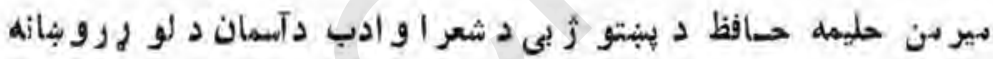

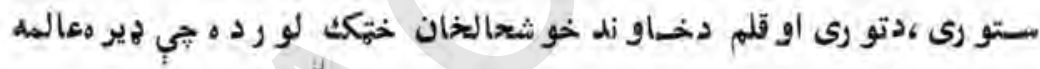
او يو هل بنيخه وه.

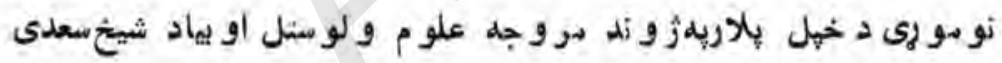

$$
\text { لاهو رى نو يده شسوه. }
$$

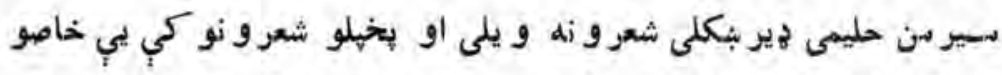

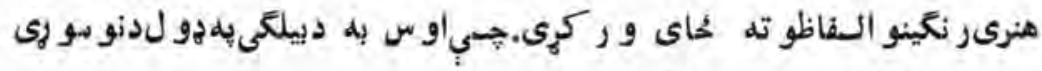

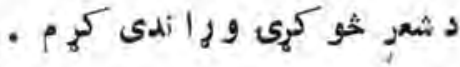

• (1) 
دأشنائبلفكر خو بنه هسى شان شسوم

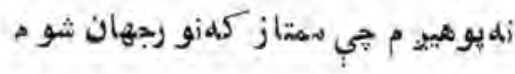

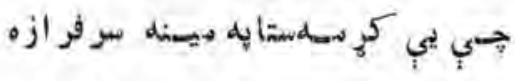

ثناخو أنه به خو ر زَّ人ه درحهان شو م

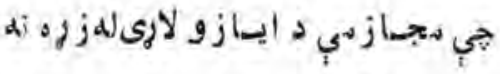

مبر بلنده ثر ميحمو د غوندي سلطان شوم

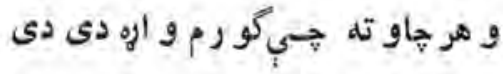

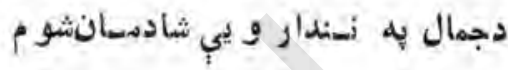

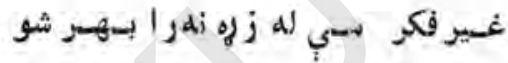

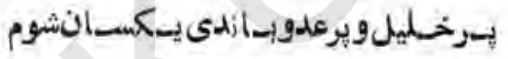

"حليسى "دغسمأ زمبكر ز يـات الهحدشو

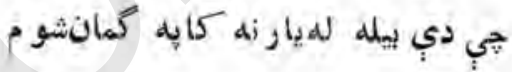

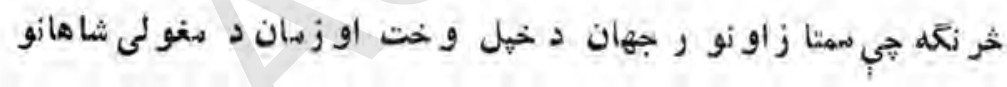

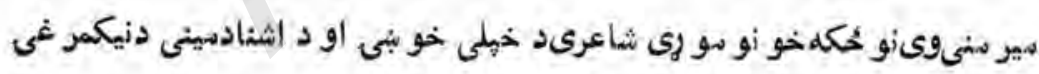

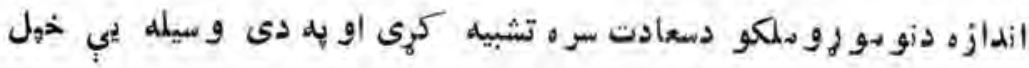
سيز و نكى عشق خركند كرى . مان. 


\section{ميز من نأزو(1)}

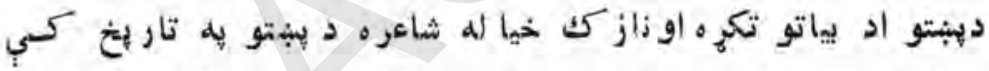

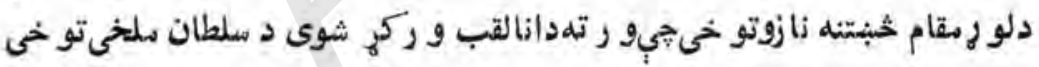

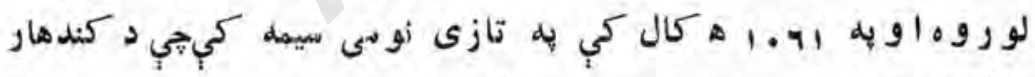

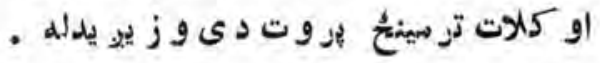

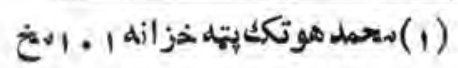




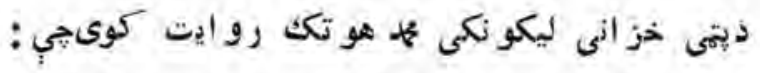

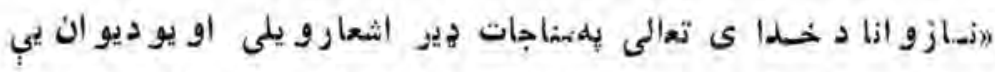

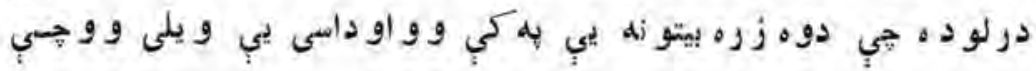

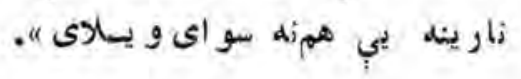

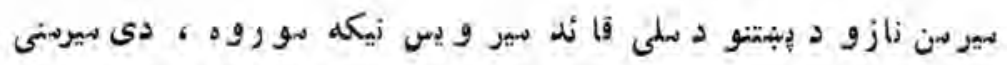

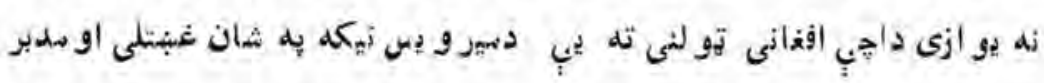

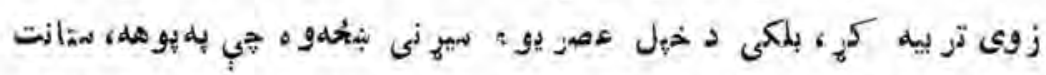

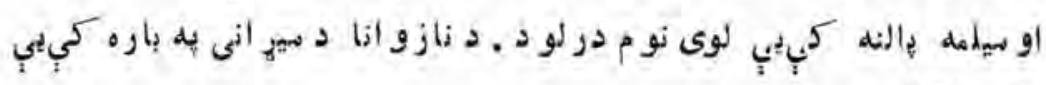
داسى ليكلى خي :

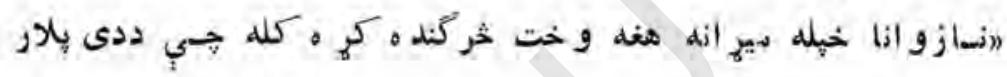

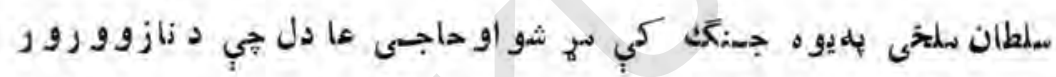

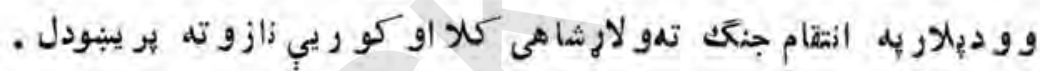

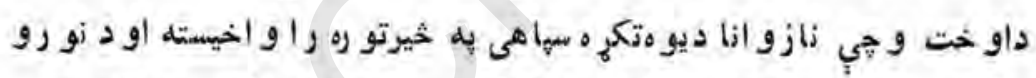

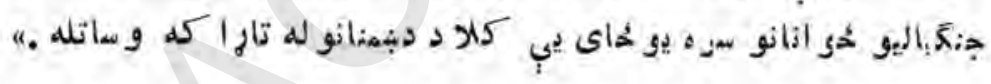

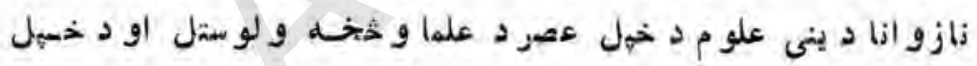

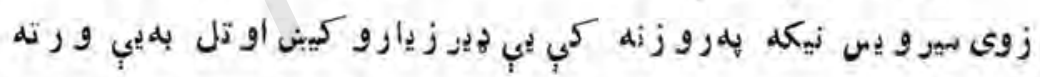

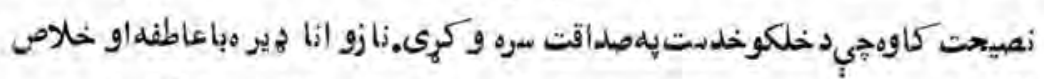

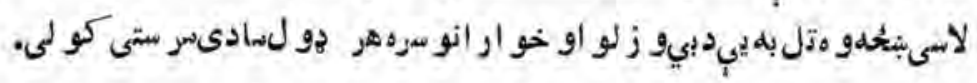

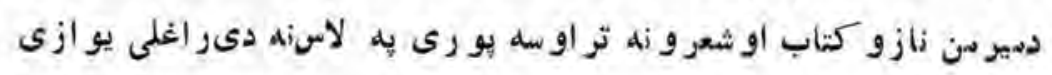

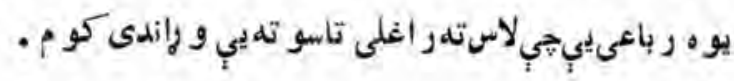




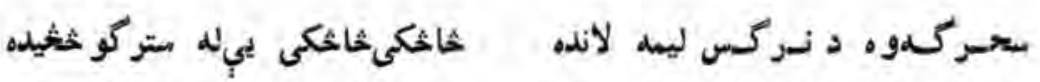

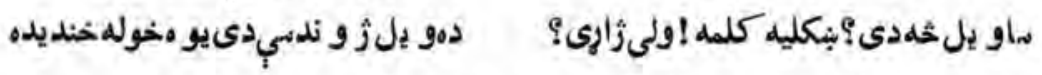

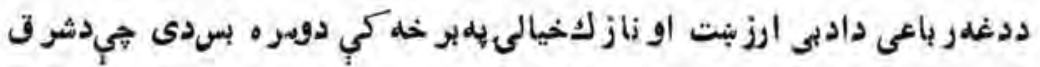

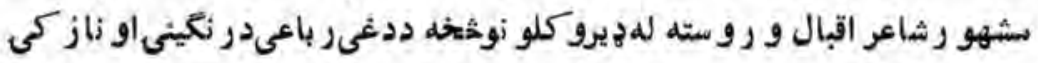
تر تاثير لاندى راغلى دهغهاحساساتيب راهيارو لى او دغه ر باعىبي به فارسى

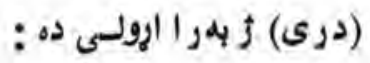

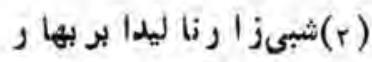

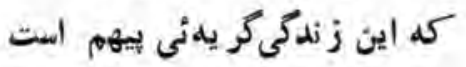
2 رخشيدبرق سبكسيركفت

غلط كر دهئى خنده يكدماست

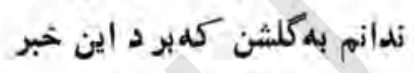

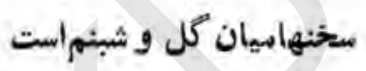

(r)داقبال كليات. 


\section{مير من زرغوزلهاكيره (1)}

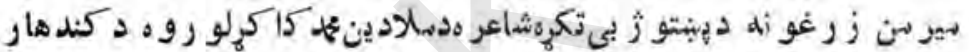

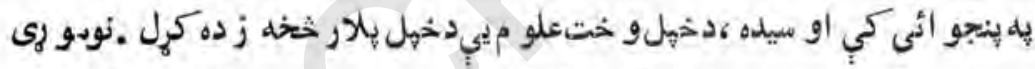

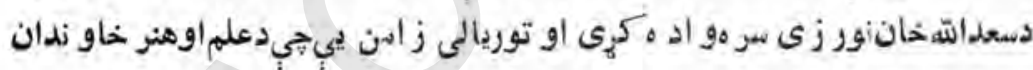
و 9 تو لنى ته و سها رل .

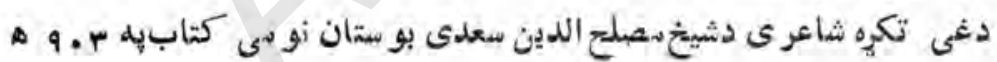

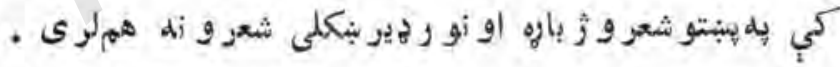

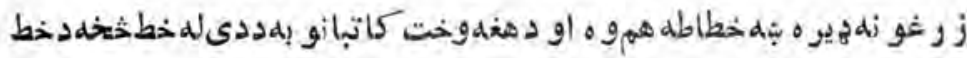

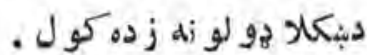

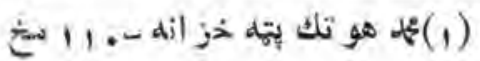




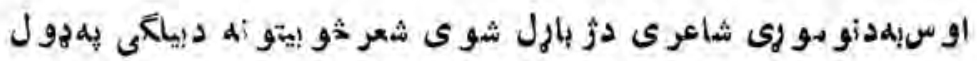

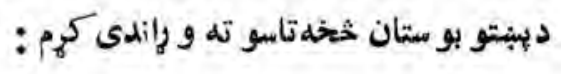

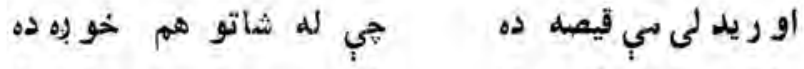

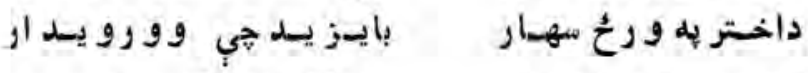

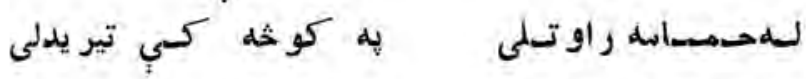

$$
\begin{aligned}
& \text { ايرى خاورى هاله بإنه }
\end{aligned}
$$

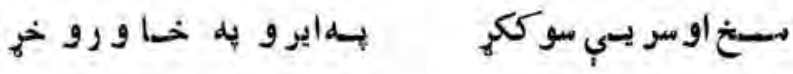

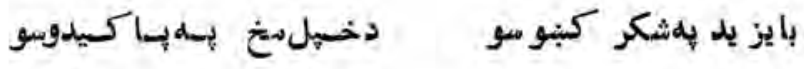

$$
\begin{aligned}
& \text { جسى زمولو ريسم دبل اور }
\end{aligned}
$$

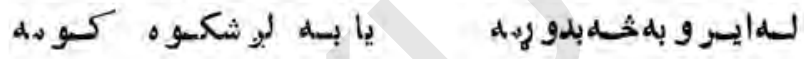

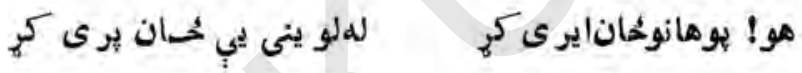

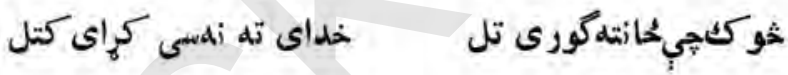

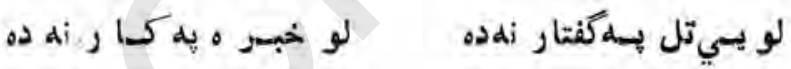

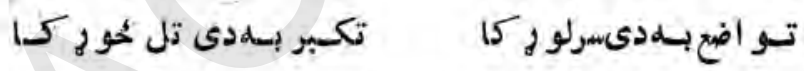

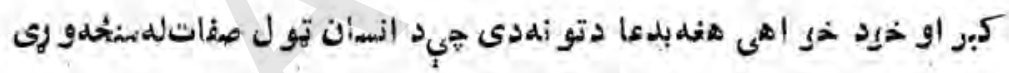

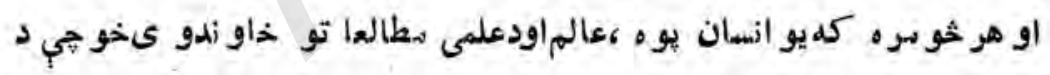

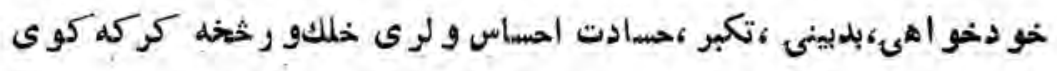

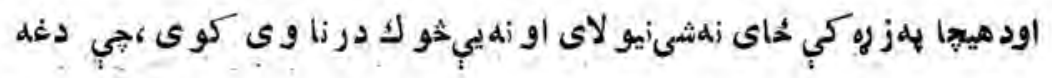

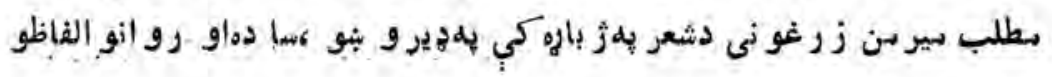

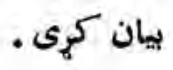




\section{(1) بع.بی زينب}

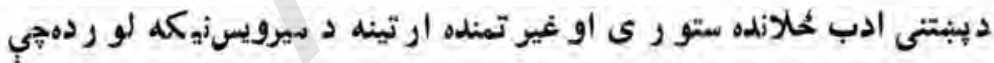

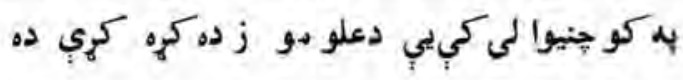

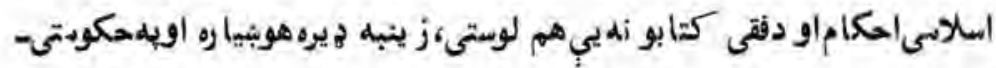

او ادار ى كارو نو كي و ارده بنحهلو او بهله تولو كارو نسوكي يب خبل

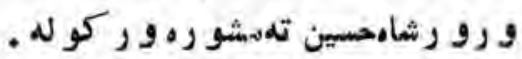

$$
\text { (1) }
$$




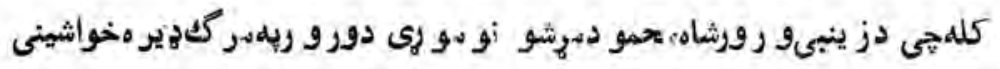

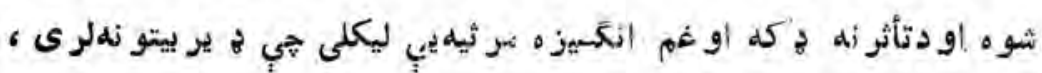

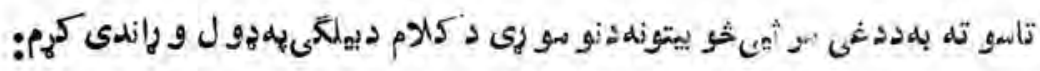

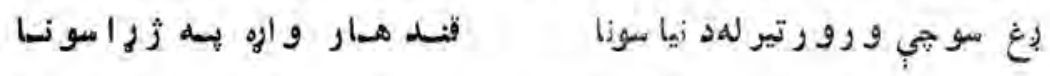

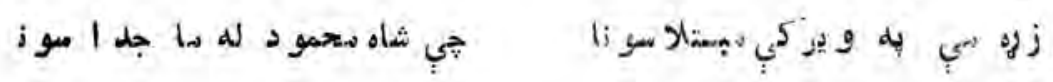

ولالودكام بسه نسام و زنغكدو نا

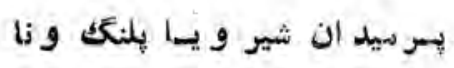

قندهـار و الره إيهه زٔرا مسو نسا

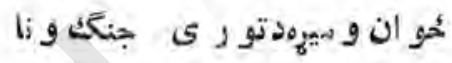
دنين له ده بهل و ينو رنك ونكا

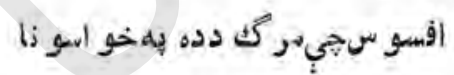

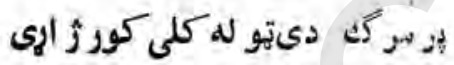
لبنكرسباه دي كلى كسو رثزارى

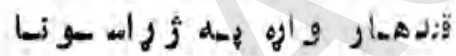

مهمو ده ! انهيو از ى خورز الرى

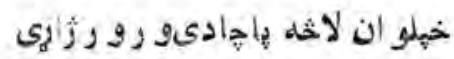

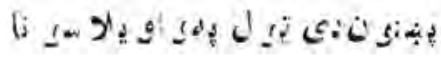
* * *

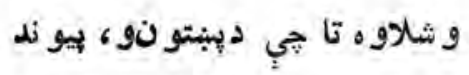
جي شانتحمو د دى كابهقبر كي بند

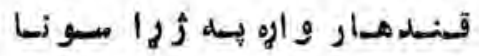

السمانه بيادى خهل ستم كاخر كند

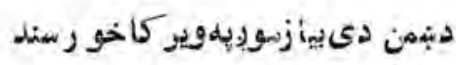
بإِركو رسو و ير شو او غو غاسو نا * * * 
بيتّو نبه مرككدشاهدحمو دسو بر باد دماندو إنغ دى خي دأو رينهي بهاد

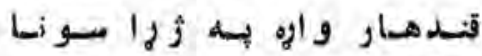

اورمنارى دغم جي كَ يثه فو ياد ز زو أهجي تل بلهو يبادسنسو هنابناد

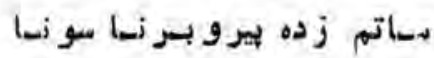

* * *

دردى كي تاته بسله موكمر احت

و رو ره إمقر د ستامو لاكي جنت

هيخدىوهر وين دخدائبلمهرو رحمت

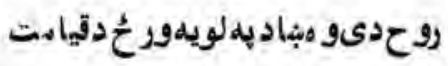

قندهار واره هله ثرامونسا

دخالق، رحم تسل برتا سو أسا

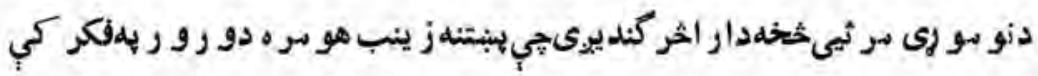

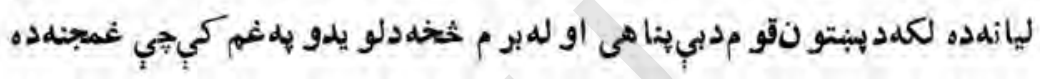
او يو از ى دخبلو رو ردمهي ينى بهغماو بنكى ألهتو يوى بلكى دغهخبر ىهير .

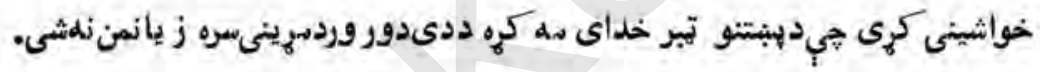

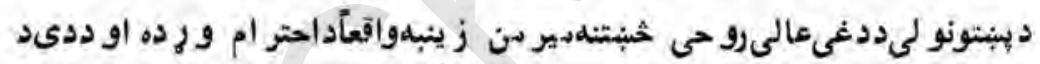

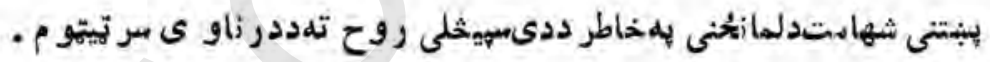




\section{ميرمنازو (1)}

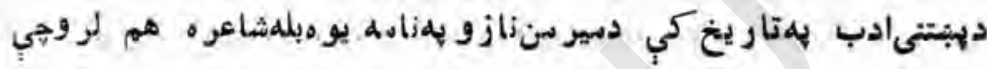

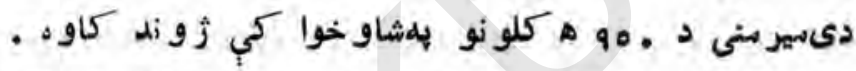

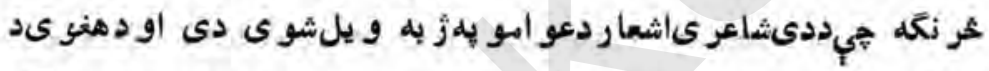

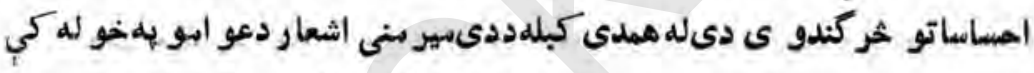
لو يدلىدى او بيتقانهزلميان يجيخهلو مجلسو نو كيو ائى .

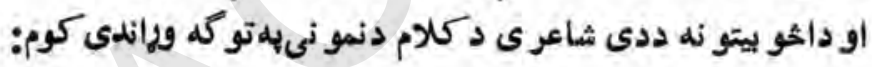

دايلبل خي آو از كاندى نه معلو ميرى

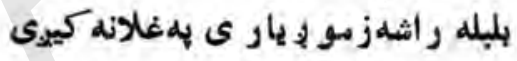

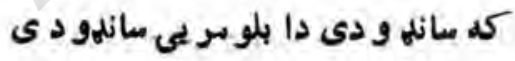

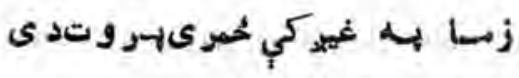

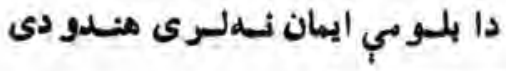

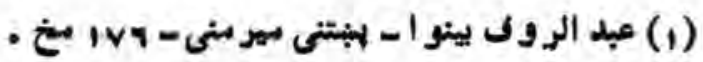
ir 


\section{(1)}

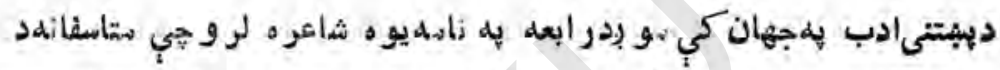

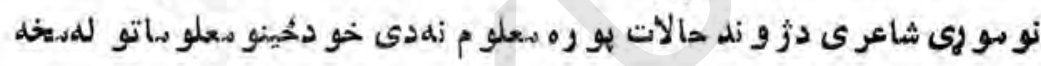

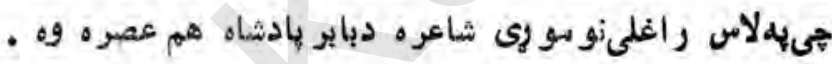

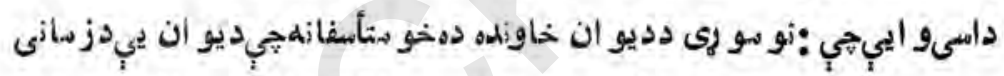

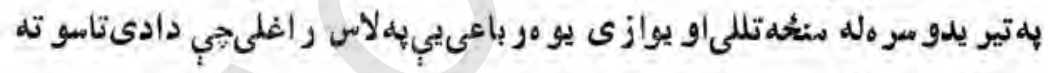

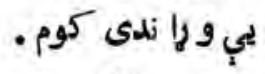

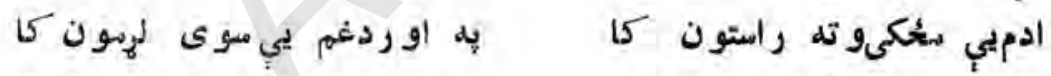

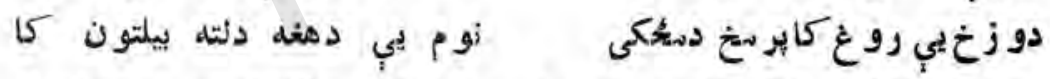

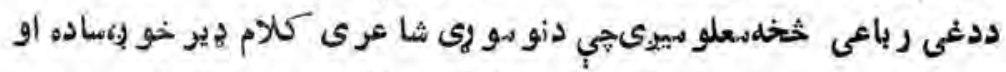

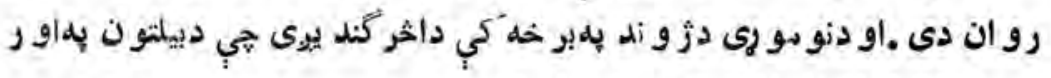
و ريته شوى او دفر اق ز هر يب خو لولى دى .

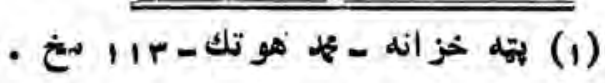




\section{(1)}

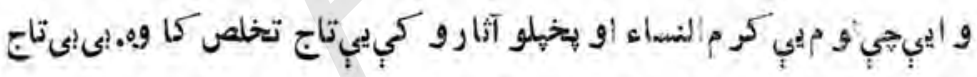

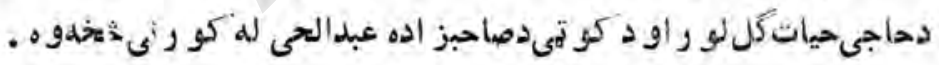

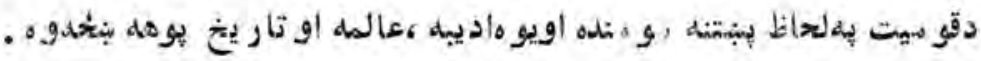

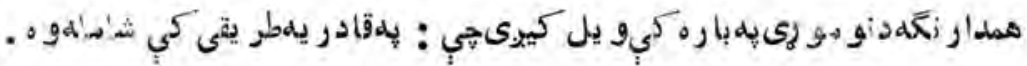

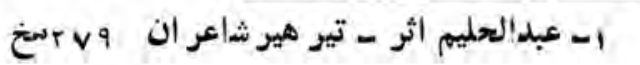


داهم دبيىتاج دكلام نمو نه :

بلهقوت كي يهليو ان

مشهو ريسي تسر ايسر ان

بـدوو كيه اي ! بلطان

زارشم زه مستاله در بان

كرهنظر رابهانسلى جان

ديسي كسو دمتـعـيسره

اى آفتاب عـالـمكير.

مر يدانسو له اكسيره

اى زبساكسامله بيسره
دكوة تسى غوث الز سان

بـاببيسكسو مهر بسان

ستامز يد خلاص للهخز ان

شسوخبر ستالـه دو ران

دكسو تي شساه هتودان

حضر تجى زمو نسيه بيره

شرق تر غر بسه بينظيره

خوش الحانهخوشتق يره

زه هم ستايم دادئكيسر،

$$
\begin{aligned}
& \text { كره نظر ر ا باندى جان } \\
& \text { كسوتى شساه مسردان: }
\end{aligned}
$$




\section{(1) رابياخر وتى}

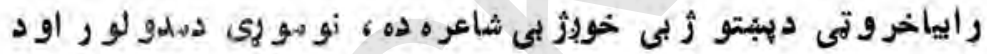

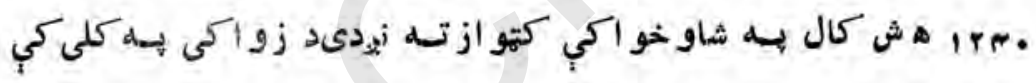
ز يريدلىده.

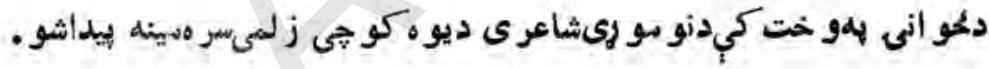

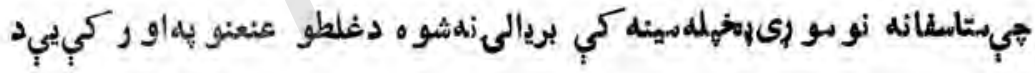

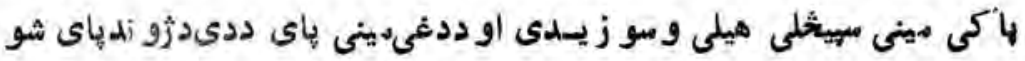

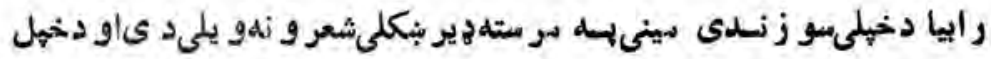

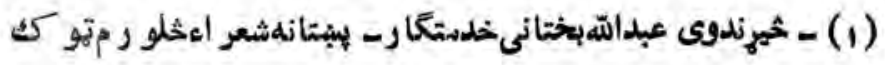




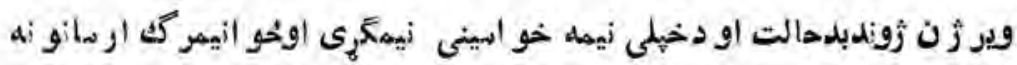

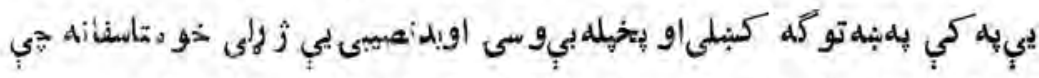

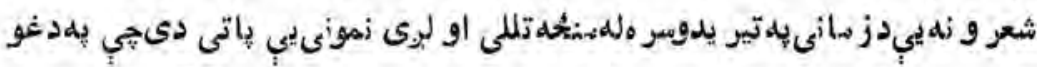
خو بيتو نو كيددى دتودىنينى او سيز و أكى عشق تصو ير به خر كنديدو ليد ليدل كيبرى .

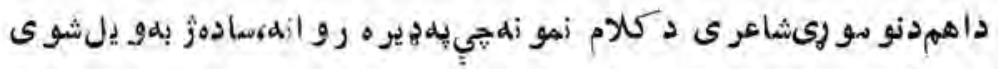
او بلهلمى كلتو ر سمباله ده .

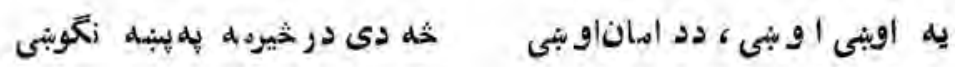

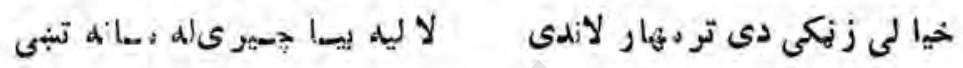
يلdتو رى، تو رى كيرد يلتوري

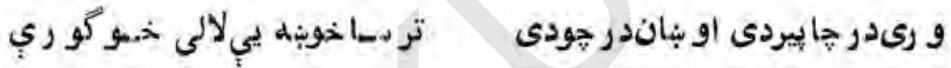

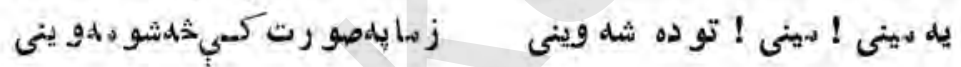

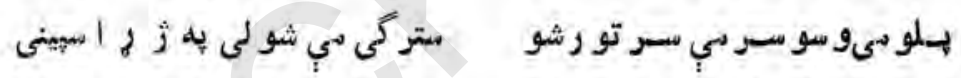

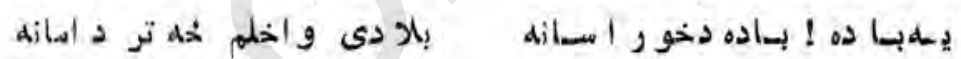

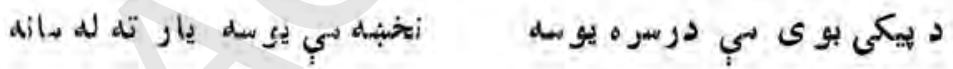




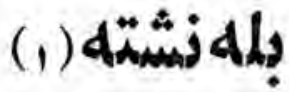

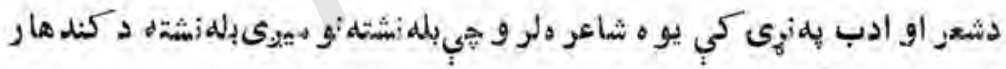

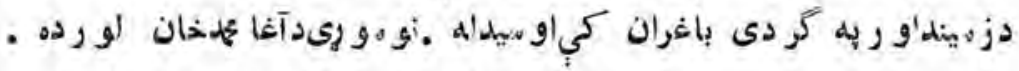

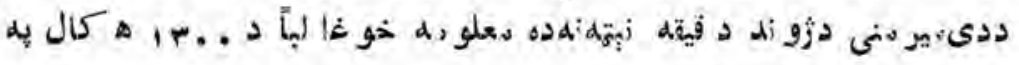

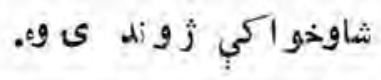

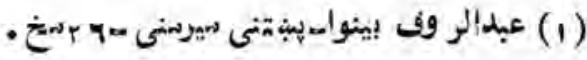




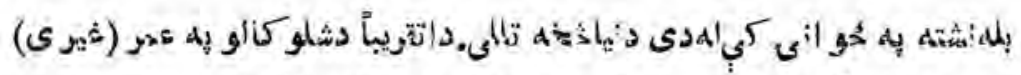

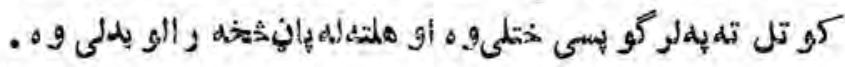

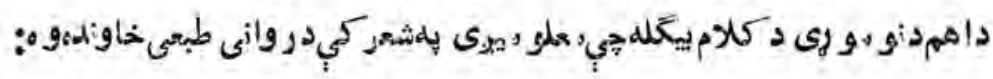

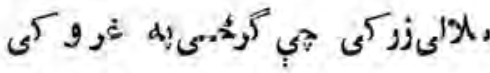

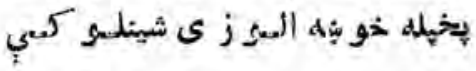

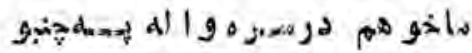

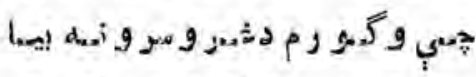

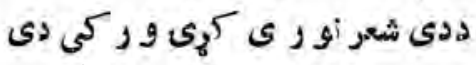

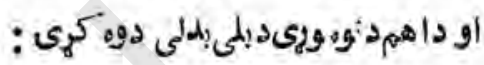

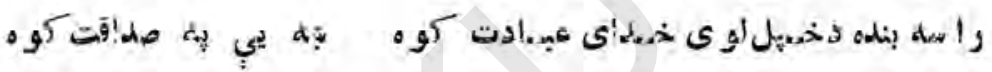

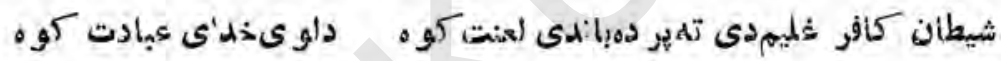

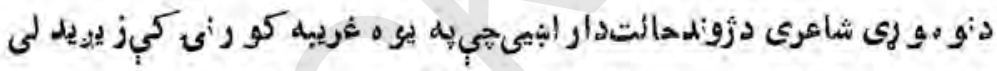

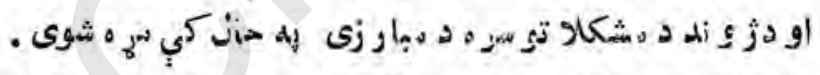

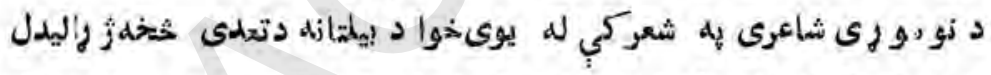

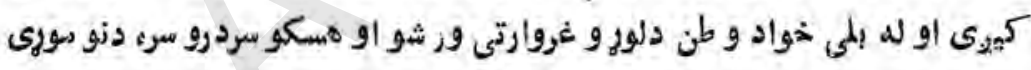

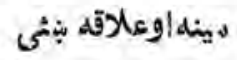




\section{(1) (1)}

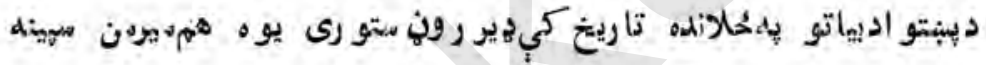

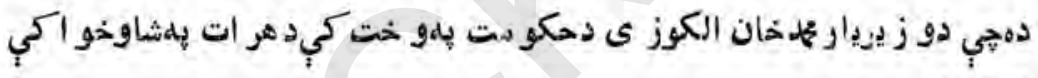
او سيدله .

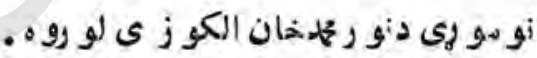

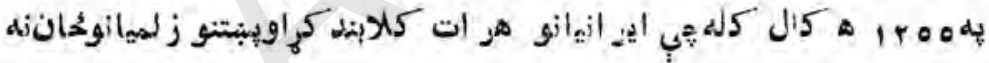

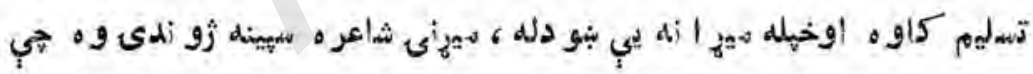

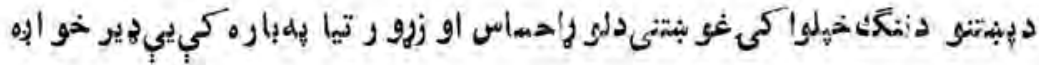

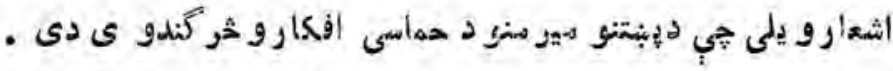

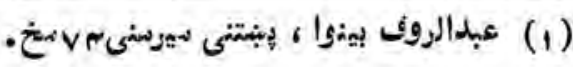




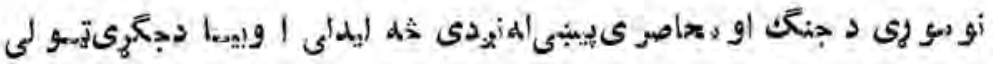

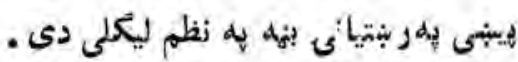

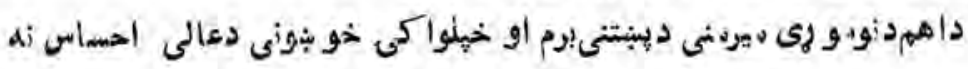

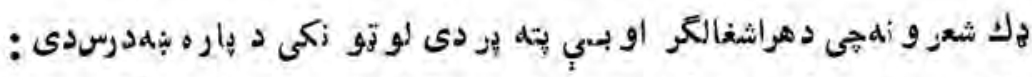

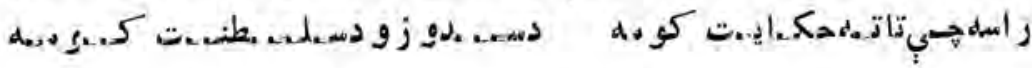

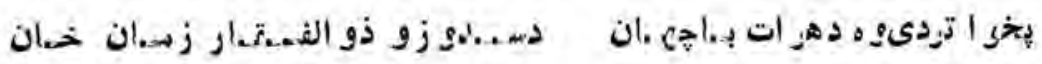

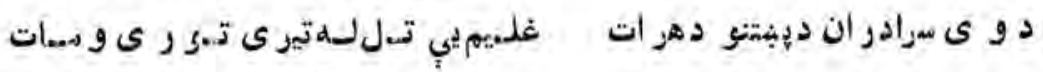

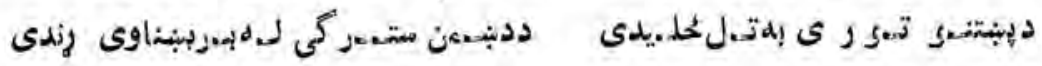

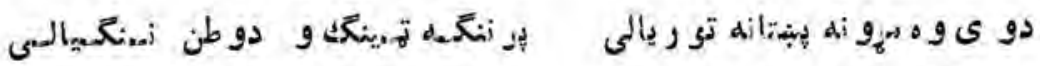

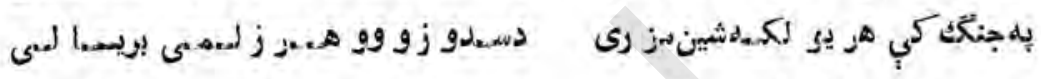

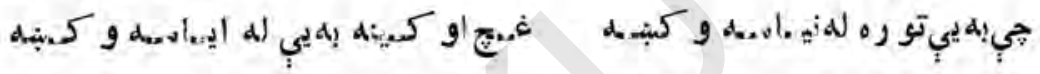

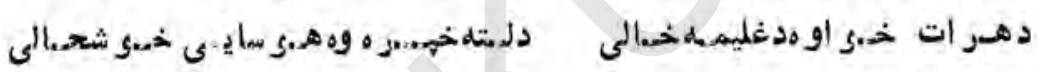

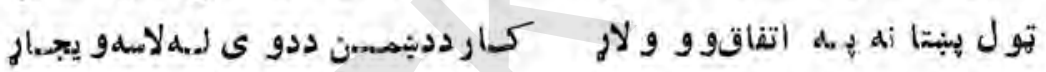

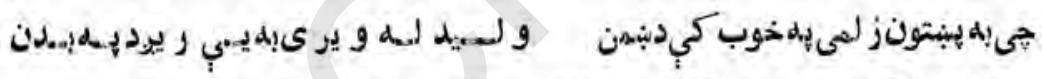

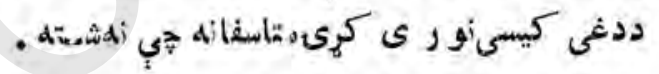

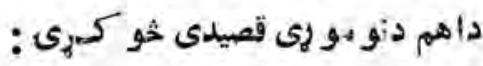

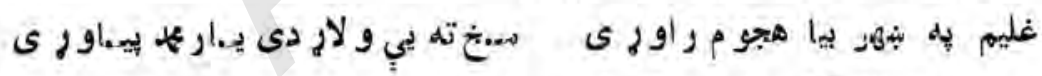

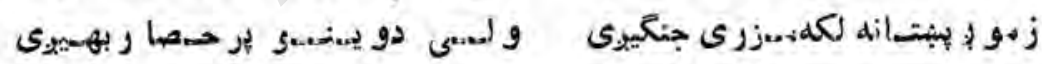

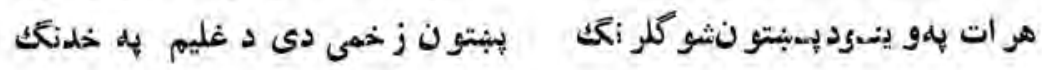

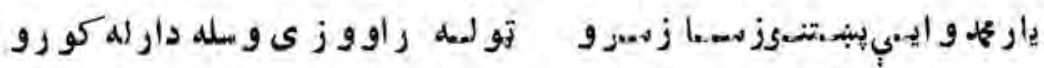

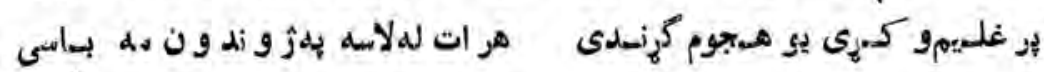




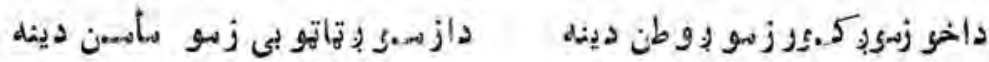

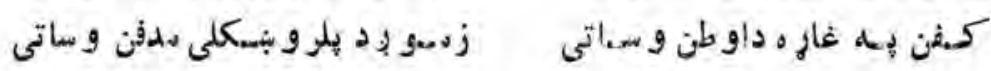

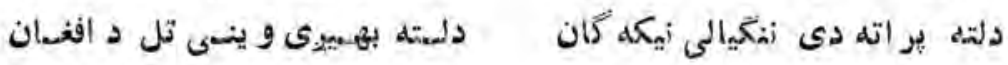

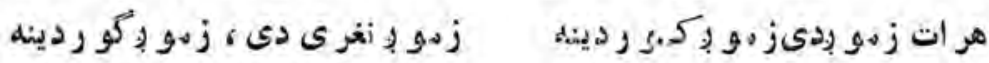

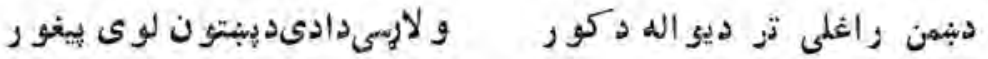

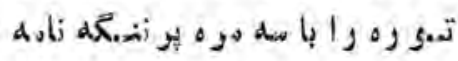

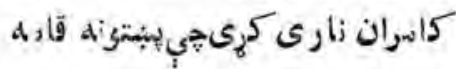

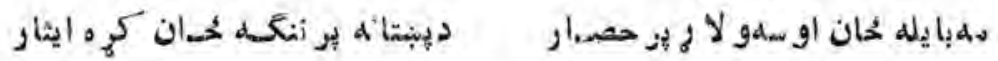

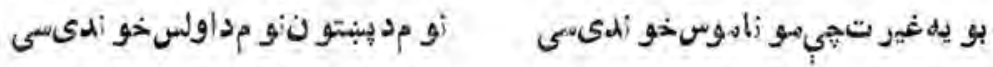

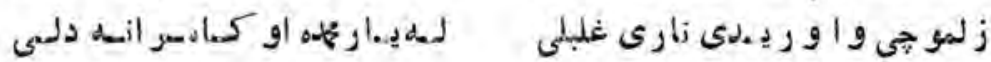

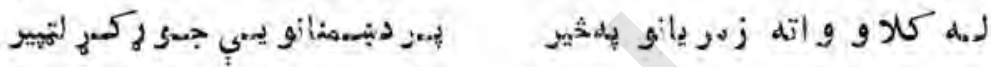

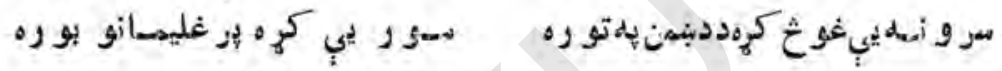

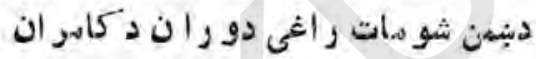

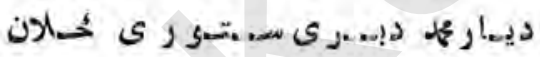

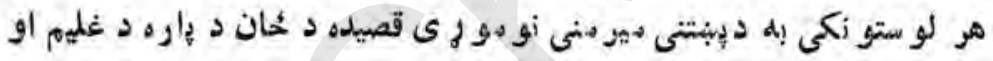

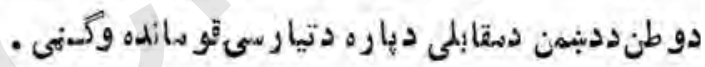

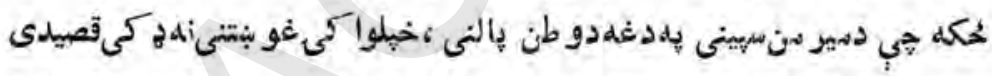

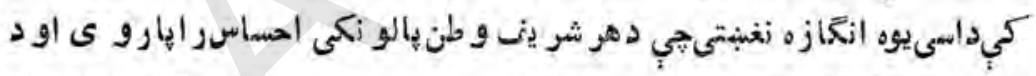

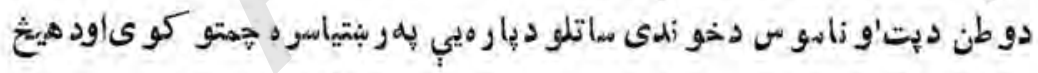

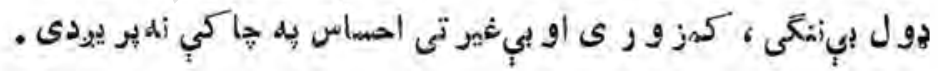

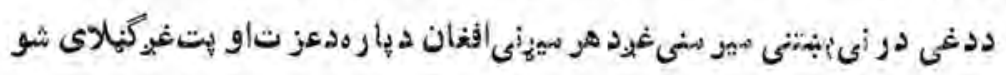

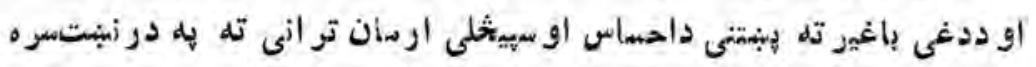

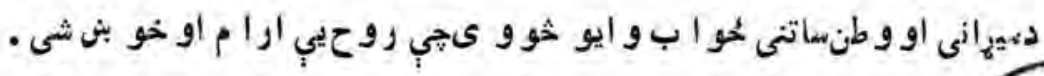

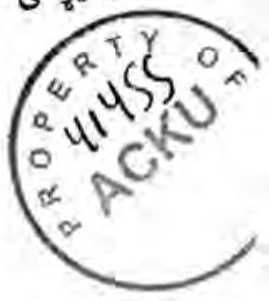




\section{مير من صاحبو عاجزه}

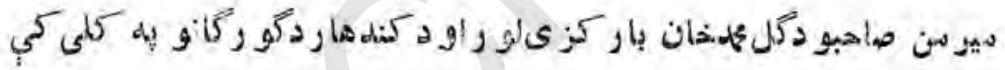

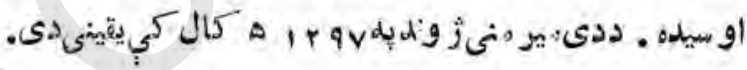

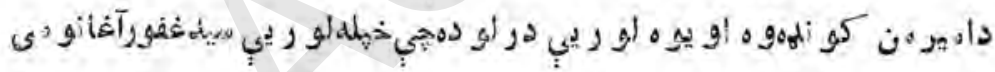
ت.

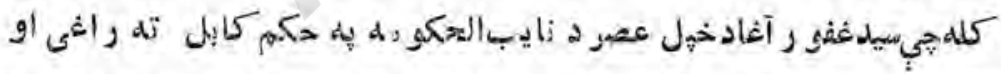

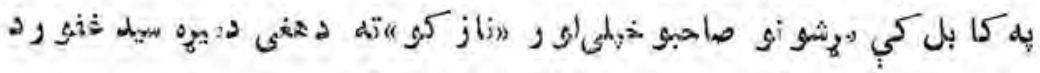

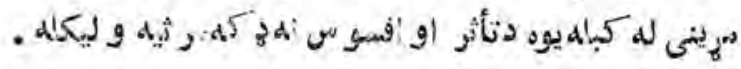

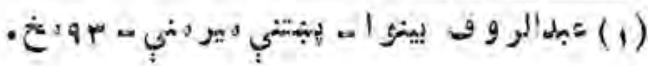

$$
\begin{aligned}
& \text { te }
\end{aligned}
$$




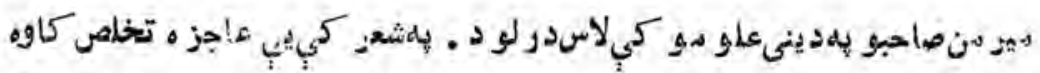

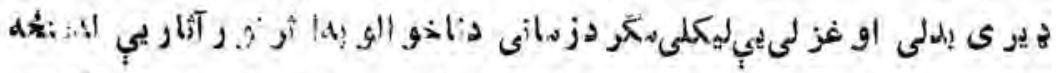

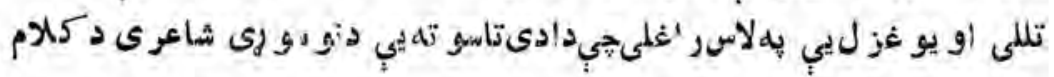

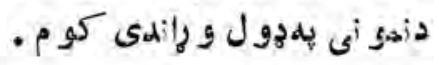

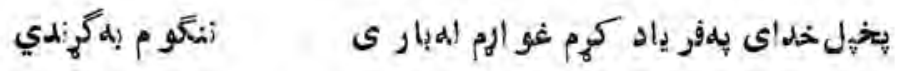

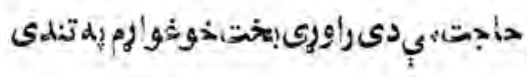

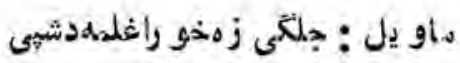

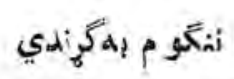

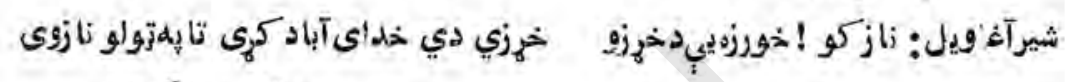

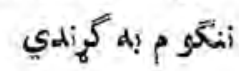

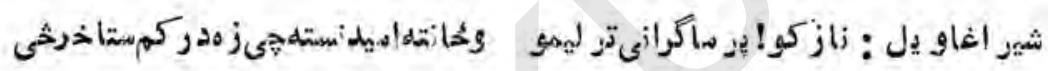

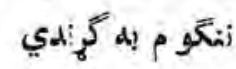

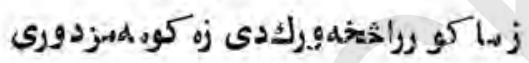

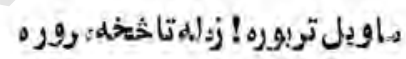
كورخابن

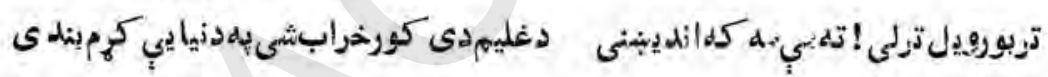

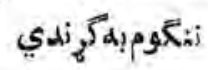

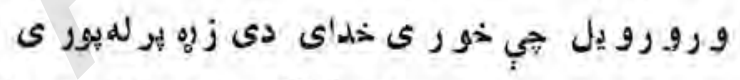

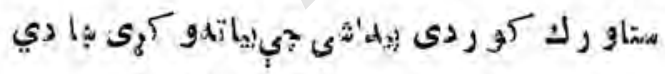
i

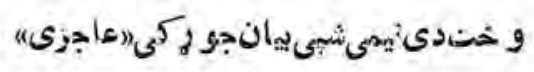

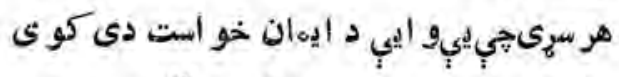

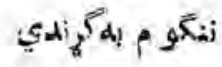




\section{(1) (1)}

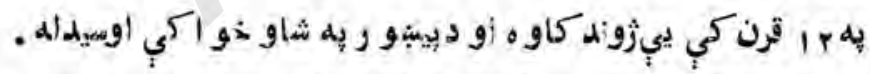

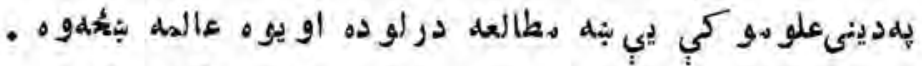

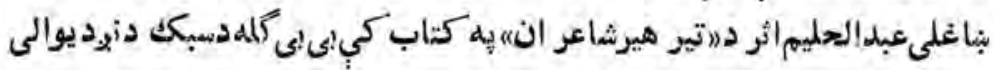

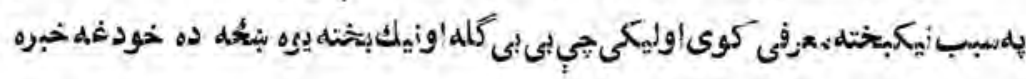

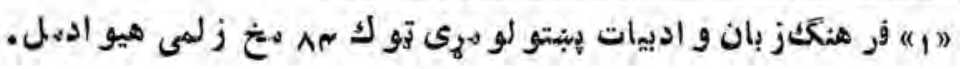




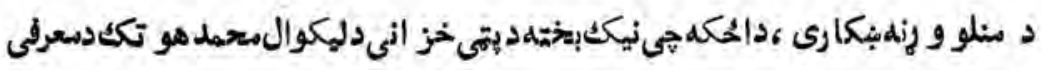

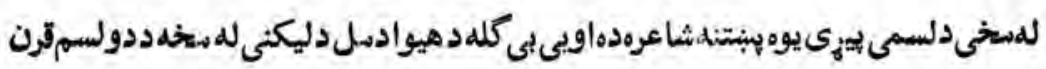
ميرمنده.ددغو دواروشاعرانوبيرمنو دز ونداوزسانتر دنئ لو ى اتين دو ىيو له بله

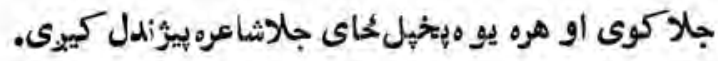

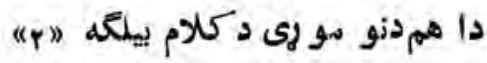
اى بنده إدهاك رحمانه

هاسه و قت دى دسباح

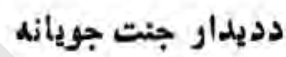

هاسهو قت دى دمباح

لا السه الا الله

ذكر د الكهم بههر مناه دناسوتدمككهادشاه

كاسه و لت دى دمباح

$$
\text { همت هير كرهـ بلهاعت }
$$

هامسو قت دى دمباح

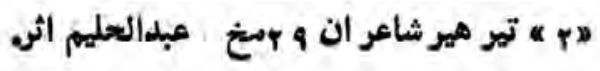
rV 


$$
\begin{aligned}
& \text { رب هي هير لضضل كرم كا } \\
& \text { خاص به وقت دصبحدم كا } \\
& \text { كل مثاه به متا عدم }
\end{aligned}
$$

هامدو لت دىدمباح

$$
\begin{aligned}
& \text { و او رباى دآدم لحسويهه } \\
& \text { سختـه لار د ه و رانسلى لويه }
\end{aligned}
$$

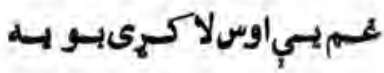

هامه و كت دى دمباح

$$
\begin{aligned}
& \text { كسلهامستيد كرى للهجـتهـ }
\end{aligned}
$$

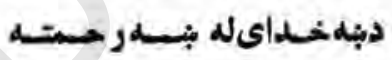

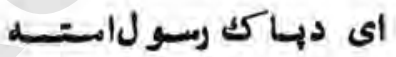

هامه و لتدى دمباح

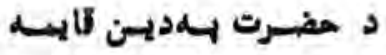

$$
\begin{aligned}
& \text { هله بنـدكى دربدايهيه }
\end{aligned}
$$

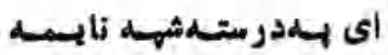

باسه و قتدوىمبباح

$$
\begin{aligned}
& \text { حيدرب خه مشلو قات دى } \\
& \text { جمادات كسم حيو انات دى } \\
& \text { و ارو مسر البـهامسـمةذاتدى }
\end{aligned}
$$

هامه و لت دى دمباح 
كلهبولتدسحسرخيزكرى

زلهدخداى به يادوتيزكرى

شياطسين بلوائه ريز كرى

بامهو تت دي دسباح

ته له ولك د متحركله

كله د توحيسد لسوله

د انسار ى و هـى بـلبـله

هاسه و كت دى دسباح

$$
\text { تهلسمخدا:سه ويسر و وكره }
$$

هاسه و كتدى دمباح

$$
\begin{aligned}
& \text { عليمان دنلفس شيطان دى } \\
& \text { يت ظاهر متا له نلصصان دى } \\
& \text { له داغم كل مو بنان دى }
\end{aligned}
$$

باسه و كت دي دمباح

$$
\begin{aligned}
& \text { ستاهلن كسي دى مسو مييره }
\end{aligned}
$$

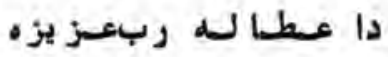

$$
\begin{aligned}
& \text { و اورهاى صاحب تسسيز }
\end{aligned}
$$

باسهو قتدى دسباح 
دواره غو إ ستركى يادييىى

خو له بهانو م دحق و نييزى

درحت با ران ور ييرى

باسهو قت دى دمبباح

نقس شيطانجي در بِسىىى

دربسى له وسوسى دى

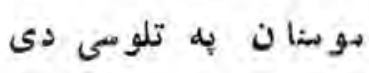

هِاسه و قت دي دسباح

ايى بله منكَدنخوبسركوبه

دغـه جها وه ليو نتسو بسه

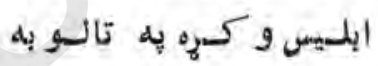

عاسه و قت دى دمبباح

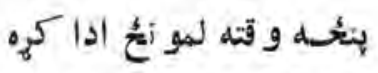

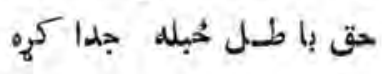

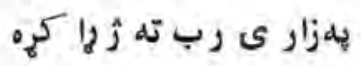

هاسه و قتدى دسبأح

$$
\begin{aligned}
& \text { لمو زئ للخدايلسر ه رازدى } \\
& \text { و رككلفريا:ه غير غهاز دى }
\end{aligned}
$$

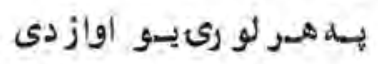

هاسهو تت دى ديباح

$r$. 


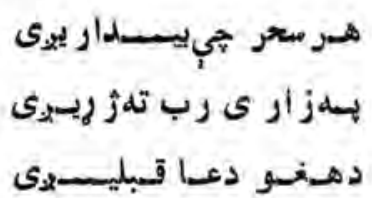

بامه و قتدى دمباح

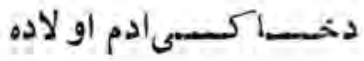

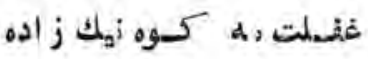

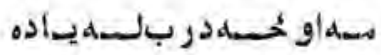

باسه و قت دى دسباح

$$
\begin{aligned}
& \text { ا غفلت لو يسه و رو انسى ده }
\end{aligned}
$$

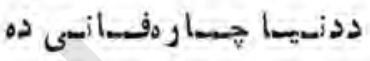

$$
\begin{aligned}
& \text { عسبسادت كسو محسوانسيده }
\end{aligned}
$$

يأسي و قتدى دسباح

$$
\begin{aligned}
& \text { هـي } \\
& \text { يسادو ل د حسق بهتسر دى }
\end{aligned}
$$

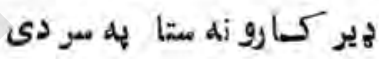

إإسه و قت دى دسباح

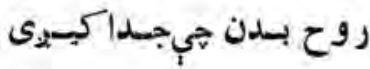

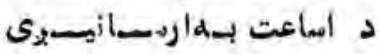

$$
\begin{aligned}
& \text { كله دلامبه دىخـه كـيزى }
\end{aligned}
$$

إماسه و قت د ى د معباح

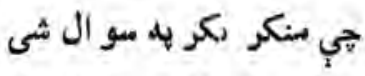

$$
\begin{aligned}
& \text { بنده هيبن هله لو جنجال شيى }
\end{aligned}
$$


خداى خبر خي هلمهدال شى هاسه وقت دى دمباح

د معشر له ميد ان هانه حي هاضر كيه و واره ناسه د عسل ميسرى هله لاسه

هاسهو كت دى د مباح

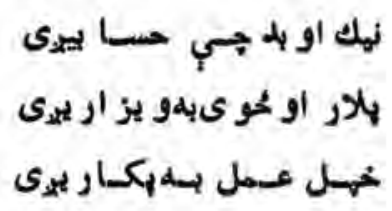
باسه و كتدىدسباح

$$
\begin{aligned}
& \text { دمسر اط بهه مسرو لاره }
\end{aligned}
$$

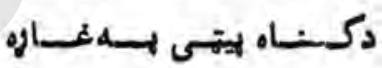

$$
\begin{aligned}
& \text { لهدى عـمه خـاصى غو اره }
\end{aligned}
$$

هاسه و كت دى دمباح

$$
\begin{aligned}
& \text { كملهخسـابى عهو اري ديد ار } \\
& \text { تسل نسعسمي جنـت كـلز ار } \\
& \text { نسيك عسمل كسيه، بلتسلو ار }
\end{aligned}
$$

ها سه و قت دي دمباح

$$
\begin{aligned}
& \text { السى كسى كلهـه خسبر داره } \\
& \text { اله كل نسهى تو بسه } \\
& \text { به الهمدانشكسر كـذاره }
\end{aligned}
$$

هأسه ولت دي دمباح 
دو همل

الرخه

اوسنى

ليكوالي

او

شاعراني 


\section{شموجان(1)}

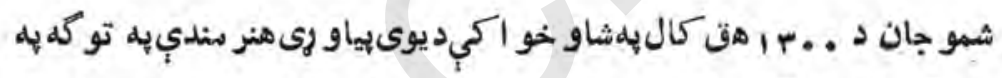

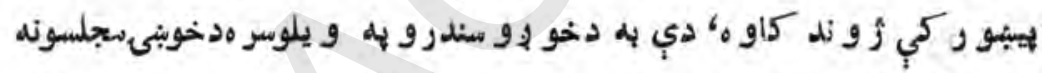

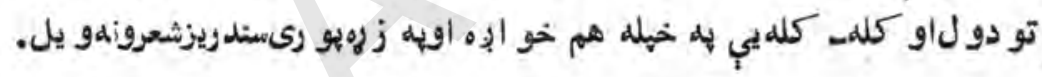

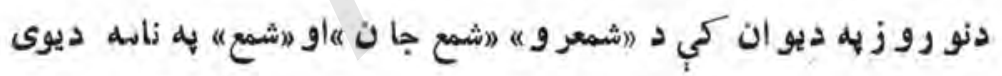

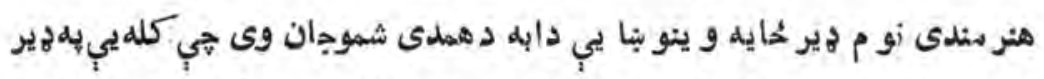

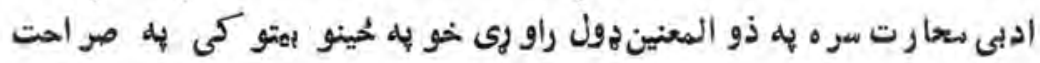

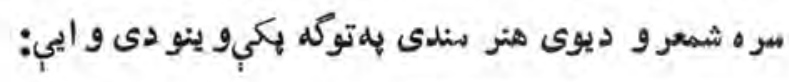
• 


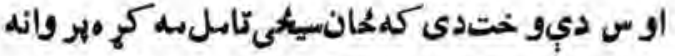

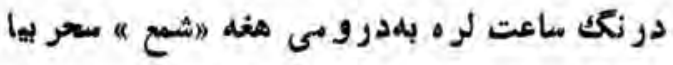

$$
\begin{aligned}
& \text { عو اريى نو روز للهتاجاموصال }
\end{aligned}
$$

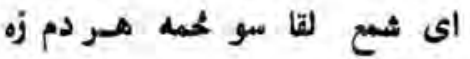

$$
\begin{aligned}
& \text { دجمال صفتدي كيبريه كشورد بيشاوركى }
\end{aligned}
$$

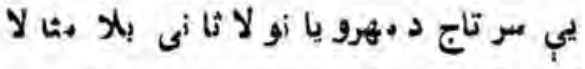

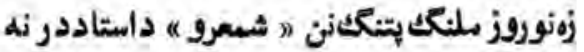

$$
\begin{aligned}
& \text { هلفو ياد به هيغو سريم حُم محرو م دى دوصالا }
\end{aligned}
$$

همداراز دنو رو زدمكتب يو اير و "سو و ر هبه خهلو غز لو كي خيد نو روز

$$
\begin{aligned}
& \text { له ديو ان سره ملحي دى داثمعرو ه هله با ب و ائى: }
\end{aligned}
$$

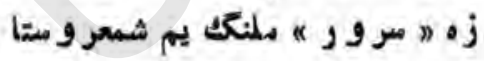

$$
\begin{aligned}
& \text { كلهشيم د جود او كرم كرى ملدوارو }
\end{aligned}
$$

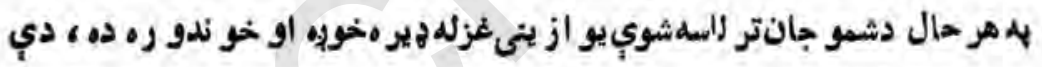

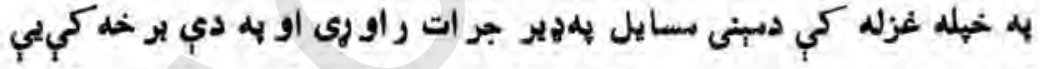

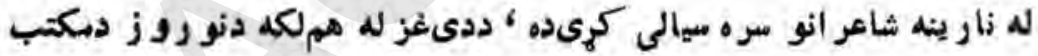
دنو رو يير و ائو غو ندى سندر يزه او دخواجه آهنك درلو دو نكىده .

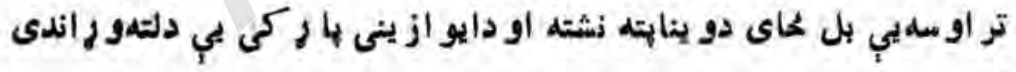

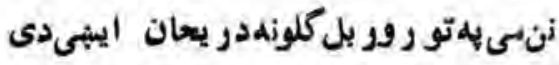

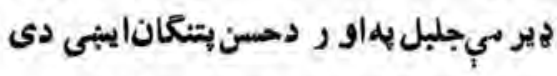

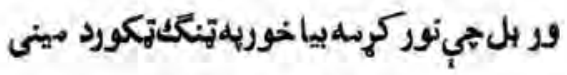
بندمي دعشق بهقس كي بلبلان ايبنى 


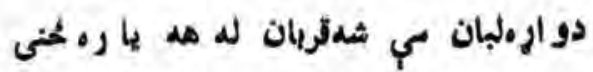

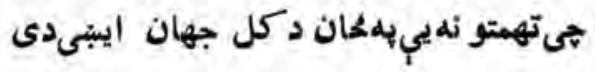

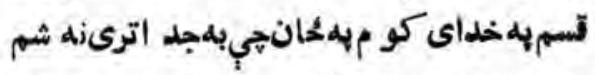

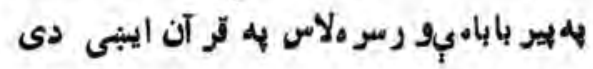

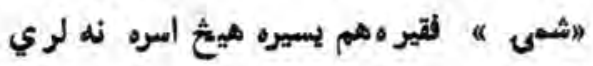

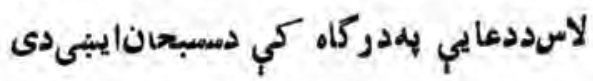




\section{قدرى (1)}

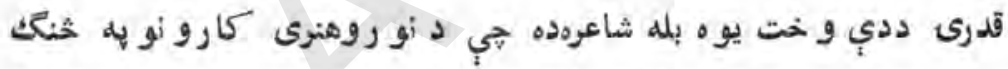

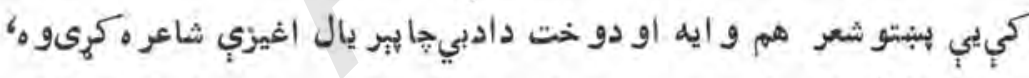

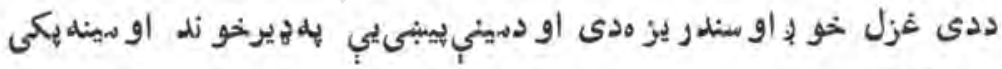

$$
\text { انئو ر كئى دى. }
$$

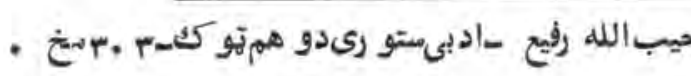




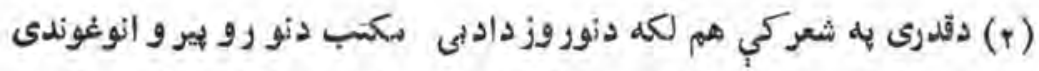

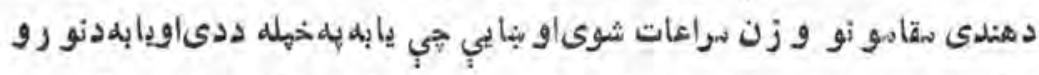

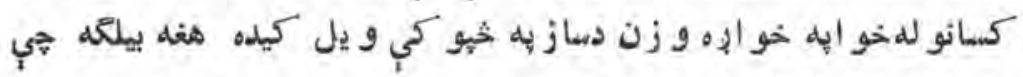

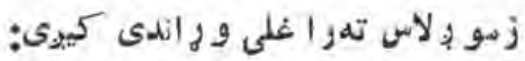

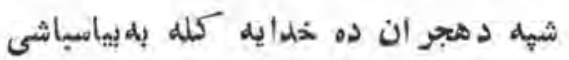

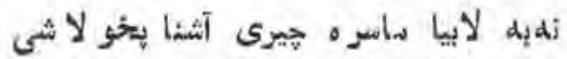

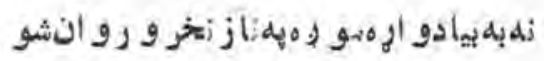

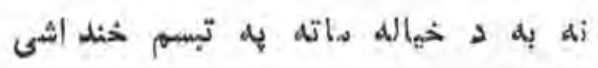

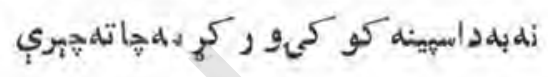

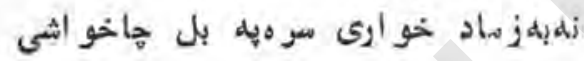

$$
\text { 热 }
$$

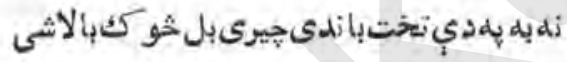

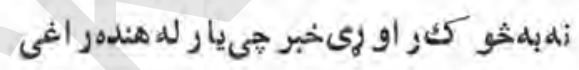

زلهبله بيدارلم خو بلدا اوده بيخت زماشى

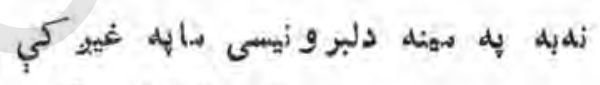

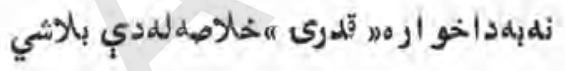

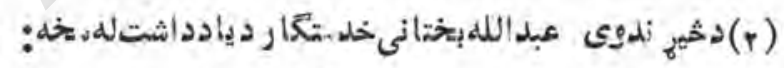

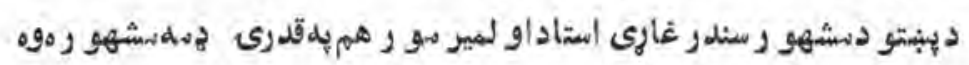

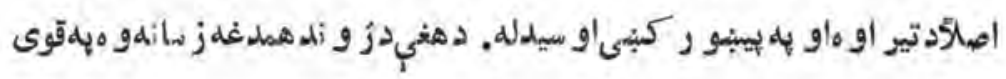

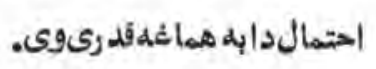




\section{زيبو (1)}

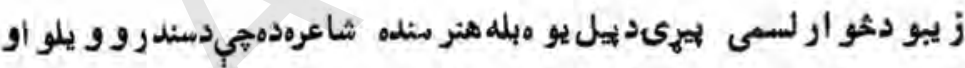

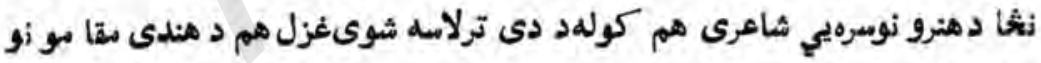

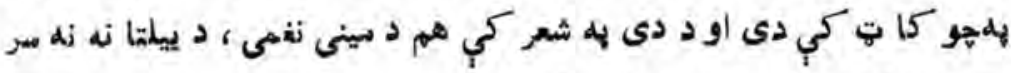

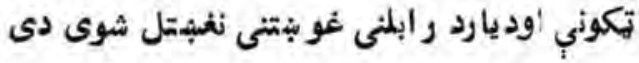

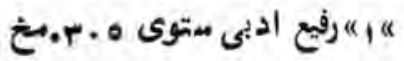
rA 
هي ادى ددى يه لاس راغلى غز لتاسوتدور اندى كيزى :

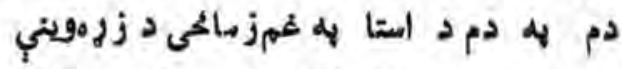
شوى بي مر تر بايه كل جابي و اره ورنكيني

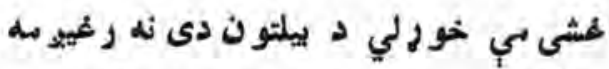

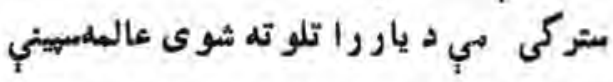
مله و ا عظلا ن راتهد ده هند خبرى وا يي تل خداييو وجي و انه ورمزه دخهل آثناد بيني

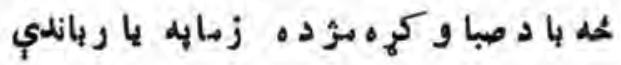
ما و وته ما تلي دي لهشكث لبان شير ينى تير بهمينئ كي شو بياشتى كلونه يار رانغى لهي لحكه بي بو تى شوي دهجران به تنور خو ريني

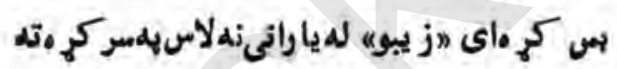

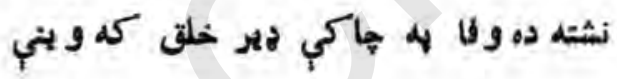




\section{(1) (يارى}

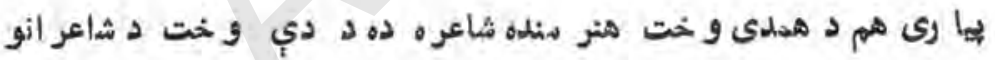

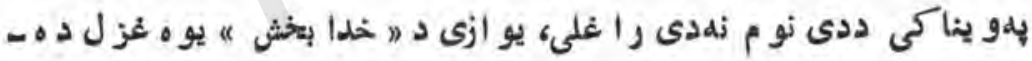

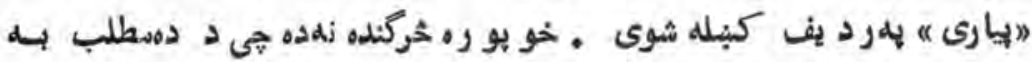

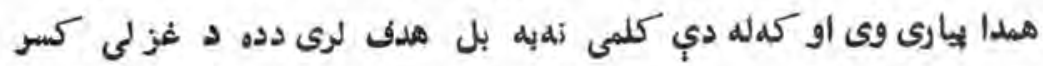

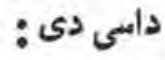

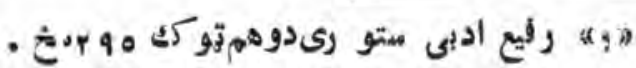




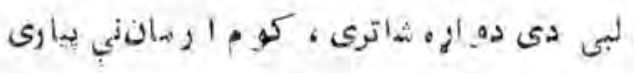

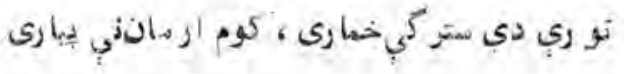

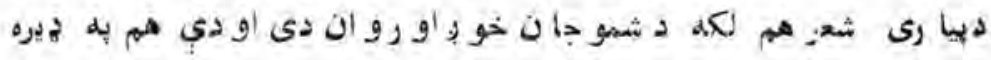

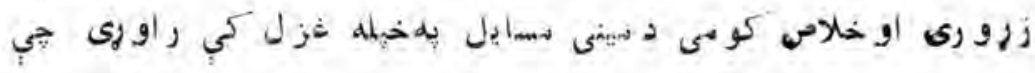

$$
\text { : }
$$

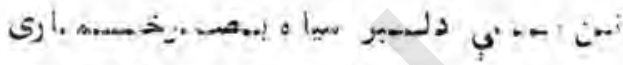

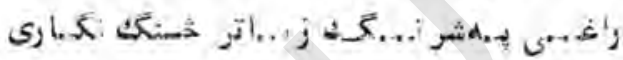

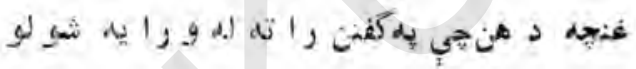

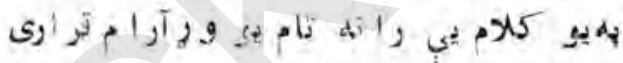

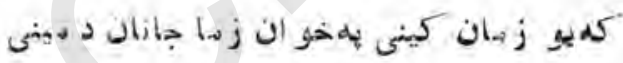

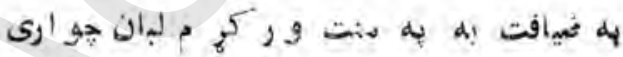

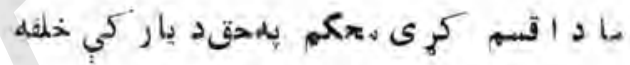

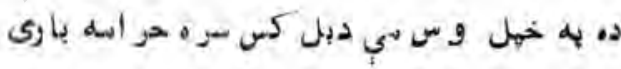

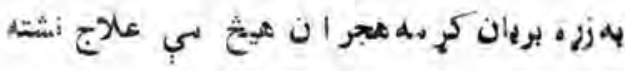$$
\text { لكه بلبل بهمر يو كل كو م. فغان كيو كارى }
$$

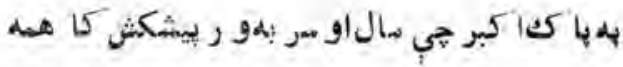

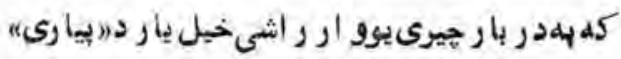




\section{(1) آفتاب}

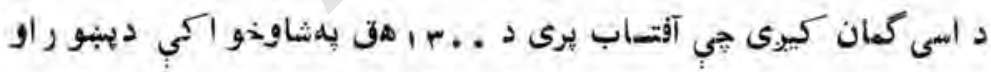

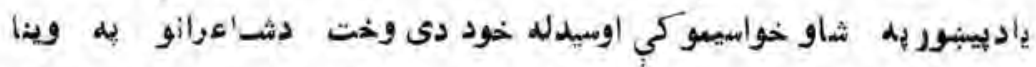

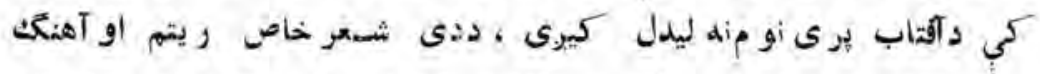

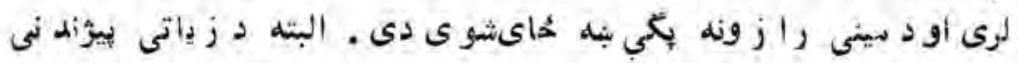

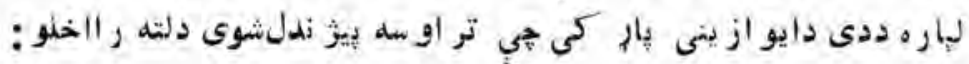

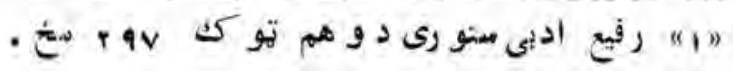


هأجب نَ لبدلى دخبل يارجشهانى دى

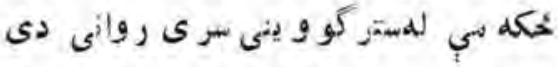

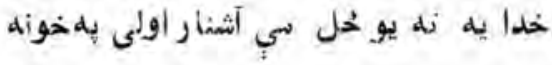

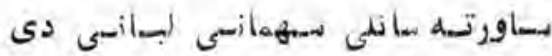

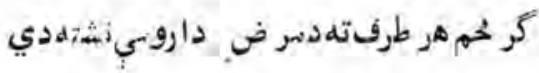

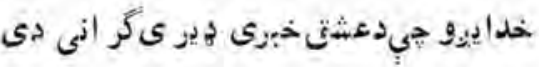

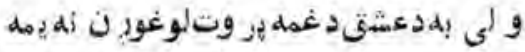
بيا راتمه أيولي رؤب نوب وراني ديى

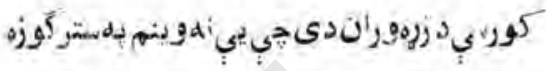

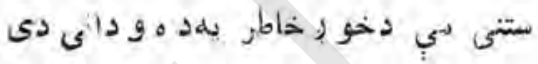

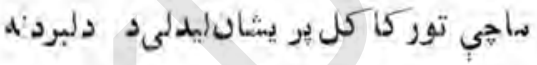

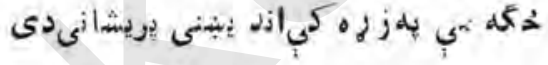

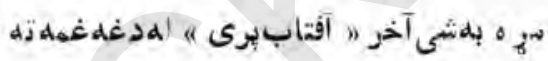

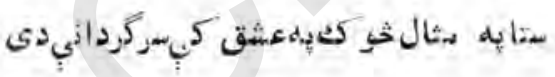




\section{(1) وابجان}

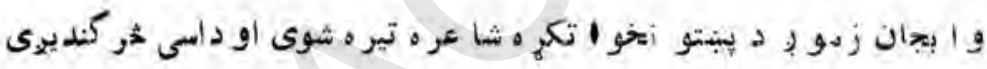

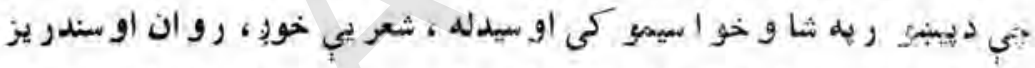

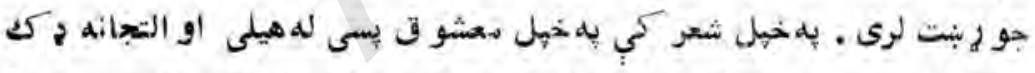

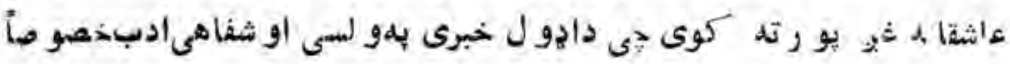

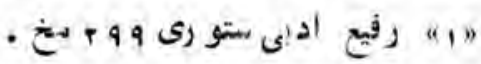




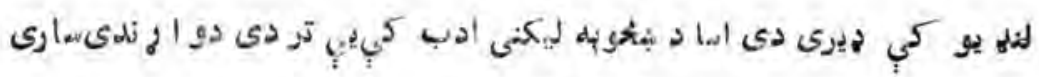

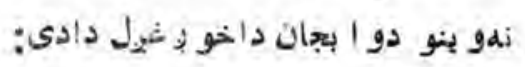

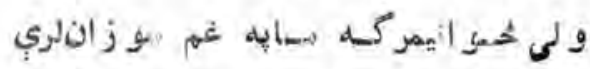

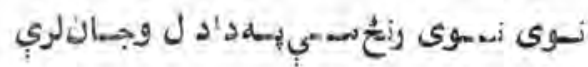

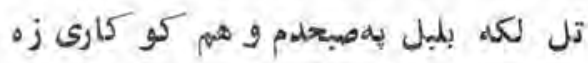

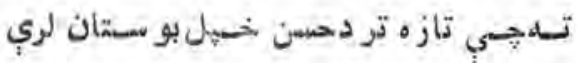

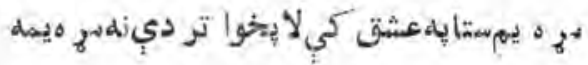

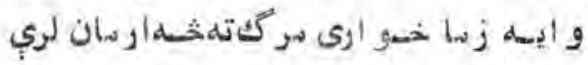

عشق دي ينه ساها رب د بي بي زليخا فوكي لي

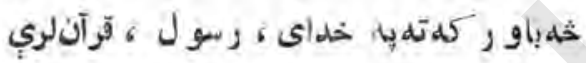

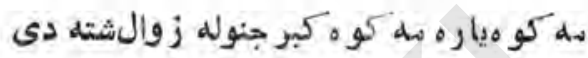

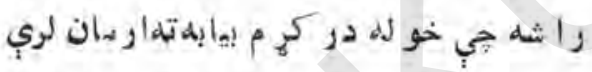

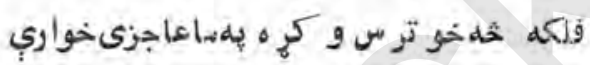

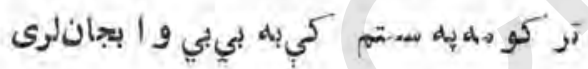




\section{(1) باجوزيى}

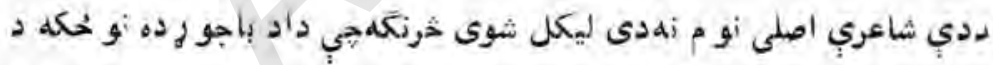

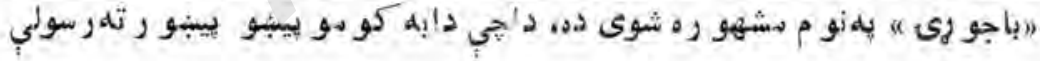

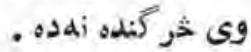

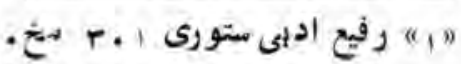
$r 7$ 


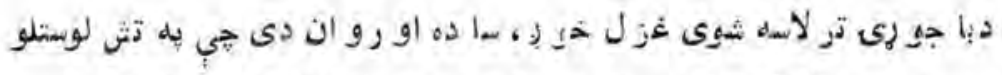

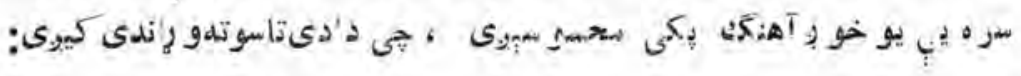

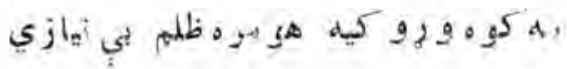

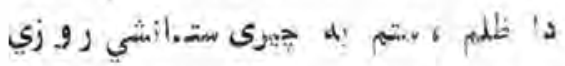

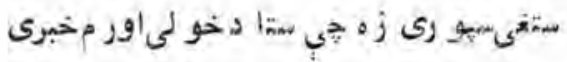

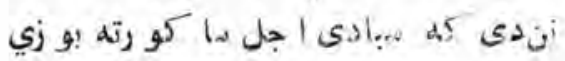

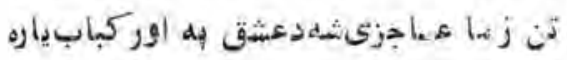

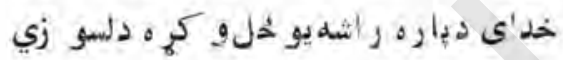

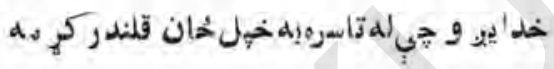

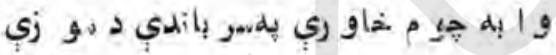

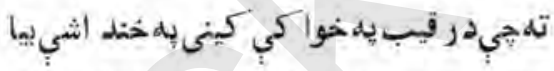

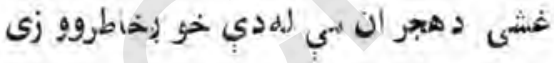

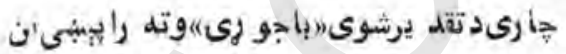

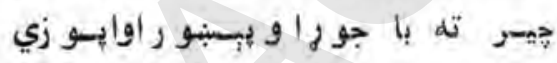




\section{(1) : $: d>1,0$}

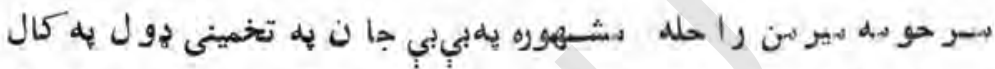

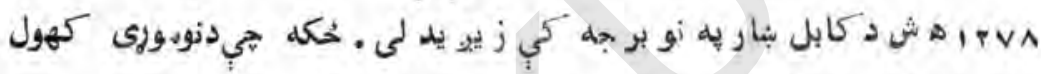

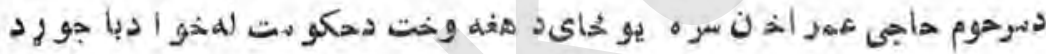

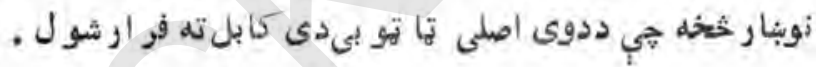
را حله بهقو مدباجو مدابو أهيم خيلو خخله ده.

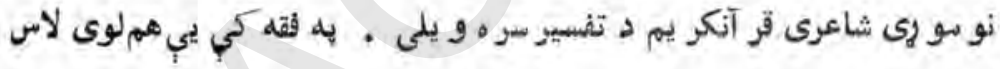

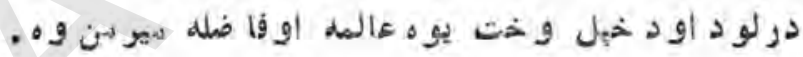

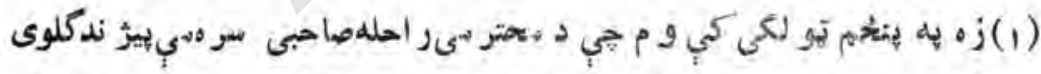

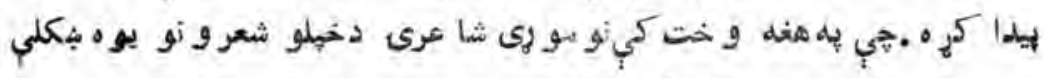

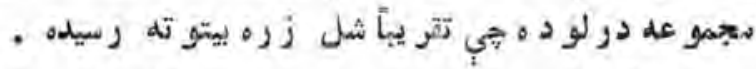

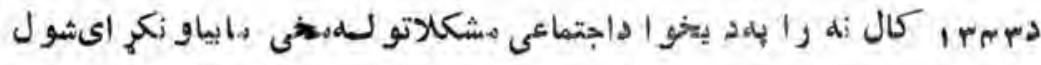

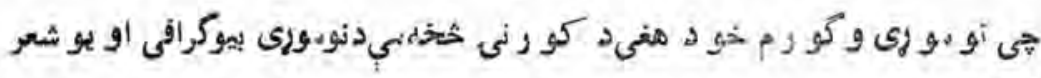
لاس تهر اوور. 


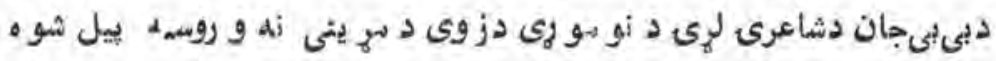

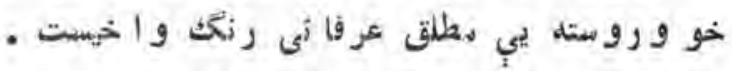

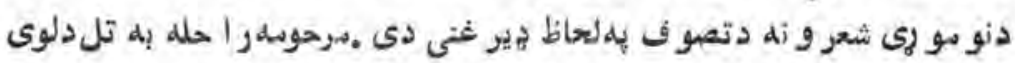

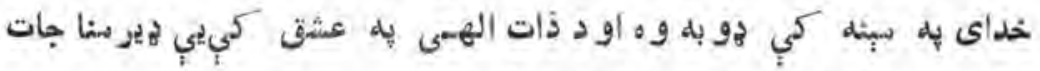

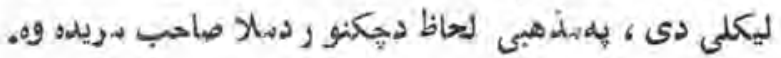

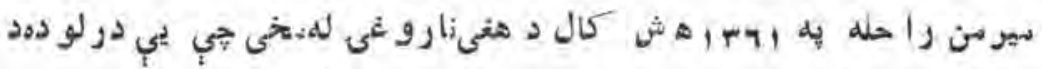

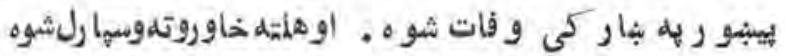

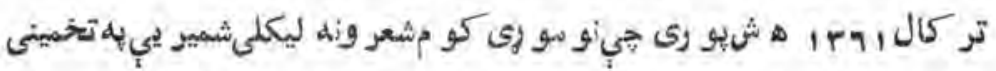

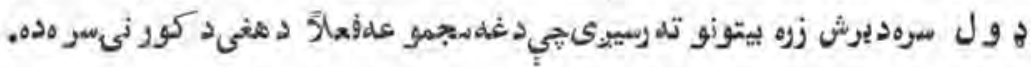

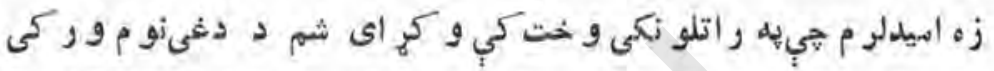

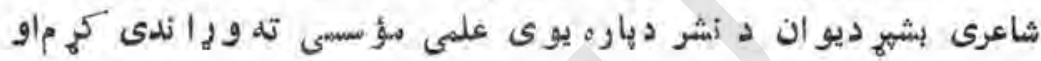

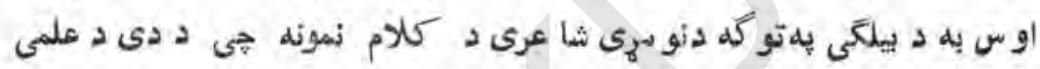

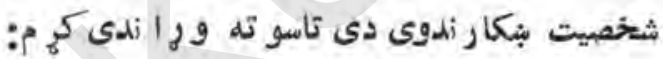

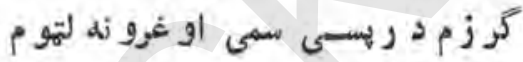

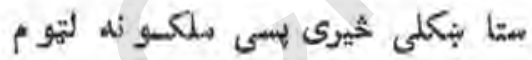

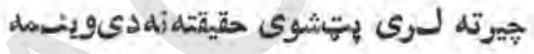

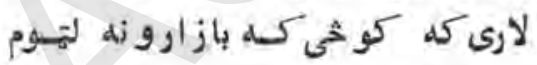

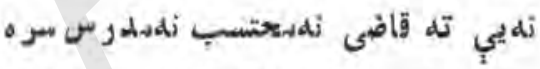

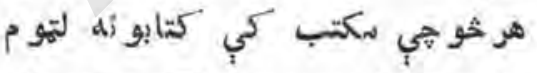

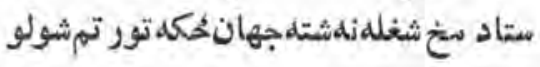

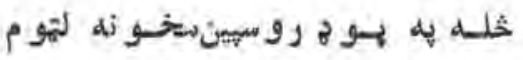

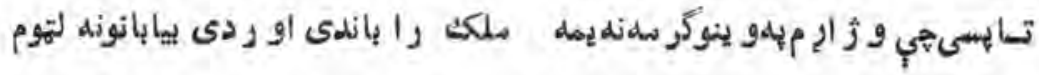




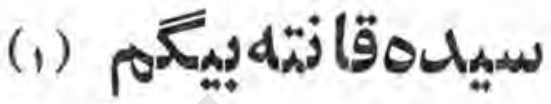

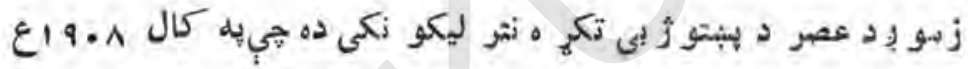

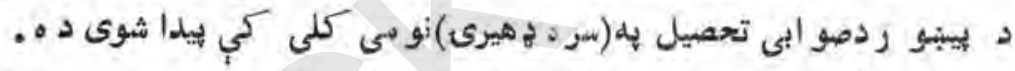

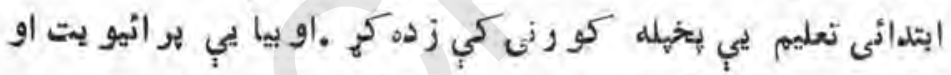

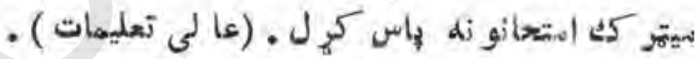

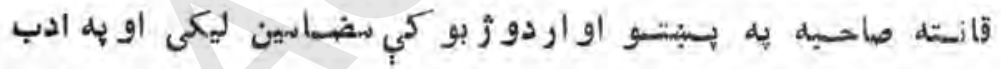

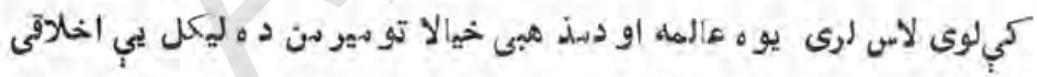

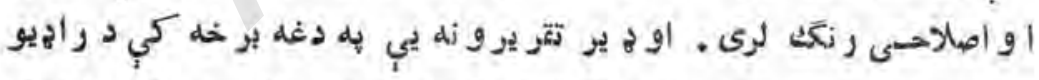

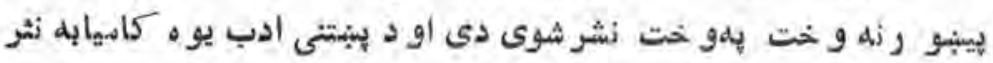

ليكو نكمى 2ه.

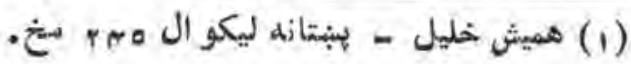




\section{دونو سو إى ليكو الى د تثربيلكه (r)}

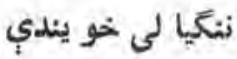

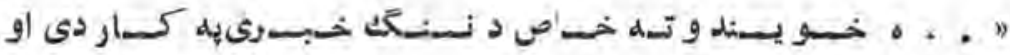

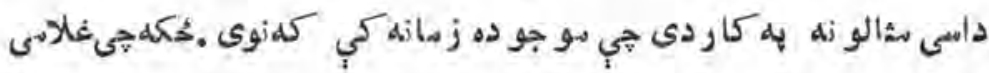

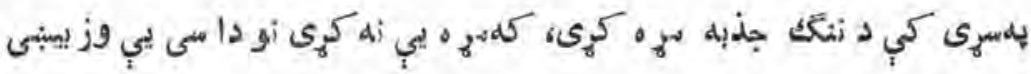

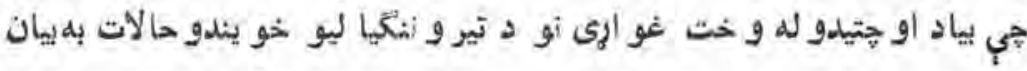

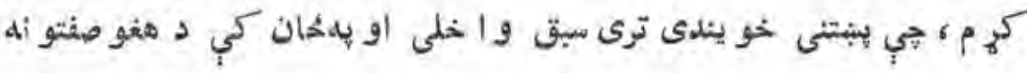

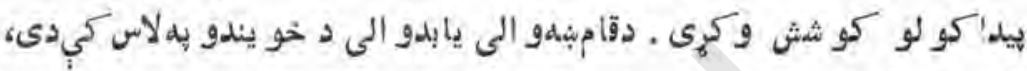

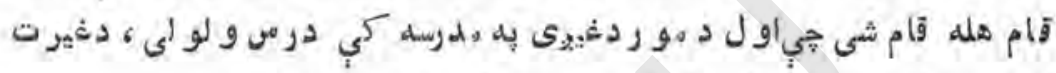

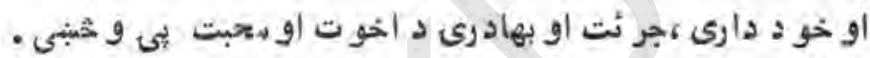

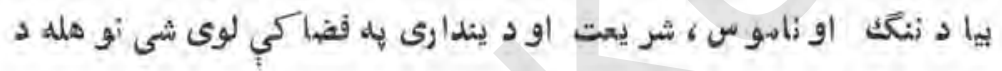

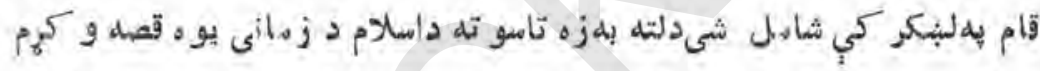

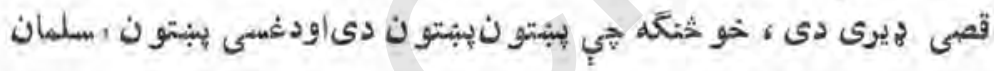

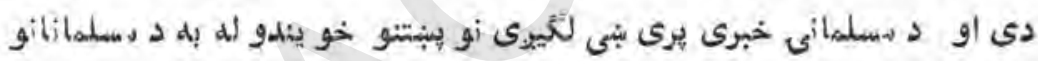

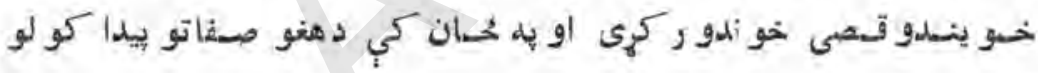

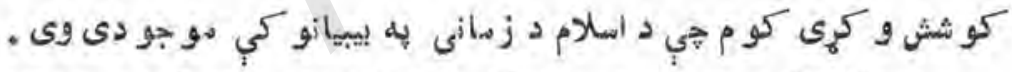

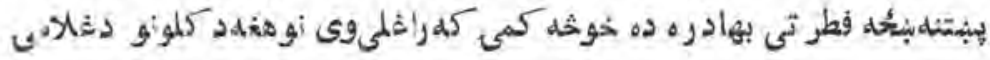

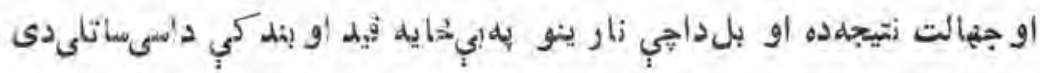
هي ينه صلاحيتو أله يب عبث شول ل.

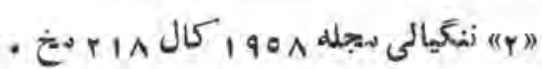




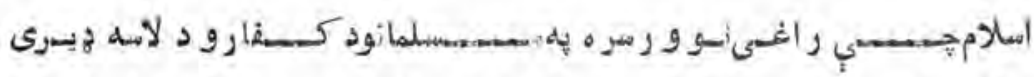

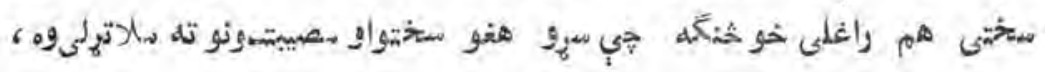

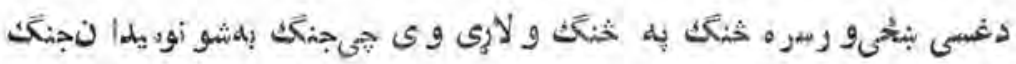

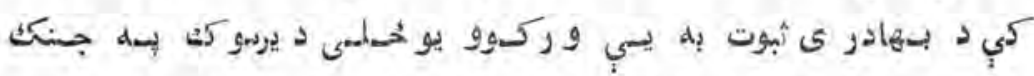

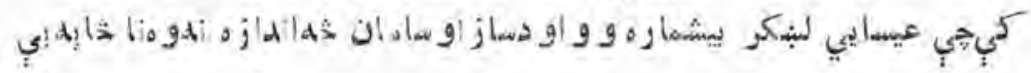

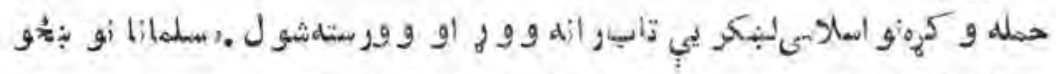

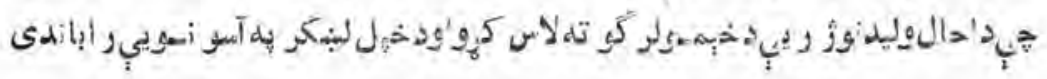

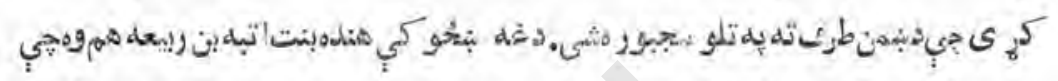

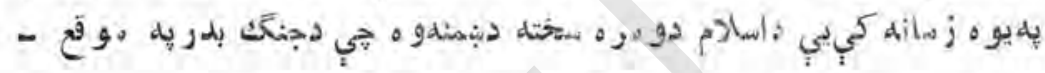

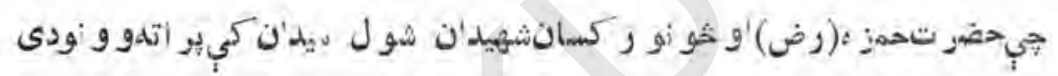

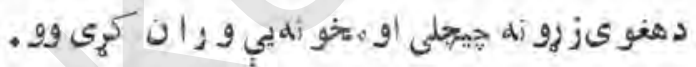

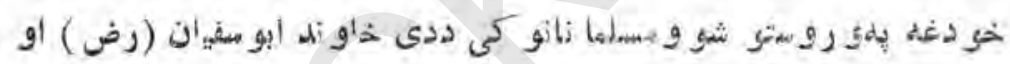

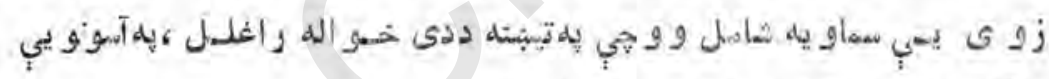
رأكيبتو دى او وى و يل ابو سمئان ؛

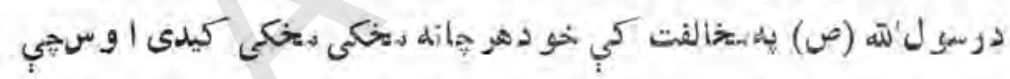

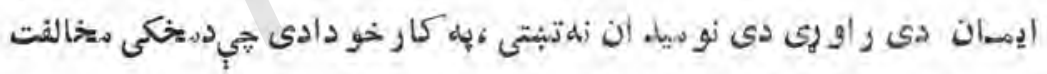

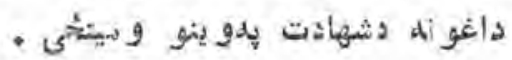

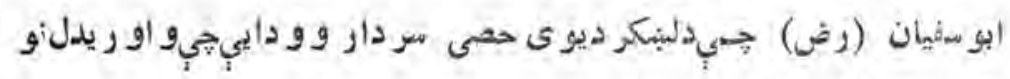

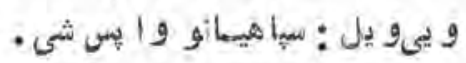

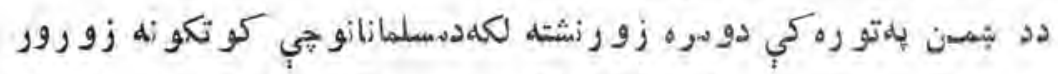

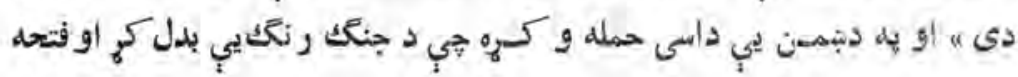




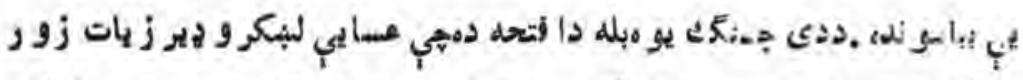

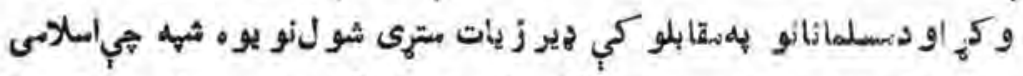

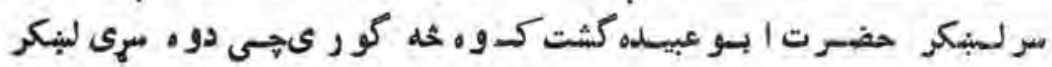

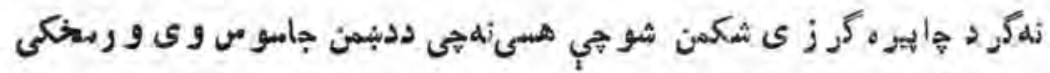

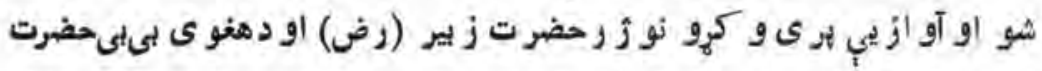

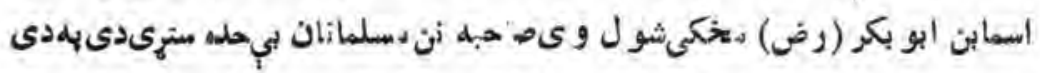

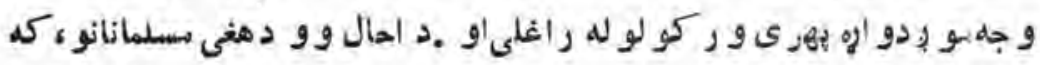

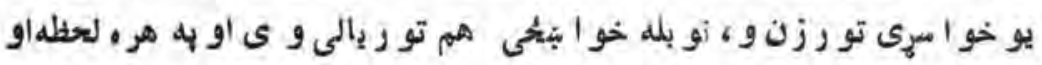

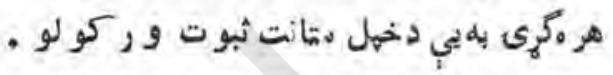

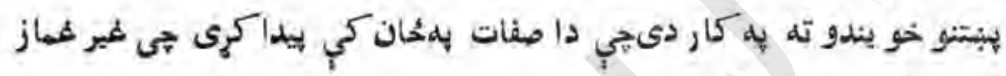
و رته بهل كو إنظرو :نه كورى.

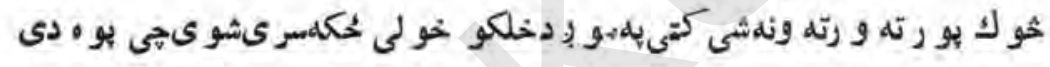

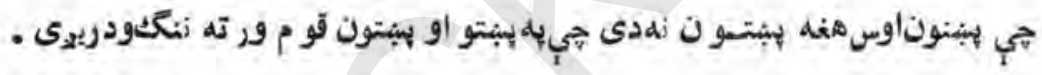




\section{سيله حميلهاه:}

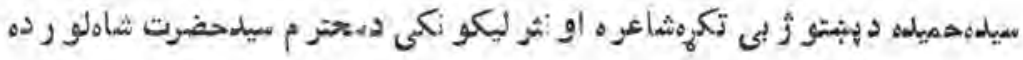
كال

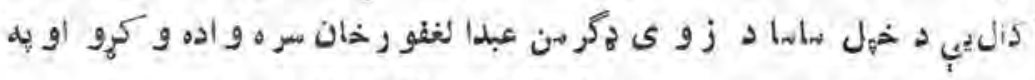

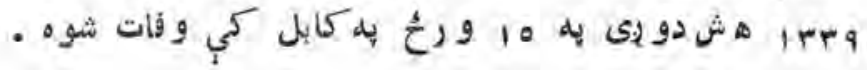
or 


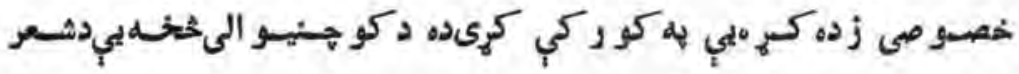

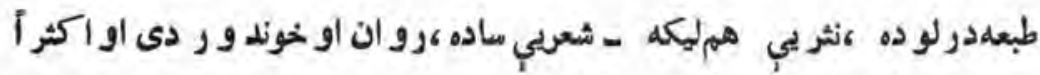

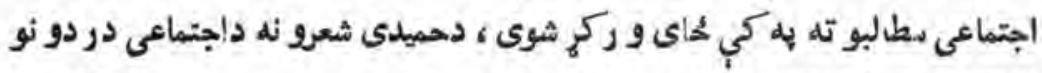

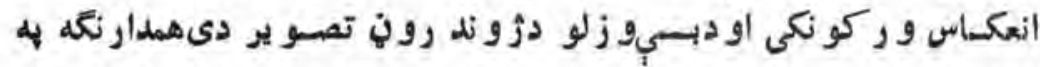

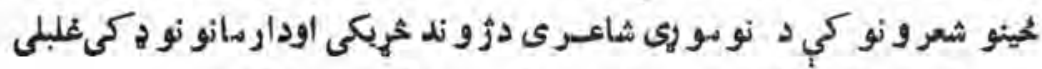

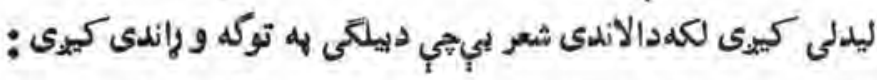

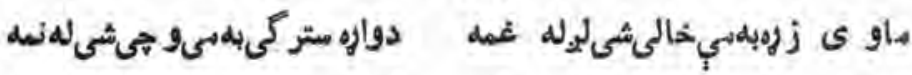

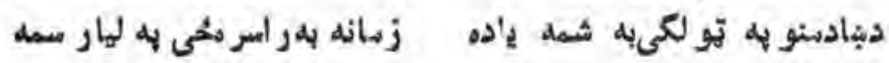

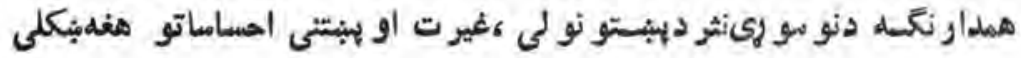

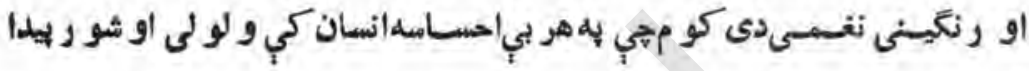

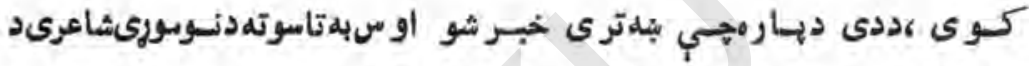

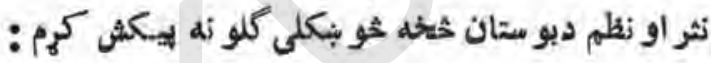
ديوى هبنتنى بينلى إرمان

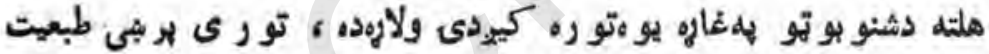

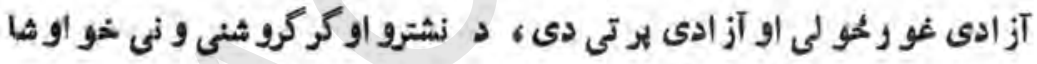

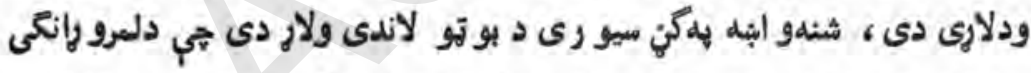

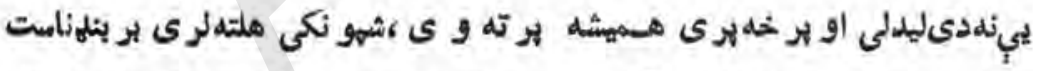

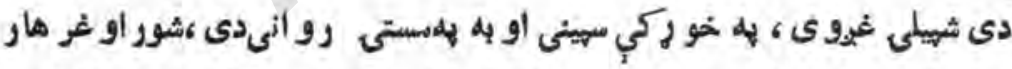

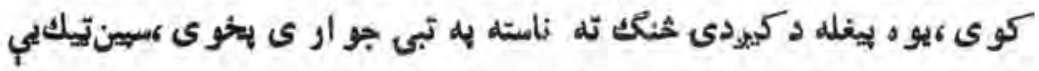

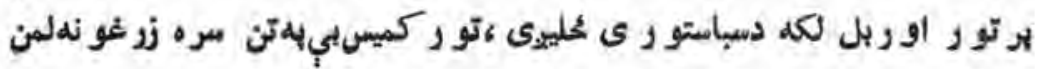

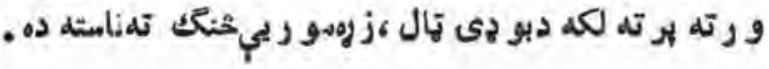




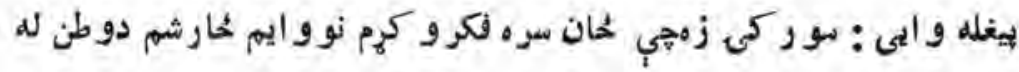
تو روخاو رو أو تسو رو تو روغرو نو نسله تر مـغوسيينو سانسيو او لو رولو لو

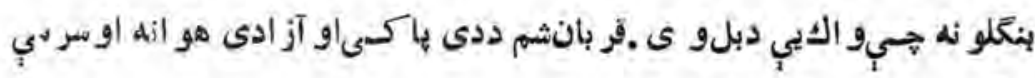
لوكى شهدوطن دآز ادى بـهلاركي .

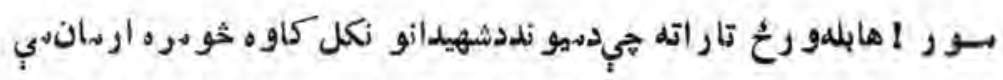

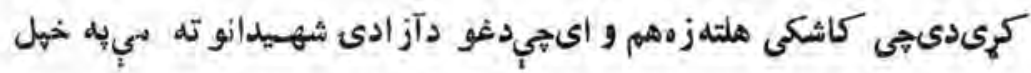

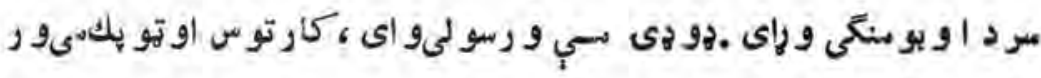

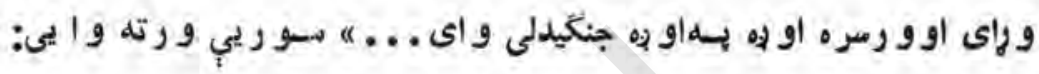
" لو رى إخهل كييه مه كاو تيروشو يو خبرو بسى اربسان مهل كوه ، كله خداى

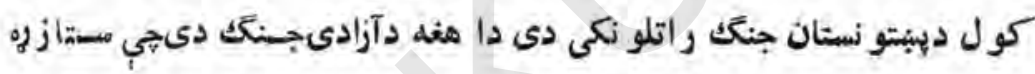

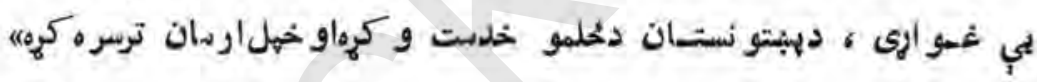

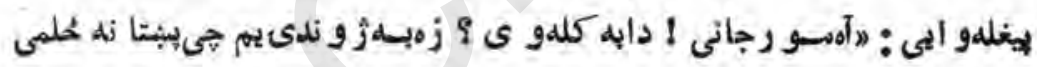

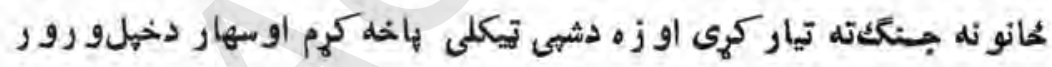

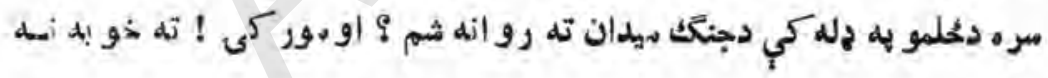

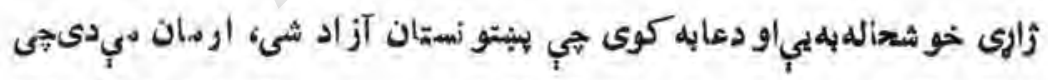

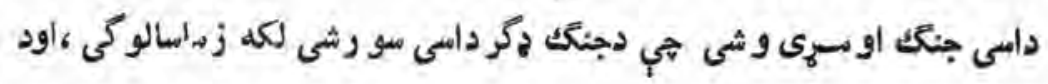

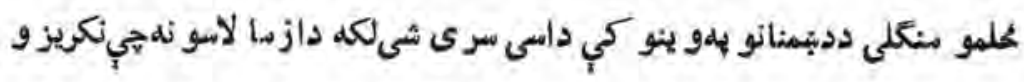

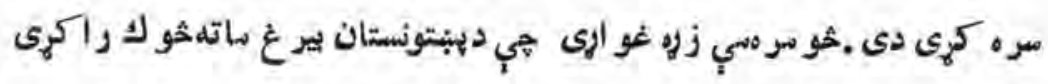




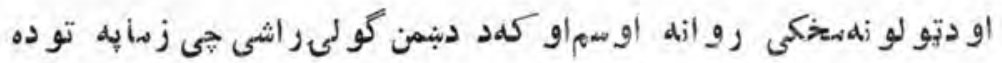

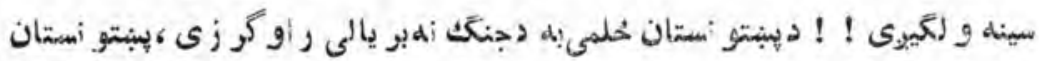

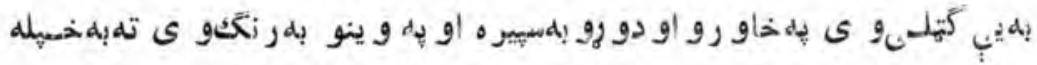

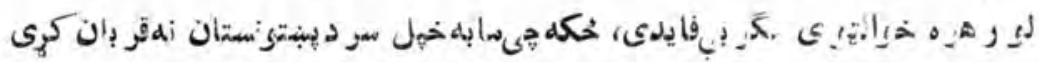

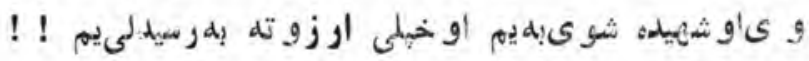

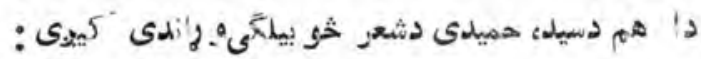

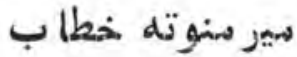

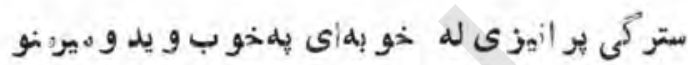

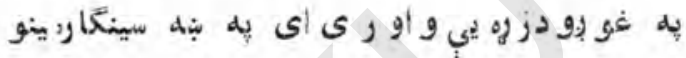

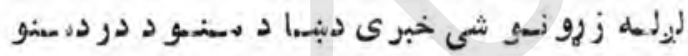

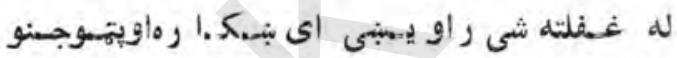

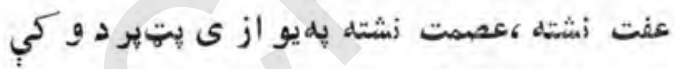

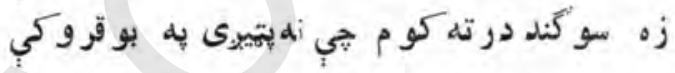

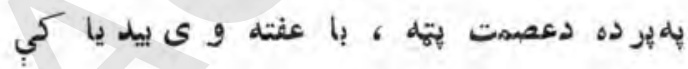

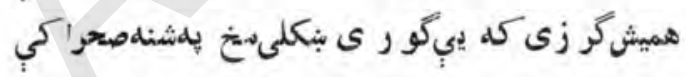

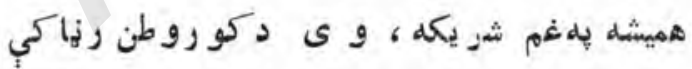

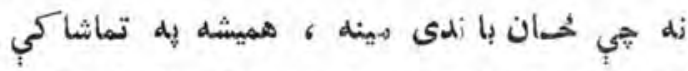
كلبي و رو ويائى ديمه وى ، ورته كاندى كوركار هسىنه خبشهى او و رخحى ،تيروى به خهل سينغار

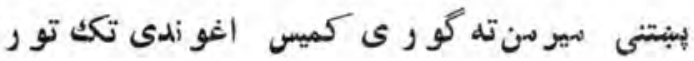




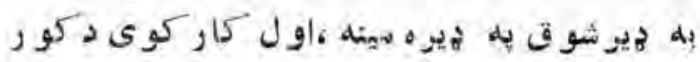

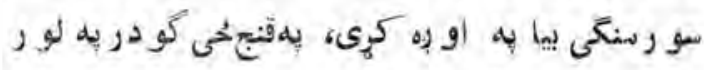

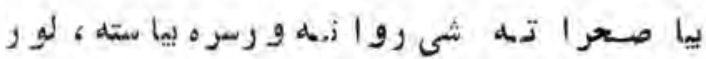

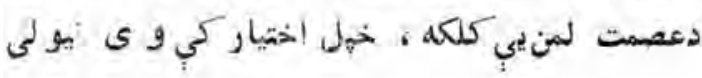

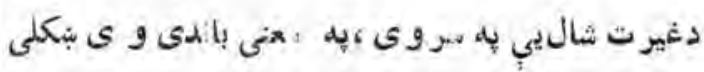

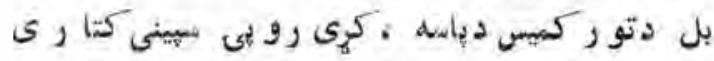

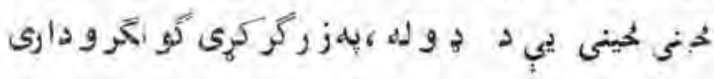

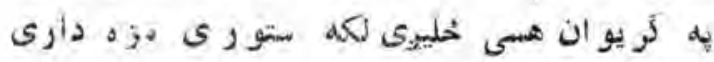

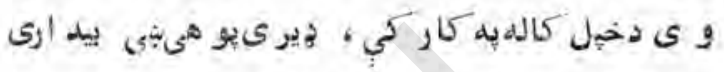

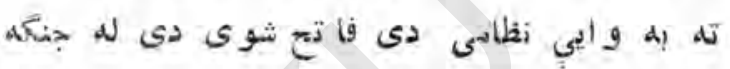

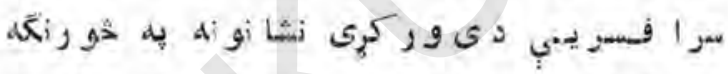

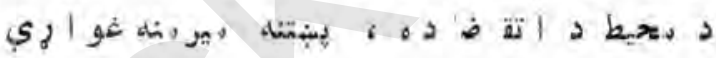

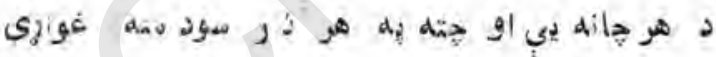

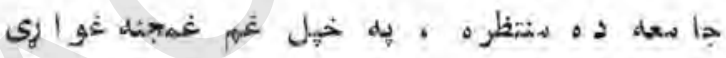

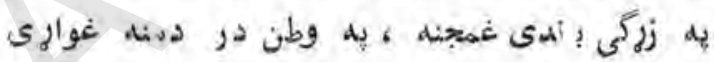

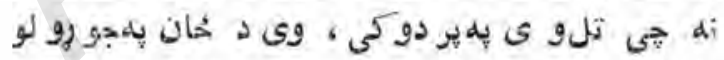

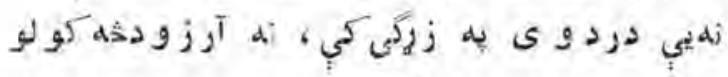
is

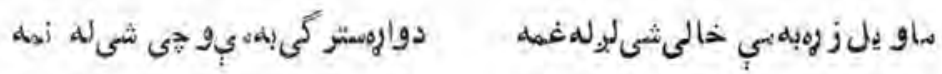

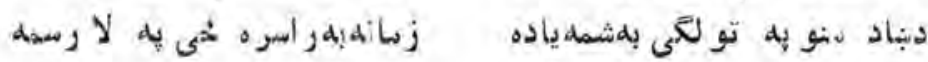

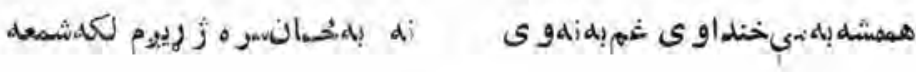




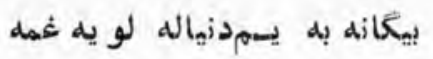
פو

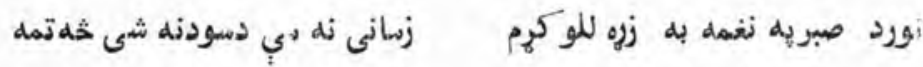

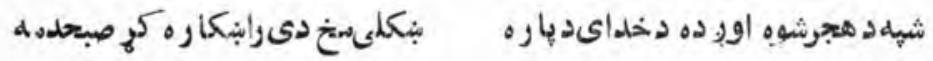

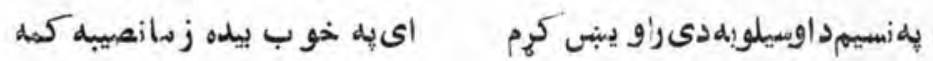

$$
\text { أنهير ييودى }
$$

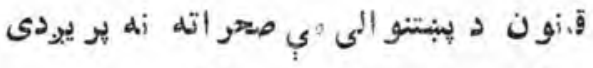

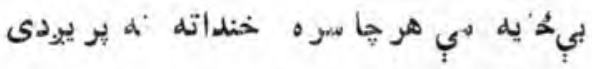

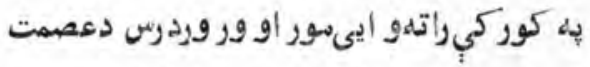

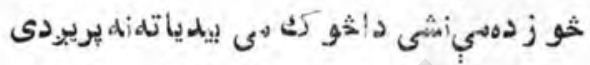

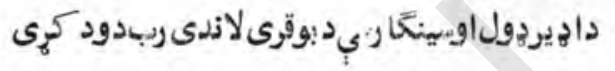

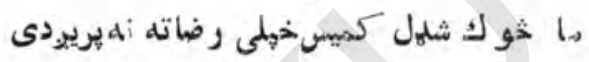

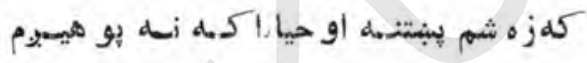

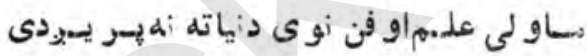

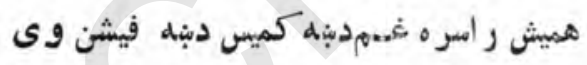

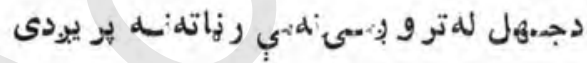

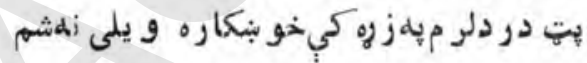

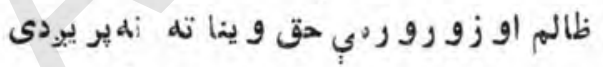

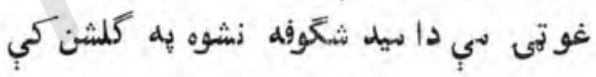

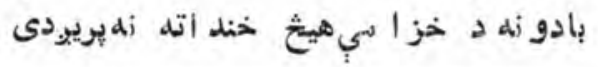

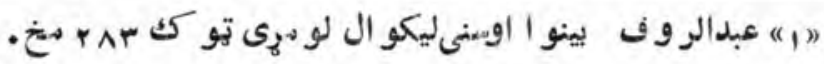

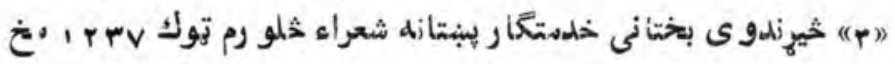




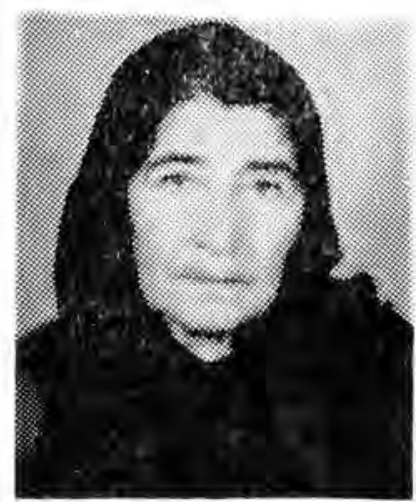

\section{(1) مير منسايره}

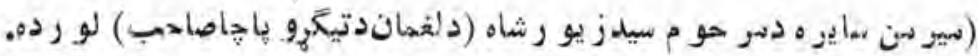

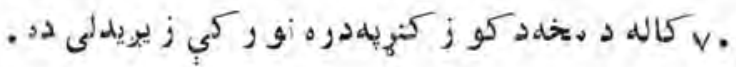

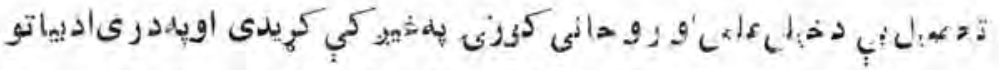

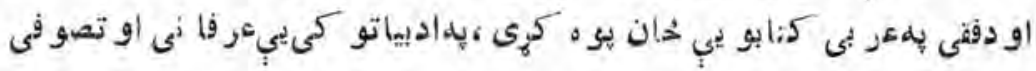




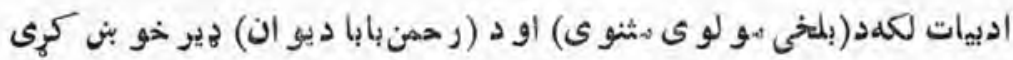

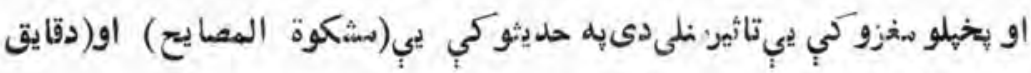

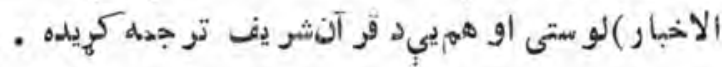

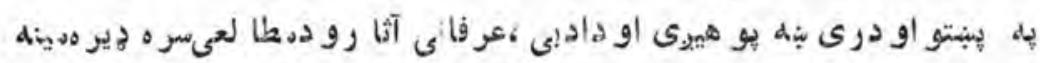

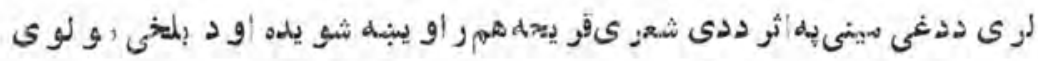

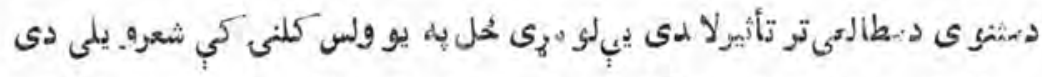

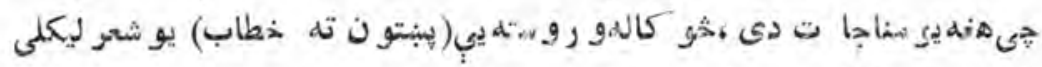

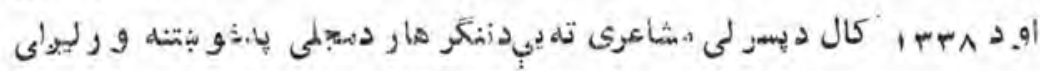

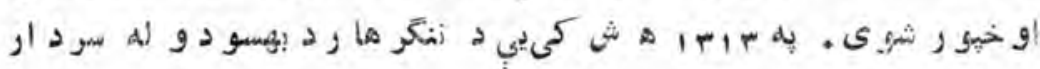

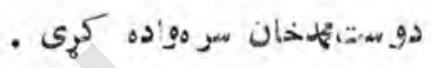

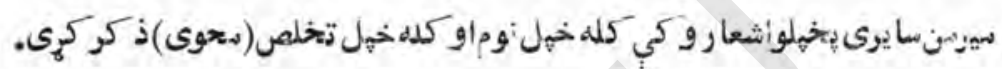

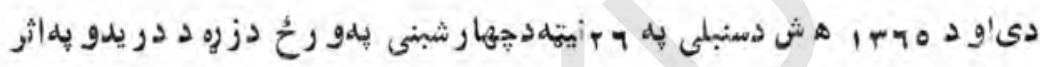

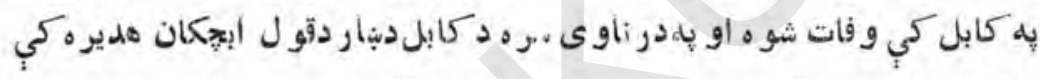

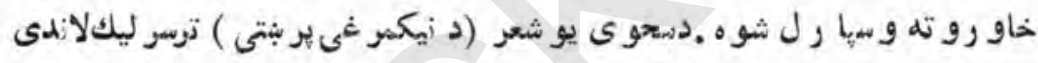

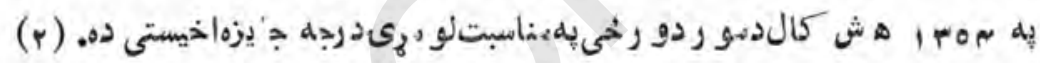

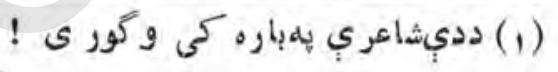

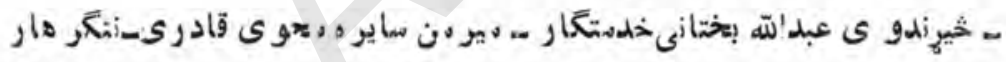

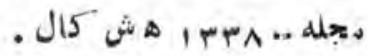

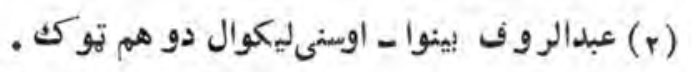

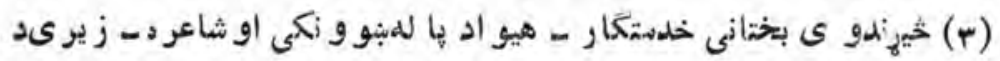

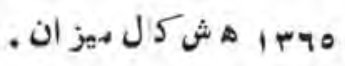




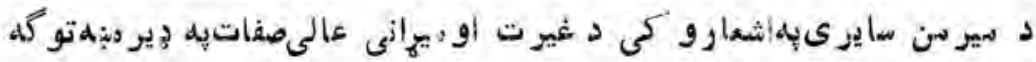

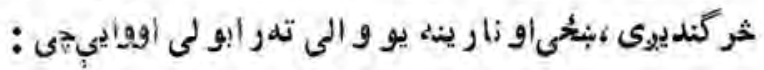

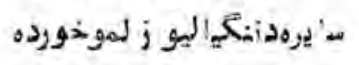

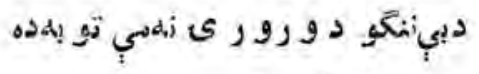

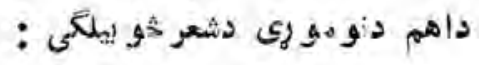
دزكيمرغى ليونبتى

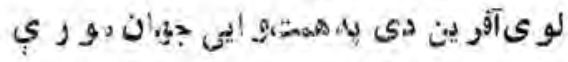

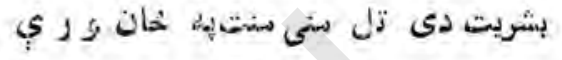

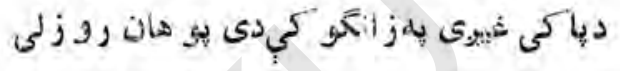

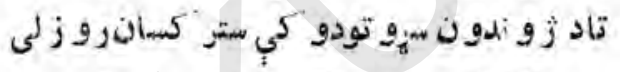

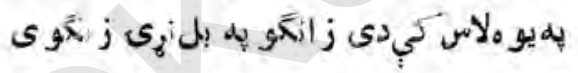

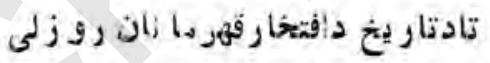

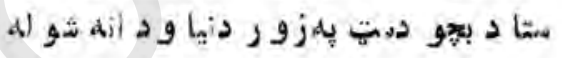

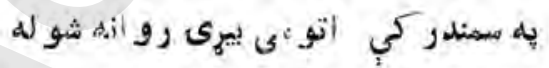

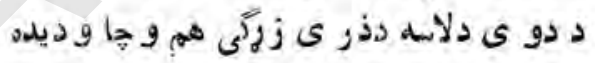

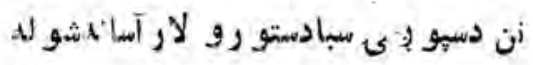

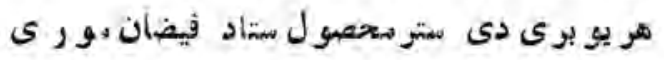

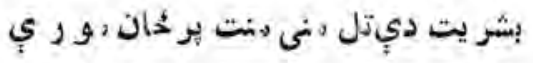

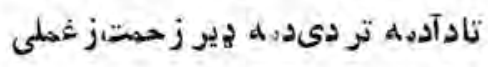

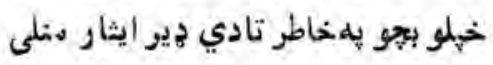
دهر يو وخت سر مدى هغنسى أنسان رو زلميلى

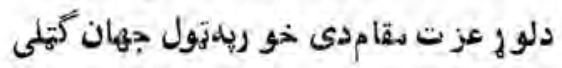




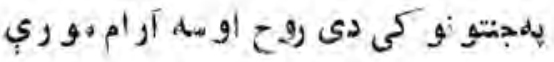

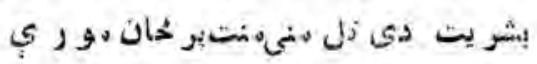

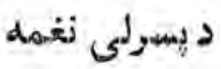

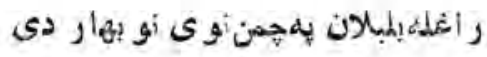

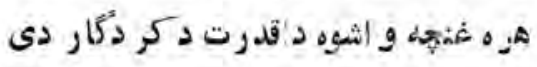

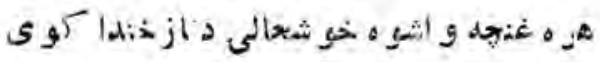

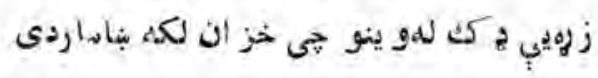

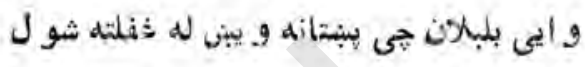

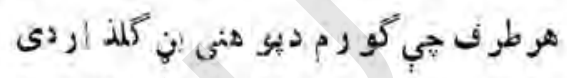

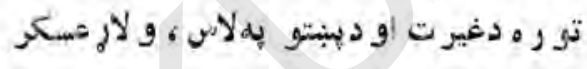

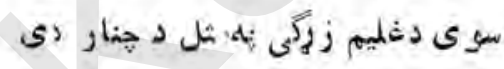

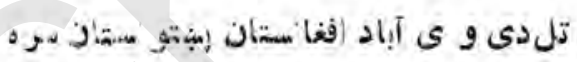

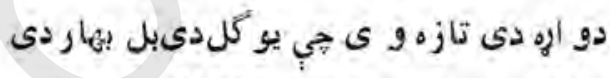

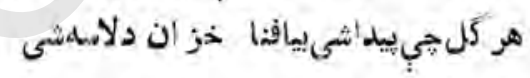

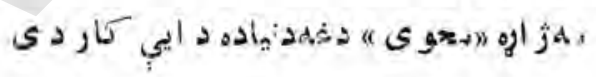
4) لر ويا د ديندار ى ألهدي تو إه ده

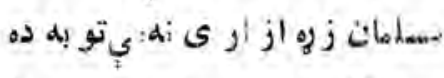

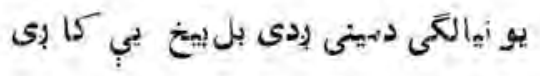

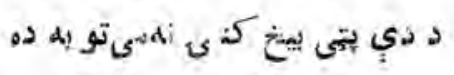




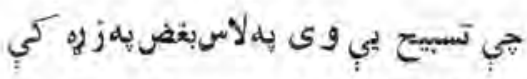
خدايلددار نغله شيتخى أله بي تو إلدده

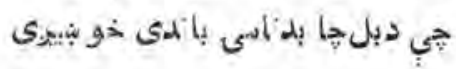

د

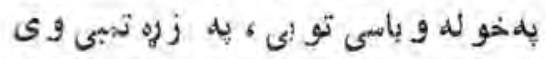

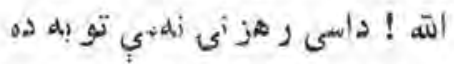

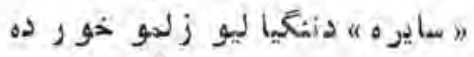

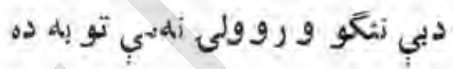

9 


\section{سيدهبشرىبيعم}

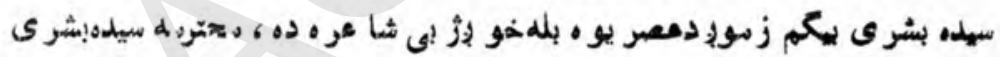

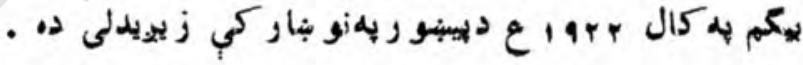

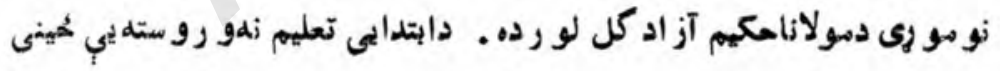

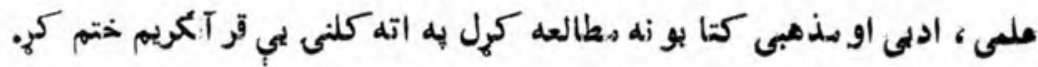

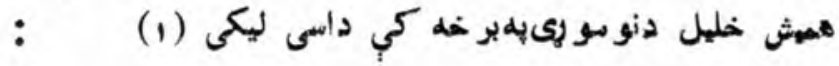

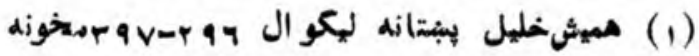




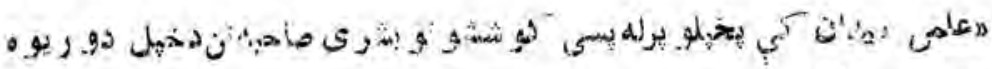

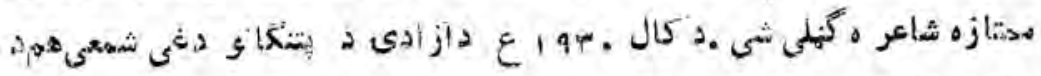

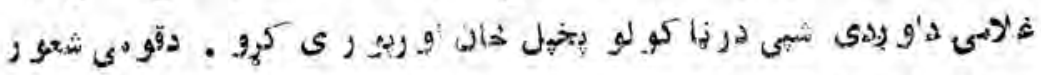

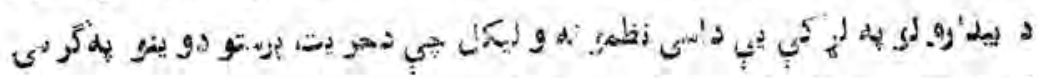

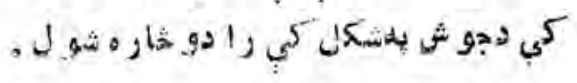

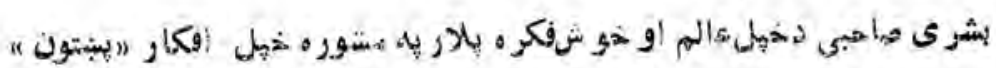

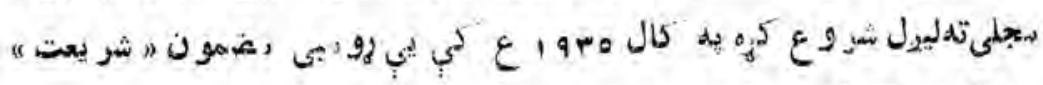

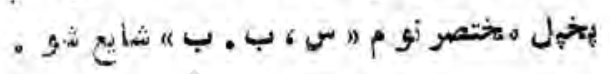

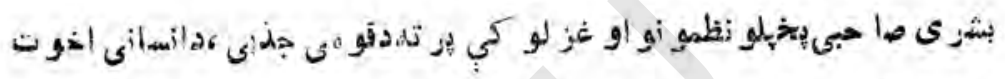

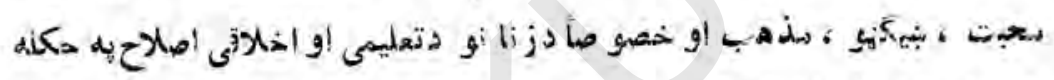

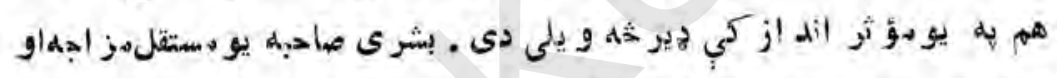

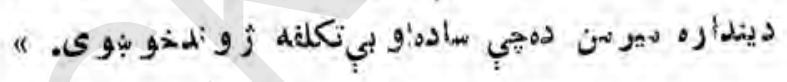

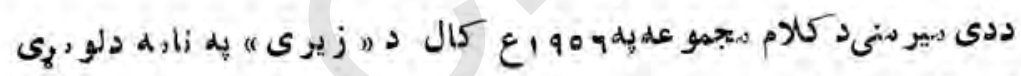

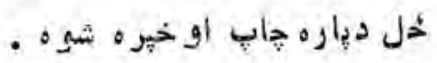

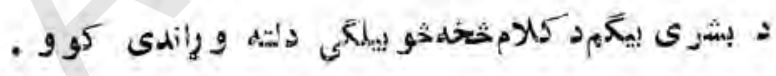

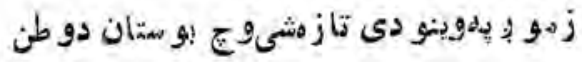

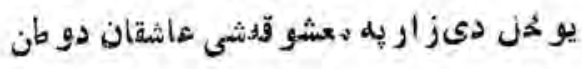

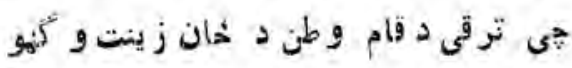

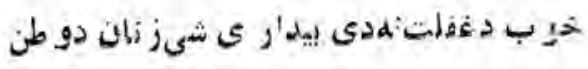

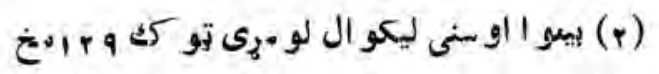




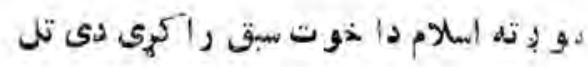

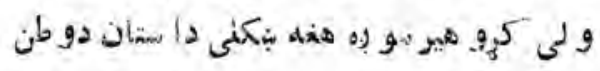

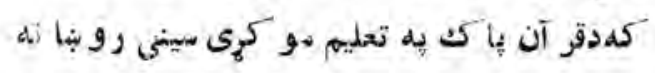

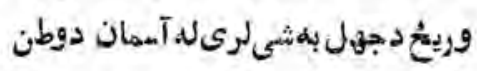

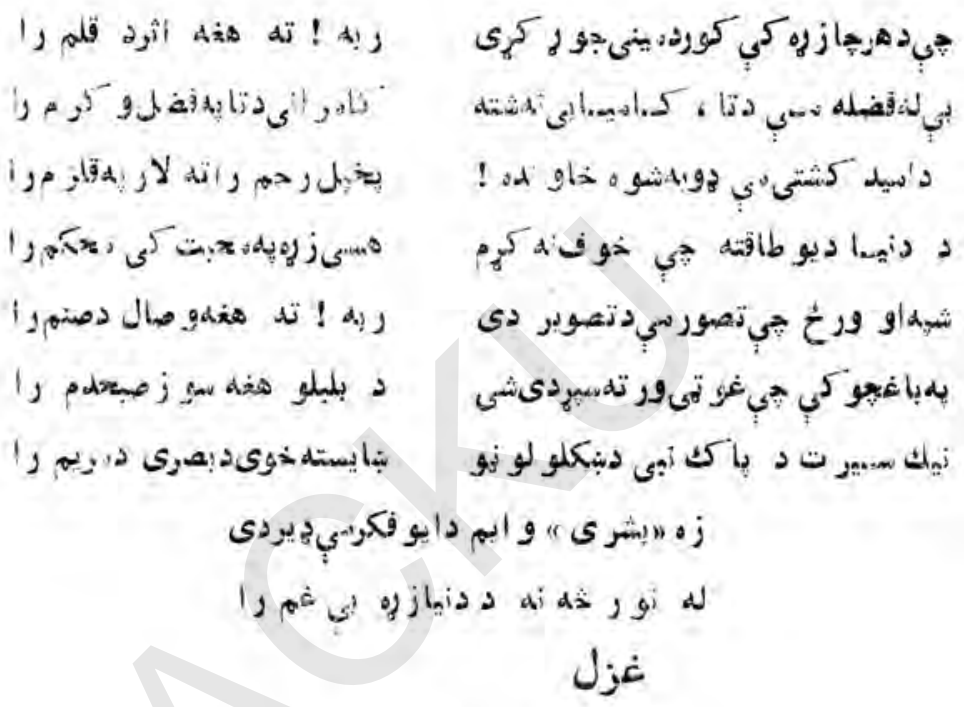

داز ددخه به نهبت كي شوكيرى تيرو م

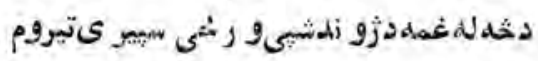

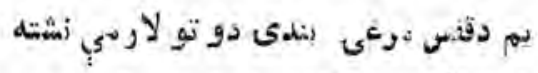

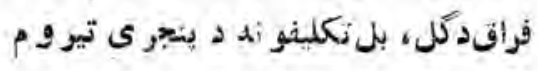

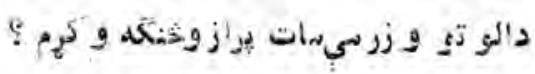

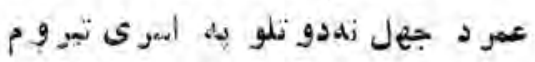




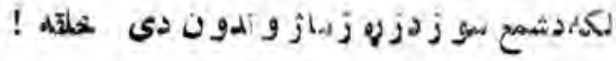

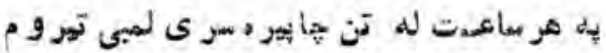

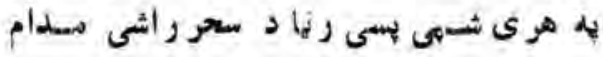

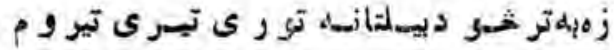

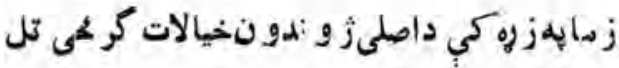
خلهو كهثو كت وايِيحى ثرونددا ديرى تهر و م

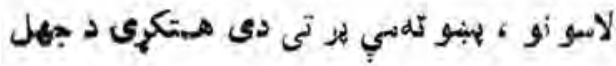

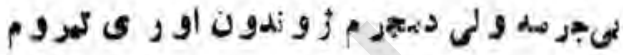

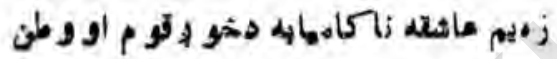

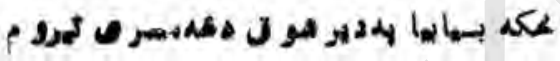

\section{دينتينى هروفيوياد}

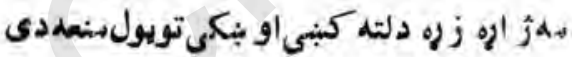

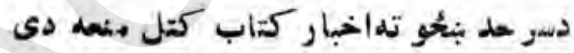

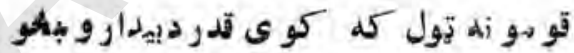
حمو ني دقو م دز نا انوو ينيو ل هنعه ديى

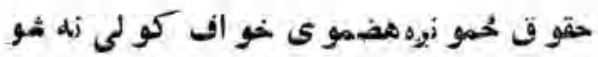

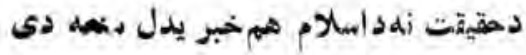
كاني

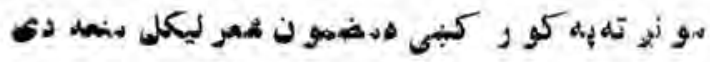

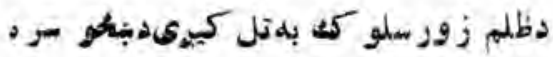

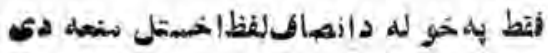




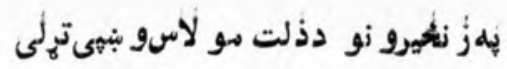

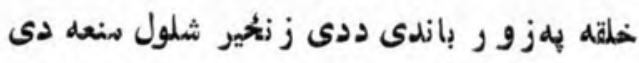

دتترل بلهغار كبنى يو بلمسر نكمو أه بر تى كي

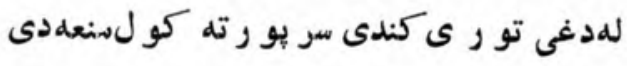

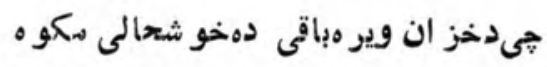

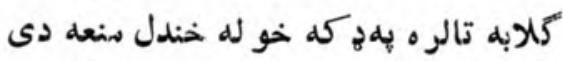




\section{الفي-جان}

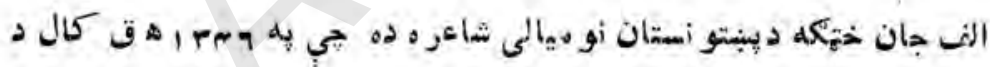

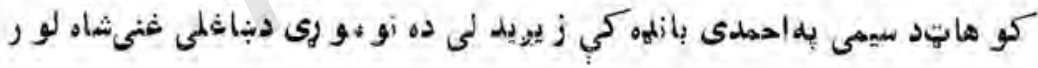

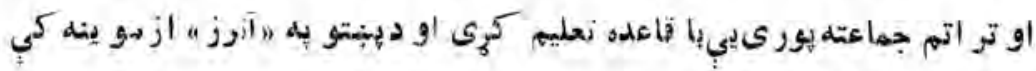

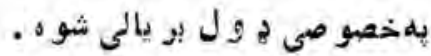

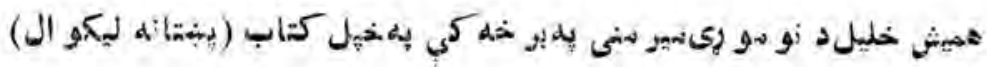
كي ليكى :

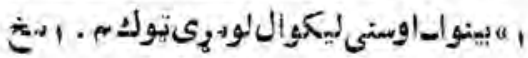




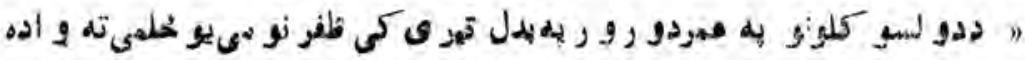

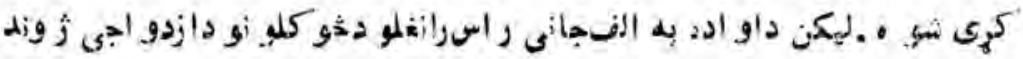

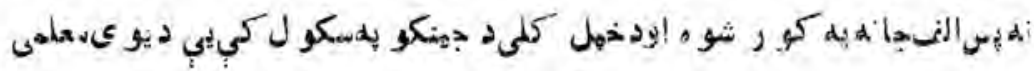

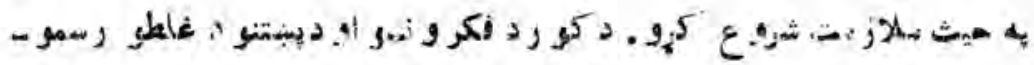

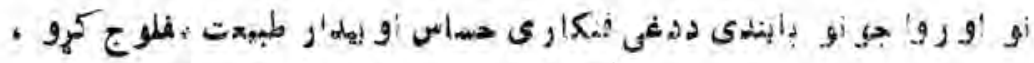

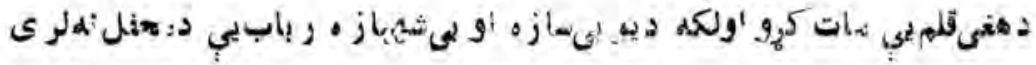

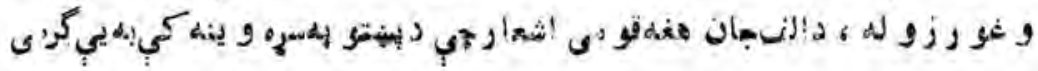

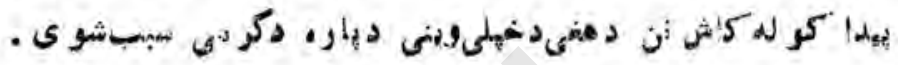

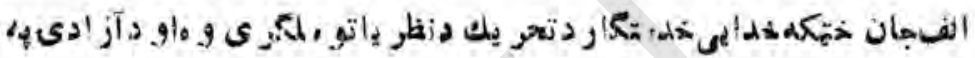

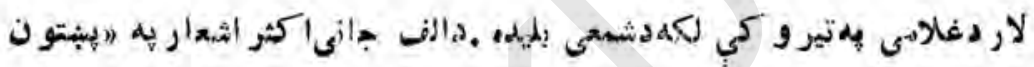

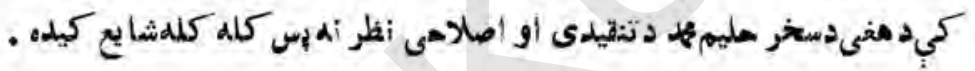

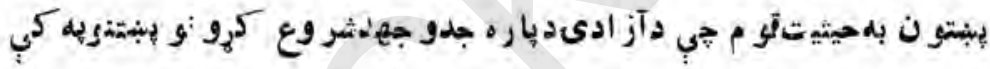

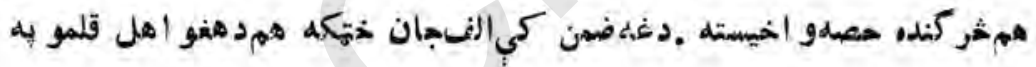

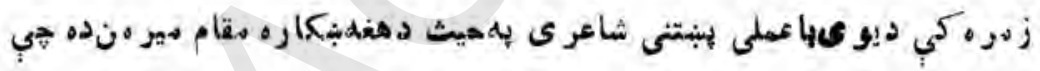

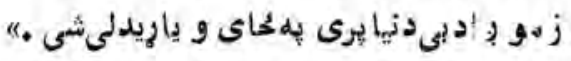

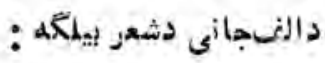

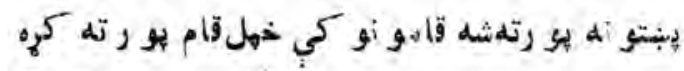

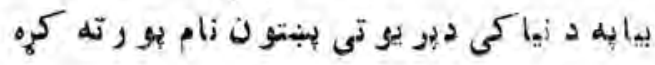

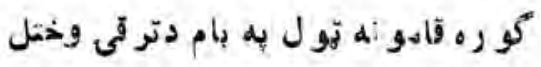

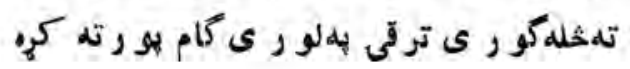




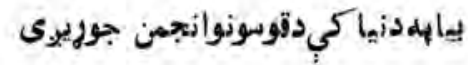

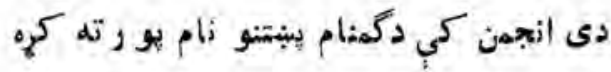
بى لهنظاهد ترقى دقو م دمكثهنه ده.

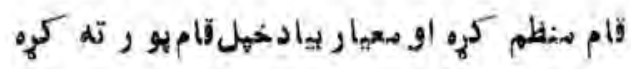

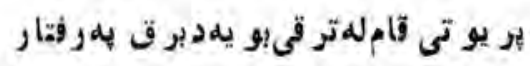

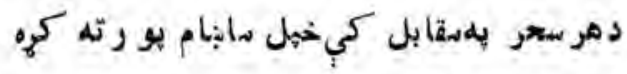
ديو خو كسو ترقى تهتر قي ده كنه

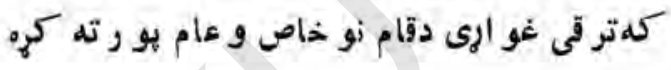

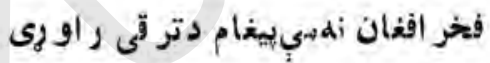
بهدو ارو لاسو داييغام بهاحتر ام بو رته كره دجهالتالز ام بهتابائدى يهكُاى لكَيرى

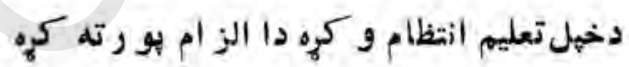
دخيلى ز بىتر قى جي دي هم هير • ألشى

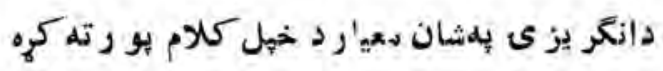

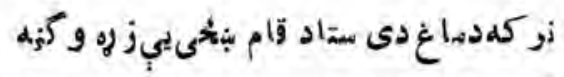
كهترقى دى و ى مقصددديهمام يو رته كريه دالف جان نصيحت يياو او رمعمل بر ى و كهر.

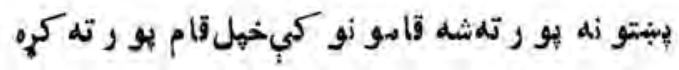




$$
\begin{aligned}
& \text { دامم دنوبوري دكلاميبلكه }
\end{aligned}
$$

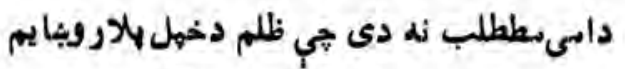

$$
\begin{aligned}
& \text { ز زونه و و يته دخهلو خو يندو بهانكار و بيايم }
\end{aligned}
$$

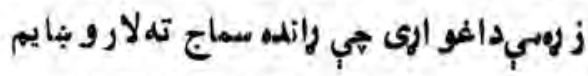

$$
\begin{aligned}
& \text { درو اجى يردى نتصو أه تار بهتار و بنايم } \\
& \text { خحايه دز بى طلالت دز ره طاقت راكريى }
\end{aligned}
$$

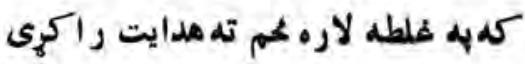

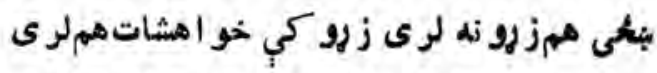

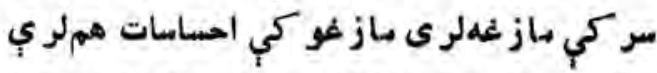

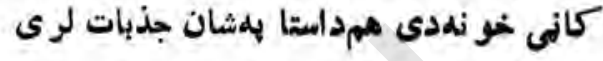

$$
\begin{aligned}
& \text { به بها لات لرى يكه ستانه ز يات لرى }
\end{aligned}
$$

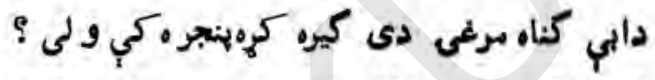

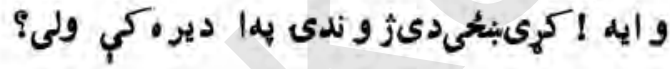




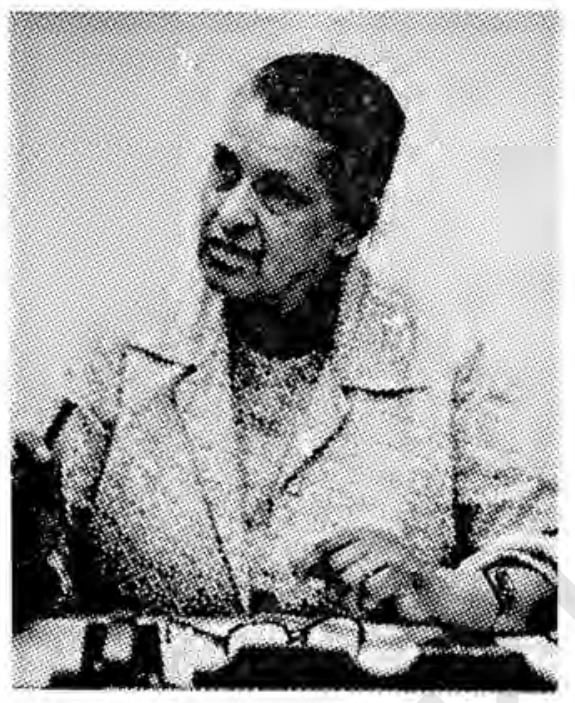

\section{معصومامصنمت}

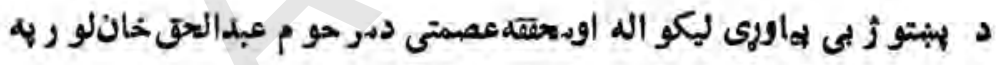

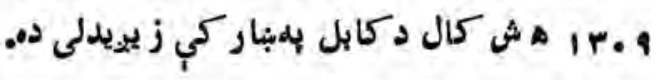

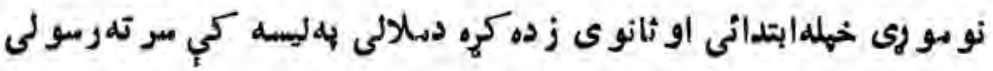

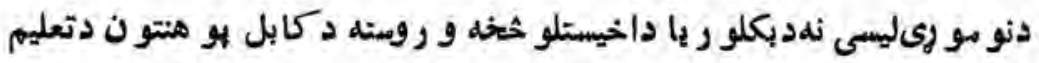

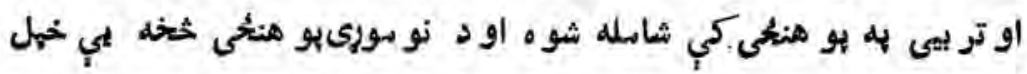
ليسانس و اخهيت. 


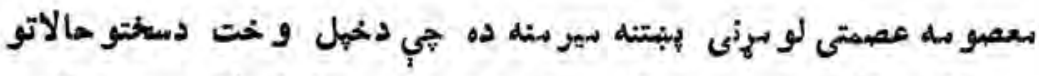

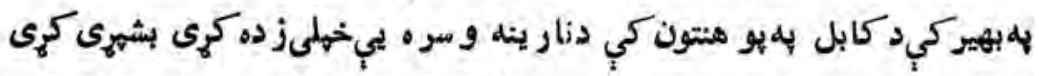

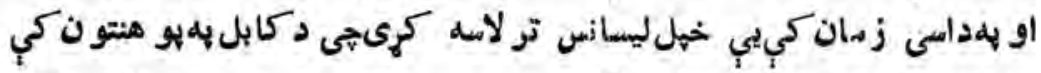

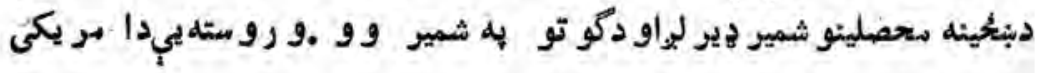

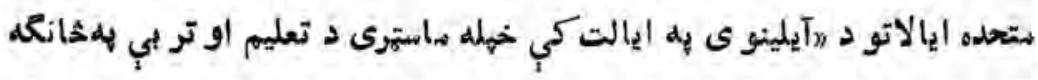

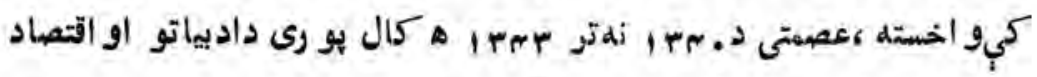

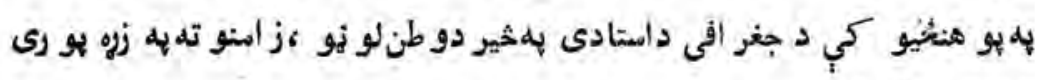

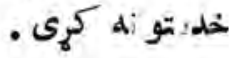

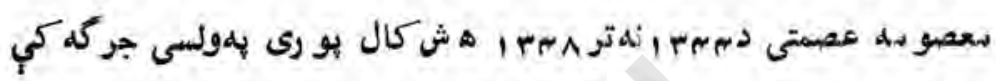

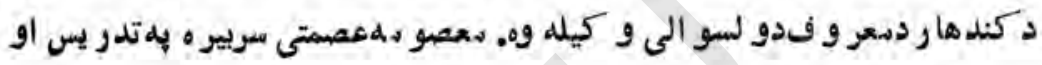

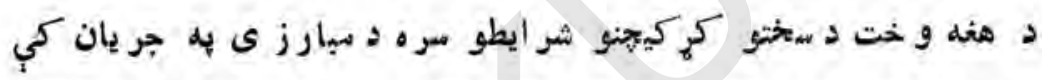

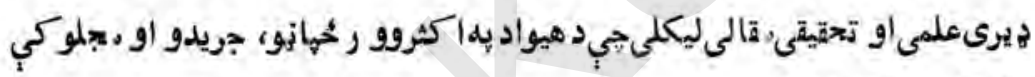
هاب او خهاره شوى.

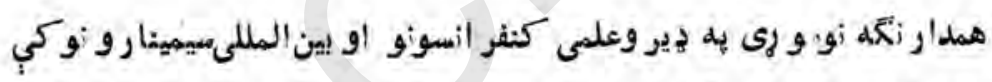

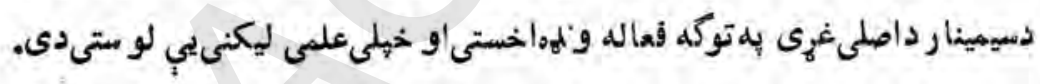

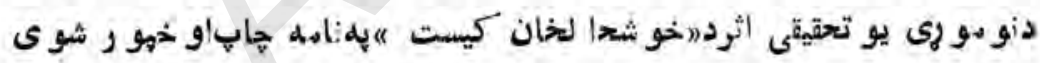

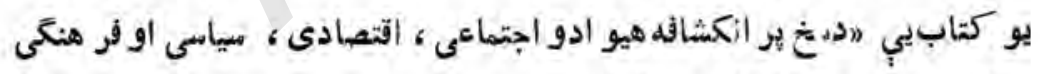

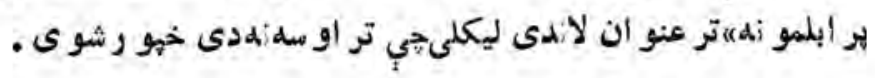

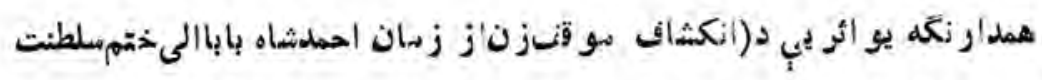

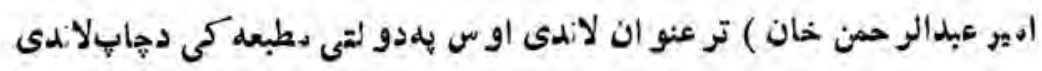




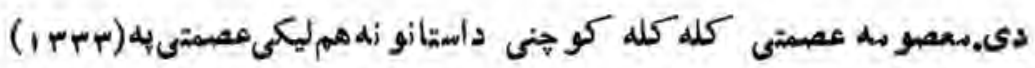

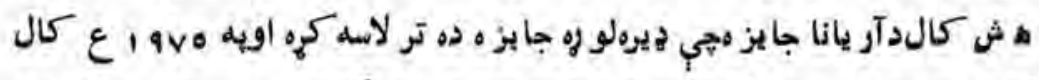

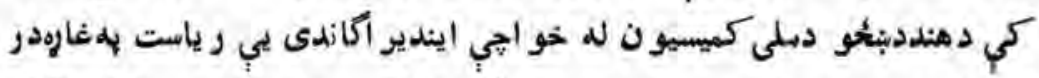

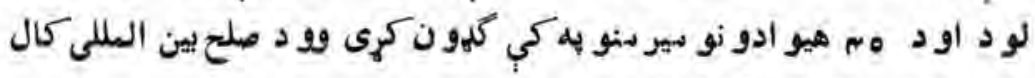

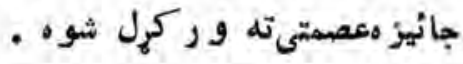

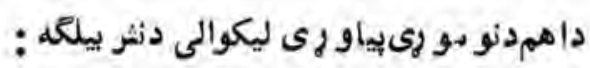

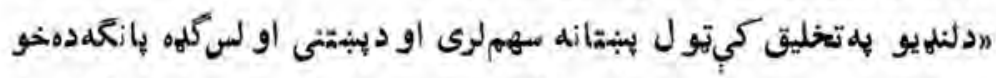

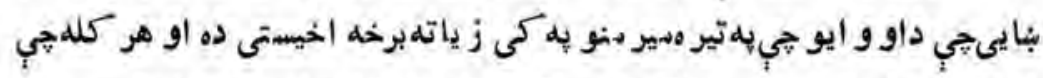

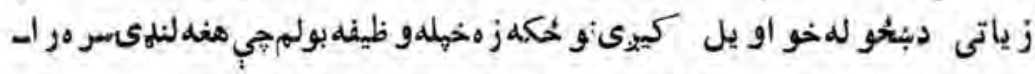

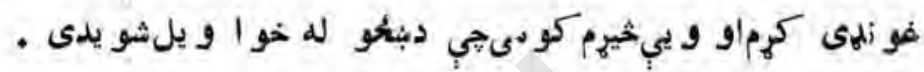

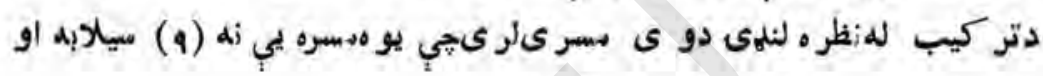

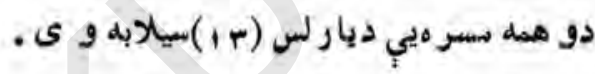

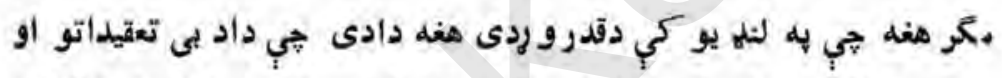

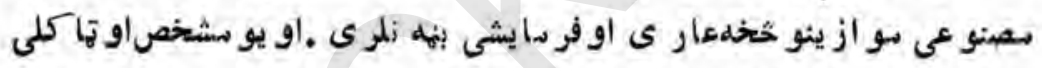

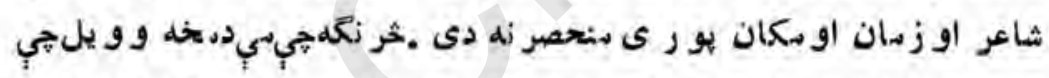

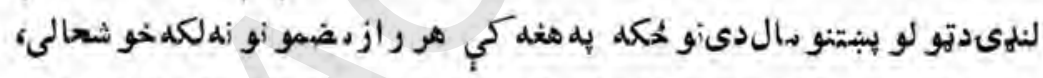

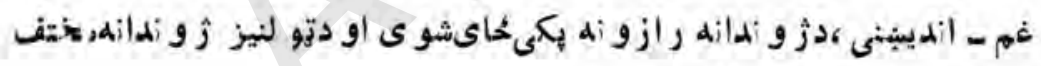

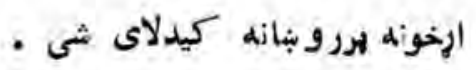




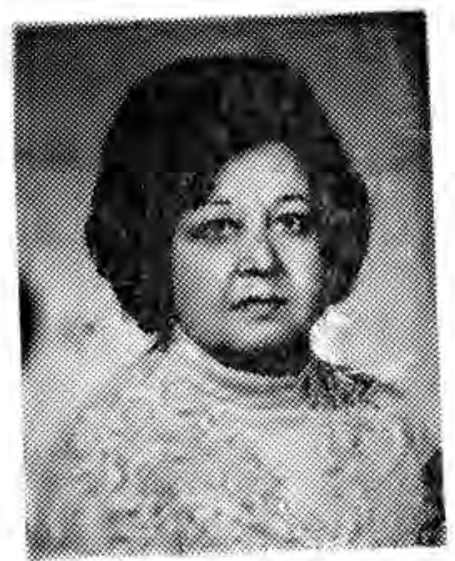

\section{مستوره شال}

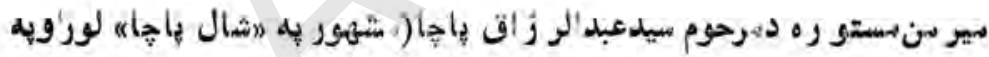

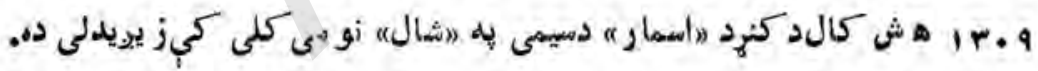

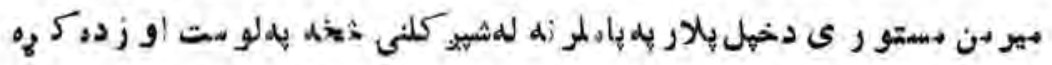
لهيل كرى كدى كدخهل

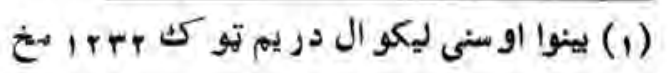




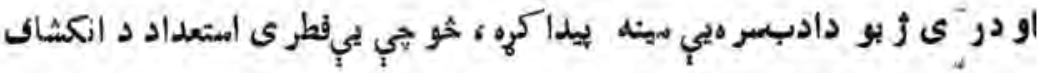

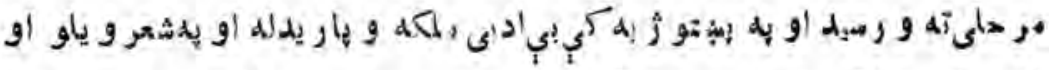

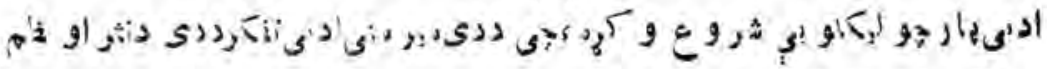

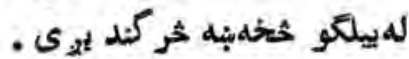

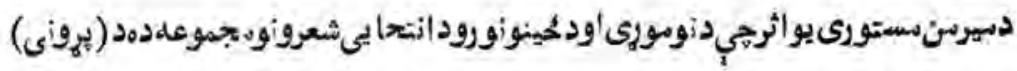

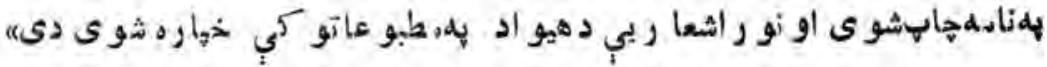
داهم دأو مو ري دنثر او نطم بيلكَى :

\section{دخدأىشمع:}

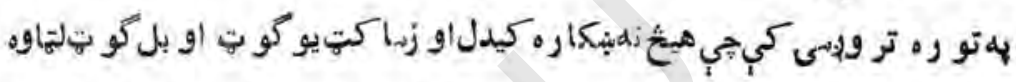

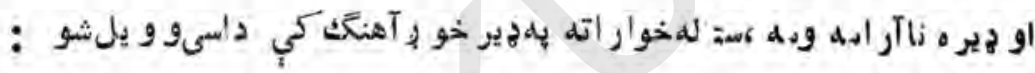

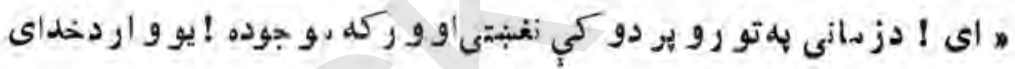

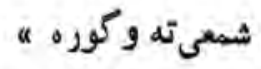

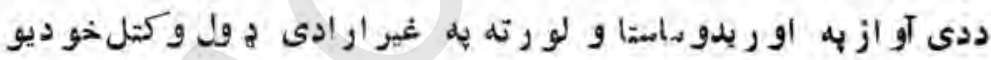

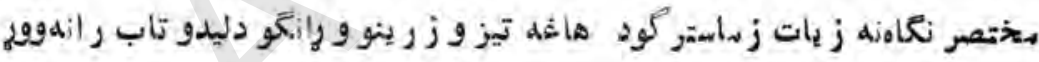

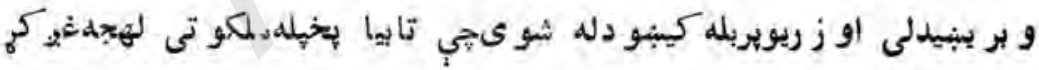

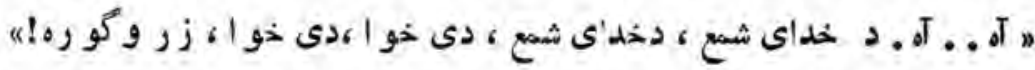

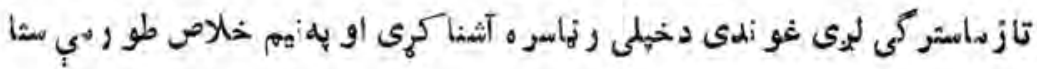

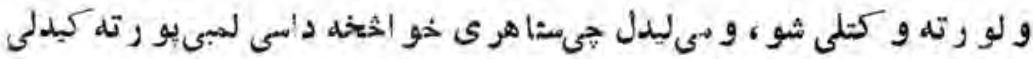

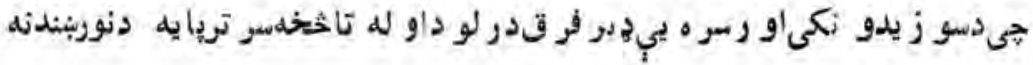




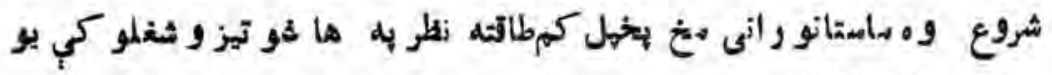

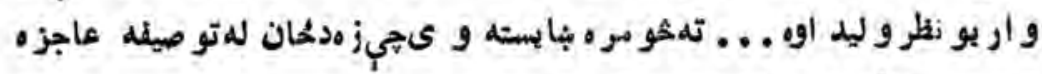

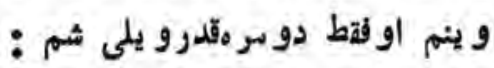

" اي دخدايى شمع ! سثارنا ، ستاجلوه، مشاجمال اويايست اوستا هر صلت د

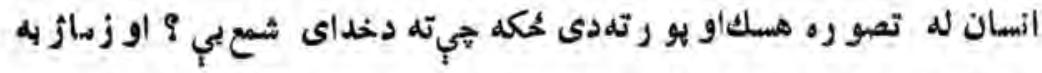

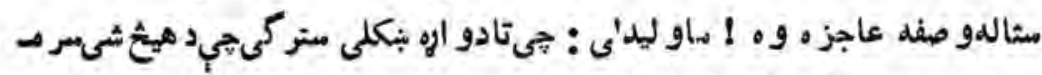

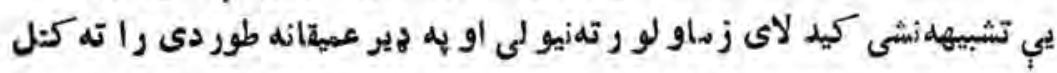

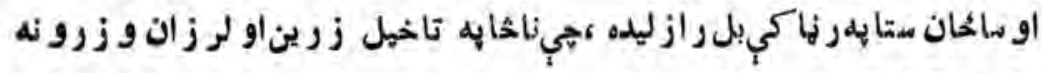

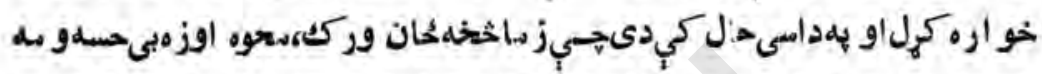

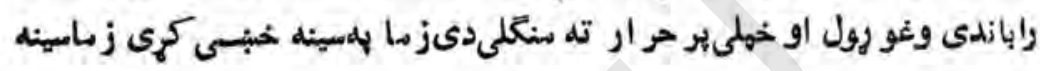

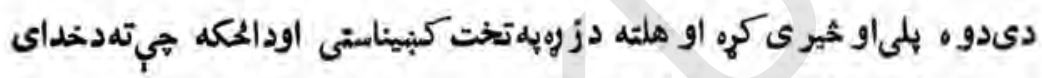

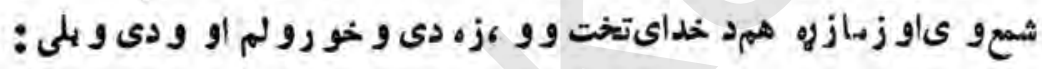

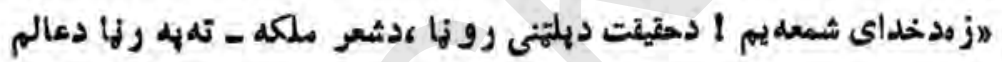

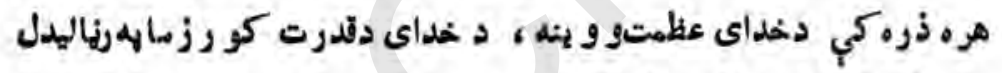

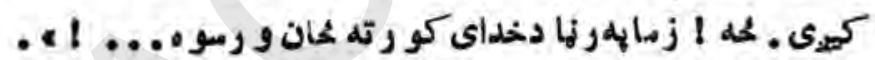

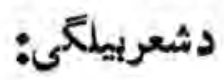

\section{روبنانdشه}

خيالو نو داسمان ثن ميكلو نه ر او ريدى

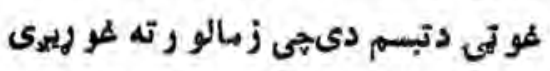

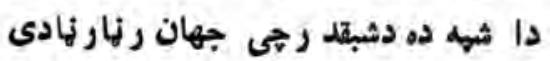

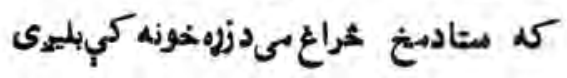




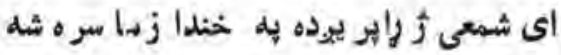

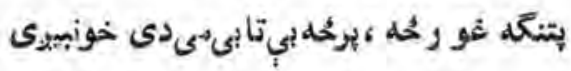

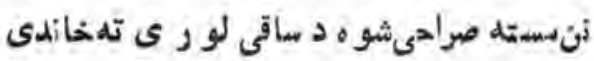

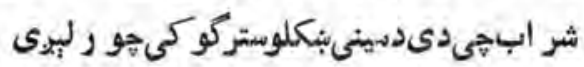

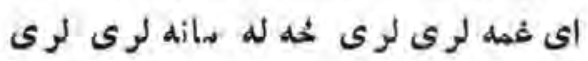

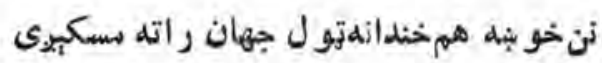

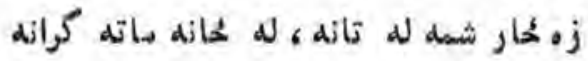

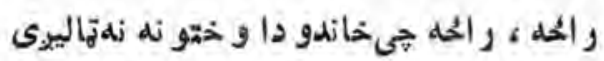

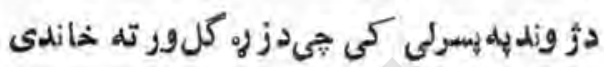

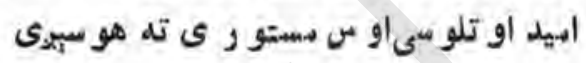
سوزاو ساز

دمبربهخمخانه كىدىشرابلرى كله نه

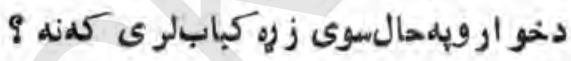
سركو مدلالهانده تهدمبر هلهتيارو كى رنا ديارو لو ر ى ته شهاب لرى كله نه

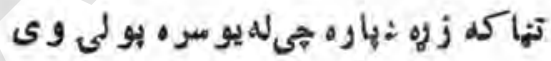
در يابدعاطفى كى ز زمحبابأرى كلهنه

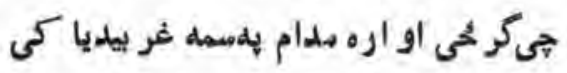
دعشق ليو نو ته كو م تثاب لرى كله نه آ له

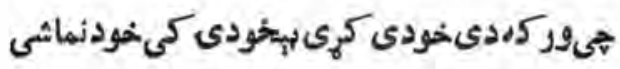

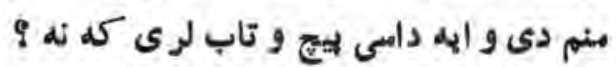


سجده د احتةرام ج-ى ثـسى تسكر اره دنسلكو اى خدايه ! و ايه بل هسى تر اب أرى كله نه ؟

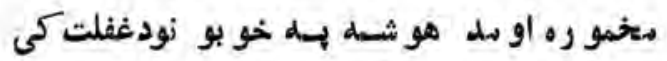

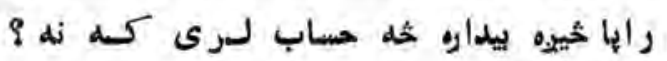

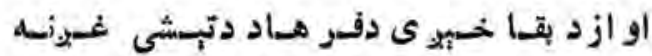
به عشق كى د شير ينى هبى تاب لرى كم أه ؟ هي درس د مو ز او سازوىمستورى بله رازونيازكي

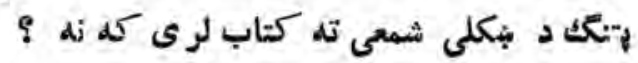
يساد غسم غبارززنسا دخسيسال لسمنسه و زيسوه

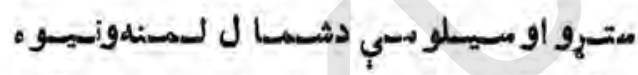
ييادى زأكر دو تهيم حير انه به خرتسو نسو كسي

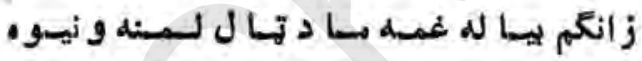

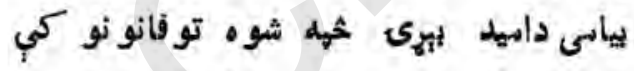

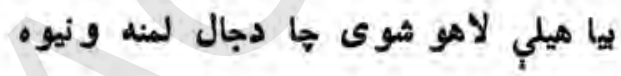

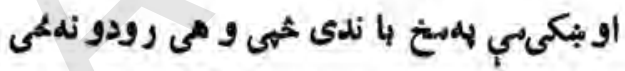

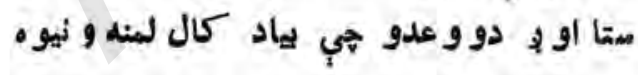
ستادبككلا لمر ته هيسو ائى و رمشخايخ شوله

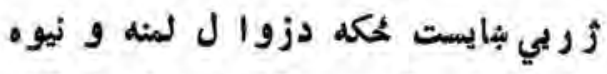

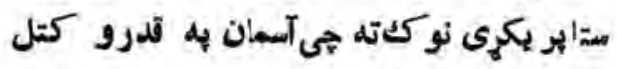

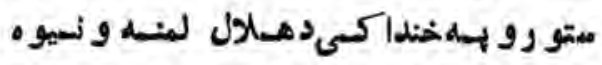


متادتبسم غو تمى ته كل سباكي وو يل

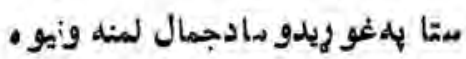

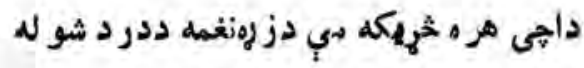

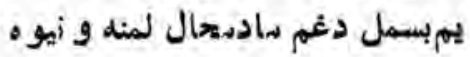

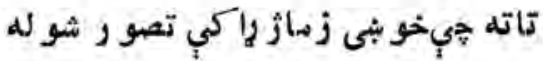

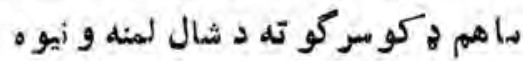
داغدا ركلوزه

زما رزاتو ره تياره، تياره ر زنا غو أدى شو ه

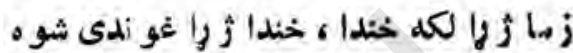

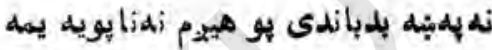

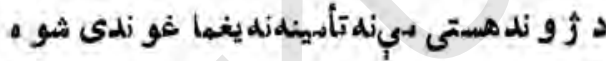

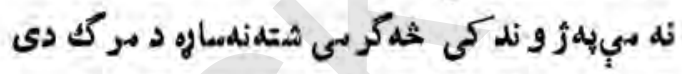

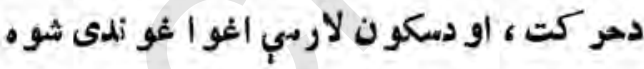

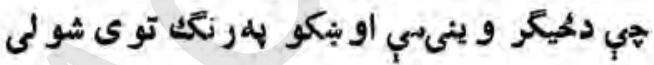

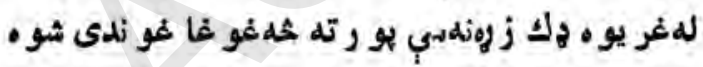

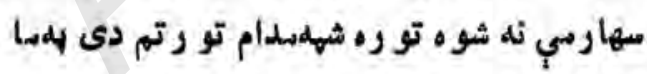

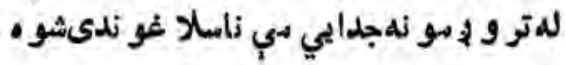
ها دآر زو دكلو هانو نه غنهل جو رهكهر شو ه تربى، توبى نيه لاره كي تالا غو ندى شو ه

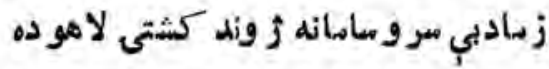

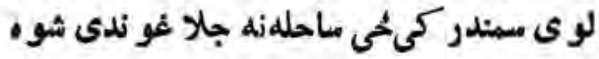


زه ناخبره و م رو انه دكلانو لو ر ته

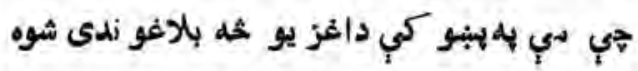

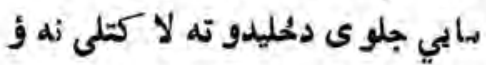

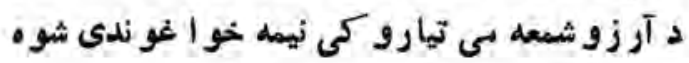

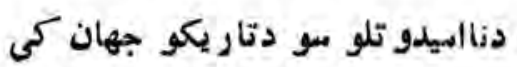

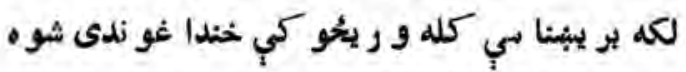

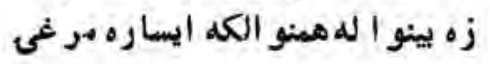

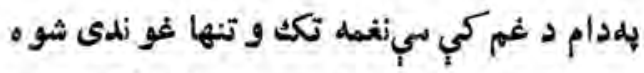

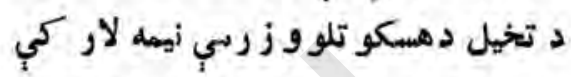

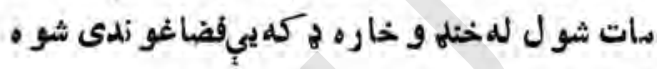

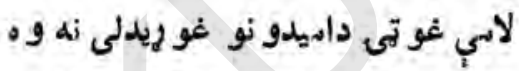
تنكى خز ان شو ملفشنى تحانكى زلهجدا غو أندى شوه باد و وا آسمان لمن كي سور شفق ته كثل يو لمبه دسر ه او رو نو د جها غو ندى شو.

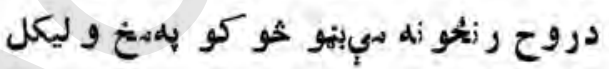
قصه د غم ترى لو ستل كيرى بر دلا غو أدى شوه

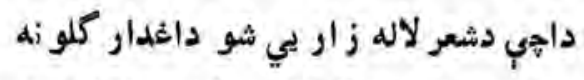

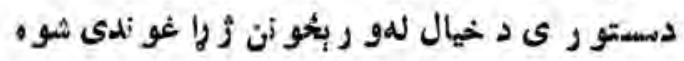
دشهيد وينا

$$
\text { ساعز رائيل سر ه خبرى ارتقاكى و كرى }
$$

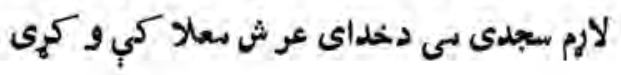
AT 


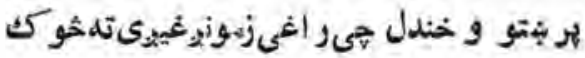

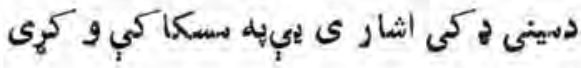
دشهادت بلميو دمت زه شو م بيخو دوغو ألدى

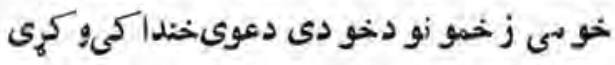

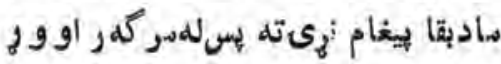

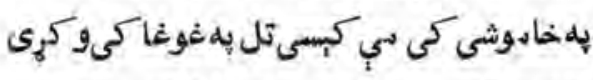

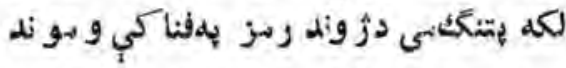

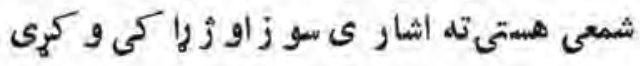

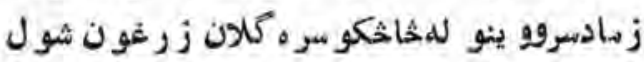

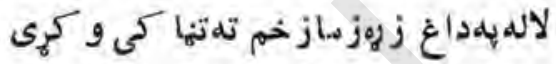

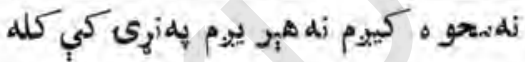

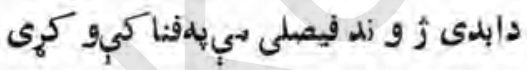

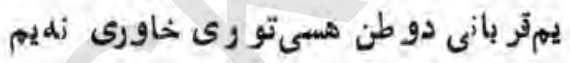

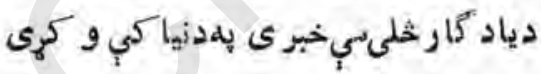
زه ترجمان در وح اوز رهد دكائئاتويهه

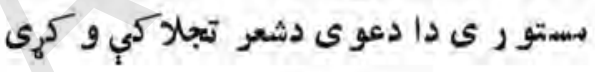
تا زماكل

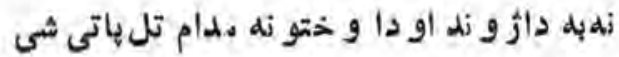

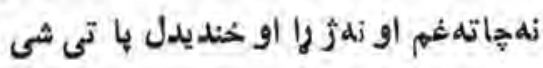
دز مانى ميلاب لاهو كري هر خهليحانه سره

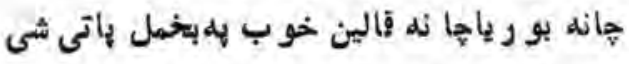
Ar 


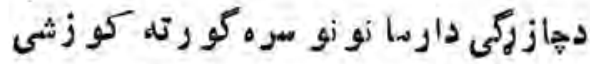

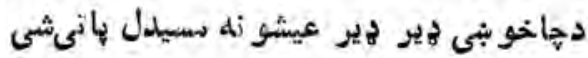

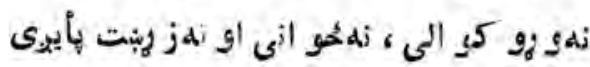

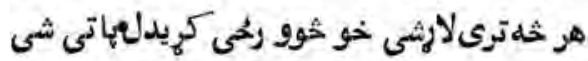

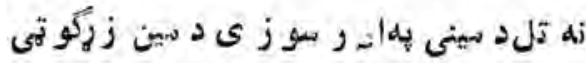

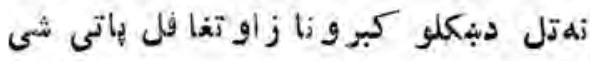


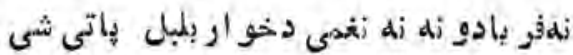

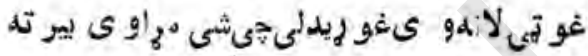

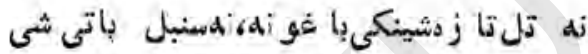

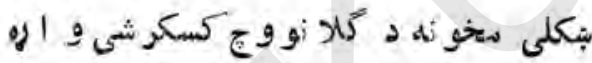

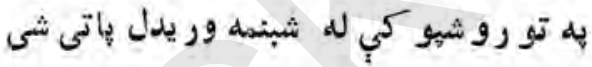

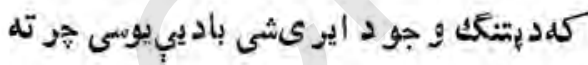

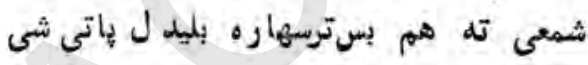

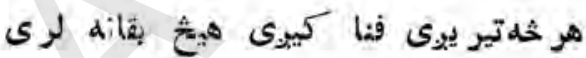

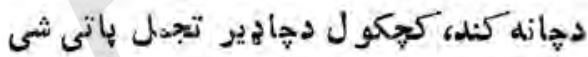

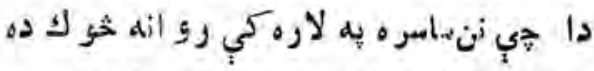

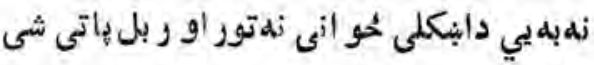

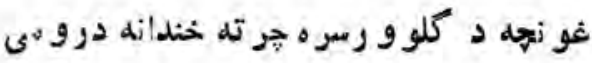

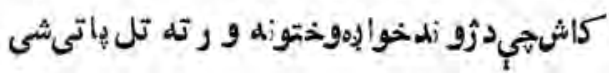




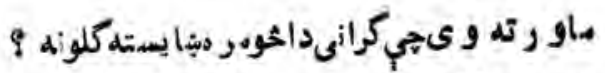

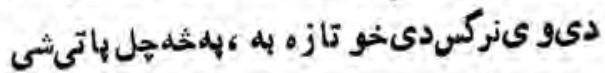
ييا يي يوكل كر ترى رابيل ها ته يي و نيو لو

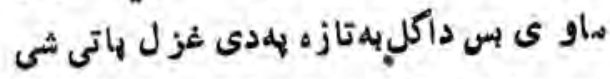

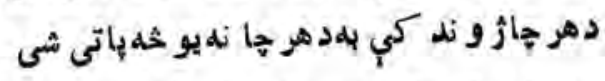

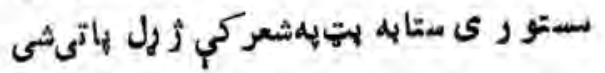




\section{مبار كتسلطانشميه" "}

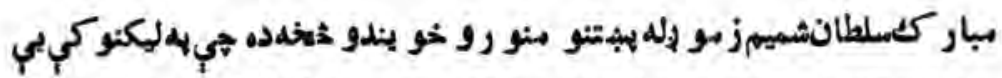

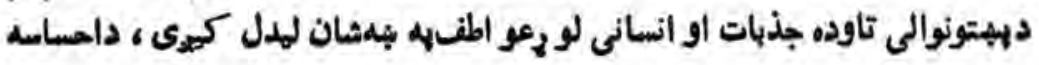

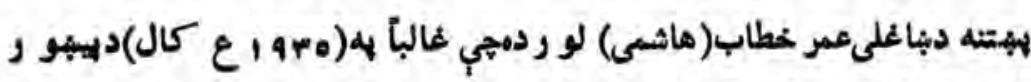

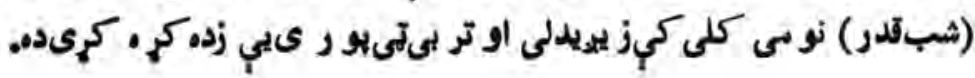
AV 


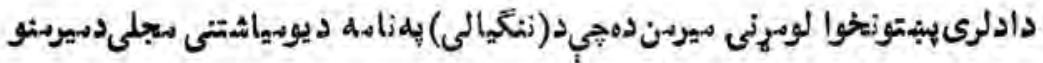

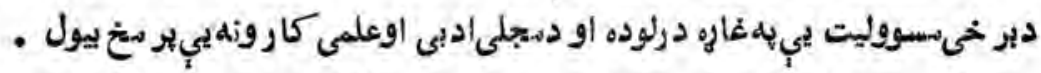

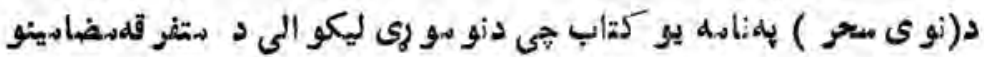

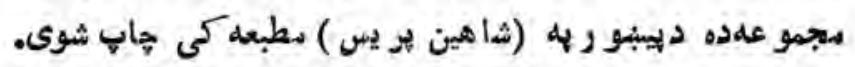

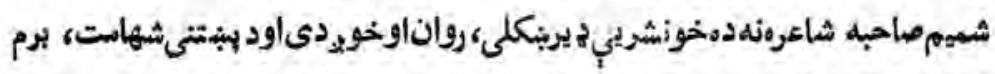

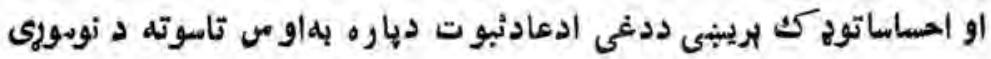

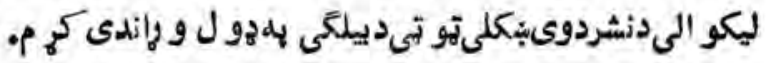

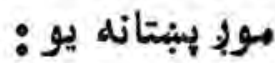

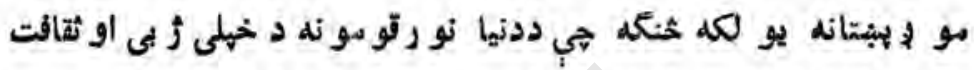

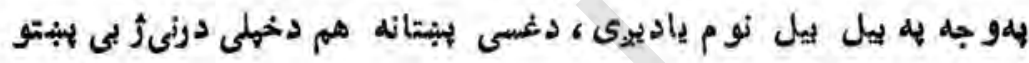

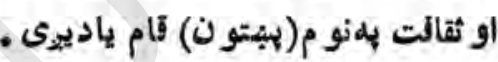

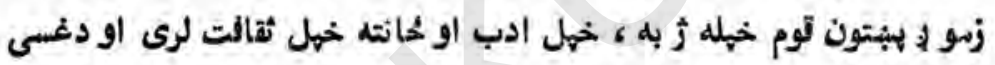

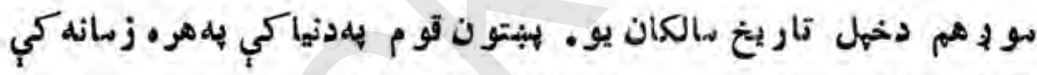

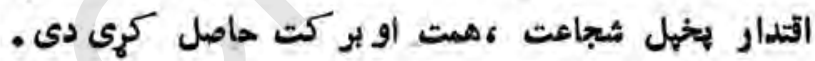

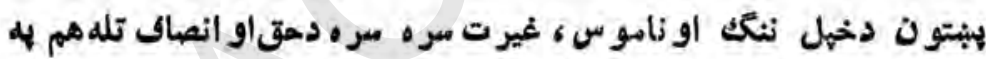

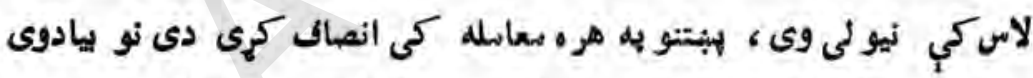

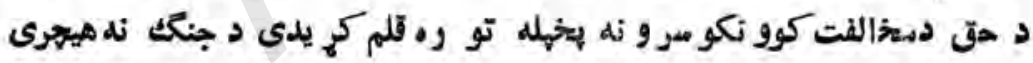

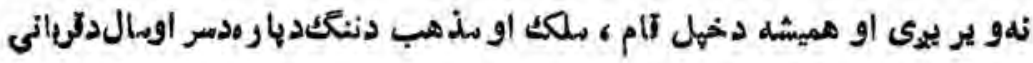
كله هيجيرى بهل شاكيرى نه. همدغه جذ به ده خي بيتتو هيجيرى د انكير يز انو دغلاسى ز نجير لهنهلو

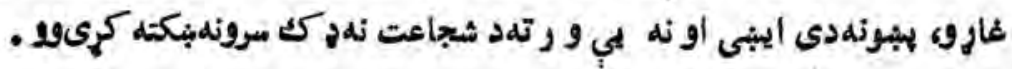

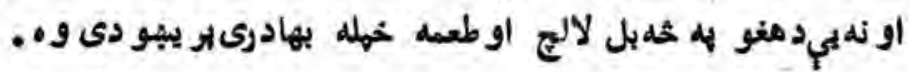

$$
\text { - ^^ - }
$$




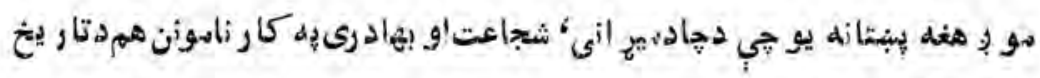

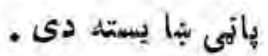

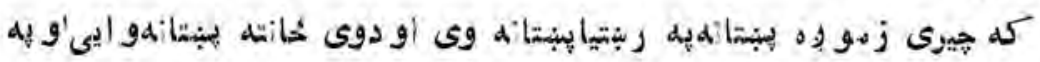

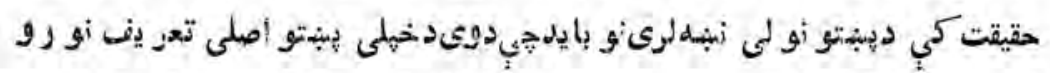

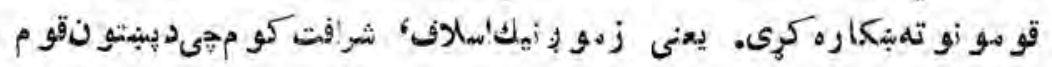

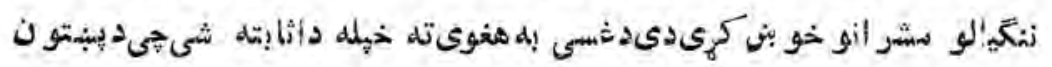

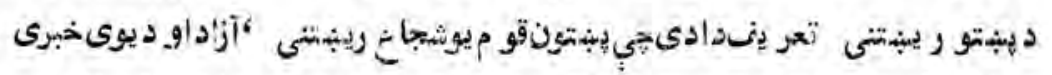

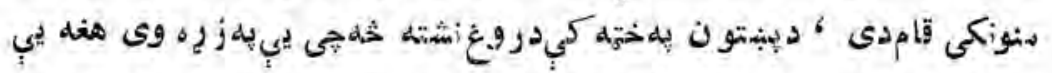

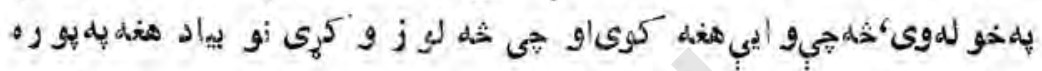

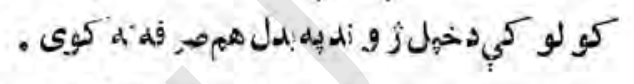

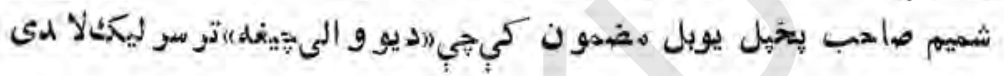

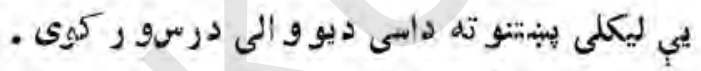

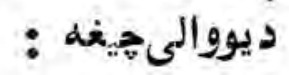

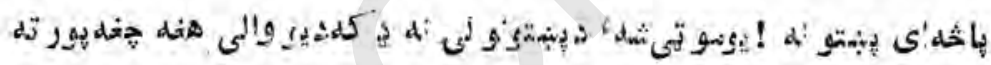

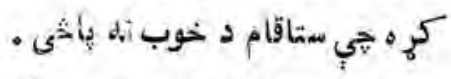

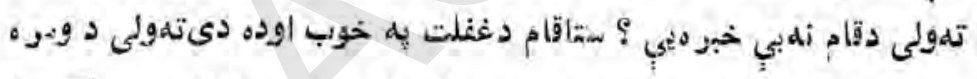

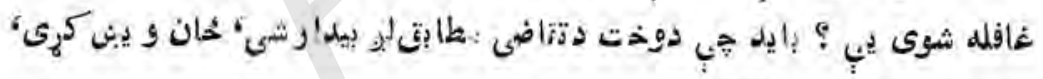

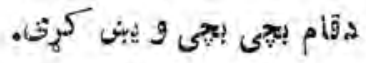

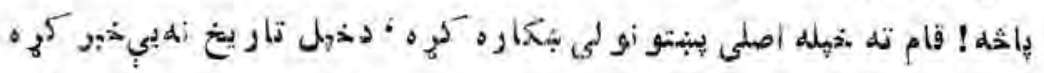

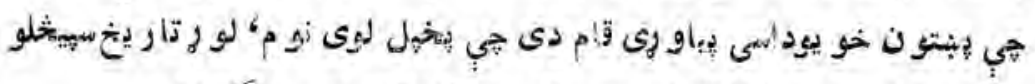

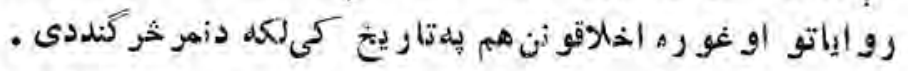

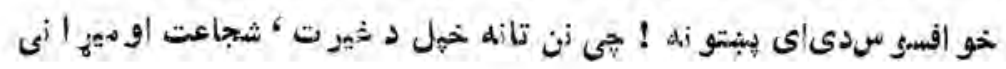




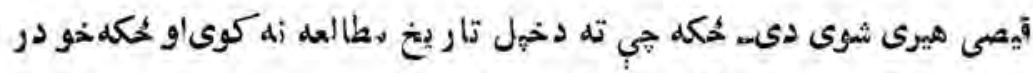

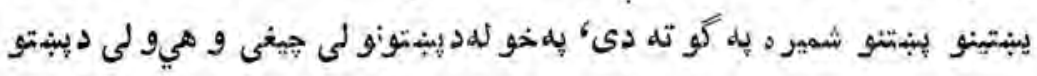

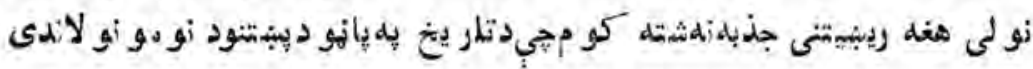
به فخر ليكل شوى ده.

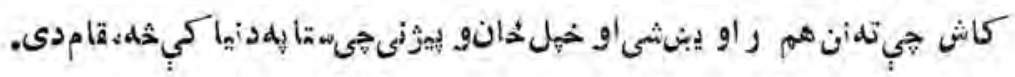

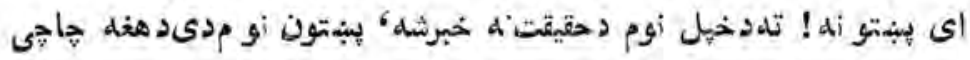

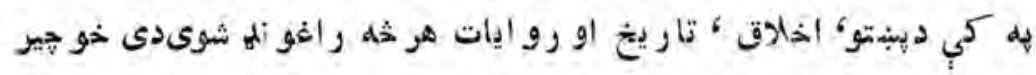

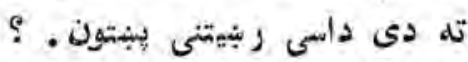

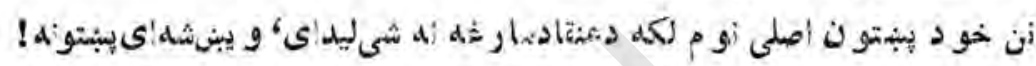

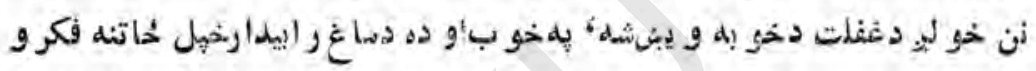

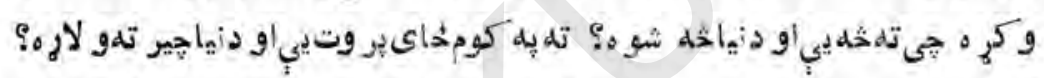

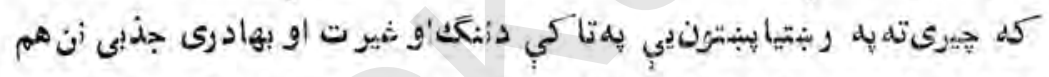

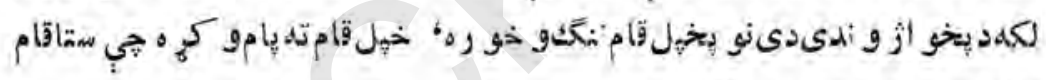

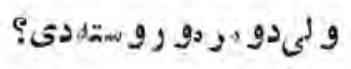

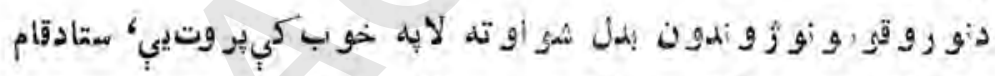

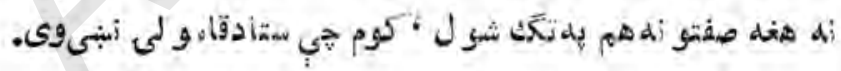

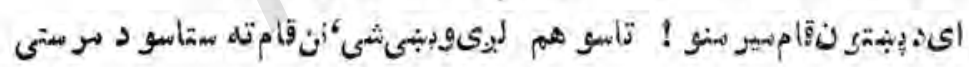

$$
\text { او تعاون ضرو رتدى. }
$$

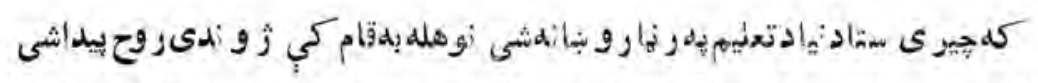

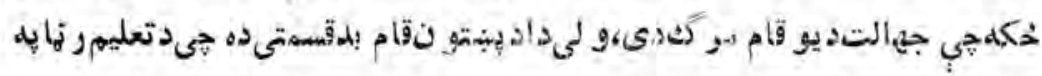

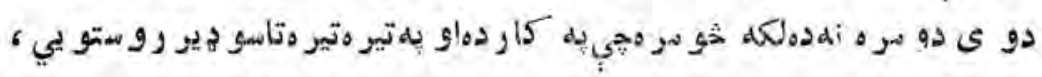

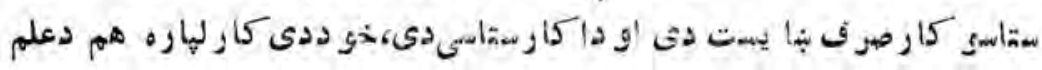




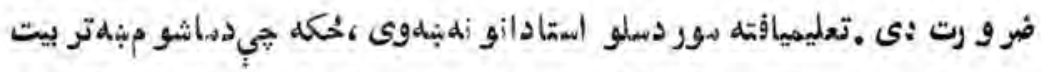

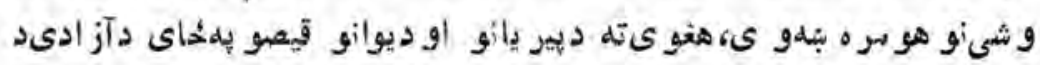

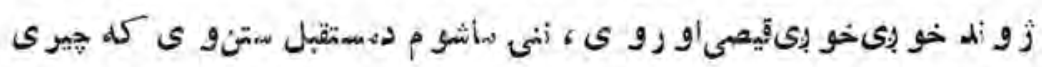

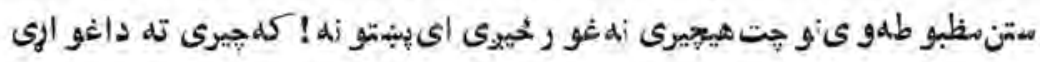

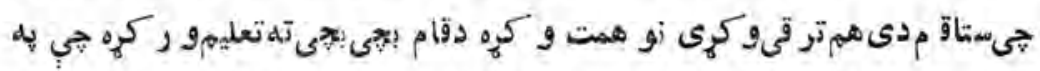

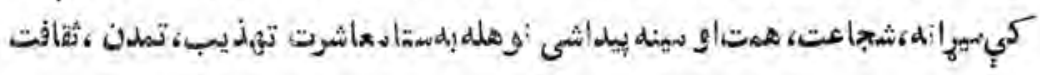

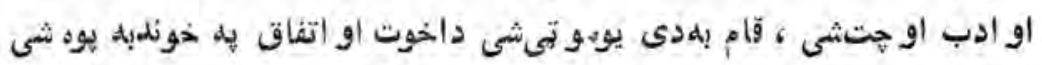

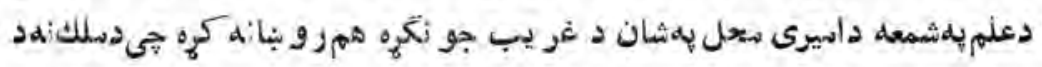

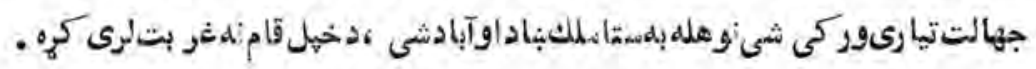

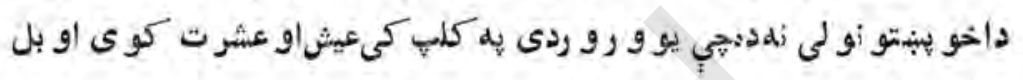

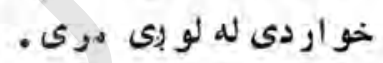

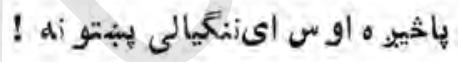

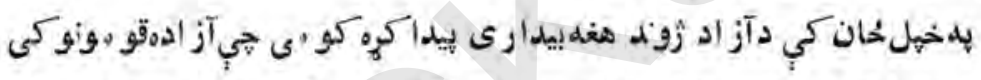

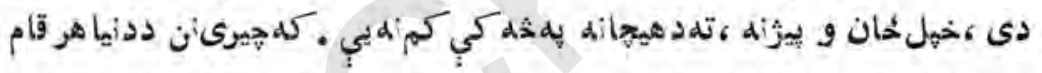

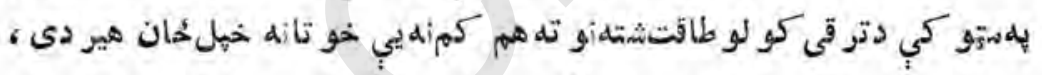

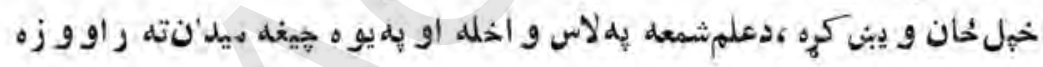

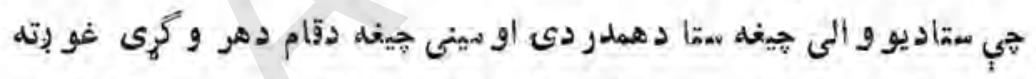

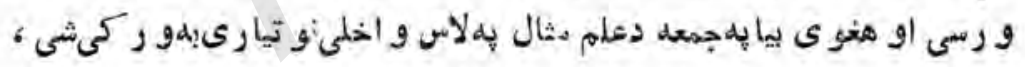

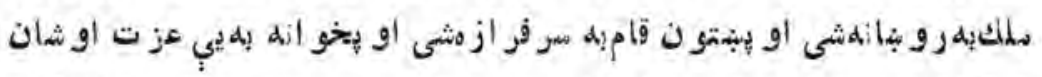

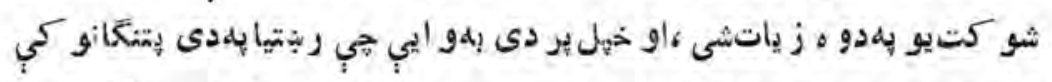

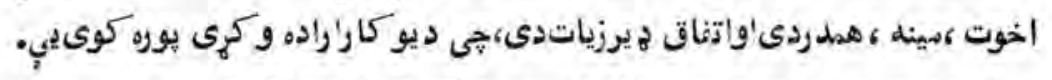
او اوس هم د زو هو ريى د داستأن يو مبيلغكه و ورا ندى كو م : 


\section{دغزيبى دنيا}

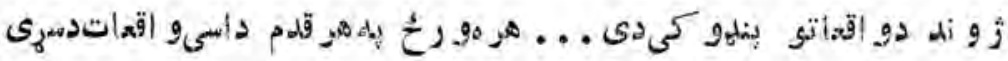

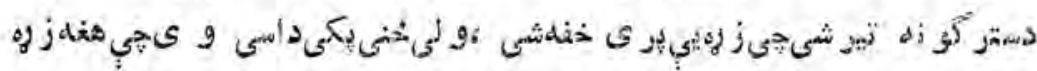

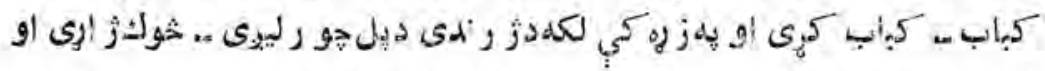

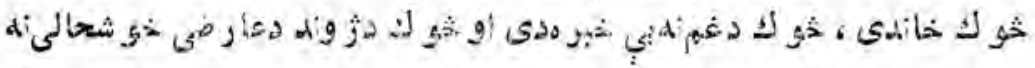

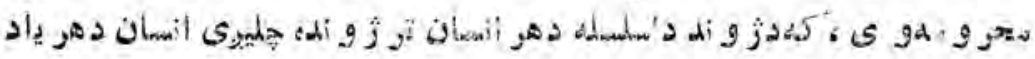

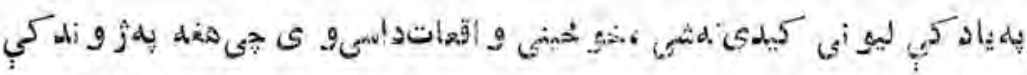

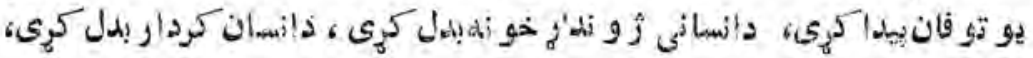

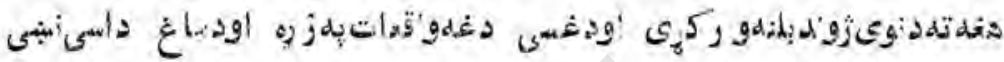

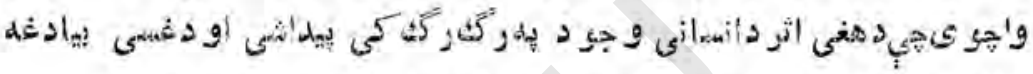

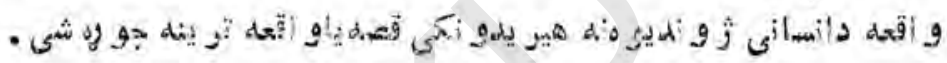

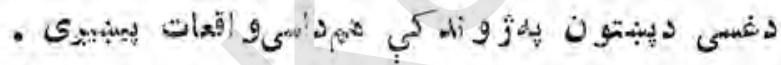

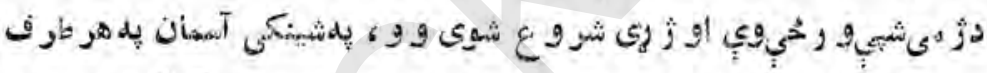

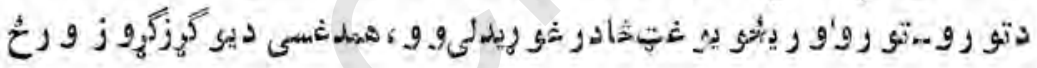
.09

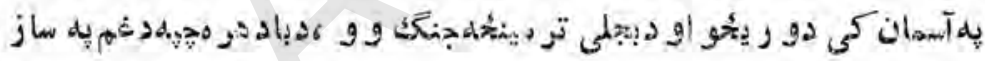

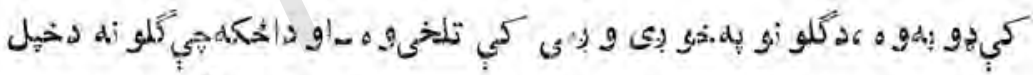

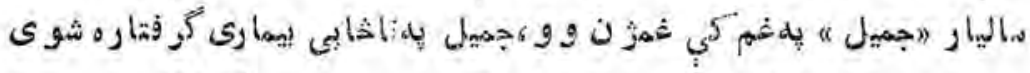

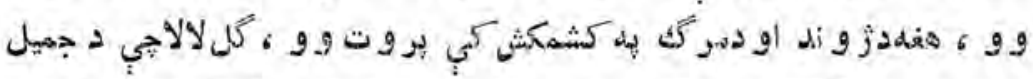

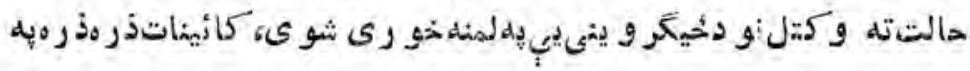

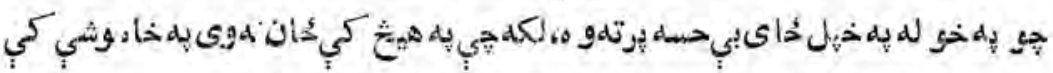

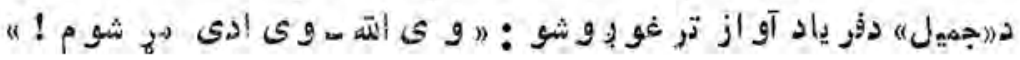




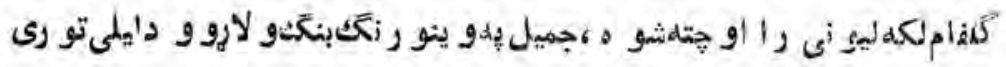

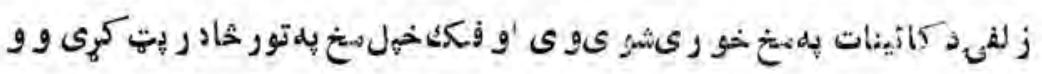

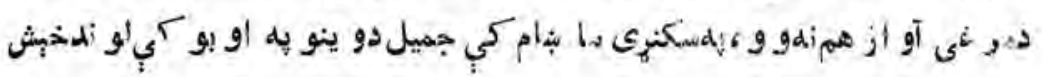

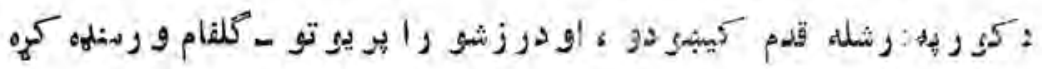

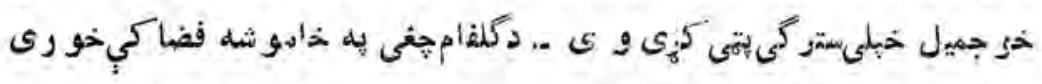

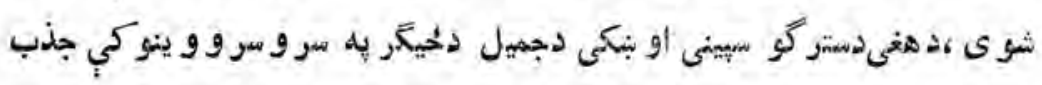

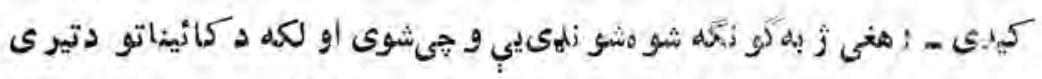

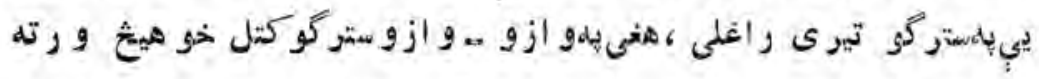

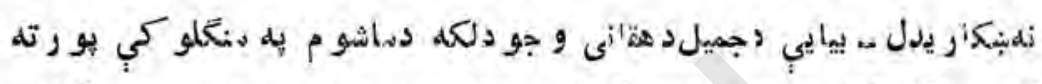

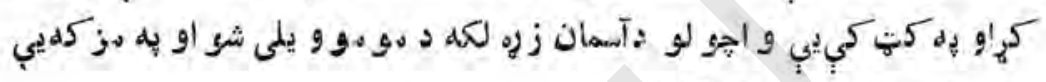

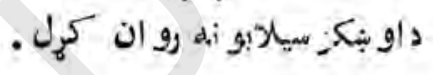

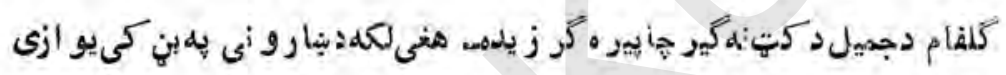

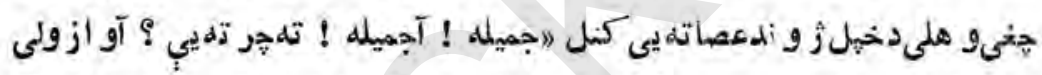

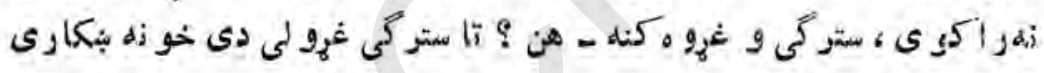

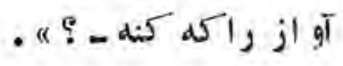

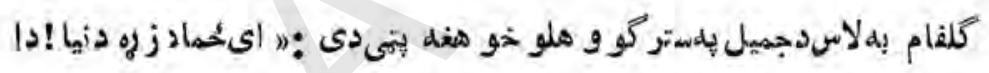

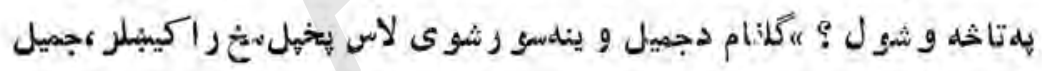

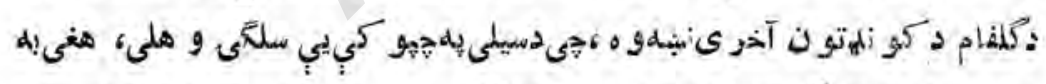

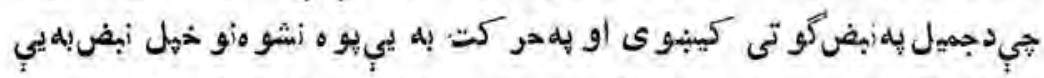

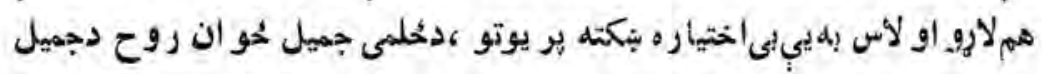

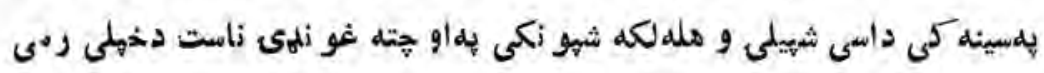




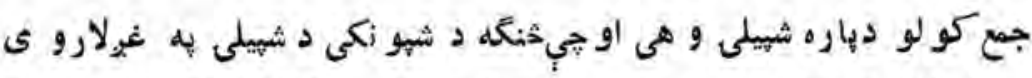

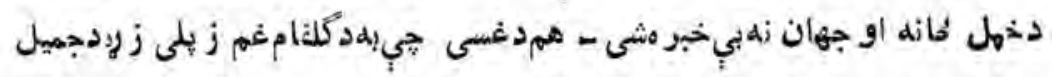

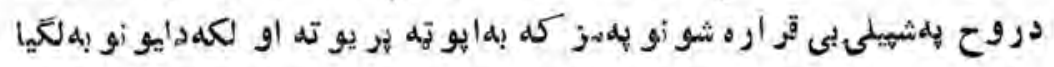

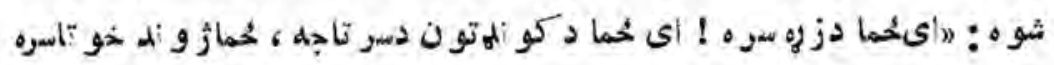

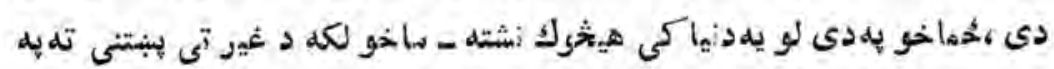

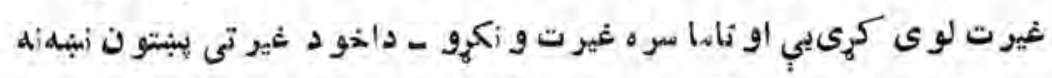

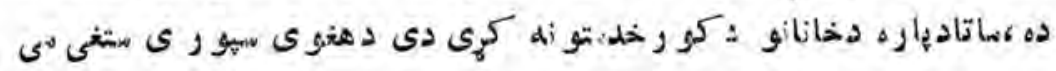

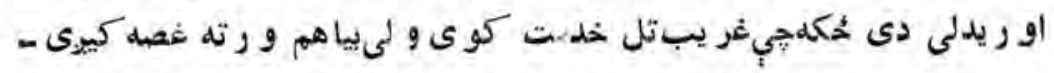

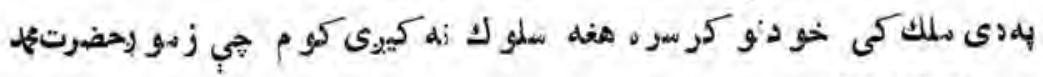

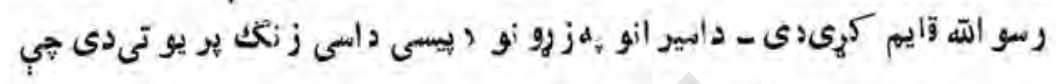

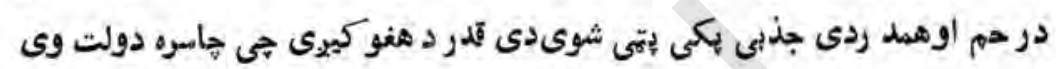

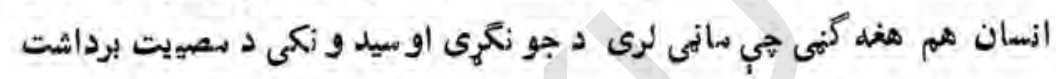

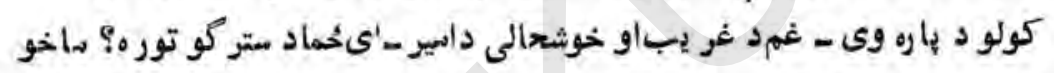

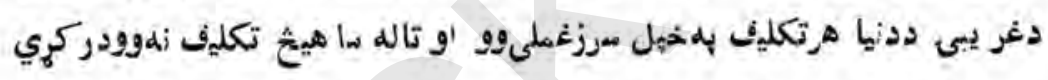

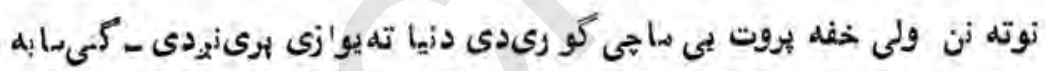

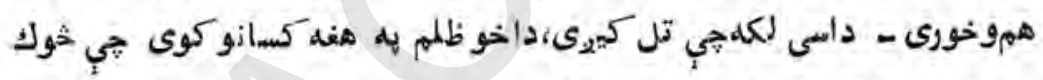

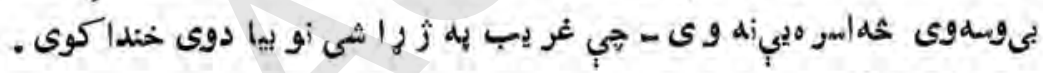

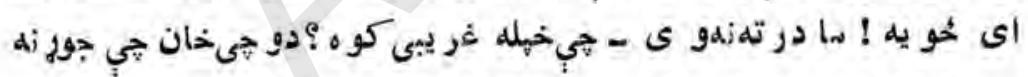

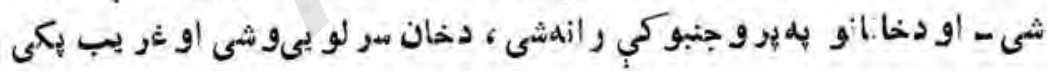

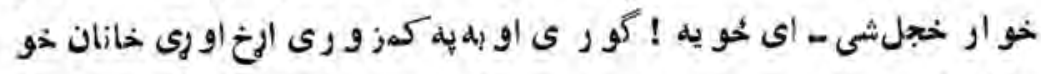

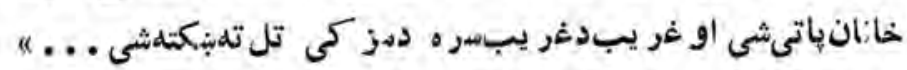

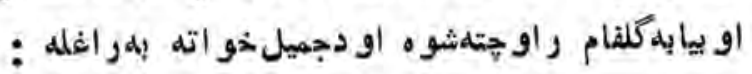




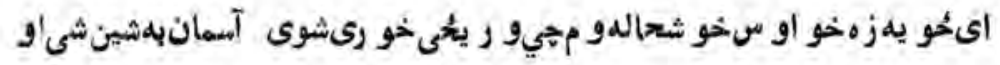

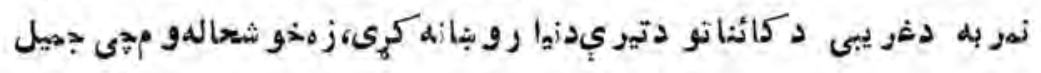

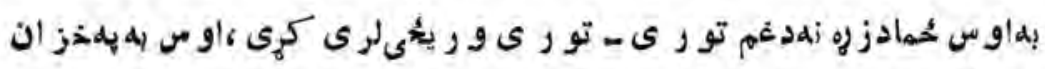

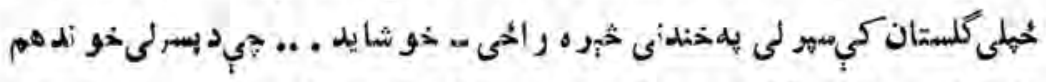

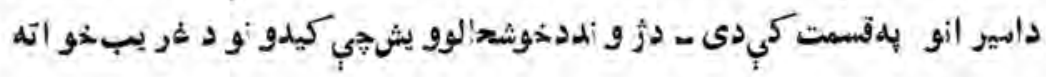

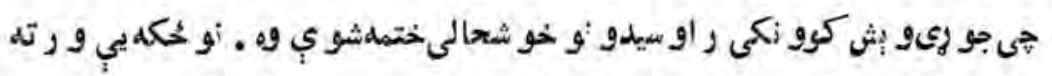

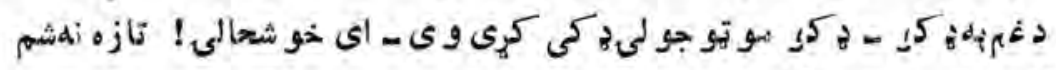

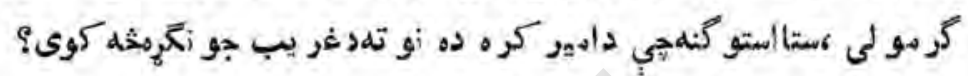

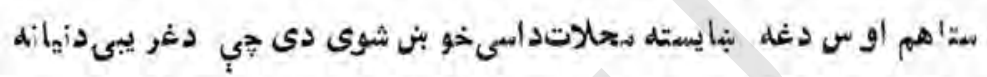

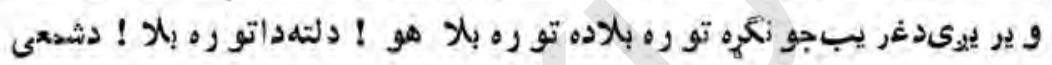

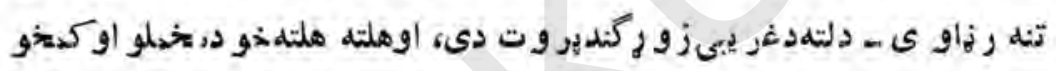

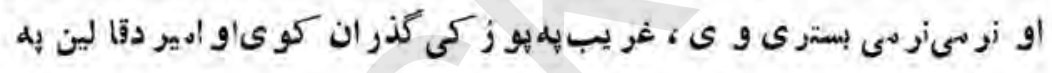

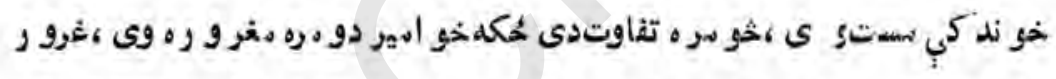

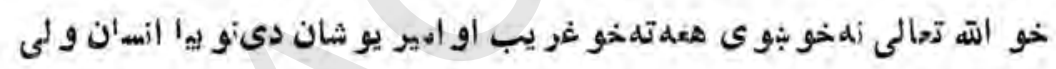

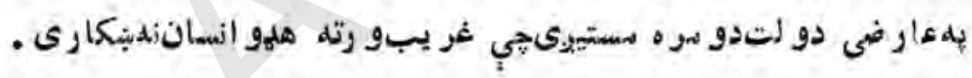

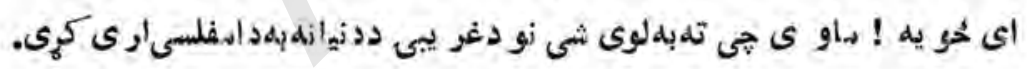

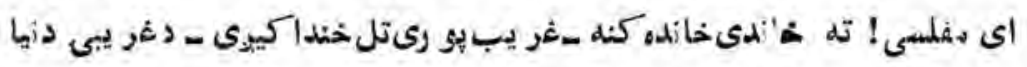

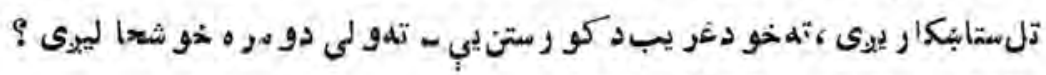

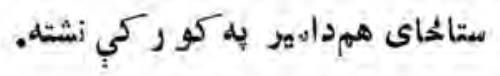

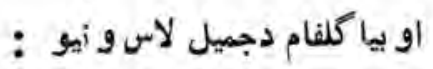

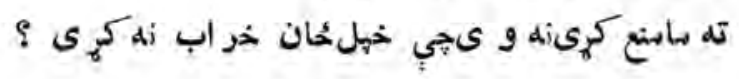




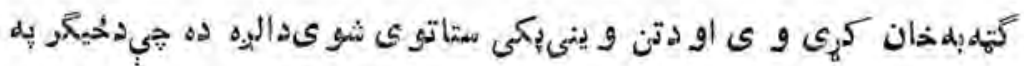

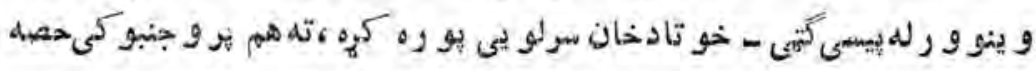

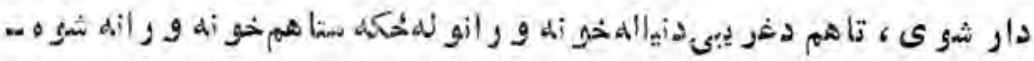

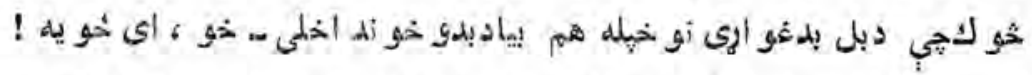

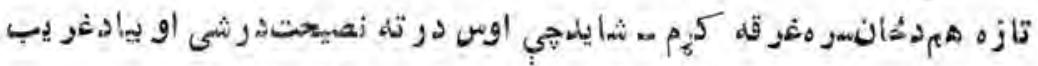

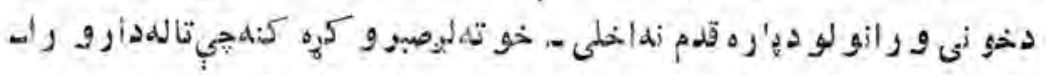

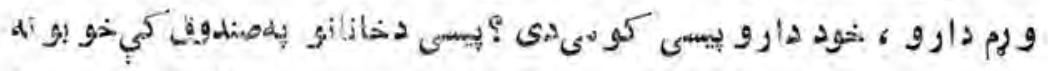

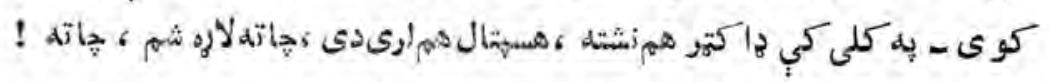

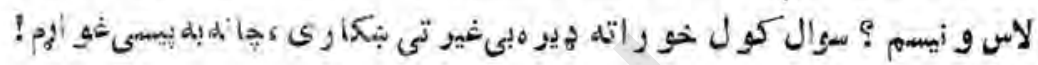

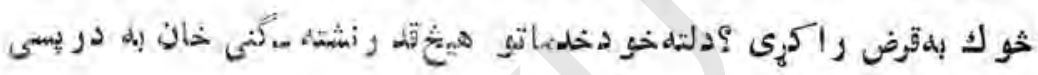
اوسخهله اغلى و ك كنيله.

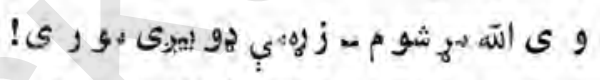

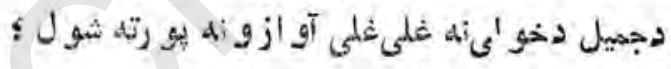

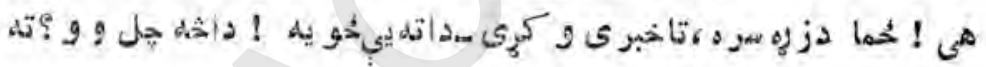

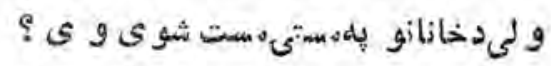

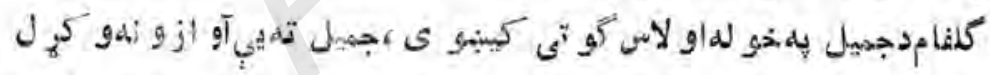

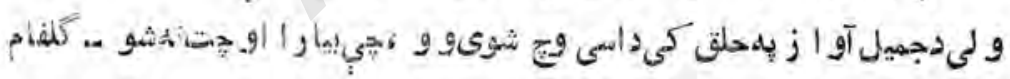

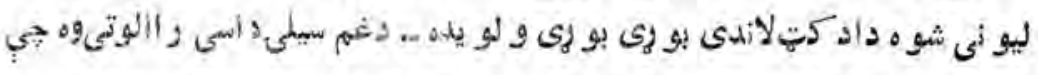

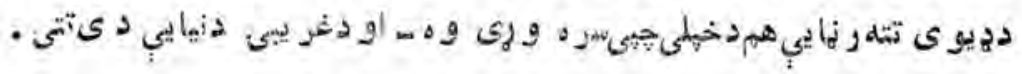

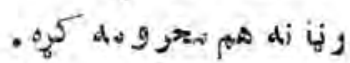

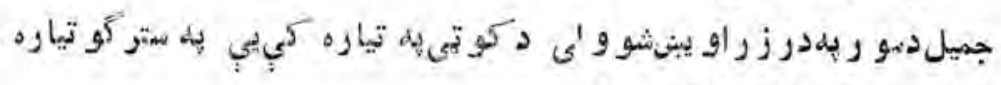

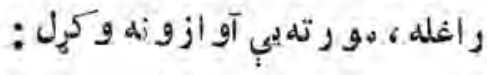




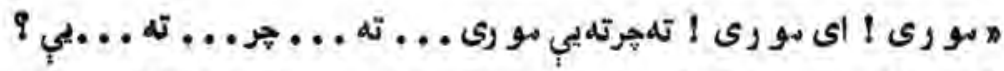

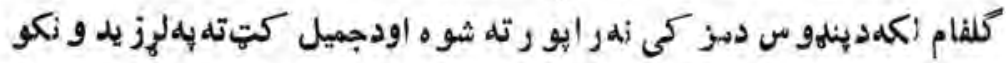

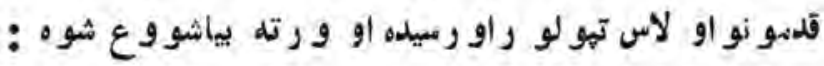

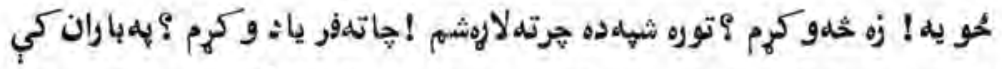

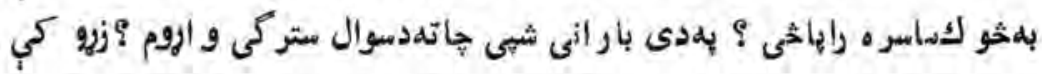

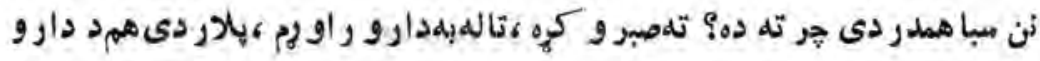

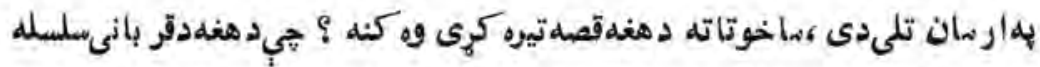

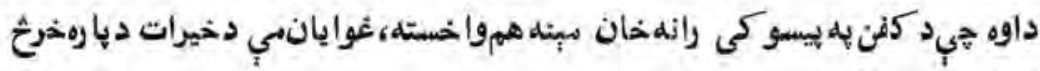

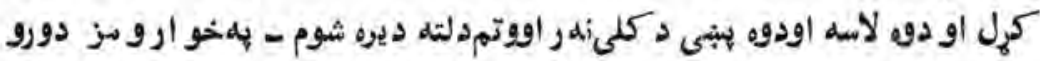

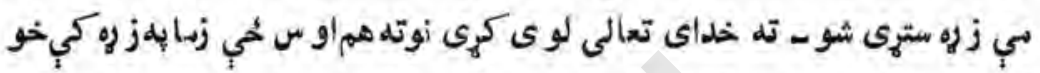

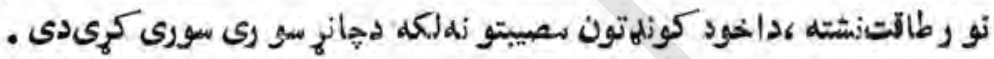

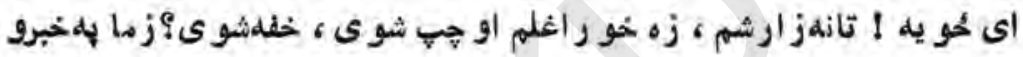

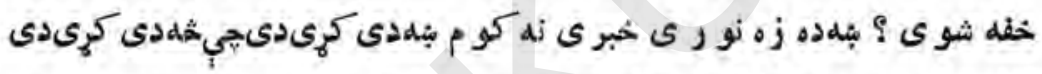

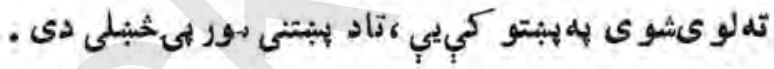

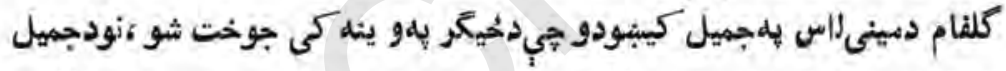

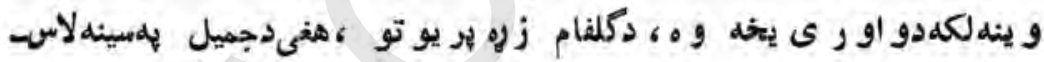

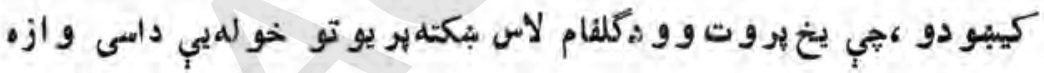

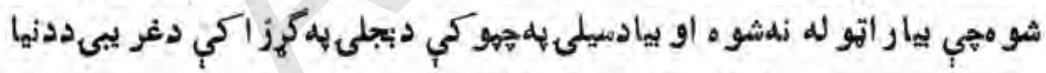

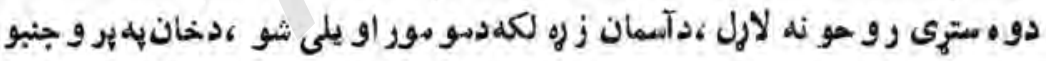

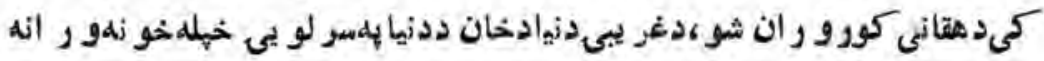

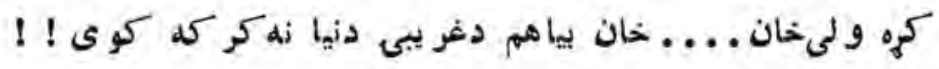

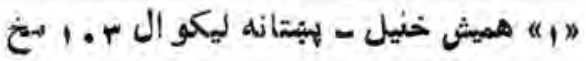

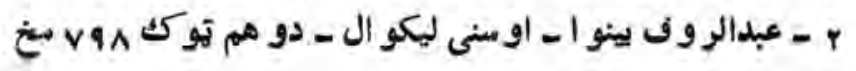




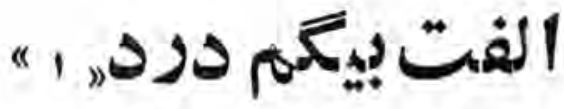

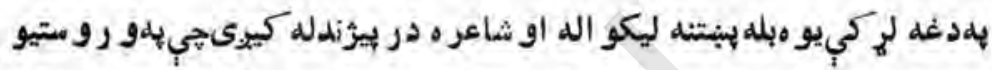

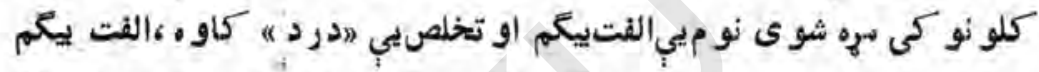

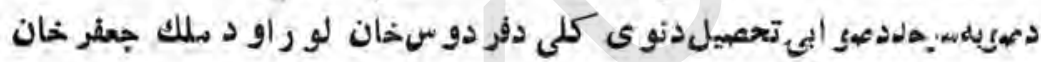

$$
\text { لمسيوه. }
$$

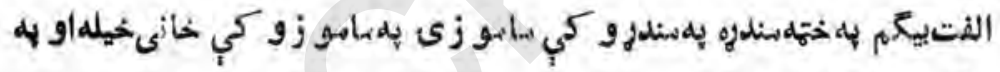

$$
\text { خانى كي بابا على خيله وه ه. }
$$

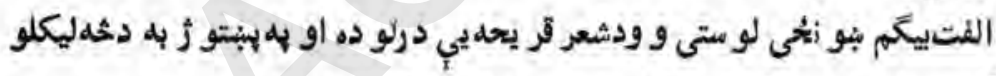

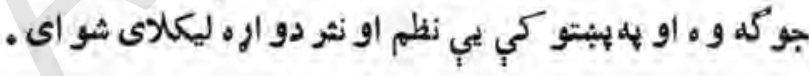

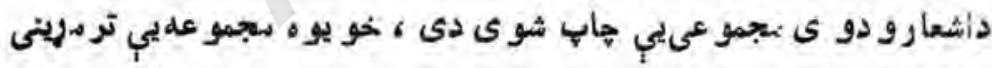

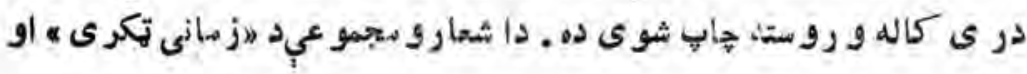

$$
\text { "حيات درد ه نو ميزى. }
$$

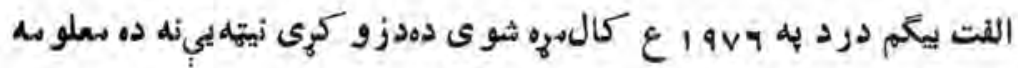

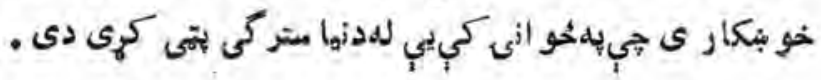


داهمد الفت يعمّ دكلاميلكّى :

دآسمان راته جو رين تندى خراب دى

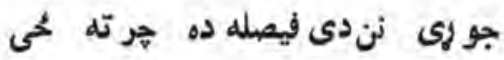

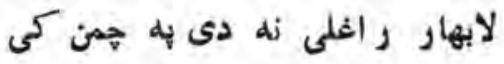
نه ترسرةدى و علده ده خرتهلحى

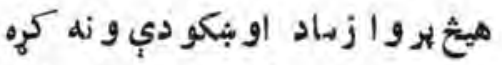

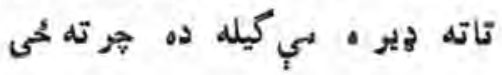
ما به خهله د رنه كهى دي تركلى

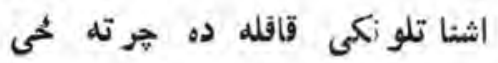
اتوال كرى سي اجل دي بله خبرو

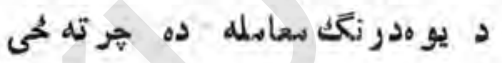

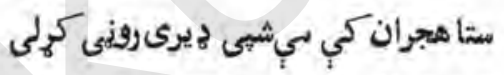
وخت دو صل يوه لدحه ده خر ته لحى

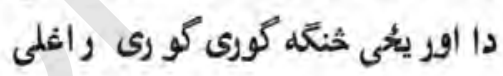

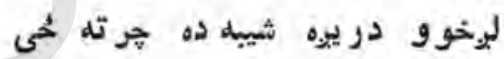

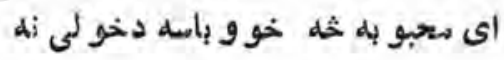
تير يدو نكى كو ر ى شهه ده جر ته يحى نن بى ستو رى دقسيمت بلغنور خيدودى

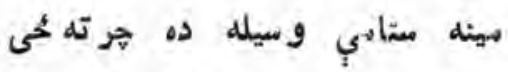
ساقى راغللى او و ريخى جام او جت كهد

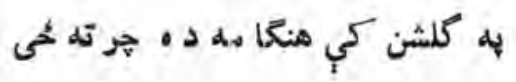




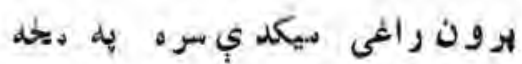

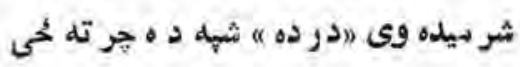
* * *

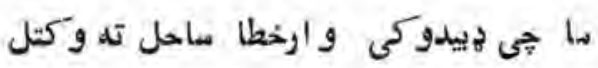

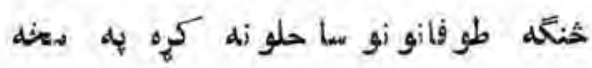
داخنكله سيلى بار ان ،زل زول بو ينبناده توره شيه

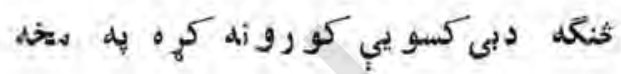

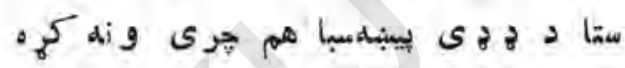

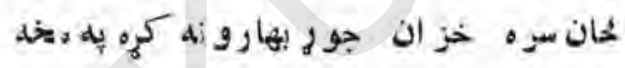

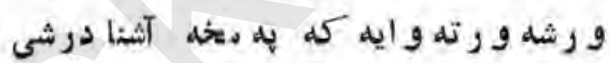

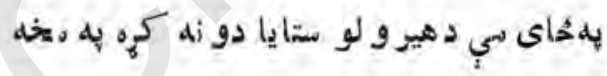

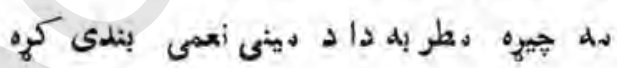

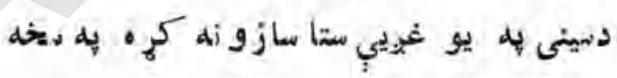

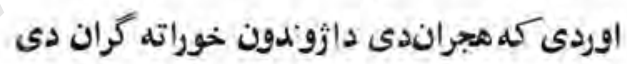

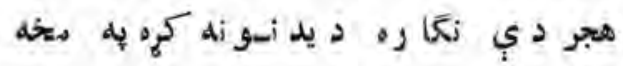
اوس دي ضورو وت ساقى درحم راته نهشتهله

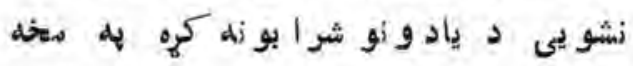

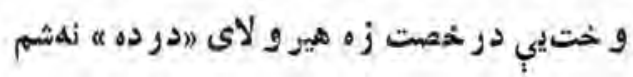

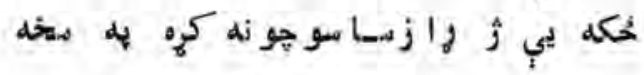




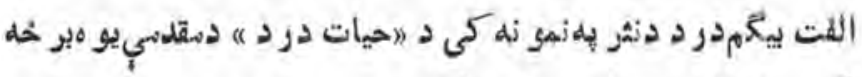

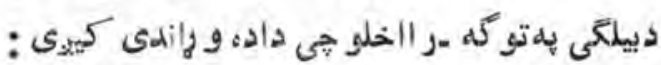

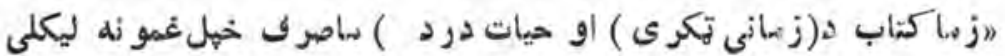

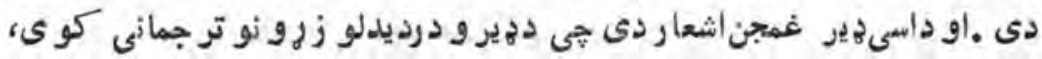

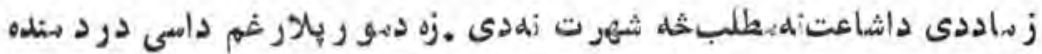

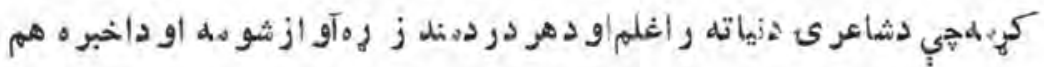

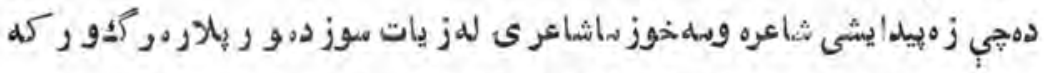

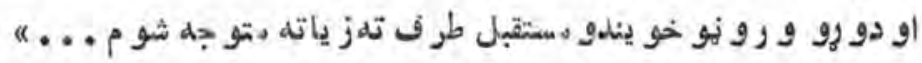

" " زلهى هيو ادنل - ييد يانى كلو نه - ه ميخ 


\section{زيتونبانو : (1)}

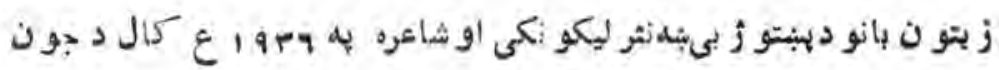

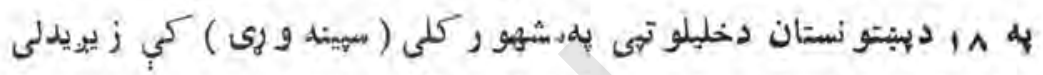

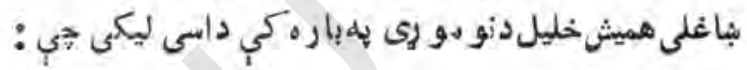

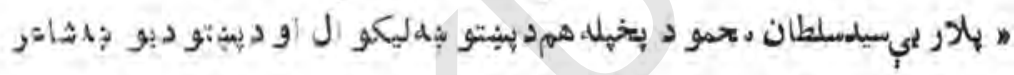
سيلدبدالقدو س "تندر ") مشر ى ز و ى دلى.

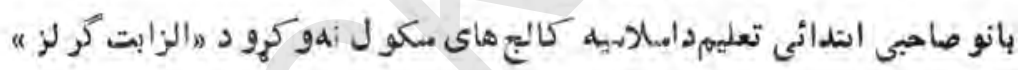

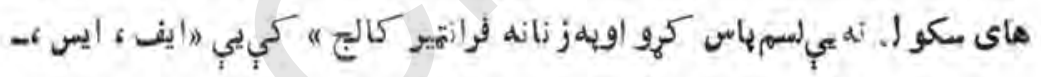

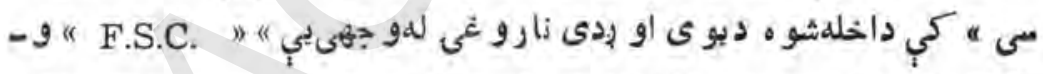

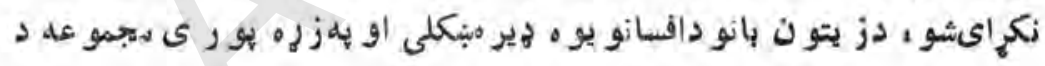

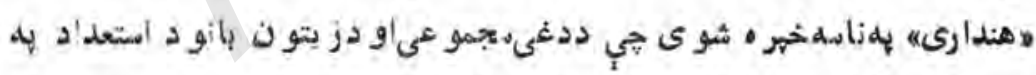

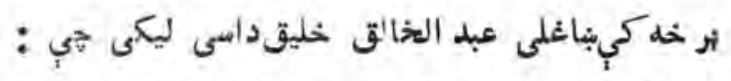

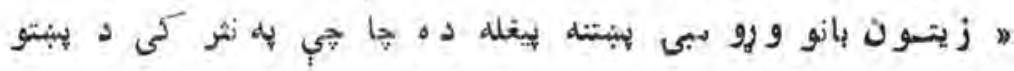

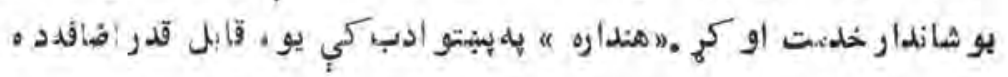

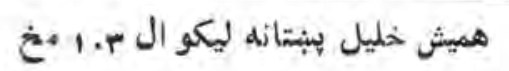
1.4 


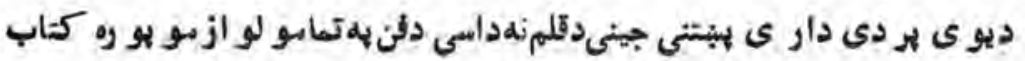

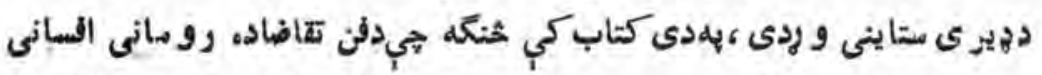

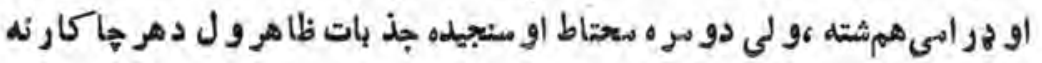

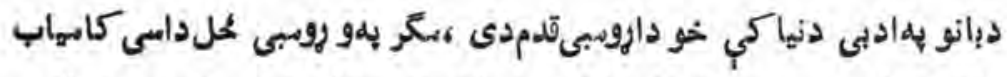

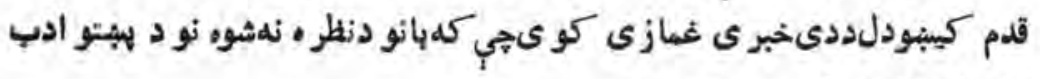

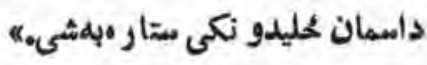

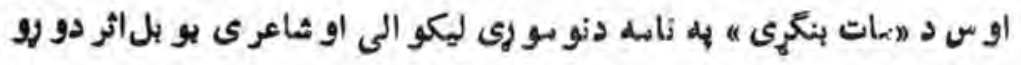

$$
\begin{aligned}
& \text { داستانو نو سجموعه هم خهره شوىده } \\
& \text { دا هم د نو مو ري د نثر بيلاكه : }
\end{aligned}
$$

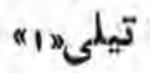

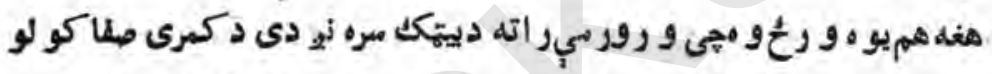

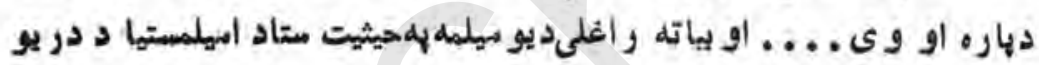

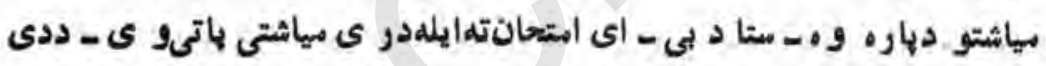

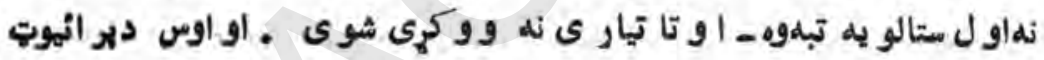
امتحان د ديار مدىعان تيا روهـ.

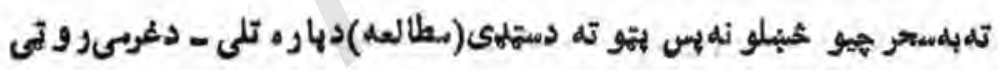

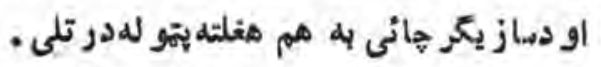

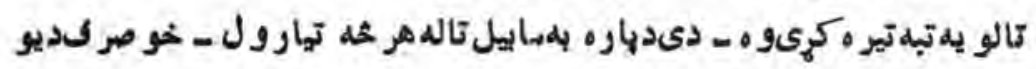

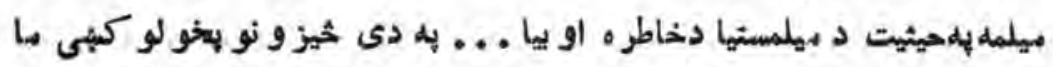

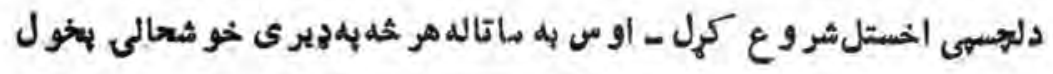

$$
\text { r. }
$$




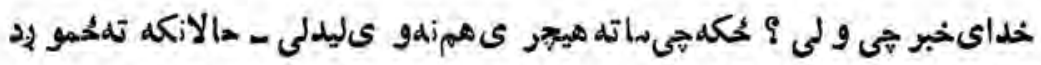

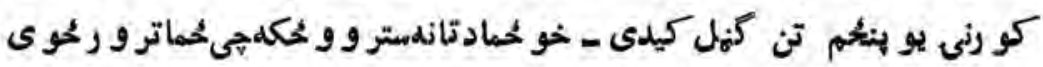
او شاهامحوى خونهو ى كنه - خو صرف بى دو رو ريو دوست و ى ياده دى

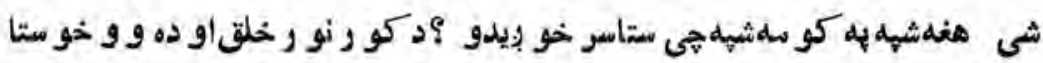

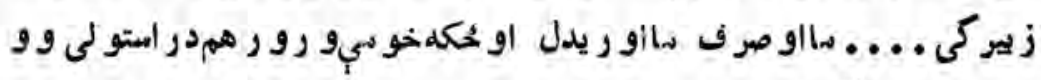

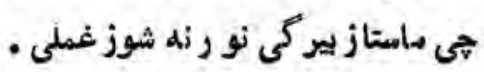

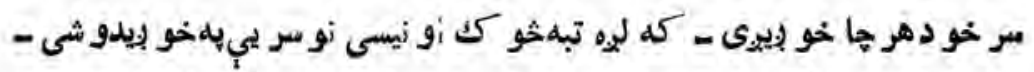

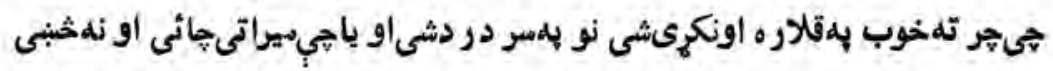

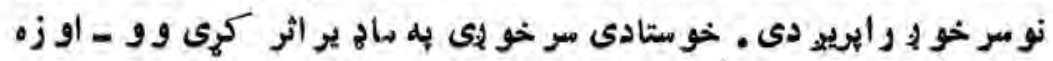
تو لمشهنdو وم اودمثوى

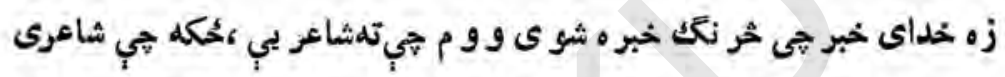

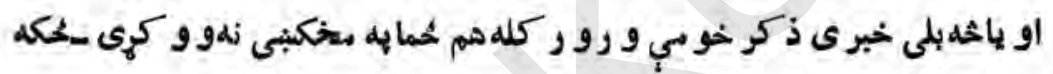

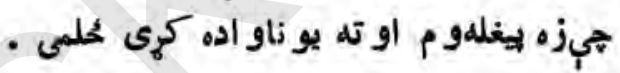

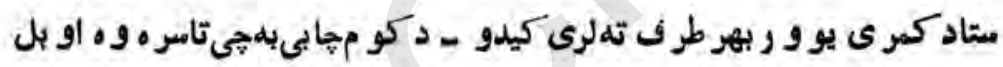

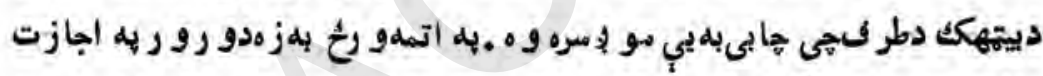

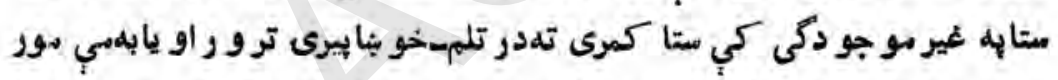

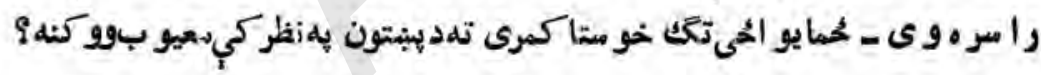

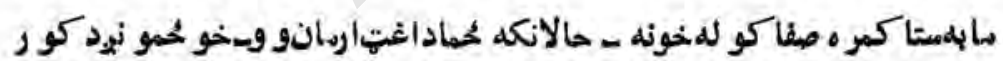

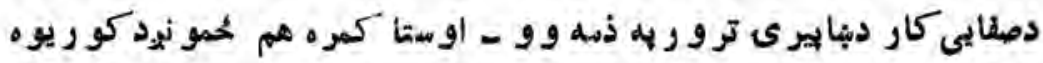

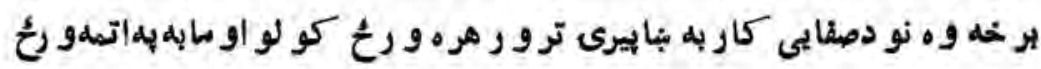

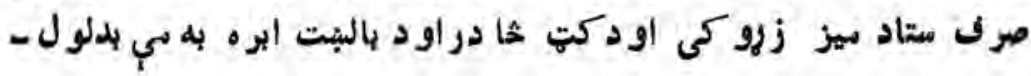




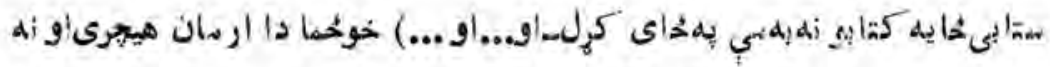

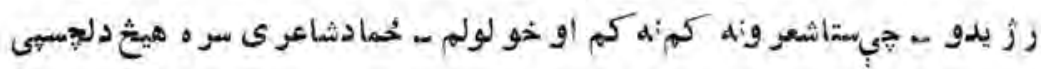

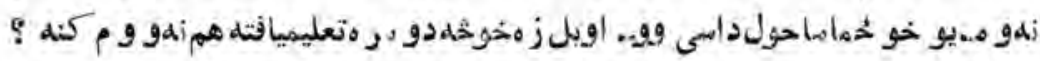

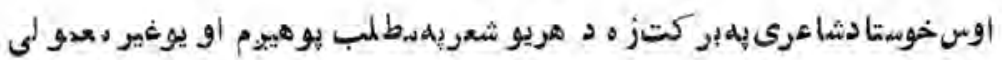

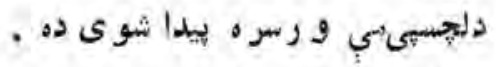

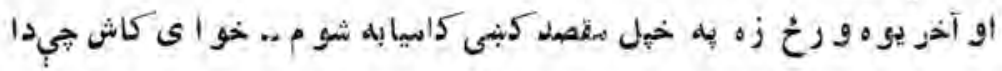
.

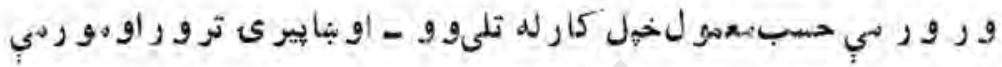

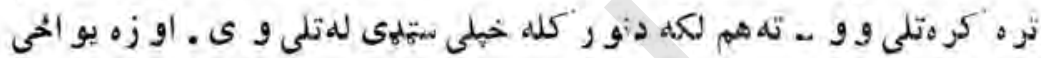

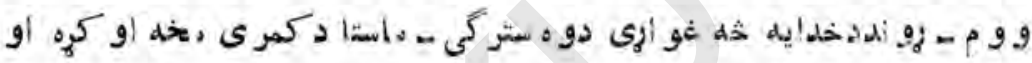

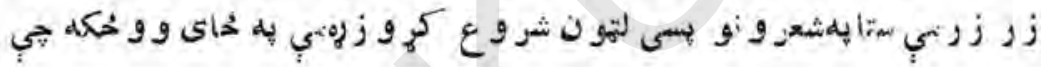

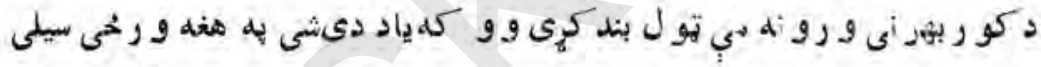

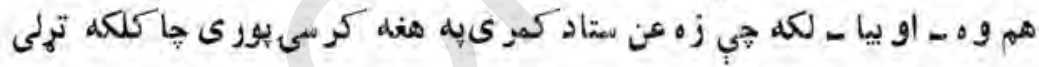

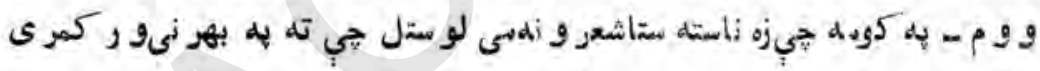

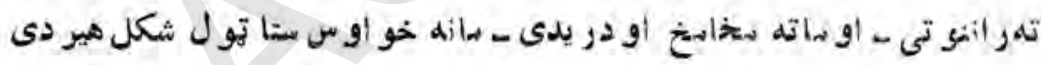

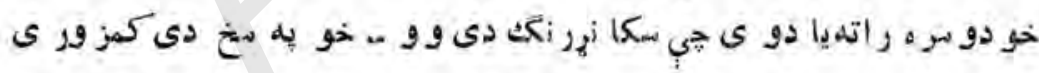

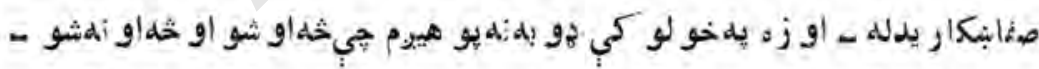

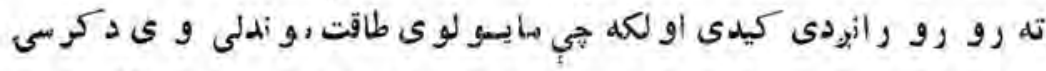

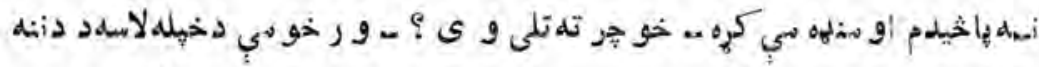

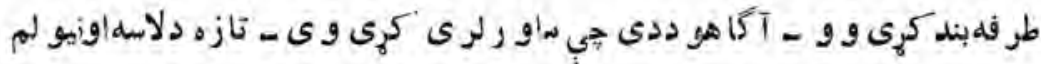

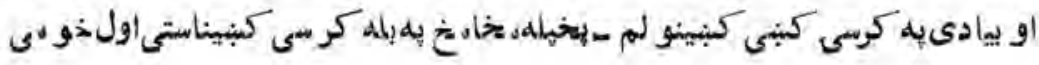




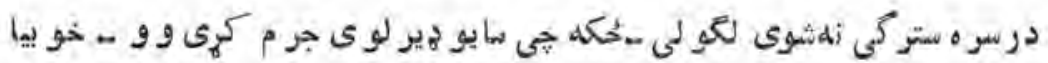

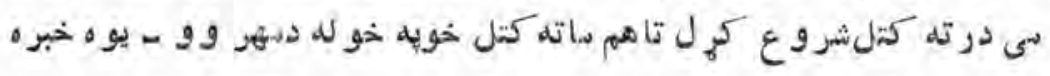

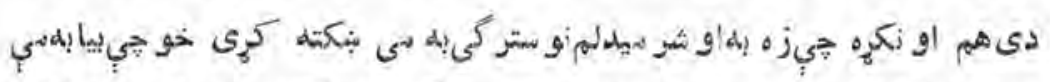

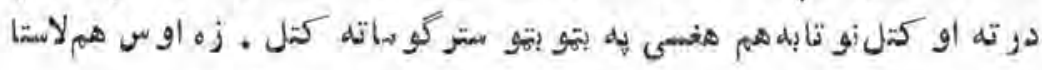

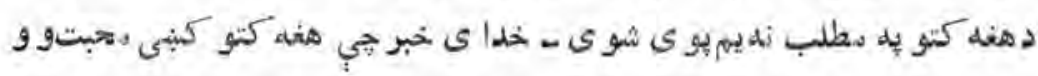

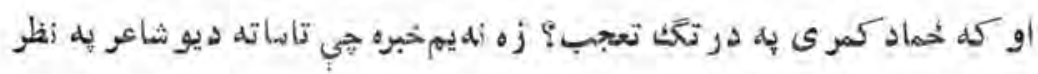

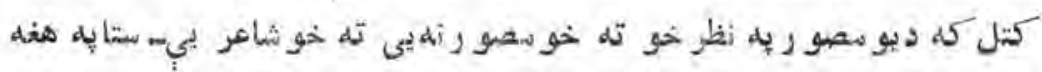

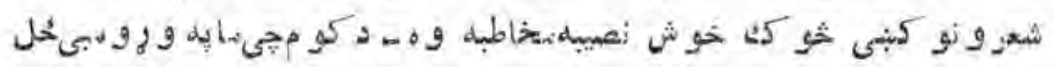
لو لو سنى 9

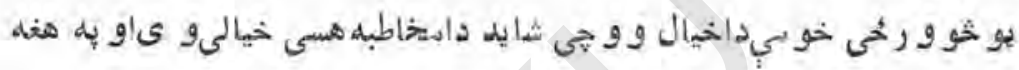

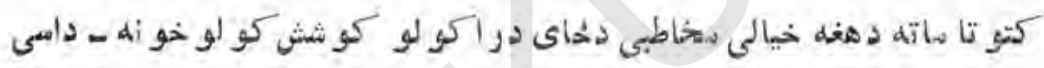

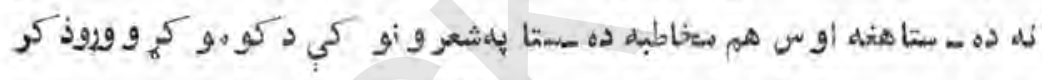

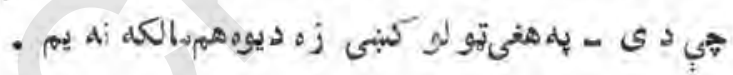

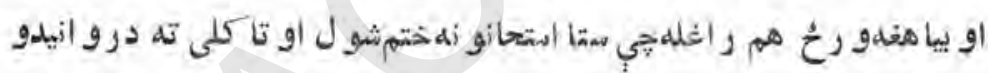

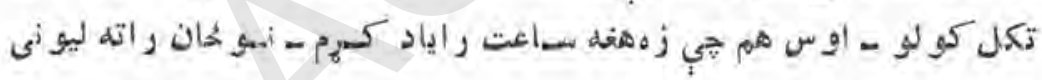

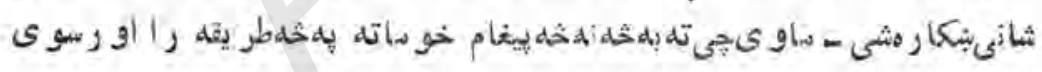

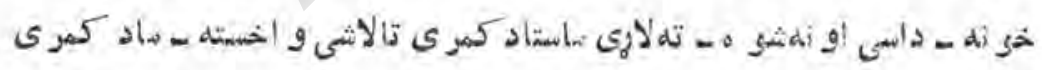

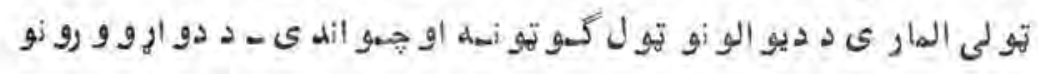

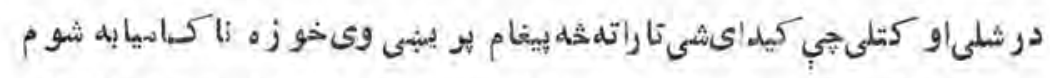

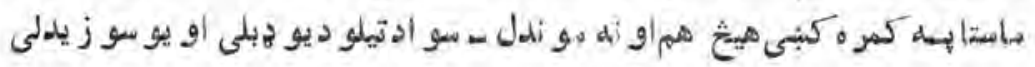

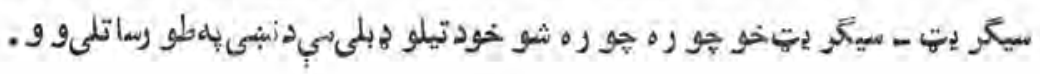




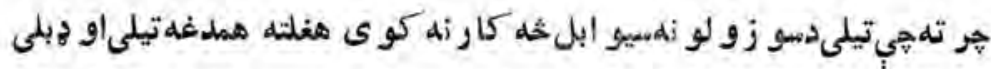

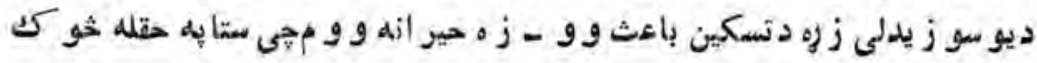

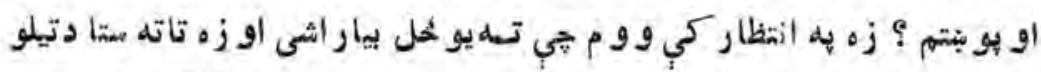

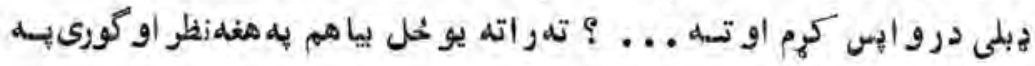

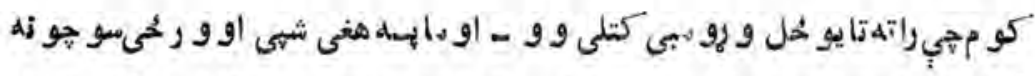

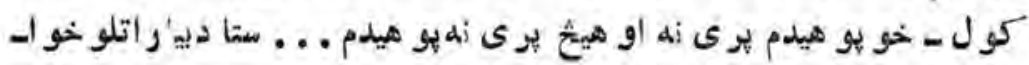

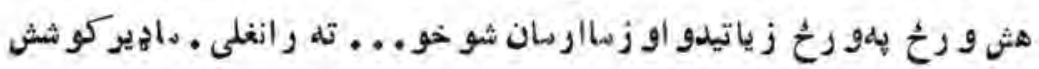

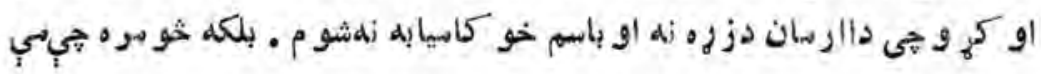

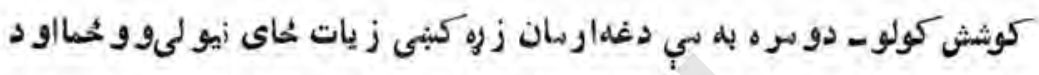

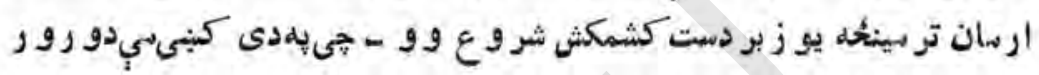

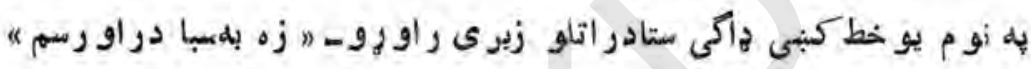

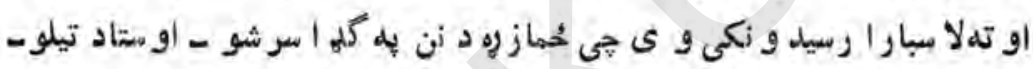

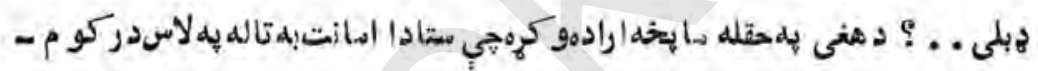

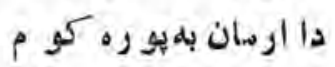

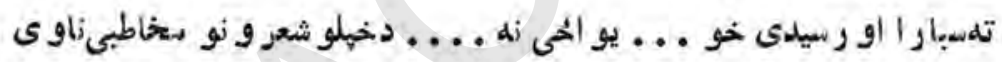

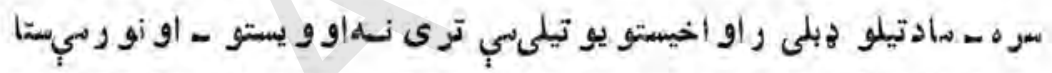

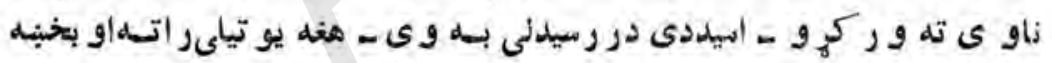

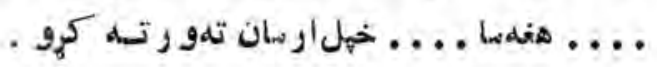
دزيتون بانوشعرد لفظى رنكينى له خوا بورو غنى اوششعرى كيفيت به كى بلهلو هـ

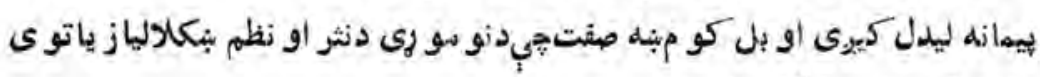

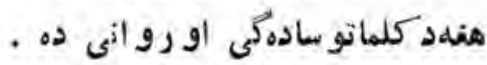




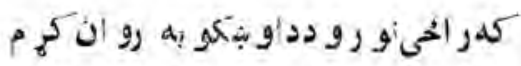

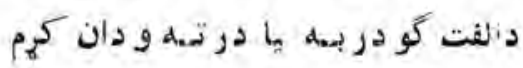

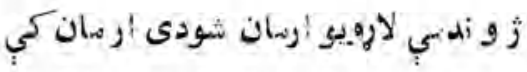

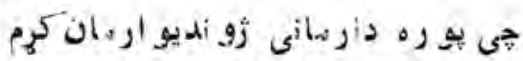

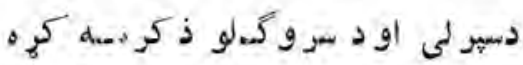

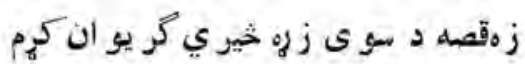

دا خو او بنكى ثحار ول د دى ستا له غمه

سر بسل هم داستاله سر خحينى قر بان كريم

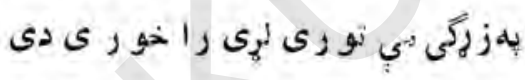

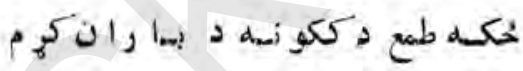

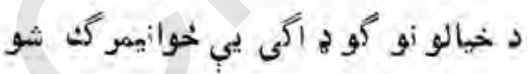

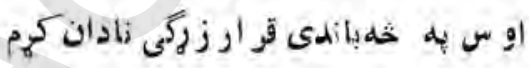

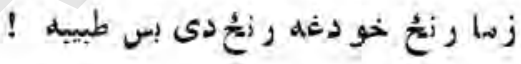

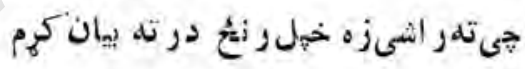

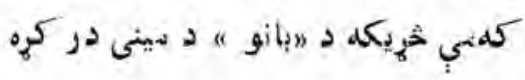

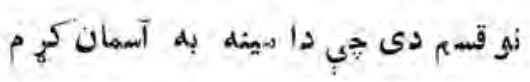

(1) بينو ا اوسنى ليكو ال دو هم تو كث بمنيخ

$$
1 \cdot \wedge
$$




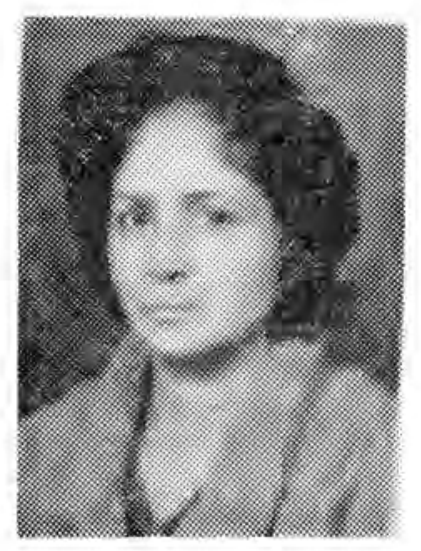

\section{بلقيسمكيز}

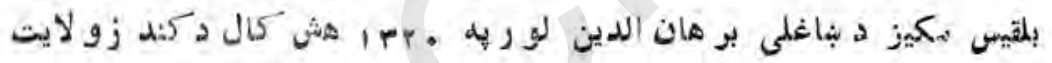

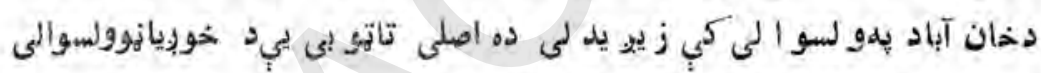

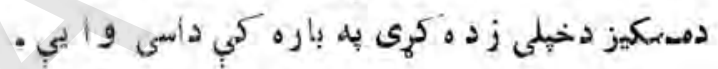

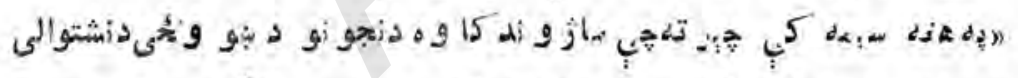

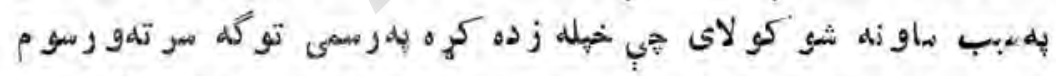

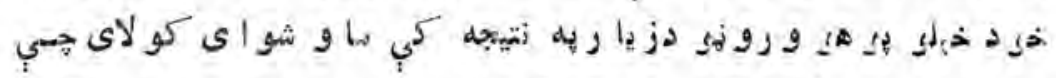

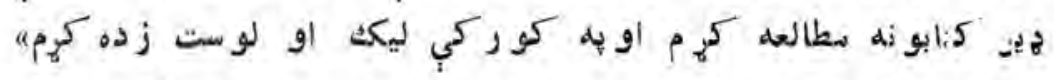

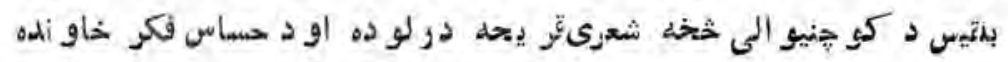

$$
1.9
$$




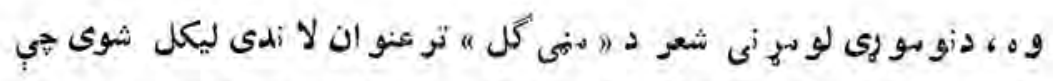

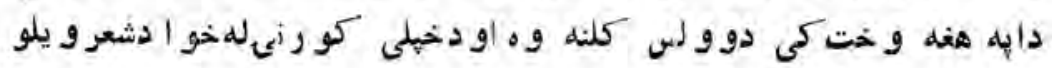

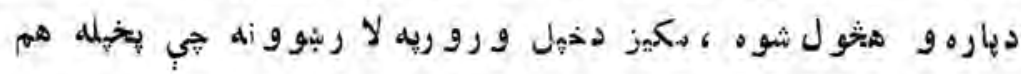

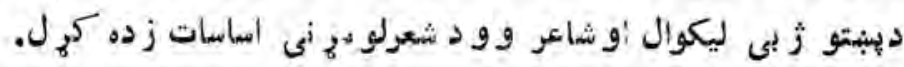

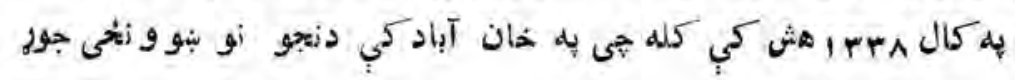

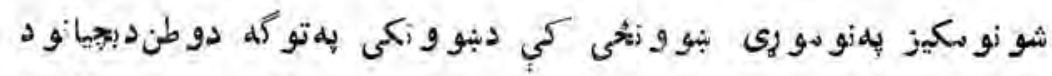

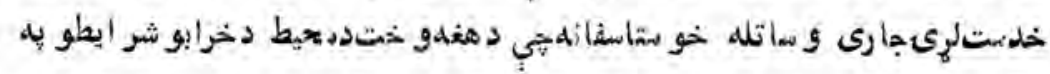

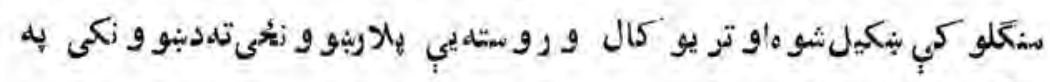
توكة دتلو ا جازه و ورنكيهـ.

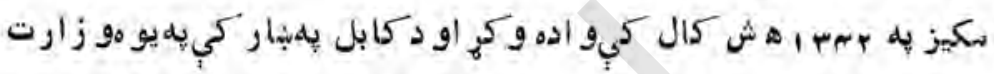

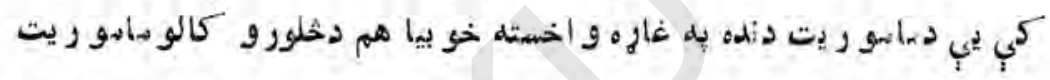

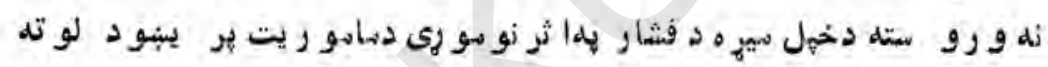
مجبو ره شوه .

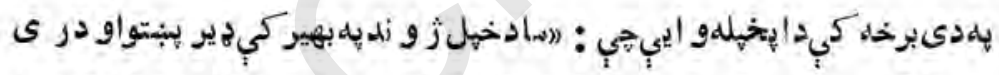

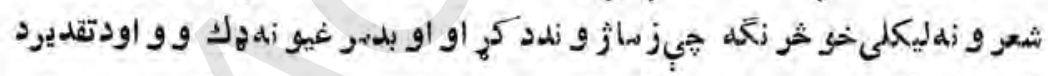

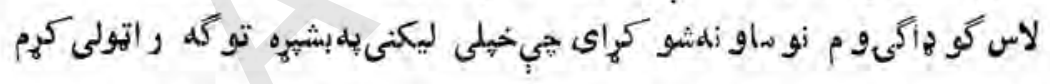

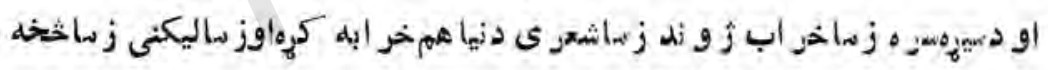

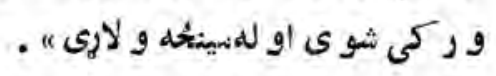

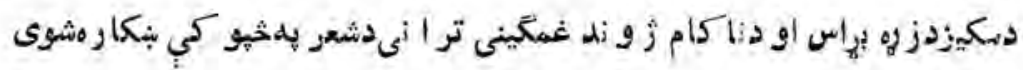

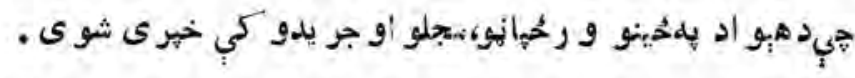

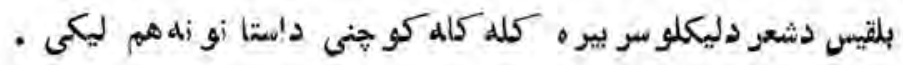




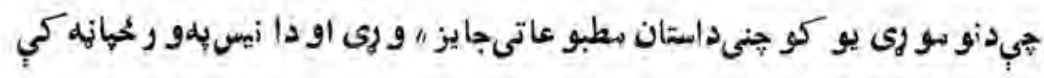
جابشوى دى .

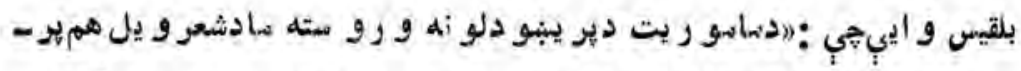

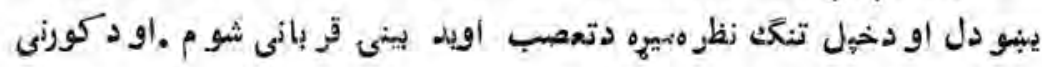

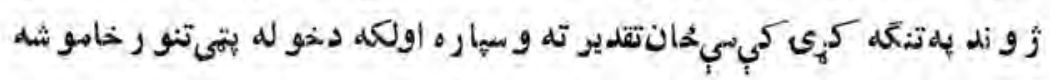
كيناستم

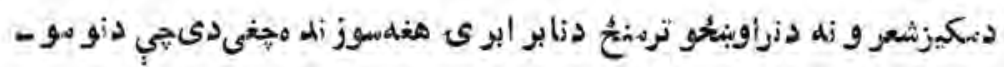

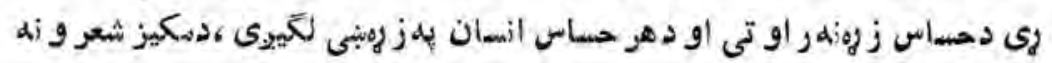

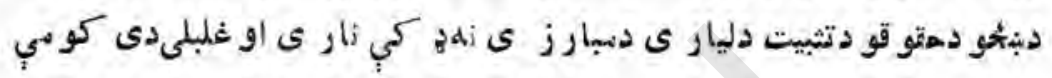

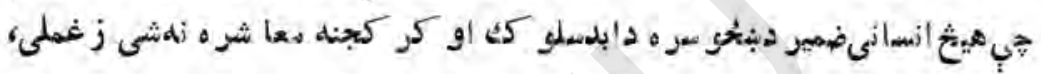

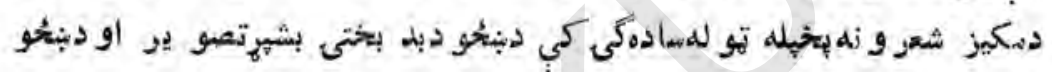

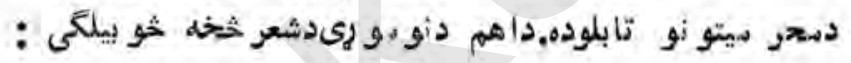

\section{دز مانى نلمم}

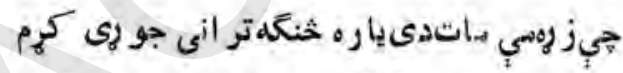

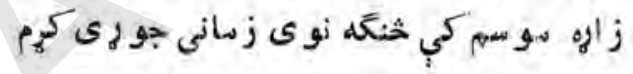

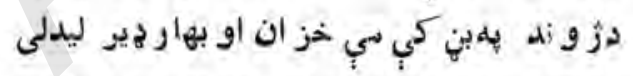

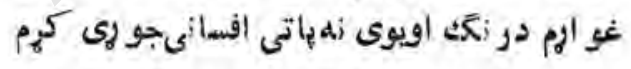
دار ها نجن عمر بله يأد به ثهل سلكى و همه

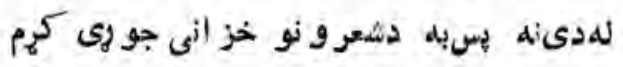

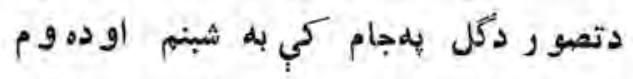

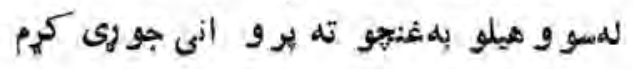




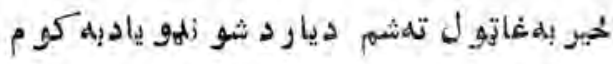

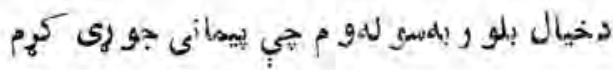

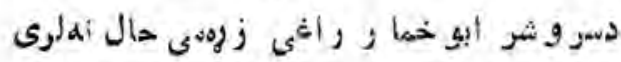

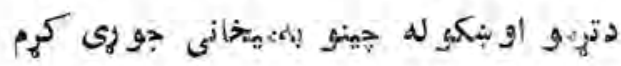

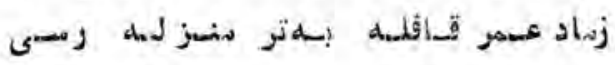

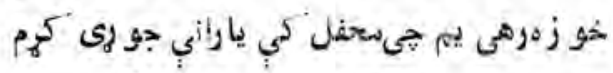

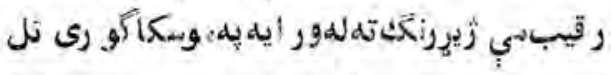

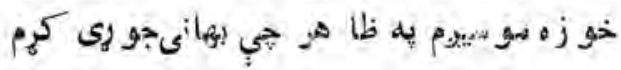

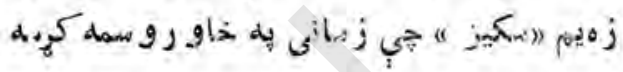

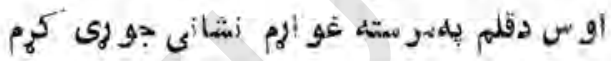

\section{vن}

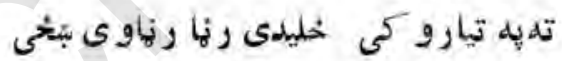

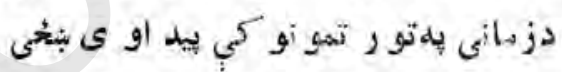

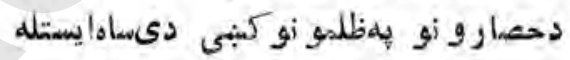

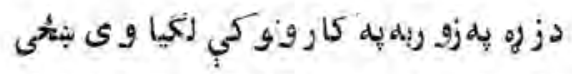

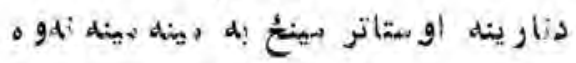

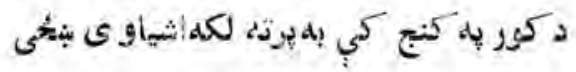

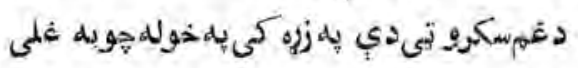

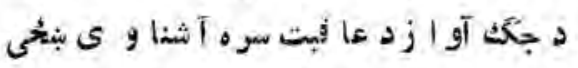

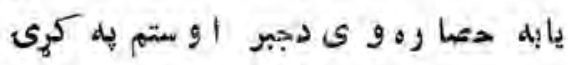

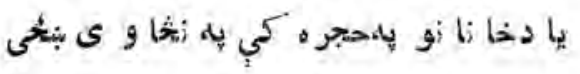


تهو ى دزو ر زنذر اله خِي إهيب خرخه كَّلى

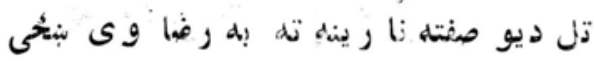

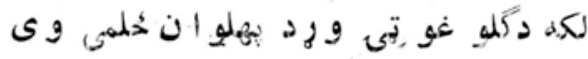

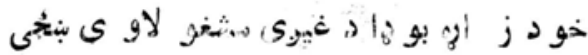

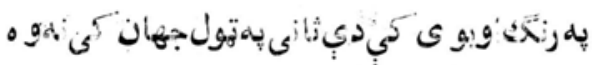

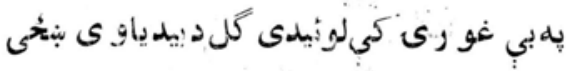

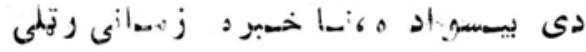

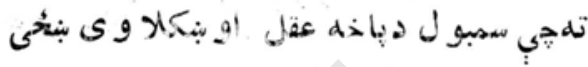

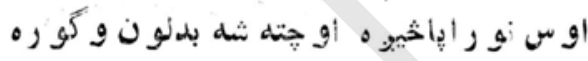

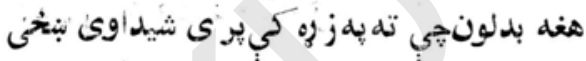

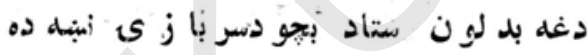

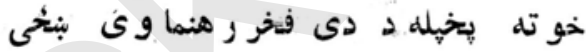

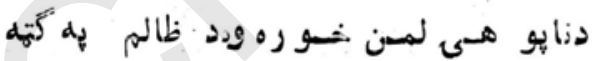
تهبلتيار و كي لكله ستو ر ى دسباو ى نبخئى

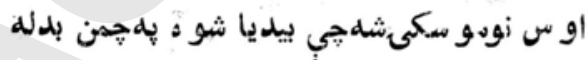

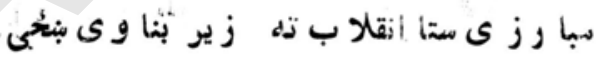

\section{توبييز}

زه يوه بنحمه يم خو تير و زمانو وهلى هيلتو رو شيو دزو ندازهله كي بي سحر أهليده

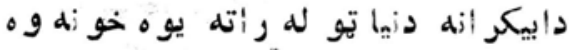
د نجلى تو ب إه جر م بنده ما بهر زله ليده 
نهمى داهل و وبى قلمبهكربو و اجومه

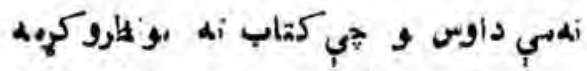

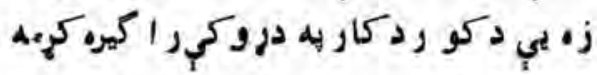

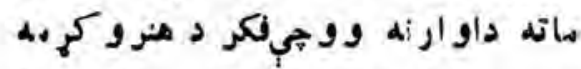

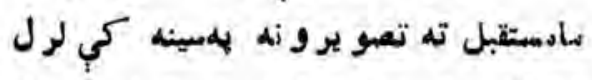

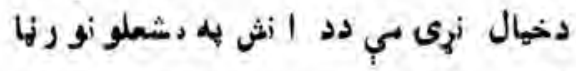

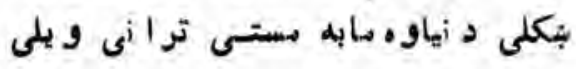

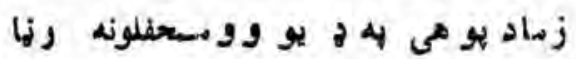

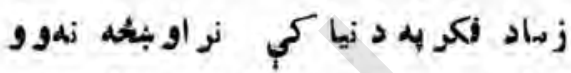

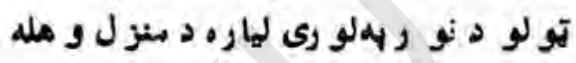

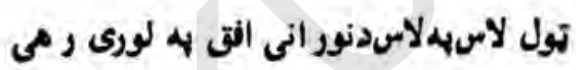
و مغه لار مجي اتلان و ر باندى تلل و ملد خوس بلهو و متركوويهوشنلهويهي بامو كتل

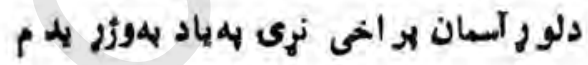

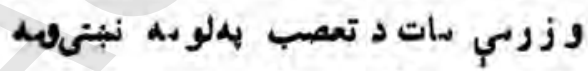

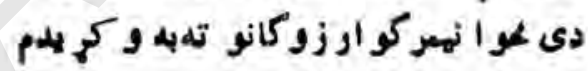

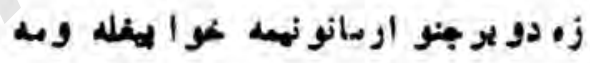

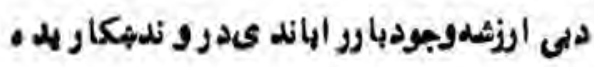

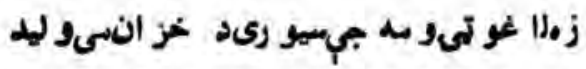

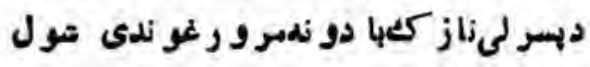

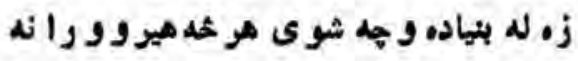

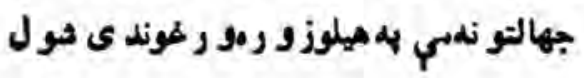




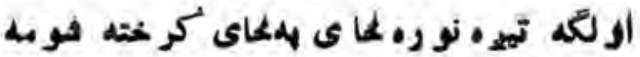

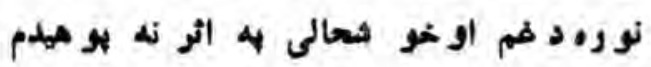

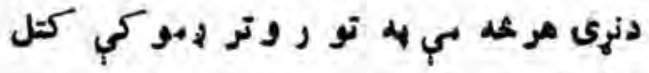

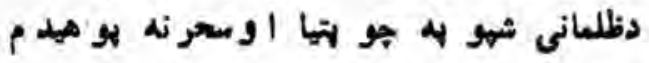

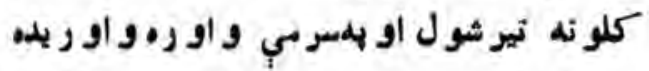
زه لا هعا غسى ستو بـانه متميدم هله لياره

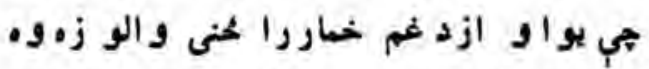

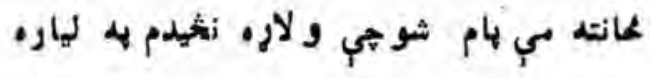
هو- ما آو ازد انقلاب و، داد خلكو آو از دنر اوبثلى د تسو يير د نيسا بد له شسوله

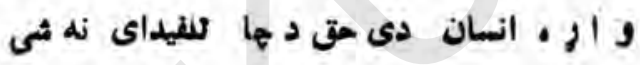

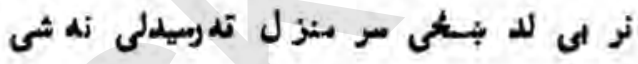

\section{نوره مى بويوده}

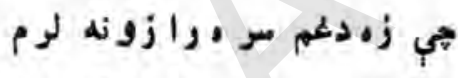

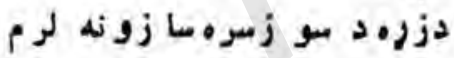

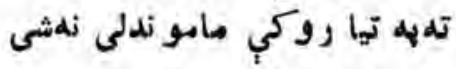

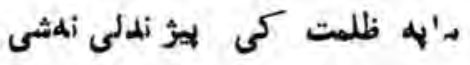

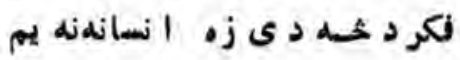

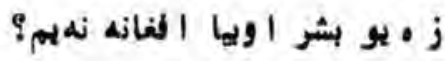

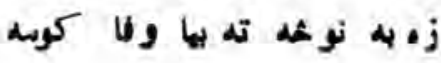

نو ربمي مهلحو رومبحم رالحنم

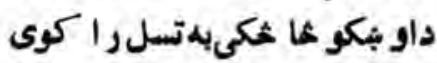
لمه، جيدنياشو مر اتدتو رو تياره

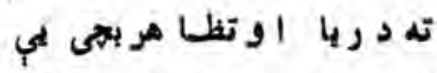

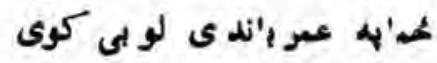

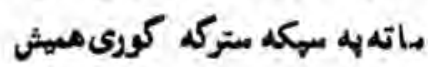

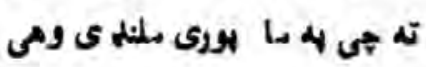




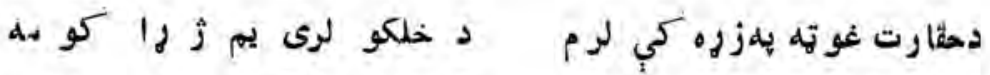

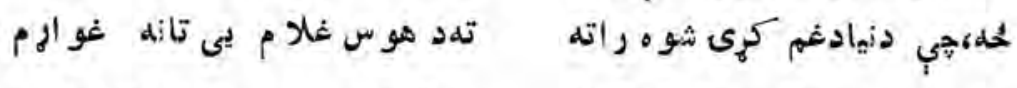

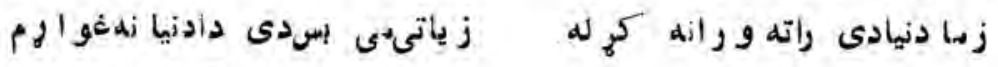

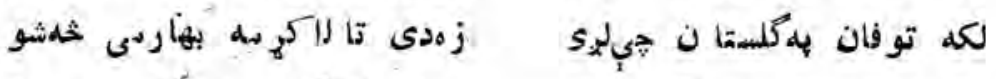

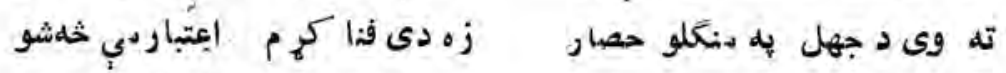

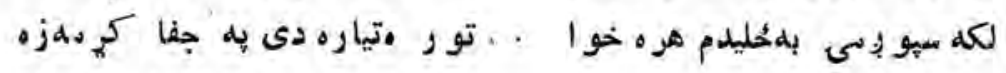

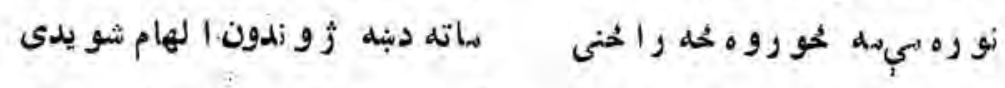

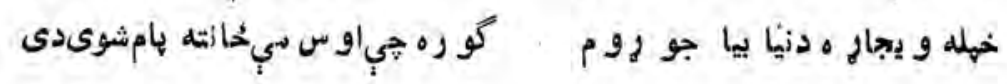
زمفنا يم

ماته مه كو رو للهو رايه ماكي تابدليدو نشته ستا بهليئه كي رسو إيم يا رونداته ابرو زتشثل

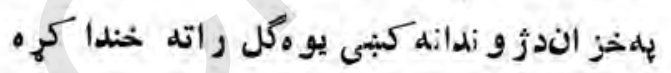

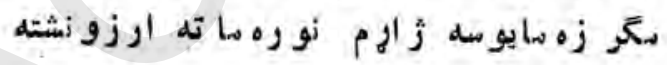

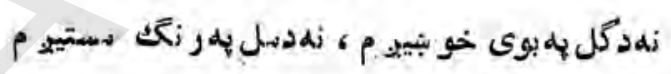

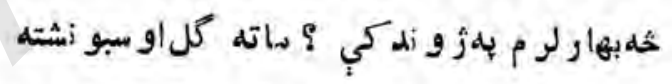

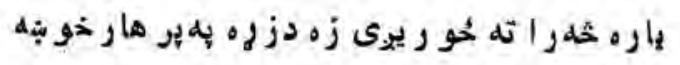
بو يو ده بو ييو ده خب فناشم هيث حاجتدرفو نشيته

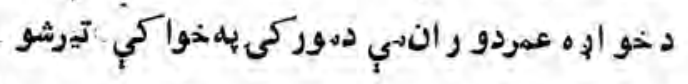

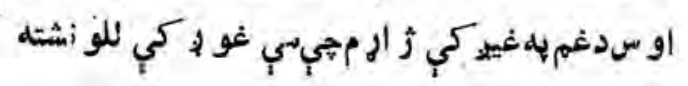




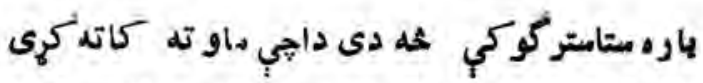

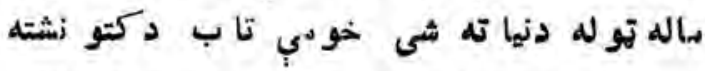

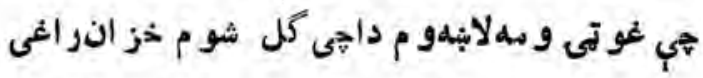

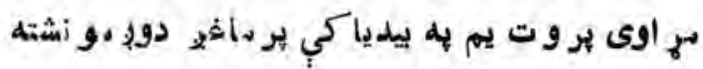

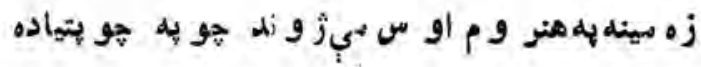

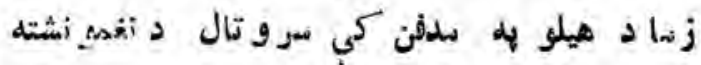

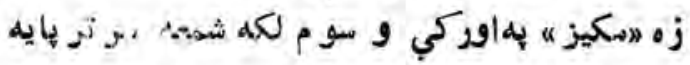

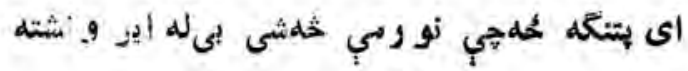

\section{و روستى هيله}

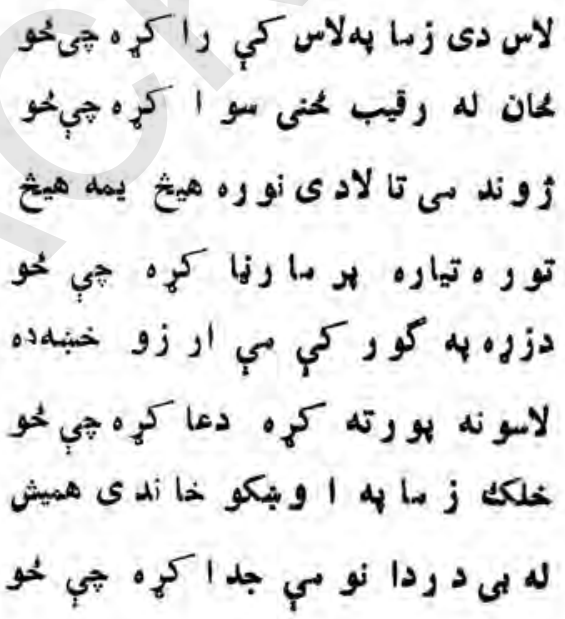




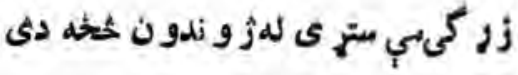

ته مم جهان ته نو ره شاكره جي يحو

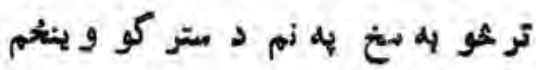

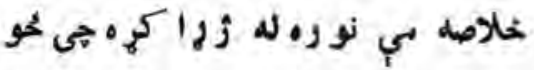

زه سادمز رى بهد تسا تير و تمه

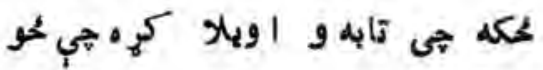

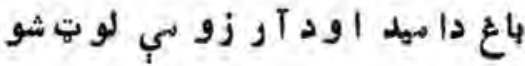

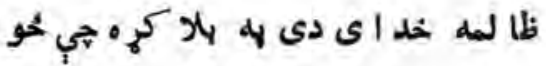

زه هل مكيز مكيز را لو يه شو مه

تاهل جل ول ور اته بلا كمه جي خحو

سركمهـ تـا لـره عـرضونسه لرم

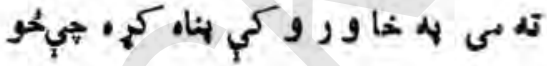




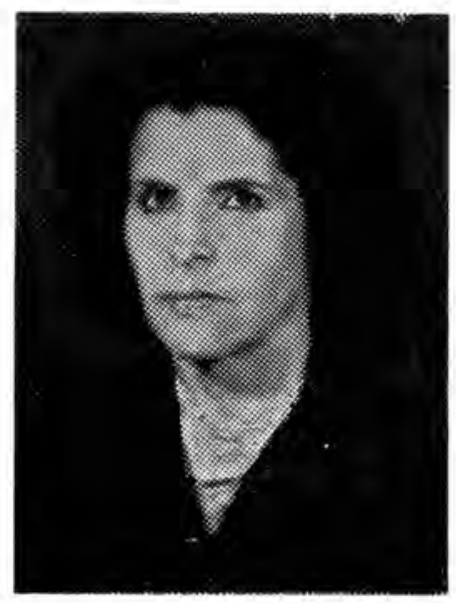

\section{شرين تاج نسرين}

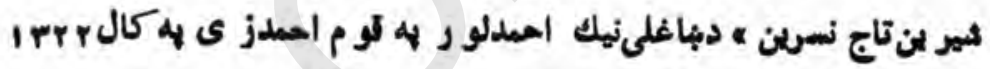

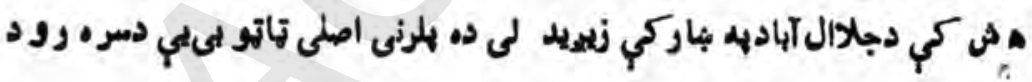

$$
\text { ولسو الى ده. }
$$

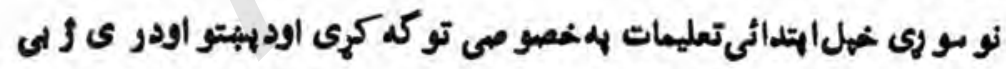

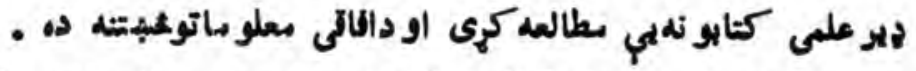

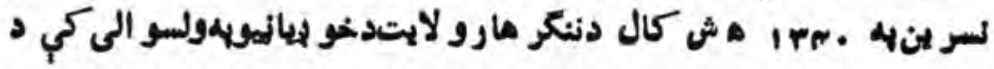

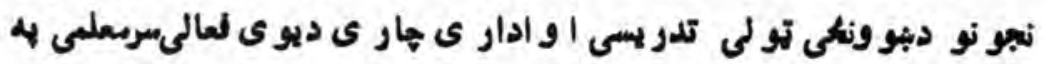

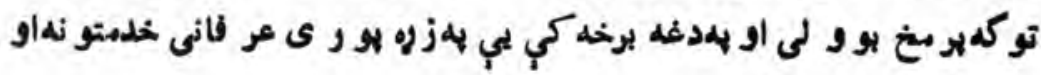

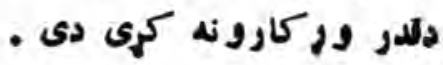




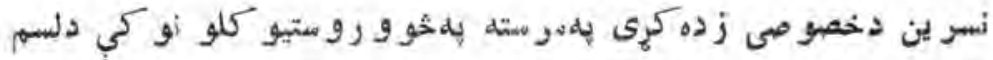

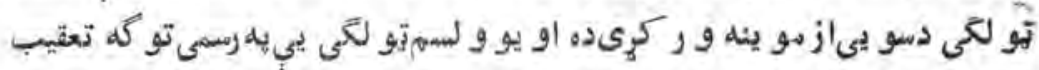

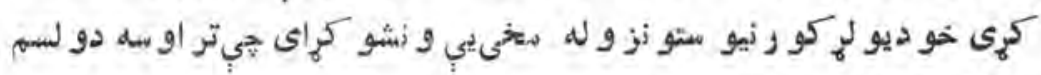

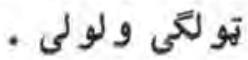

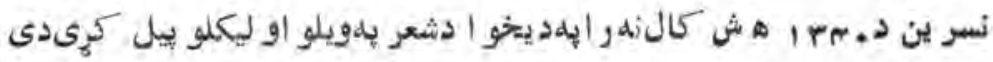

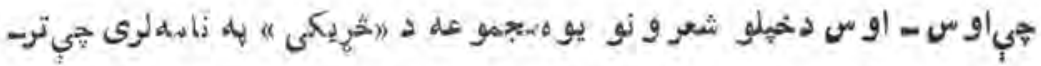

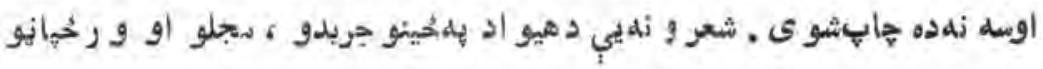

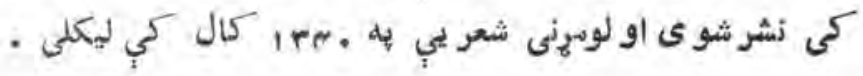

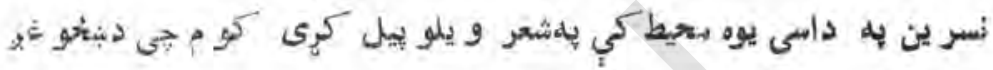

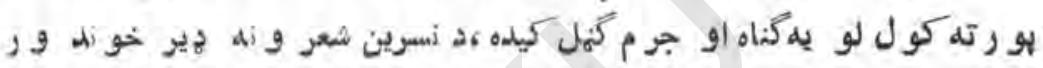
ساده او بى تكلفه دى ، هغلو ايى خيى :

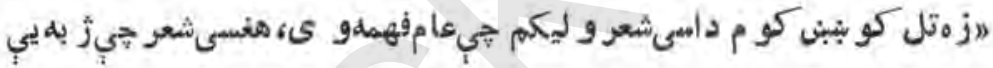

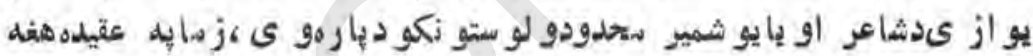

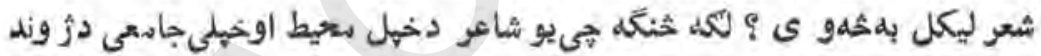

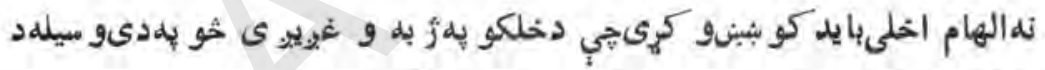
خلكو هلهزو كى نتوز

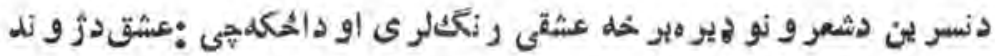

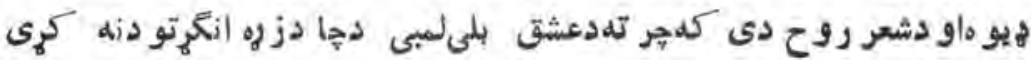

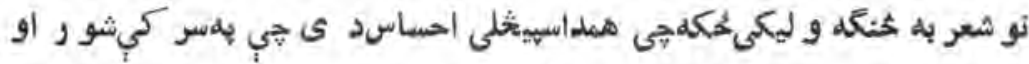

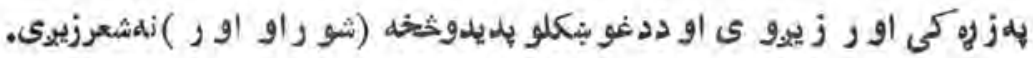

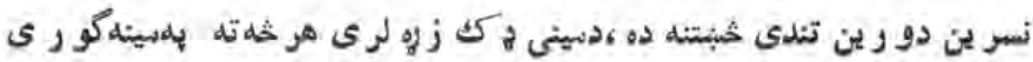




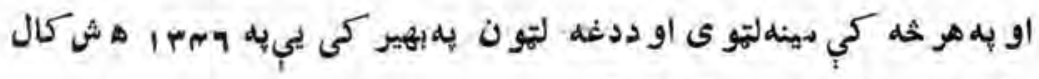
دبناغلى غلامنبيسوه و اده وكري:

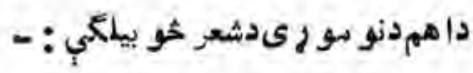

و نdiيزم

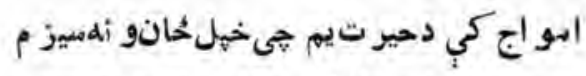

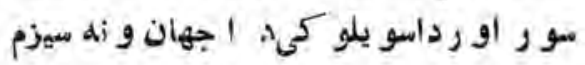

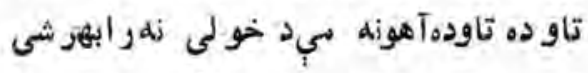

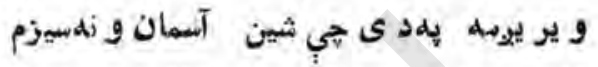

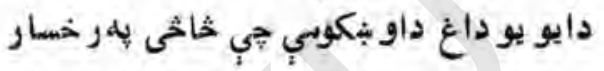

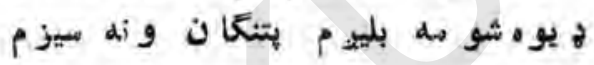

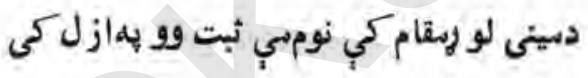
د) لام) و( بى ) بهنحُ كي اين و آنو انهسيز م كميا ردر باندى كرانوى اينسرينىلبريام و كريه دعثق له او ركّم لو بى جى جانان ونهميزم diend متانه كهبهيكتك شو له زمادينه نمغو اري بياز روبي دبل ها بينه

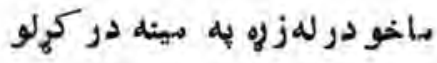
تاولى ونه كريه بله بمتيا بينه 
لاس بلهرد نيا نه به ربتتيا شونه

ملهيجي ياره ماسر ه شو م ستا دينه

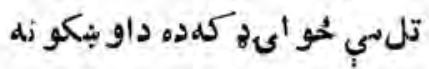

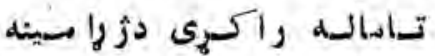
نو رماسر ه ملهاخله دجسفا نه كار نسلمبــائى و فا ستر ه جفا ديسته

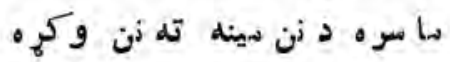
ثو كث به بيارز وأندى وى تر مبإينه

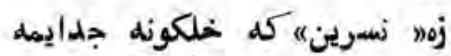

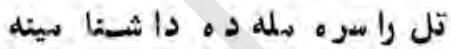

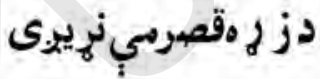

دا الختر بلهالمتشر دى هيبي تابلهاتيو يخىى

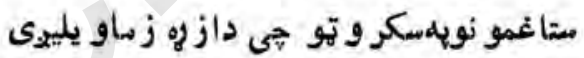
متاديدن ز نالختر دى ستاو جو دنىهم بر ات بى له تانه زما متركى نو ر هيحاته زه فهيخى

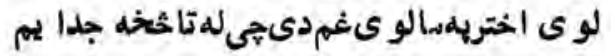

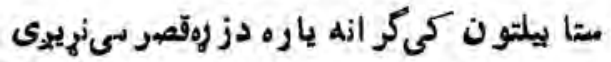

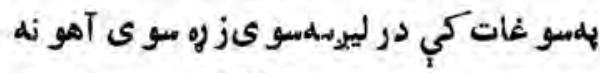

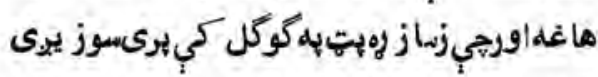
محو ريدلى سهن ستاساته اجل شو برى بو هيبم

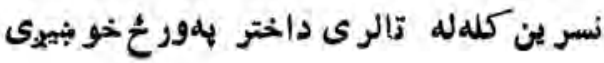




\section{هيخي}

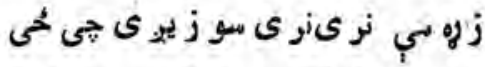

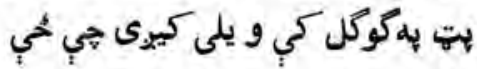

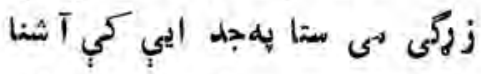

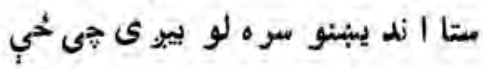

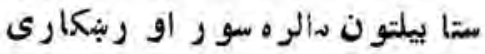

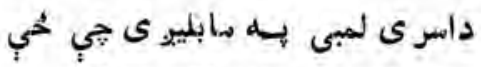

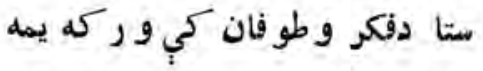

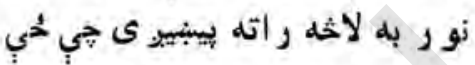

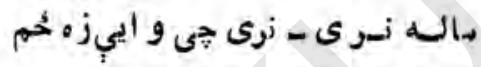

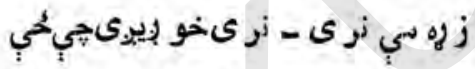

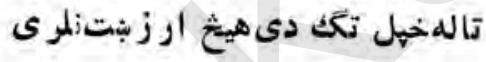

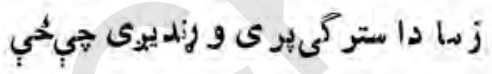

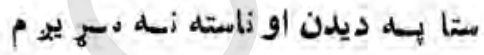

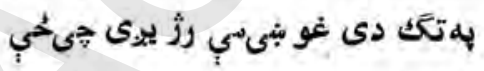

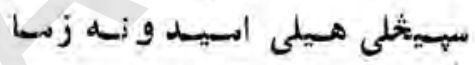

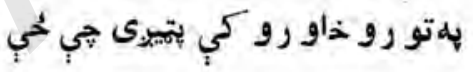

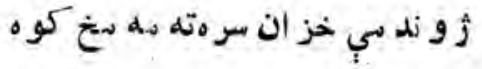

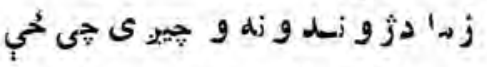

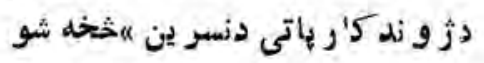

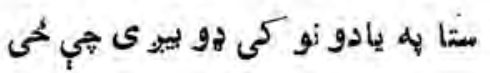




\section{دا غو نهراسره دى}

$$
\begin{aligned}
& \text { ستا غمو نسه ر المبر مدى } \\
& \text { تمتافكرو و نه رأسره ددى } \\
& \text { \% } \\
& \text { تو لثشو لهالو م فهو نه } \\
& \text { ستاو عدى او ستالو زو ند } \\
& \text { هير غمو أه راسرهمى } \\
& \text { لِك تنها غم كي تهم هو به } \\
& \text { * } \\
& \text { * } \\
& \text { لمه هالعه او بـه كير م } \\
& \text { ستا غمو سبر هليو بييوم } \\
& \text { در يابو نسه را برهمدى } \\
& \text { خهلو او بنكو كي لبمبيو م } \\
& \text { * } \\
& \text { * } \\
& \text { خيانست ملكر ه ماحبت كي } \\
& \text { ز هو هل لييو ه شر بت كي } \\
& \text { مكت جامو نه ر امره مدى } \\
& \text { ستا هجر ان دىناته زئ } \\
& \text { * } \\
& \text { * }
\end{aligned}
$$

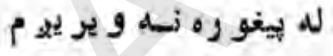

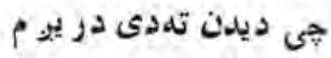

$$
\begin{aligned}
& \text { تهمتونسه راسر مدى } \\
& \text { * } \\
& \text { تستا دبنكلى بنا يستهله ن.بنى } \\
& \text { * } \\
& \text { تل بهز زهر بي زلز لى دى } \\
& \text { ازربا نو نسه رامسرمد ى }
\end{aligned}
$$

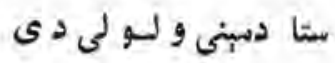

$$
\begin{aligned}
& \text { بتا ددو و ستركو ليدو بيا }
\end{aligned}
$$




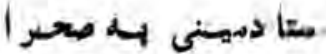

$$
\text { عالدونسه رامرهدى }
$$

*

$$
\text { فكر بـل خو اكريموم }
$$

$$
\text { طو فانو نسه راسر مديى }
$$

*

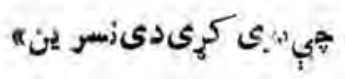$$
\text { ستاخهوالو انلهر اسر هدى }
$$

\section{كَل مـرغبو يمه تثها}

$$
\text { متا دمكر او غعسونسو }
$$

*

$$
\text { كه هر خمو دى هير و م }
$$

ستا دعشقاو خو إيىينى

*

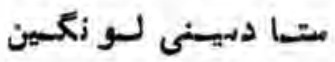

دعالم نسه إيمانسه

$$
\begin{aligned}
& \text { دهيلوكل } \\
& \text { دنيا بهستركوبي تياره ده خي تهنهيب آشنا: }
\end{aligned}
$$

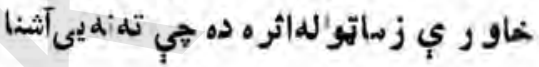

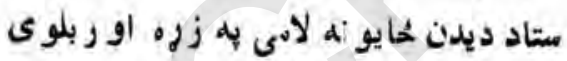

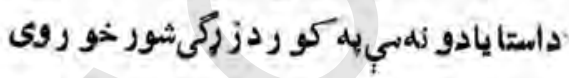

مبتا در قيب ديدن ههماقيامت لانو رجو روبى

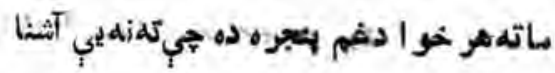

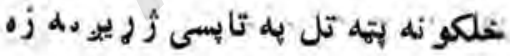

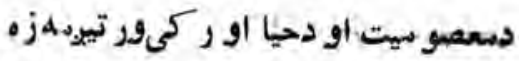

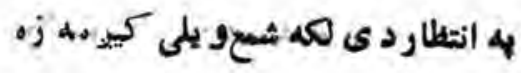

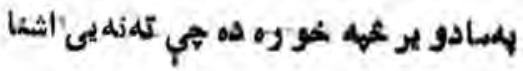




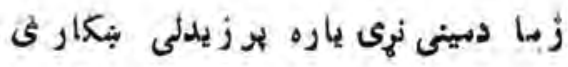
دارمان بيغلهنى سر تو ره تر هيدلى بنكارى ئري

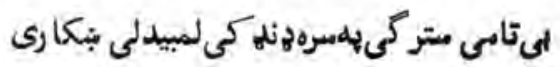

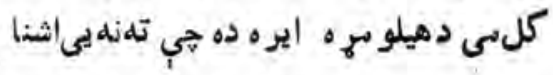

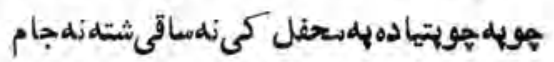
و ركى د مينى قافلى د ى لتو مله كلفام

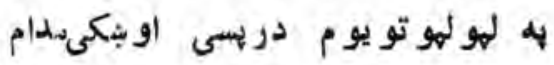

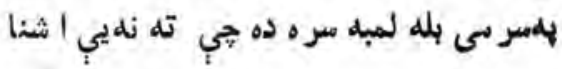
خو است

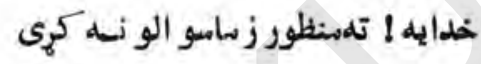
يار زمساد غسارى اميلو نسه كرى مده د اشنسا رامسره لارهمكيى ته زما بو وه تول إرسانونه كئى

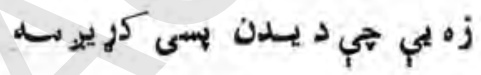
هائهته منظو رزما خو استو نه كرى خير دى كه اشنا سأ يجو روى ديد ام خدايه ! ورنهلوي تيول لغمو نه كرى

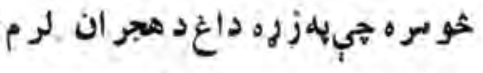
تول بخهل كرم و ورته كلونسم كيى 
كي و وته د مينى مو ز يله برخه كره هك كي عشق خورونهتولخخوندونه كرى

\section{ترخهنغمه}

كلهي لارشى له كلثن نه كلثن حمه دى روح خي لار شى له بلدن نه بدن خه ديى خهل كهول اوخهل تاتو بىر اتهاو رشو له تالرى دا شينكى خو إهو طن علد دى

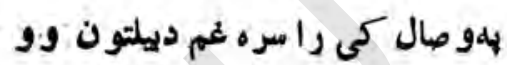
موز ماو ركيخ كتلهفملز و ندو نمهدى زه به و يوه و م د مركث او حلككدن نسه ييلتو نر اغعىاو مونو مرككنكدنعمدى د د نسر ين "خو إى خبرى تاسر ه و ى

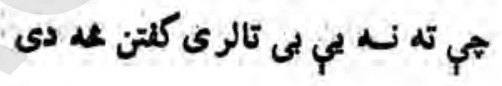
كلم

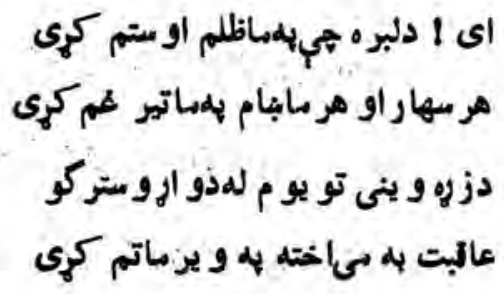




$$
\begin{aligned}
& \text { ياد مت را نه بيلهت يارا بنكارو.كري } \\
& \text { بت بتو نى جي كئى ز زهره زما قلم كهى } \\
& \text { دوقيب ستر هخلالهه مسا نسه تبثتى } \\
& \text { جلا كارن ولى ما مسرهمتم كرى } 9 \\
& \text { دو صال بـه اميل در شمهل ستا در تـه } \\
& \text { ته بى لا به زله دهجو خنجر عم كري } \\
& \text { ايى" نسر ينى "دادغم شعردىيبر ات شه }
\end{aligned}
$$

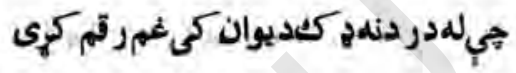

$$
\text { تلوسي }
$$

دبينى ثهل بيه شهل و ه ارزو كانى كلهيلدى

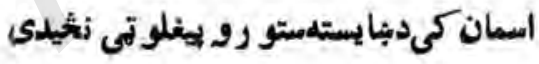
ماقىر اته نيولى وو دمر و لبو دكث جام دبينى تنكى شهه و ه نشىخم كى هو يدى دماجيه كورغمو و ديبلتون كوركى

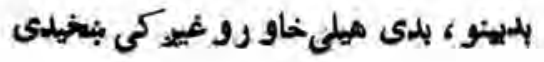




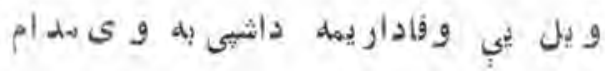

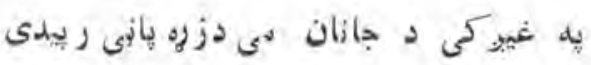

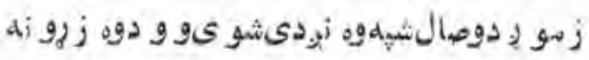

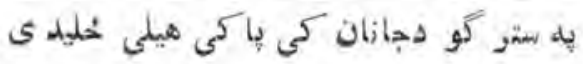

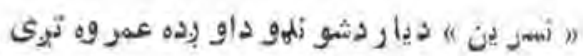

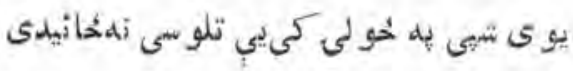




\section{تورييكى اندر}

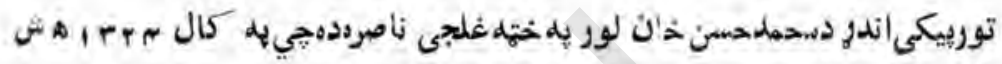

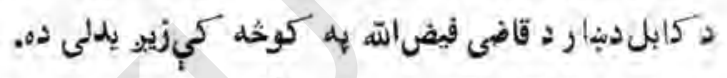

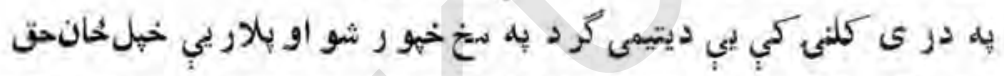

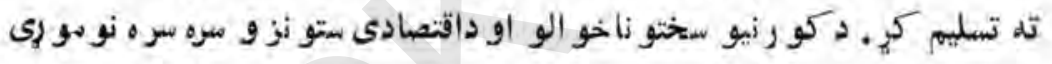

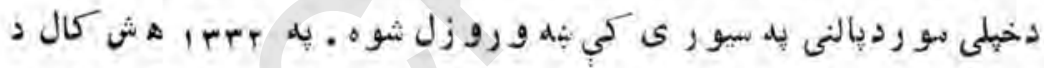

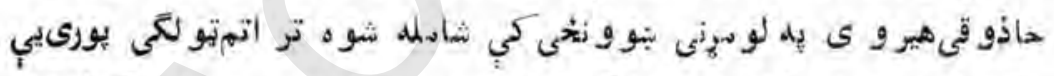

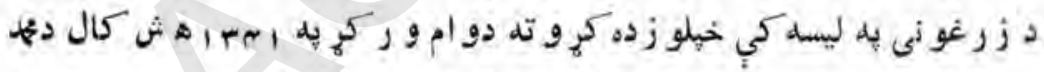

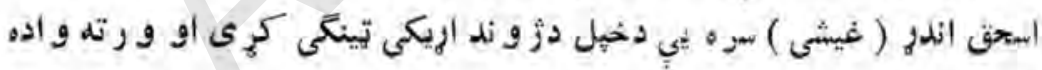

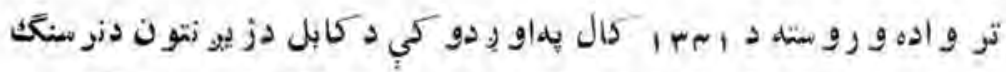

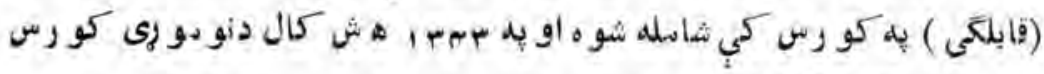

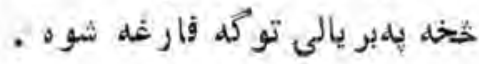

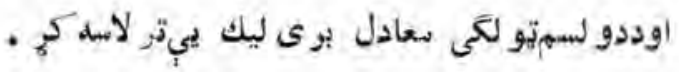
ir. 


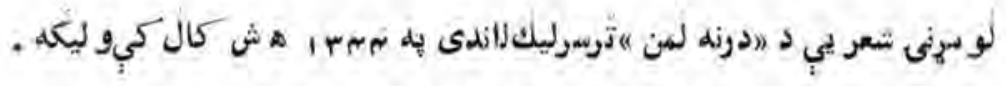

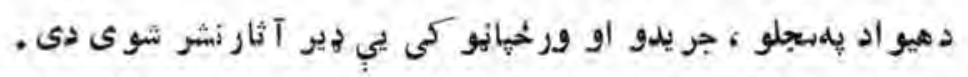

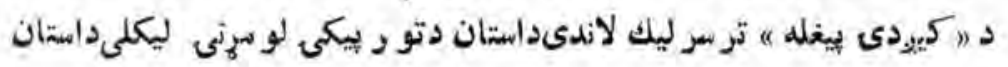

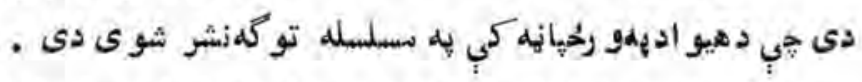

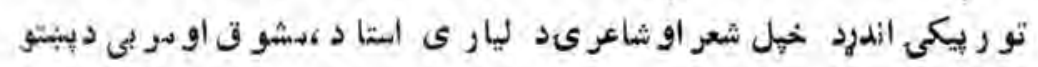

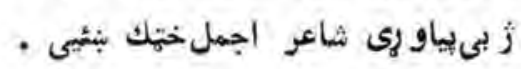

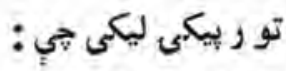

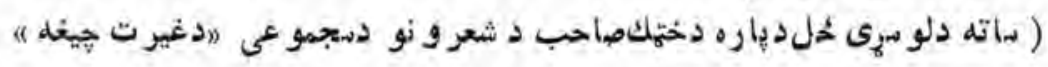
دلو ستلو نه و ورو سته دشعر و يلو احساس او علاقه بيد اشوه اوبهدي لاوه كيزّاس

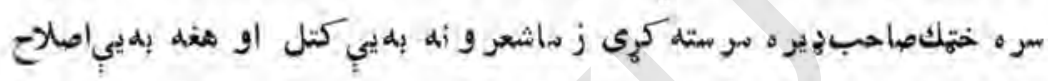

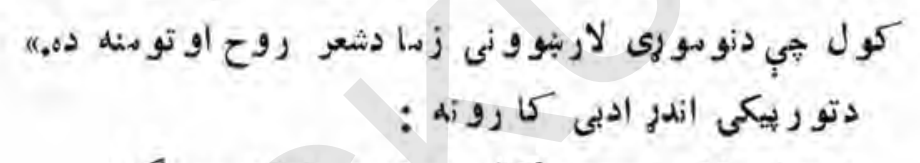

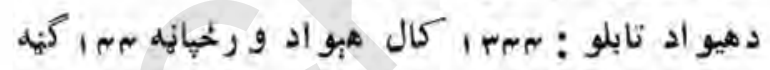

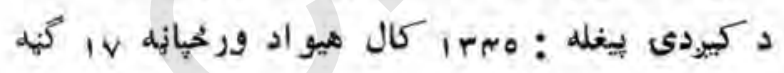

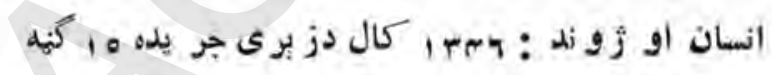

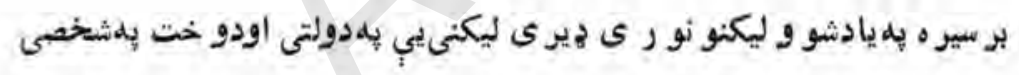

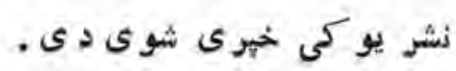

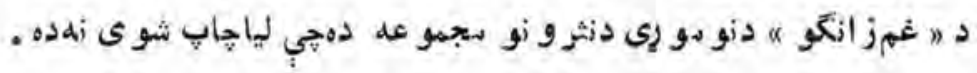

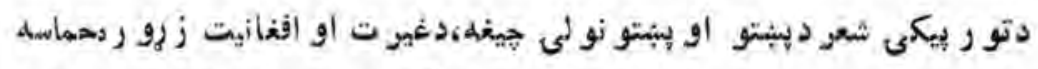

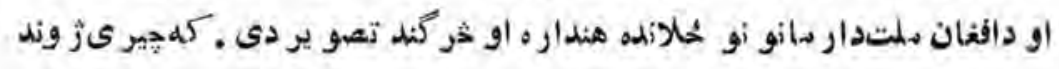

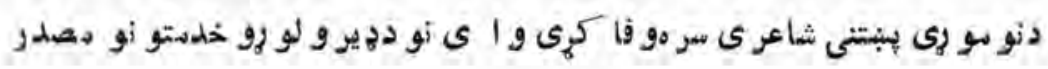




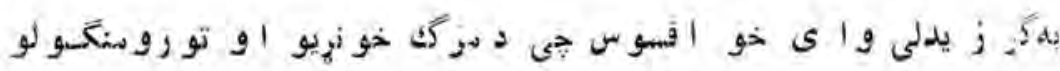

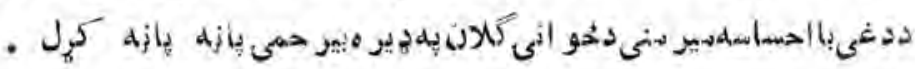

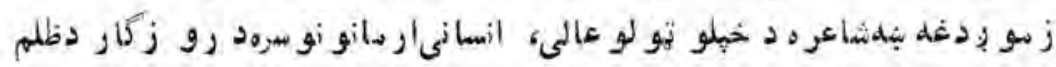

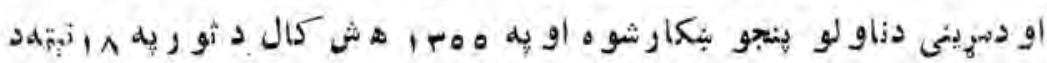

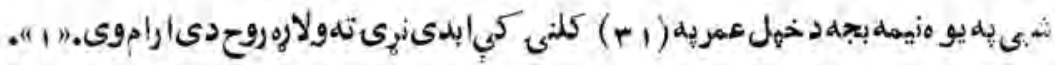

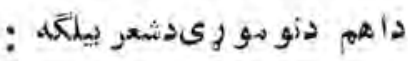

$$
\text { isdigs }
$$

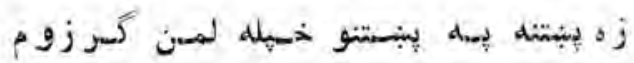

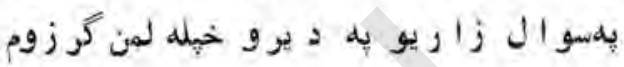

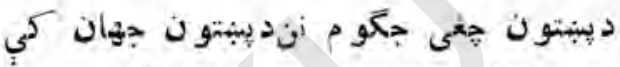

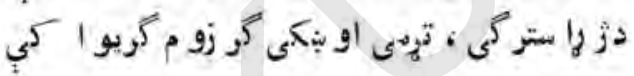

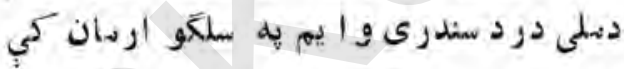
بلمسرتو رسر ، تو لو حجر وخهله لمن كر زوم

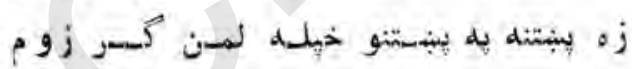
$* * *$

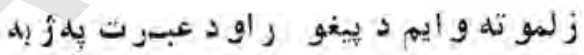

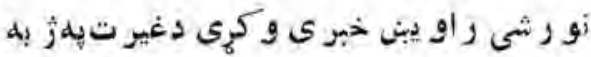

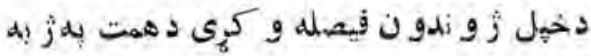

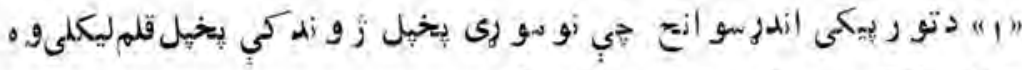

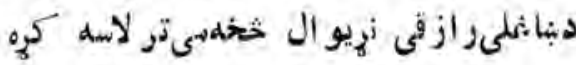




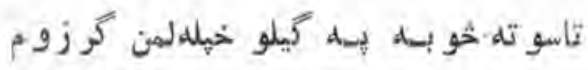

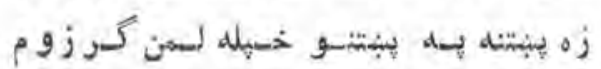
* * *

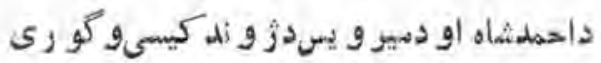

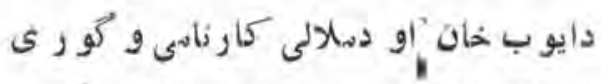

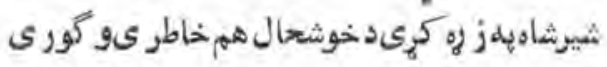
ز زياتى و ر كيوف سمو ، غر و خهله لمن كر زو م

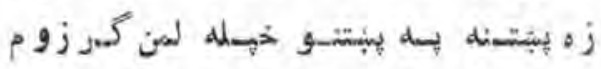
*** *

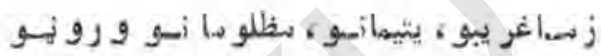
استعمارك و كرئ لو خاو رى إيو زلانو 9 رونو

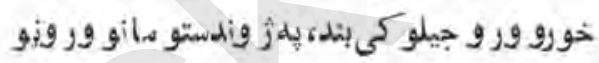

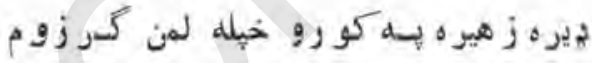

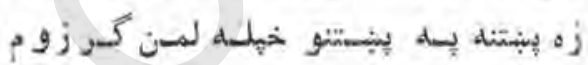
*** *

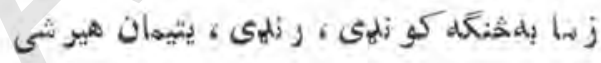

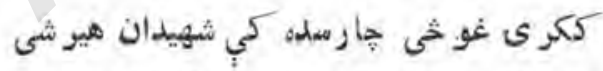

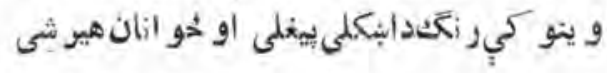

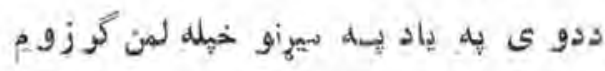

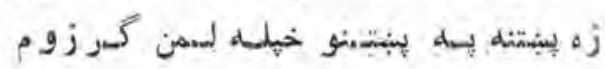
*** $*$ 


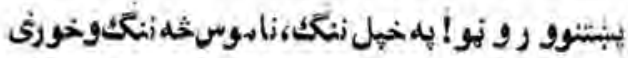

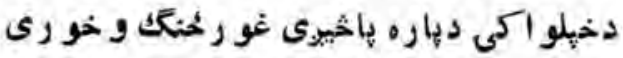

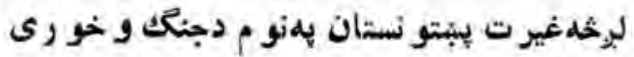

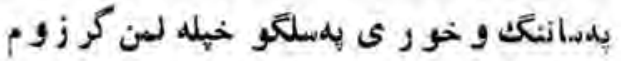

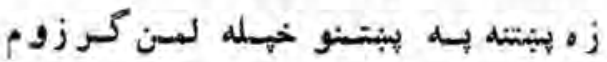
* * *

زه بينتينه غو الرها

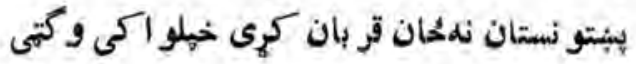

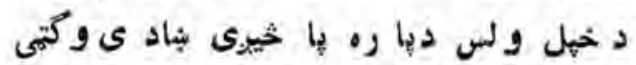

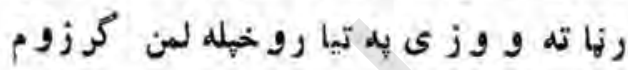

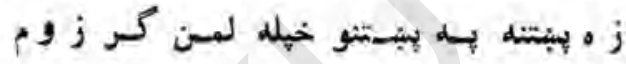
* * *

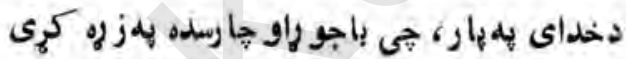

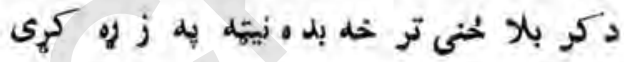

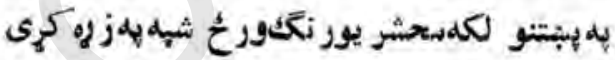

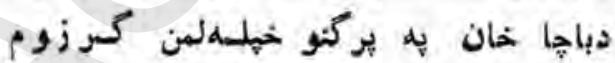

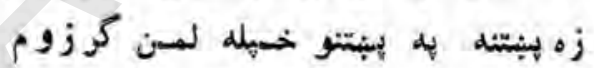
* * *

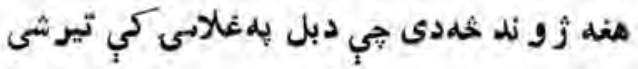

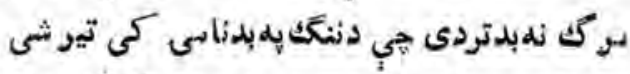

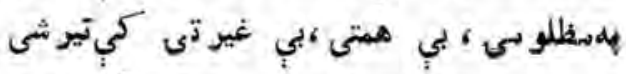

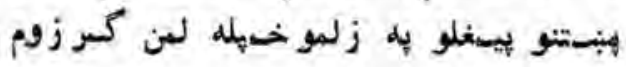

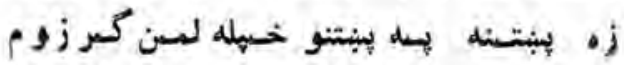


دباجٍا خان فدا كار يو باندى نئك وخو رى

هلدى بيى سارو قو با نيو باندى ننَك و خو رىى

تار بيخ يرىويارىشهكار يوباندىنيكتوخورى

دده به حال إسها ثر يدو خهله لمن كسر زوم

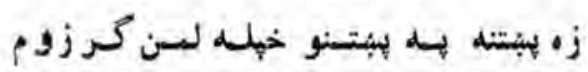

به لرنسو او برأسو خهله لسمن كر زوم

* * *

:

راتيول شيى بنبتو ببنتو نستان جسورود

داكسر بـه ددهيو رنله بيخهل و ينو و رانو و

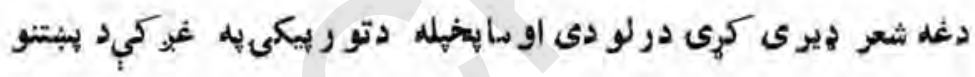

او بلوخو و وو نو ديا دو نى دو رخحى يله مناسبت دينتو نستان به كبي كي او

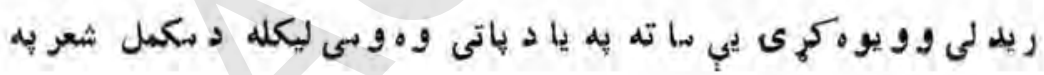

- مو ندلو بر يالى زله شورم 


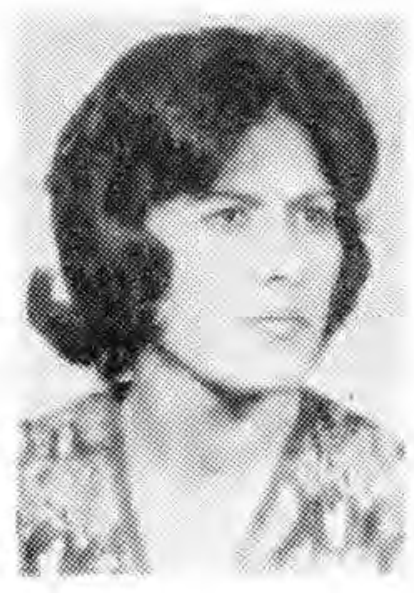

\section{زرغونهوشتينزيور}

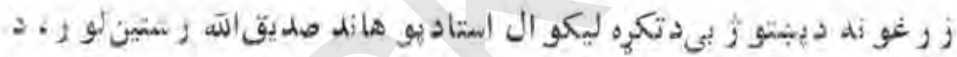

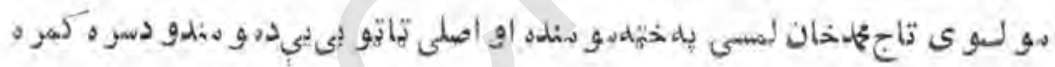
o. 3atace

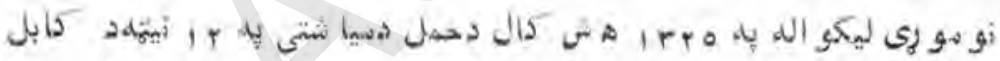

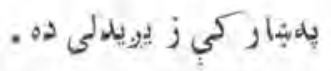

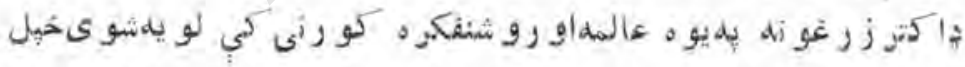

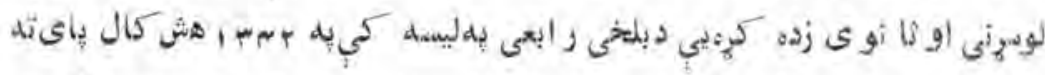

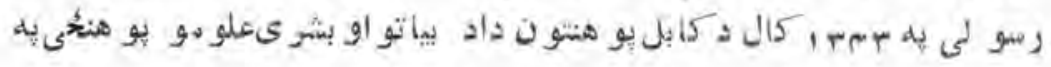

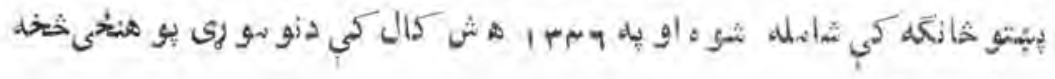

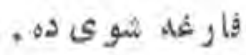




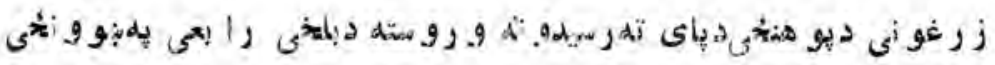

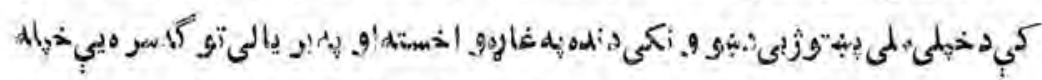

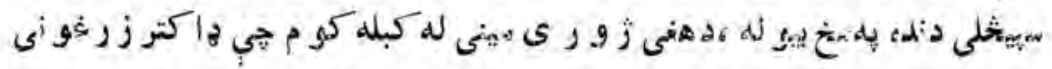

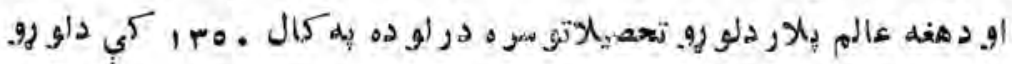

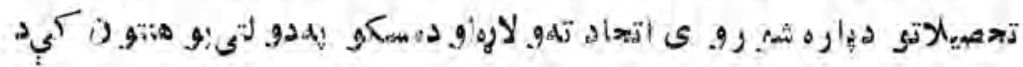

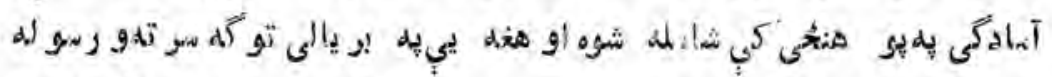

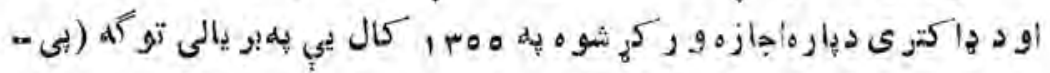

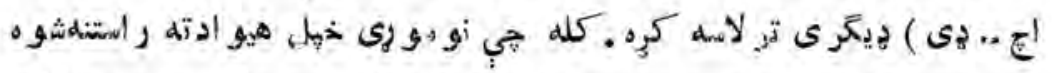

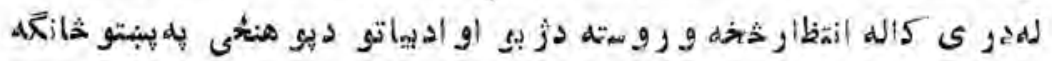

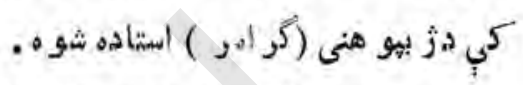

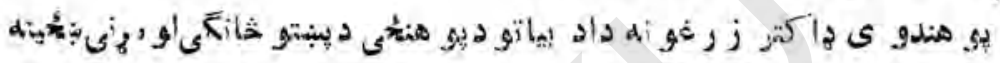

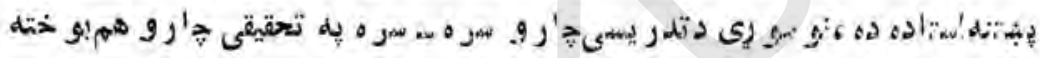

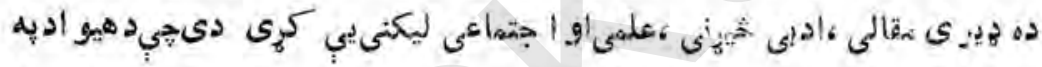

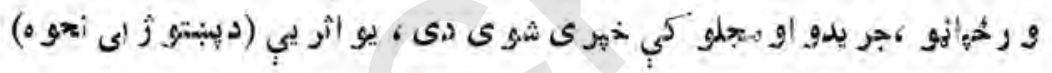
.

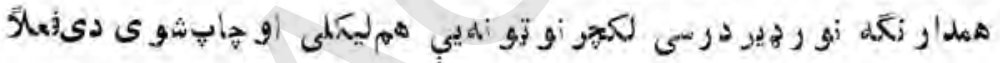

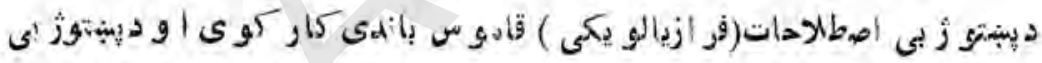

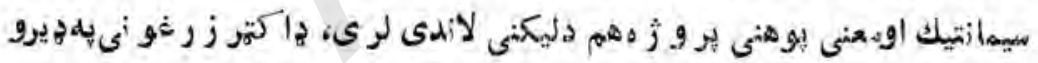

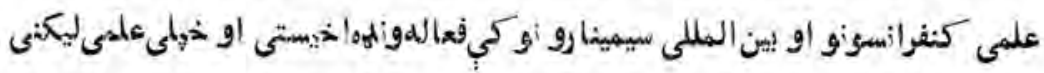

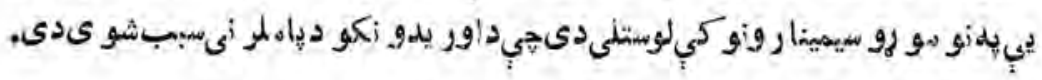

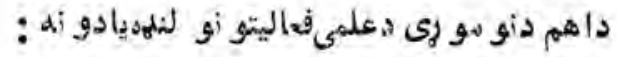

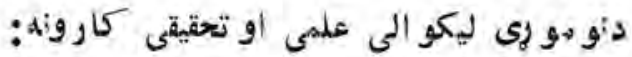


- Al

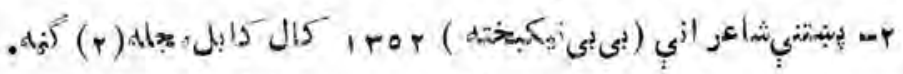

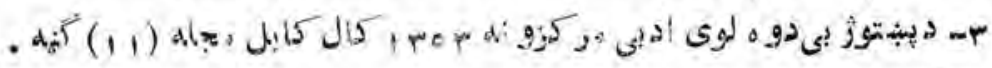
-

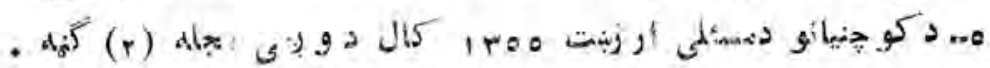

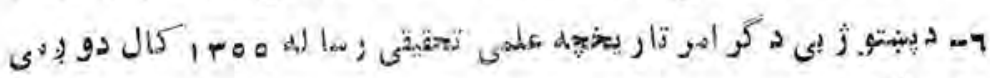
- $4 s^{2}(r) a d x$.

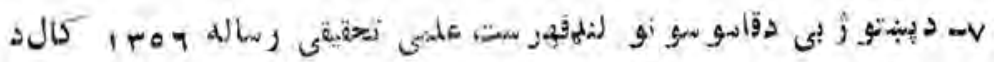
. 9 .

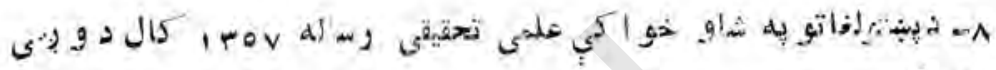
مجله (r) كنه.

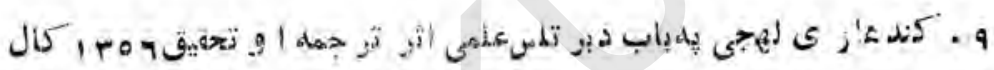

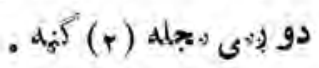
•

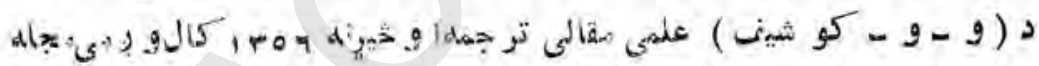
- $4.5(\sim)$

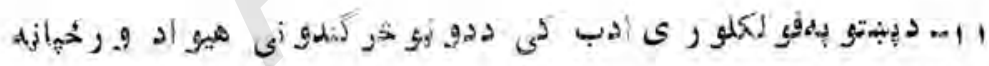
. J 1500

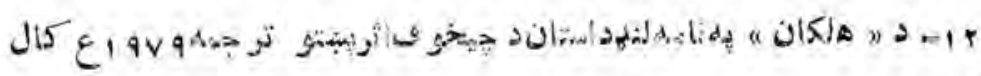
.

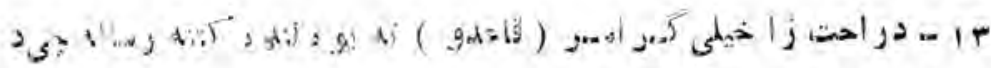

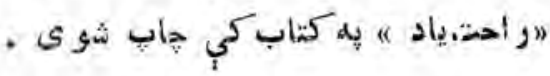




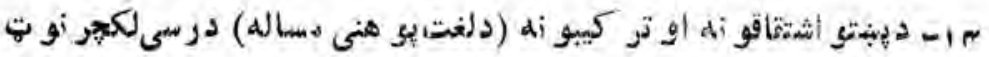

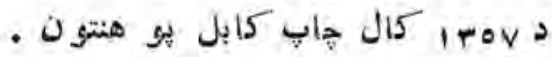

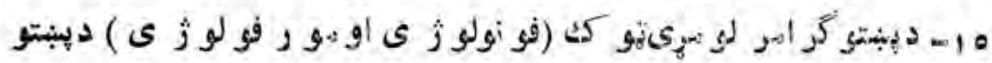

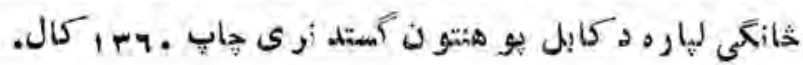

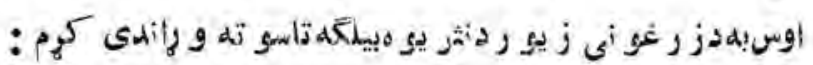

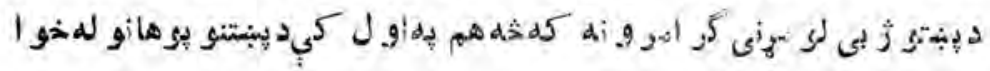

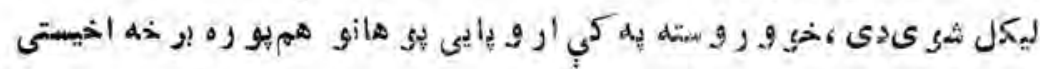

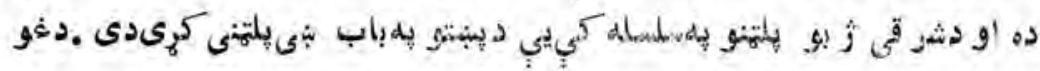

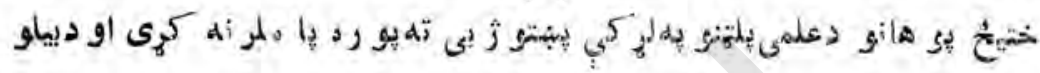

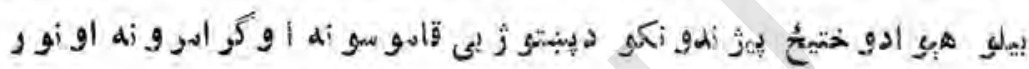

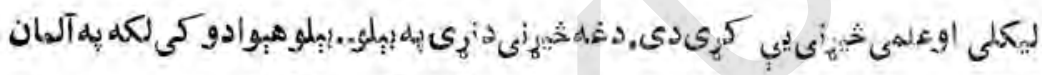

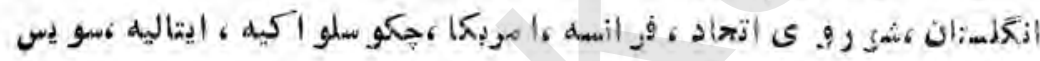

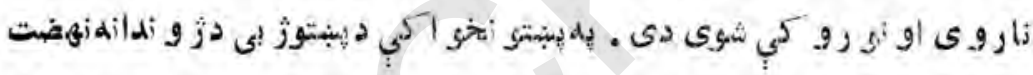

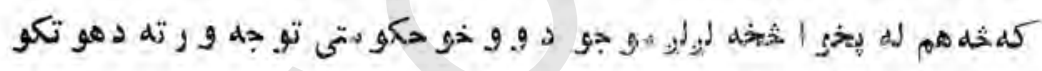

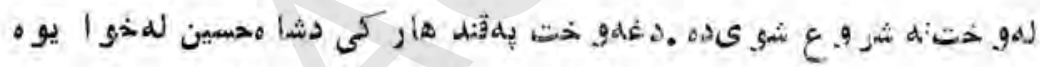

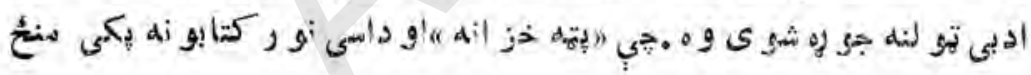

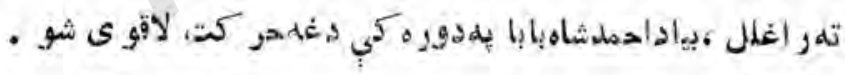

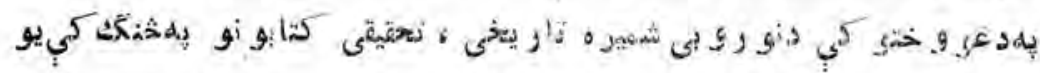

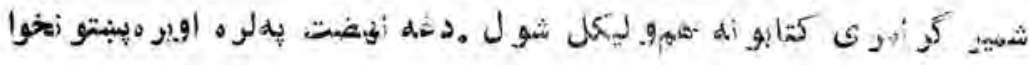

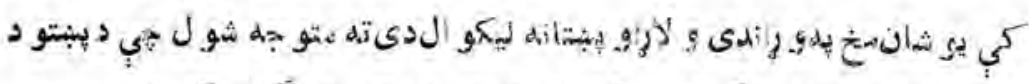

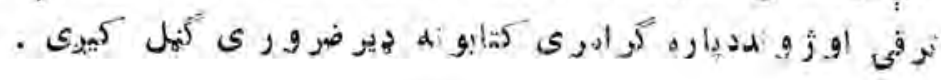




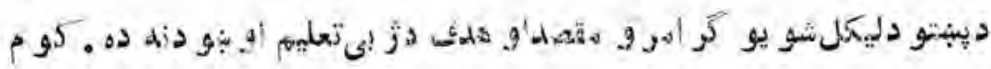

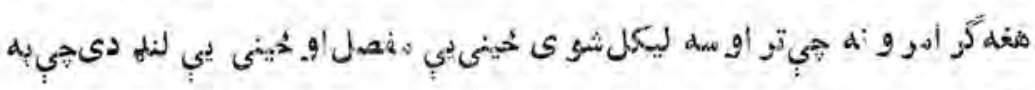

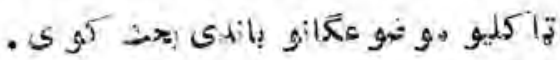

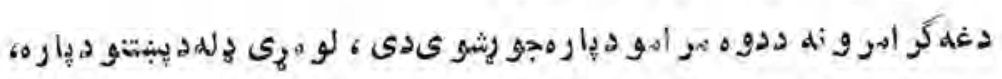

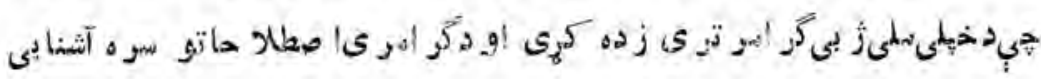

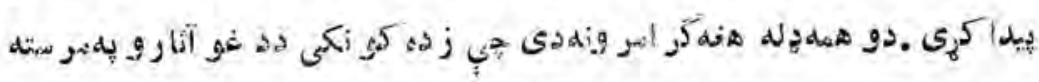

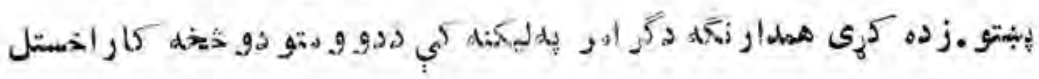

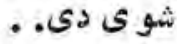




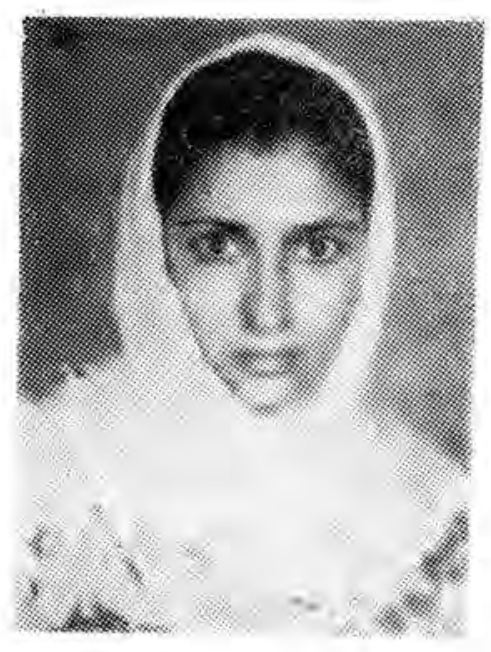

\section{زسيمهلمتين}

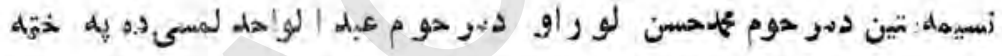

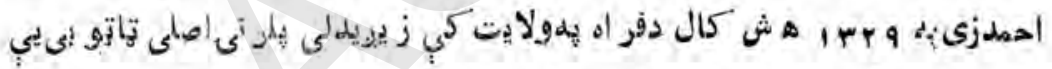

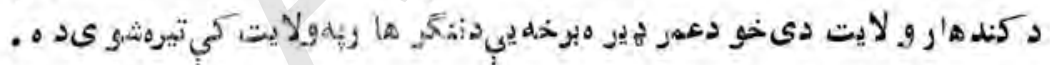

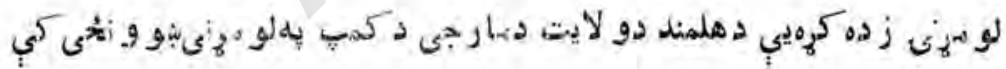

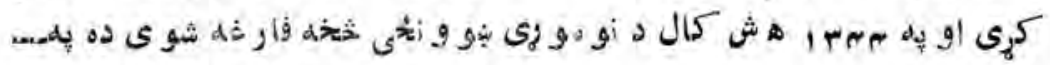

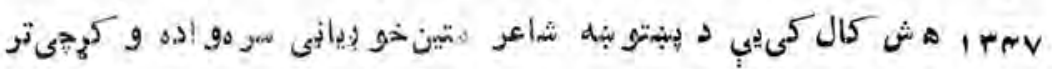

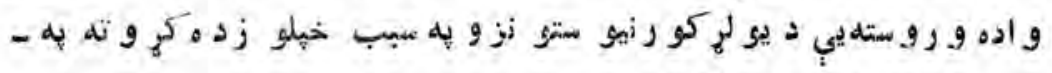

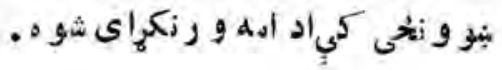




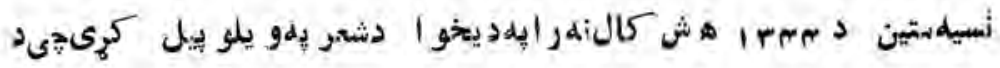

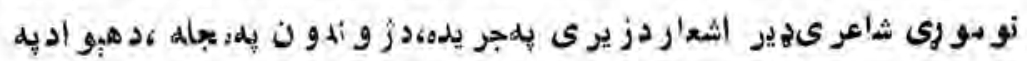

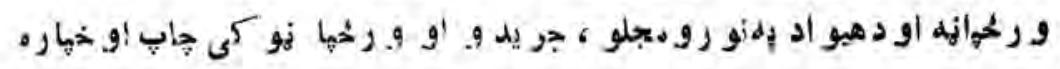
شوى ديى.

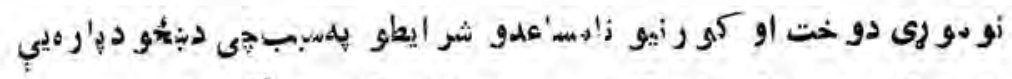

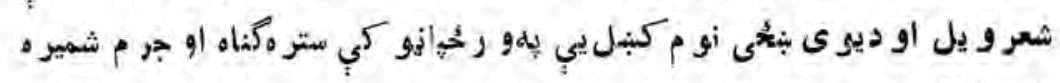

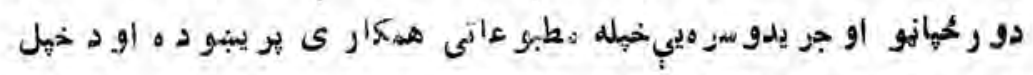

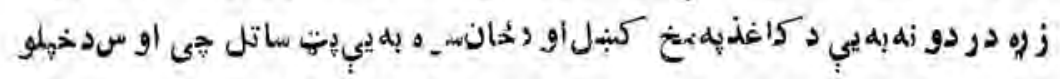

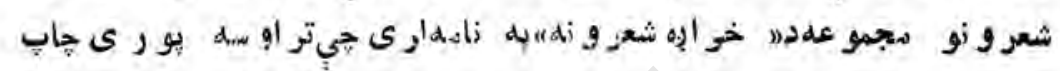
شوى ألهده.

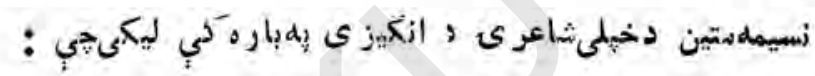

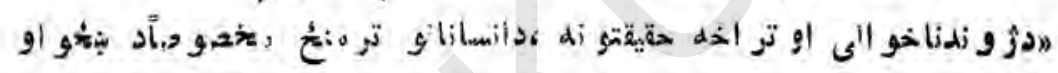

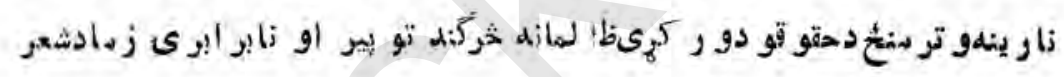

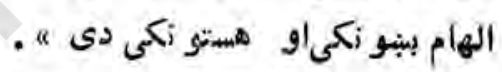

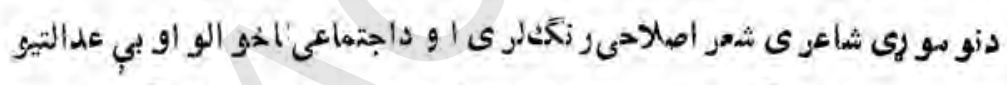

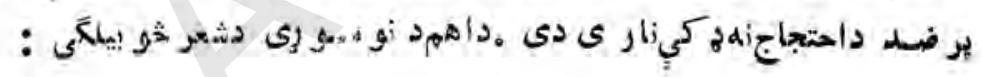
ليويشانى

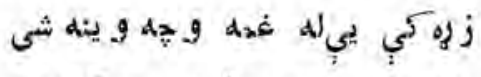

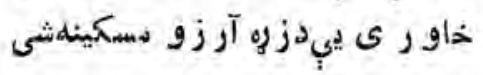

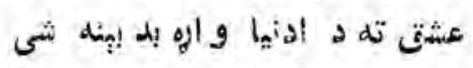

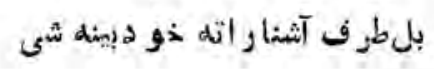

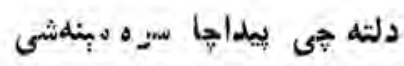

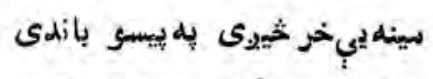

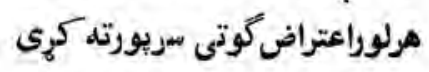

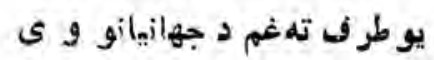




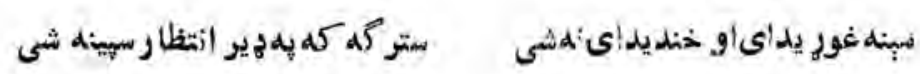

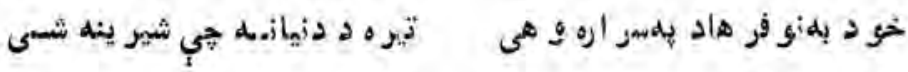

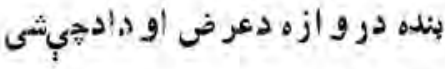

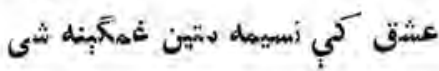

\section{خورى}

هملهاو آر زو ده درز وندون خو رى

نندى بايد لي ليوى لهإِرو ن خو رى

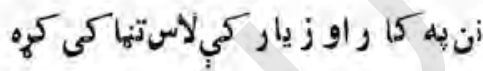

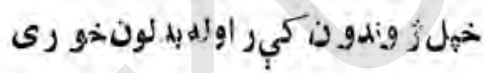

خبل قام ، خهلهناوو ره بى آباده كريه

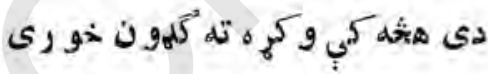

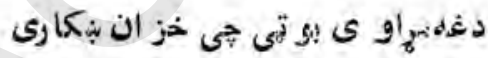

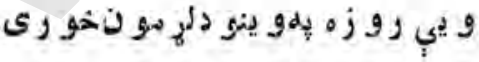

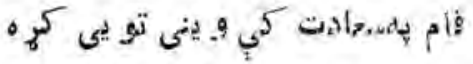

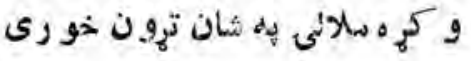

دغ.ته زنسيمه بتيين آر زو لهبرى

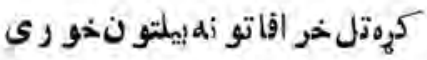




\section{دوطن زلميانوته}

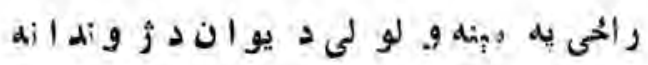

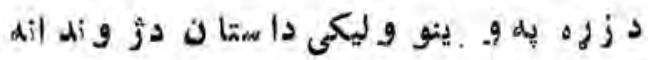

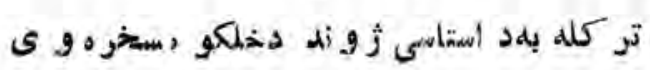
dil له

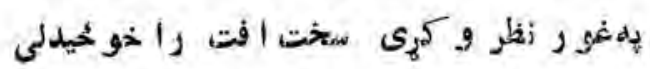

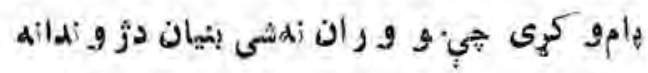

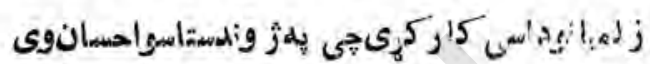

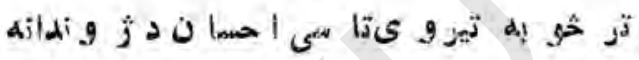

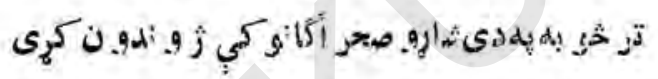

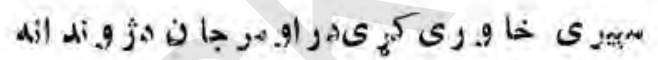

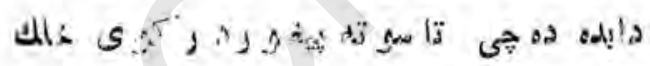

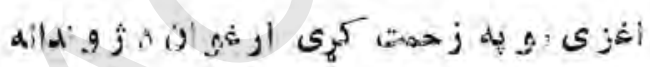

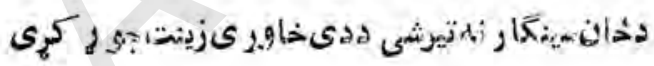

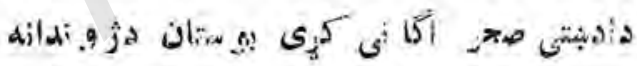

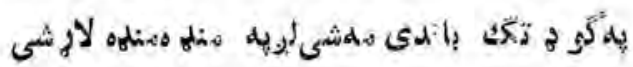
تر

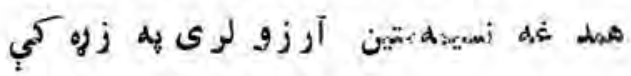

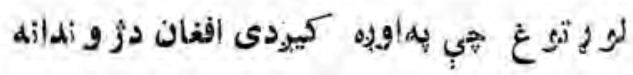




\section{تلوسيه}

هو س دز ره شى بهله

فكسر جسى 9 بستهم داستسا بسدل

كظر د ى ثمله ثسيو اشنا بدل

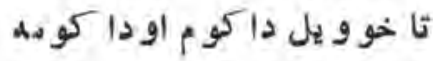

عز م دى شو به زن مبا بدل بهحان كيور كه هعهلافى خهشوى و لى دى و ينها نز يبا بدل

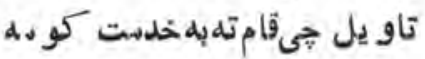

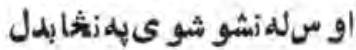
تاو بل جیىز هو شر ابى نسه يده ايى بو الهومسه كر لى حا بهل

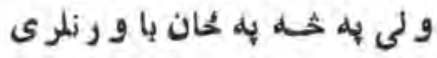
بومهل شوم فكرو وزما بهل ل

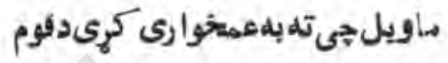
كريى نأكسو ملكر تهابدل هid بيمان دي و لى هير كي آثئا

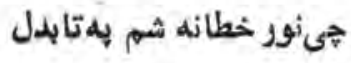
كابه كرم شعركي وموا بدل اوس سي بنه 9 بيوزندى فككر به كري

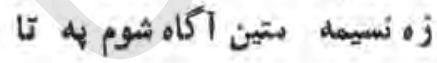

\section{دو غدجئه}

2 غقلت به مينه مسته حثز وئدون مره آشنا شه

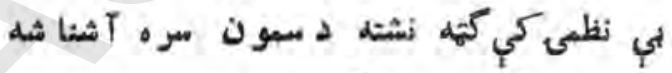

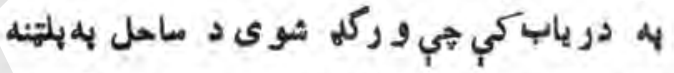
و ارخطانه شي هيثكله د هلتو رتم كي بلتر كو مهتير و ى در و ندانه شهى تو رو شهولحنى بهر شه سباوون سر آشناشه

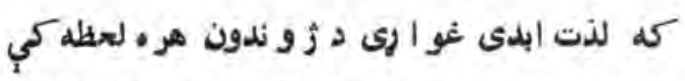

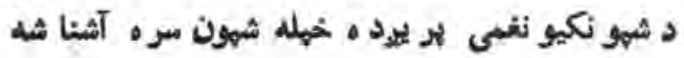


لهمتاع د نو روخلكوخهل عزت كلدبه كاردي

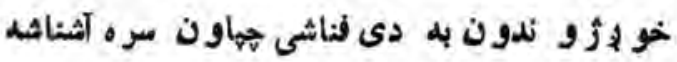
بهتروو ترخو دخلكو تيو ونه خو ر ى درته و ايم

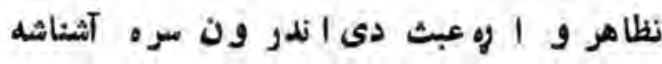

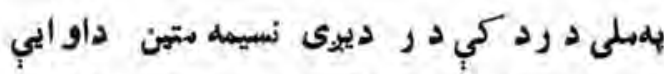

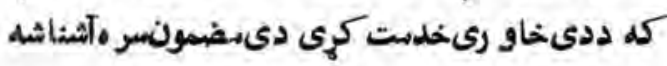

\section{فرياد}

زماخو اركو تي زاككى ميث خالى لهعم نهشو

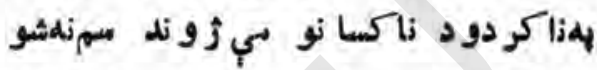

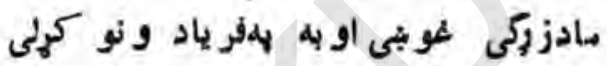

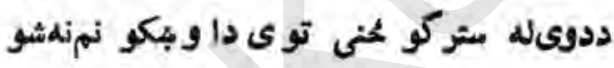

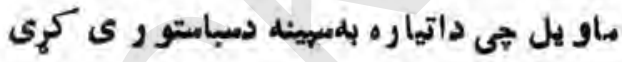
دسبا متور ى باندى روي هغه تو رتم نلهشو

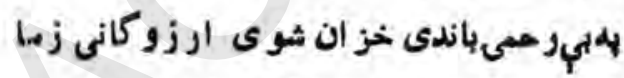

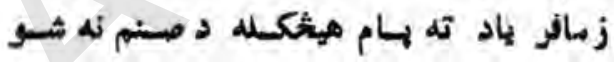

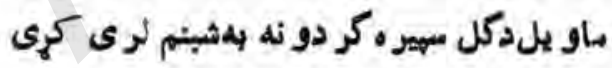

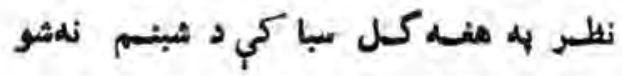

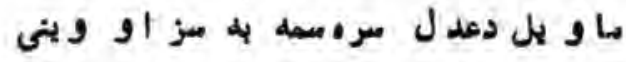

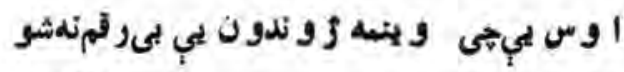

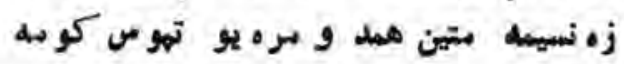

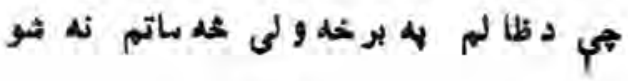




\section{هيلd}

د بيتونوالى به اساس باندى كذر ان كو.

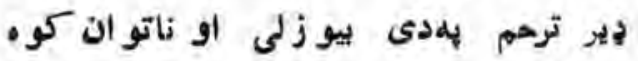

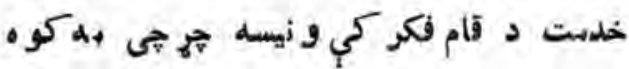

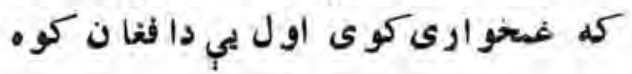

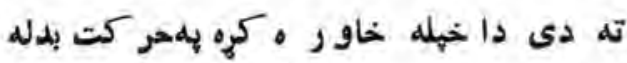

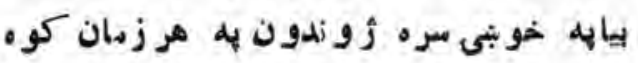
دكو نهو ، رنهو غنغوار ى هم كله كله كو -

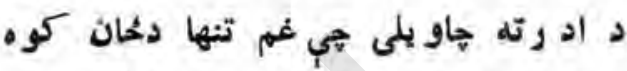

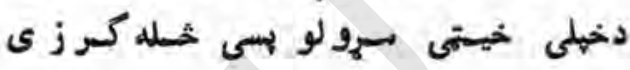

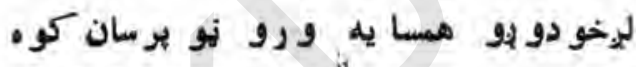

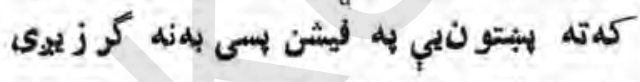

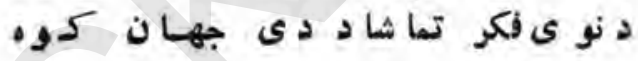

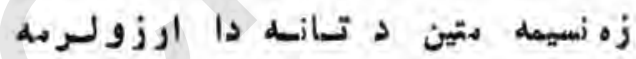

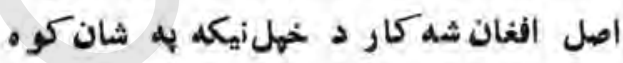

\section{ديوى ييغلى ا رزو}

دو ملاسى بلام به وك هم اى شير ينه يارمتاته

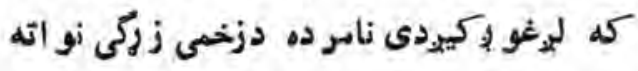

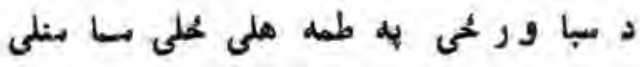

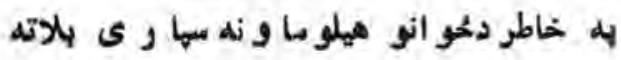




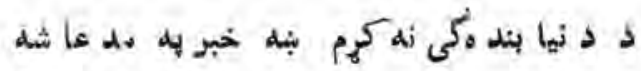

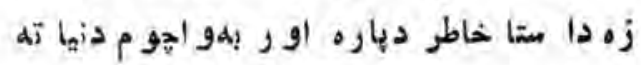

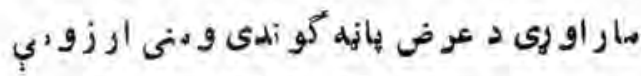

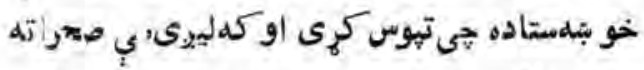

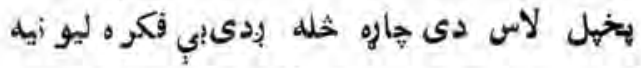

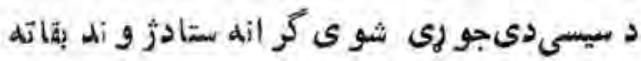

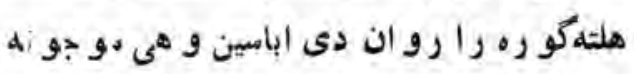

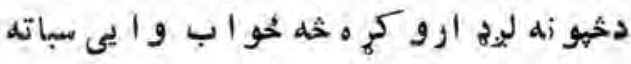

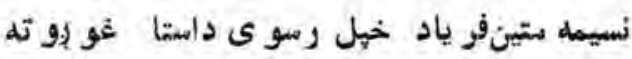

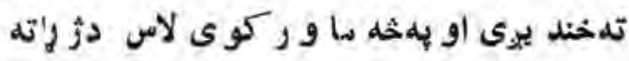

\section{بِي! خبرته}

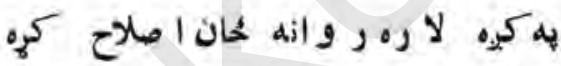

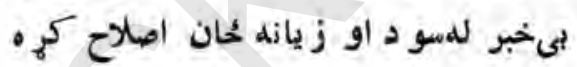

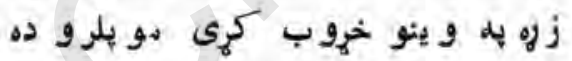

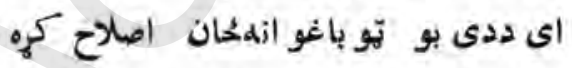

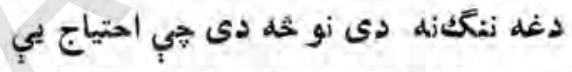

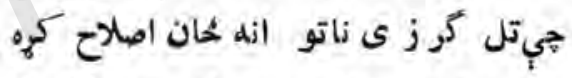

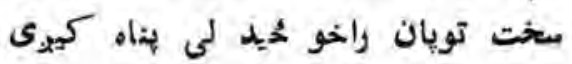

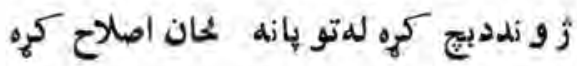

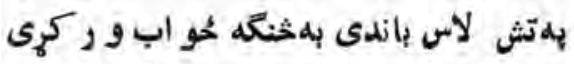

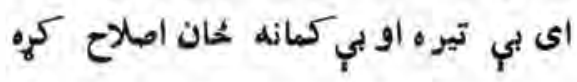


داجو نكله مانه ترثو يو ردى و رآنيوى

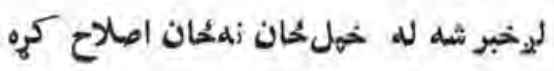
عاقيست إله جهـا نسيانو تسه رمسوا شى دغلو هلمه بي ايمانه محان اصلح كريه اقفتخار دبل به نو م كله بنه كار دى هلهدى فكر كي ستو سأه حُان اصلاح كره

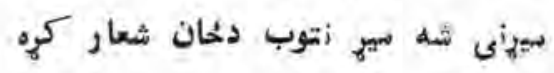

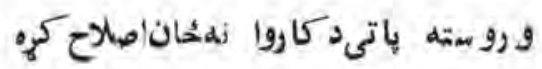

\title{
خهل غوارى
}

\begin{abstract}
ستا خخه دا خحدنت كول غو ارى

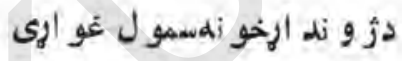

دز رو نو كوركي محاىنيول غو إيى

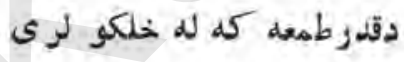

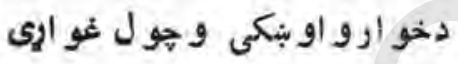

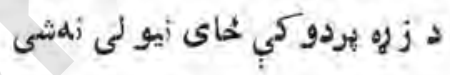

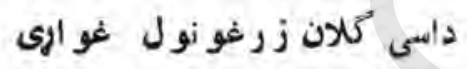

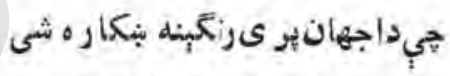

دا و يده قو م بيد ارول غو ارىى

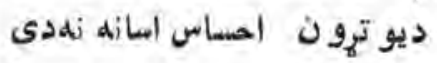

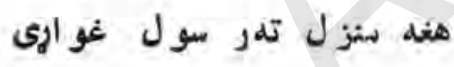

ترخو به دايتئي بهلاره كي

زأ بو د ى هيلم شئه ول خو اريى

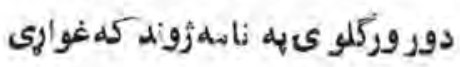

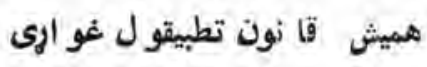

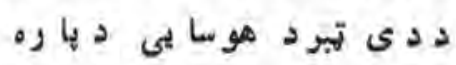

$$
\begin{aligned}
& \text { بس نسيمل نتين نو ر هيث نلهو الرى } \\
& \text { هد أر النو أرول غولئ }
\end{aligned}
$$




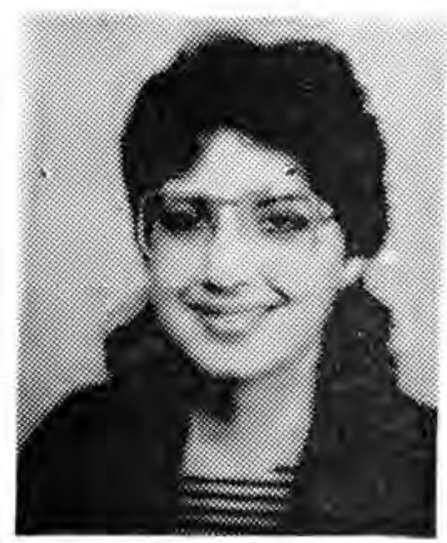

\section{شريذه شريف}

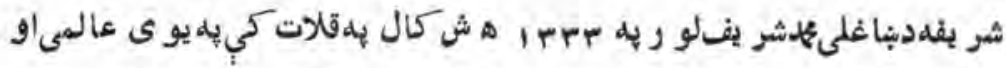

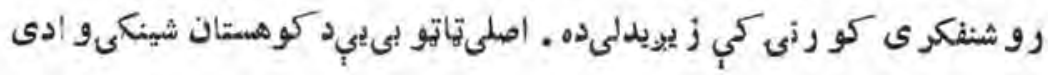

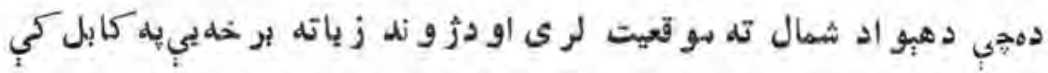
تيز ه شوى ده. 


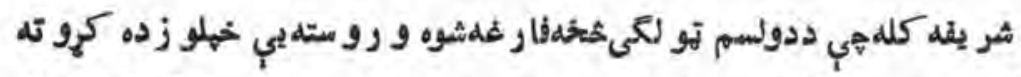

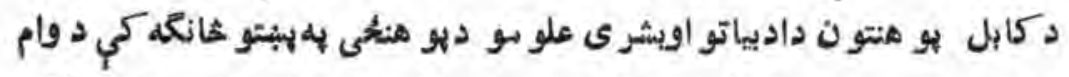

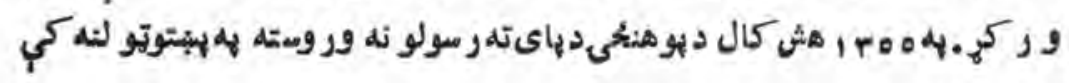

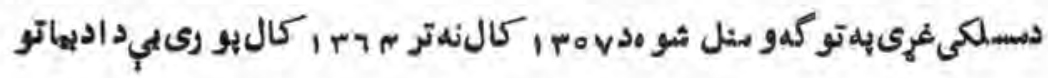

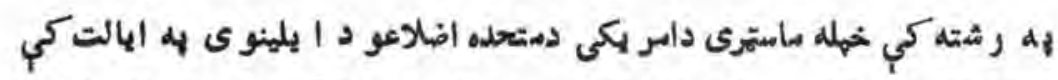

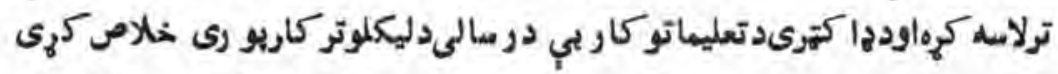

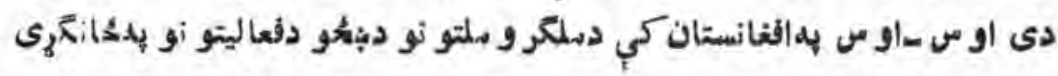

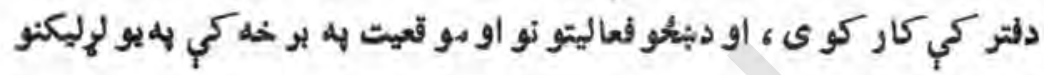
او خيرثو بوخته ده.

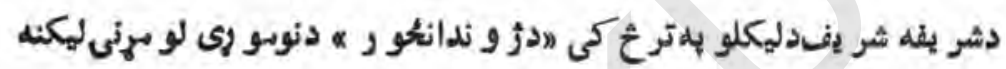

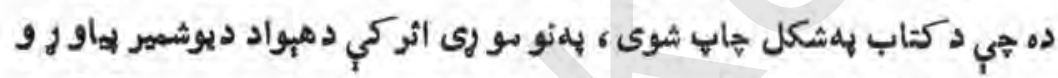

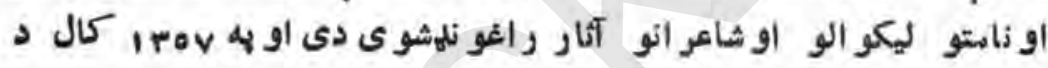

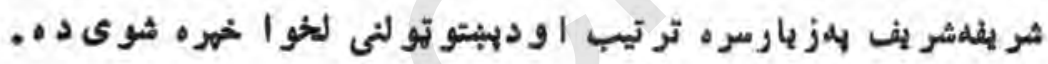

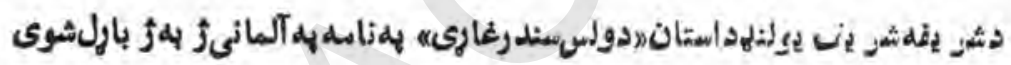

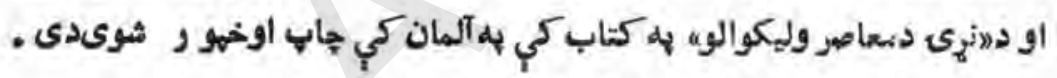
دنو مو ري دادبى كارو نو لنله يادونه :

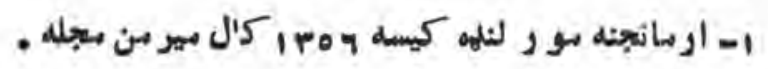

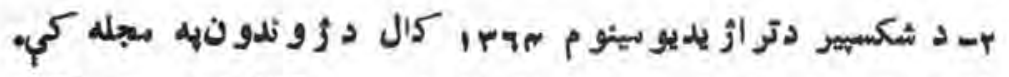

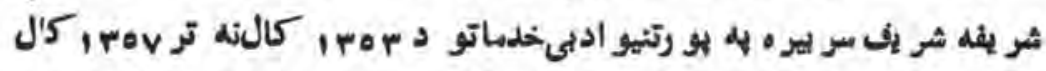

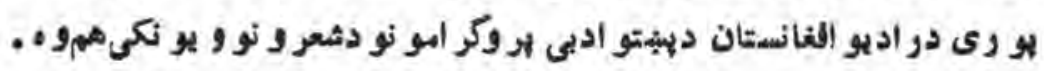

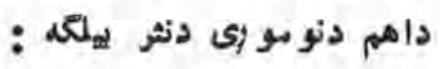




\section{دهيلو بهير}

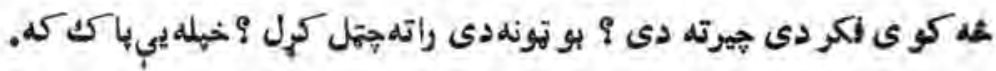

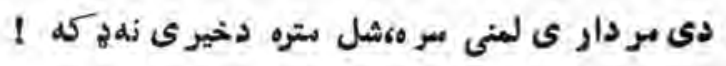

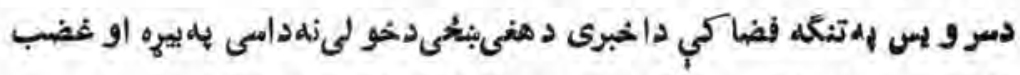

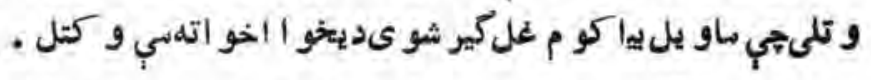

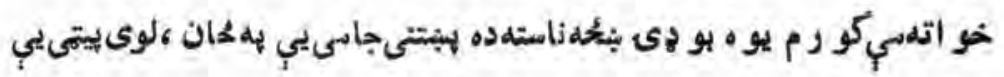

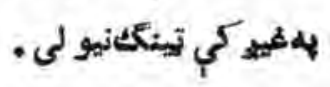

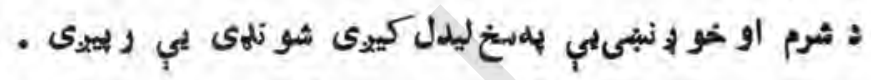

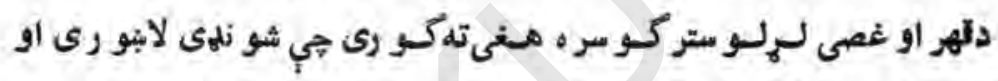

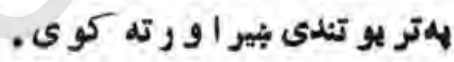

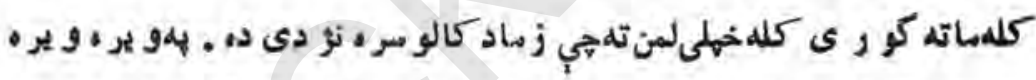

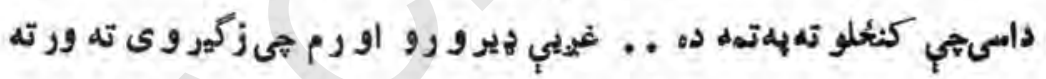

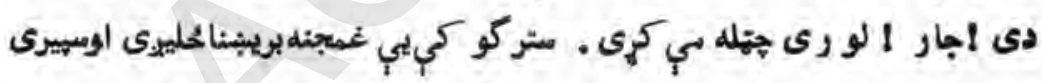

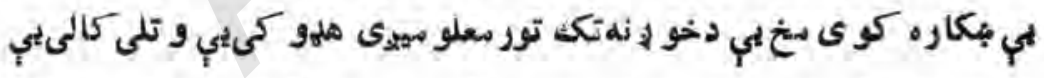

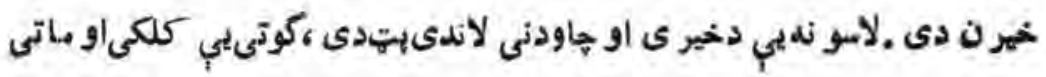

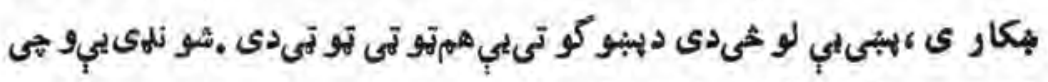

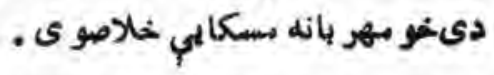

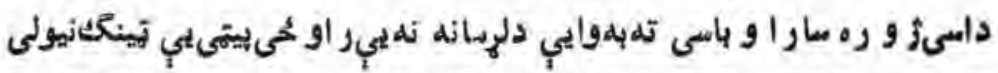

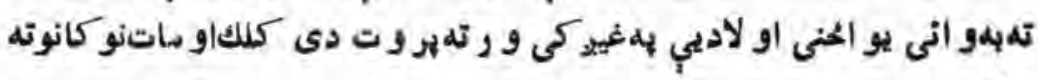

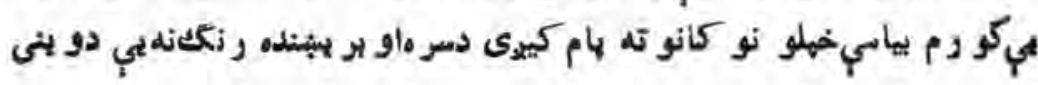




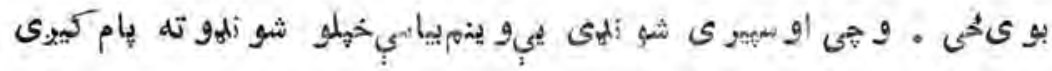

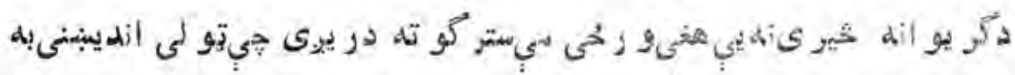

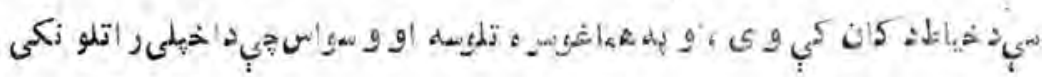

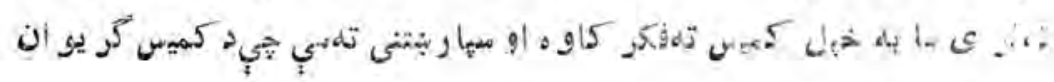

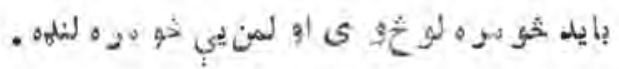

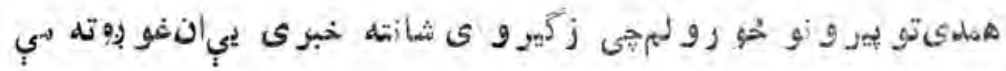

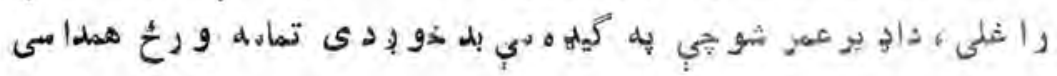
سو زيى.

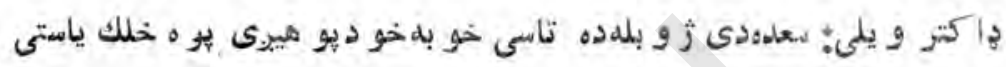

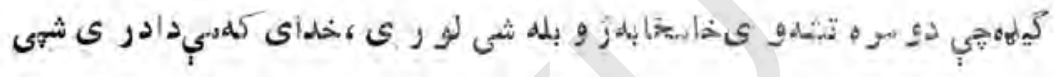

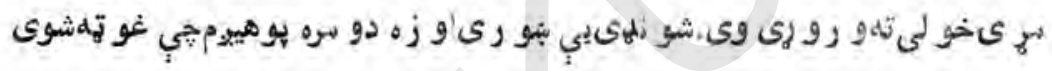

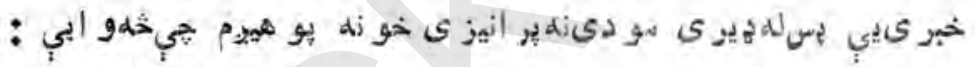

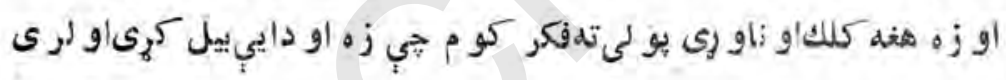
- مـا تلتي يو التو

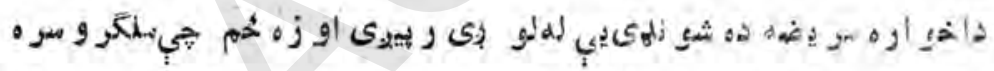

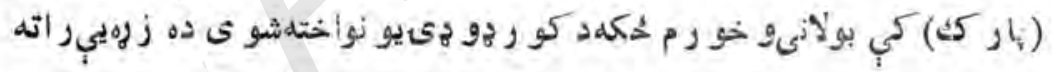

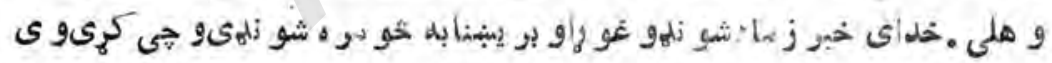

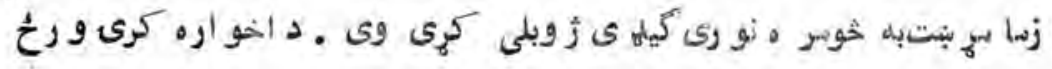

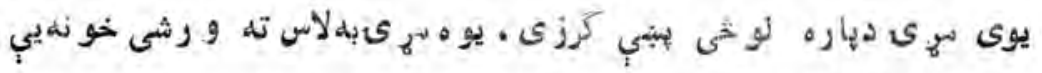

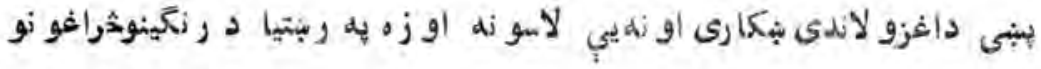




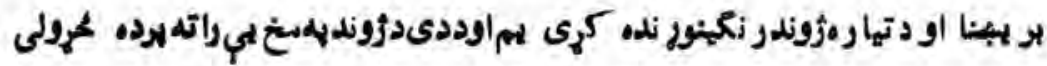
***

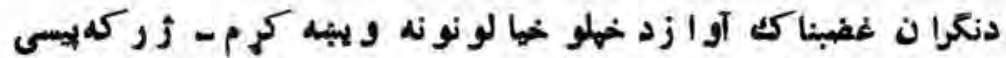

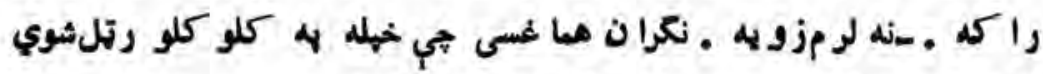

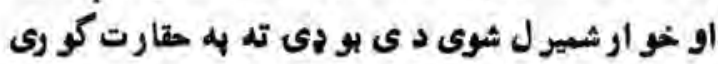

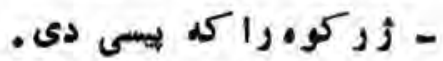

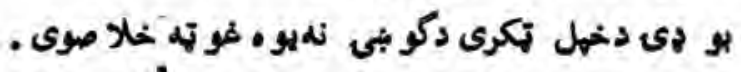
ـ داده زو يه يو شاتز ده بولى لرم مو اليى خله.

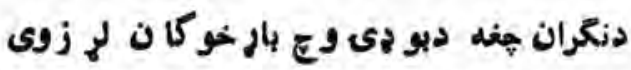

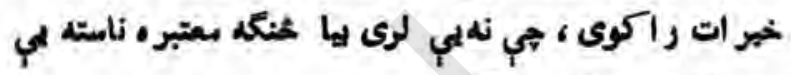
لهىتربيساثى خيدانو رى كيهنى.

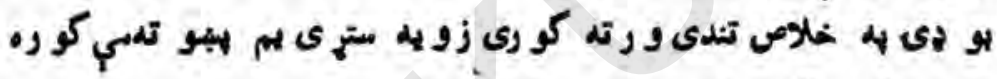

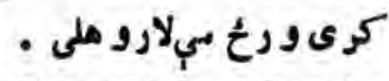

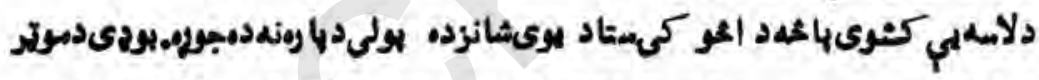

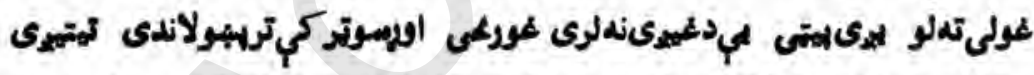

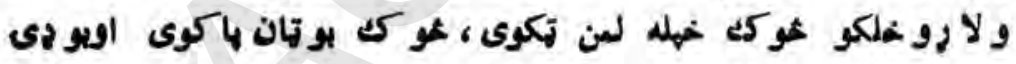

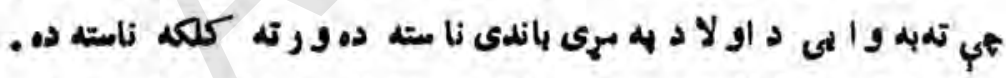

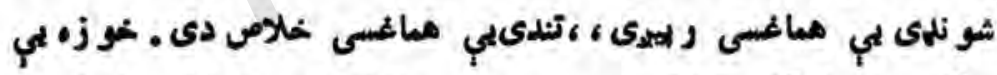

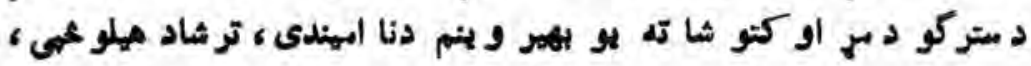

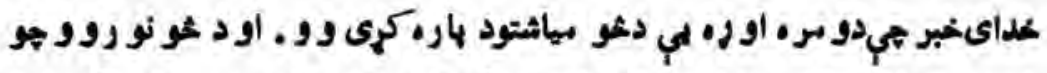

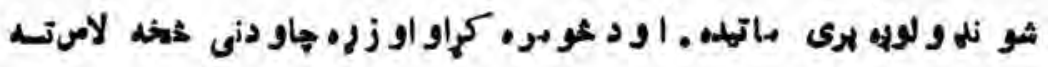
را لهلى و. 


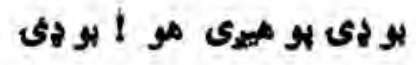

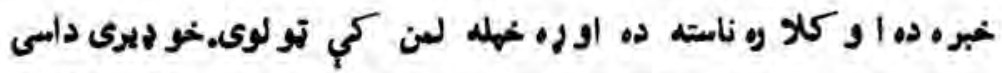

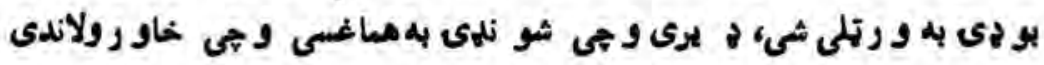

شى.

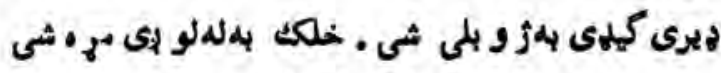

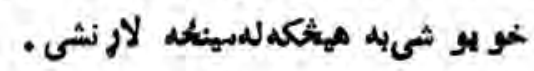

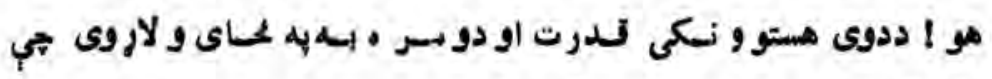

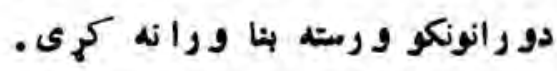

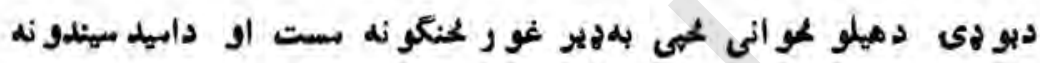

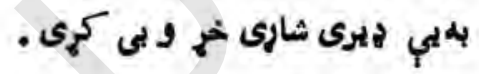

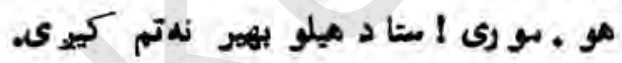




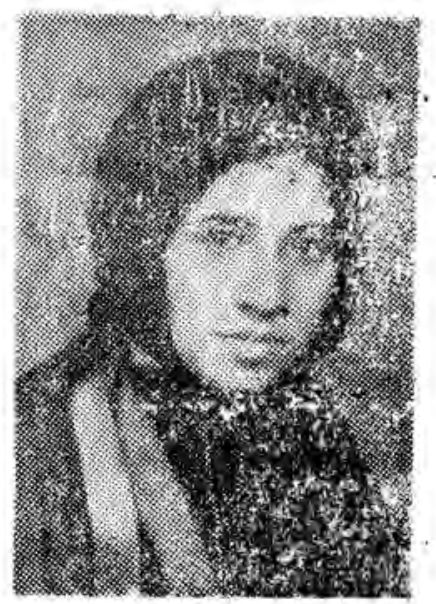

\section{عارفه حليمى مختشار}

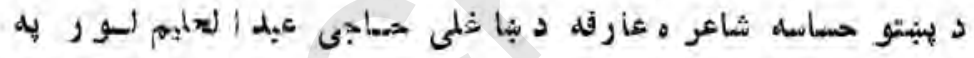

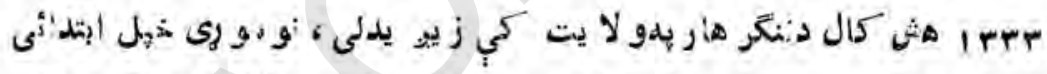

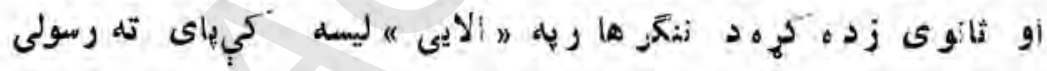

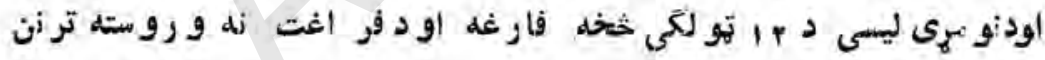

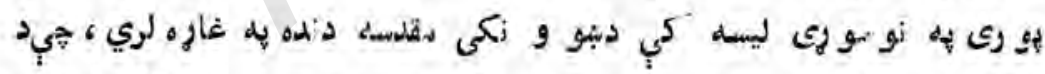

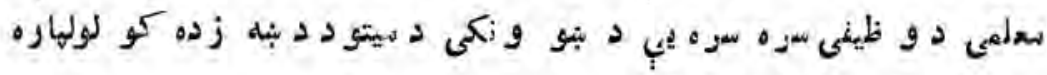

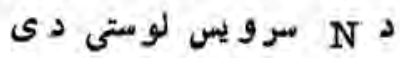

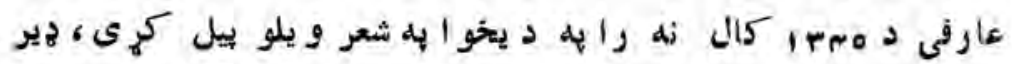

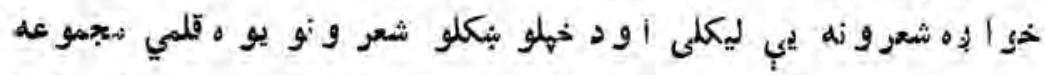

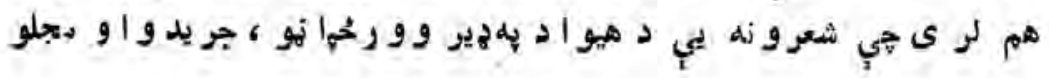




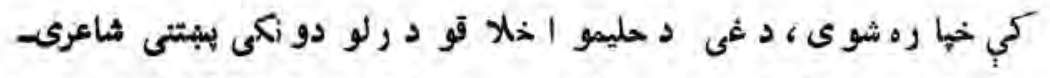

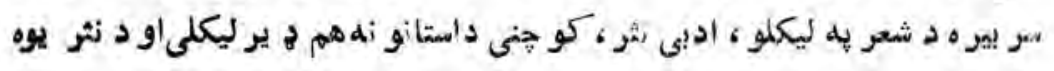

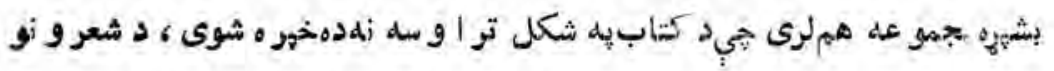

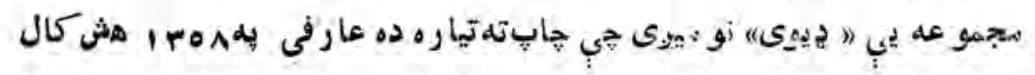

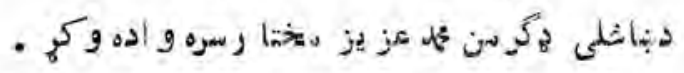

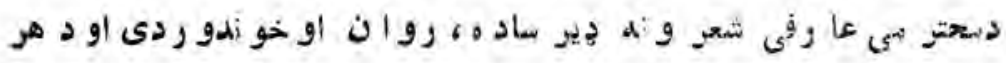

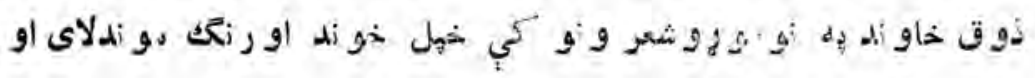
احساسو لاى شى .

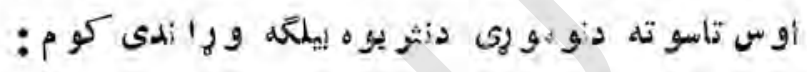
تاثر

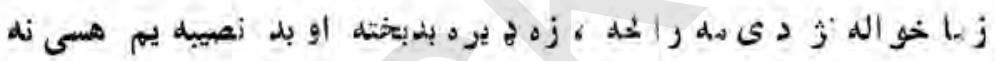

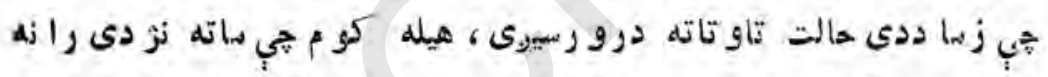

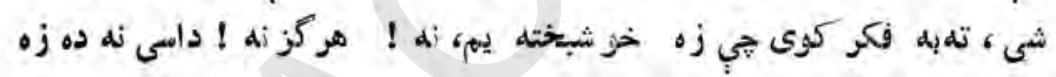

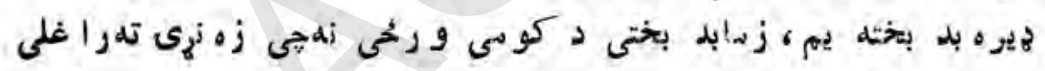

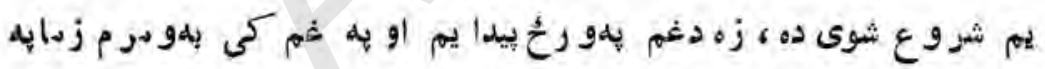

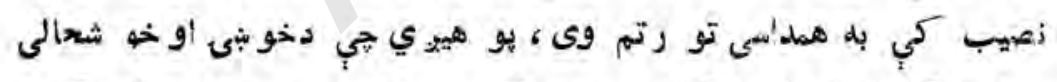

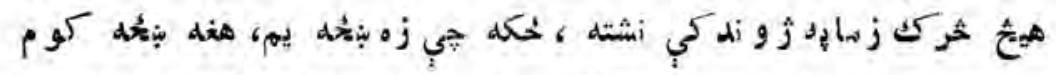

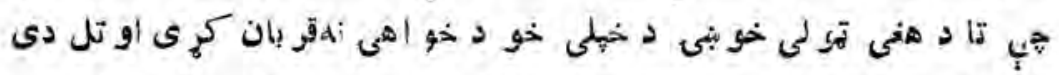

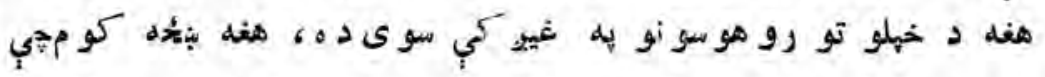

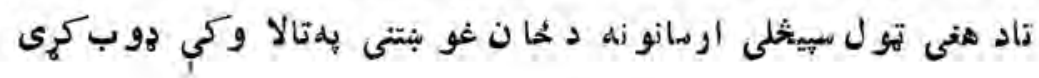


تو ثه ماته ني دى مه ر الكحه ، تر هنومه رالحه ترخو بو رى جي زهمم ستا به هير حلى لهدا كم م اوخهل مو جوديت بهتاديوه بو ره انسان بلثخير

ومنلى ثمب

اود اهم د نو مو ريى دشعر يدلكى :

هبثتنه إيملهوايي

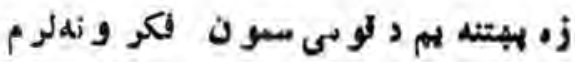

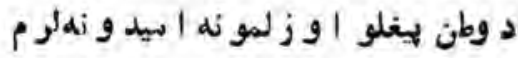

ترمو بلمو إ د نايو هى تو رو تياروكى نامت يو

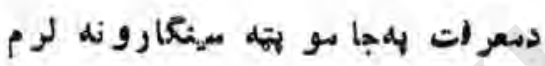

زهاد تن ده ميورك نهدآو ازخيزى

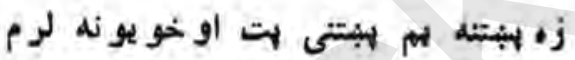

دح د لارى نه ميثكله او يتلى زهشم

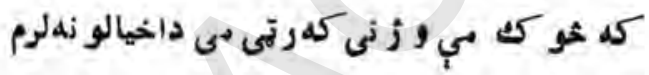

وطنه عو بو ري هى ماه وى به مرى كى زها

مستا د لو رتيا ثيه أبادو لو تينكثمز مو زهلر م

متاعر عو نلهى دبيتو بهيرو نه بلكلز ارجو رك م م

زه فر هادى عزم همثت اوطاقتو نه لرم

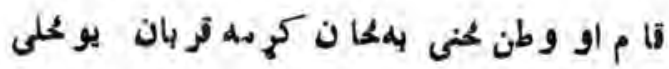

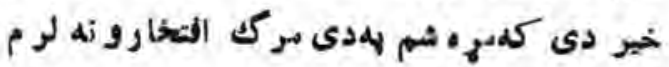

10A 


\section{الفانى ميندلى}

اى دالغان دكو رديوى اي بثتنى بو رى اى دميز ويس او احمد شاه اوز رغو نى مو رى وطن تل ليخركيى تلمتا به كارنامو باندى دغهر تبنو شته للتا بقى كار نامى مو رى نى

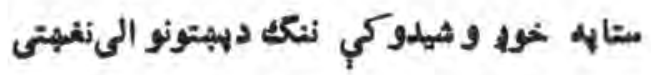
درسديزت لرى كا نكو د زهانى مو رى داتلا نو اتلمو اله دا سيتا ز زبهي نسدهده

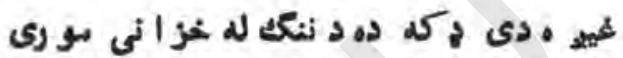
دام وطن اولاد درو زنه كمى له مينه مينه

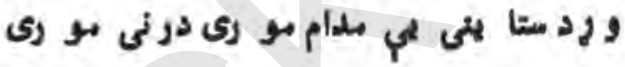

\section{فم}

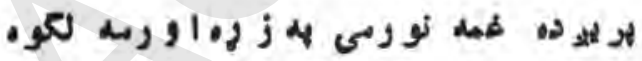

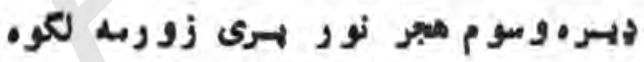

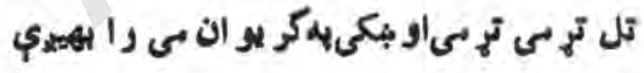

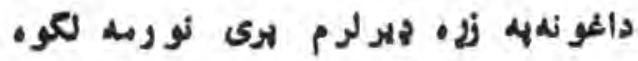

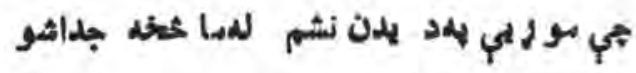

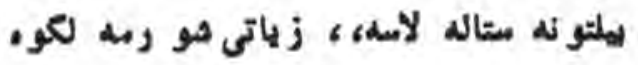


خز انسي بلهو انى كلهشودز و ندزلهشو م ييز اره

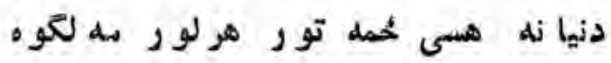

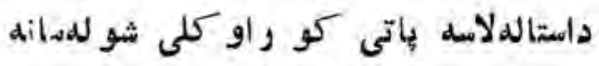
داتو لى ها رى ستا دى بهلبل تو رده لكو ه

\section{مه كوه}

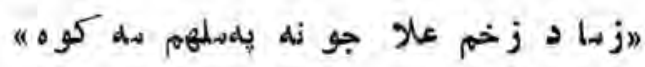

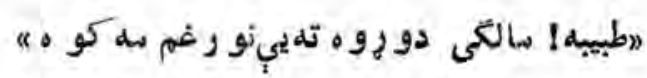

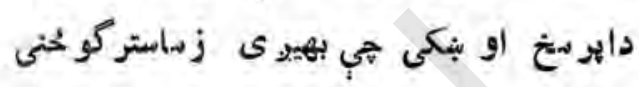
و ينى د زوره دي رار و أى خيال دنم مهلكوه

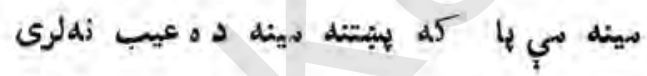

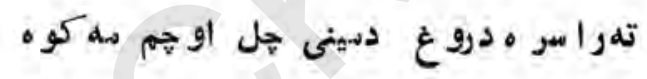

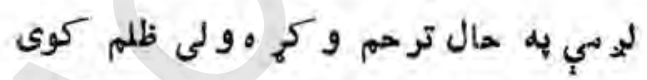

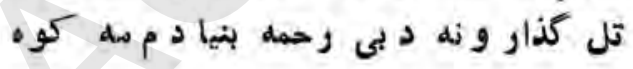
هي دى دلاسه بو رو نهأ و ميى د دينى تكليف

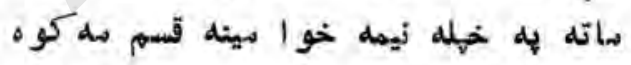

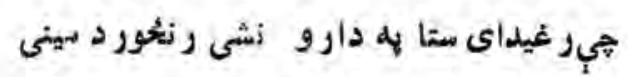

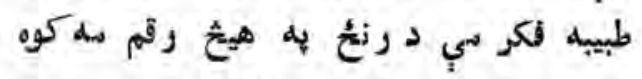

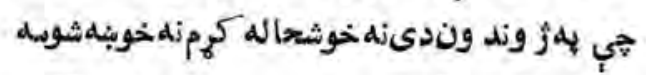
و رو متلهد موكلمي عبث و ير او هاتمبهد كون 


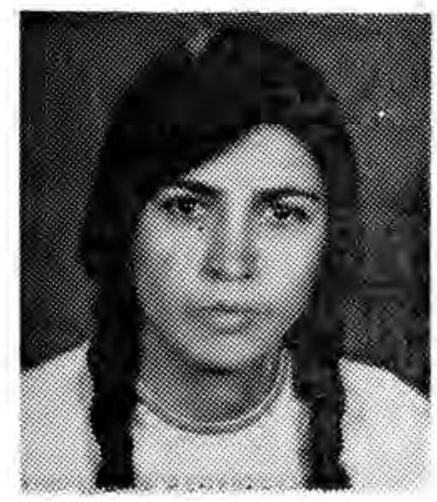

\section{نوثيروان كروخيله}

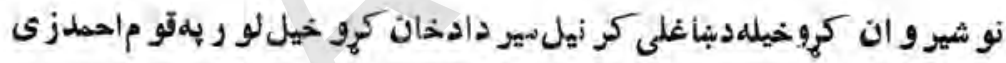

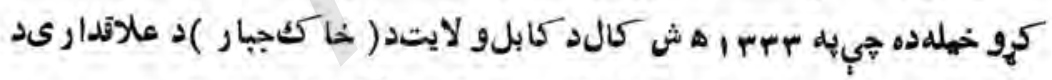

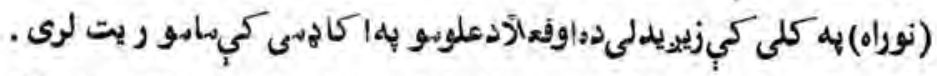

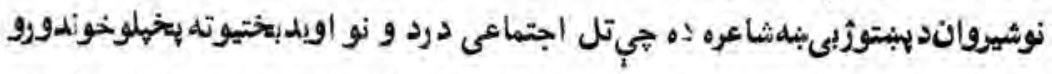

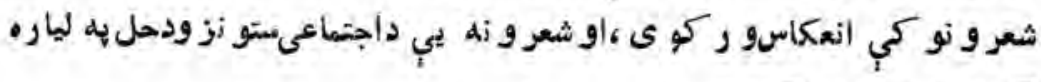

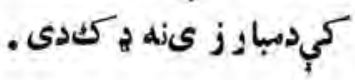




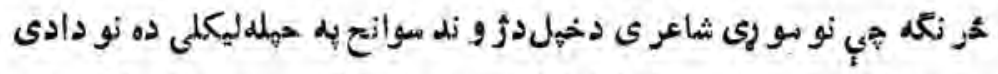

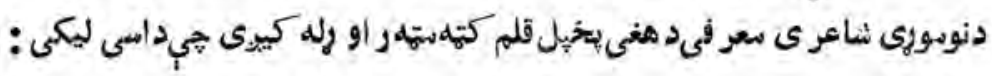

$$
\text { درني نظهوى صأ حبي ! }
$$

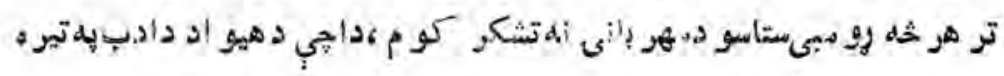

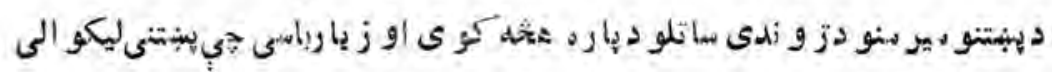

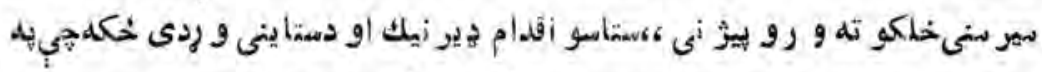

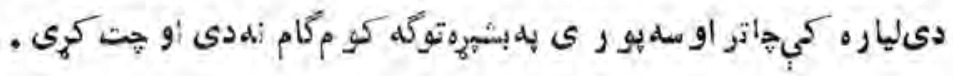

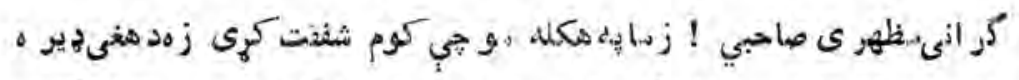

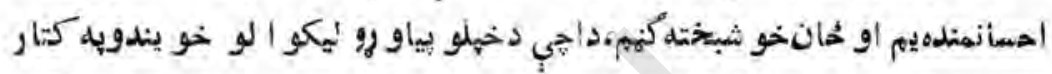

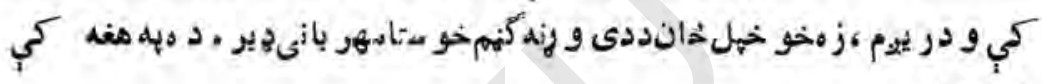
- ملهi

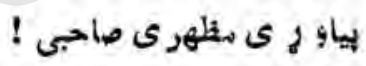

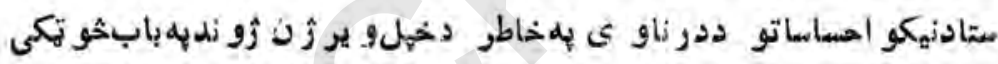

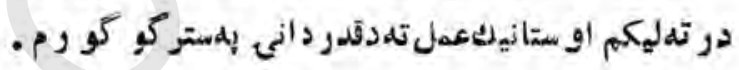
الاضلى منظهرى

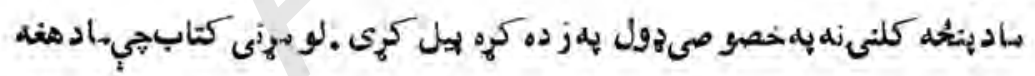

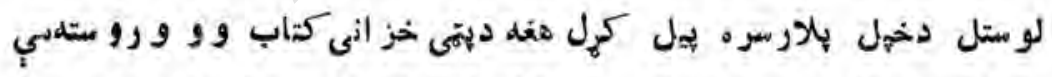

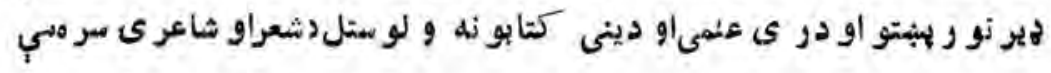

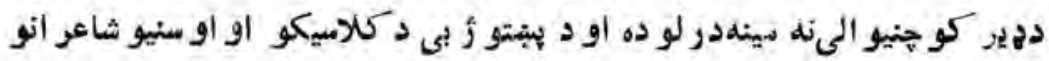

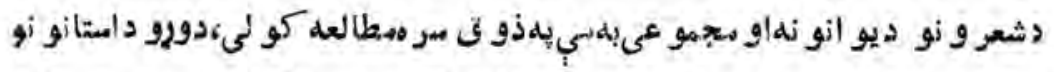

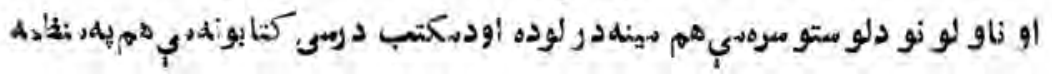




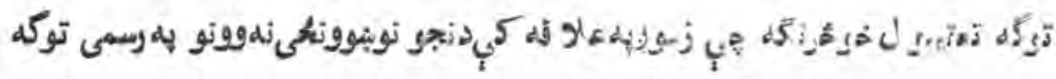

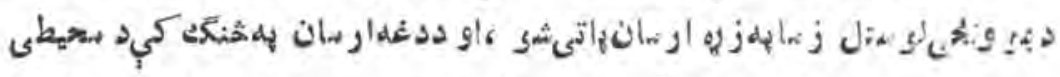

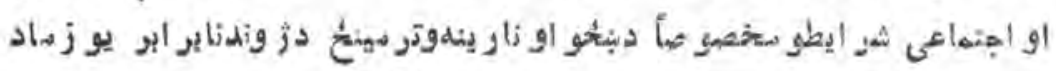

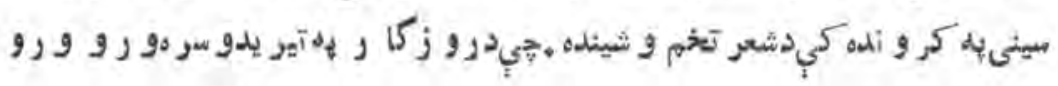

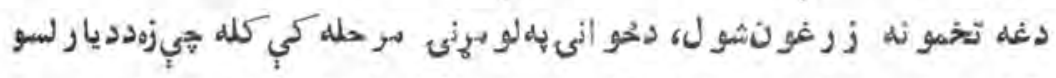

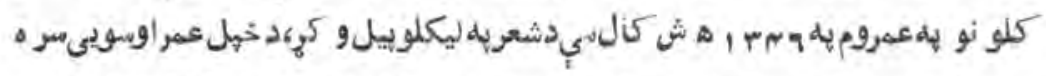

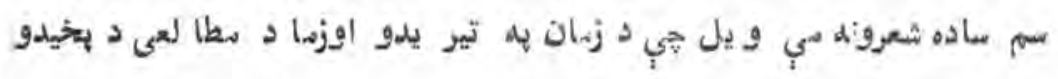

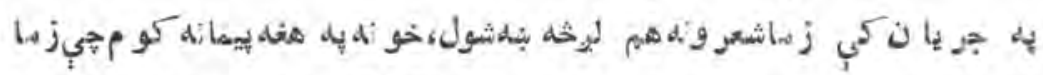

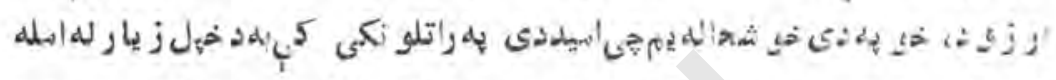

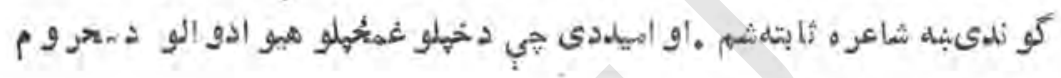

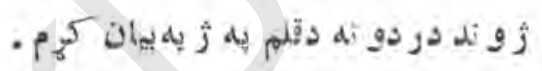

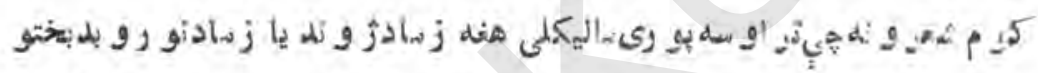

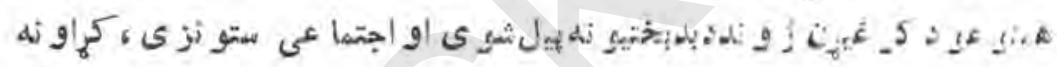

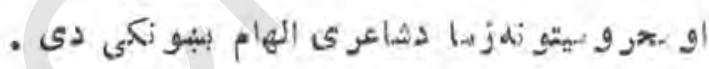

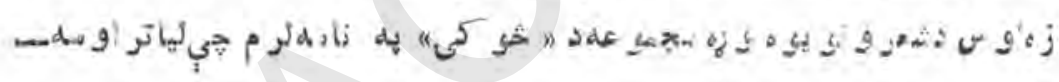
بو ر ى أهدمخيو مشوى.

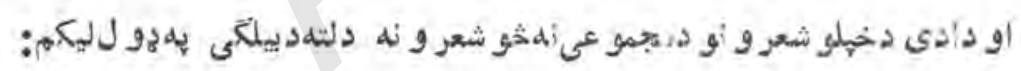

$$
\begin{aligned}
& \text { كاركره بيخله وايي }
\end{aligned}
$$

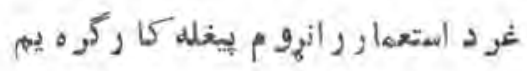

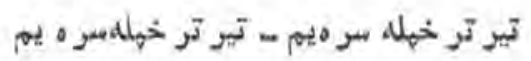




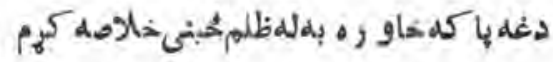

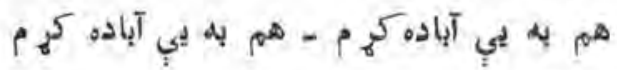

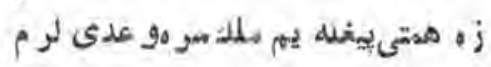

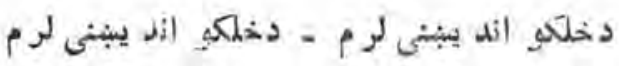

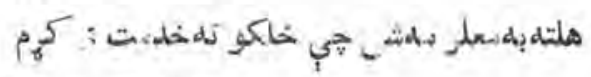

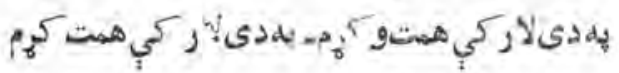

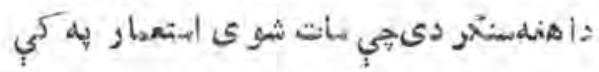

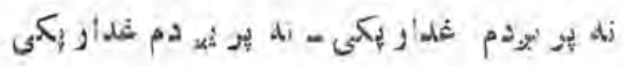

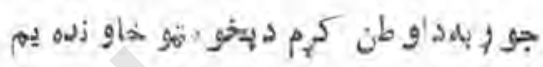

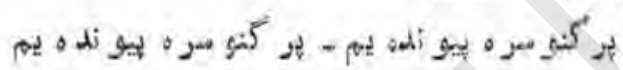

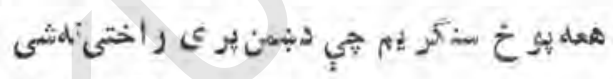

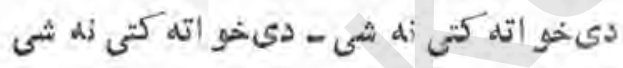

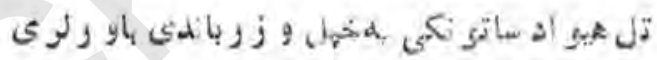

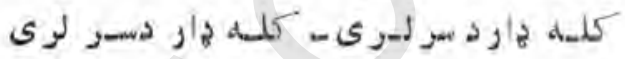

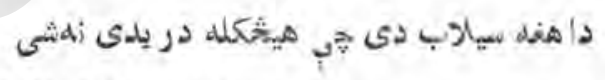

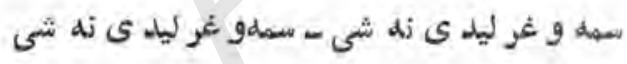

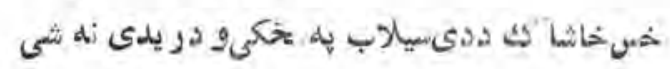

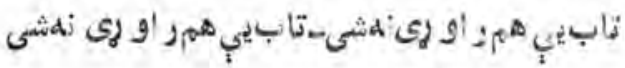

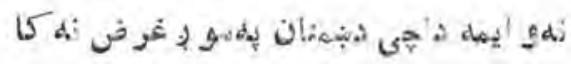

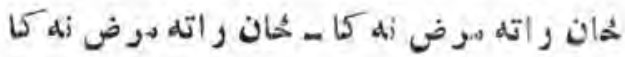

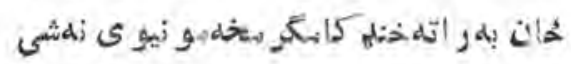

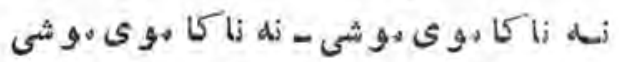




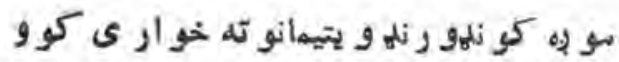

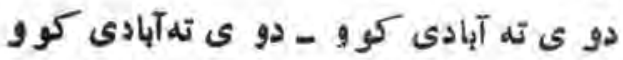

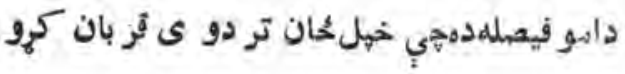

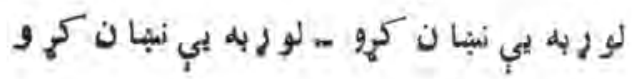

$$
\text { خ خهلواكى موري }
$$

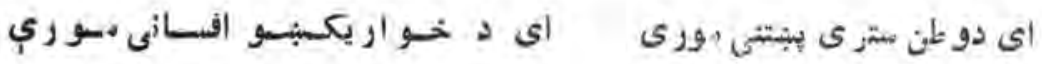

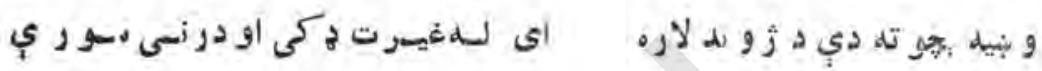

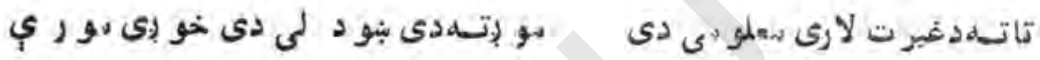

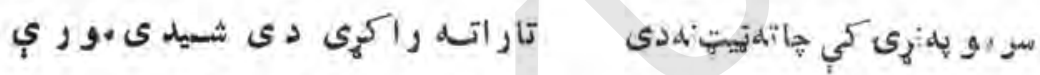

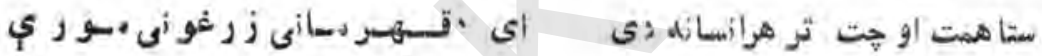

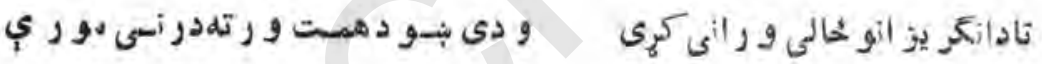

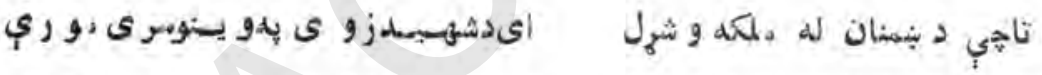
ماندي كرئربان

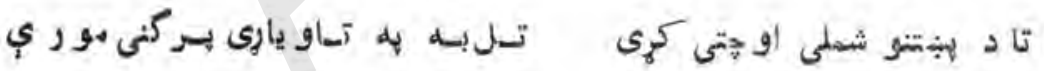

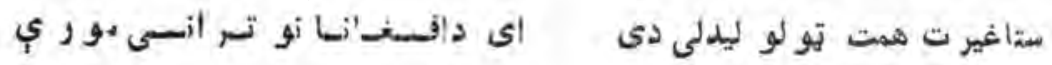

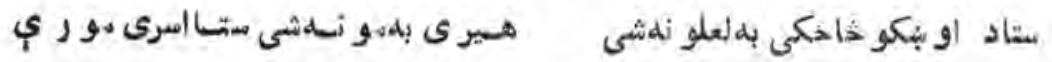

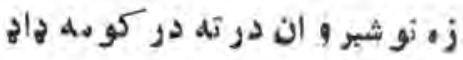

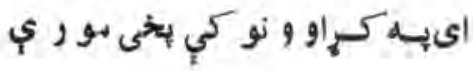




\title{
وطنه
}

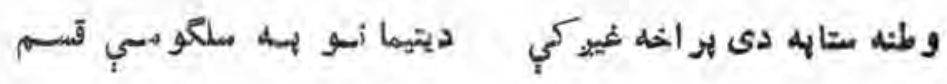

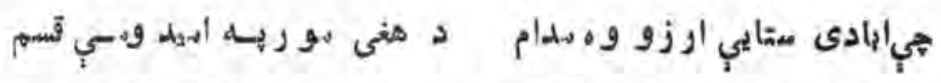

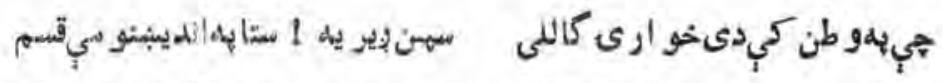

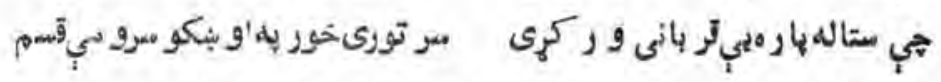

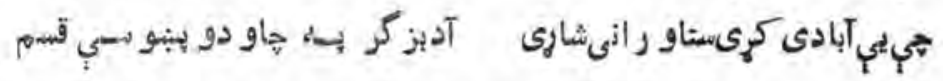

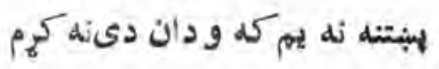

$$
\begin{aligned}
& \text { وطنه ! بنكلى كستاندى نه كئم }
\end{aligned}
$$

\section{برندىستركى}

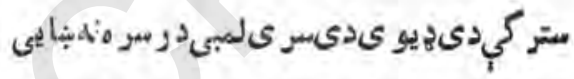

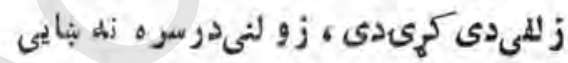

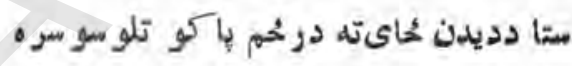

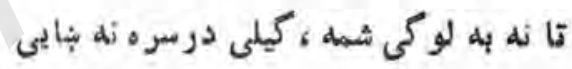

ليرثه لبكيسو كيسو به نيئه خحانر اوينايه

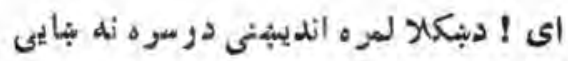

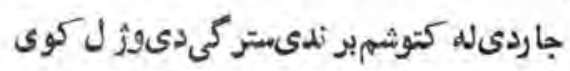

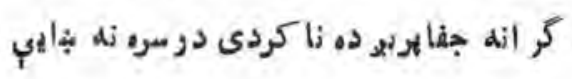




\section{د وطن زلموته}

تر اوسلمحو هنلهياستى بهمتو كميقوت تلرى

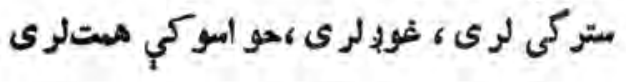

$$
\text { اوس همبر دو ختدىسستىو ركدلفخهل كحانه كرى }
$$

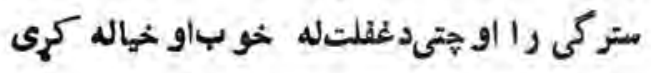

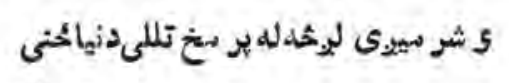

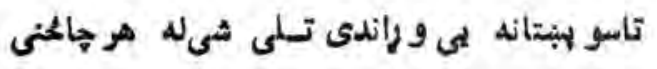

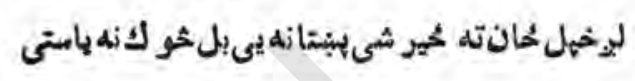

مو رمو بيتينه ده له مهزجابه هيخ كم تلهياستى

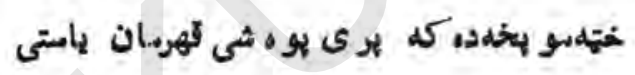

زو رلرى قوت لرى زمرى هي او الفان ياستى

خاو ومد زيكو به تاسو و يا ري النخار كوىى تأسو لو رته كو رى هيله تاسو نه دكاركوى

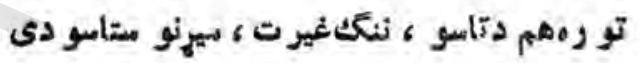
ليخخيل لحان تهحير شيى دامير اث دنيكو متاسو دى دي

$$
\text { نئيو ازى نه ياستى ححو انانو و رو ر تر بو رلرى }
$$

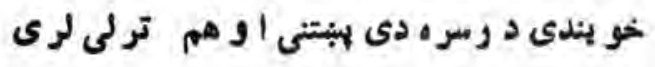

$$
\text { وكرى اتفاقدو رو ر و لىلاسو نه و ركيى تول }
$$

مر باندى همتكوز ار، سهكثليم تهو ركهى تول 
كللهو جيو رك كمل دبيمنان لهخهل وطنحخى

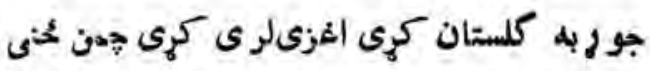

وسو محى هغلدبنعن خي متامى كو رو و انى غو اري

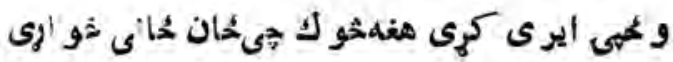

داوطن 21 متاسو دى به تاسواباديري!يه

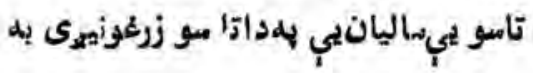

\section{دوطن مينه}

اى وطنه إ متا رغو نه بي ياد يجى

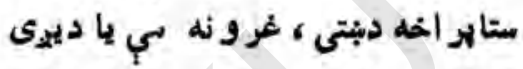

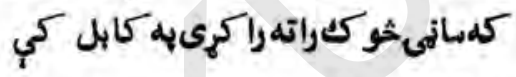
د وطن شينكى با عو ثه مي ياديخى

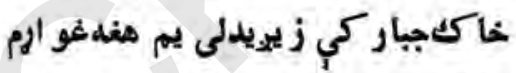

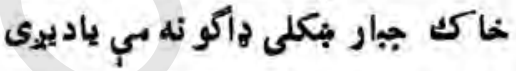

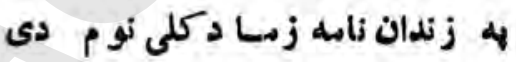
خهل هغه كلى كو رونهني ياديزى

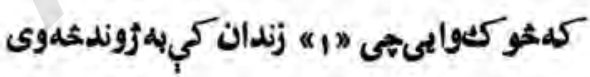
خو رم سو كنلخي آه دودو نهديى ياديتي

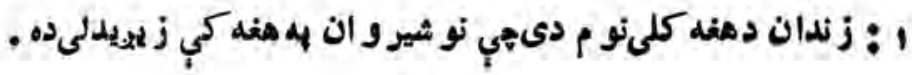




\section{سور ماتم}

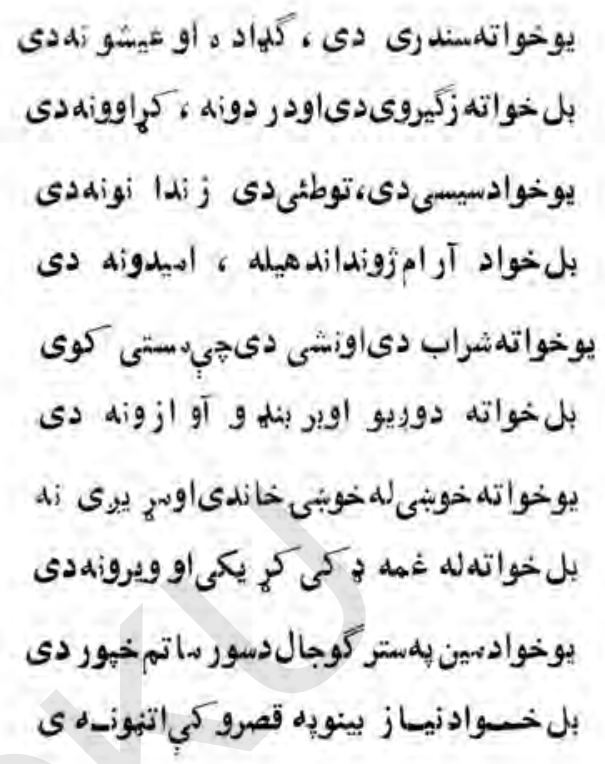

diditiot

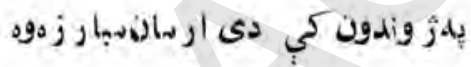

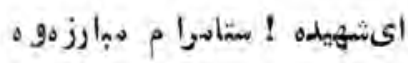

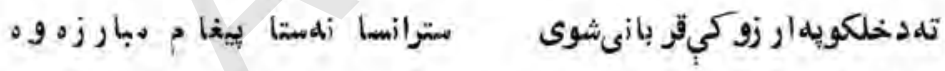

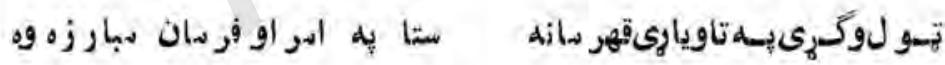

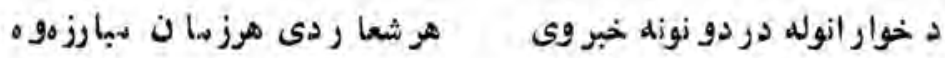

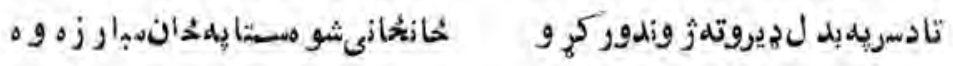

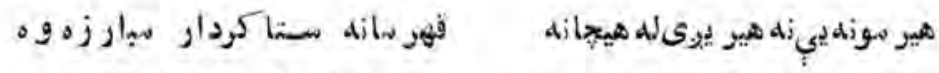

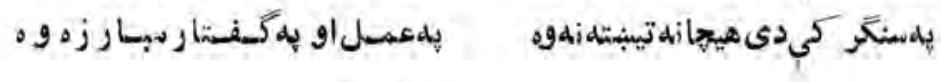




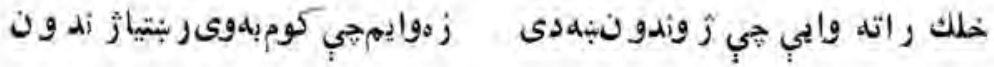

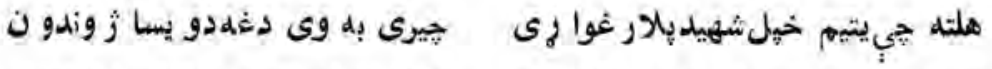

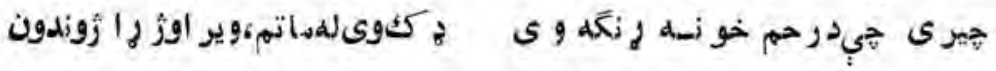

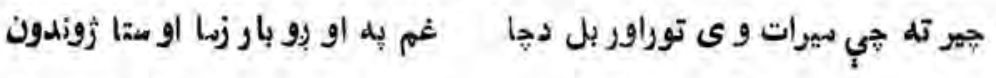

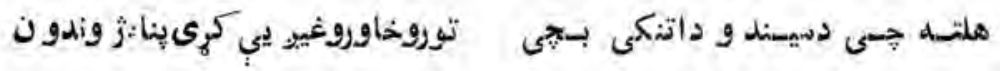

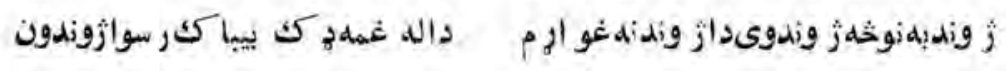

$$
\begin{aligned}
& \text { هسى سب لـه خولى خبرى خـله كإِى }
\end{aligned}
$$

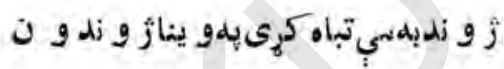

\section{دمانيوقهرهان}

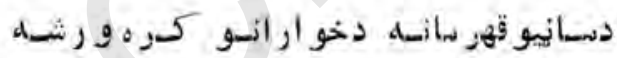

دو لس لسه كراو و نسو ، بد بختيو نسه خبر شهل

زلهدبل بلهوينو غتشوى، زوروفشىىاو اوحتشوى

بو رى مو رنه سير اتو يبغلو دغمو أو زسه خبر شه

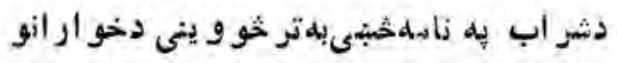

دابيبا كله دستى ير يور ده له نشيو نسه رابهز شسهله

دعالى فكر خاو نده ، غر بيان بير خان راتو ل كره

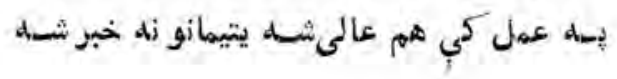




\section{دوحمن يه هدل يره}

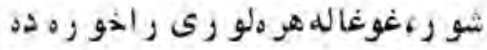

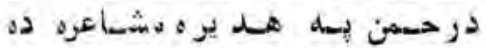

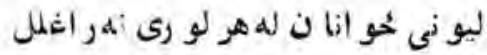

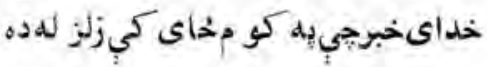

$$
\begin{aligned}
& \text { شـاعسر انو مساكتيرلى روانسيسرى }
\end{aligned}
$$

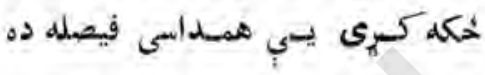

$$
\begin{aligned}
& \text { له اتهكه ، له حتر اله و ر ته ر اغلل }
\end{aligned}
$$

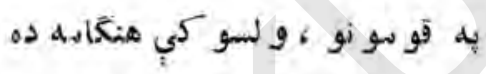

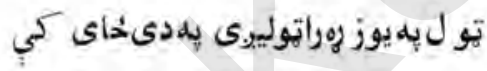

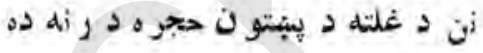

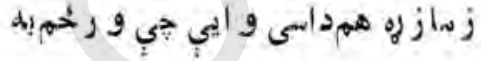

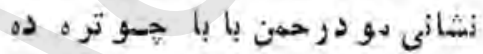




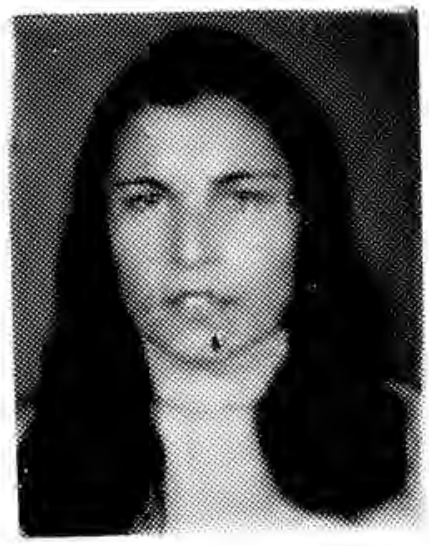

\section{ناهي_د}

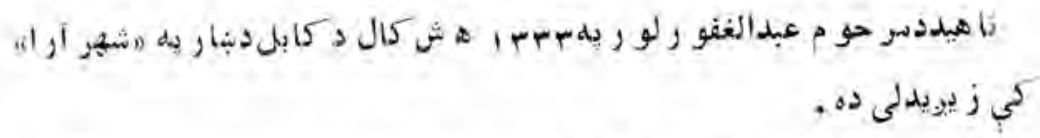

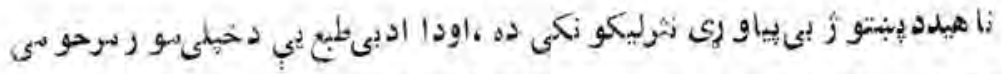

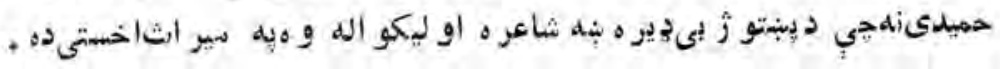




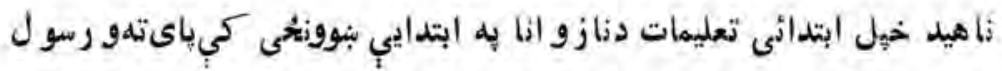

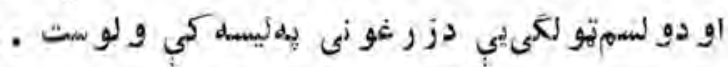

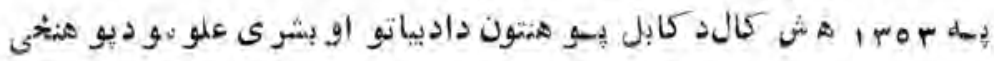

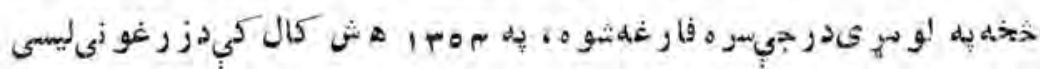

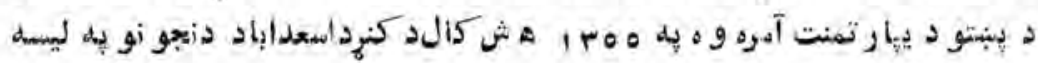

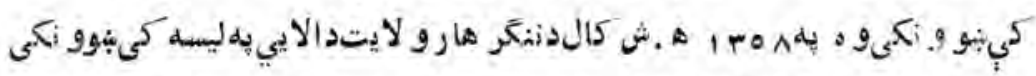

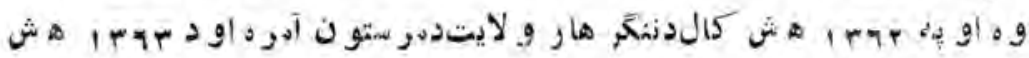

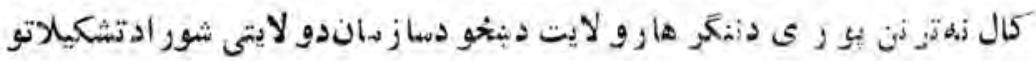

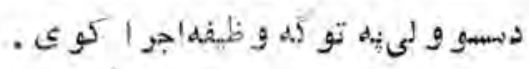

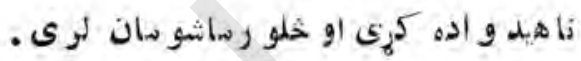

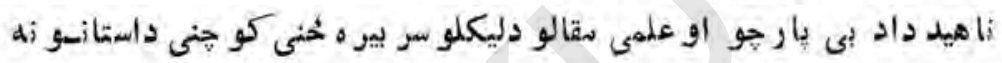

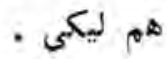

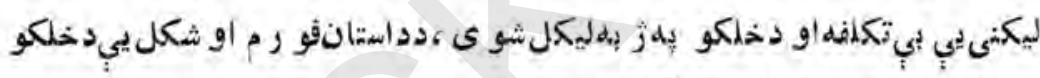

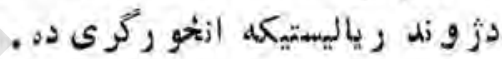

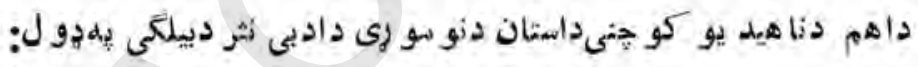

ز زانصيب

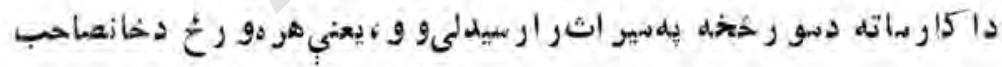

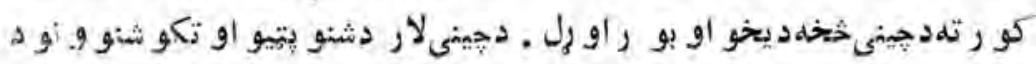

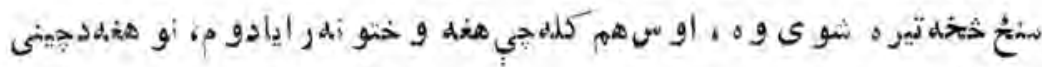

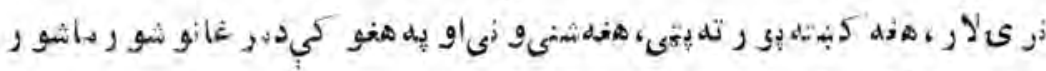

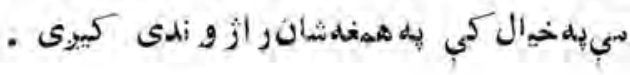




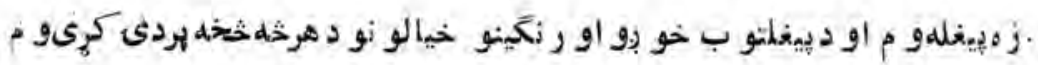

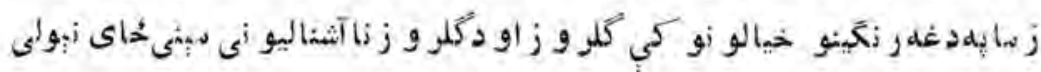

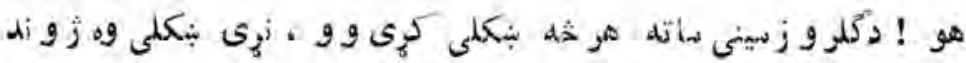

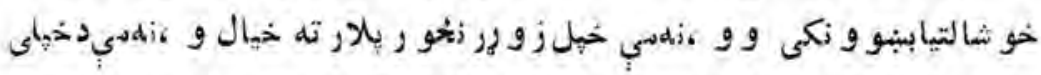

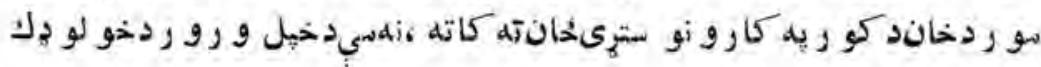

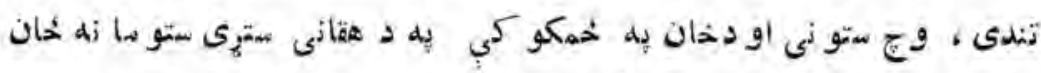

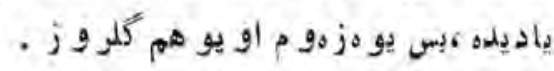
* $* 2$

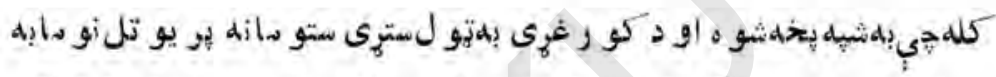

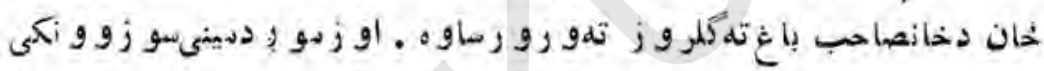

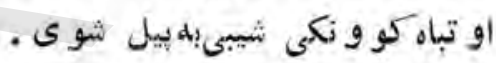

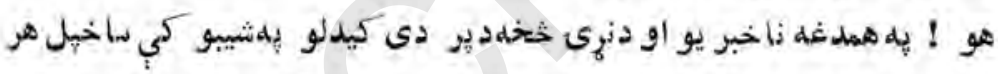

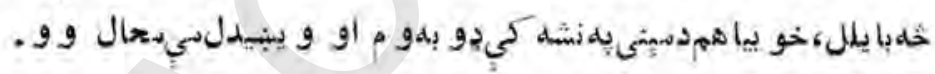
* * * *

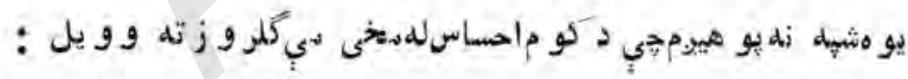

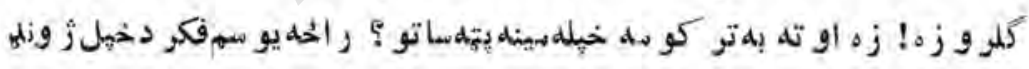
. 959 arsody I.

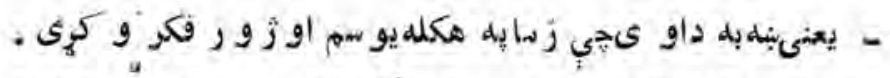

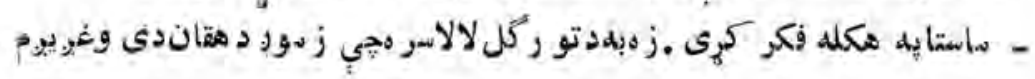




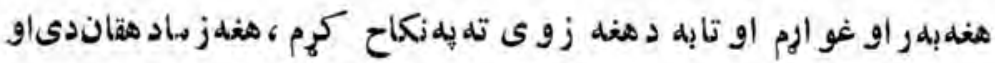

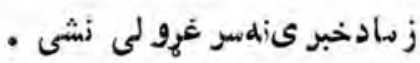

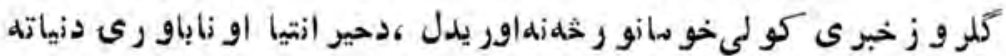

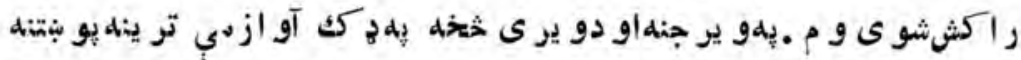
-

كلرو زه

$$
\text { و لى ته ؟ }
$$

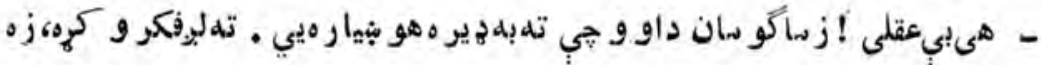

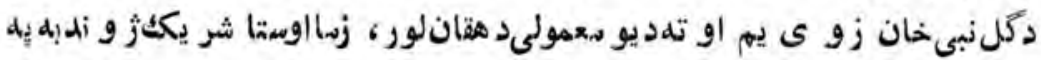

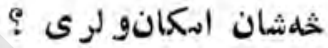

$$
\text { زمدوإه أو يبنه شو مخو هيره ناو ختله... }
$$

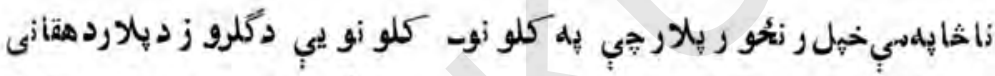

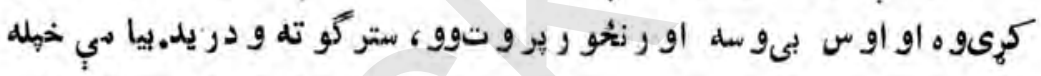

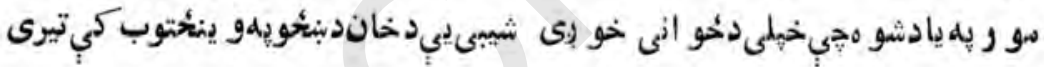

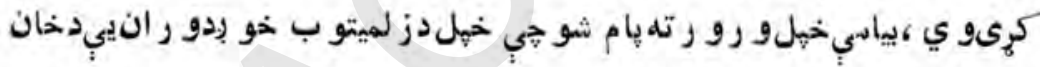

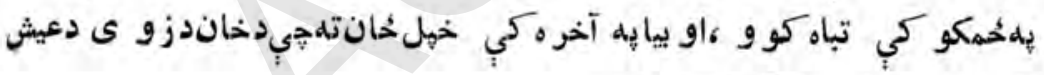

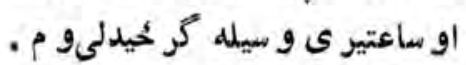
* * * *

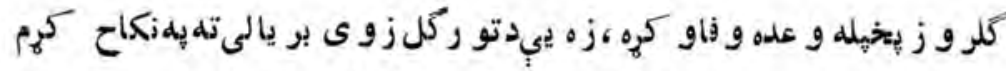

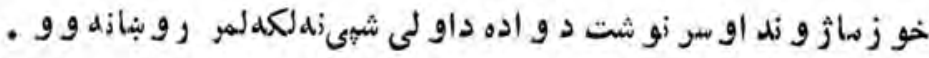

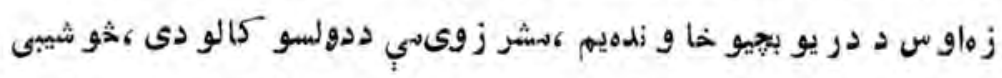

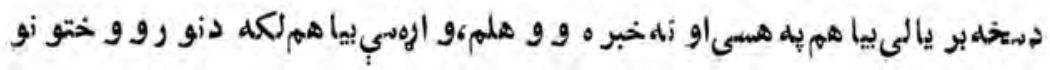




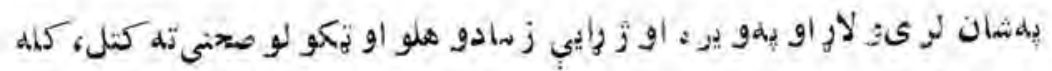

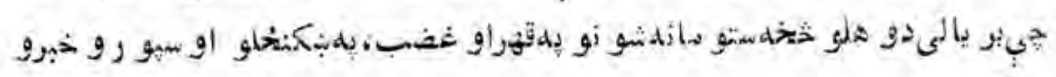

$$
\text { . } 2900 \text { sos }
$$

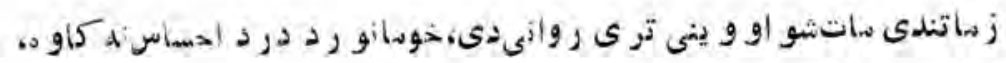

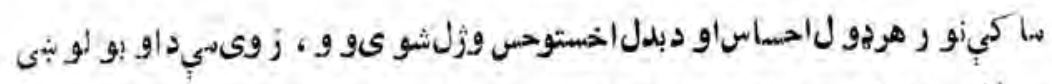

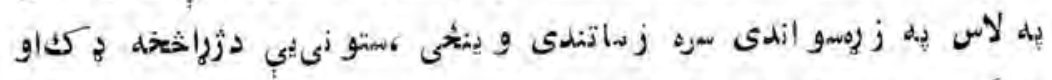

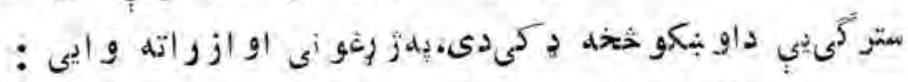

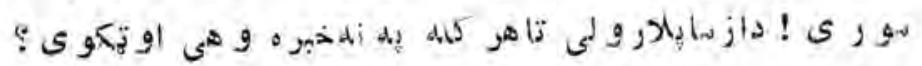

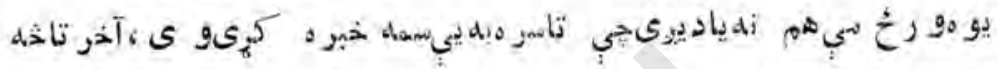

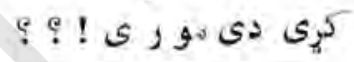

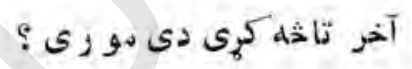

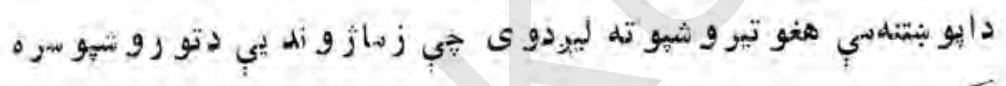
... 5 is

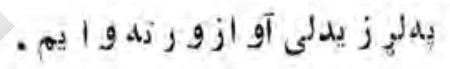

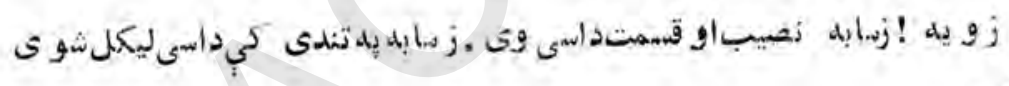




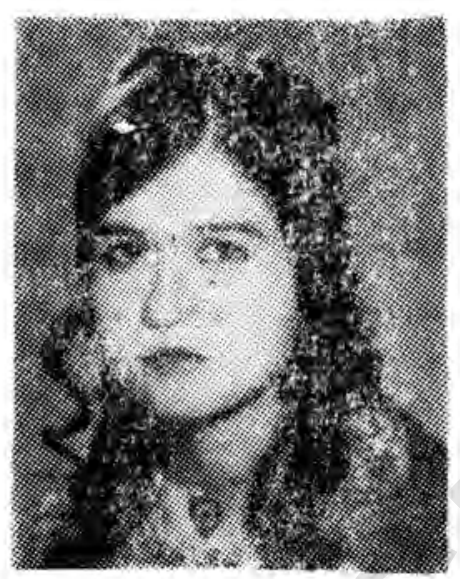

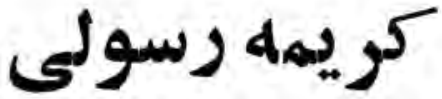

كر يهلهر سو لى ديتيتو داو سنى ادبعحو انه شاعره دمر حو محاجى عبدالشكو ر

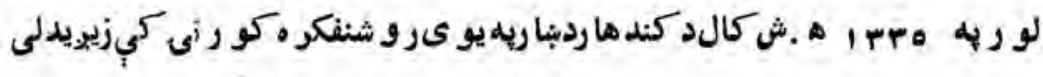

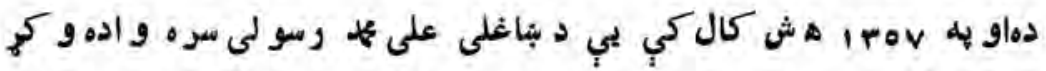

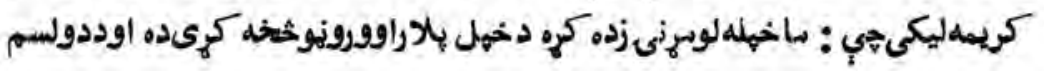




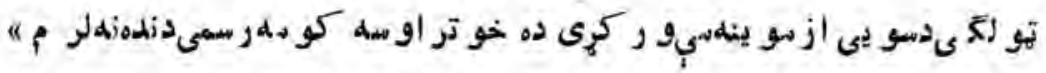

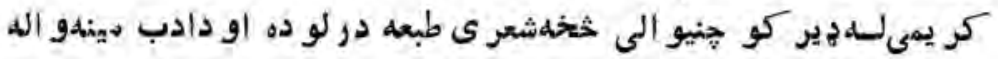

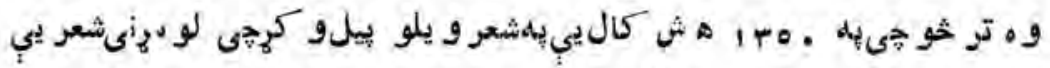

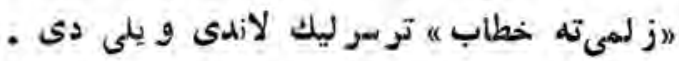

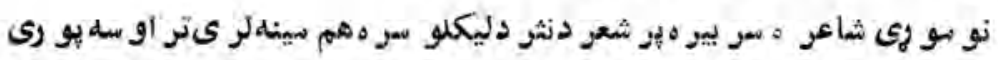

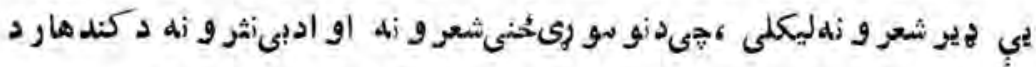

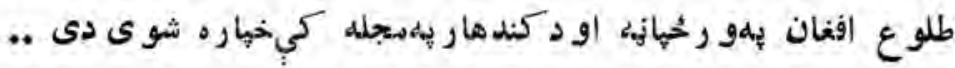

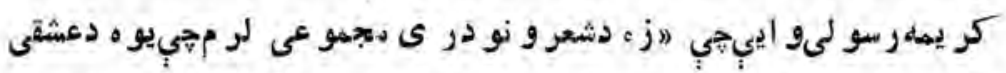

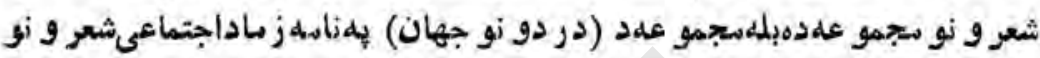

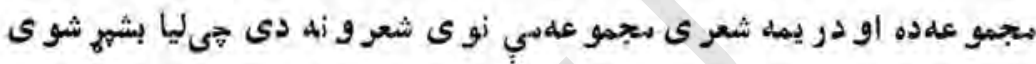

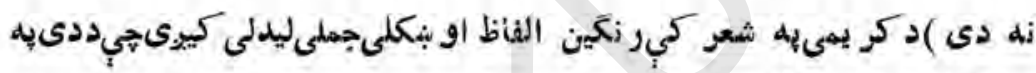
ناز كت خيالى دلالت كوى

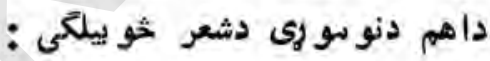

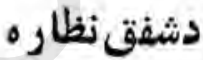

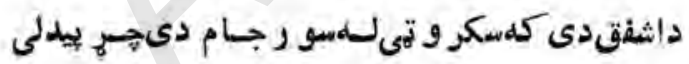

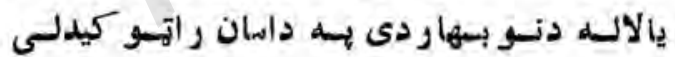

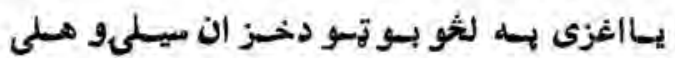

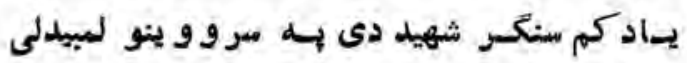

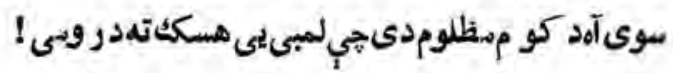
يأسالو سسو ر دليلا دى به آسمان راغسو ر بـلدلى 
يا دسرو و ينو بهير دى يابه كو م ميدان غز ا ده ياسو راو ردى جابل كري كم فلك دىعيو زيدلى

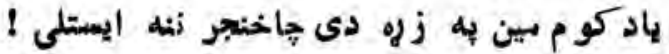

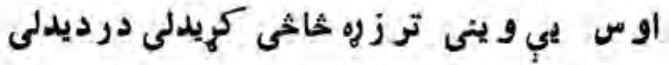
يا كارو ان دسرو ياقو تو به آمعاندى رابلن شوى

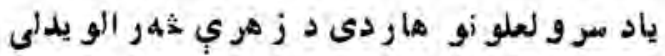

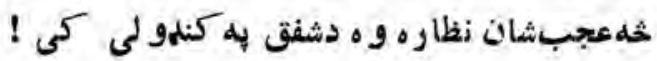

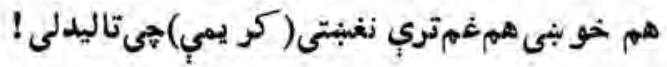

\section{dي}

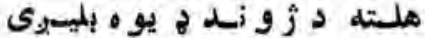

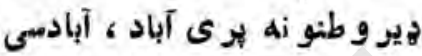
بهو هله مبسابو هله بسةار اكوى يو هلدوانيكادمدأكروو ن جوروي بو هل دوريابدى طو فازونهلر ى

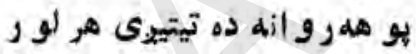
موتهدمنو ىر و ألدون مشار او لى

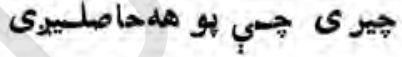

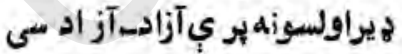

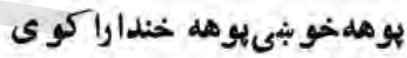
مو هلجهان بهوهلزوندونة جوروى يو هـلبو ينهـاده تيكرو أهلرى

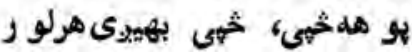

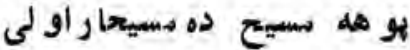

\section{ائبهار}

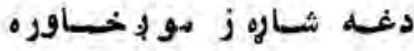
داز مو إنمينه زمو إنشكن لمدى
جسو ركهة

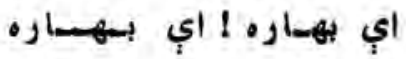

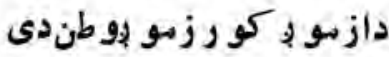 و رك, 


$$
\begin{aligned}
& \text { رأبساد كسةه سيير ه غـرو أسها } \\
& \text { لار ى فـوشك ه ه بسه كلو نو }
\end{aligned}
$$

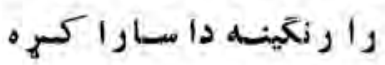

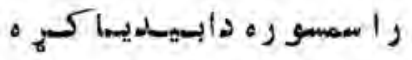

$$
\begin{aligned}
& \text { داتنكى ـ تنكى حو انانهم ! } \\
& \text { داو حشى ، و حشى كاكلان هم ! } \\
& \text { بلهز و ندو ن يب ار استه كره }
\end{aligned}
$$

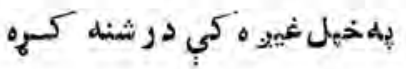

\section{كهنlم}

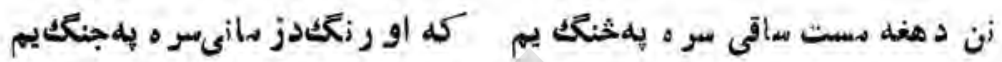

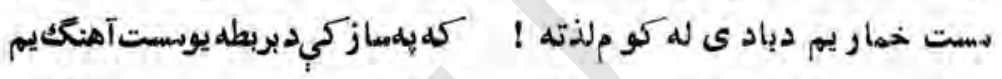

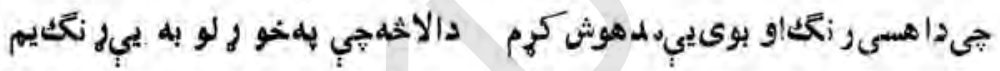

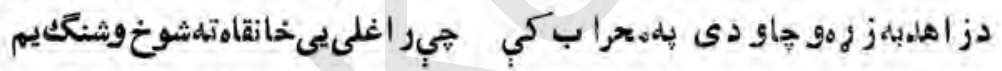

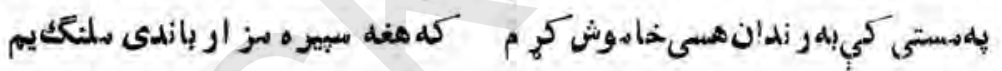

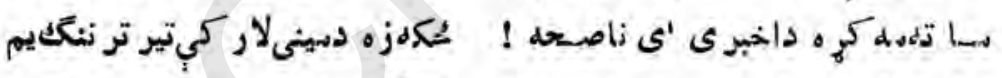

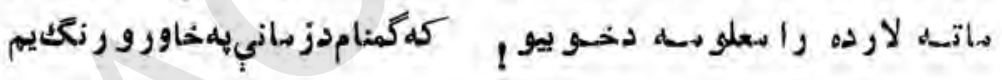

\section{تdidi}

به زمره رازو زه توكيدل تهنهو ى

كالان دلمينى

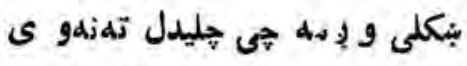

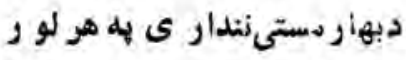
ستب آبشارو نهخو و شيدلثهنهو ى

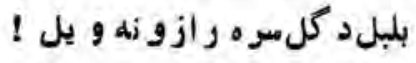

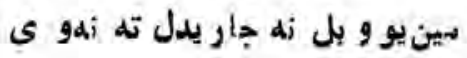
هلته ددينى بزم كاه و. جو ره 


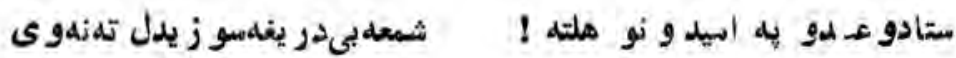

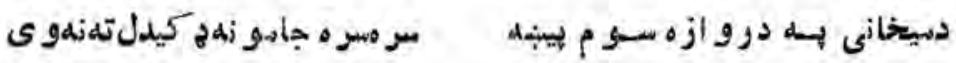

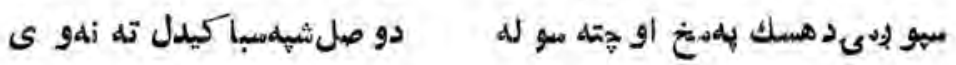

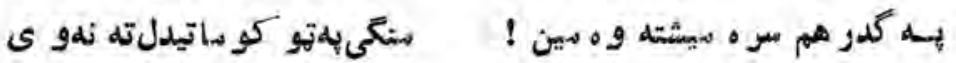

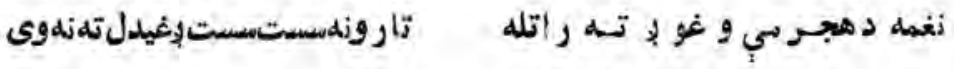

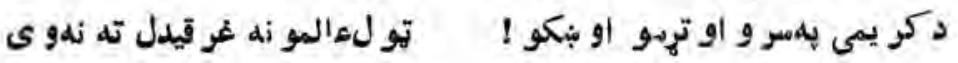

دنظرسودا

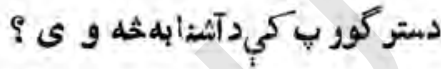

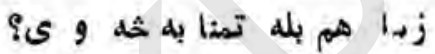

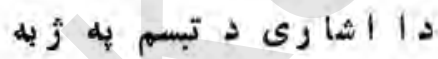

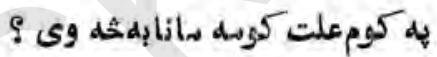

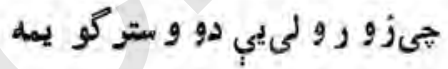

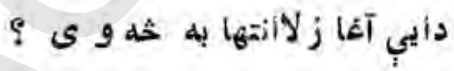
زن يبي د نينى ليونى - ليونى دده دشوخ نظر ميو دا بهحلهو ى 9 خيردى كلهسني خزي خزان تالا كى دده دحسن همبر ينينا بلهحلو زه هم آشنا ر راكيناستلى يهه كوره اقبال كى لاز مأ بهحه و ى ؟ 
تصور

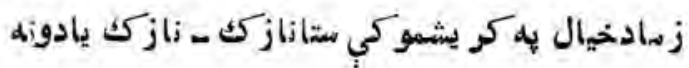

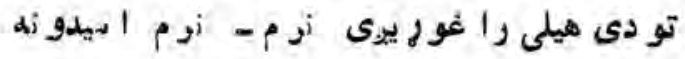

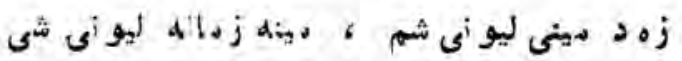

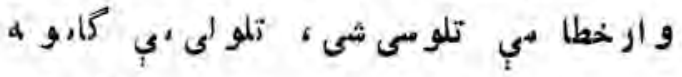

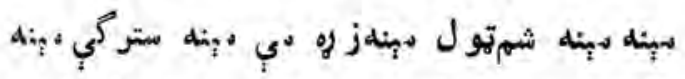

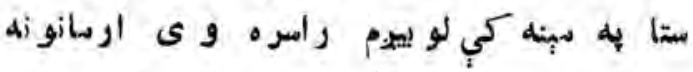
به ورو - و رو سلكو درته سازم افسانه كرم بيا داو بنكو سوغات در كرم در تهو ايم خهل غثمو نه

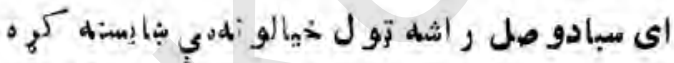

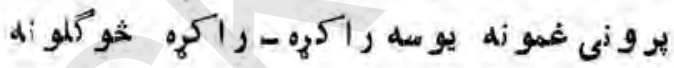

بي لرواساقى

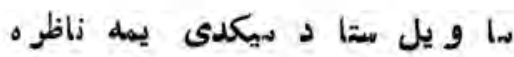

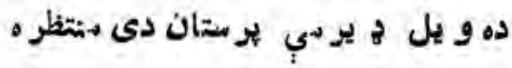

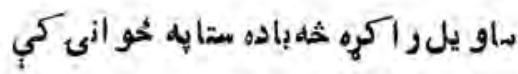

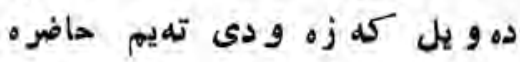
ها و ويل حممه رسو ايى إله كريه جو رول

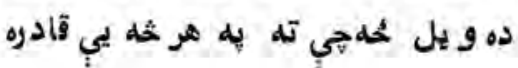


هاو يل تل دبنكلو وبه هيله خاندم

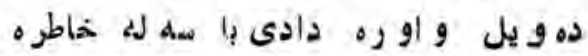

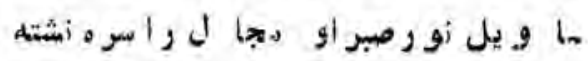

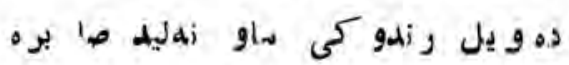

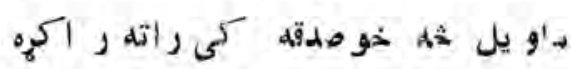

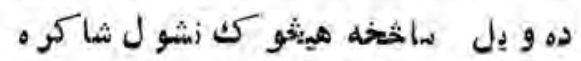

\section{غر ور}

در تسه ر اغلم بستانودر ه

لـه عـالفهلبيكازسه ثـوم

رنغ الوتى بنه خهر

لنيى تهنا كى كر يوان ثيزى

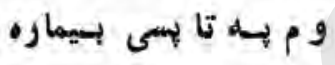

ستألهفمه مر ه غمىشو لهى

صبر و ر كففكر حيوانشو

ر اغلم ستادى بنا ه كاه ته

ستالهستركو دو ار ى شمم

يو ديدار بي و و نطلو به

نور سيز رهر ارنيُو روسه كره

دهستى غرو ردى مر يوده
تسرتسا جـار ثشمهل دلبسره

به دشتو أسو آو اره شوم

ثو نسلهى 9 جيى شير ه ز يسهن

مسر بسبر ، ستسركى ز هيرى

له هيكز روح نساكر اره

او بنكى نو رى ياقوتىشوى

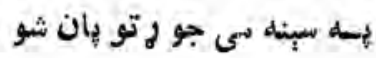

خسو بهله سوى سياو تساته

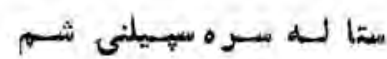

تسرتساو كرزم زعبو بسه

او س نو ر اشه خر و ر مهكر مانه

رضا زما لها 


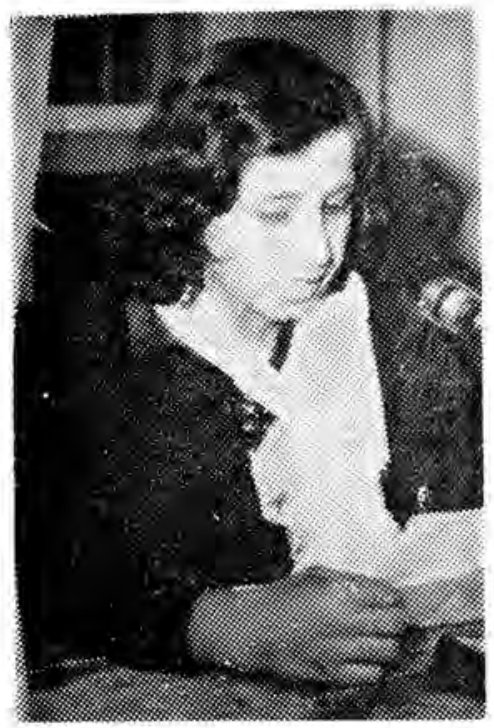

بلقيسيسمحمبربى حةيق

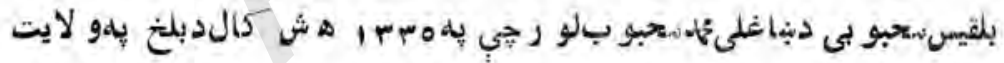

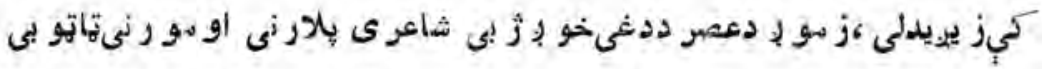

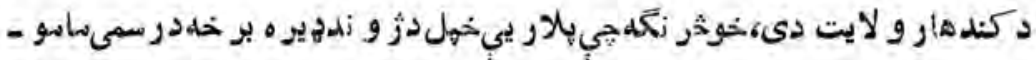

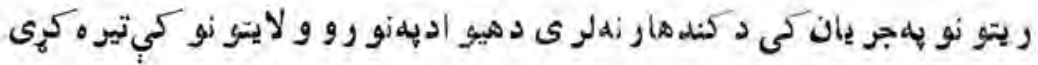

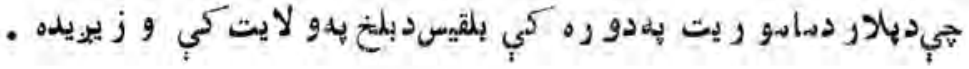




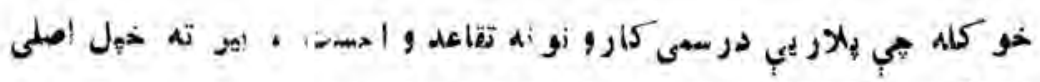

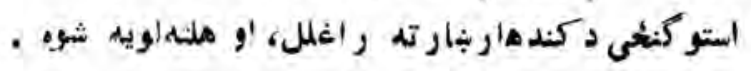

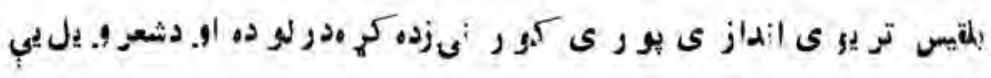

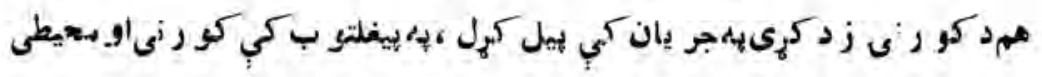

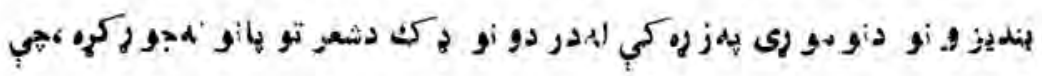

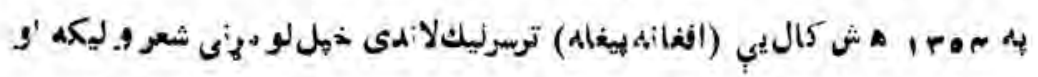

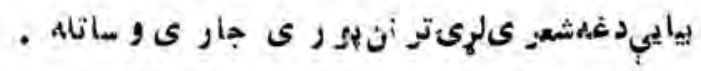

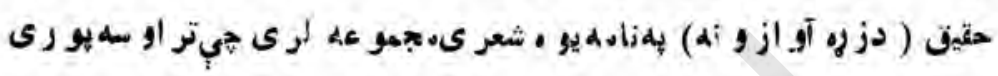

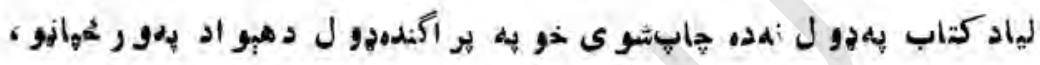
جر يدو ، او سجلو كي دنو مبو زي هيو شعر و نه خهاره شهو دشعر و نو دييتو نو

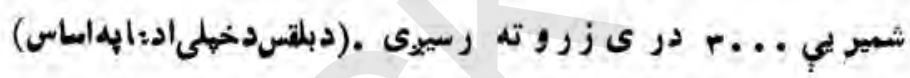
بلقيستعبو بي حقيق و ايیىجي:

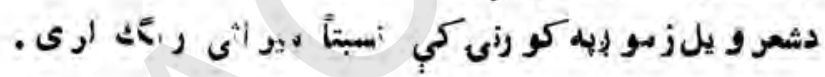

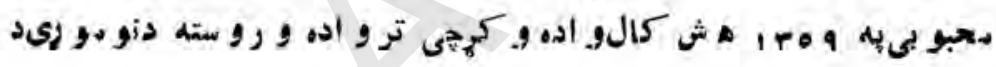

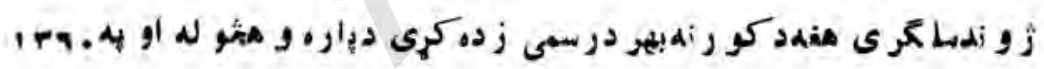

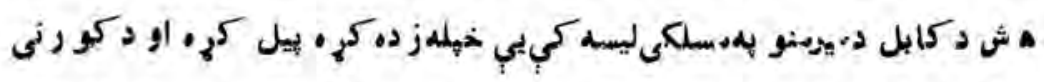

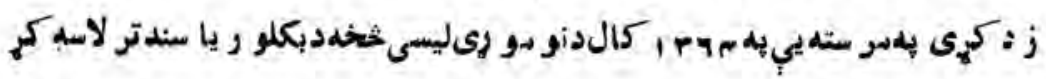

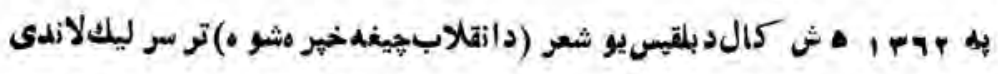

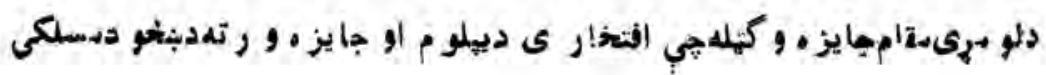




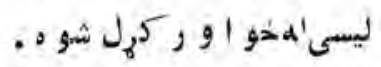

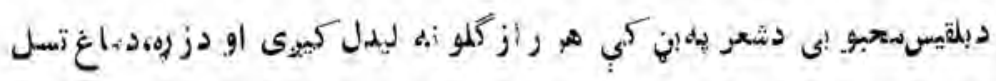

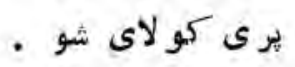

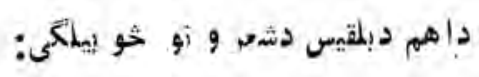

\section{د تنها يجىسوو د}

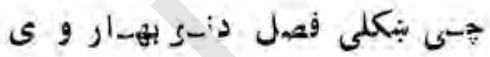

$$
\begin{aligned}
& \text { زرغو نفرشو أله هرخو ا هو ار و.ى } \\
& \text { غر و. أسـة رغو أله كل او. كمز ارو ى }
\end{aligned}
$$

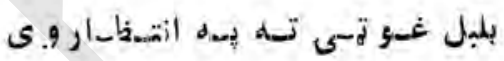

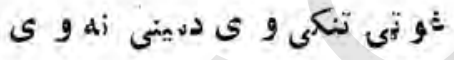

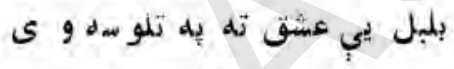

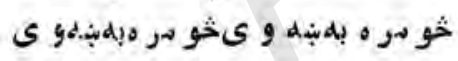

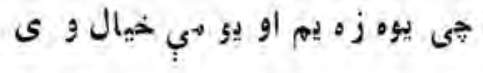

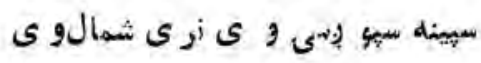

$$
\begin{aligned}
& \text { راخخه لمرى غنم و ج-نجال و ى }
\end{aligned}
$$

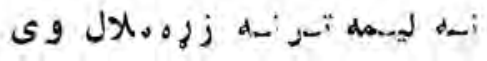




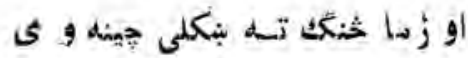

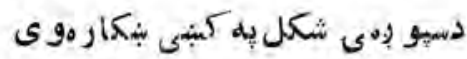

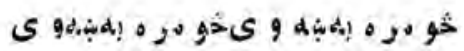

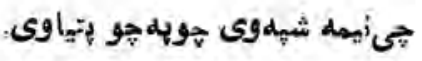
بر اخه صحو اوى بِّكلى فضاوى أه iاه =حان وى او زهله بار ما وى ها جو وه كرى دخيال دنيا وى

د السمان مخو رى جـردها إيرهوى

ساغو لبر يزو ى زوه آديو دهو ى

خو +رم إبلزب

جي ألهو يلو ى 'و أه شنو دو ى

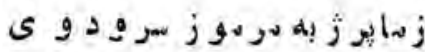

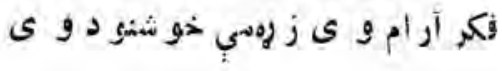

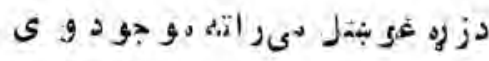

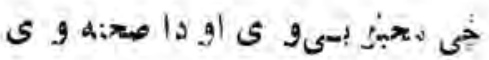

سكو ت غايبهو ى غور غا و بيدةوى

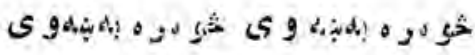




\section{ذمينى سموالونه}

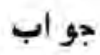

Iال

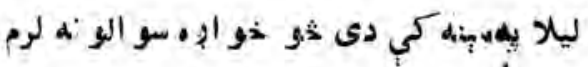

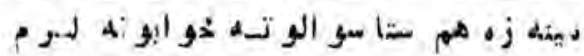

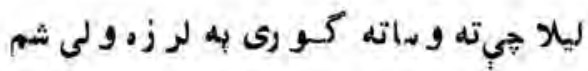

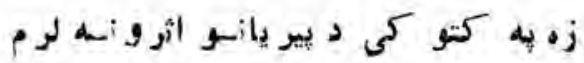

دز هـ آر ا مثبي سمة آرام آر ام كتو و ري دى

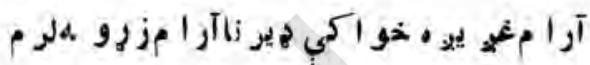

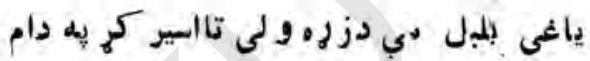

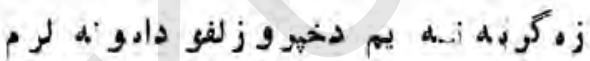

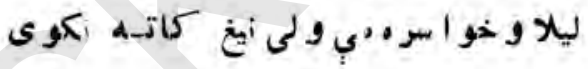

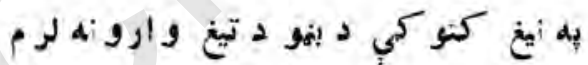

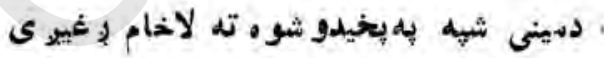

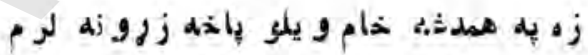

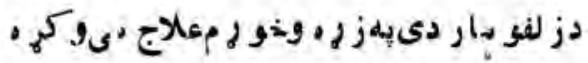

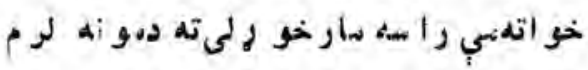

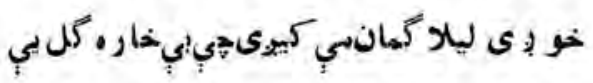

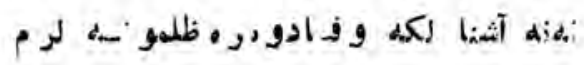




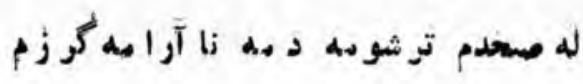

$$
\begin{aligned}
& \text { زم حقيقى دين تسه دو مرم عذابهو أه لرم }
\end{aligned}
$$

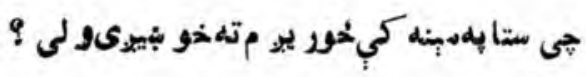

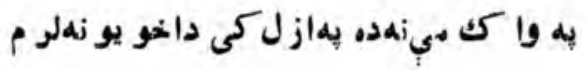

\section{افغانه بيغله}

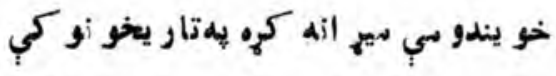
ز.0مو ولب بنده كر مدظلم به جيلو نو كي خو بلمزه دخهل ميو ادله كار ملاس ترلى يم ثو بو رى بلهو م مداحنئير و iهبهلاسو نوكي خو بو رى بهليته للجهاiأه بهلير دو كىيم ثو بو رى بهز و أدمكو متو رو ظلمتو نوكى ننسي الفانى ودو و نهلرو اندىد هدف بهلور هاته ممدرتكثاشارى كاند ى هلهر منز ونو كمي

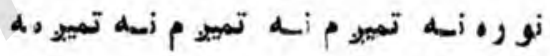
كعهل نو م كتمهد هيو اد بهله تار يخو نو كي ثو بهدخار و يو او د مال بهخير خر خيم مه ثو بو رى بهز وندكوم بهداسى يهنو رو نوكي 


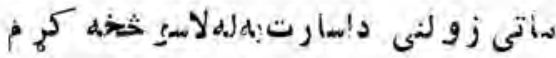

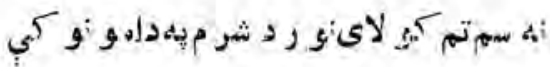

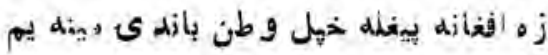

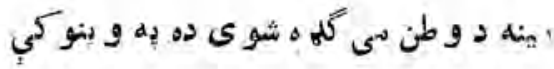

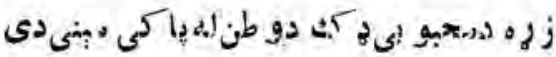

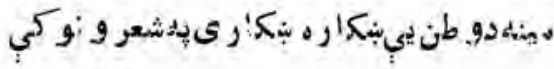

\section{سوله}

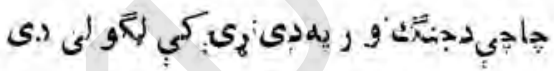

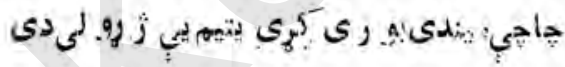

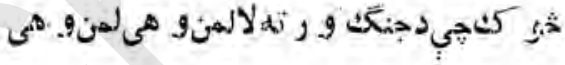

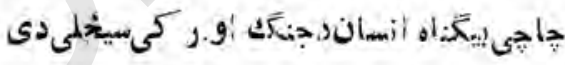

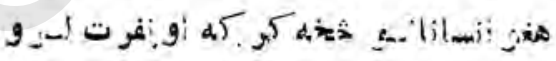

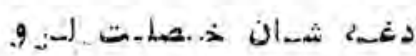

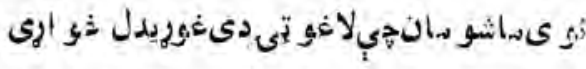

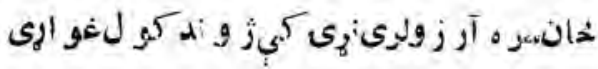

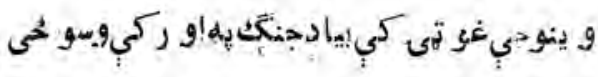
خكيه جي غلمه دابشر نبسل فو رو كول غو اري 


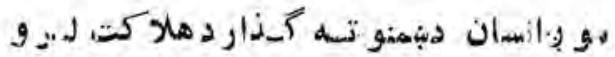

$$
\text { 9. }
$$

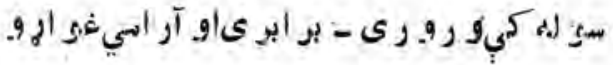

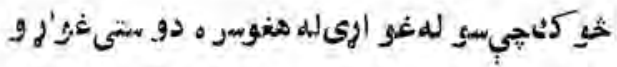

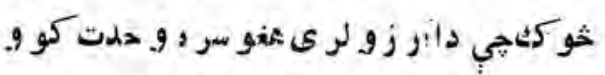

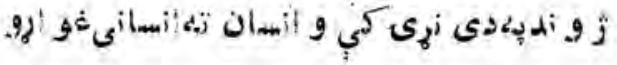

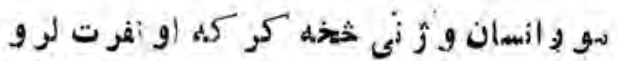

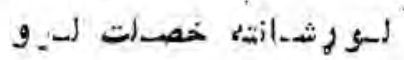
زماكر ان افغانستانه d_il-t.to domb = s |

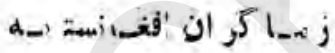

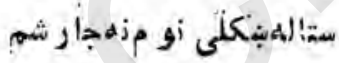

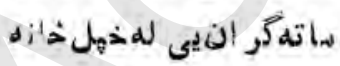
* * *

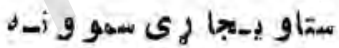
do. ز زما هدف سمة آباد ى ده

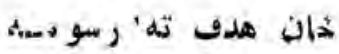
$* * *$ 
داستا كي كي و لسو نسد

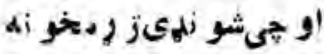

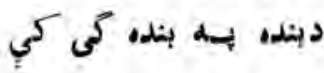

تيو كله +ياشتى'

***

زيه برى رحهم دباد ارو

i di

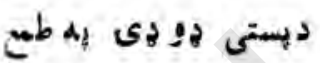

تل ذّل رل ديدو ى إهيانو

* * *

خو دخانبهدسترخو انبانه

و مثرو رأكَاه نهمنو نسه

وشر ابنرثُ:كَّبر اتهو و

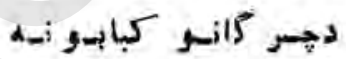

***

ثنز اب أهو م مإهجابو كي

وه دخو اردمركو و ينه

دمثللو م:ز

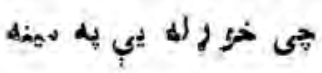

$* * *$ 
خو نن ثله و ينم وطثه 1 دا دخو ب يو • نهنار م ده

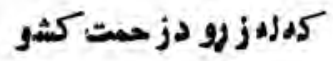
نسن وتسلى شر اره ده ***

ستا بلهمعله او بهشر و كى نن دعدل زلسز له ده مقا إهلاو ر ب خهر ىسوى متـا دخلكو لمافلـه ده $* * *$ ارتجاع لهمبركسمكوم مسو

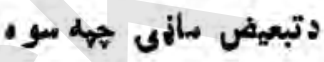
دمطلو م دمتركيو لرى دستم تسورن ثر دهو مون ***

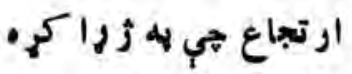
د ملى وحسلت ثير مو ون كاد شهيلى دامر الفيلل و هاد مسوى زره ذارثو وه

** 


$$
\begin{aligned}
& \text { (سعبو لى ) ملدبيىو زلو } \\
& \text { زحست كشو و لسو يسم }
\end{aligned}
$$

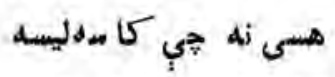

$$
\begin{aligned}
& \text { د تيتهخو يو مفتخورو يم }
\end{aligned}
$$

$* * *$

$$
\begin{aligned}
& \text { خهله و ينسله تسو يومس } \\
& \text { ست' ميرى ز رغسو نوبهد }
\end{aligned}
$$

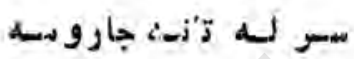

$$
\begin{aligned}
& \text { تسا معراج تده رسومه }
\end{aligned}
$$

***

$$
\text { اقغانdبنيكهو ايى }
$$

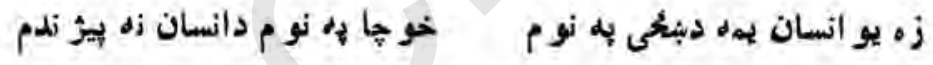

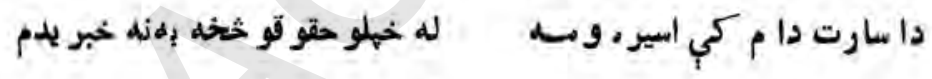

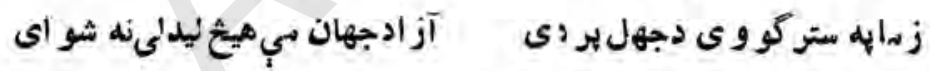

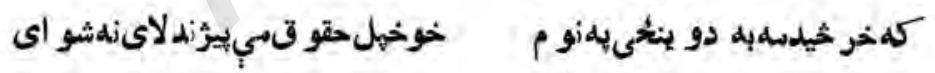

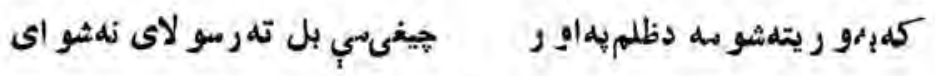
** *

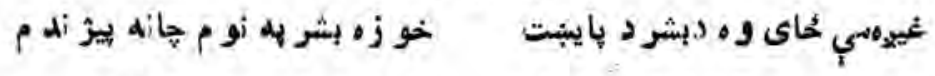

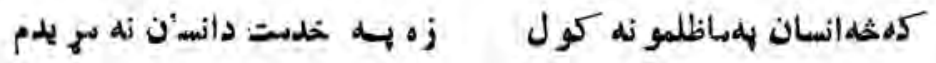




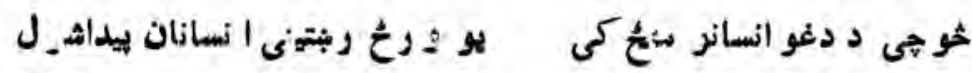

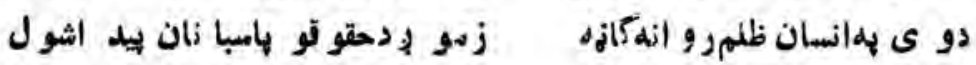

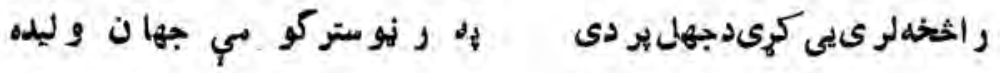

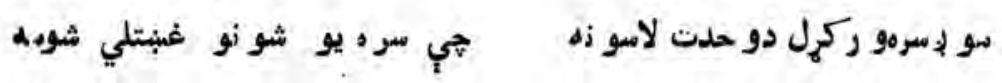
$* * *$

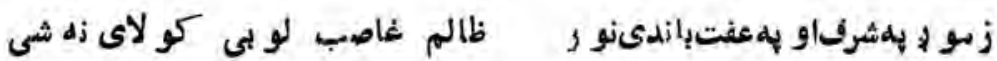

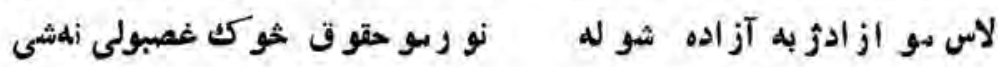

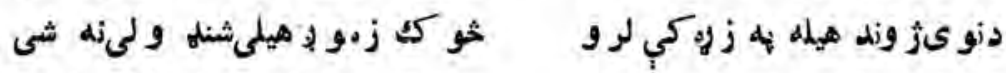

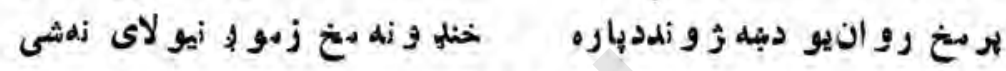
$* * *$

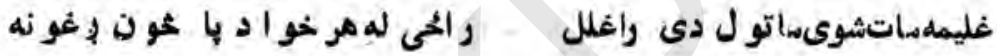

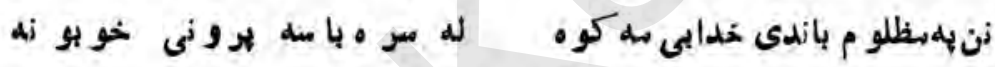

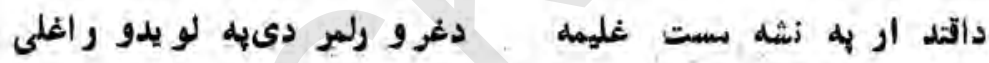

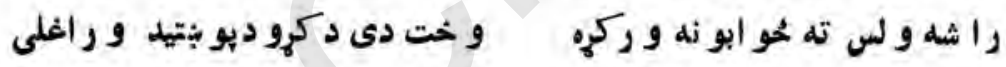

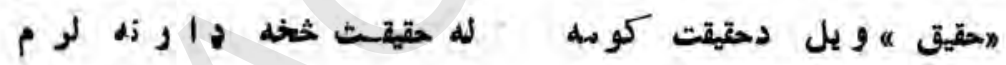

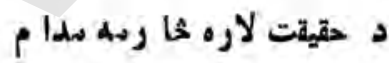

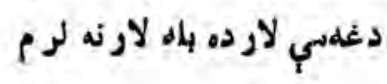

$$
\text { دزئ Tزري }
$$

ولارم و ز الهدته دأو ى تهجهاد كي عهلغو أوى

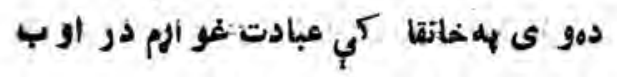


بياسي دابى بخو له عاشق زه داتهوس و كمي ده و بل شر بت غو ارم دخهل اشنادل او ب ولارم وكلز ا ته لدبلبل نهمى تهو سو كر

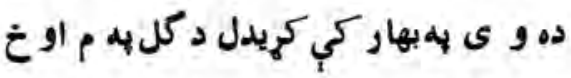

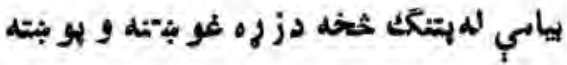
ده، وى كله و اصل شمدريو مس ه به ش او ب

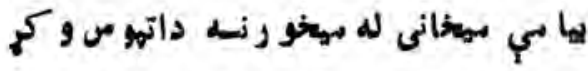

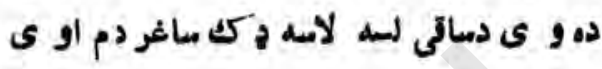
ليعا بى له يهو زلو نه دزرمدآرزو و هوبتمل

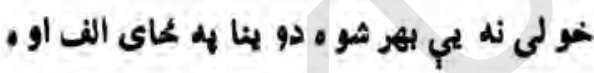
راغلم(سحبويى) تهساويلمتاز له دونهمهغوازي دىوى زو نددعدل او و حلتغو ارم لههو ت

$$
\text { لرى كه نه }
$$

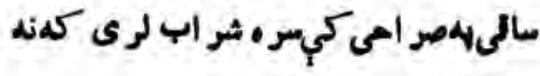

$$
\begin{aligned}
& \text { ملكرى يميشغو نه دوكباب لرى كه نه }
\end{aligned}
$$

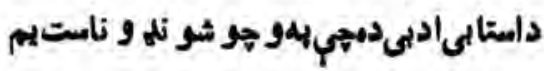

$$
\begin{aligned}
& \text { ه4 باب دمهلمنو بو حهد آداب لرى كم نه }
\end{aligned}
$$


دعثل معندروبي طغيانى شو ترى و يو ير م

دعقل دئهليو حـه اسباب لسرى كم نسه

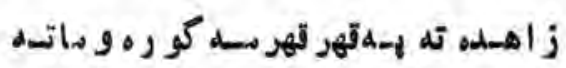

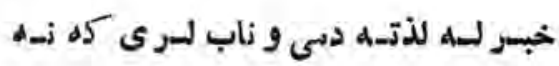

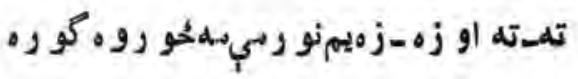

طاقت ددل آزارو دعـذاب لـرى كه نسه

و قار او در عا ز هدخودو اره ستازتصيب شو -

لهو زو بهماتشنه دانكو ر آب لرى كه نسه

دزكر عندليبه بال او بهرخو دى زصيبد ى

او حتاو حت هرو ازلكه عقاب لوى كلنسه.

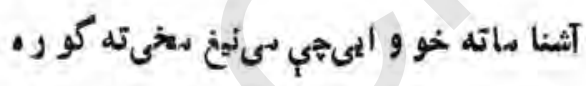

تسه مغ ته داقُّاب دليدو تاب لرى كمه نسه

خطيبه خطاب دى لجزز ور غو ندى بنكار يرى

دنو ى زو ندانه به جاب خطاب لرى كهثل

زا هده ته خهبحان دتكو ا دارو سالار بو لى

حبرد ( معبو بى ) له اجتنأب لرى كله نسه

19v 


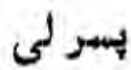

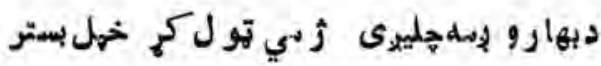

راعلى نو بهانر دى دهيوا د دهه لسر او ير

راتمبكلى بكلى ثبكار رى تولدبيتو نهاور غو نه

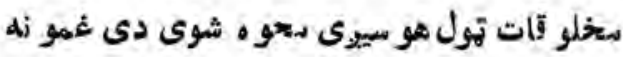

هار يدلى غو ندىنكار ردششاعر حساسخيالو نه

انعكاسيب الحساسدى ثوخوائهو ايه خو بو نه

دادسئو رو هار شليد لى جى راتو شى شو الهدكر

كه كلو نه غو رايد ائ وطن إله سمه غر

$-191-$ 


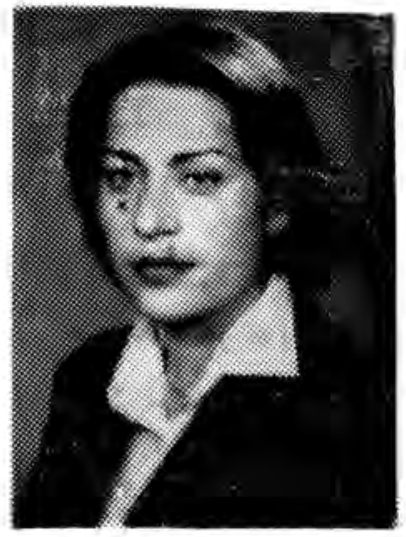

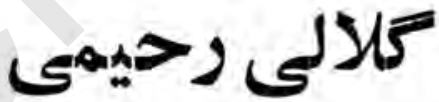

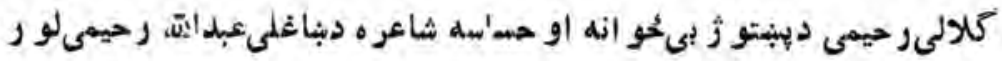

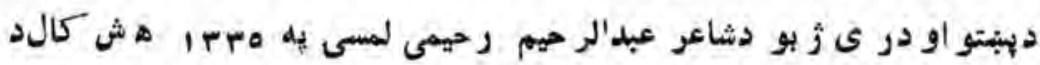

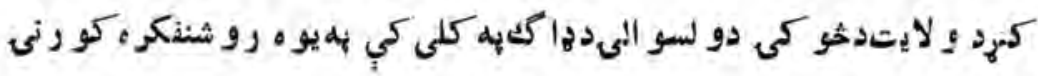

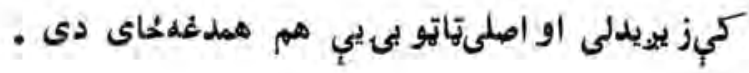




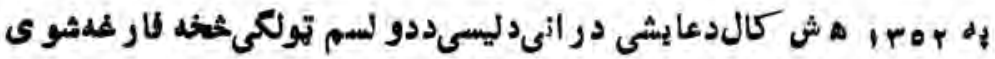

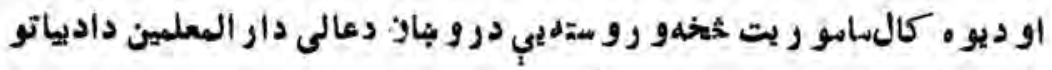

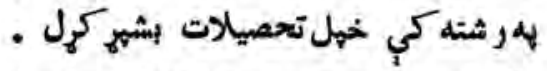

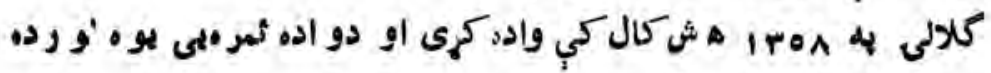

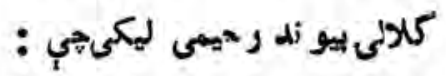

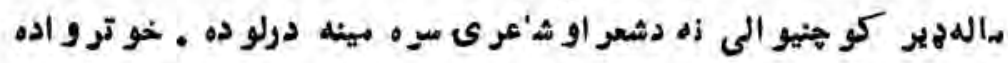

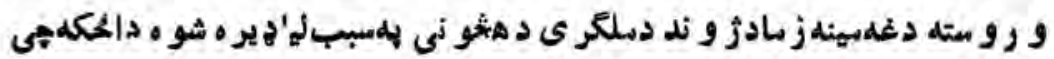

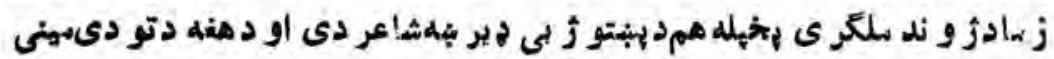

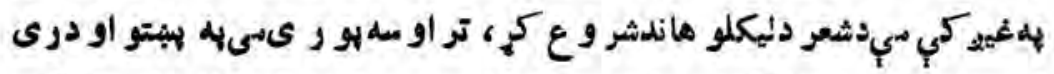

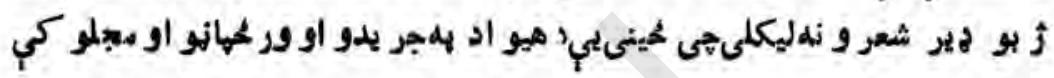

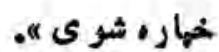

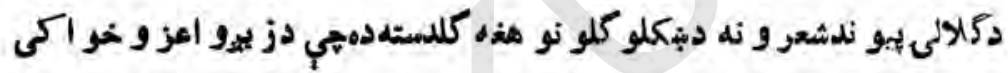

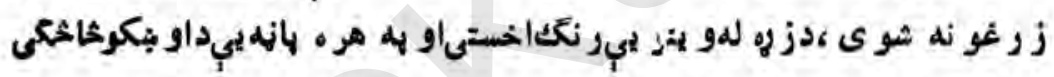

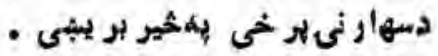

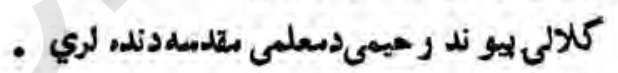

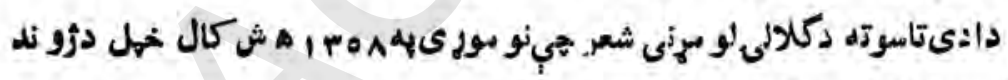
ملكر ى تهليكلى دييلكى بهدو ل و ور اندى كيرى .

$$
\begin{aligned}
& \text { دكلو بن كيسيوكل } \\
& \text { دنسو روكلو بي لهرو ا نشتئه ده }
\end{aligned}
$$

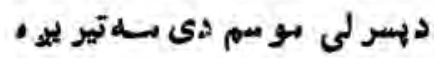

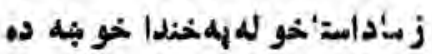




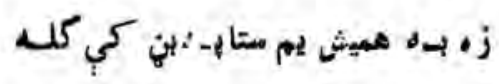

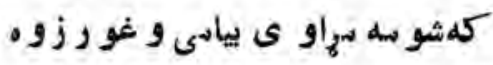

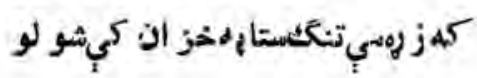
نو سبيلهز و ندنهلمركت تهبيا خو بنهده سا سره خيال دهمز و لانسو زهشته ؛ ستا د شعرو نسو بي و ينا خو بنه ده كو ره ! كله بيادى ر اته و و يلمى: "محو انىدى دهمزو لانسو سعره سيالـه او مسه كحه مميشه دكسه دخيالـه اه سه " بيا إهدىنوم بهنو لىوانهخلم كور ب ؛ بيابـه دى مغ بهله بر و نسه و ينمه

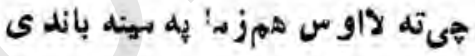
دهناشودهانو دخيالو كهي كمان كددى باهي ر زنشتهله دى زما رهه مينه نو خله و ائى راته 2 آخو بونسم

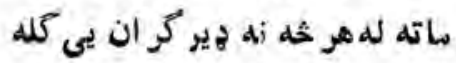
زلمي خحو انى نلهبي سيالى خو بنه ده

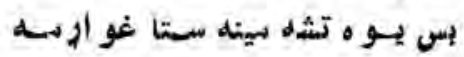
د زيهو كوبي خندا خوبنه ده 


\section{دو طن ميندو خويندو}

$$
\begin{aligned}
& \text { 2 رنسه لوكى شم } \\
& \text { دوطسن ميسنيمو } \\
& \text { مر تو ر ع مهل شيى } \\
& \text { با تو رو خو يند و } \\
& \text { *** } \\
& \text { ستركى معرى ندكرى }
\end{aligned}
$$

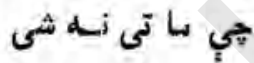

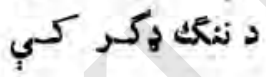

$$
\begin{aligned}
& \text { جي با تى نسل شسى } \\
& \text { *** } \\
& \text { تما سسى روزلى } \\
& \text { ستسر اتـلان دى } \\
& \text { سنكر يي سو ردى } \\
& \text { ثنى كلى دي } \\
& \text { *** } * \\
& \text { دوطن بسولى ني } \\
& \text { دبثتى او غرو نه } \\
& \text { به غرو ربهاتى } \\
& \text { دبسن كسلهونه } \\
& \text { *** } \\
& \text { T.P }
\end{aligned}
$$




$$
\begin{aligned}
& \text { هلهمر ه ميدان كى } \\
& \text { زله شـا ته كير له له }
\end{aligned}
$$

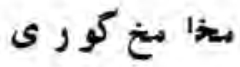

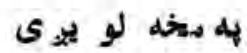

$$
\begin{aligned}
& \text { *** } \\
& \text { د جا ملـلكر ى } \\
& \text { دمُنو و رو: لهن } \\
& \text { د ها بجيان دى } \\
& \text { di } 9 \text { की } \\
& \text { *** } * \\
& \text { دو نه لوكى شمه } \\
& \text { و و طن ميثل و } \\
& \text { مرتو ر ي ملثى } \\
& \text { باتو دو خو يندو } \\
& \text { *** }
\end{aligned}
$$

لهجنَّنفرت

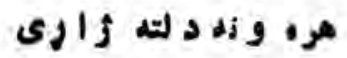

$$
\begin{aligned}
& \text { هو مهدان كي شهيداندى وند }
\end{aligned}
$$

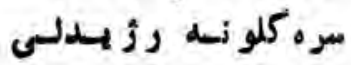

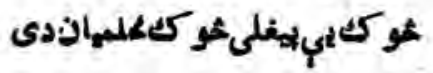

$$
\begin{aligned}
& \text { * * } \\
& \text { rop }
\end{aligned}
$$


دلته هر يو كر يو ان ثير ى

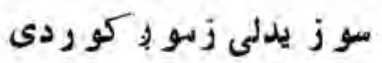

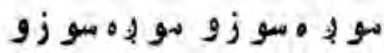

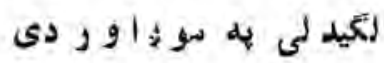
* *

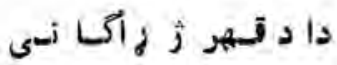

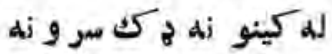
داسوى متر كى لمنفو ته

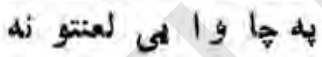
* *

مرالم يا د د لقه اتم دى

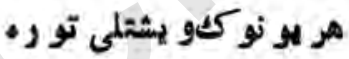
هر ز 4 ركبتدلته رستم دى هر همور ز مو لحبأ تور ره * * تول به يو آواز لكيا دى ضل دجنكت يو ضد دجنكك بو ثيخ سو واور ر نه يو الو مو إِ للهجنك سر مبهجنك بو 


\title{
ربتبنينى مينه
}

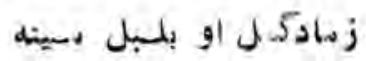 \\ اهخحو بنسيرى إستي و فا ده

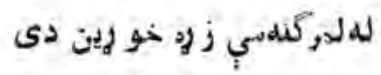 \\ حي لمو بو يو زى لاغو ريجيى

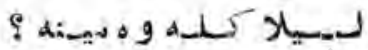

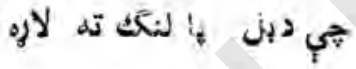 \\ 2 \\ رو غوندى كرخيل بيه شاره \\ هيله سـر ه هـرى تير يوى

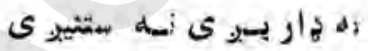

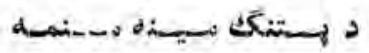 \\ هي سو زيوى لا خو بنيوى
}



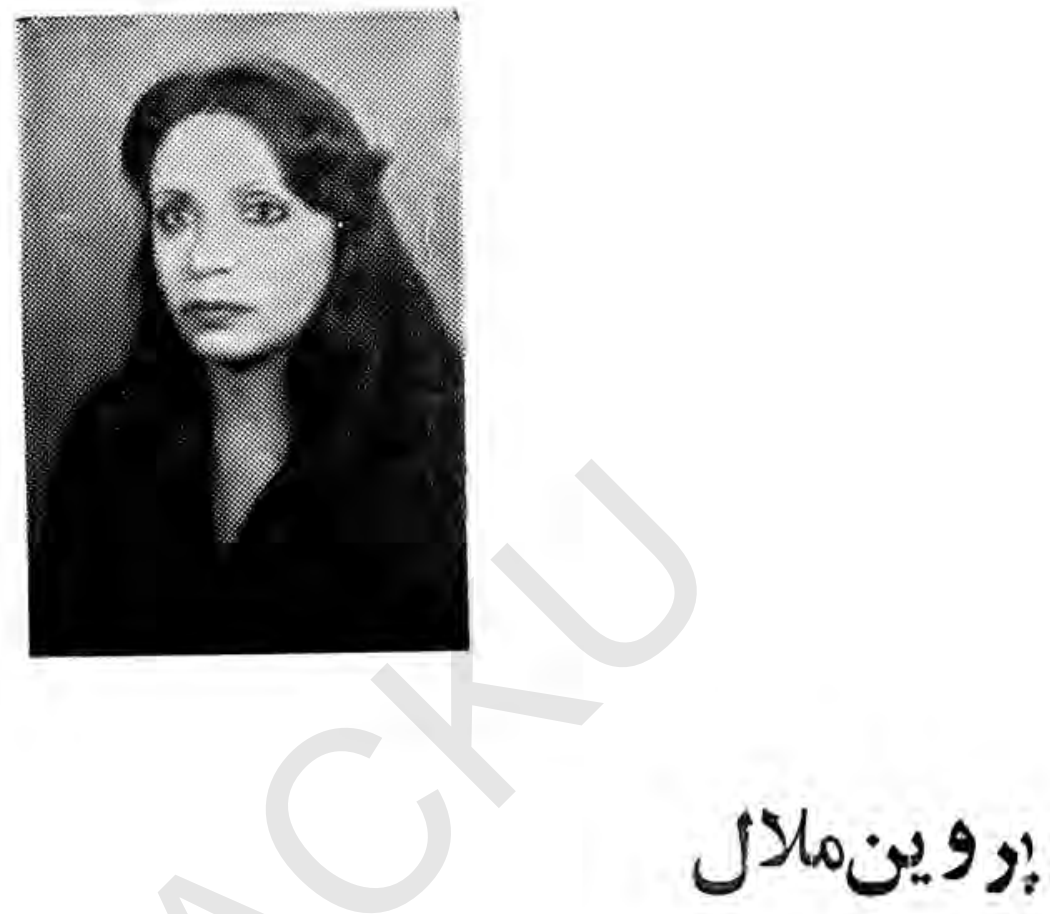

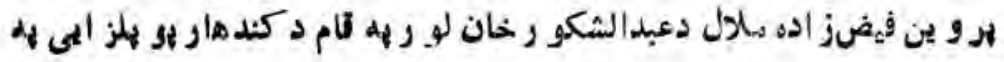

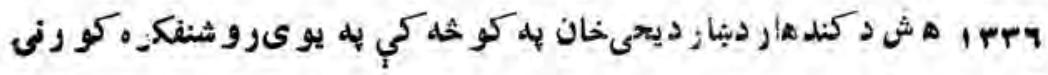

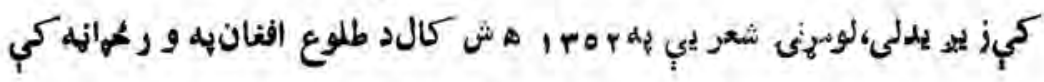
دنو مو ري إيه مستعار نو م زشرشوى دى . P. 


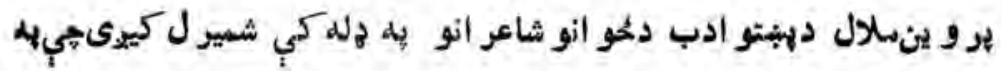

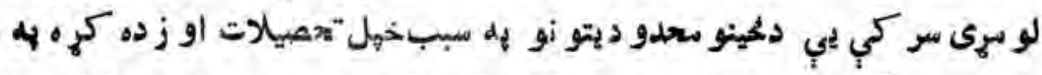

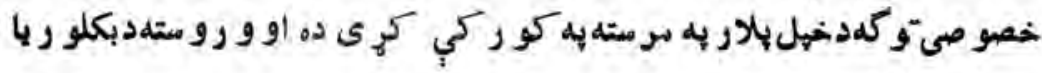

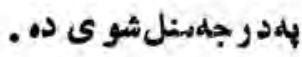

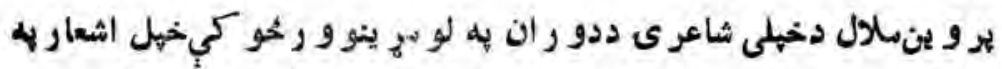

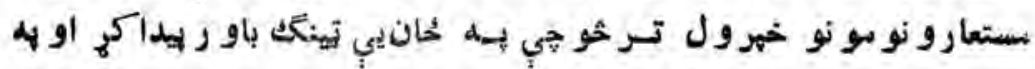

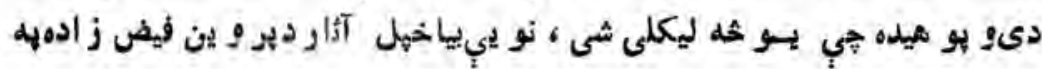

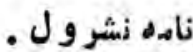

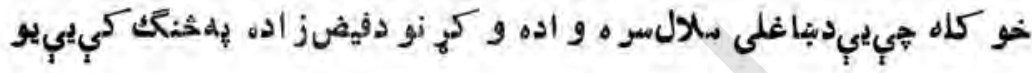

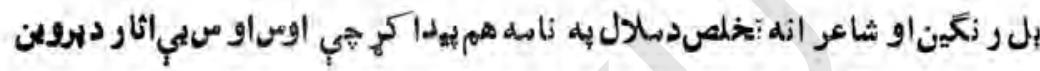

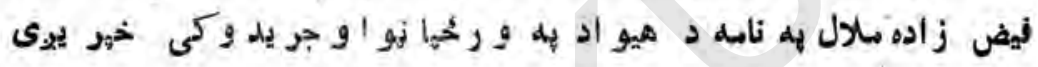

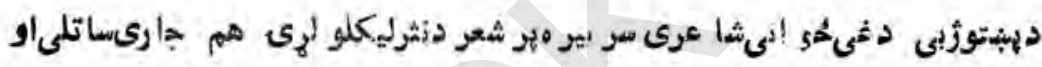

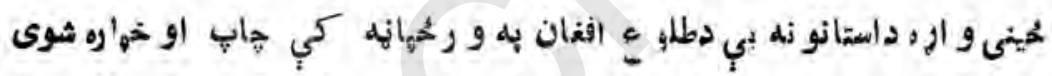

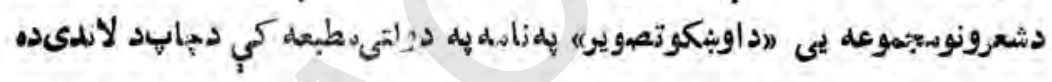

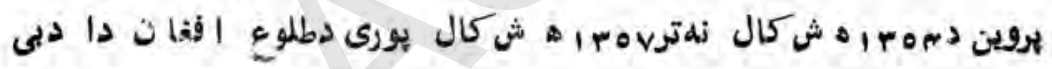

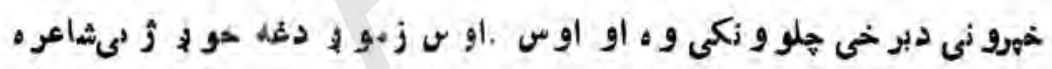

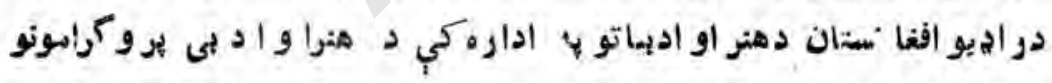
د حلو لو دنده لرى .

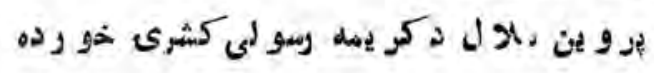

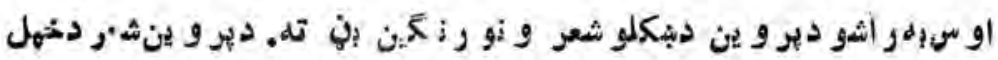

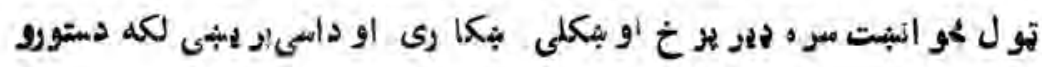




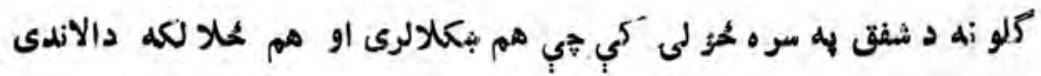
خو كر ببىيب .

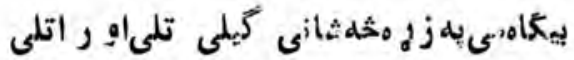

$$
\begin{aligned}
& \text { دز بعيلمسر ماتى خو جملى تلى او راتلى } \\
& \text { دز لفو فرش شيجو إكي نودخيال بهل آسداذوكي }
\end{aligned}
$$

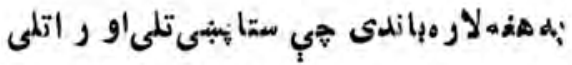

$$
\begin{aligned}
& \text { مالالدهر كاتهبيدساحل لاوه كهه و. ركه } \\
& \text { ار ماندسيمد إيه غييوكي برى شيى تلىاو ر اتلى }
\end{aligned}
$$

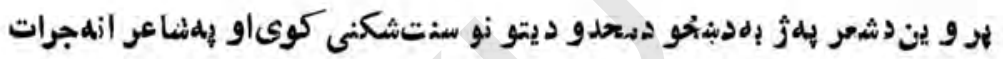

$$
\text { سو مو ايى: }
$$

$$
\begin{aligned}
& \text { ایىساتى ! تو بلمبيو اكحي. } \\
& \text { راكر مراكي مهيالةر اكئه }
\end{aligned}
$$

$$
\text { ياداجي: }
$$

$$
\begin{aligned}
& \text { سأدتيقى و نديهناسهلاس به يو ه جام كيببود }
\end{aligned}
$$

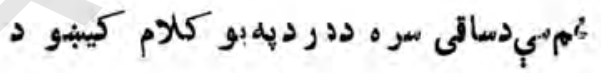

دمينى دشفزل بر هز و نه ديرو ين دشعر دبنكلاّو سنه ده او د هغى در نكين

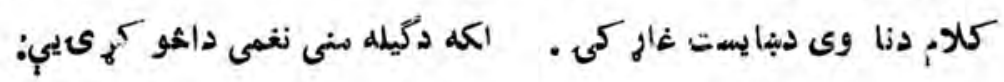

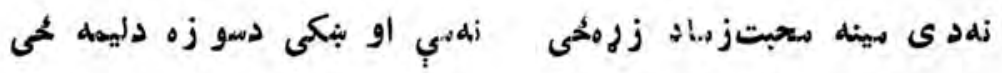

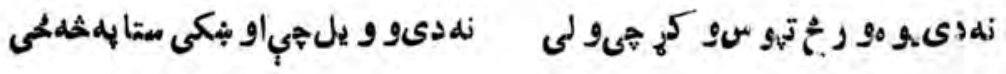




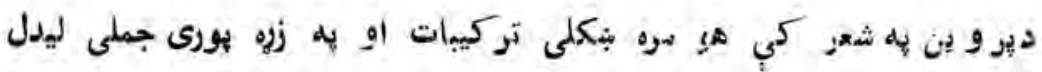

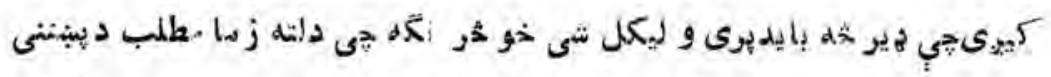

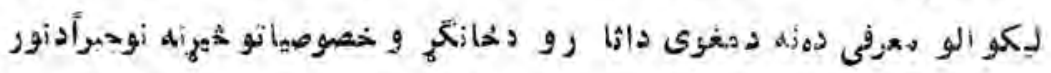

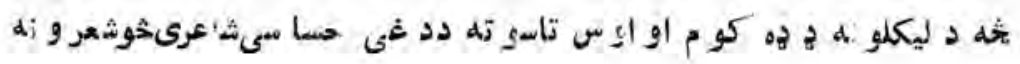

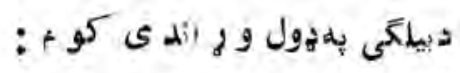

doxidisdals

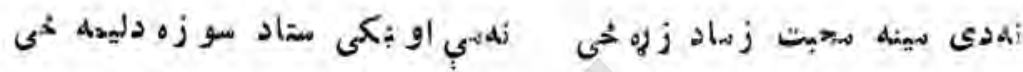

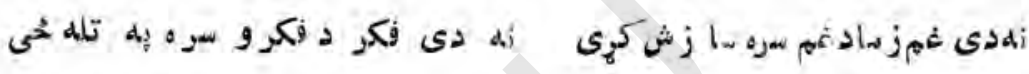

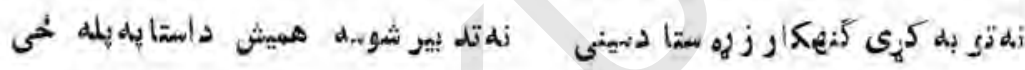

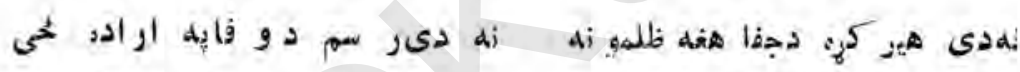

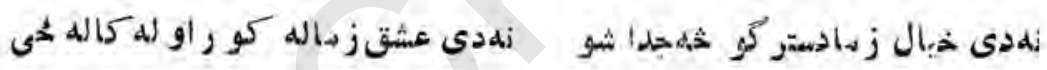

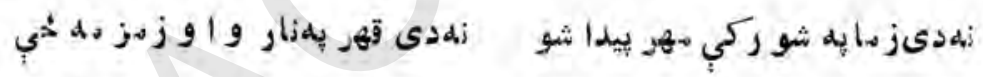

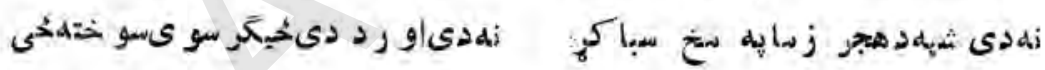

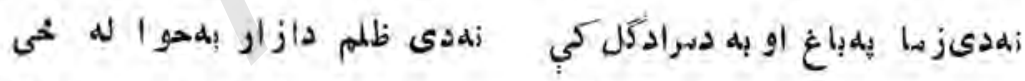

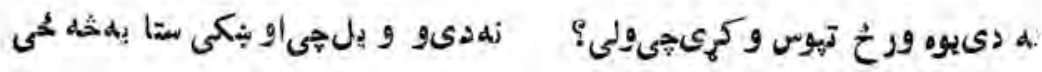

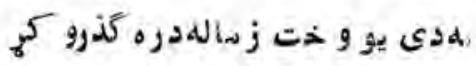
له

$$
r \cdot 9
$$




\section{دو يريا ئه}

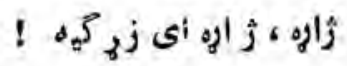

do: d)

جيى لاله ئه سار ا شينه شى

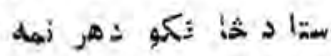

* *

كي

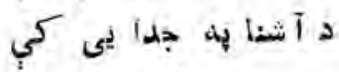

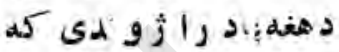

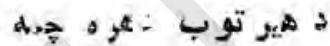

* *

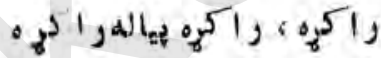

اعى ساقى ! تو إه سى و اكيه.

زله ملى و جوى لله غمه

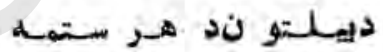

* *

ك. ندىديميتيولهيتو كي

يهدى و ز انو انديبننو كي

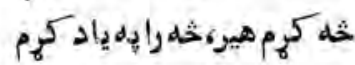

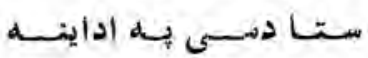

* * 


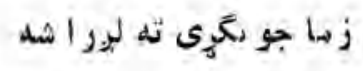

ديار ديده يو ه بر يبنة: شه

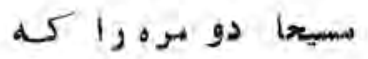

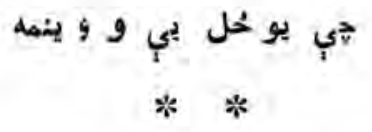

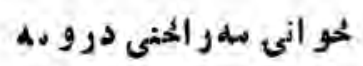$$
\text { مهانه }
$$$$
\text { هي دلمينى محو اب و اورم }
$$

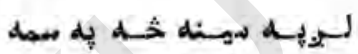

*** $*$

$$
\begin{aligned}
& \text { رو حهلي. خه فو صتر اكريه }
\end{aligned}
$$

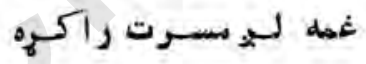

$$
\begin{aligned}
& \text { جى تقديو تهبه تدييز بثم }
\end{aligned}
$$

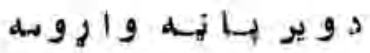

$$
\begin{aligned}
& \text { هيله }
\end{aligned}
$$

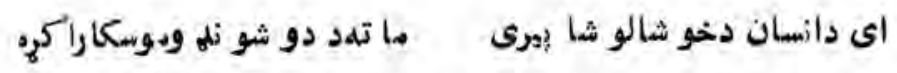

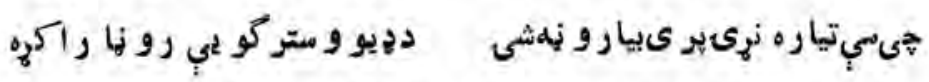
$* * *$ 


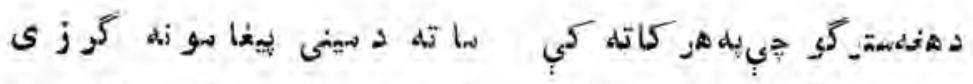

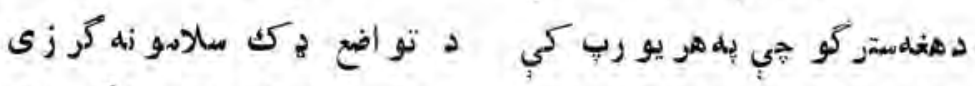

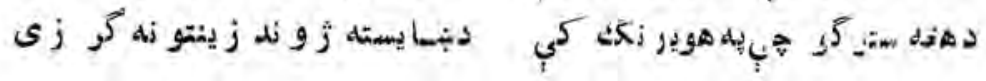
***

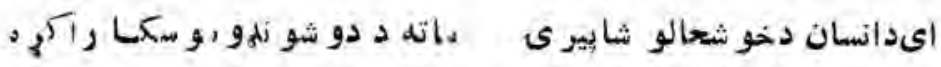
***

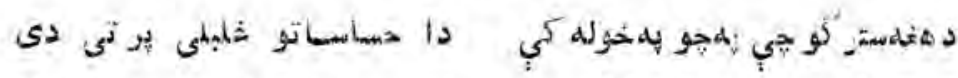

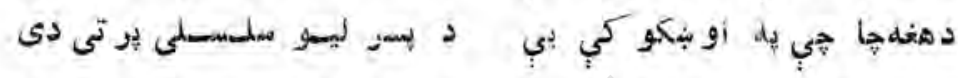

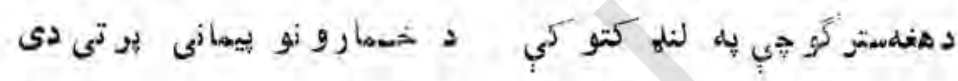

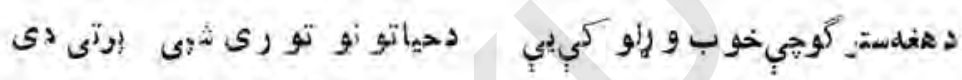

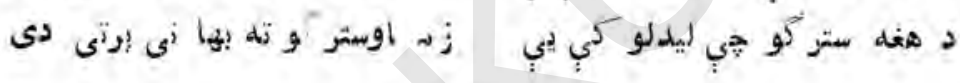
*** *

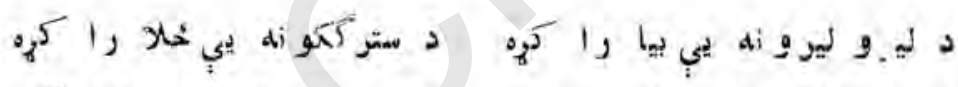

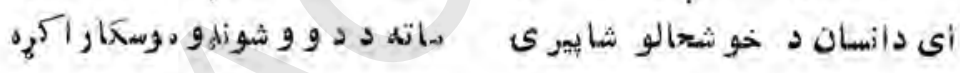
$* * *$

\section{2خيال ثبى}

نو جو شي نلهو تصو ير و كي تصو ير و نه جو ريشو .

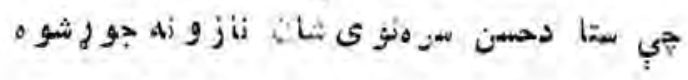

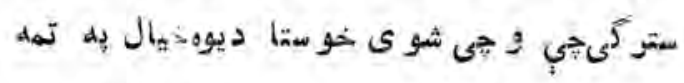

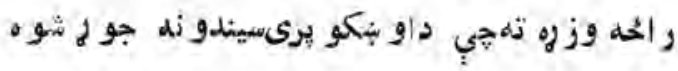




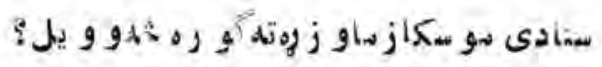

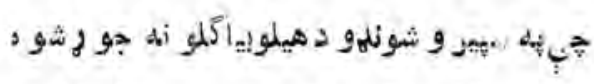

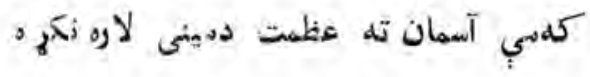
بيار أتلو أيفهيو خهبه

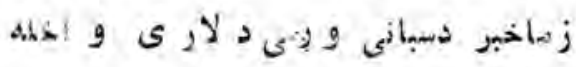

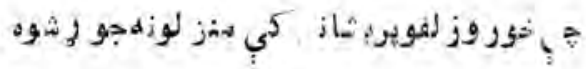

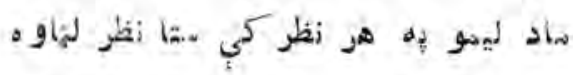

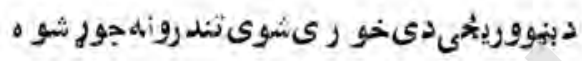

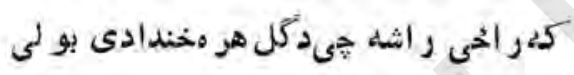

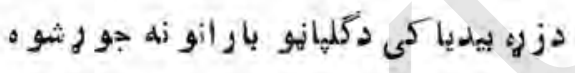

\section{دبنهو هتر}

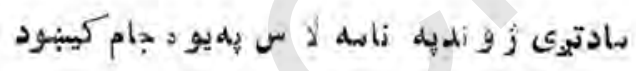

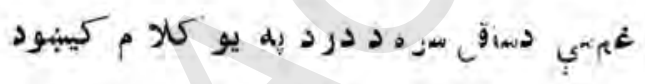

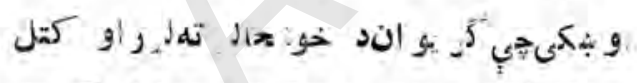

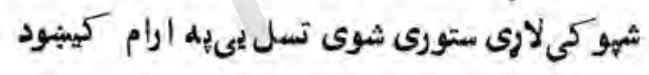

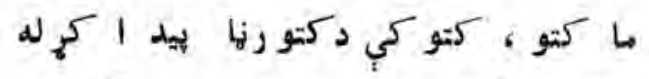

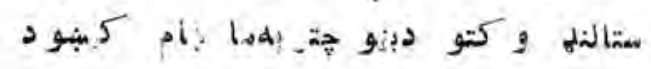
دا دزونه اوز دى لارى تحواوس راته سشكلى شوى

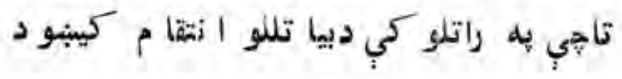




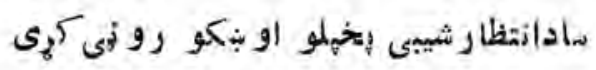
تهدبلسبا شوى داو عدى لادىيو بيغام كيبنو لاس د هيلو تش شوم ستاد بينى با زارونوكي

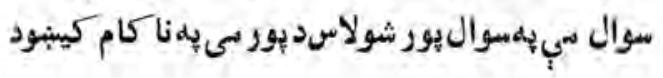
ذخيال لته

$$
\begin{aligned}
& \text { داكو هى - كوهى غمونه } \\
& \text { دا ترخه خوإيه بياء ونه }
\end{aligned}
$$

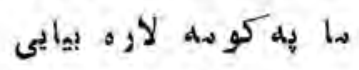

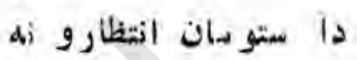

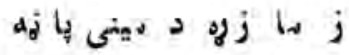

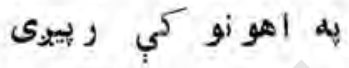

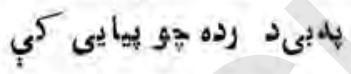

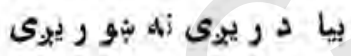

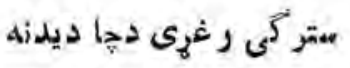

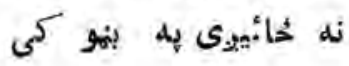

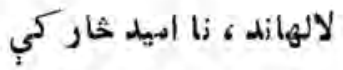

$$
\begin{aligned}
& \text { بيا هو بيزى يلهنيندو كمي }
\end{aligned}
$$

شيى د شيو سلسلى راو رى

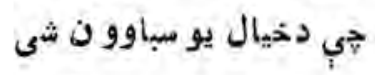

دائل

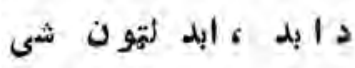




$$
\begin{aligned}
& \text { د زتلى روح ماشو مثي }
\end{aligned}
$$

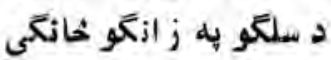

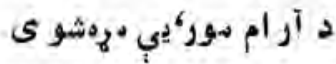

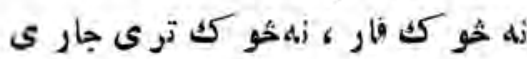

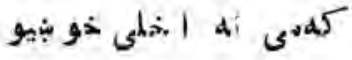

$$
\begin{aligned}
& \text { او }
\end{aligned}
$$

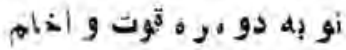

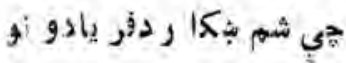

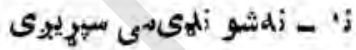

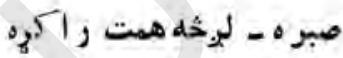

$$
\begin{aligned}
& \text { بيايب خيال زمادخيال شو }
\end{aligned}
$$

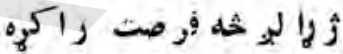

\section{خوابر مخيالونه}

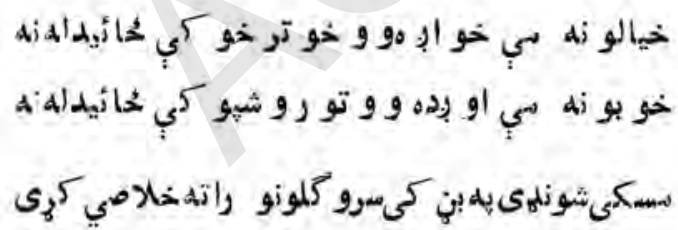

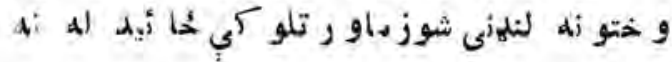

ما خهل الميد و نه د الستا لار عته درو المتول

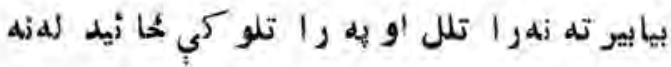




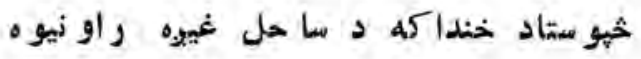

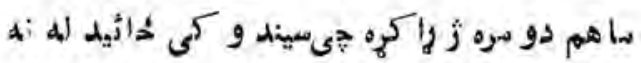

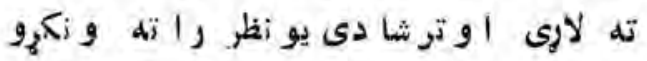

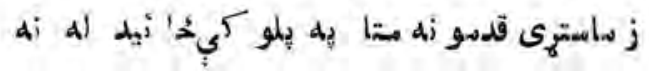

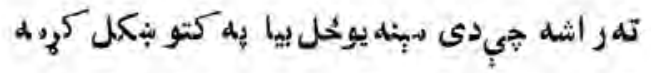
كاتهنب بيغاخوب كَ متا كتو كي حُائيدلنه ليونى احساس

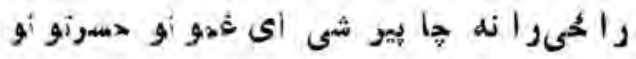

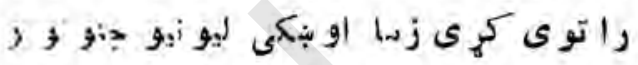

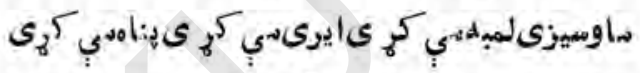

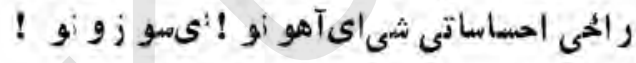

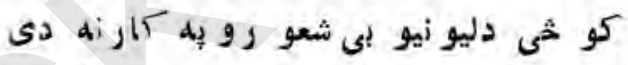

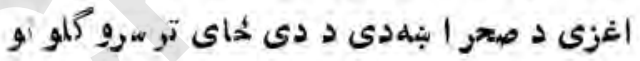
دسو رشفق لمبهمينو خو نينو ستركو ثرخى

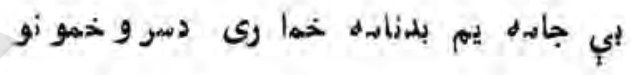

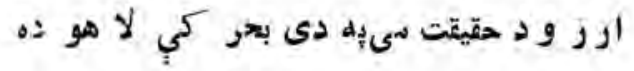

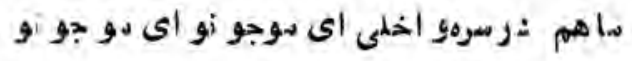

\section{قسم}

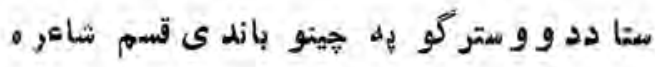
ثيرى 
ستا دزوكى به ار هانو باندى قسم شاعره ستاد ادب هيلمر نكيينو باندى قسم شاعره

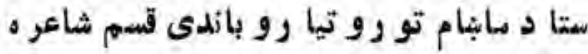
ستا د الميد إهل قافلو با ألد قى قسم شاعره ستاد هو س به هدير و باندى قبم شاعره

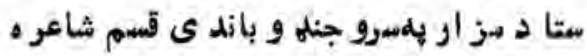
$* * *$

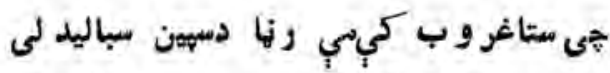

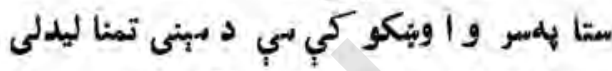

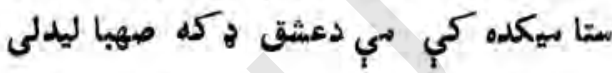

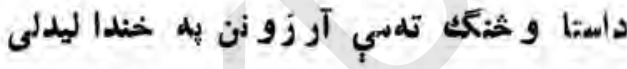

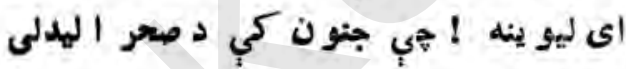
زيوى درباندى إى سجنو نه هاليلى ليدلى

\section{داو بنكو تصو يو}

بيكاه تي بهز ور خه شانى كيلى تلى اور اتلى

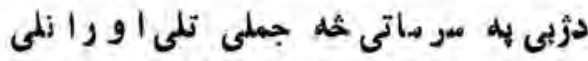

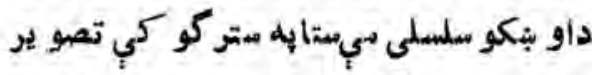

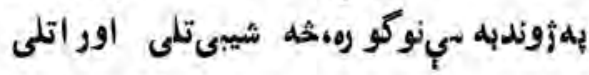
خوإى هيلىنا هيلمشوى بلخوريز ره كي ويدى د ذذ هن بهبر دو كى خلترخى تلى او ر ا تلى 


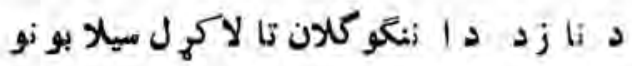
كر بو ان باندى د ستو رو جةازى تلى او ر اتلى دز لفو فرش ميجو ه كي لودخيال به آسدانوكي

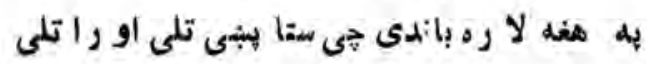

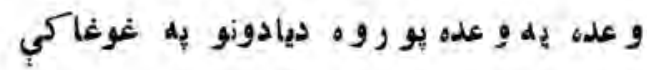
سبا ته د وختو و اشار رى تلى او وراتلى

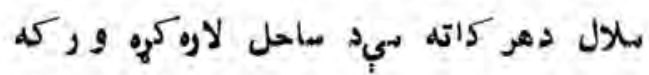

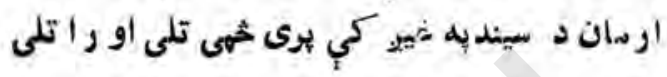




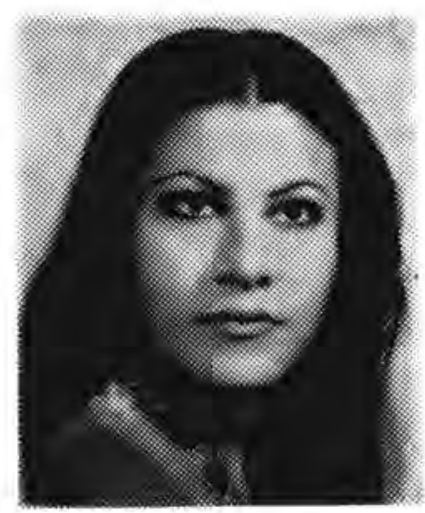

\section{ورة انمكه سافى}

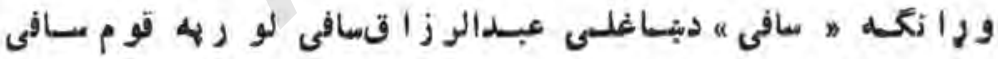

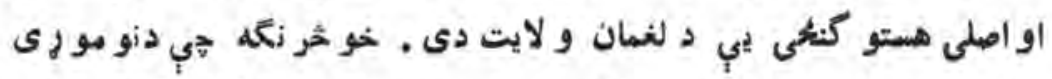

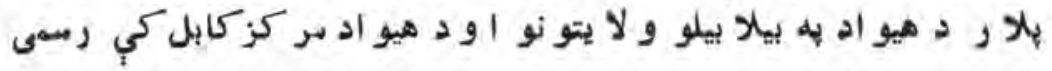

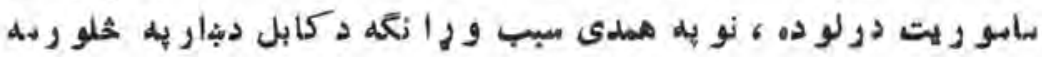

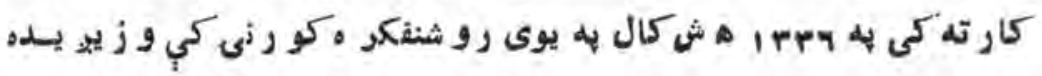

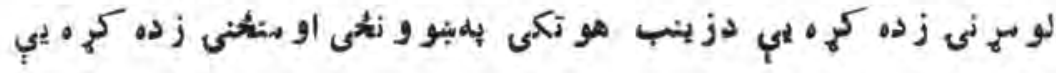




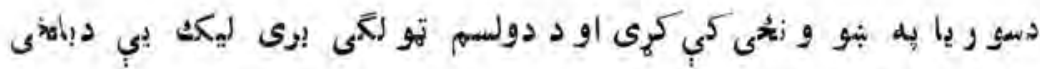

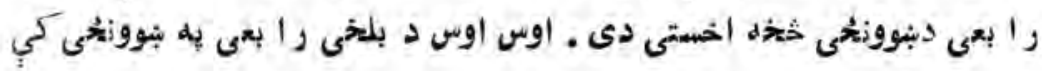

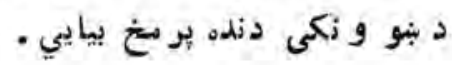

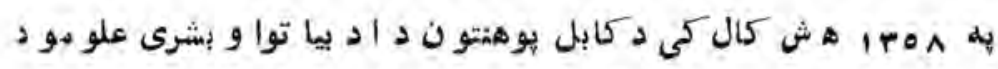

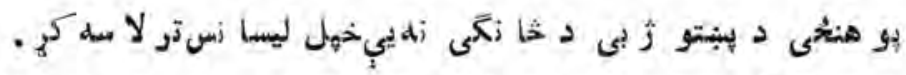

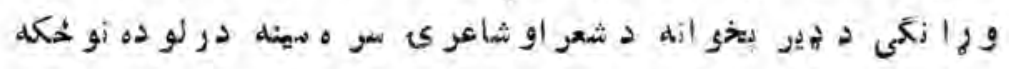

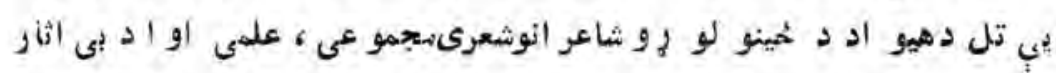

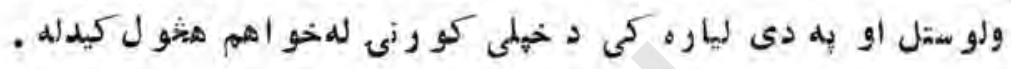

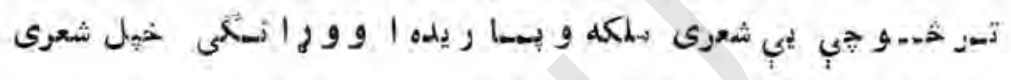

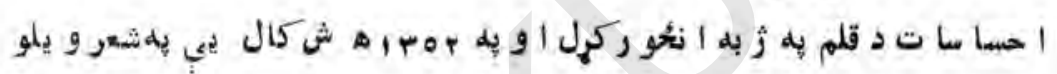

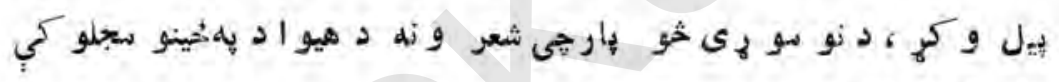
جابٍ شوى دى .

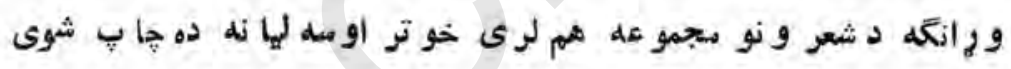

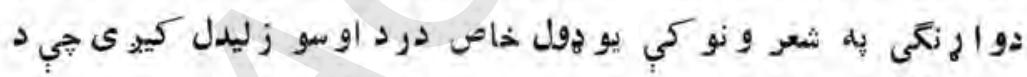

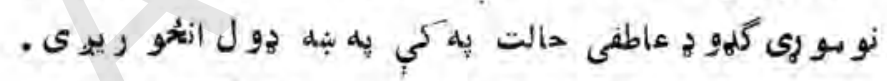

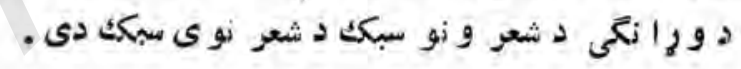

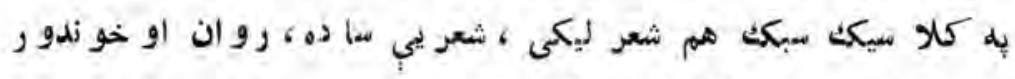

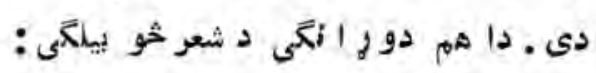

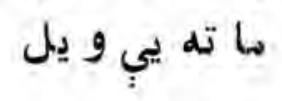
ستا د نازم هير خيا لو نها

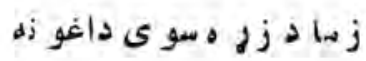

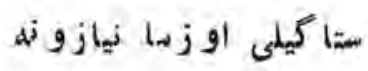

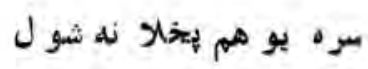




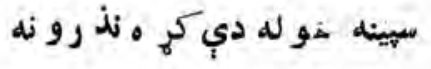

$$
\begin{aligned}
& \text { جيا بي إده يه خا و رو بلو نه } \\
& \text { خداى دي د د رئى جنتو نه }
\end{aligned}
$$

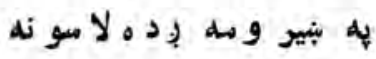

$$
\begin{aligned}
& \text { هي يو ده راني شله توغاري } \\
& \text { بيابله }
\end{aligned}
$$$$
\text { تالتو م }
$$

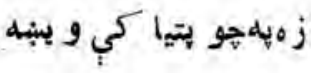

$$
\begin{aligned}
& \text { تهله غو غا كَ }
\end{aligned}
$$

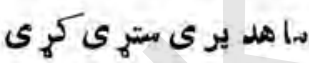

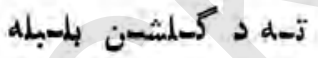$$
\text { زه شو كير و كي ومو م }
$$

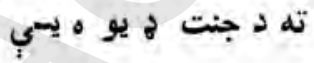$$
\text { ز ه مهيرىخاوزئو مر م }
$$

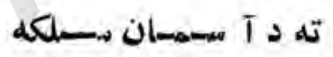

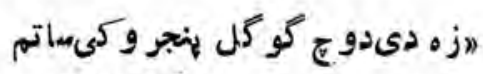

$$
\begin{aligned}
& \text { تهلي شين خمن له باغهو نه ثشى " }
\end{aligned}
$$

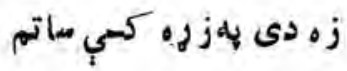

$$
\begin{aligned}
& \text { تهبي زو ندون نه شه ى }
\end{aligned}
$$




$$
\begin{aligned}
& \text { كومه كناه بلهماكي } \\
& \text { كو مه ولهابه تاكي } \\
& \text { جى ديوازى كريه } \\
& \text { ستا د جفا نه قر بان } \\
& \text { متا دوفا نه قو مان } \\
& \text { بيلتون }
\end{aligned}
$$

$$
\begin{aligned}
& \text { يليلو نهزا كر دى بهدىترشو زميادوم }
\end{aligned}
$$

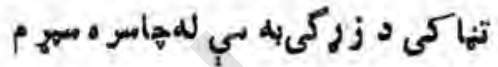

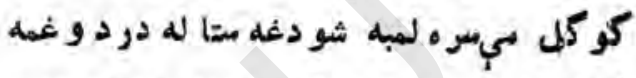

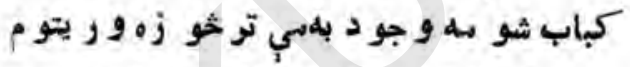

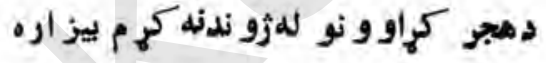

لاسو نهد بيو انو ، مريد انو بنكلوم

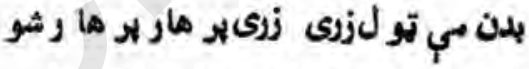

توثو بهز. زدىاو يوهارو نه تو لو مائ

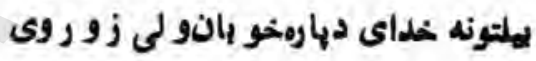

تصعيم مي دى نيولى ننو اتى بلهدرئم

$$
\text { هيله - خهال }
$$

$$
\begin{aligned}
& \text { متاد عشق ثب مهلمو د نشيو } \\
& \text { له همهالو كي د بي لهبه شوم } \\
& \text { هابي ثرو وند ته تلو مه شى } \\
& \text { هي هر و ارى بي نظر ثى }
\end{aligned}
$$


كله ز يات كلهثه كمششى

حقيقت خور اته و اليه

دادى ثر نكه السون ديى

نهمى هير نه بي د اليادشى

خو جي خيال كي كله ر اشى لهى

ليونى شمى ، غرشنى شم

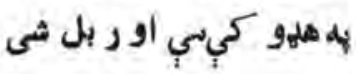

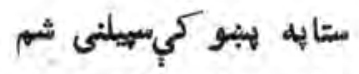

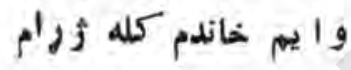

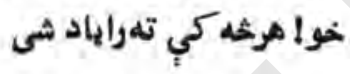

نه بيزوندنه يوخه و مو ند

نه دى خهال رالحنى كم شو

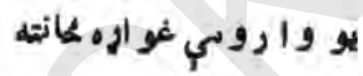

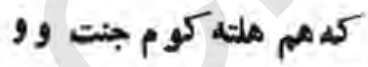

كه هم هلته كوم دوزخ وو

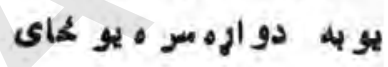

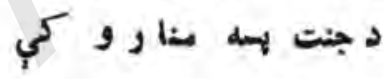

دا خوزم تنها شو مباتى

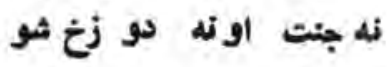

كم بي نه كري مهله لوسان

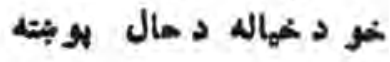

$$
\text { rpp }
$$


يو خله و امي و وهمبو الو نهل

دغمسجن زره فويا دوزنه

ناكسر ا رهد د يد ن يسم ! يه خدا يو و به كما نكند ن يم زملهز و ند نه يم معتو هأنه بيا ونه كرى كيله يو و اروسب وى خي راشى

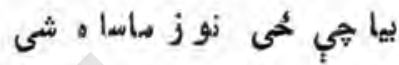

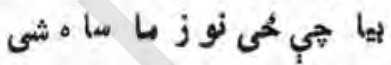
هيله

متا ياد و نله ملسيلى شوى

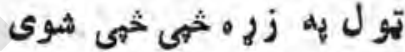
هو ج خهه بي متا خبرى هو يو موج يب مر فلمرى

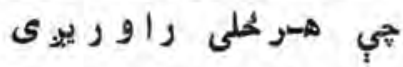
ر نئو دزهه مي نرى رغييوى

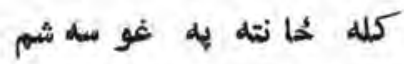

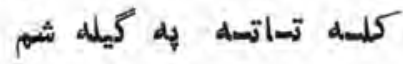

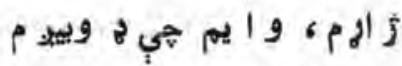

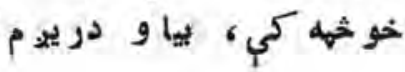




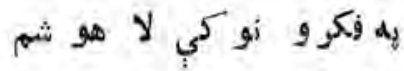

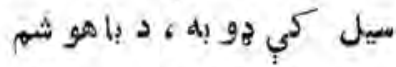

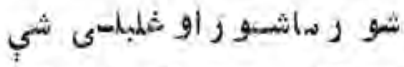

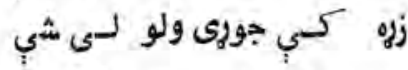

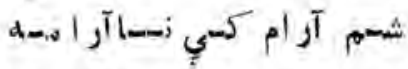

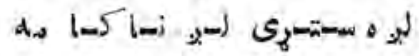

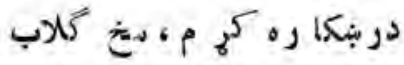

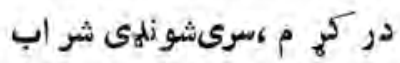

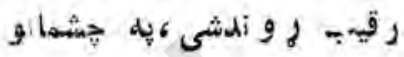

$$
\begin{aligned}
& \text { تسل إيزاشى كلـه خو بانسو }
\end{aligned}
$$

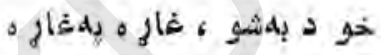

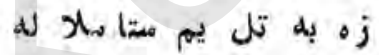

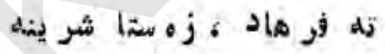

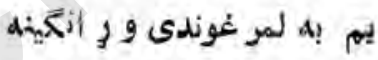

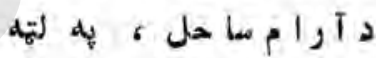

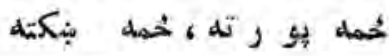

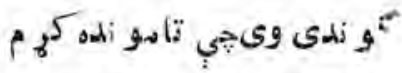

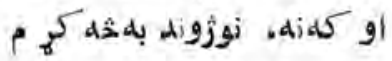

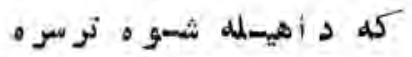

$$
\begin{aligned}
& \text { oر } \\
& \text { عو ألم غيي كي ستادلهشهم }
\end{aligned}
$$

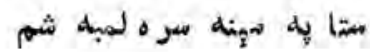

$$
\begin{aligned}
& \text { PYO }
\end{aligned}
$$




\section{خوبب ليدل}

حوب و دنم جي ته يب

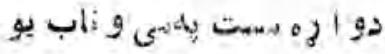

(5) 100

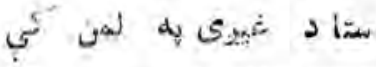

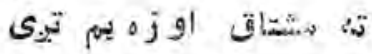

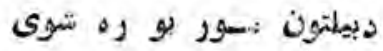

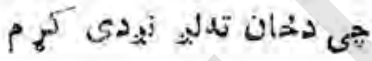

ها سرى أو بنكمى تو يولى

ستا د عشتق المإد يرى نينى

دمستى

مأهمر را كبنلى خهبل شائته

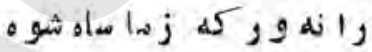

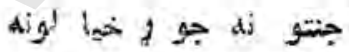

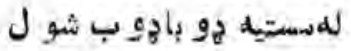

هيرى

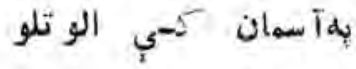

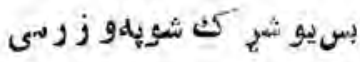

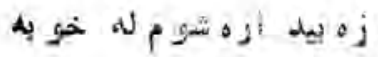




$$
\begin{aligned}
& \text { دو بو نو د نيا ورا نه } \\
& \text { زه اوته سر ه ج-ه } 1 \text { وو } \\
& \text { مر • يو هم بخخل نه و } \\
& \text { بيا هغd مر و ر تيا وم }
\end{aligned}
$$

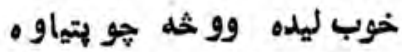

$$
\begin{aligned}
& \text { هله محان لله به رٔها شوم }
\end{aligned}
$$

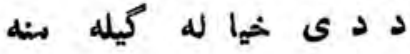

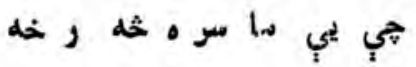

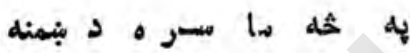

$$
\begin{aligned}
& \text { خوبكي سه ر راحه خد بونه } \\
& \text { خوب كي وركت شه دا خيالونه } \\
& \text { } \\
& \text { كله ته تي مب را ياد شى }
\end{aligned}
$$

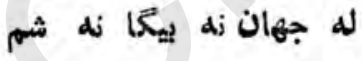

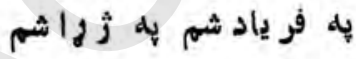

$$
\begin{aligned}
& \text { حمم لله ميفى بله بيد ياشم } \\
& \text { به هر لو ر به هو مخو اكى } \\
& \text { تهيجي ور كك بهييأبان شى } \\
& \text { زه حهي زَ زو ند لتو م تاكي } \\
& \text { را زله وحه زها مساه شى } \\
& \text { به مر خاو رى بلززه هـتى }
\end{aligned}
$$




$$
\begin{aligned}
& \text { كو }
\end{aligned}
$$

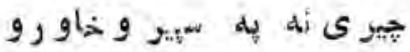

$$
\begin{aligned}
& \text { كر د جن شوى مئا :ته }
\end{aligned}
$$

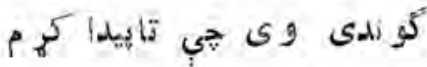

$$
\begin{aligned}
& \text { بيأ } \\
& \text { زه خوشاءر ه نهيم }
\end{aligned}
$$

زه خو ثاعره أله بم

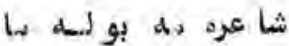

زه 2 دورد و9 يو نكىى

مز

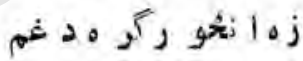

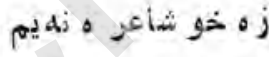

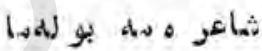

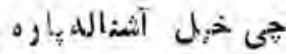
هميش شمر و زله لمكى دسور كوشونله و كيسى شينكى حالو أله ليكى

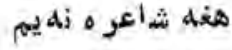

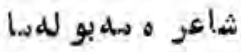


ز

بنا دى هيث أل إيثز نم

تل بيو زلان ثر ارى

خو الريتها ن أرائ

زه خو شاعره زلهيم

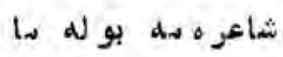

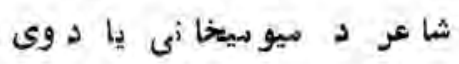

خيل د عيشو زو سلسلى يا د و ى

جى د بلبل سوى نارى يادوى

با دآشنا زلفى خو رى يا دوى لفي

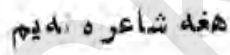

شاعر م. شمبو لمها

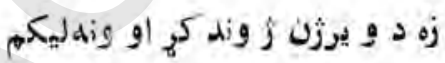

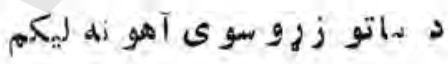

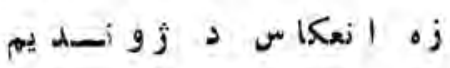

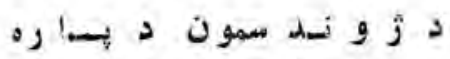

لس لهو

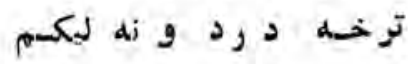

rq 


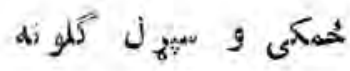

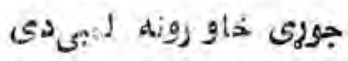

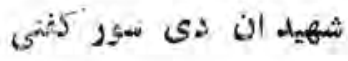

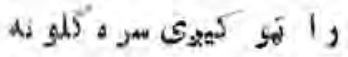

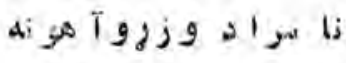

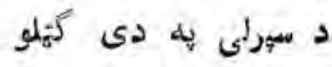

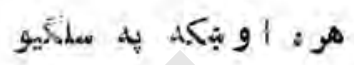

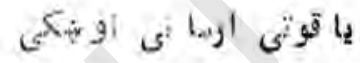

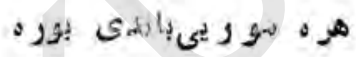

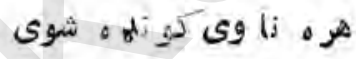

هر مخور خيرى

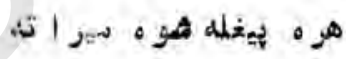

* * *

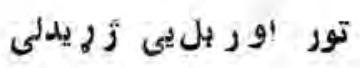

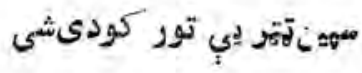

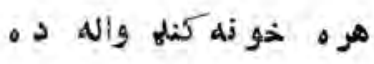

د دى و ينو يه ثمو كي

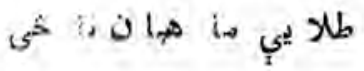


سرى او بنكى سركى زرو نه

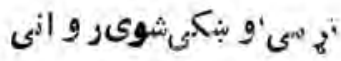

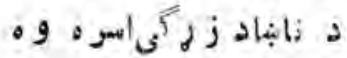

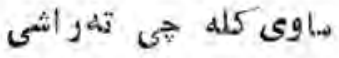

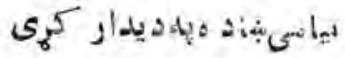

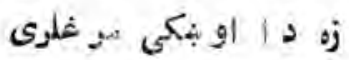

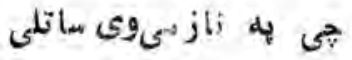

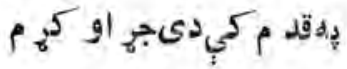

$$
\begin{aligned}
& \text { جيى لهى ستادد ديا دو نو }
\end{aligned}
$$

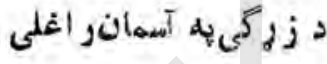

$$
\begin{aligned}
& \text { ستا } 2 \text { هجر به لسمبو كي } \\
& \text { دزإكى به جهان راغلى }
\end{aligned}
$$

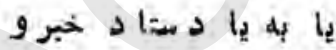

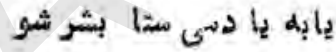

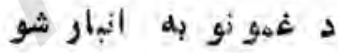

$$
\begin{aligned}
& \text { ما مداتيلى دا مبرى اوبنكى }
\end{aligned}
$$

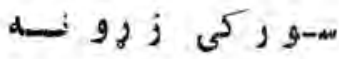

$$
\begin{aligned}
& \text { شاو ى كُ رى كلمته راشى }
\end{aligned}
$$

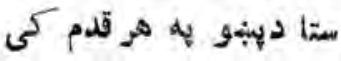




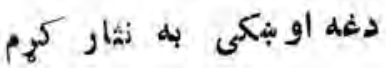

خو ! افسو س خى تلمر انغلى

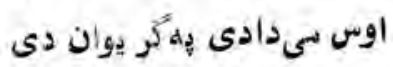

مسر غسلرى راروانس

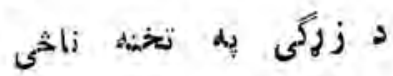

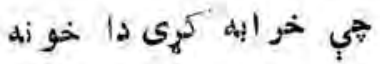

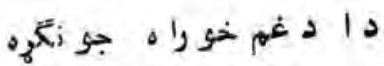

دا بله ناز سا تلسى اوبنكى

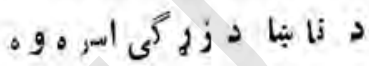

rrY 


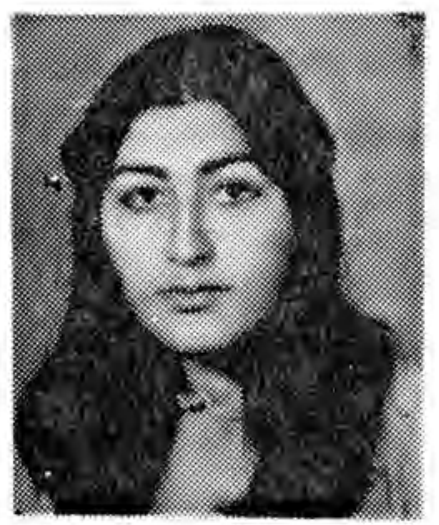

\section{كلغوتمى خاوري}

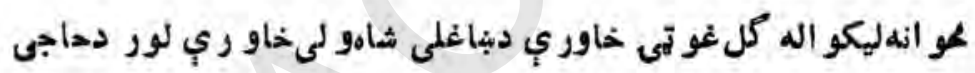

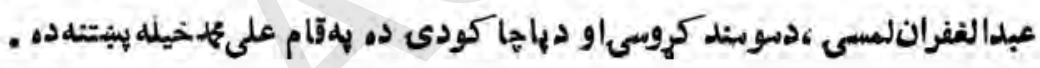

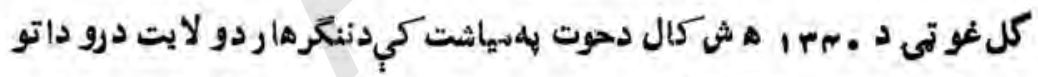

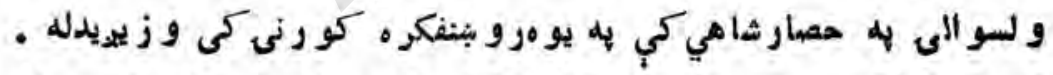

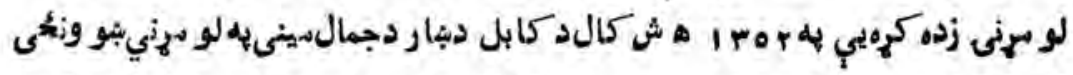

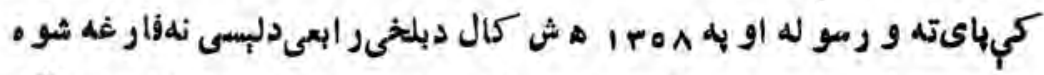

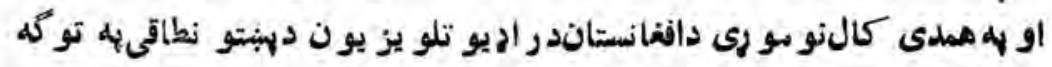
. 


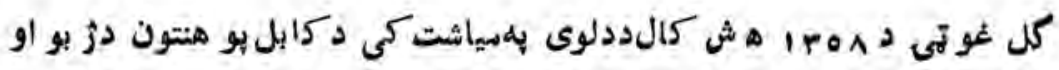

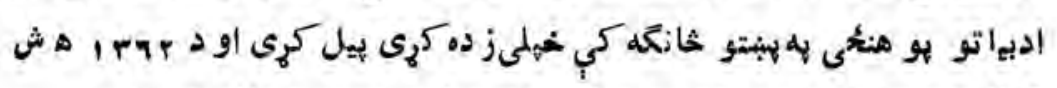

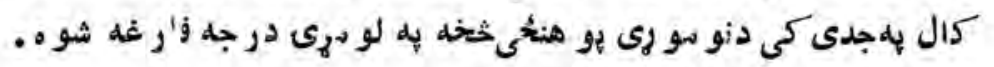

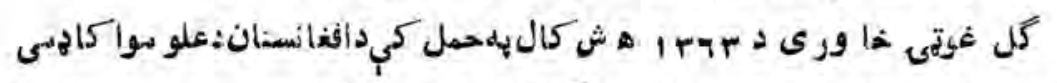

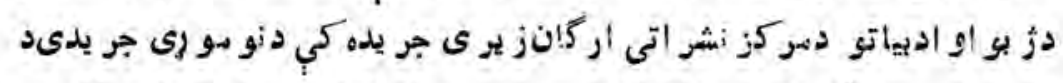

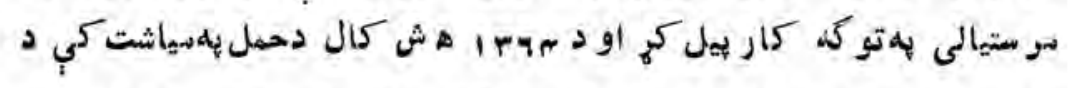

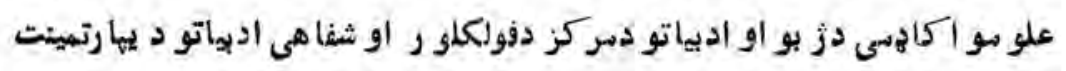

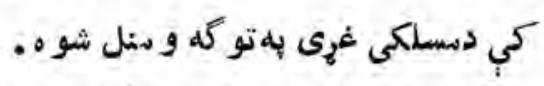

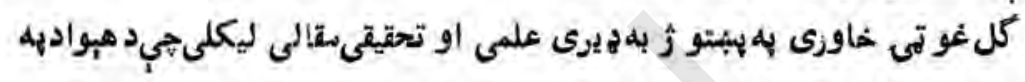

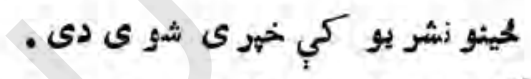

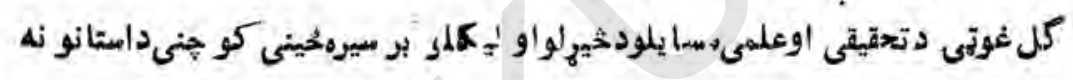

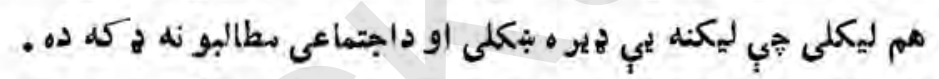

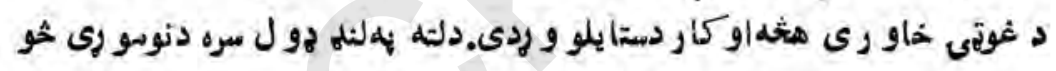

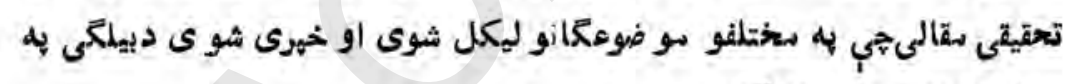

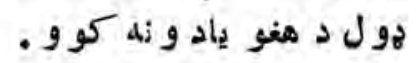

1 - دخوشال ختك تفكر تهيوه لنيه كثنه | جر يلهه.

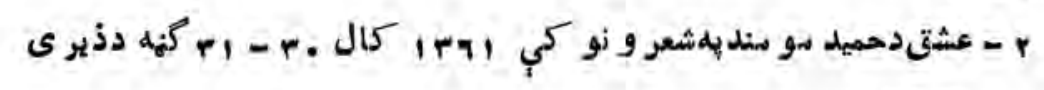
جر يده.

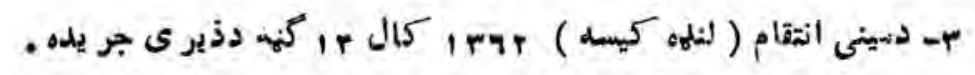

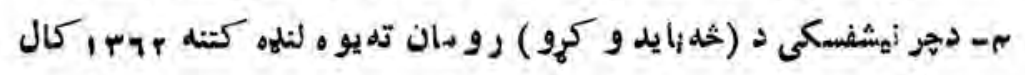

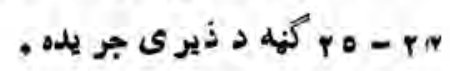




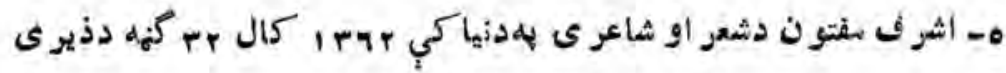

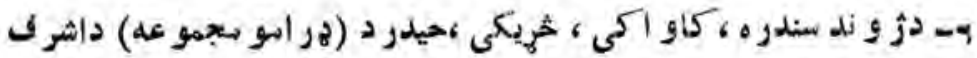

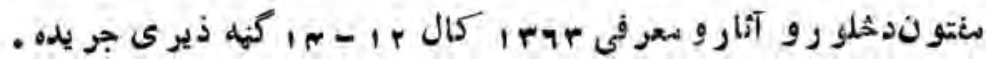

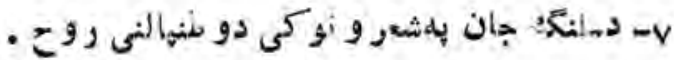

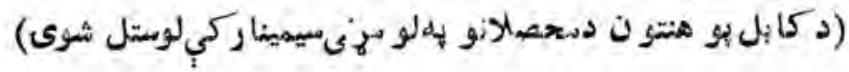

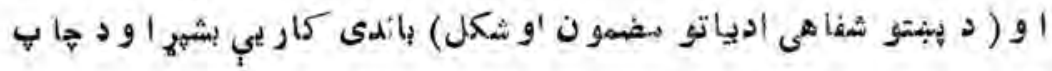

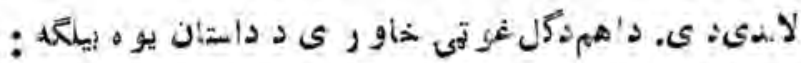

مينهاو انتقام

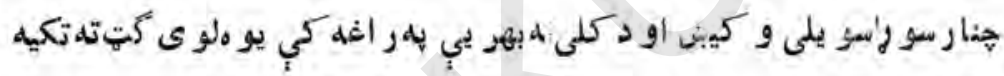

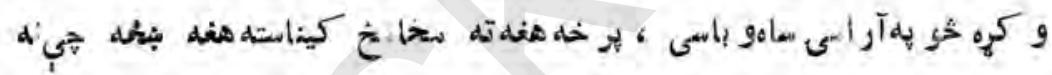

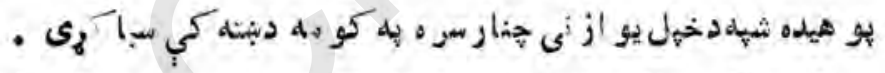

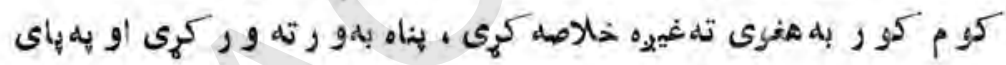

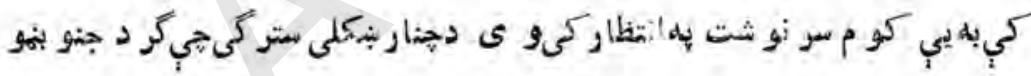

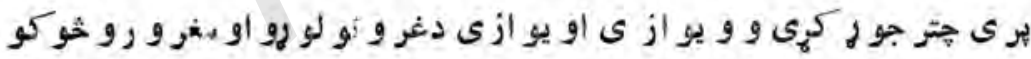

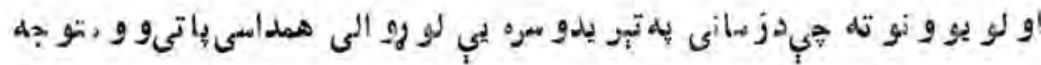

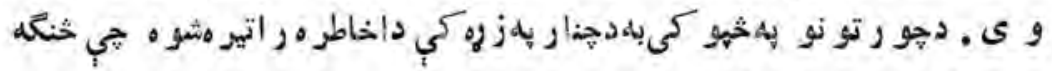

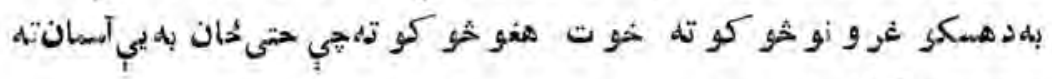

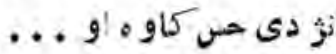




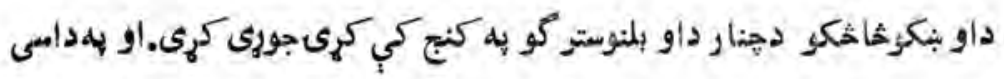

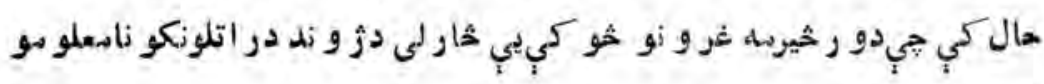
أيبنو جهو رت يو ? لـ.

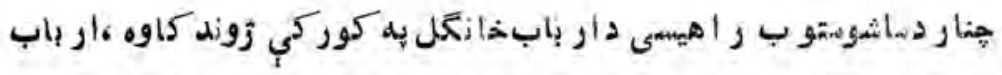

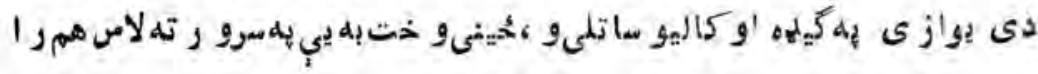

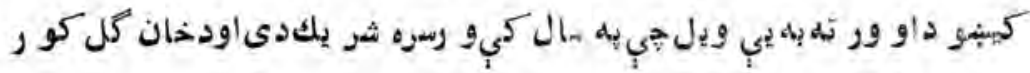

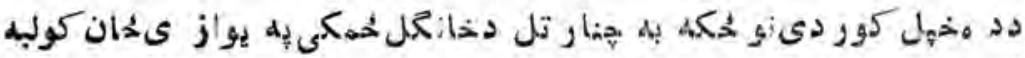

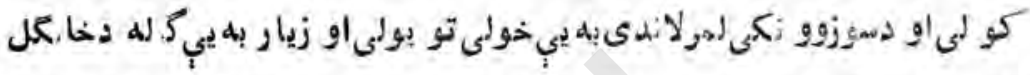

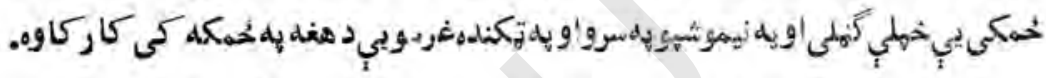

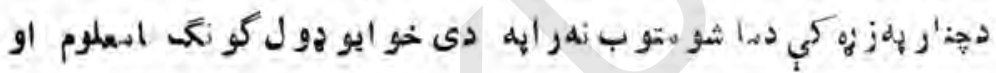

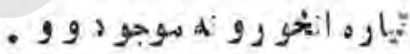

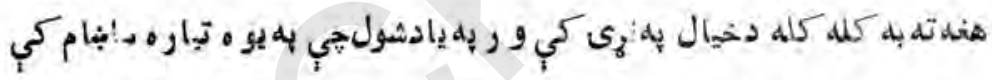

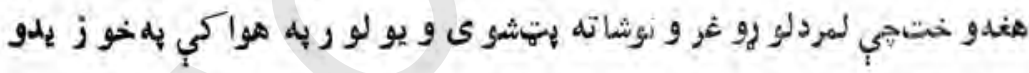

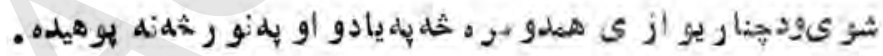

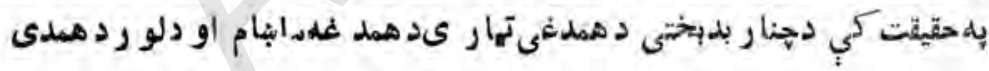
خو ز يدو نه بيل شوى

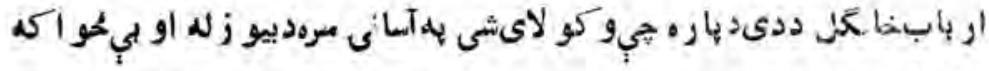

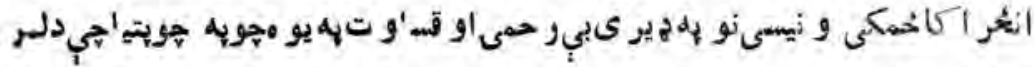

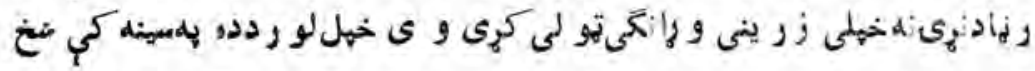

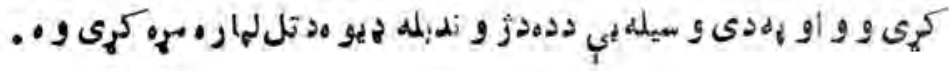




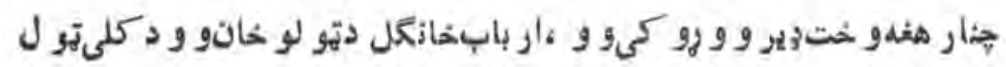

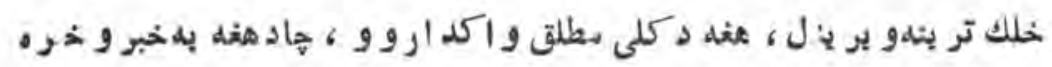

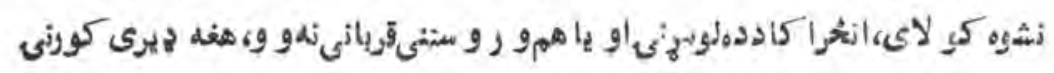

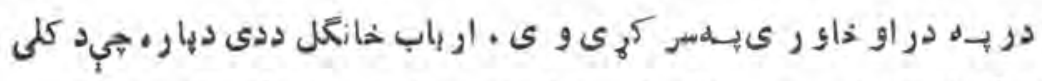

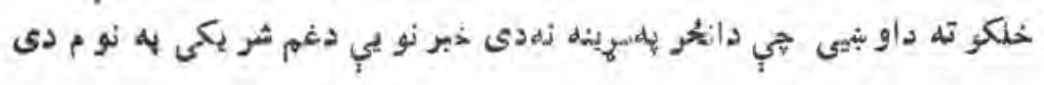

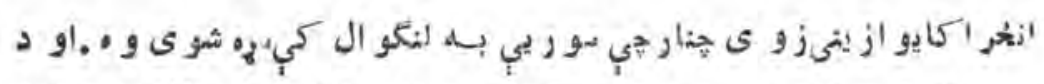

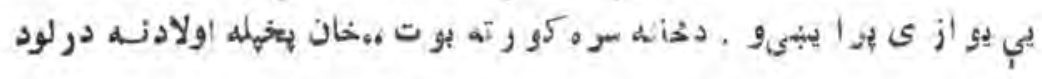

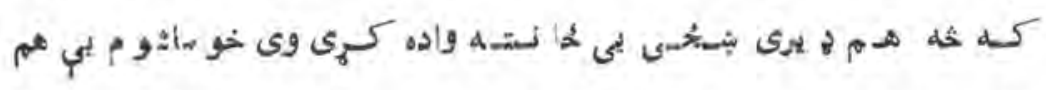

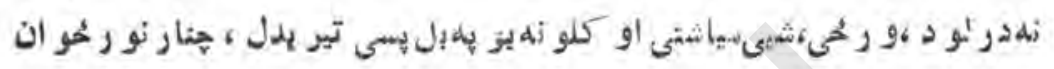

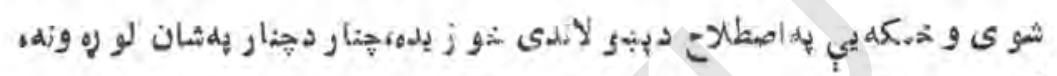

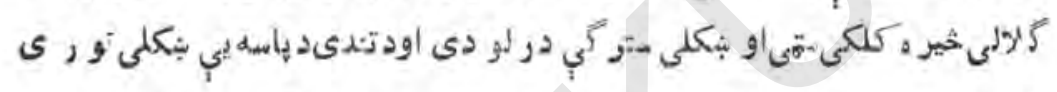

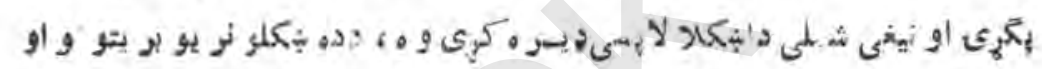

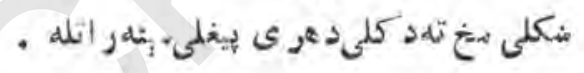

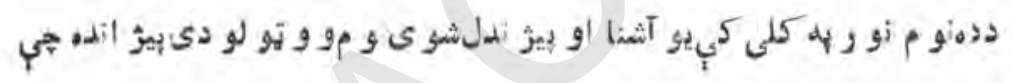

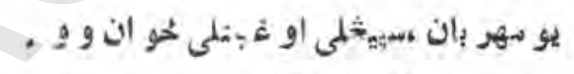

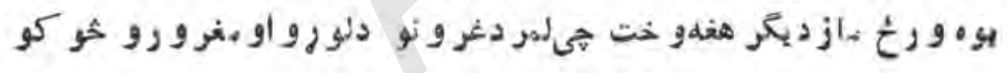

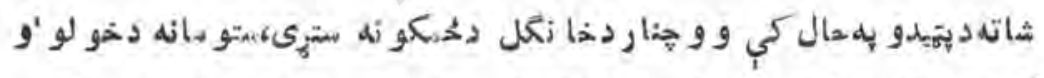

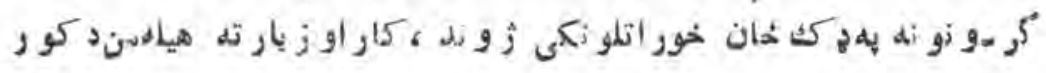

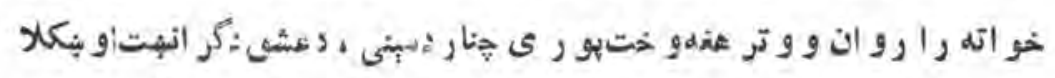

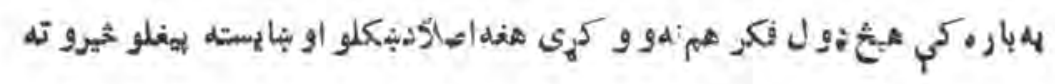

\section{TrV}




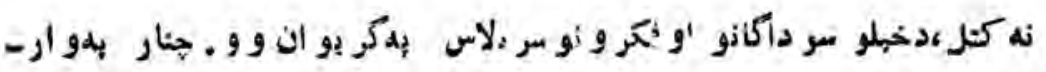

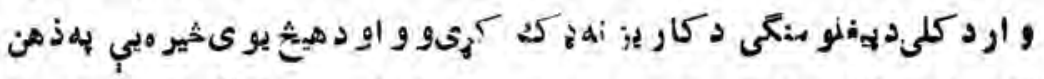

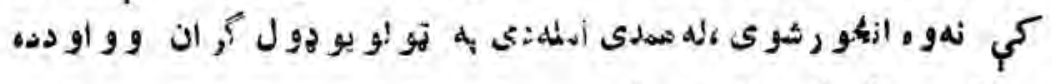

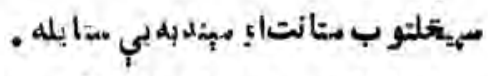

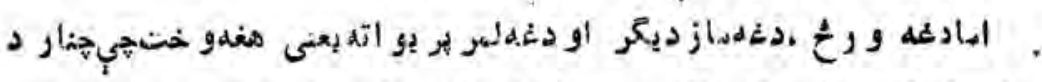

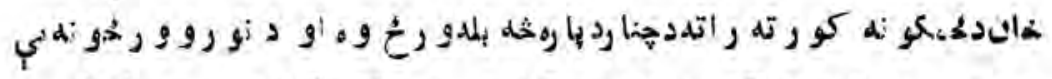

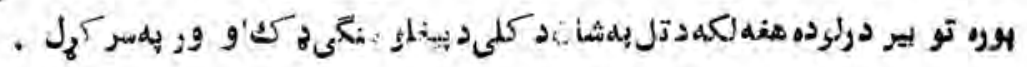

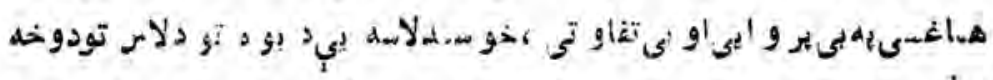

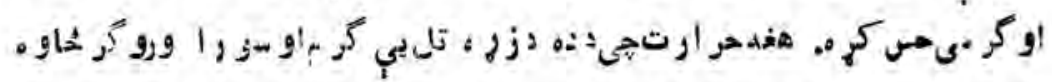

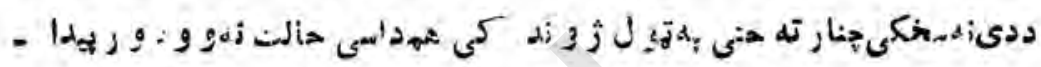

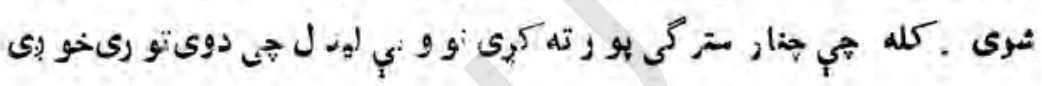

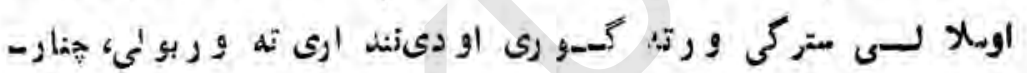

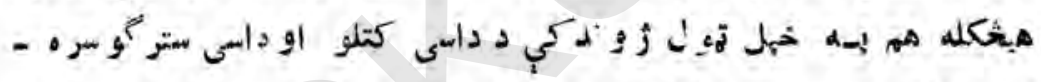

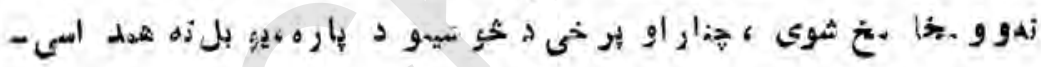

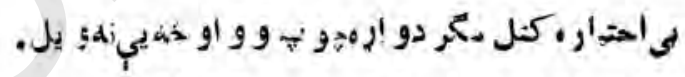

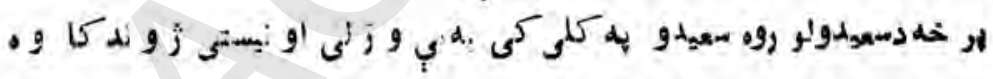

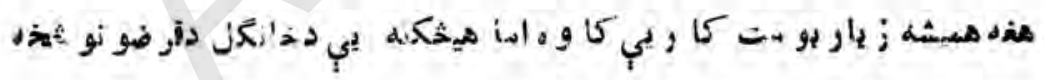

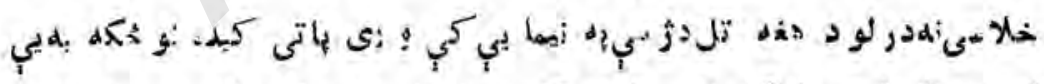

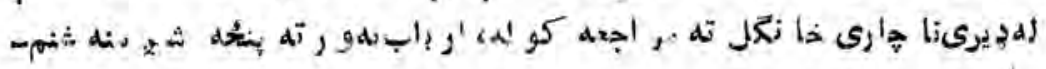

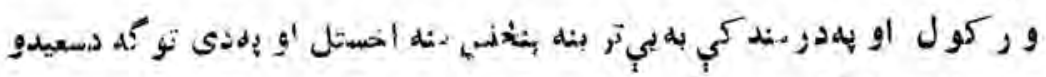

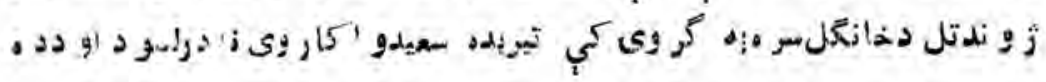




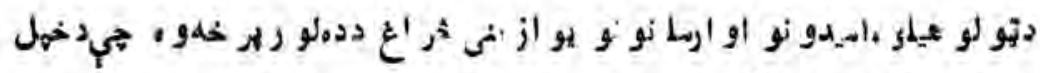
مان

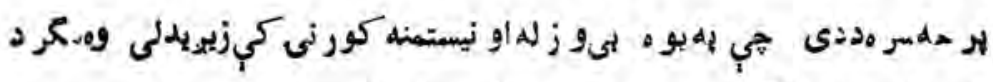

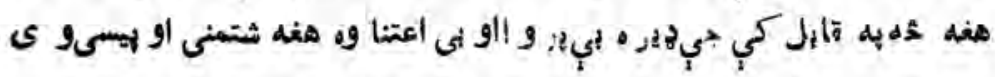

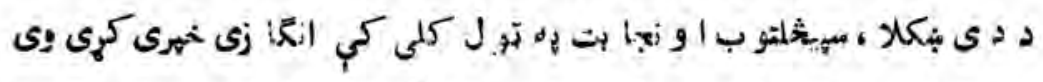

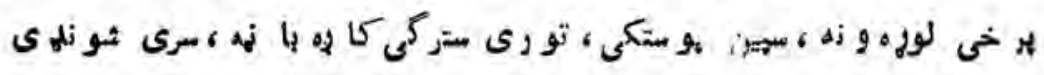

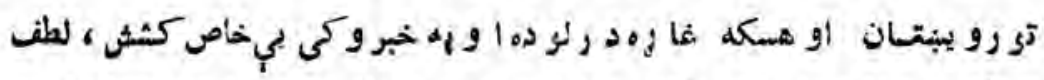

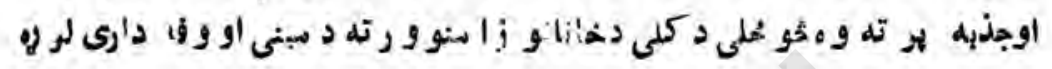

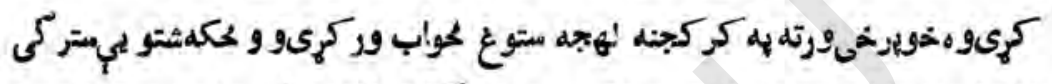

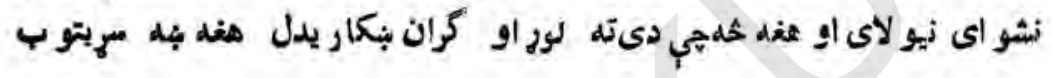

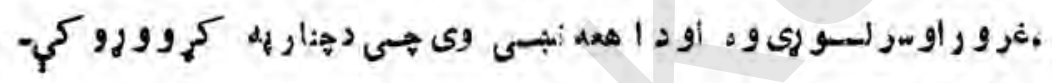

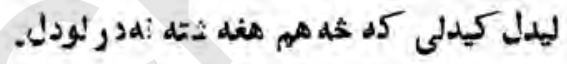

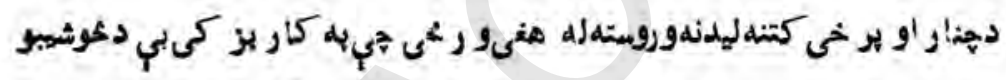

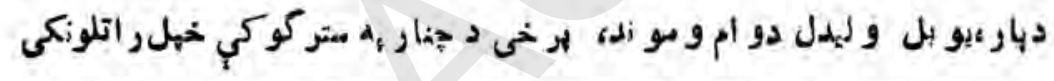

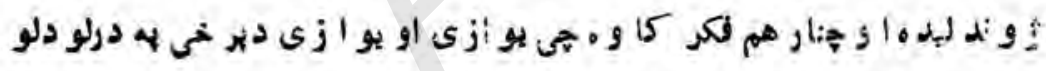

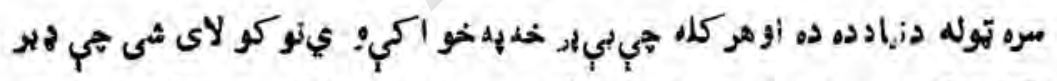

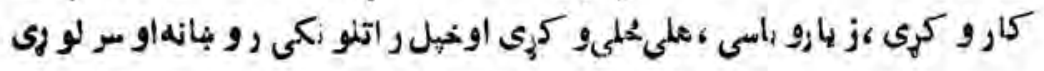

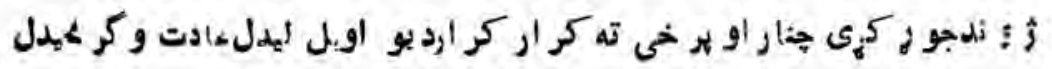

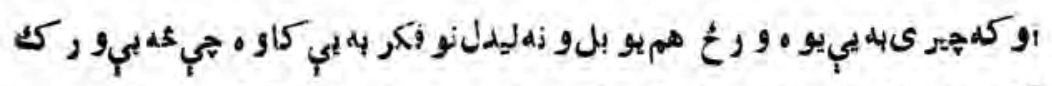

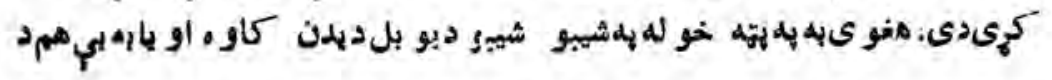




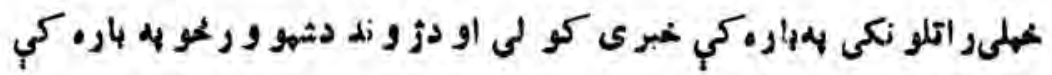

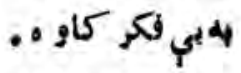

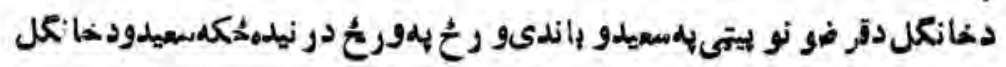

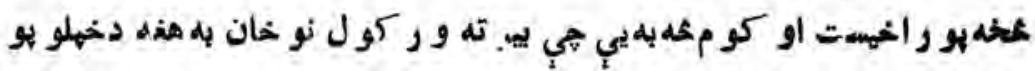

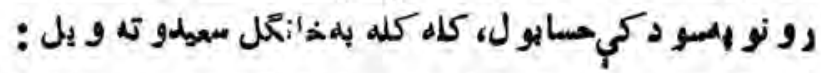

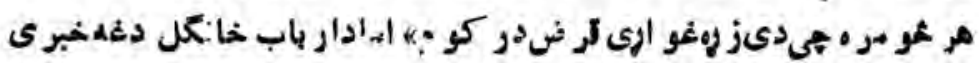

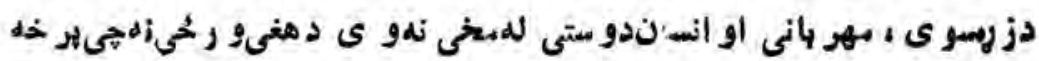

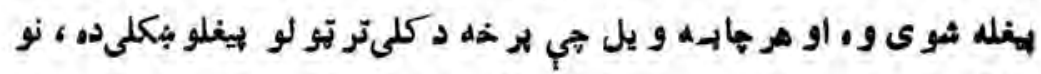

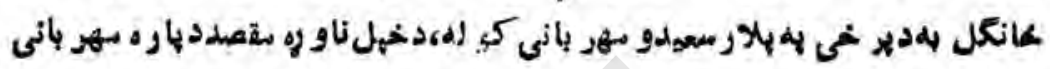

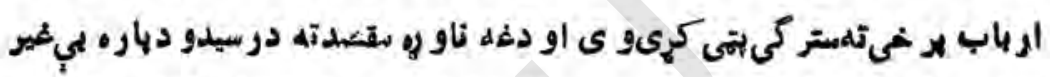

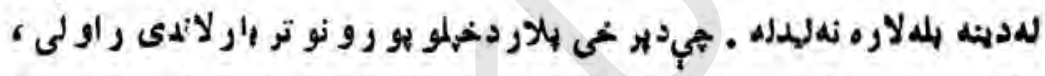

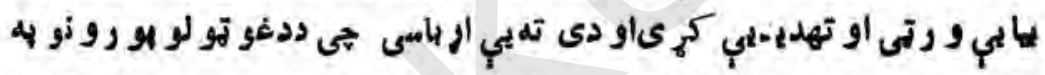

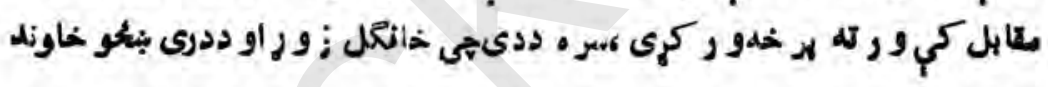

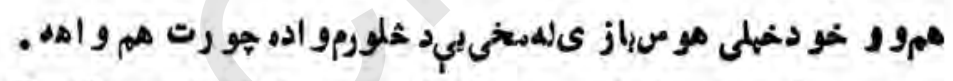

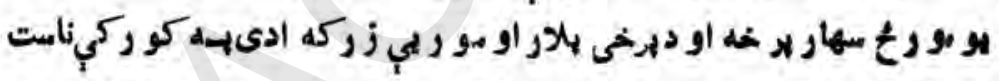

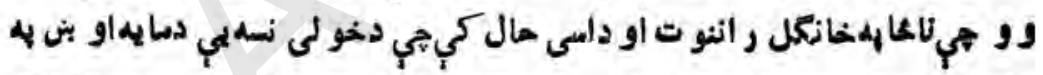

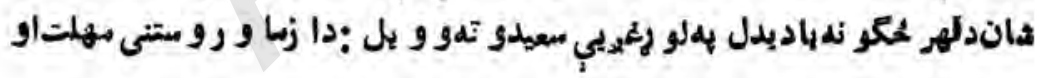

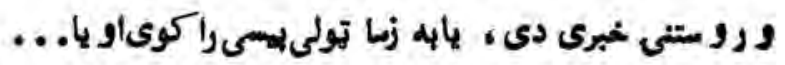

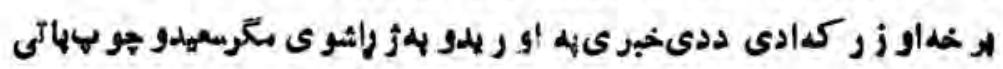

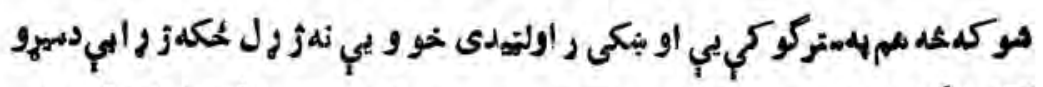

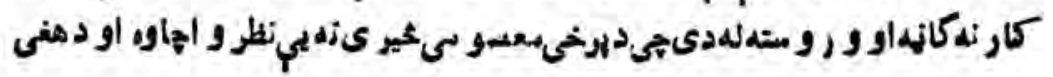




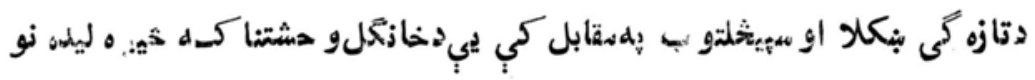

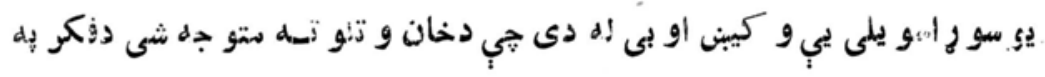

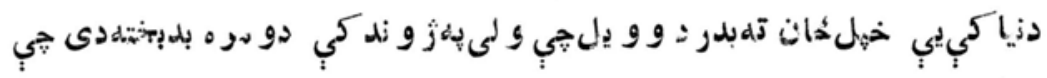

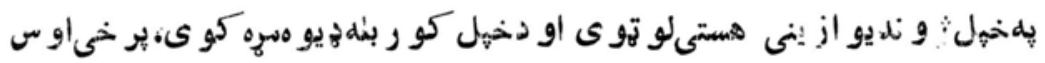

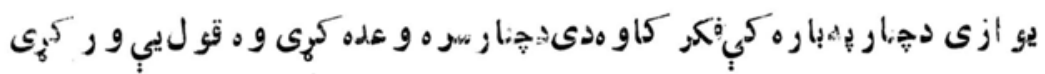

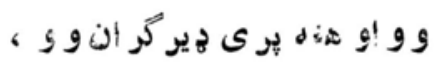

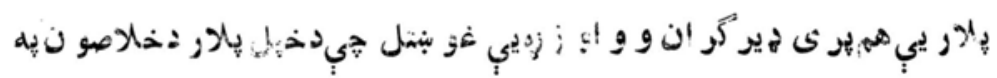

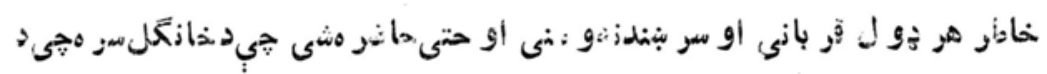

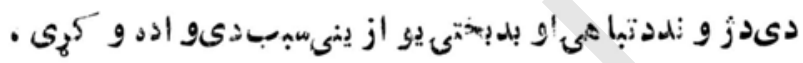

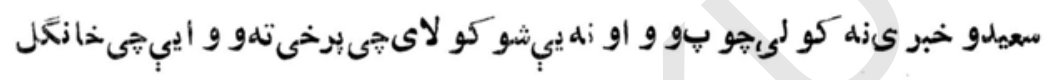

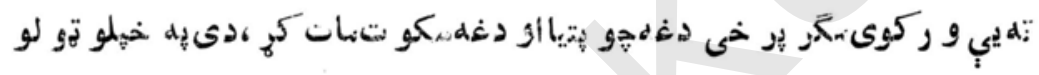

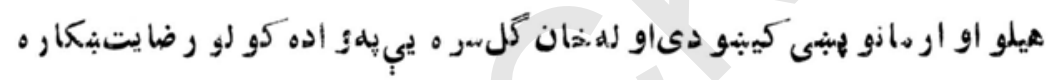

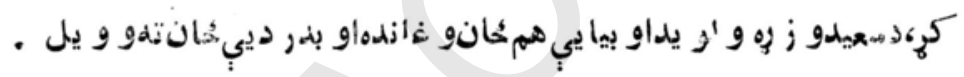

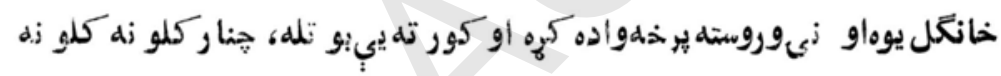

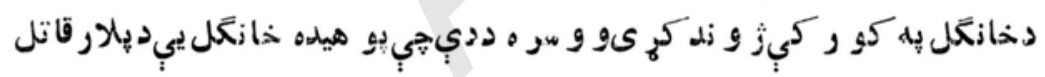

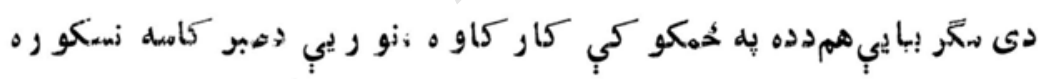

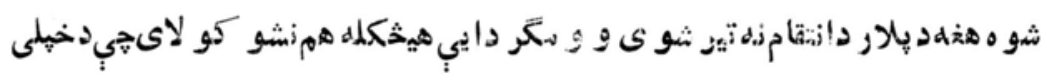
مينى، دخهل عشثقاو دخهلى بر خى نه تيو شى او دذخهلو ار مانو نو غو تهى دار باب

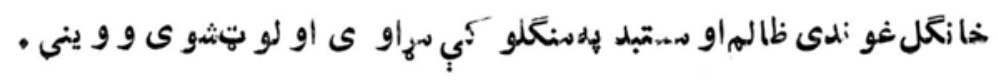




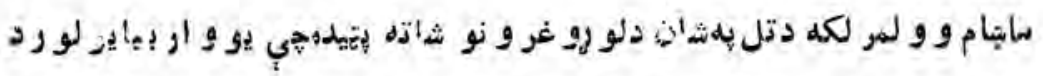

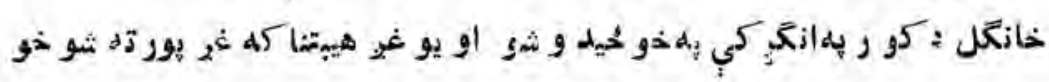

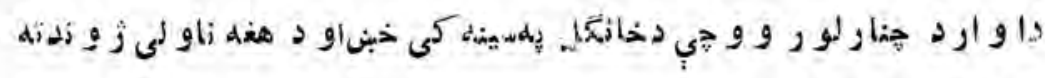

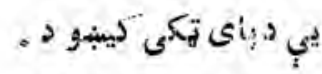

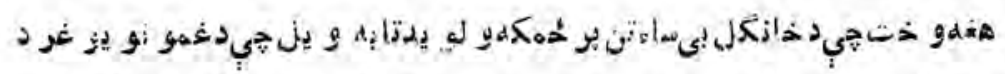

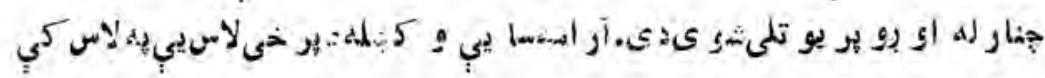

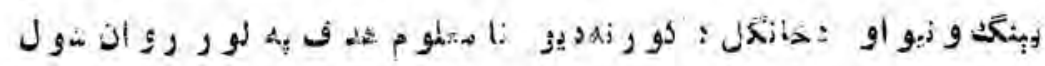

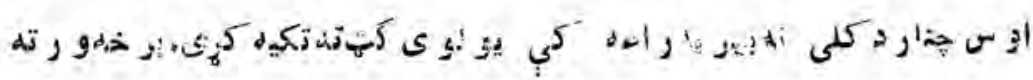

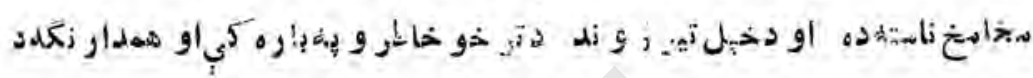
راتلو زكى 


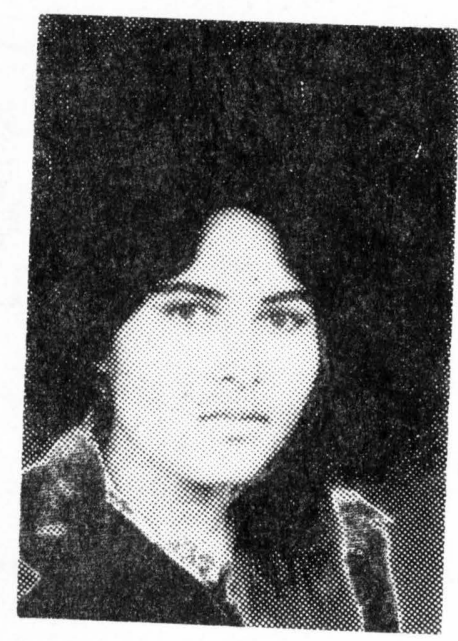

\section{صفيلهاليقى}

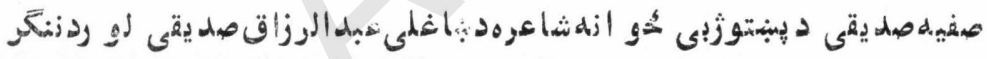

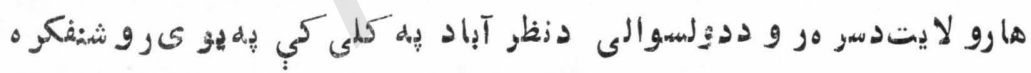

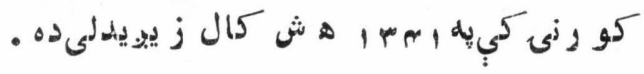

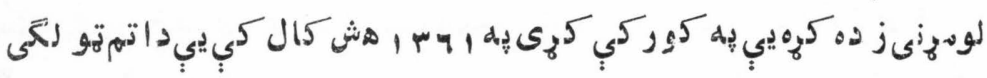

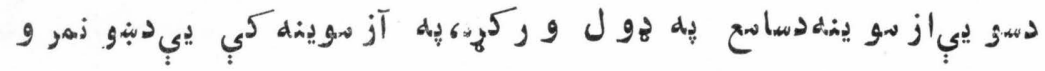

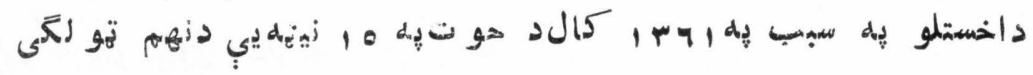

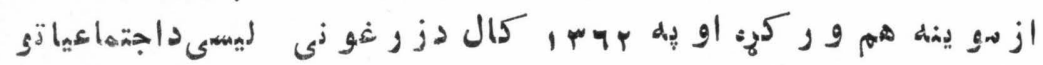




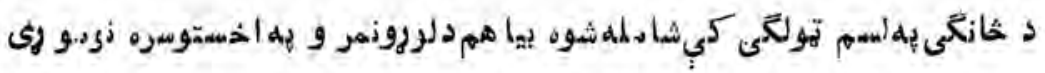

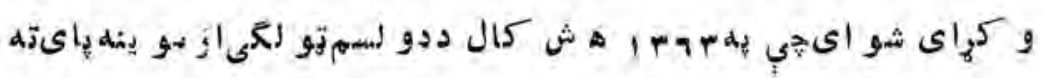

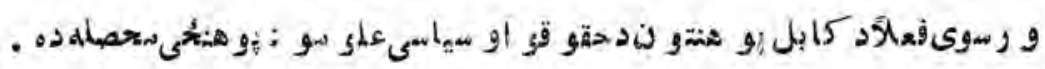

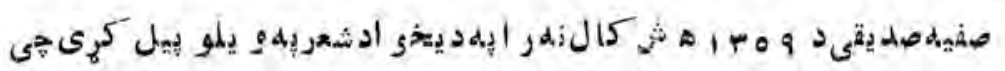

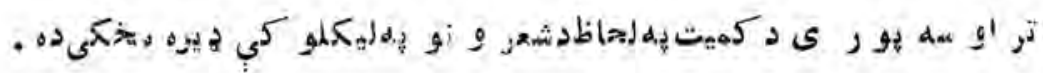

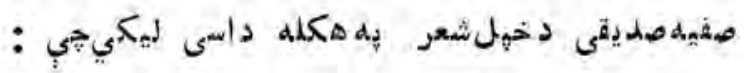

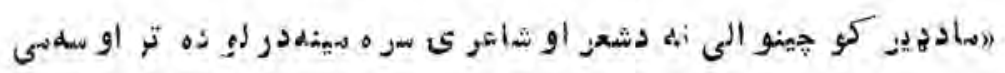

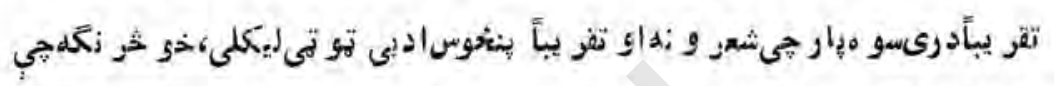

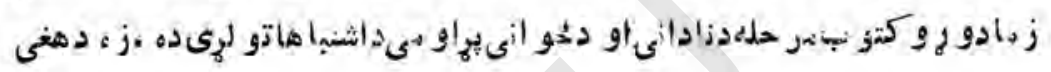

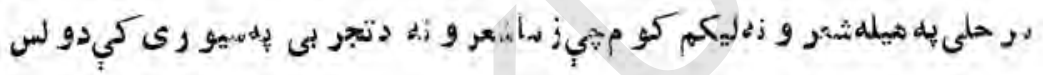

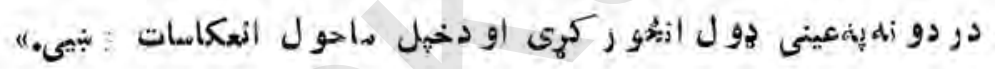

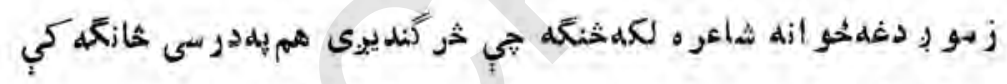

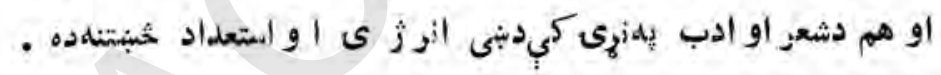

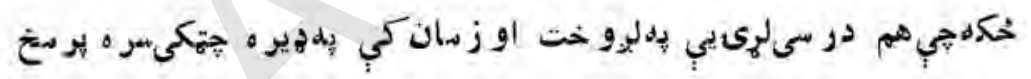

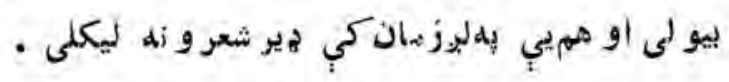

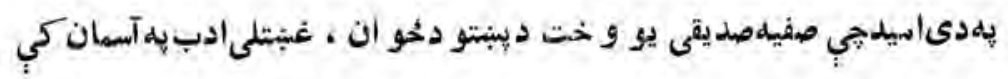

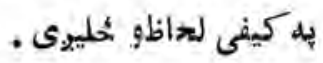
تأسو ته دنو مو ري دشعر خو يليلى و رإندى كو م : 


\section{مازرل}

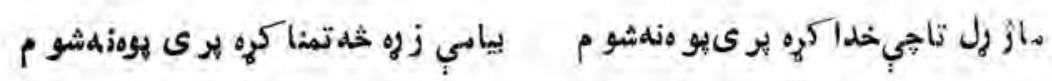

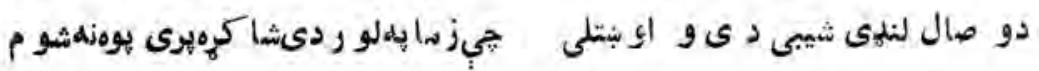

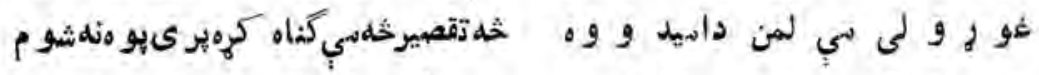

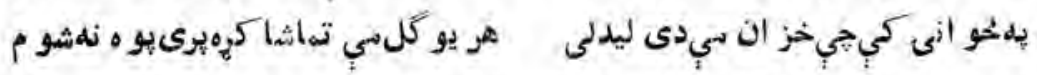

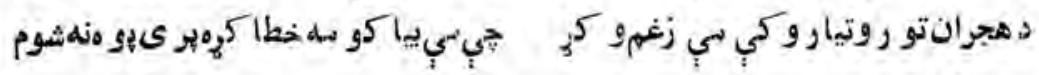

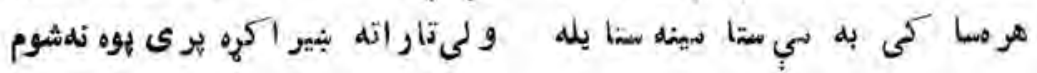

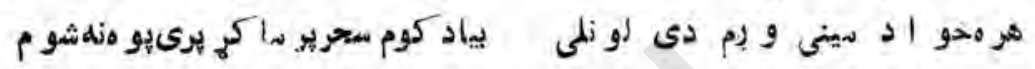

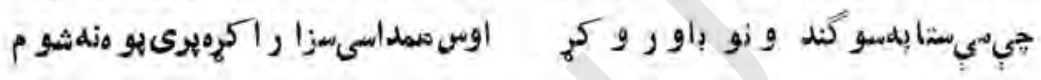

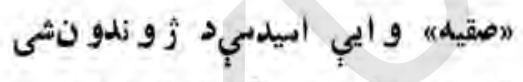

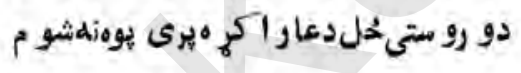

\section{دجر كو و طنه}

بر مايب كران أىنزمر و وطنه

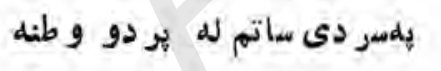
رازبي و تلىله يو دو وطنه ايى دا تلـو جنزيا' لسو وطنه

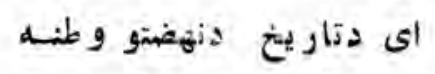

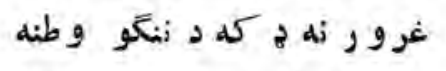
ليملزازموى دد نكو غرو و وطنه
زماو طنه جد جو كو وطنه

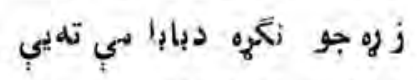

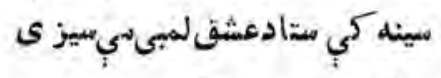

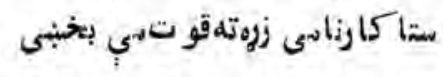

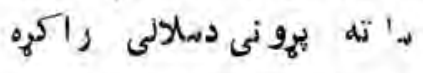

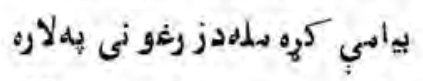

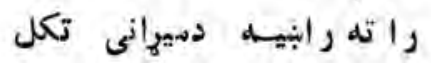


اينه كبابدي كر، دردو و طنه

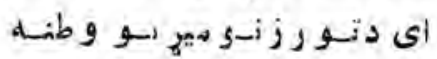

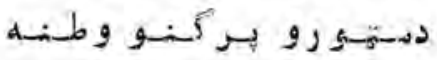

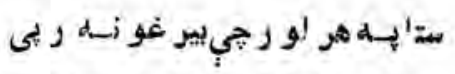

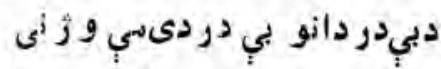

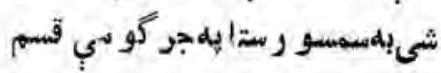

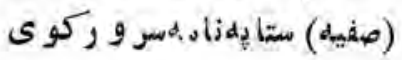

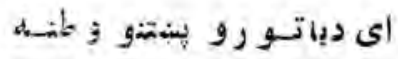

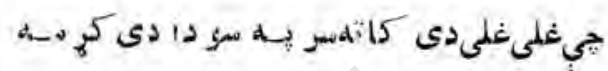

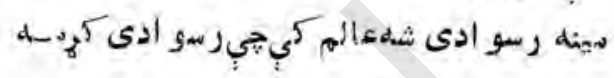

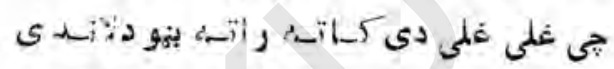

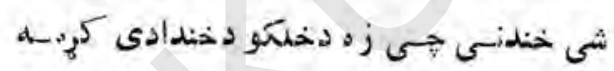

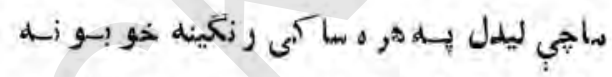

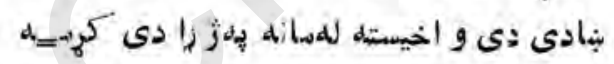

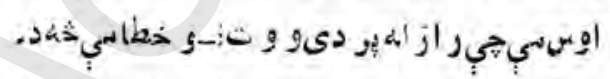

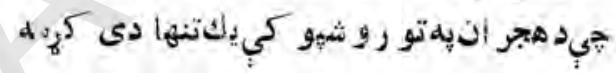
نا جي دستر كو بله كنجبو كي سو كند و نه كمول

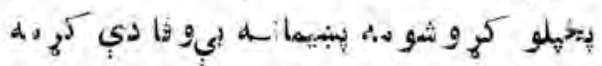

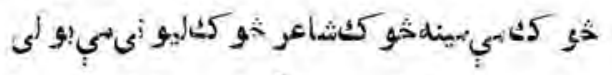

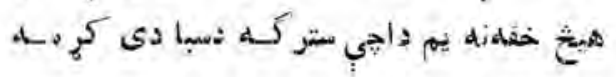

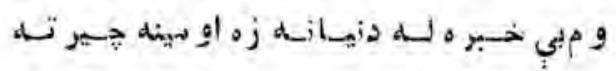

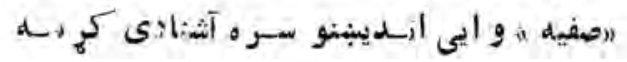




\section{دشاعر باو ر}

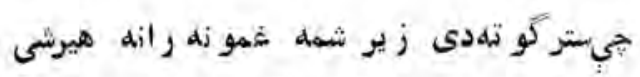

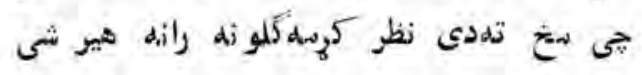

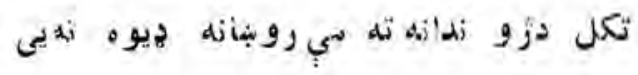

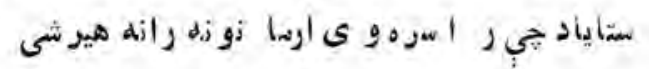

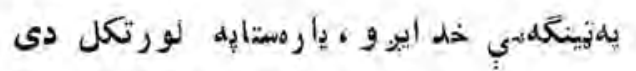

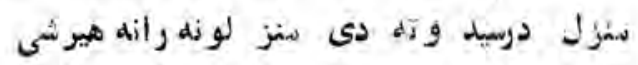

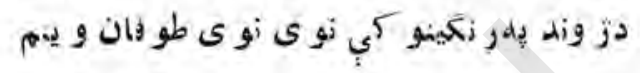

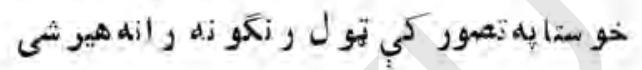

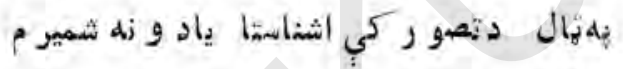

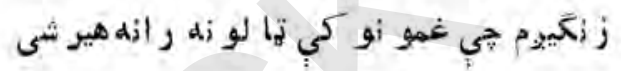
بر د ى شم لهدنيا نهله جي تلمكو توكي و اخلم

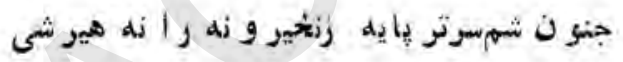

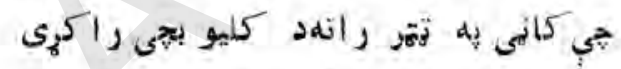

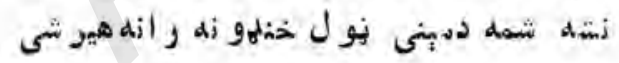
أشناجيدى دهينى بيابان كي لارهمار

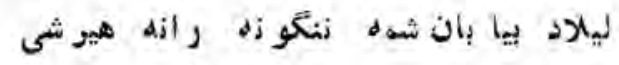
هاند السى ليونى دليونسو سرم به بنه ليم

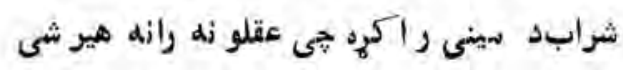




$$
\begin{aligned}
& \text { معنى درقيهانو به كو گل سي ماو به سردى }
\end{aligned}
$$

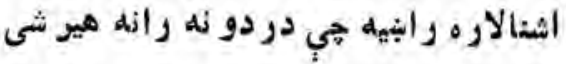

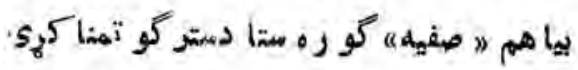

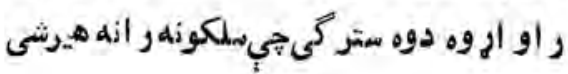

$$
\begin{aligned}
& \text { سركر دانdورو }
\end{aligned}
$$

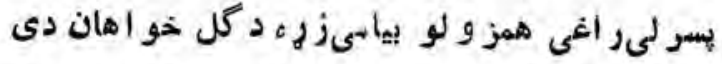

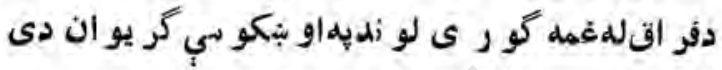
خه يلهددى

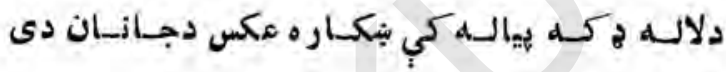

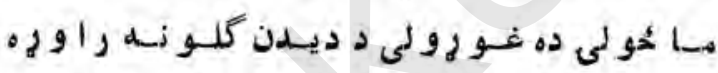

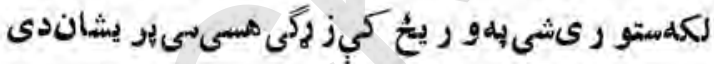

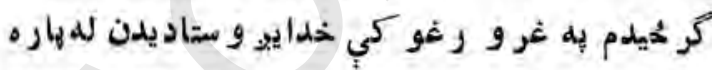

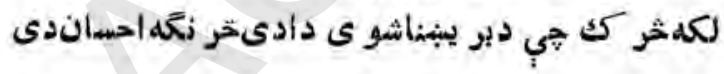

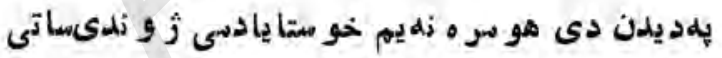

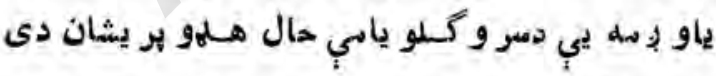

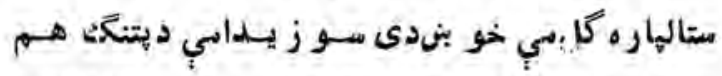

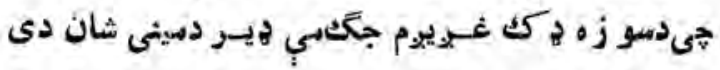

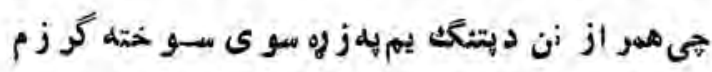

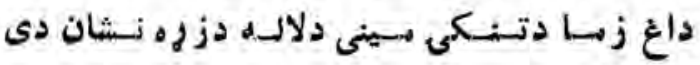


بيا بهار ر اغى جيى زه ددى دسر وكلو نسه تيو س كرم

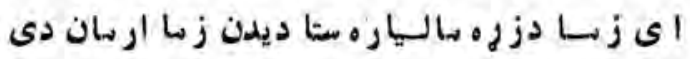

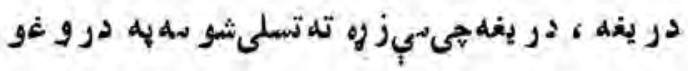

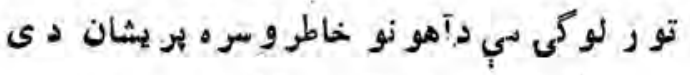

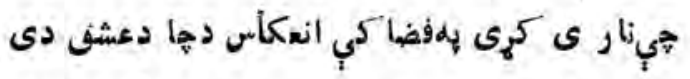

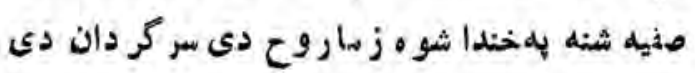

\section{دحسن بنا يبرى}

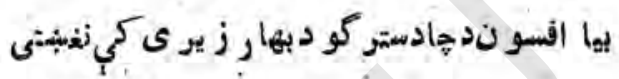

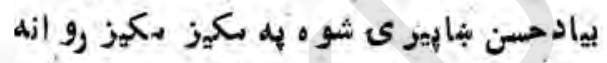

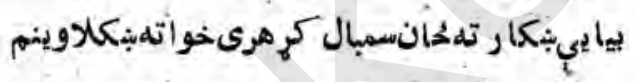

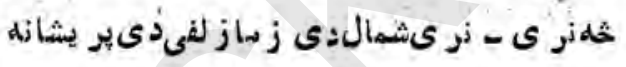

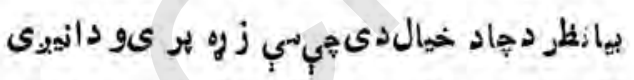

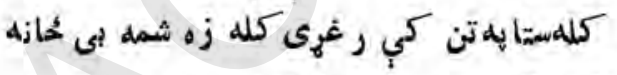

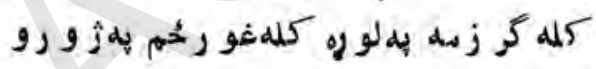

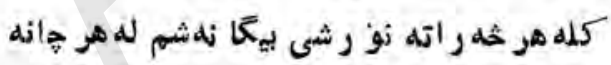

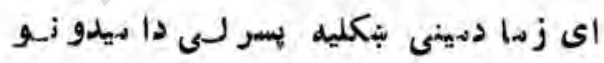

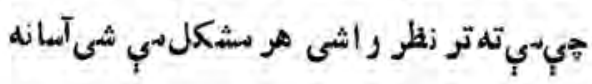

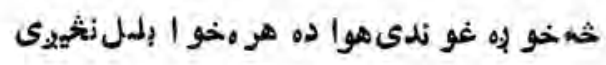

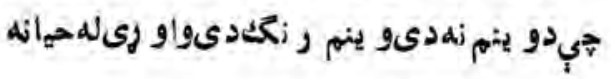




\section{دبنهيمى}

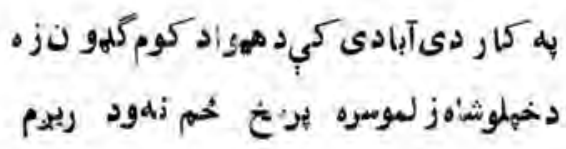

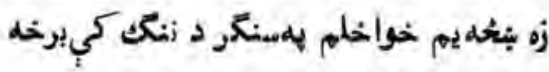

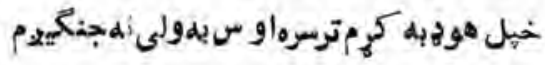
ترهاغوبهانردخ حممجيد' تهول وطن ممورشى

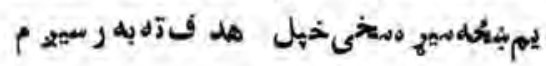
كرم بحتو • بلهد جهل داتيا رى خلكولهز وندنه عر فان بله هيو ه به شمرتو رتم كيجبه بليم م

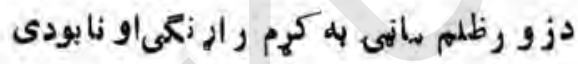

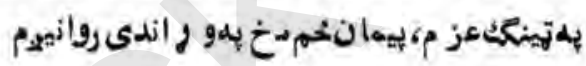




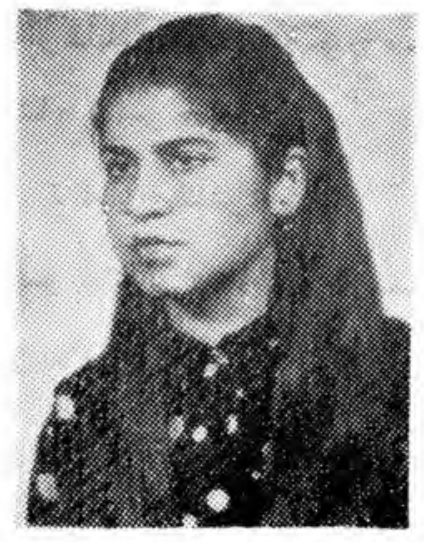

\section{نوشابه شهيد}

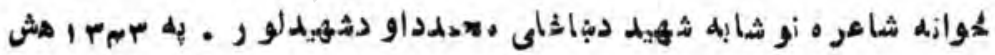
كال دبهسو د و بهيو •كلى كيجي دنومو ردى اصلى تاتو بى دى بلهيو معالمه

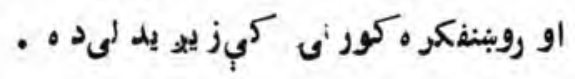

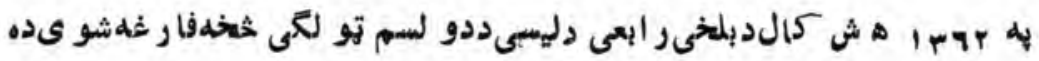




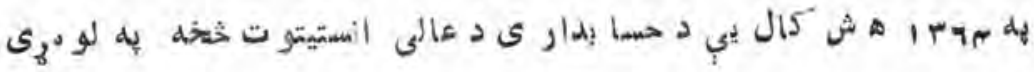

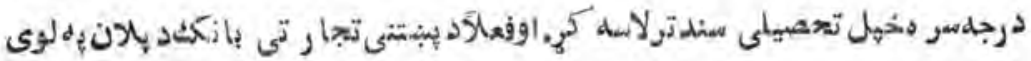

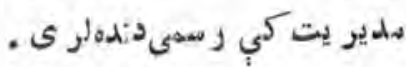

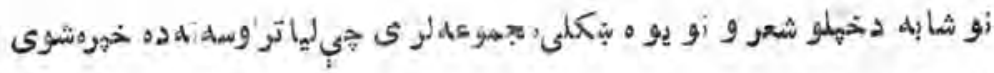

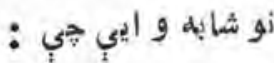

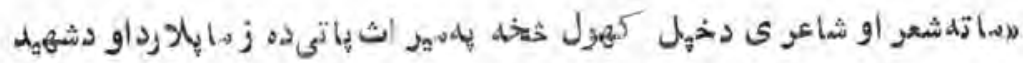

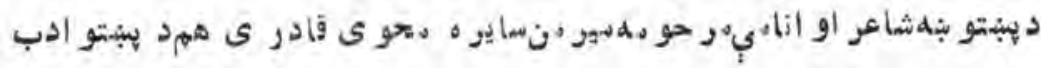
كألمانده خير ه هده

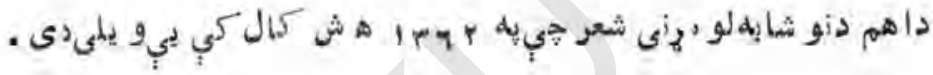

\section{لينيتو نولى}

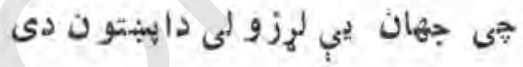

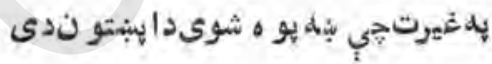

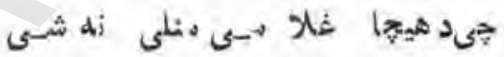

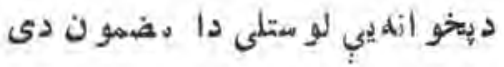

دو طن دسمسور تيا ،خدمت به لار كي

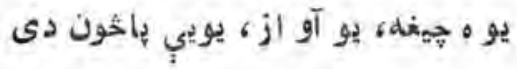

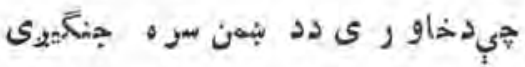

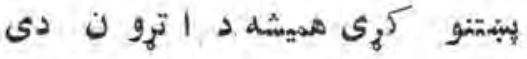




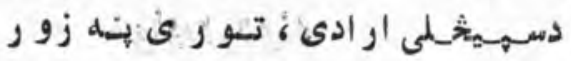

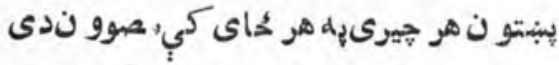

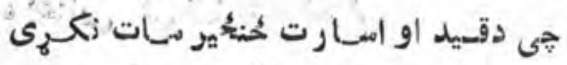

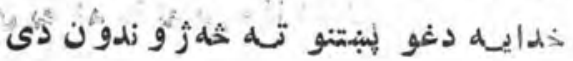

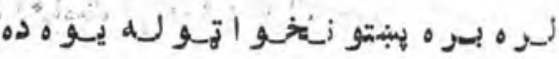

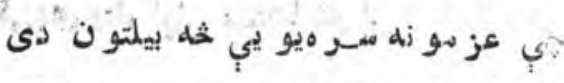

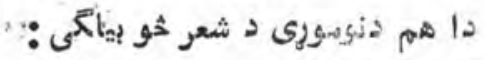

و طن. ته

و طنه

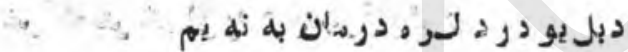

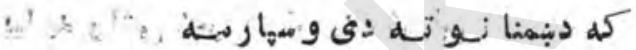

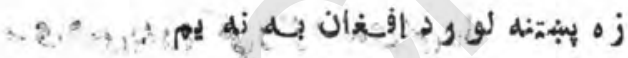

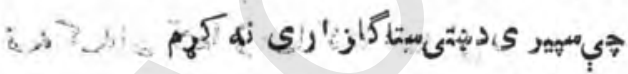

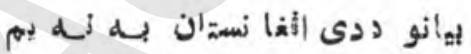

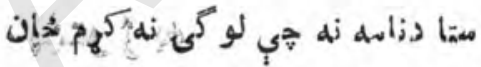

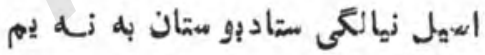

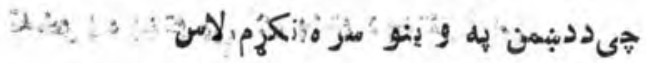

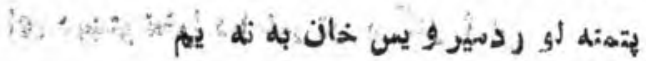

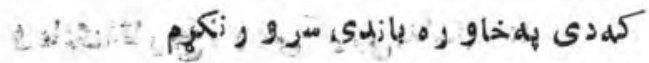

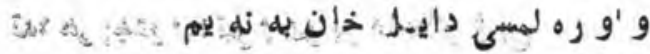




\section{خوإيمدردونه}

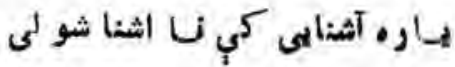

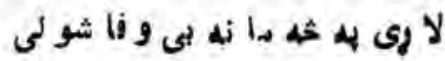

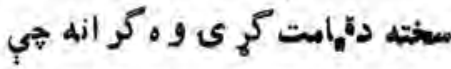

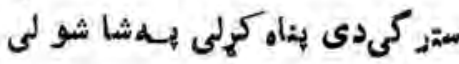

$$
\begin{aligned}
& \text { ها هيى تر عنه ميله دخو بنقى كيه له }
\end{aligned}
$$

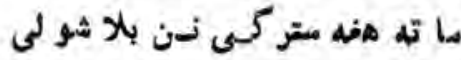

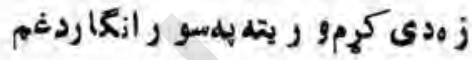

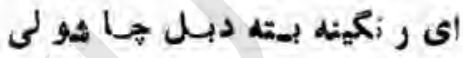

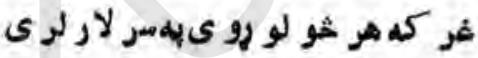

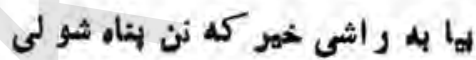

\section{لبيتو ر بله}

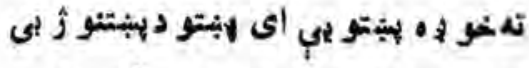

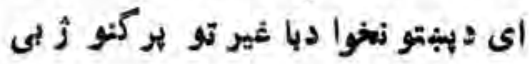

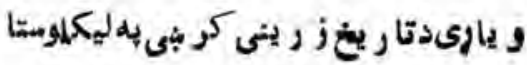

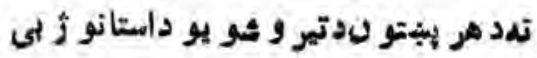


جاهى خخهل قوم او ملت نو ماوحتشسا تلىدى

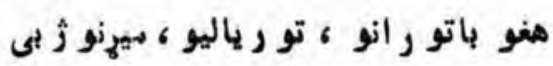
تهدهر ببتون دشجاعت او ابر و نبنه يب اي دستر يبثتون دشهامتاو ار ادو زُ بى تادهر بِتبتو ن هره ميرانه بنه ستايلى ده

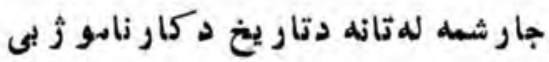

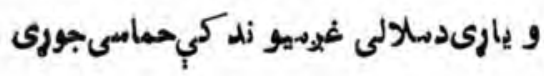

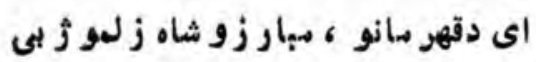

\section{دغمو ريف}

دميلو لمره بـ وف فــونـدى شـوى ير دى غماز سر ه بخلا غو نسل شى شوى ستركى شو ى وهي ستا دخيال به طمعل

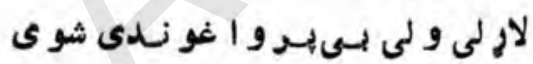

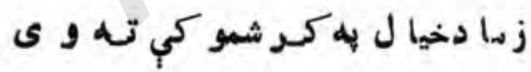
بىتادى هيلى اوس تالاغو نسلدى شو ى

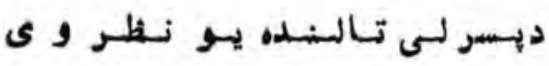
ماته نن هغسى بر يبنشاغو نسدى شـوى 


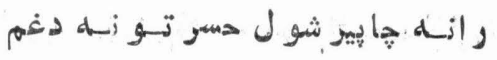

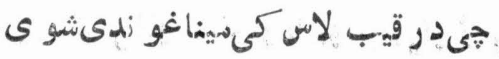

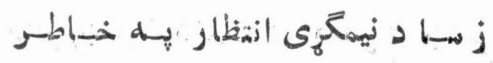

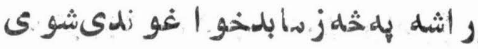

\section{وو طن شنميه تزه}

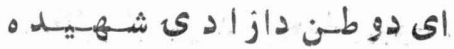

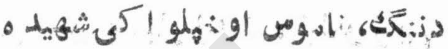

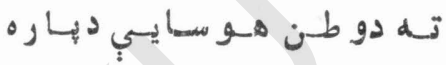

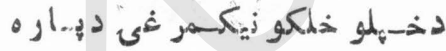

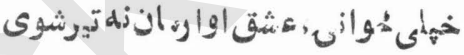

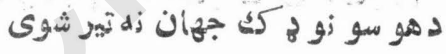

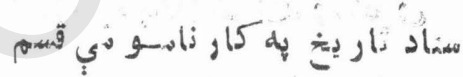

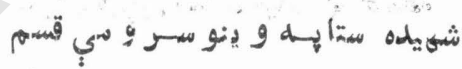
***

ستاغلميمان بـه نا بـود يدوى ضر ور

بهاd تهيتو ستر كوبإه و ركيوى

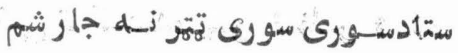

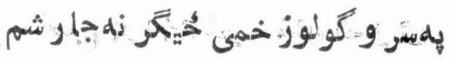




\section{د او بنكو تصو ير}

كنو كيسى ديار خهل البدو نه غوندى بنكارى

نو يكهد بي خبر و كي آهو نه غوندى بيكا رى

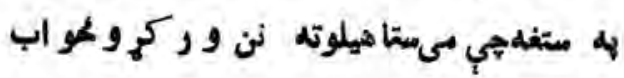

الشنابه ا مو يلو كى حسر تونه غوندى يذيكا رى

جىليارد ديد نو نودر نه و ركم كم • بيلتون

نطر كي دىداسسي محكه غر و نو نغو ندى ثبكارى

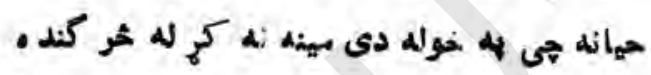

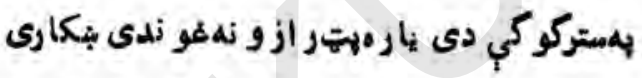

دا اونكىى وحسوتدىستابه متركو كىه نله شوى

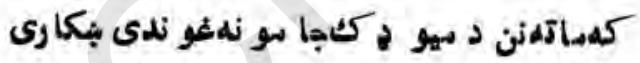

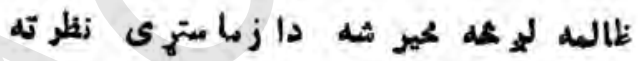

2 ا و بكوبه تصولركى

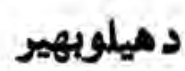

نن هى مىمتا داجدايقزو روى لحكه بي كلى امو للى خبر وى

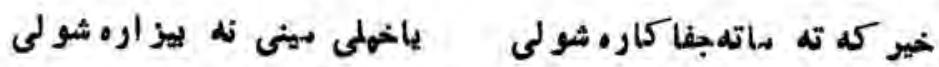

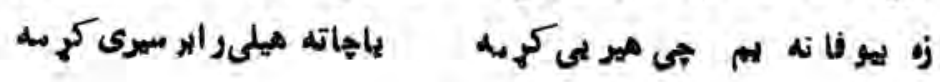




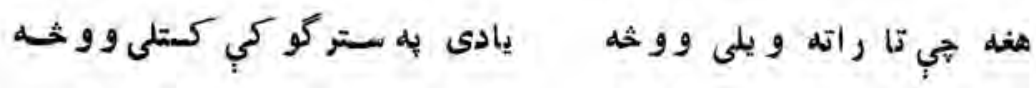

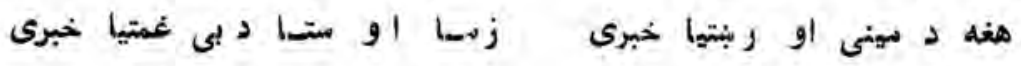

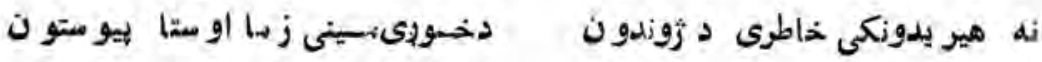

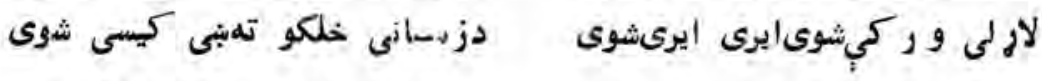

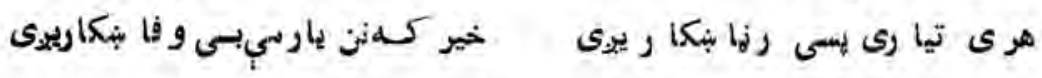

$$
\begin{aligned}
& \text { زه خو اميدو رته لرمد سمون }
\end{aligned}
$$

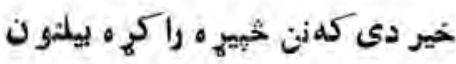

\section{زمانعميبب}

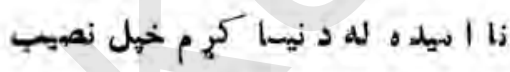

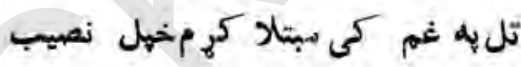

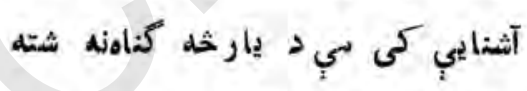

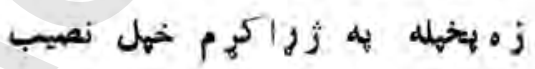

زه د هـ:جوتسوروشهونه تبتستيدسه

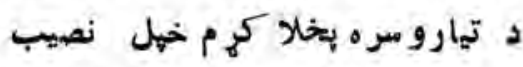

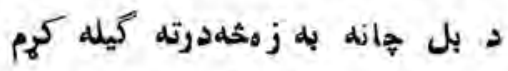

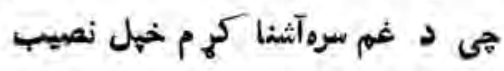

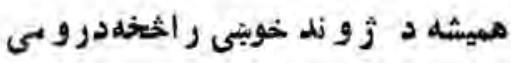

د. زاكسو د تعدا كميم خهل نصيب 
زهد وحل به نشه كي ونه جه واوبه

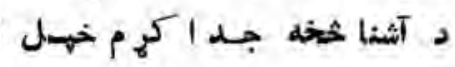

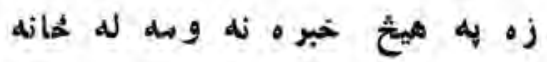

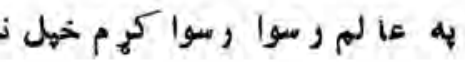

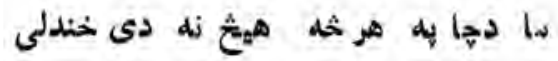

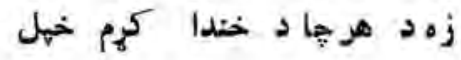

لهه غما زه كيله نسه كسوم هيخكله

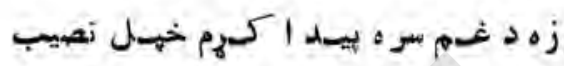

زماخوبثه

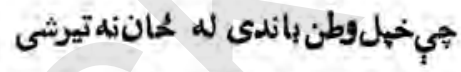

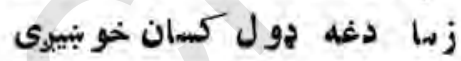

د سوركلونو او با غونو نه مى

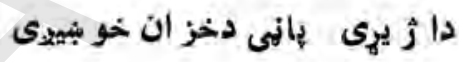

دها إهخو بن و ى بلهايى او دو لت

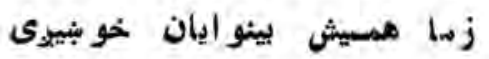

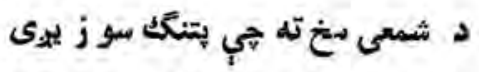

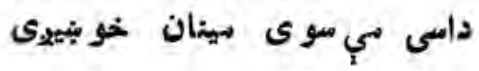

rog 
د ما بابه خو بنه و وى خندا اوخو بنى

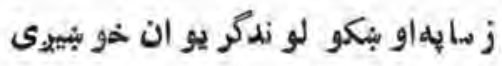

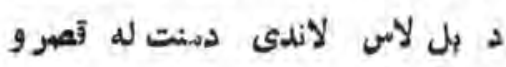

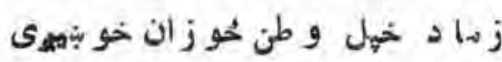

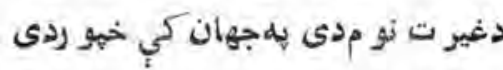

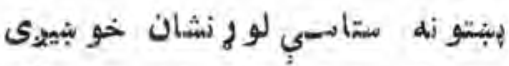

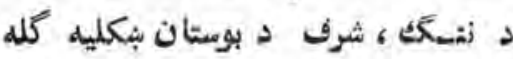

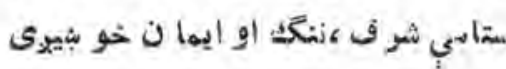




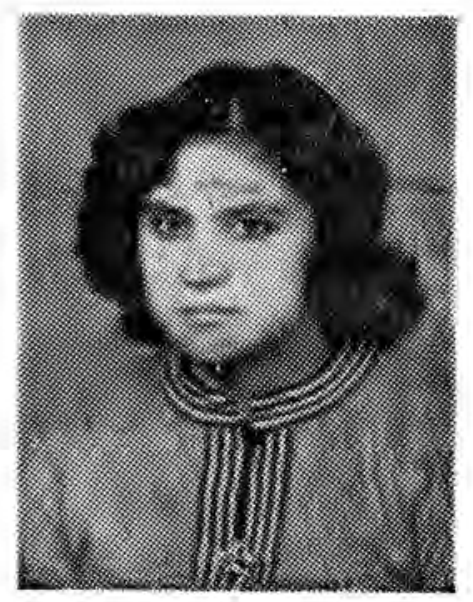

\section{هوا سلكى}

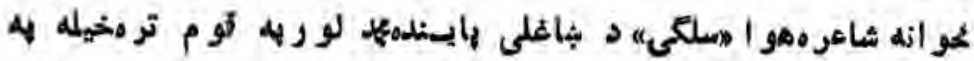

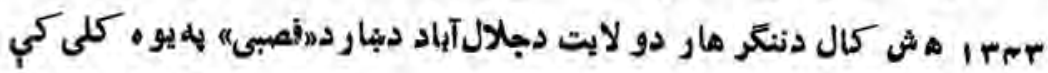

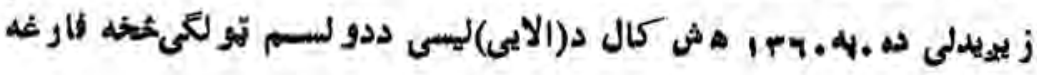




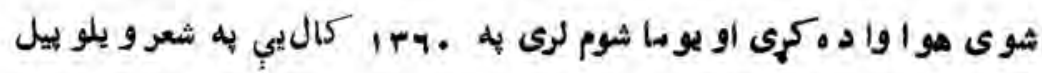

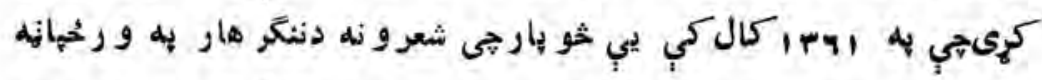

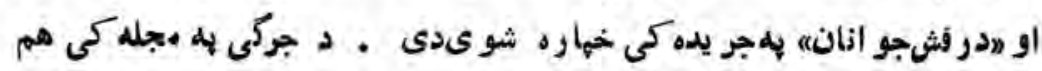
د نو مورى ه يوشعرو نه خسها ره شوى دي.

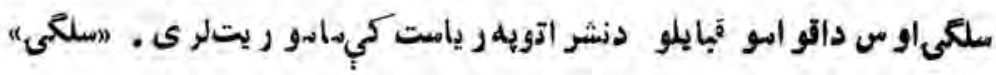

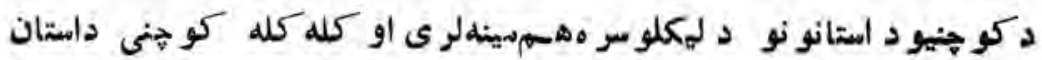

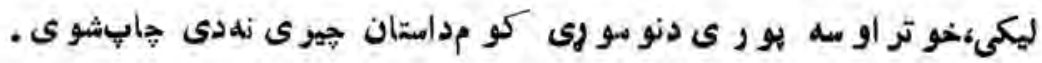

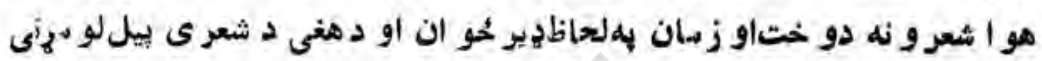

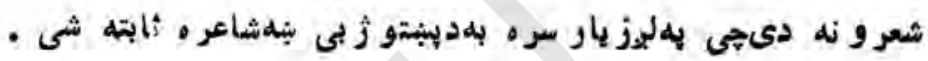

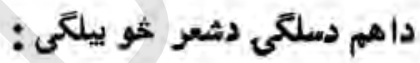

\section{غزل}

جي د آشنسالخوا امرى غلى شوى دمحبتسي ازكاز ى نلى شوى

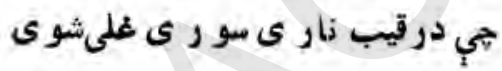
شو مه فارغه تهمتيو نوكنى

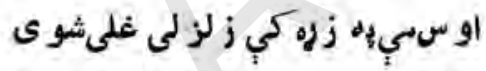

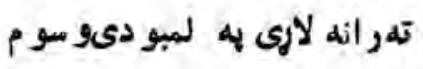

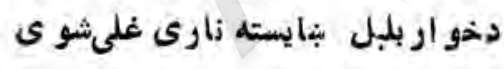

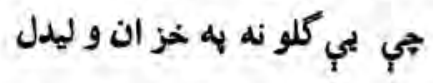
هيى ماقى ته

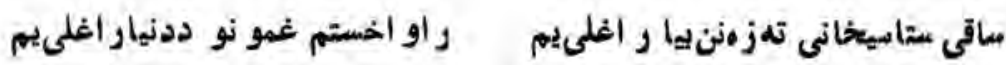




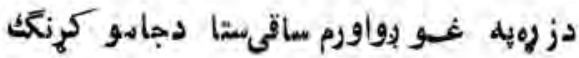

$$
\begin{aligned}
& \text { طو اف تله د ساغر اود دسينا راغسلى يـهم } \\
& \text { هي غمر أحنى ثيير كهىنذر انهر اتهستى كرى } \\
& \text { د دو مو ب بيسمانو يه تمدنا راغـلمى يسم } \\
& \text { ليملهي و ريى يه ستركو كى خو الهه متا دجفا }
\end{aligned}
$$

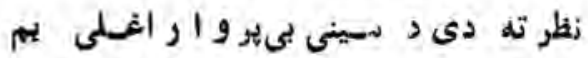

$$
\begin{aligned}
& 3
\end{aligned}
$$

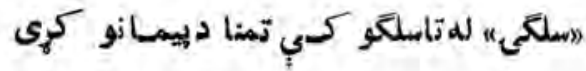

$$
\begin{aligned}
& \text { به غم كي دب:لا د خهل آشنـا راثلىيم }
\end{aligned}
$$

\section{وطنه}

$$
\begin{aligned}
& \text { اى زمار وح زماليه'ن و طنه } \\
& \text { در اله لوكىشهز ماكران وطةه }
\end{aligned}
$$

ش'ناو شو كت ير وتدى

$$
\text { بهلو رو غرو كي دىعظمتير و تدىى }
$$

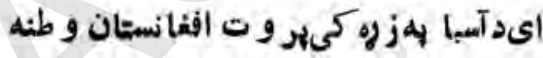

در نهلو كى شهز مأهال اوز زهاحانو طنه

$$
\text { م:أهر مثو كم متاترم دغيرت نيّهده }
$$

و اوه بلمى د امتاله خيو مى نشكيالان و طنه

در نلولوكى شهز ماهـال او زمالحان و طنه

در نهلو كىيى شه شحان

$$
\text { ته بي دشعر يب عنو ان }
$$




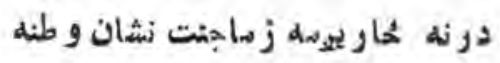

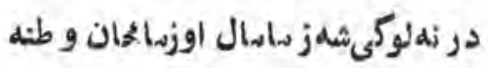

هم لو بولى يمه تا تإلهونه كي رو زلى يمه

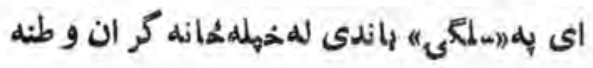

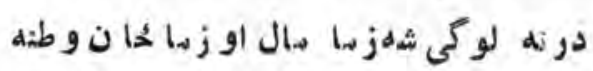




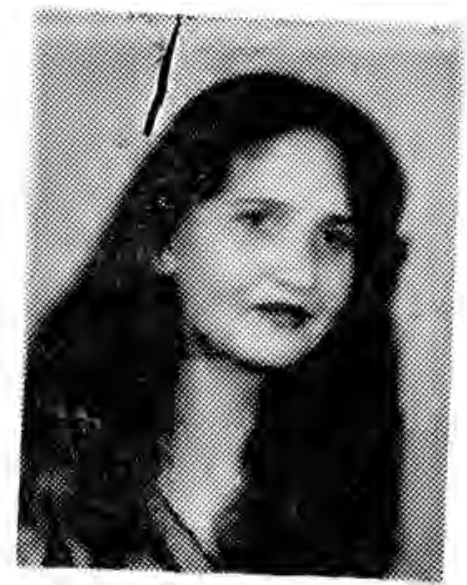

\section{ليلايلما}

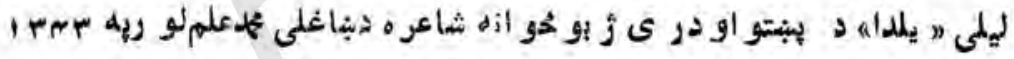

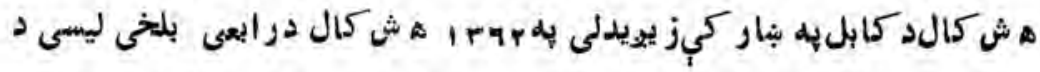
دولسم تو لكى نلفار غله شوىده فعلآدم و ونالستانو به ا تحاديه

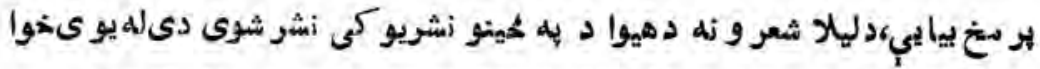

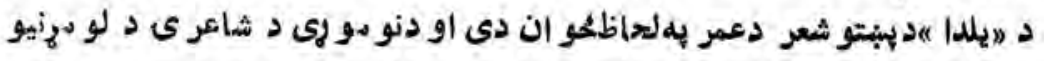

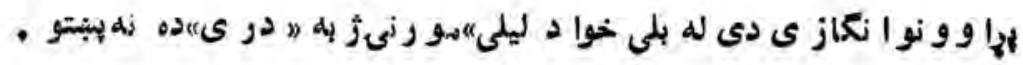




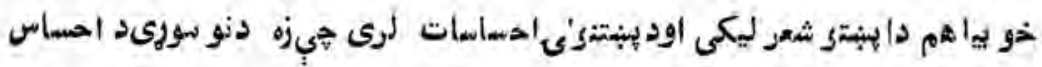

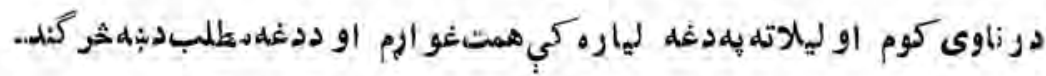

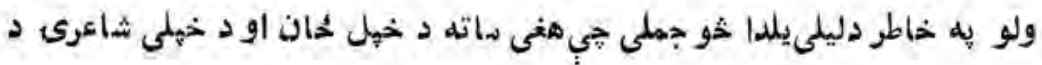

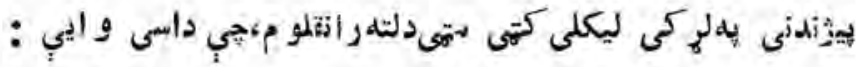

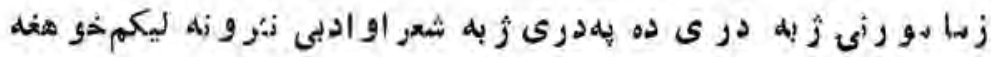

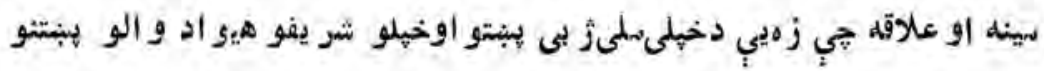

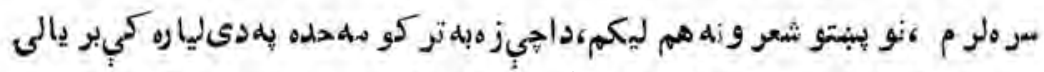

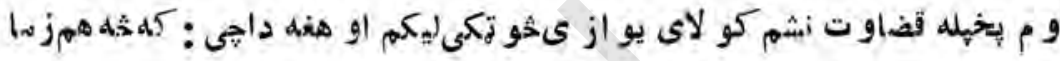

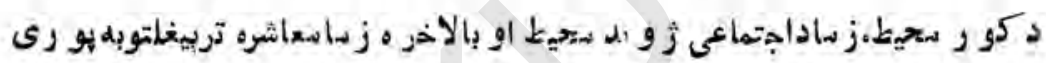

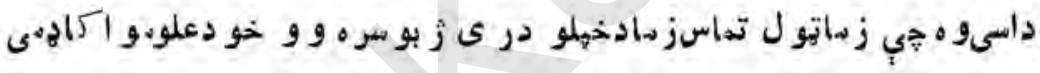

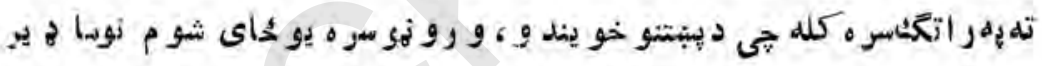

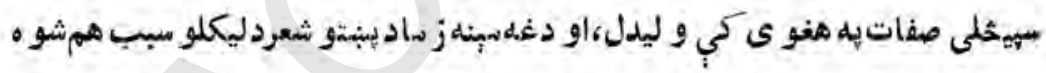

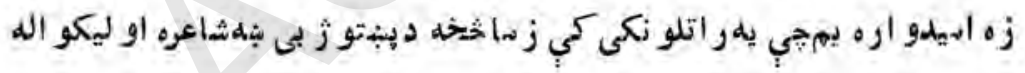

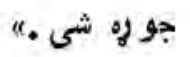

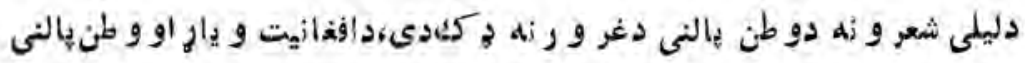

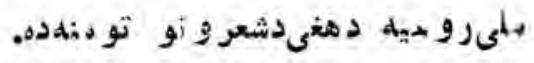

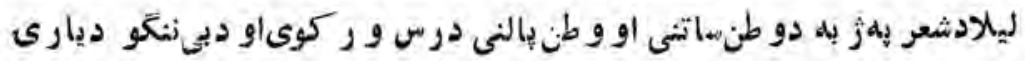

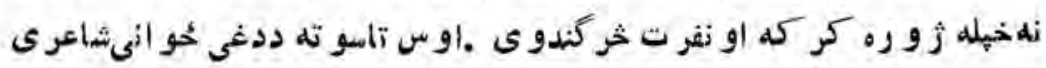
لشعر خو بيلنَى وه اندى كوم : 


\section{برد يس بارته}

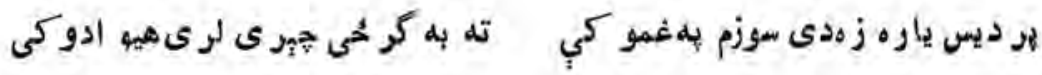

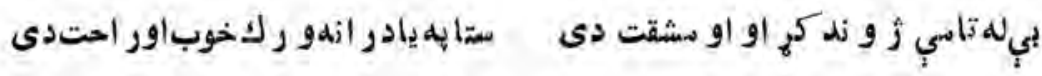

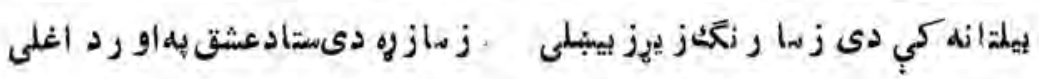

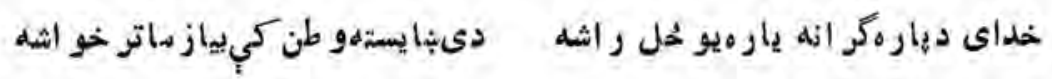

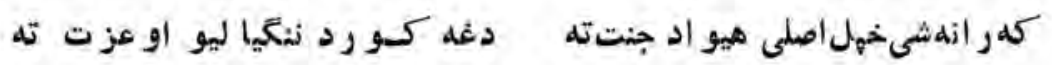

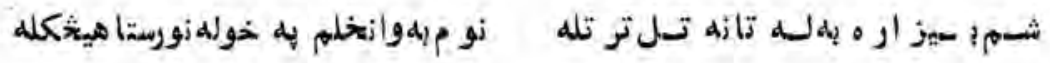

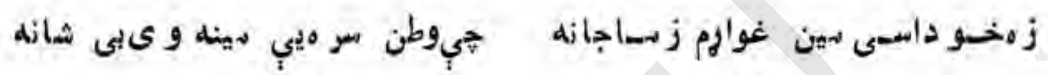

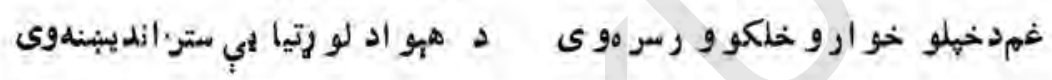

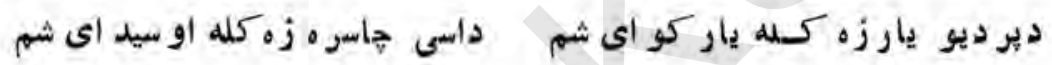

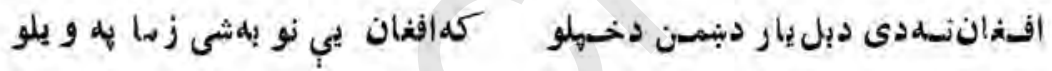

$$
\begin{aligned}
& \text { دمادى يكك بلهلو ستو بلهرا ر رو أن شى } \\
& \text { خهل هيو اد ته بلهر استو لم بهيو ه آن شى }
\end{aligned}
$$

تاتهوائم_تايهستا يم

اى ووطنه ! اى خستسنسه !

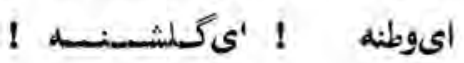




$$
\begin{aligned}
& \text { تاتهو اليم تأ بسه ستسايسم }
\end{aligned}
$$

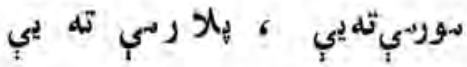

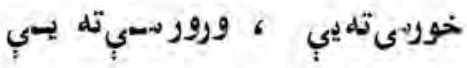

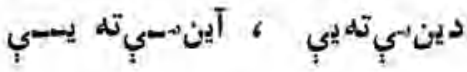

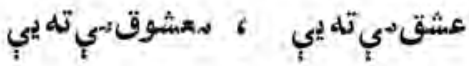

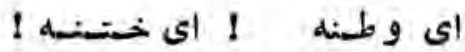

$$
\begin{aligned}
& \text { اى وطلسيه ! اى كلد شئه ! } \\
& \text { تساتسه و ايم ؛ تـا به مستايم } \\
& \text { زها الوها ن - ستا آبسا دى ده } \\
& \text { آز ادى ده - خهلو و اكلى ده } \\
& \text { بسر غـلميمو - بهسيروز ى ده } \\
& \text { ديتيسم، كسو نلهىخسو بنسي ده }
\end{aligned}
$$

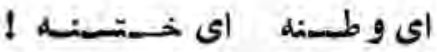

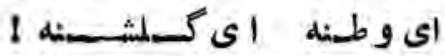

$$
\begin{aligned}
& \text { تاته و ايم تسمابسه مستايهسم }
\end{aligned}
$$

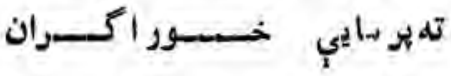

$$
\begin{aligned}
& \text { خداى بو هييى تَّول جهان }
\end{aligned}
$$


هـر يفهان ان اوغليمان

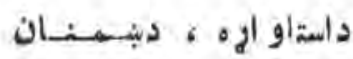

جـ

ايى ووطنه ائ ختـنه

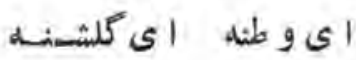

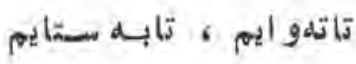

اع ووطنه ! زنساجـان

ور كو م ميتسياد بنمنان

و حثيـان،ستــمـعـر ان

ز زيبنا:كسره ،لسو تسمسار ان

بساو ر و كم ايى و طنتس4

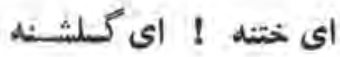

تاته و ايمم تابسه متتايم

خوا إنهخيالوزنه

نن بيا خو اونه حيالوألهدآشخا مي بحو رو ى

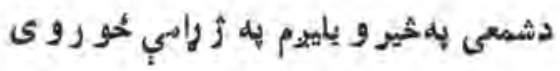

$\times 99$ 
لغمو زهددنيا را باندى ، هيق كو لائلهشى

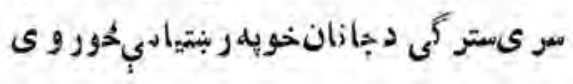

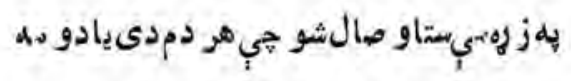
دسر و شو نلمو خندادى هر سبادبحو روى لى

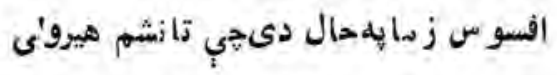

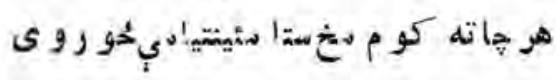

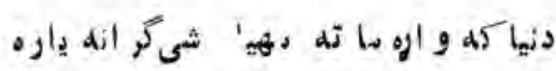

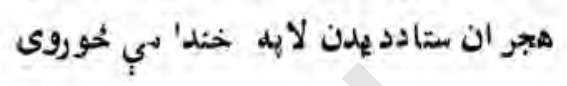

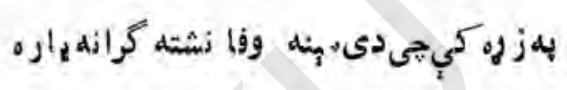

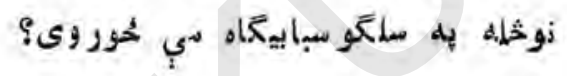

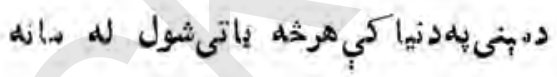
تهكو ره " يلداه بارهموه خو ادى بحور وى دوبن عشق

$$
\begin{aligned}
& \text { ز مدكر انو طن نهتيو يداى:ثمبم }
\end{aligned}
$$

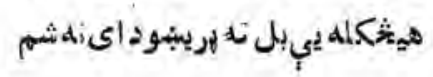

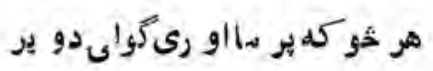

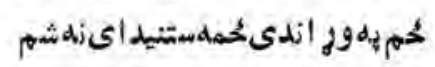




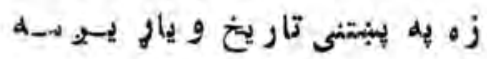

$$
\begin{aligned}
& \text { زهله خهل تببر بر دى كيد أى نه شم } \\
& \text { دادنيز و يس خخان او احمدشأد نير اث } \\
& \text { خهل د نيثتمو كو ر بهي ثير و اع أله شم } \\
& \text { أدزرو }
\end{aligned}
$$

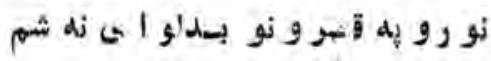$$
\text { جار بي و ر ذلهسر شه دادى بت خخو زله }
$$
بدحا له سر و و ينو كي ليد ايزلهشم خو لهبdدىله تو رو خاو روه كله كرم

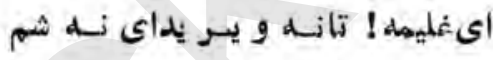

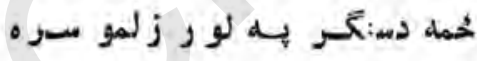

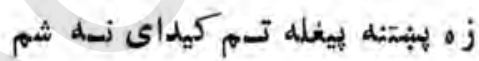
هادخهل و طن مو رسر هلهو ظ كرى

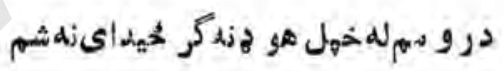

$$
d+\hat{t}
$$

$$
\begin{aligned}
& \text { زندكى دغمخهيهده هيى خي تهنه يجي } \\
& \text { يلمس بله مير ه لمبه ده حي تسلنه يي }
\end{aligned}
$$


درقيب بـه لمسيليلازى بيو فاشوى

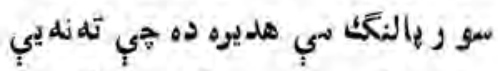
ز زاستركى ستا به ستر كوجهان كورى هي

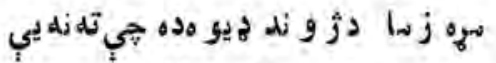

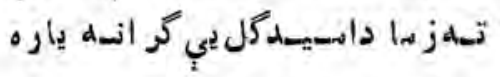

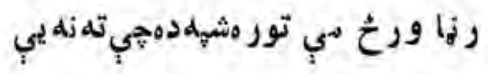

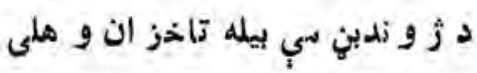

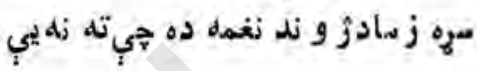

\section{مرهشمعه}

ها سر ه تسل دى د جـهانغـمو زئه هابر ه مل شو ل دهبران غمسو نسل

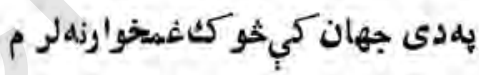
بىله هجر ا نكو م و فا دار زيه لو م

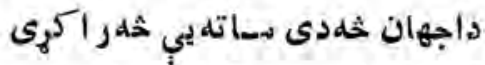

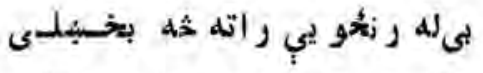
خلك بهخئد ازه به زر را يسمه تل

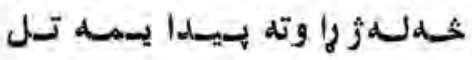
نسو ره ب-ه-ز اره للجهـان نهيمهـ هيره زار اضه د جسانسان نه يمهل

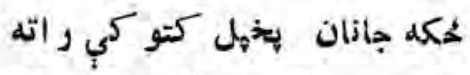

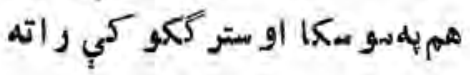




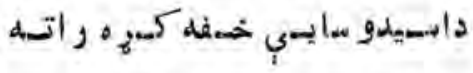

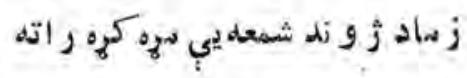

\section{د نسينى ليونى}

$$
\text { دبنهو زمبل كي وائيراته بيادهنينى از }
$$

دنو سكا خهو كي زغبنتى دخو إنى ىبينى آغاز

$$
\text { مو زو ى دعشق بهشمعهداز هأنادي اده هيلمى }
$$

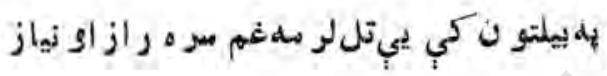

$$
\text { يار انه كيبى }
$$

هر خحاو سرواته نعلو مشولزو ندسىشو معو زاوكداز

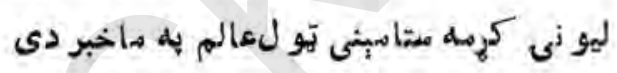

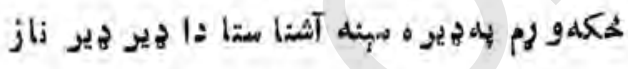

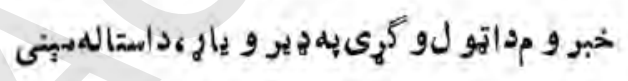

رمو م دنو لو غو إتهخيل دعشق دنى او از

\section{دوطن لمن}

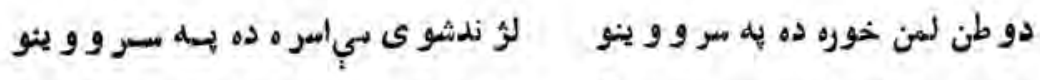

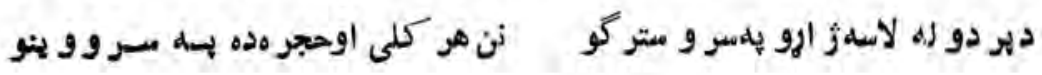




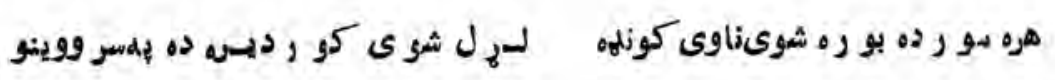

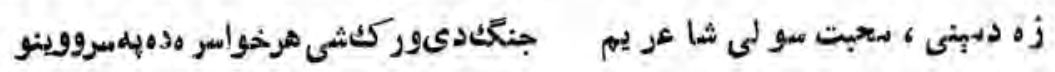

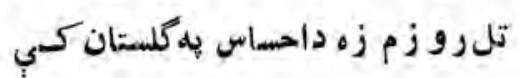

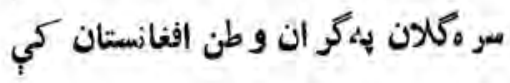




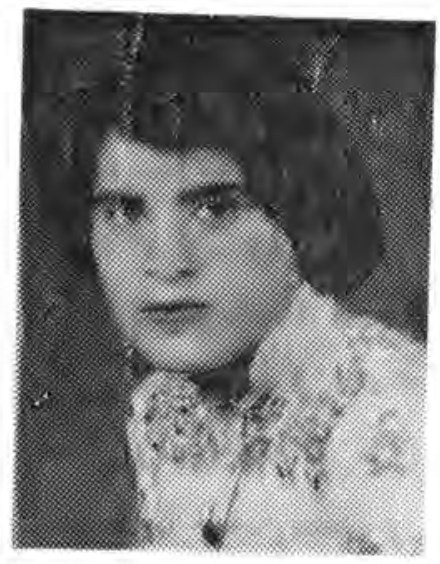

\section{ز رلبنتةه حفيظ}

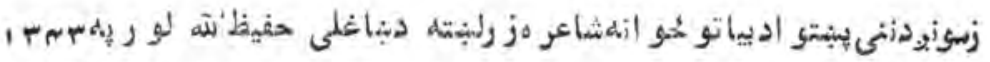

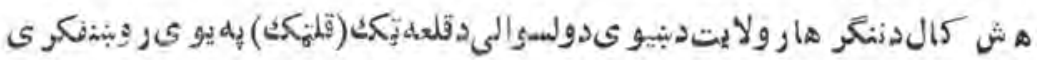

. 


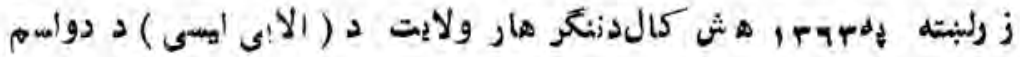

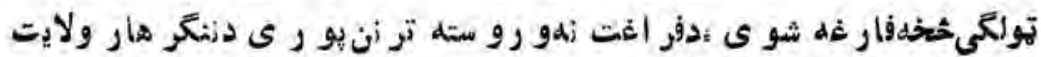

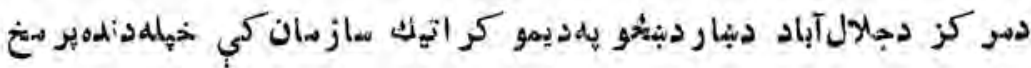
- يبايیى

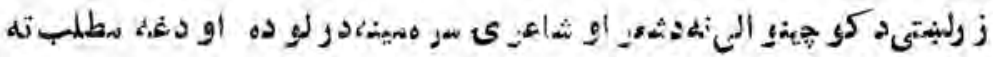

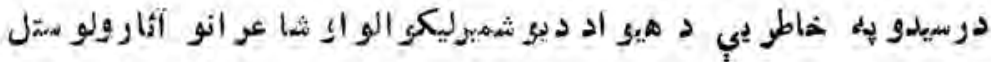

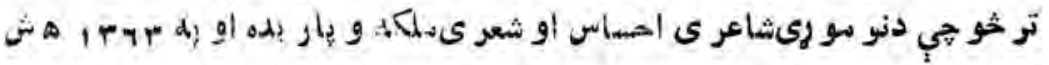

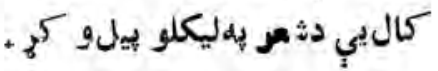

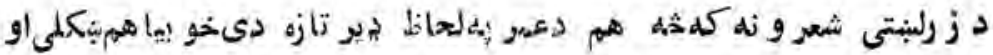

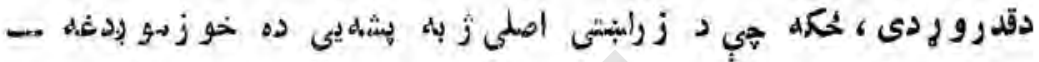

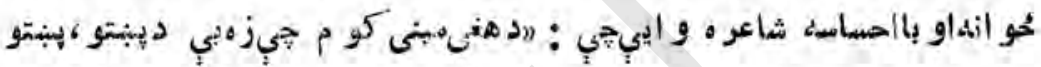

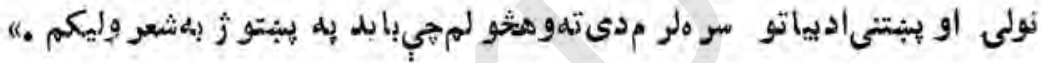

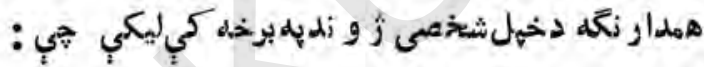

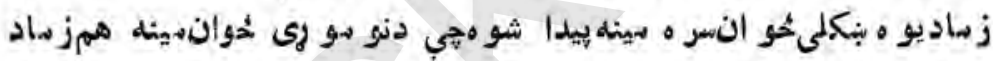

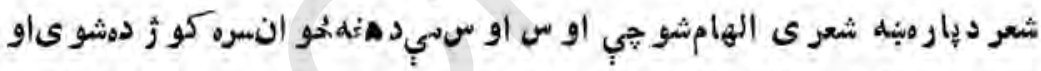

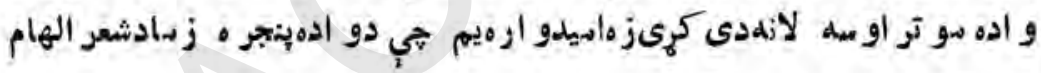
يبو نكى نينهخ ابه زله كرى" .

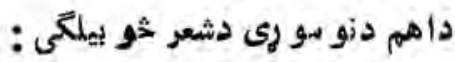

\section{لمرن}

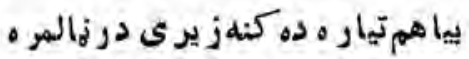
تار اتهمه ر او ري ز ير ىدمبالمر ه 
زنو إو طن تهله هب دهر صستركى ننها نيولى

به خائيفانو رناو اهوه رسو المره

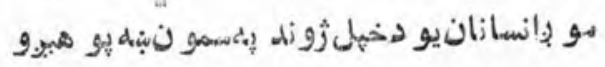

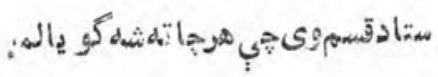

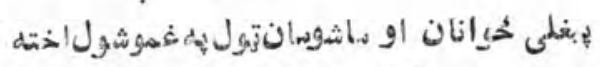

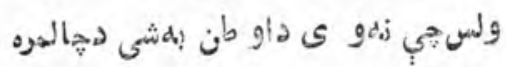

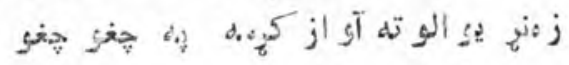

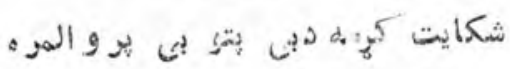

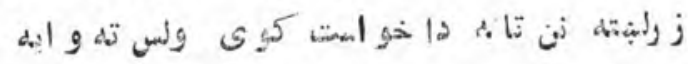

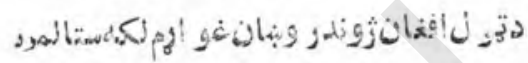

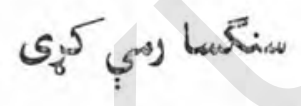

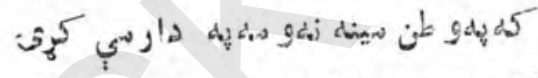

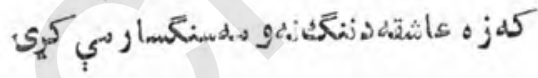

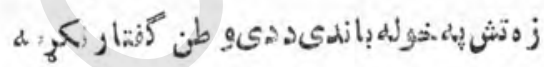

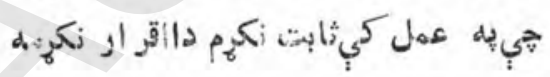

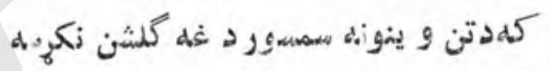

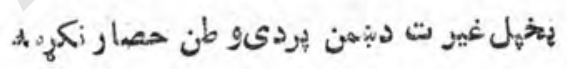

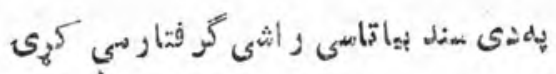

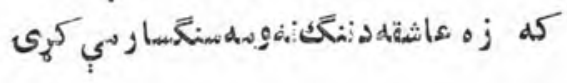




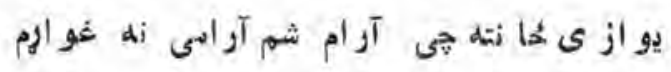

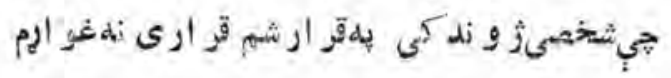

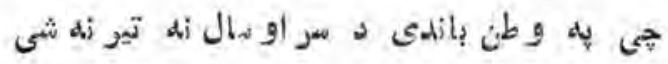

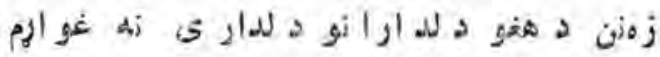

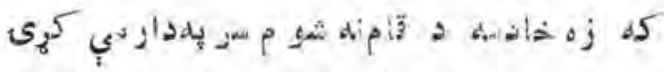

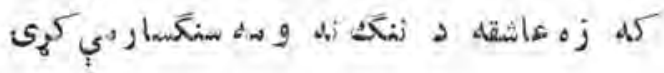
$* * *$

$$
\begin{aligned}
& \text { ز } \\
& \text { غس... }
\end{aligned}
$$

\section{do}

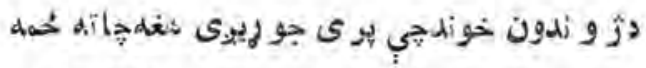

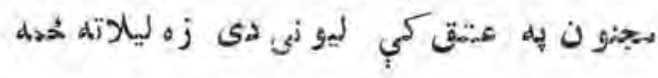

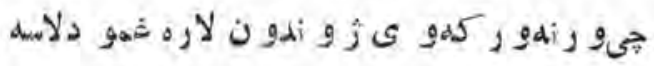

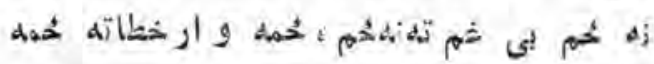




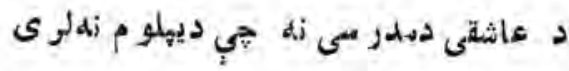

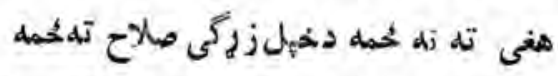

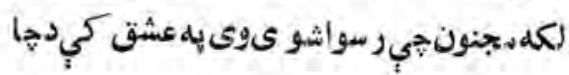

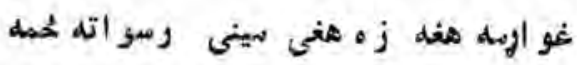

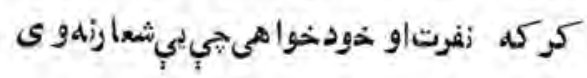

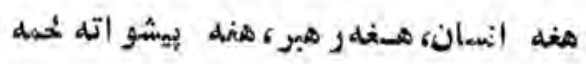

\section{خوبنمبيق}

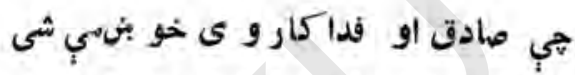

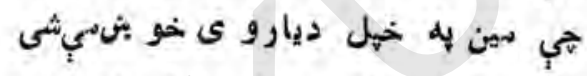

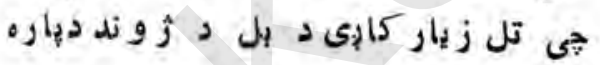
كريدلى به دى لارو د زيوفكرو ، دو دو نسو نسخالف و ى

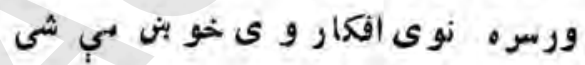

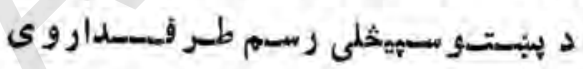

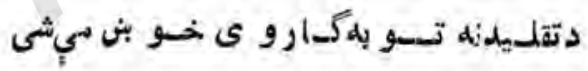

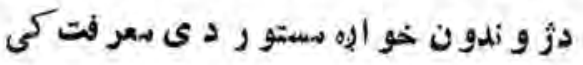

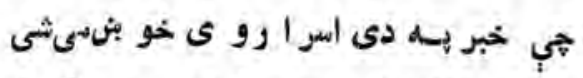

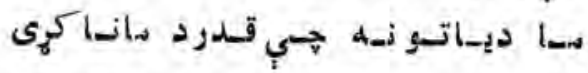

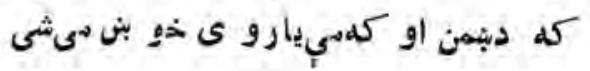


جسى كسواى شى فرق د حقى اود د با طلو

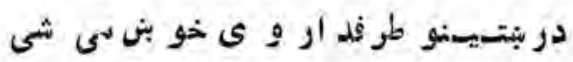

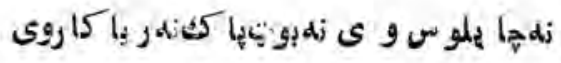

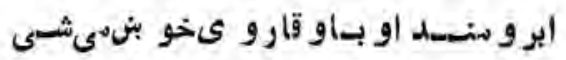

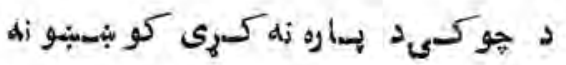

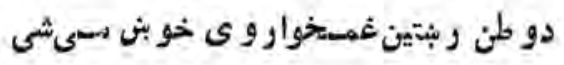

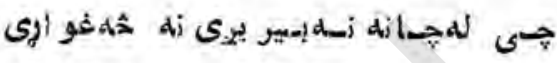

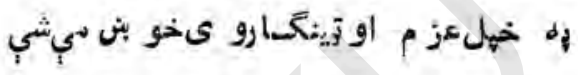
جسي بهنم ديبسو زلانو كي غم-نجن و ى

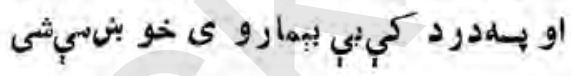

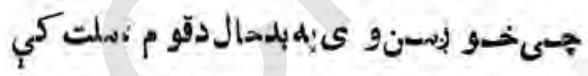

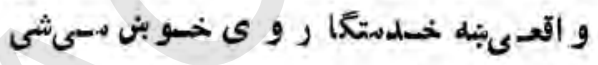

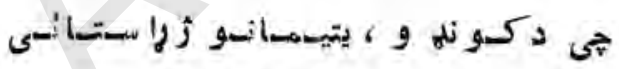

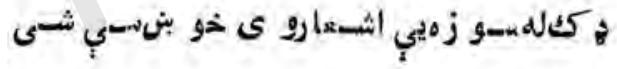
هـ-

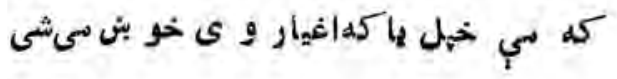

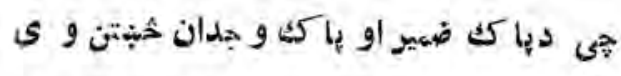

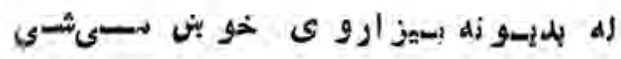




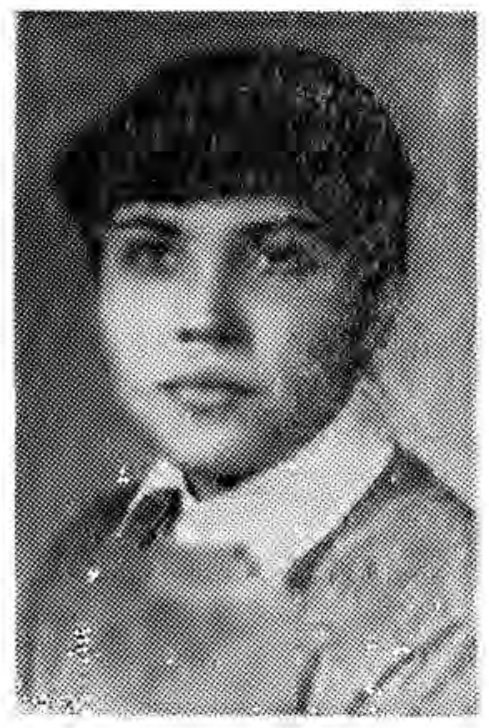

\section{نفيسالنهى}

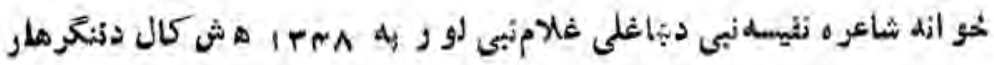

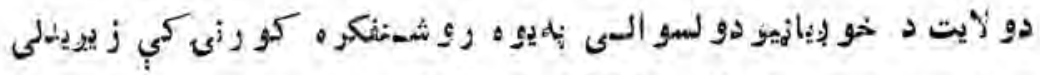

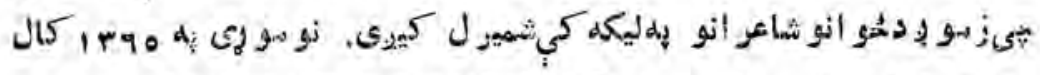

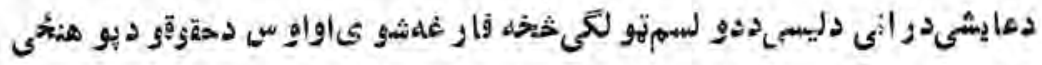

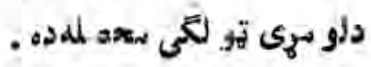




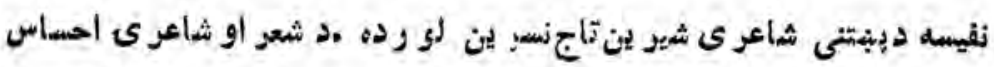

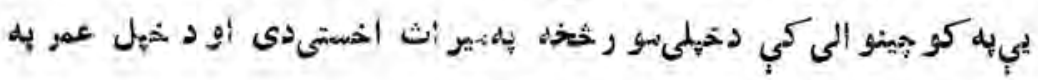

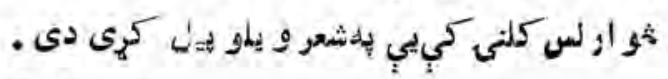

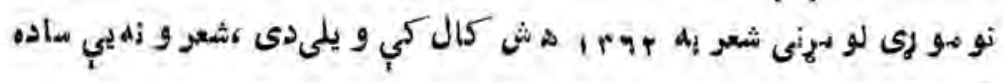
اء بنكلى دى.

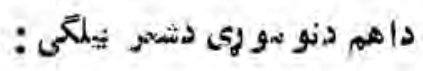

\section{تنده}

زها دنسينى قاقلى هيخ دويدلى نه دي

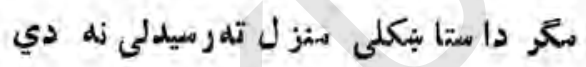

تلهز سارُ و نديبيتهمي هبلها وسهيملى عشق بي

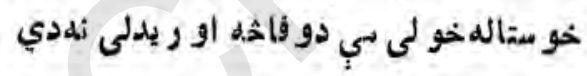

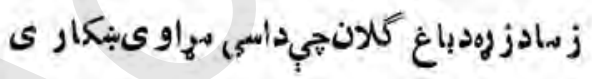

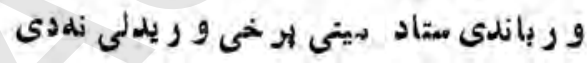

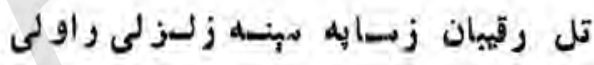

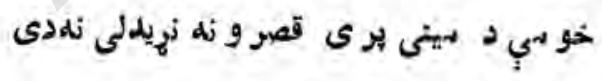

ستا د جفا بلولمبو كمه هر ثمو و ستيز لـم

خوخاطرى دى لابهلز زهاكى سو ز يدلى نهدي

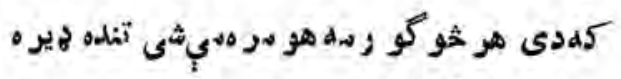

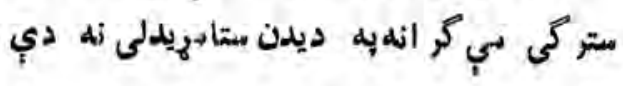

\section{rar -}




\section{ترون}

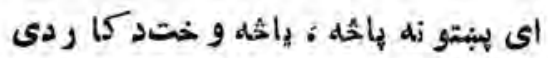
دو زكار معرى زلهـر مرى بيسز ار دى لهم

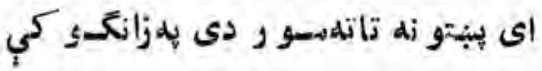
شهاهت دوس يـي دركئى بهه للو كي لهي

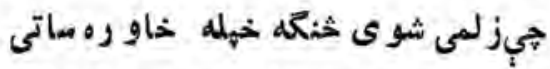
بامو أه خو ر ى دغليم له خو ا نهله ماتى

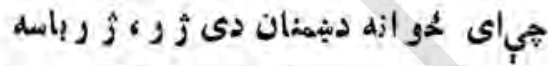

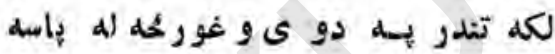
د غليم به خو ذه بل أو ر دغيرت كره

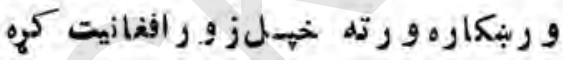

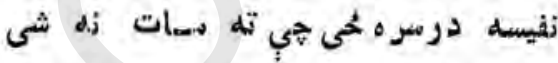

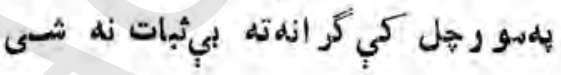

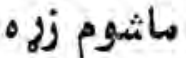

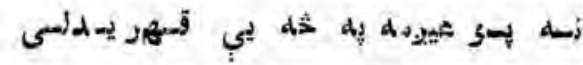

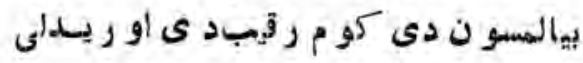
مابسيو زلى تسمنفوت هيه مستركو كسو ر ى

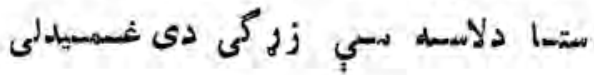
TA 


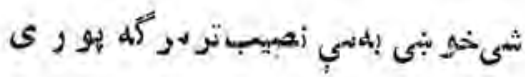

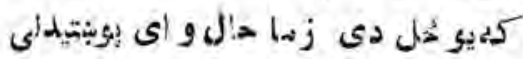

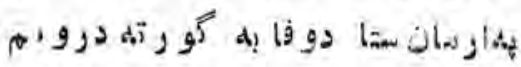

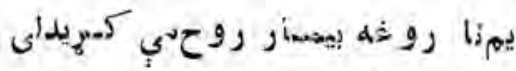

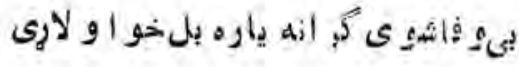

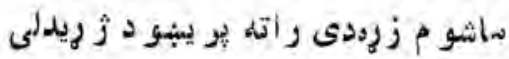

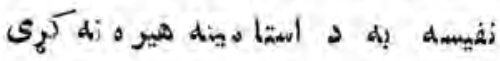

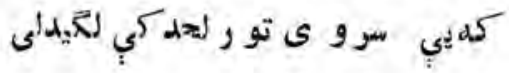

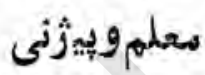

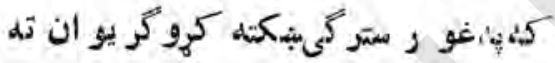

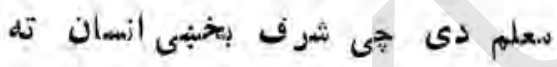

$$
\begin{aligned}
& \text { 2 تفعيل ألهيب عاجز زما قلمه دى }
\end{aligned}
$$

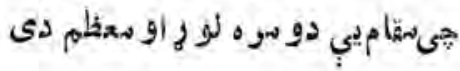

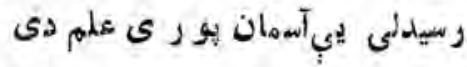

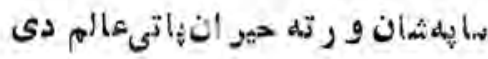

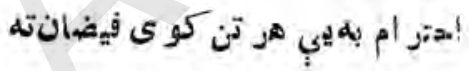

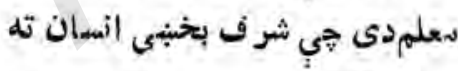

جهالت ثته تيارو خشخه بي به بر كرو

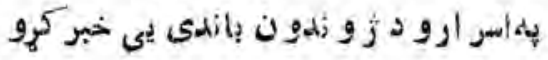

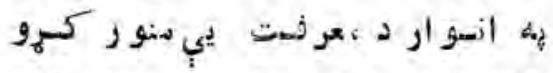

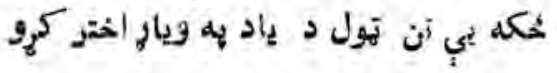




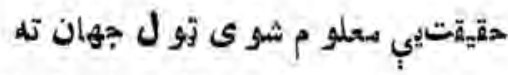

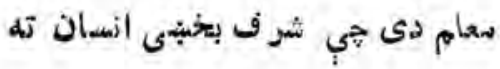

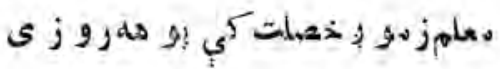

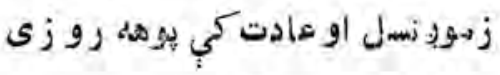

$$
\begin{aligned}
& \text { له }
\end{aligned}
$$

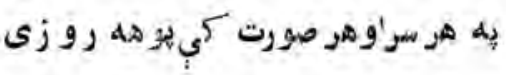

"نفيسى" حاجتي أشتيك أو ر إيان ته

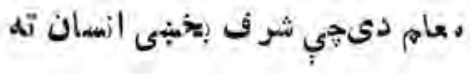

$$
\text { ا } 1 \text { ز ادى شهيد ته }
$$

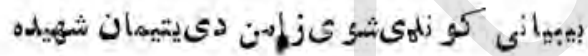

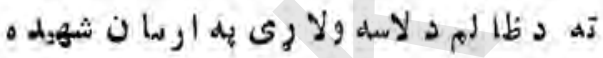

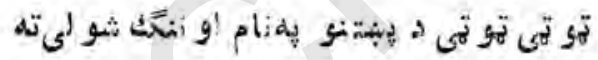

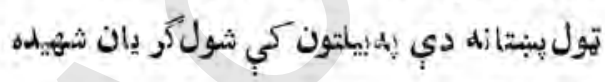

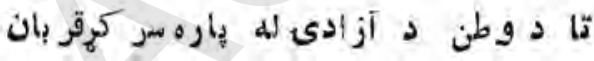
قر بان شم سمادبنكلى جيمه او و جدان شهيده

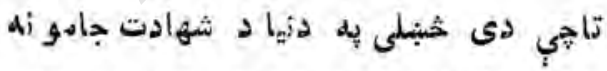

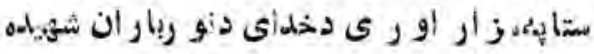

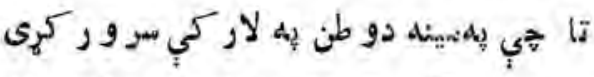

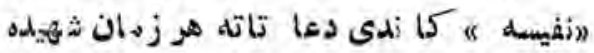

\section{rNo}




\section{زئه نه كيزىزنا}

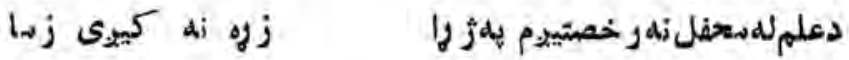

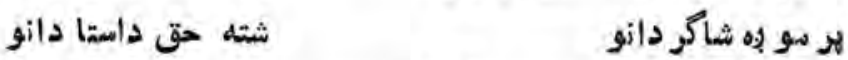

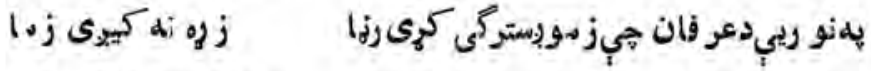

$$
\begin{aligned}
& \text { دعلم بلهبهار }
\end{aligned}
$$

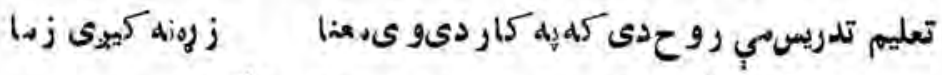

$$
\text { عروفاندى ملستان }
$$

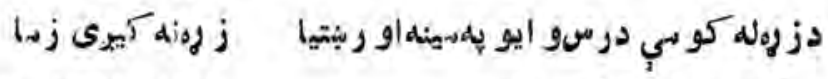
للهعلم اولهادبزادله

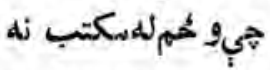

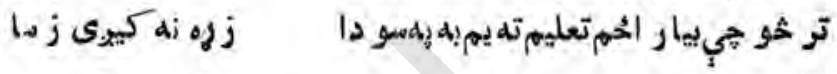

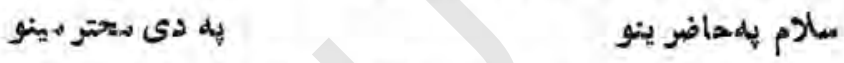

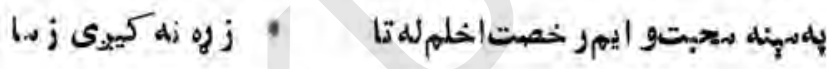

\section{د بنبتو كور}

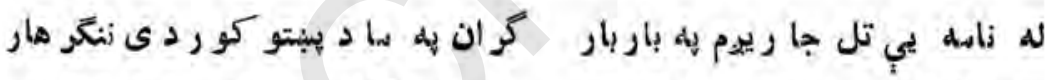

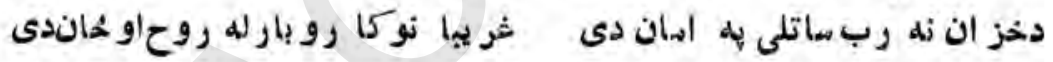

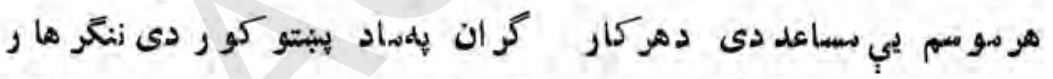

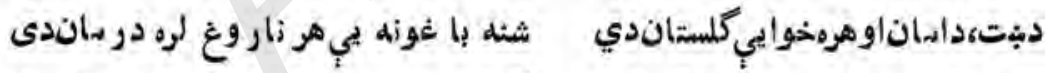

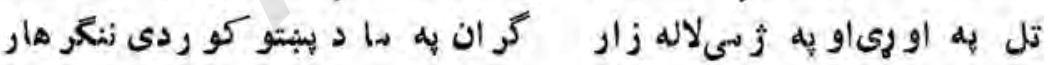

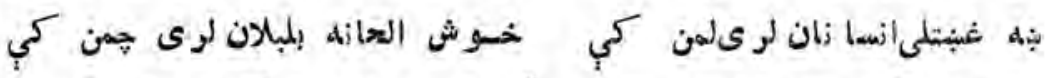

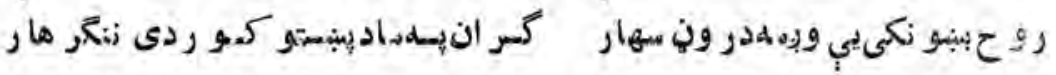

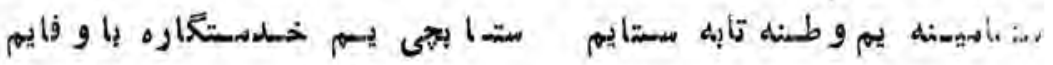




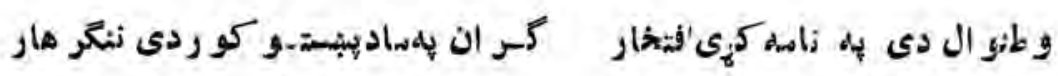

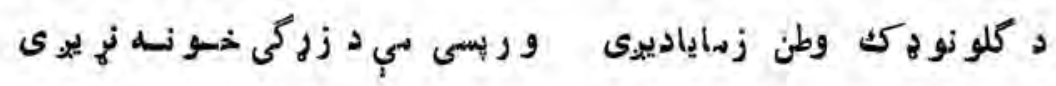

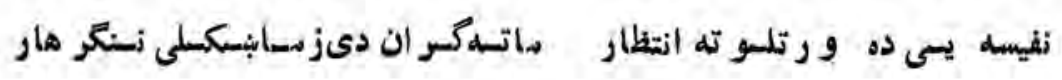

\section{dá dod}

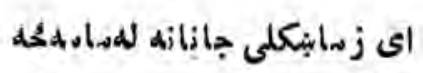

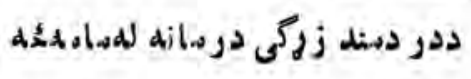

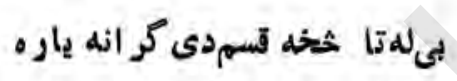

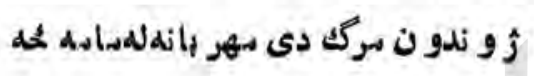

$$
\text { ديددستركو بيدلبر ه ستا ديدن دى نى ندي }
$$

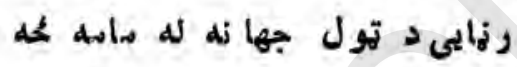

$$
\text { تهزهادز ره ار ام دزو ند ارزو يي }
$$

اى زلهانو ر د خشمانه له هانه لحهد

$$
\text { ثو وبلزره در تهر اغلىيم رحم و كهيه }
$$

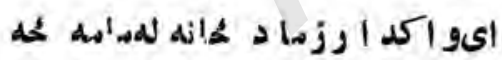

$$
\text { ز ندكىسي مستا لـــدو بو ر ى ترلى }
$$

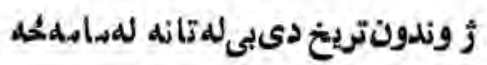

$$
\text { نفسيسله لومبـه دا هيله لـه تأنسل }
$$

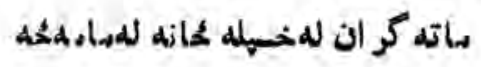




\section{ظالمته}

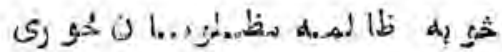

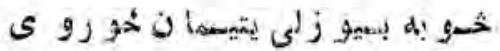

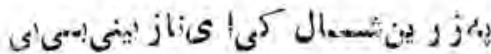

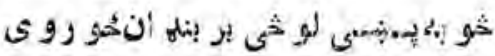

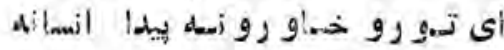

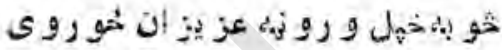

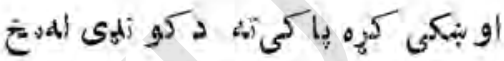

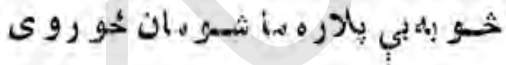
تمسيز دحسق او د بسا طلل و كيهن ته

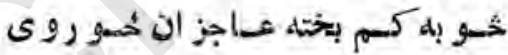

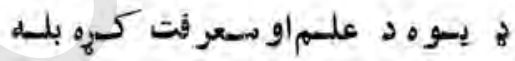

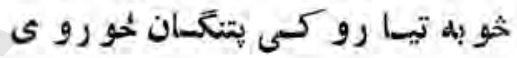
اى جهالت او نا يوهى خورليه

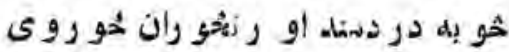

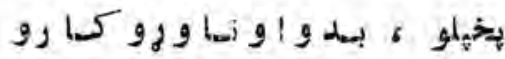

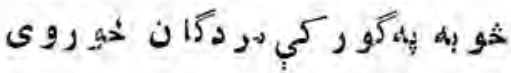

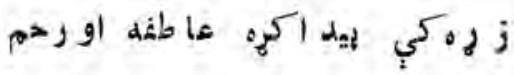

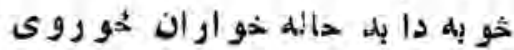


كبر ا مظهرى ملمورو

91

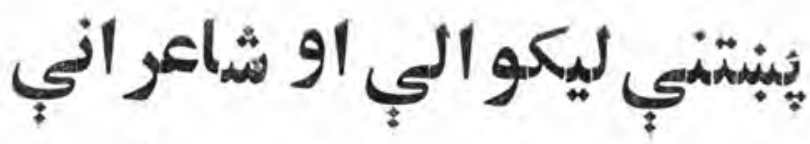




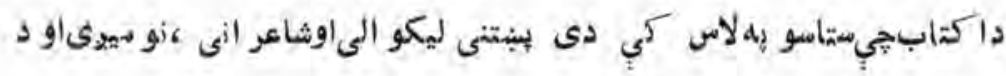

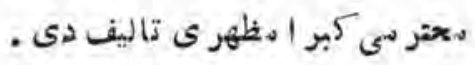

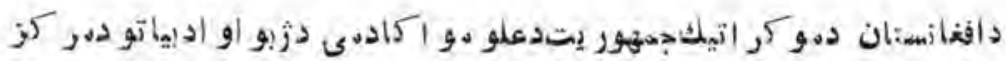

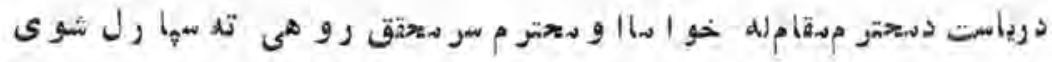
و بي 2

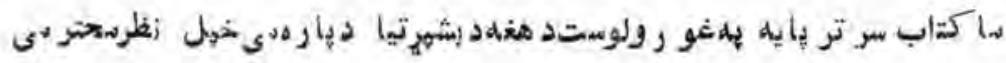
. ليكو الى آله و ليكا.

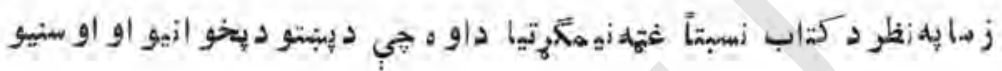

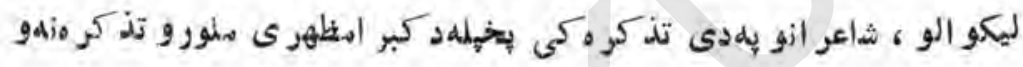

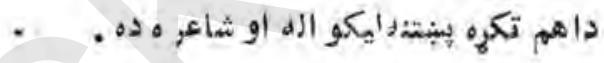

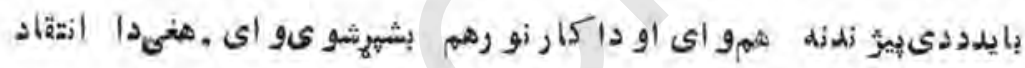
خو و هilid

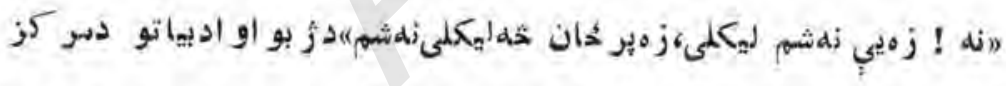

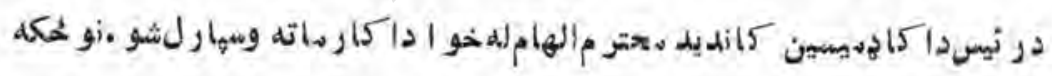

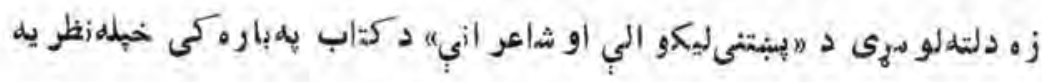

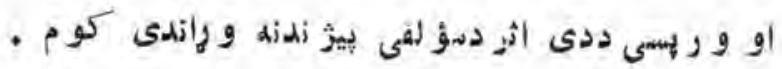


بِبنتني إيكوالي اوثناعراني

** $\quad * \quad *$

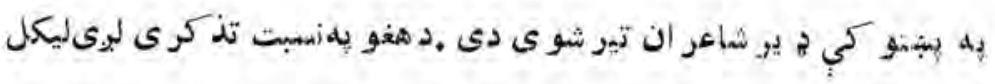

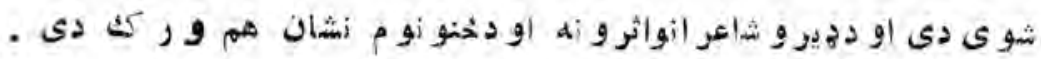

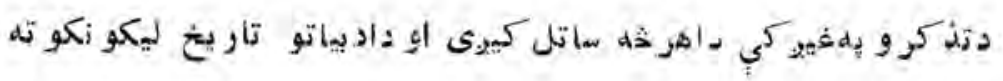

$$
\text { . }
$$

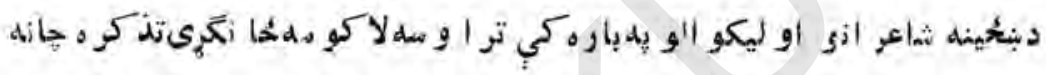

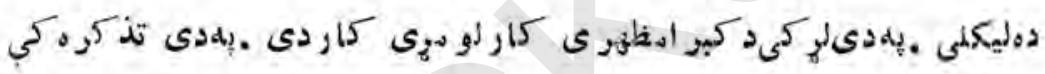

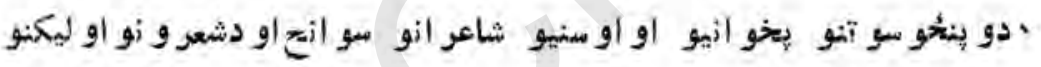

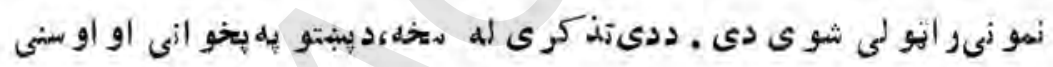

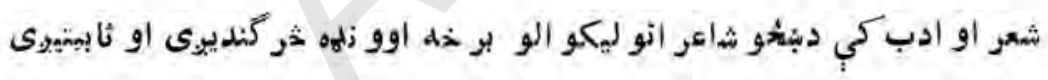

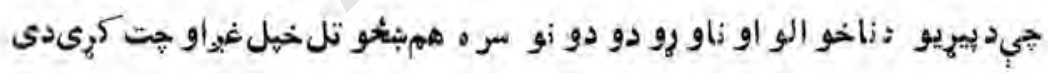

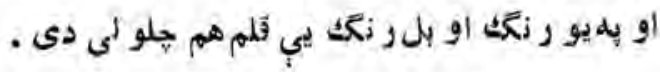

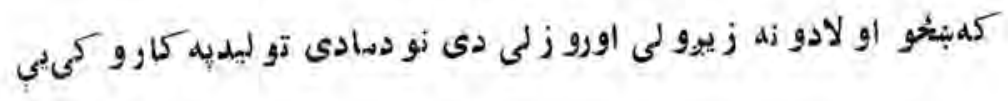




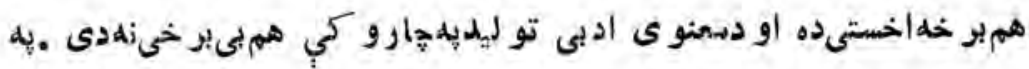

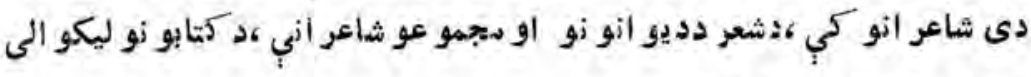

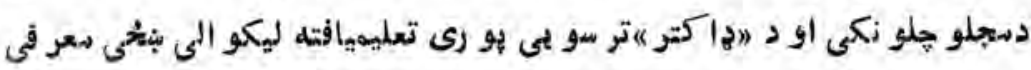
شو ىدىاو نو م و ركى اولياحو انى ليكو ألى او ثاعو اني هم .

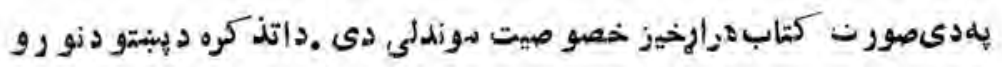

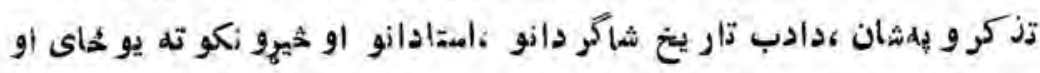

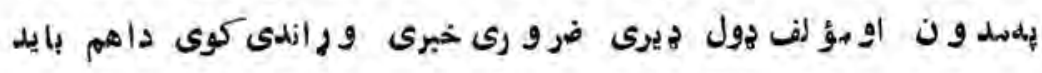

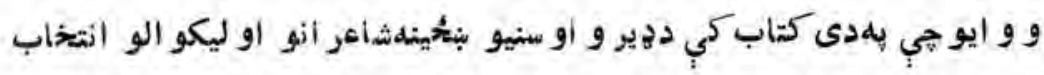

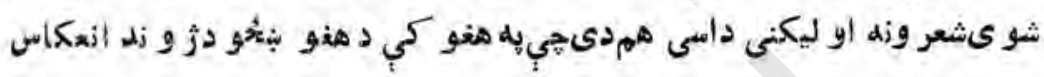

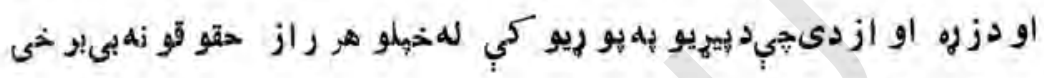

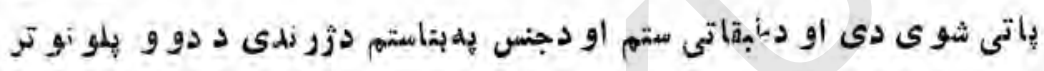

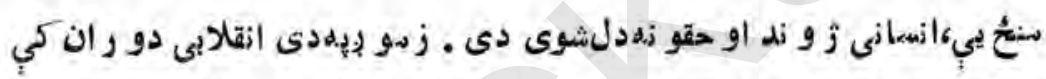

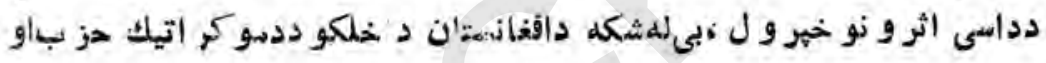

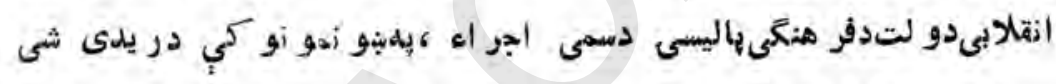

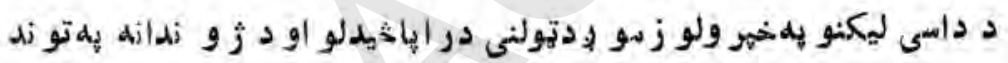

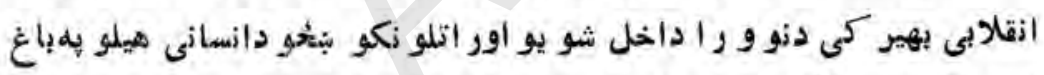

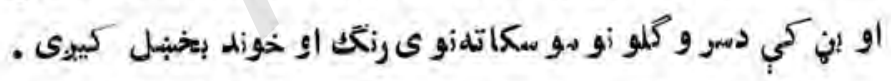

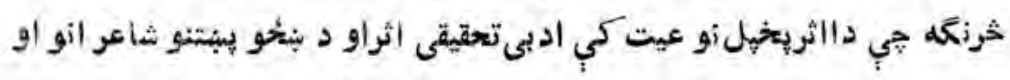

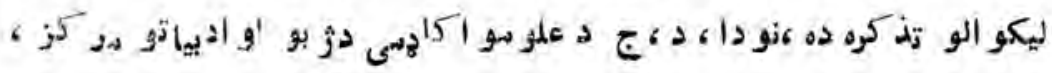

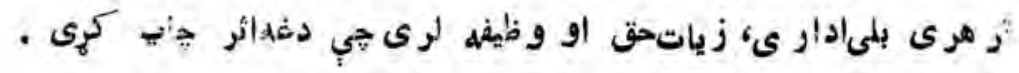




\section{كبر ا مظظهرى ساو رو}

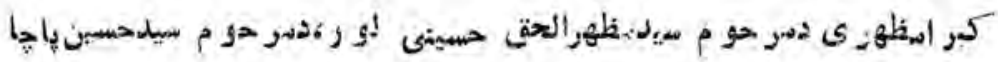

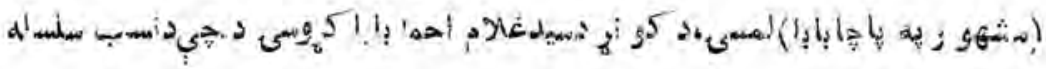

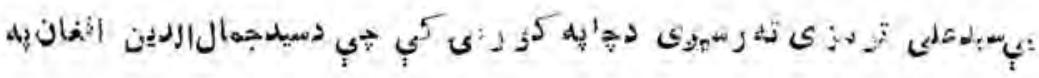

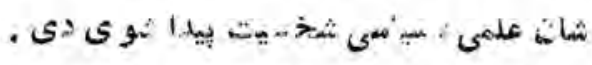

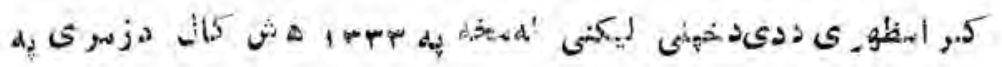

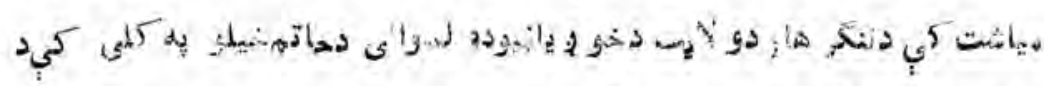

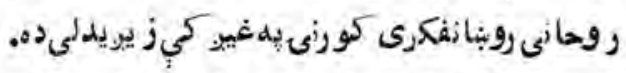

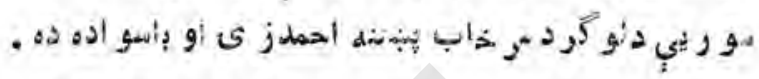

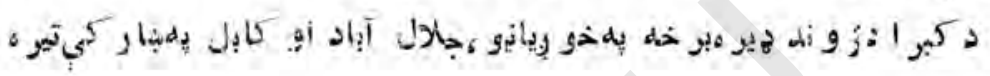
شوى

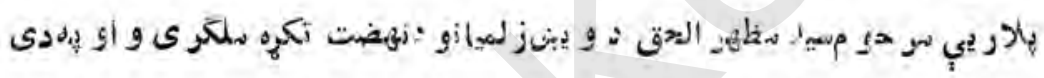

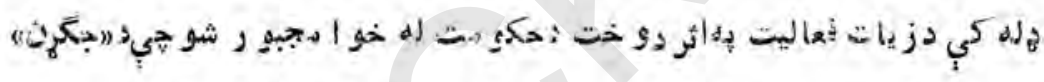

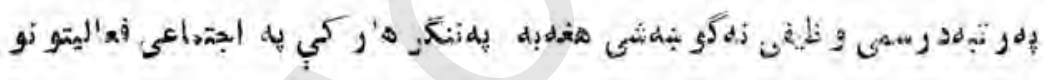

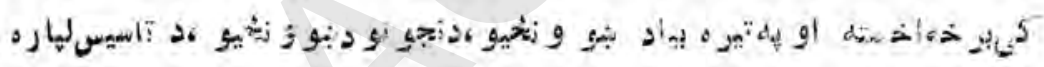

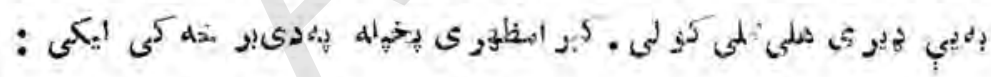

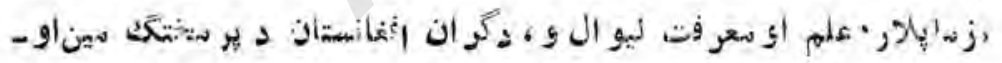

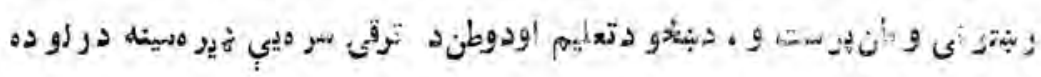

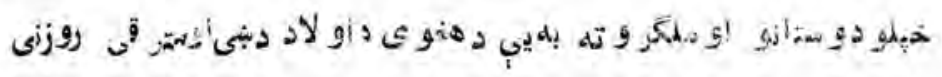
خملور 


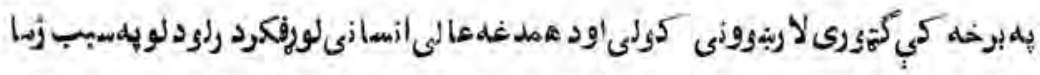

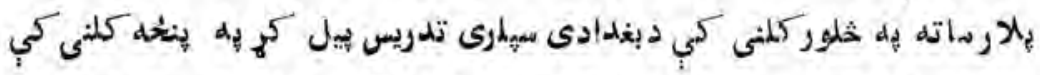

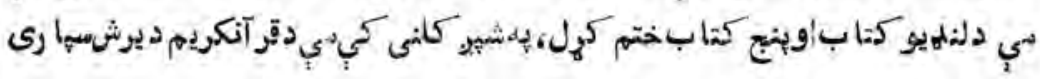

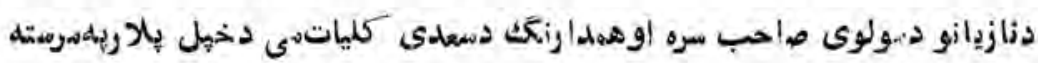

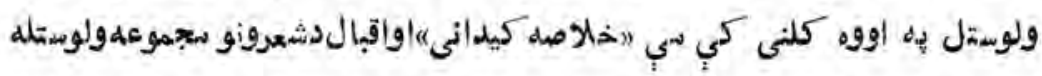

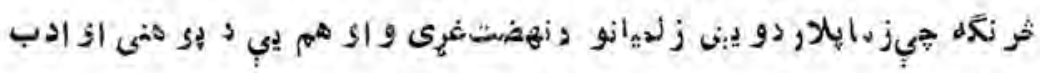

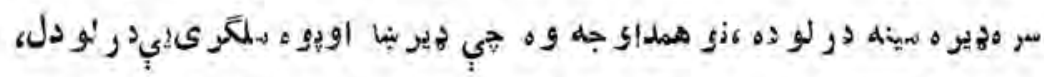

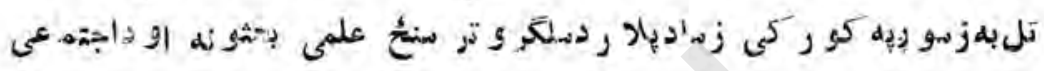

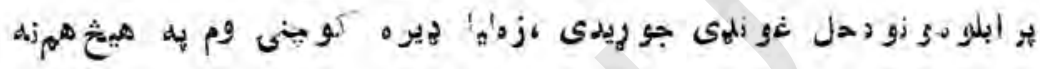

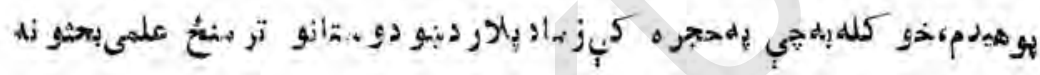

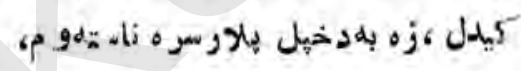

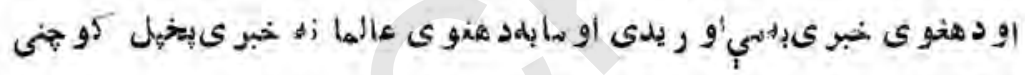

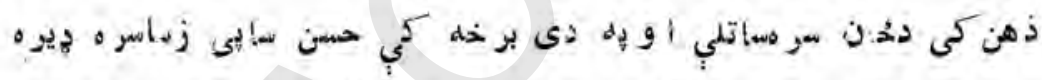

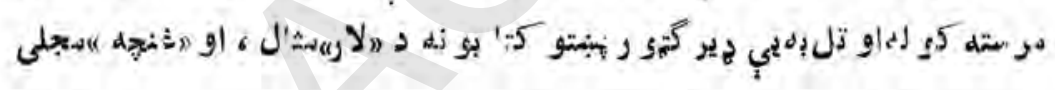

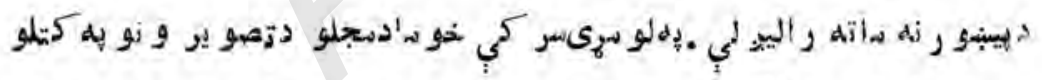

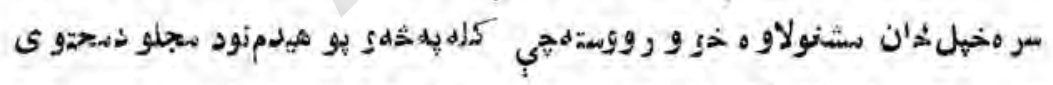

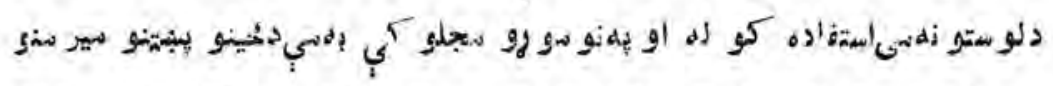

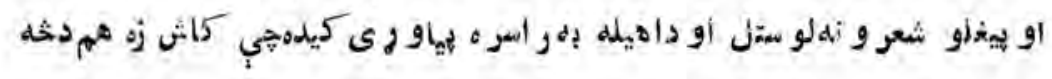
ليكلوو رو اقى.

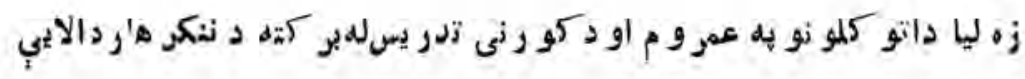
بن 


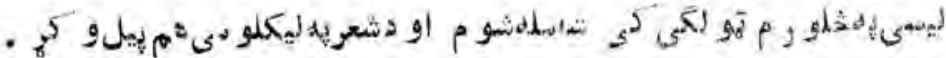

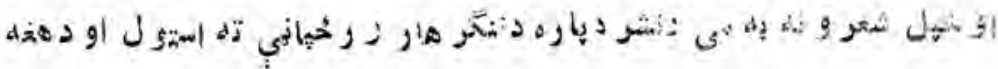

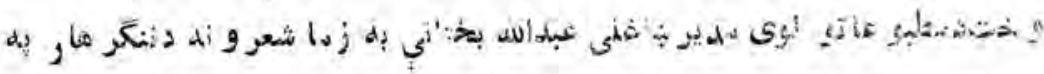

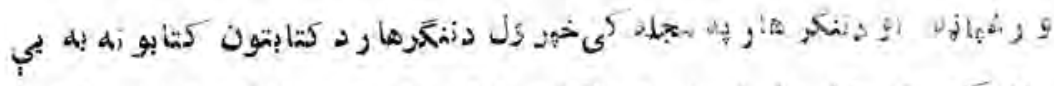
•

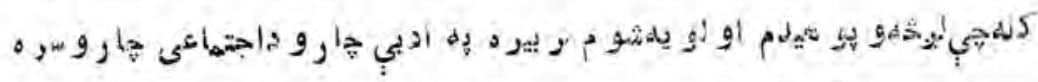

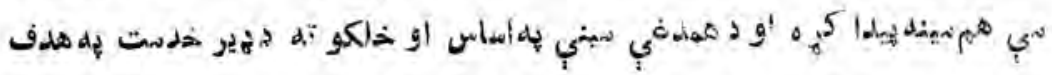

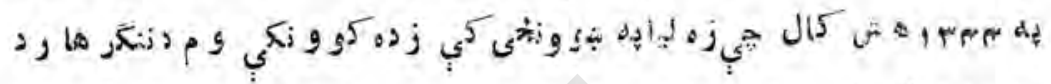

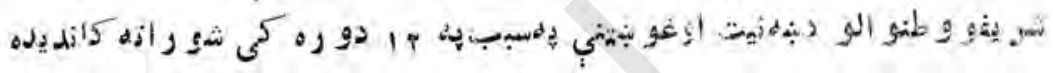

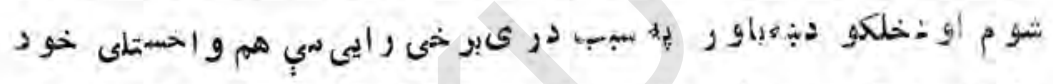

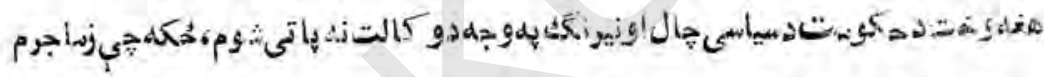

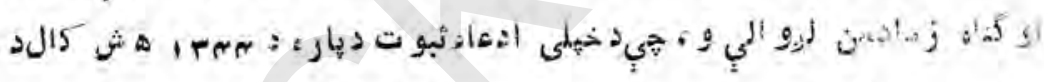

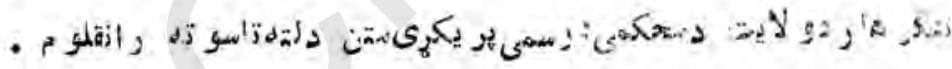

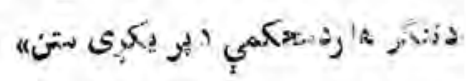

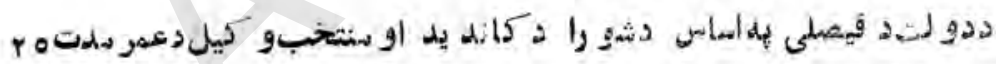

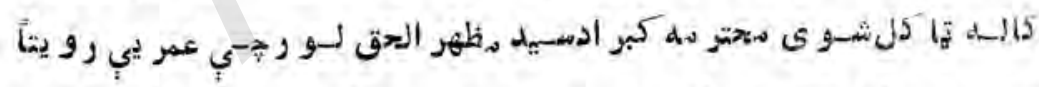
"r

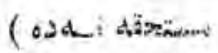

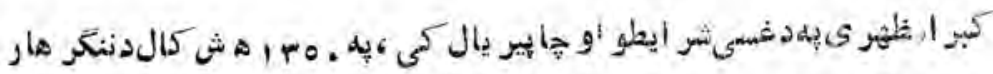

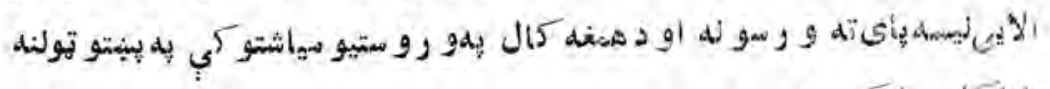

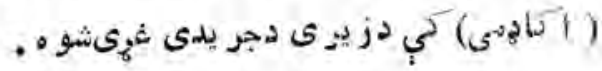
ثيو 


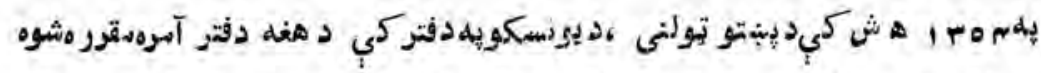

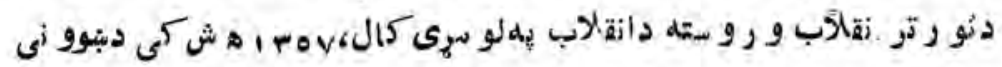

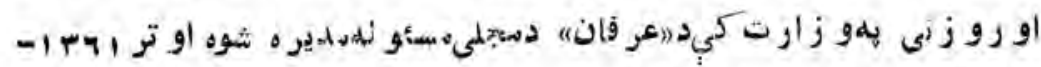

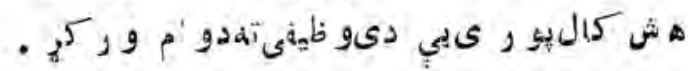

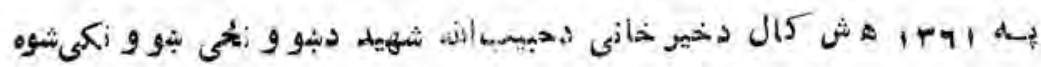

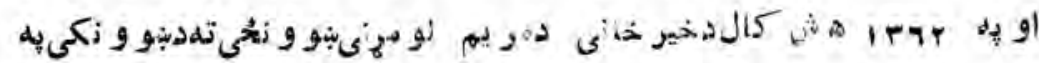

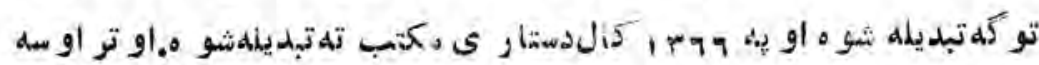

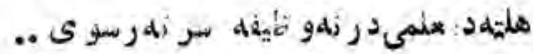

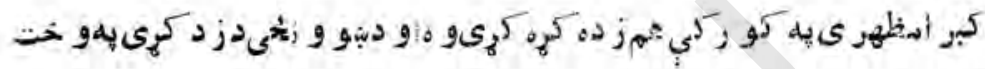

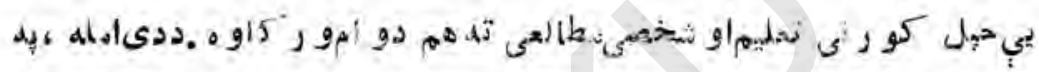

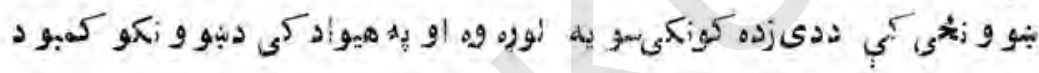

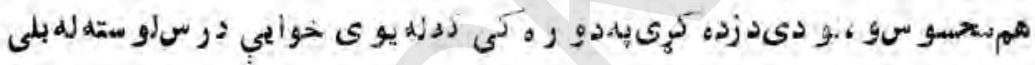

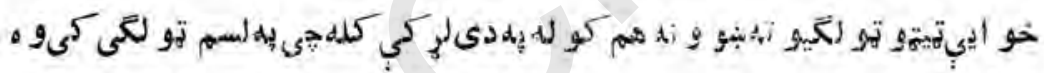

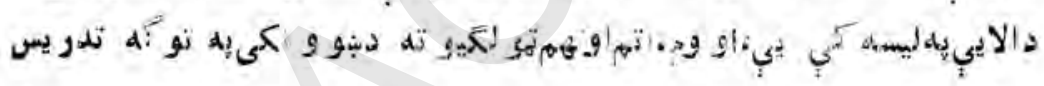

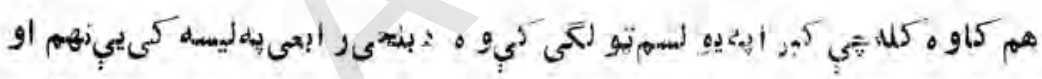

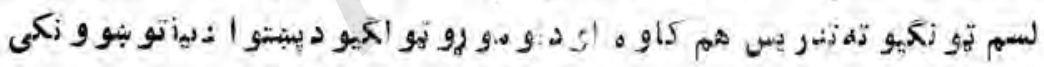

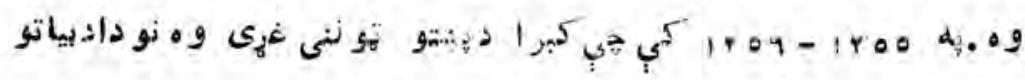

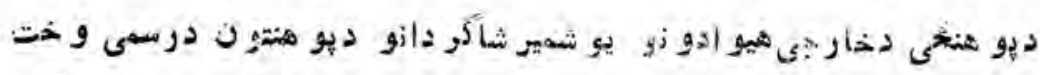

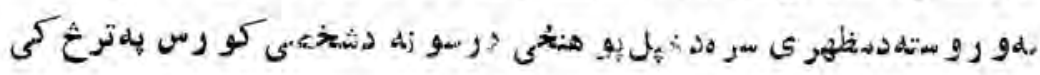

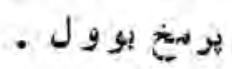




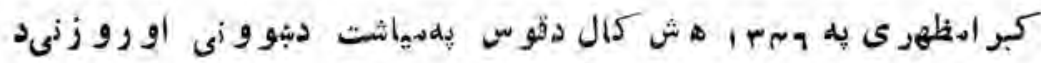

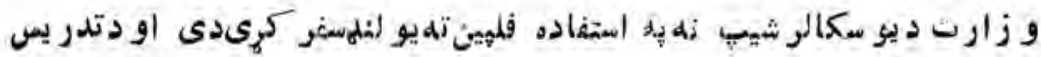

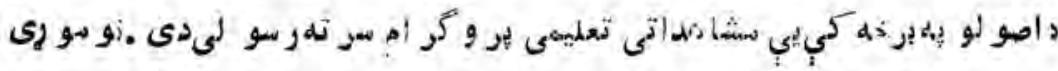

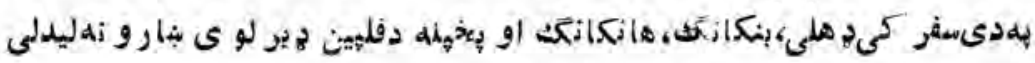

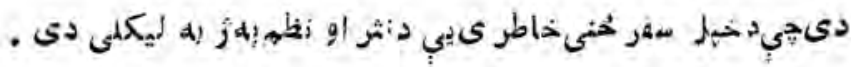

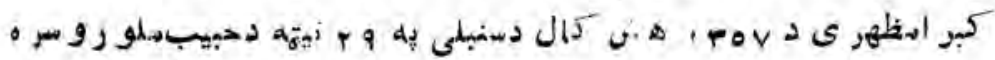

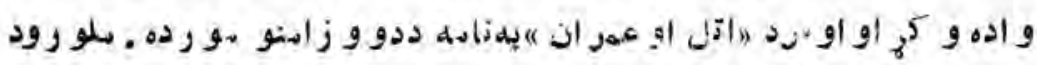

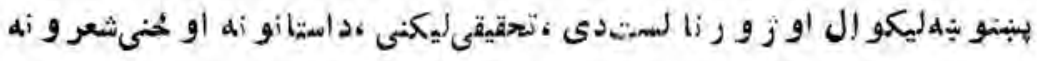

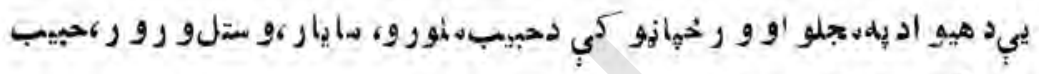

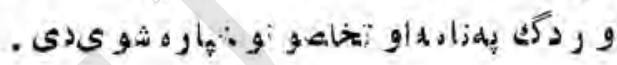

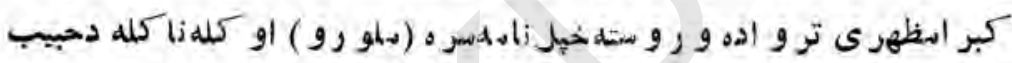

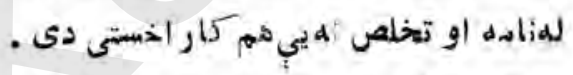

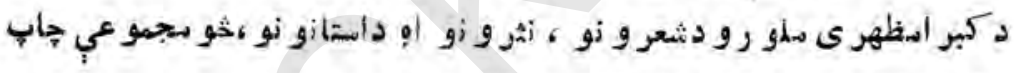

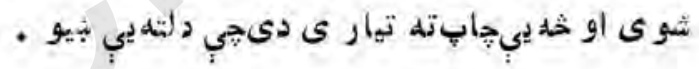

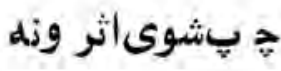

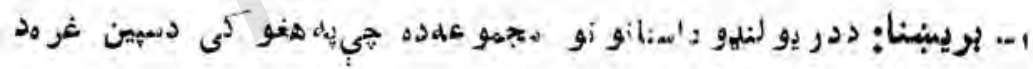

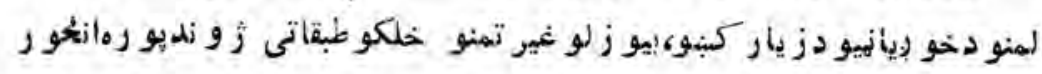

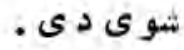

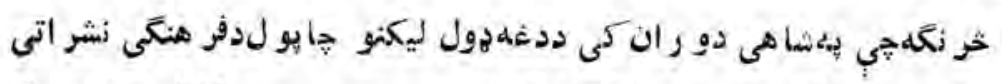

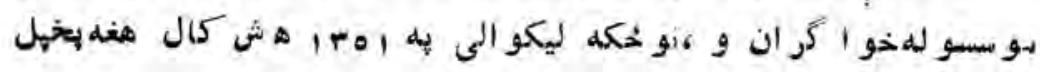




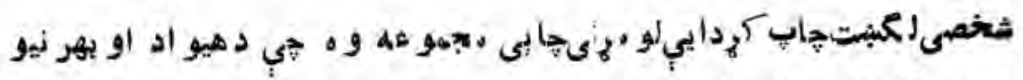

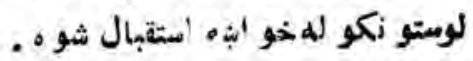

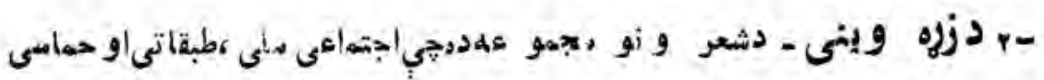

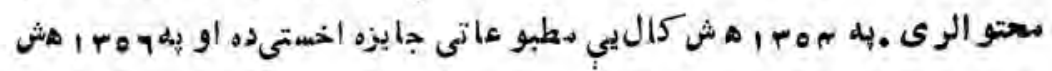

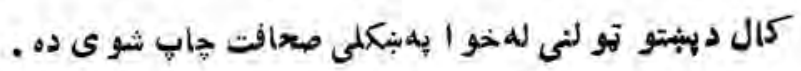

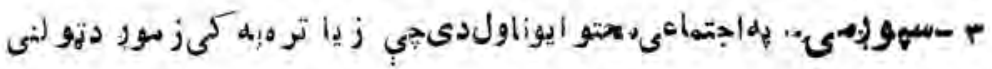

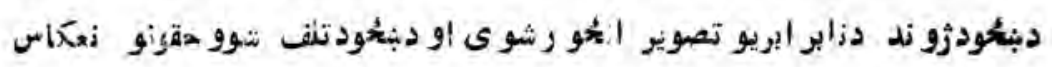

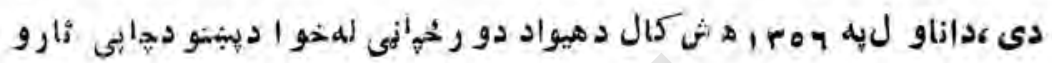

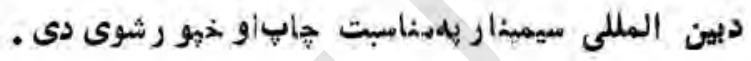

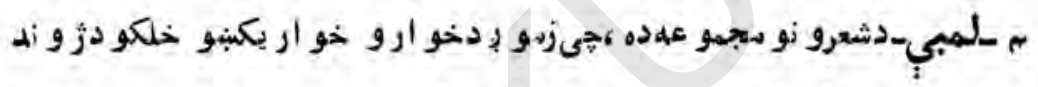

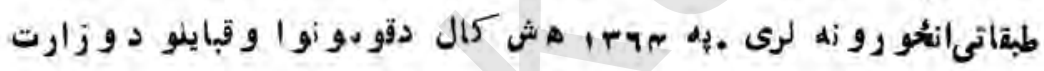

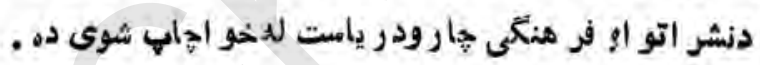

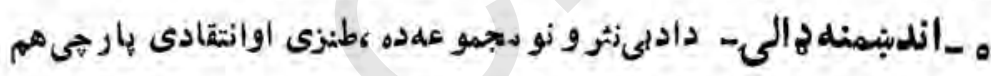

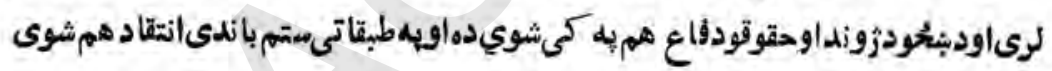

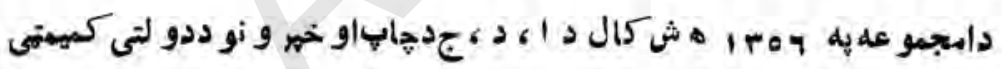

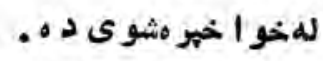

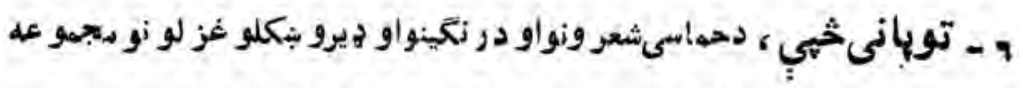

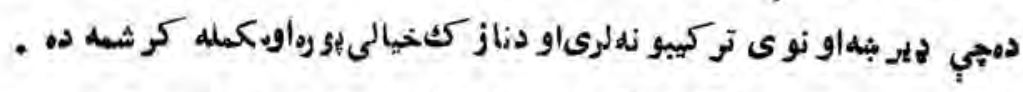

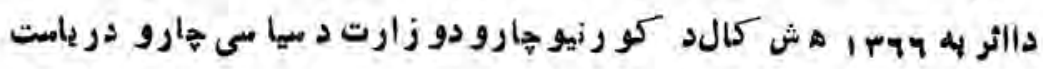
لمخو اجاه أوخهر، شوى ده. 


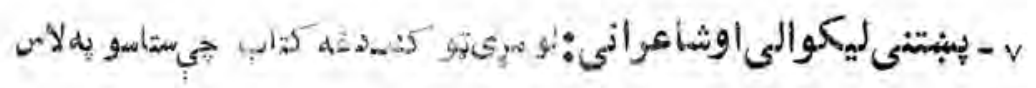
كى

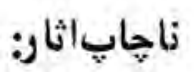

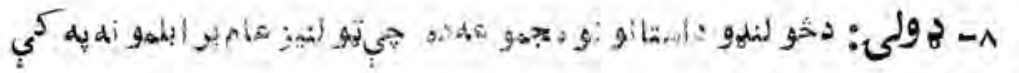

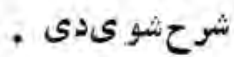

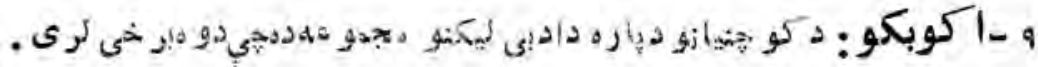

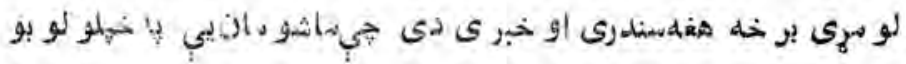

$$
\begin{aligned}
& \text { اوساتنير يو كي ه اليب. }
\end{aligned}
$$

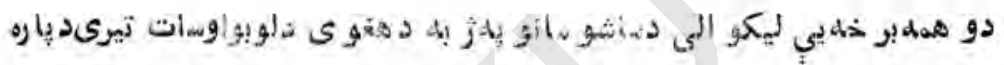

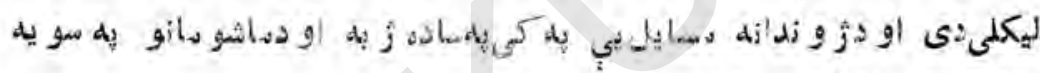

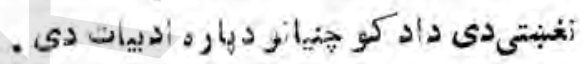

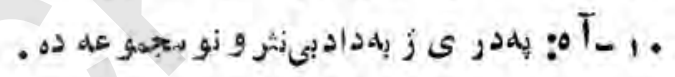

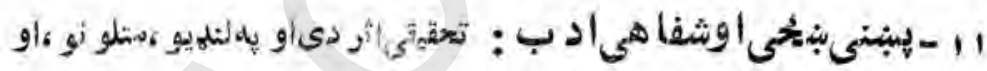

$$
\text { نارو كي دبئخو خمر ه او بر خلمبنئي }
$$

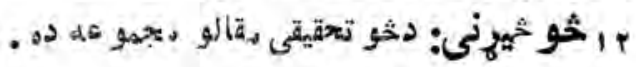
r r ا- دبلوشو سيند: دشعرونو نجموعهده. er منزلونهاوتهكر وزله_دخلو ريزو او قطهونجموعلده.

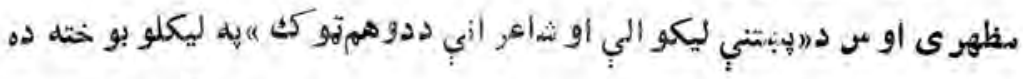

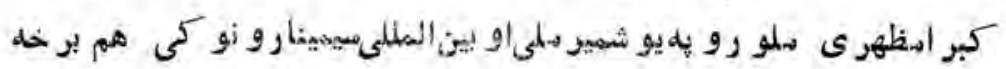

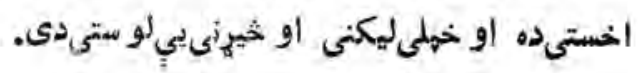
ل) 


\section{ـ كبرابظهرى ليكوالى.}

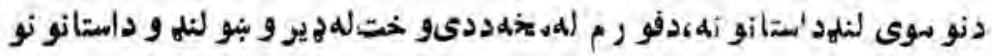

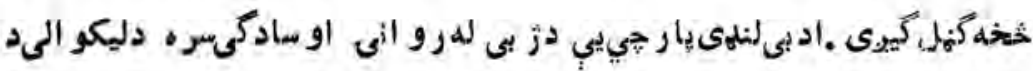
خيال لو رو الى او دفكر خز و رو الى خر كندو ى .

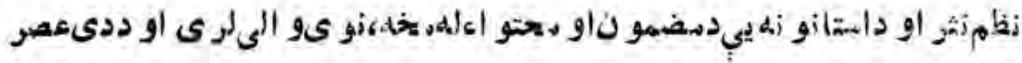

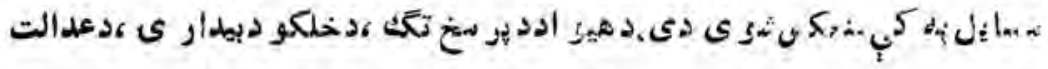

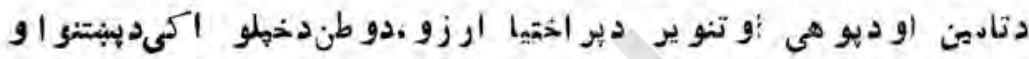

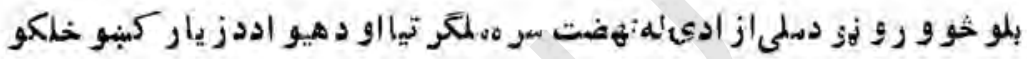

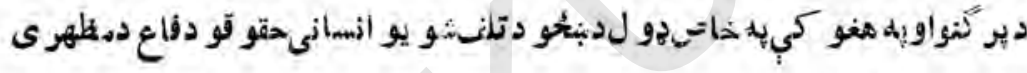
صاحببدليكنو عهدهبشمو نو زددى .

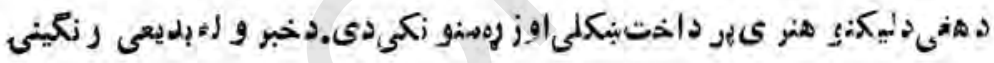

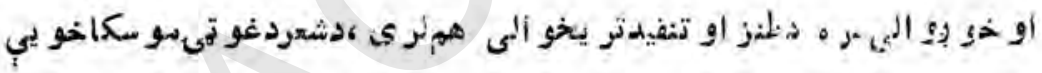

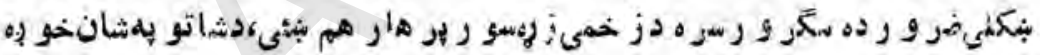

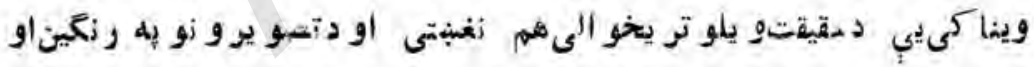

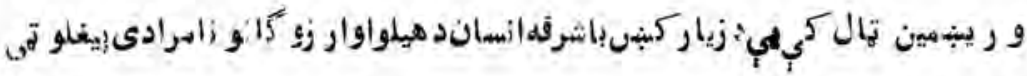
- مَّ

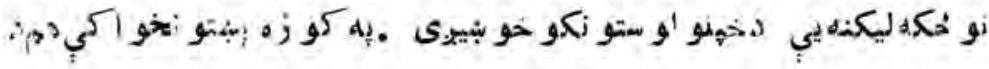

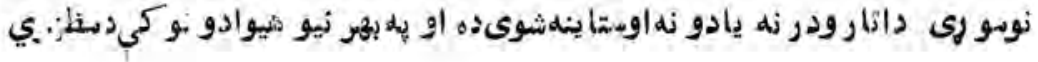
بولس 


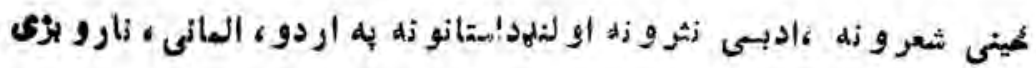

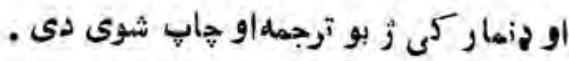

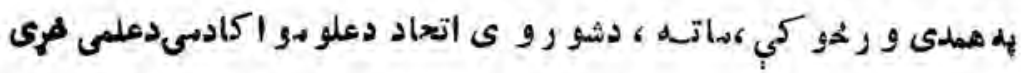

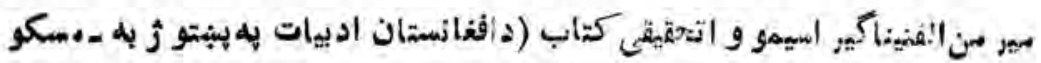

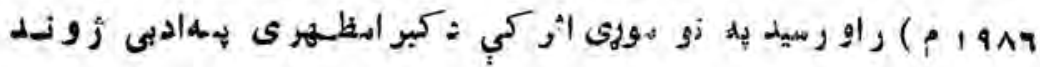

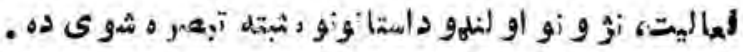

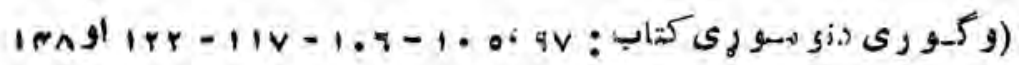

. (dist)

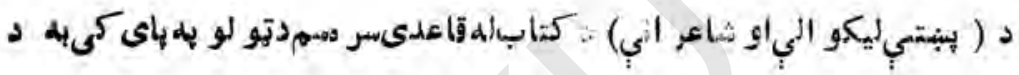

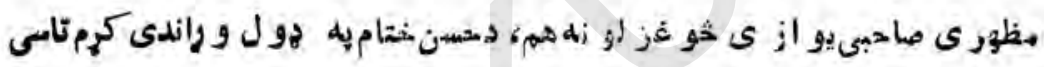

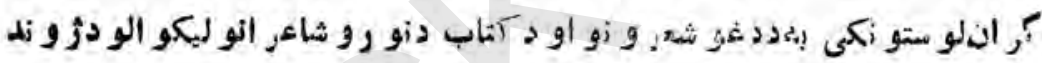

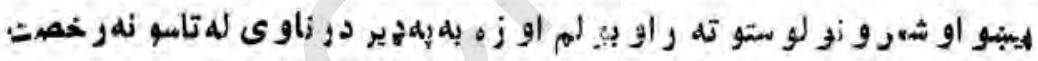

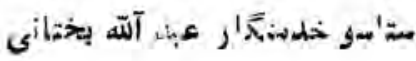

$$
\begin{aligned}
& \text { 15 بل خيو خدانه } \\
& \text { al desirad }
\end{aligned}
$$

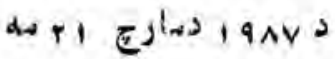

دولس 


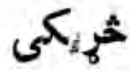

تو رونه بنكار ى دتو رتمو نو

د تو روتكو به تورو زروكي

نعصوبس ستركى بعصودي شو لهى

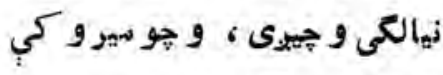

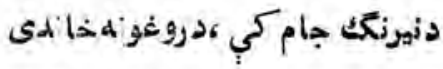

فو إب نخييى ، مبكرخهيو كي

غشى و ر يري ، ستو رى دو إيوى

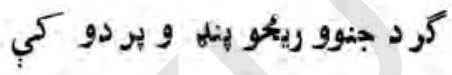

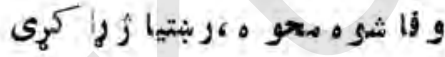

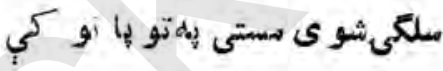
غهونه هأته ، غمونه تاته

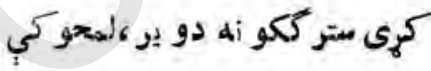
به بوأدو وكو رى، بى حيا ستركى

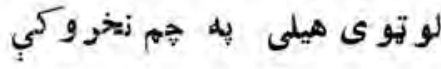
تو رازدها دم مخوله خلاصه كئى لمى و ينى زمو ز بيبنى بلهسهل غر و كي

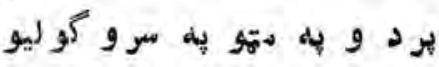
زو ند رانهاخلى تو رو تياروكى دارلس 


$$
\begin{aligned}
& \text { هر لو ر غو غا ده او و او يلاده }
\end{aligned}
$$

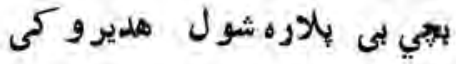

$$
\begin{aligned}
& \text { اي بسرليه !بسو مم د كنو }
\end{aligned}
$$

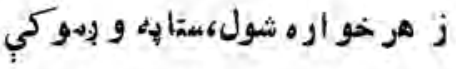

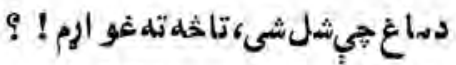

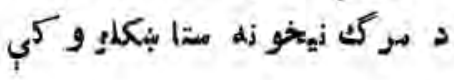

\section{دنظرغبار}

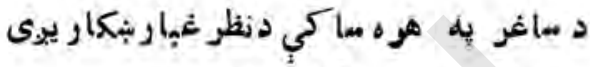

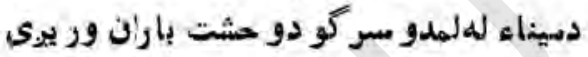
حسر تو نه ليونى شَول ، تخيل دمبا زخيوكي

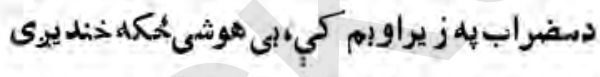

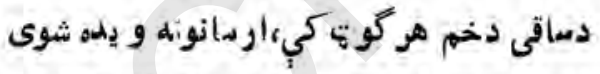
تصو يرونهتولهإت شوى،دبتاوبنكى راخخييدى

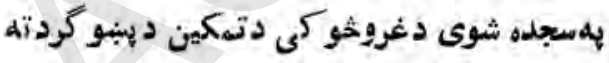

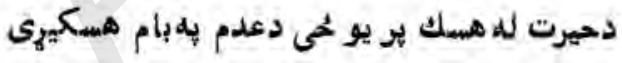

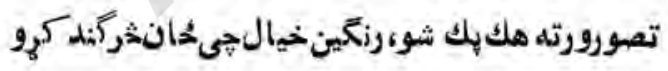

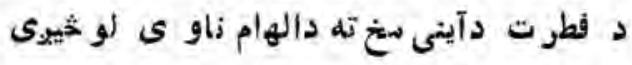

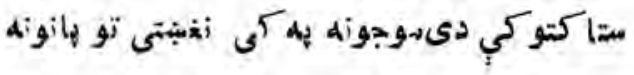
ستركى سلهر يو.كر ازه ، جهانو أه مي و ر انييزى

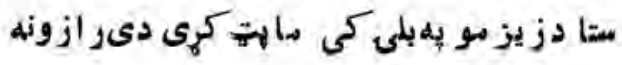
ثخوارلس 


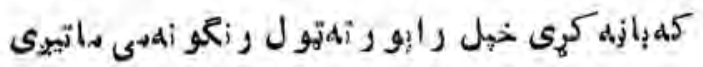

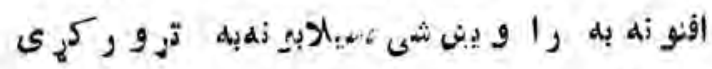

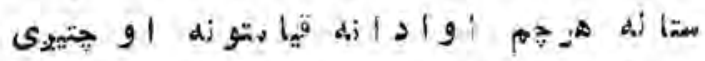

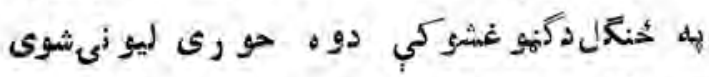

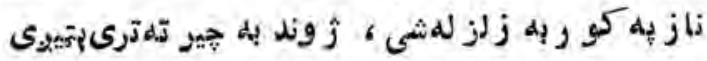

$$
\begin{aligned}
& \text { د خهو }
\end{aligned}
$$

كله هر خود دياركوثله شمى

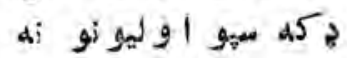

هر قدم كى تهكر

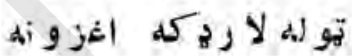

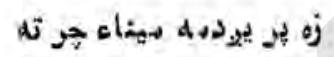

ماقي جر ته ،صهي! جرته

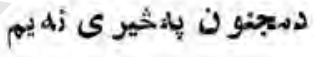

$$
\begin{aligned}
& \text { زه كزوز ر ى و ار خطا } \\
& \text { ليلايبير ينبوددابل غيبوته }
\end{aligned}
$$

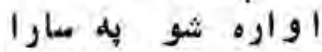

زه بو ييودمه ليلا حير ته

$$
\text { ربنتيا حر ته ،و فا جير ته له له }
$$

$$
\begin{aligned}
& \text { بس دى ملهجيمه زاهده } \\
& \text { ال زها موى داغونه } \\
& \text { عبث خُله بمتريوى محُان } \\
& \text { خندوى نى ير هرو نه }
\end{aligned}
$$

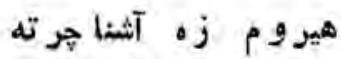

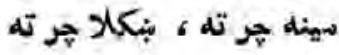




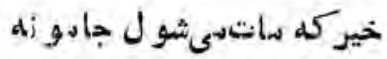

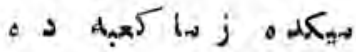

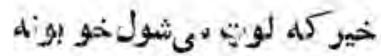

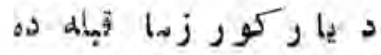

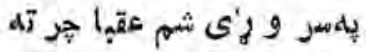

$$
\begin{aligned}
& \text { زنكلة د دين أو دنيا هر تله }
\end{aligned}
$$

$$
\text { سهوب }
$$

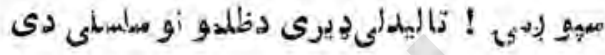

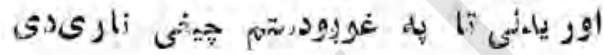

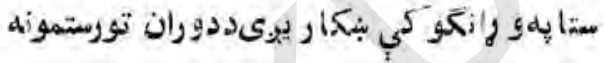

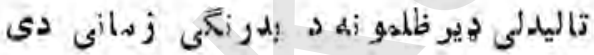

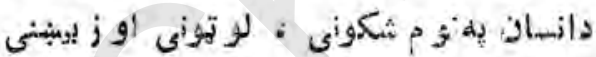

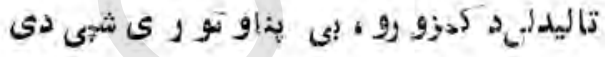

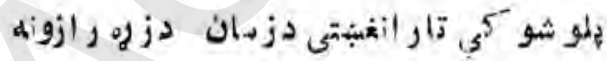

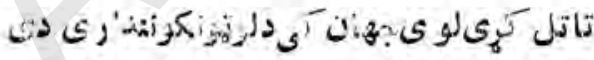

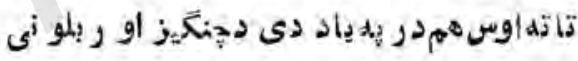
ى

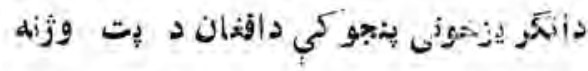

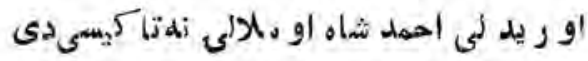

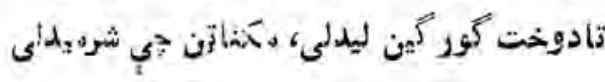
شها رس 


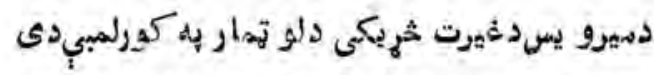

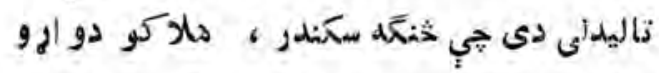

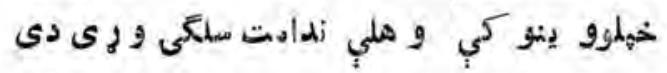

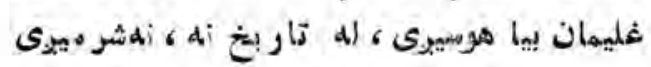

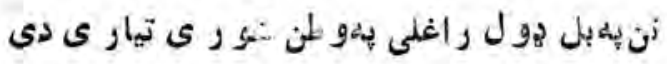

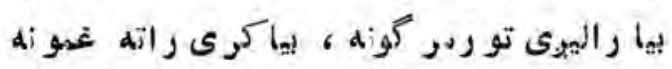

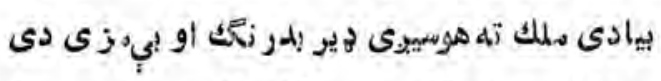

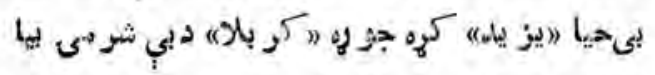

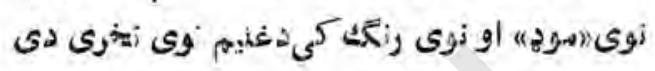

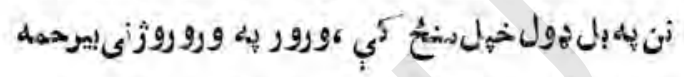

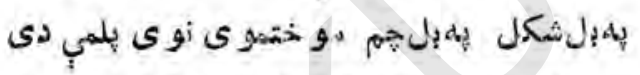

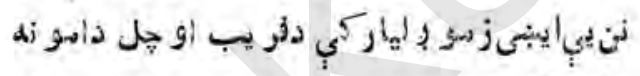

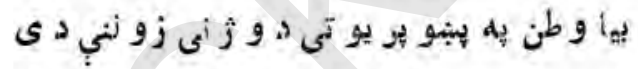

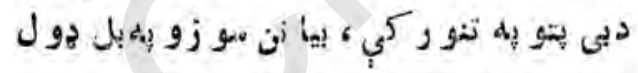

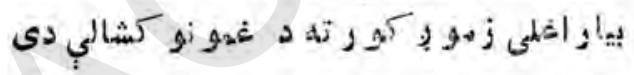

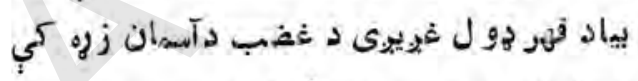

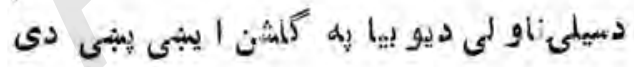

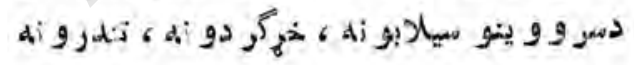

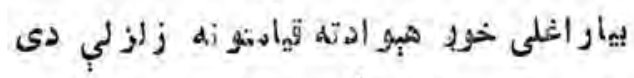

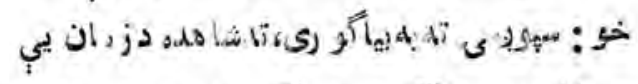

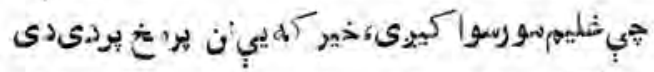

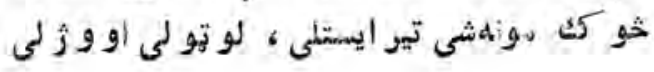
اولس 


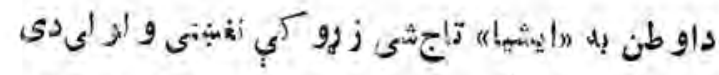

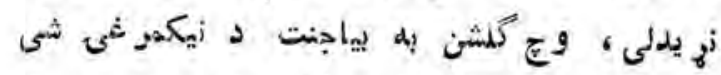

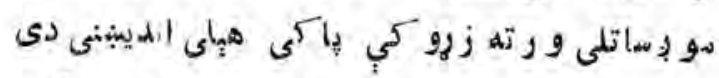

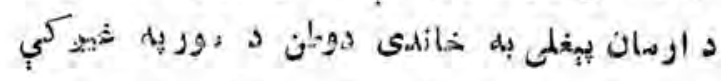

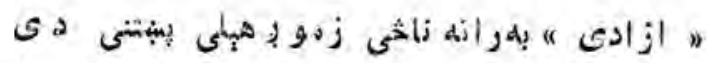

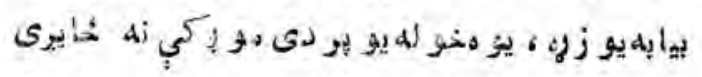

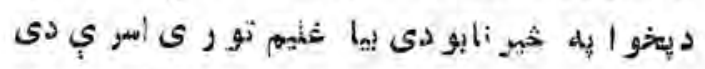

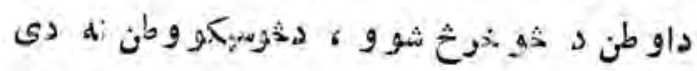

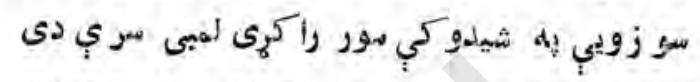

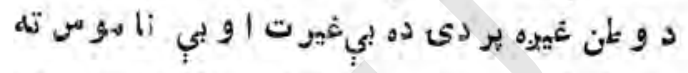

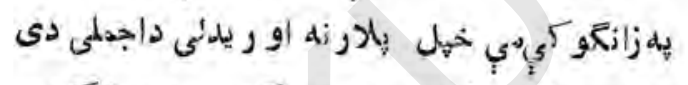

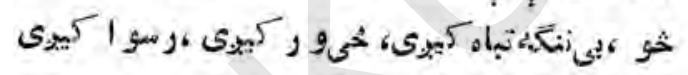

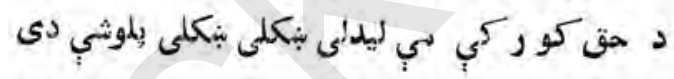

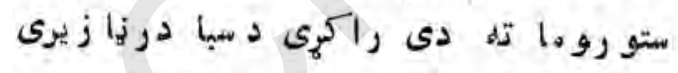

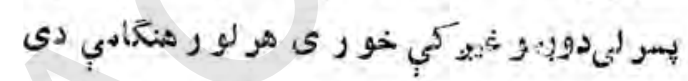

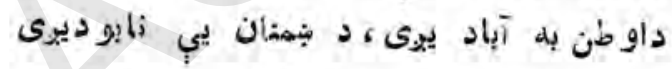

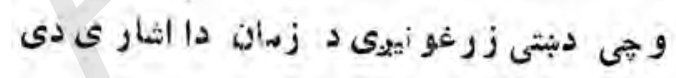

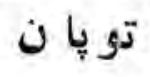

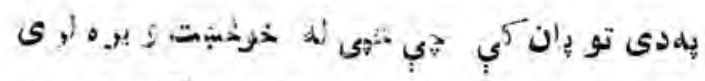

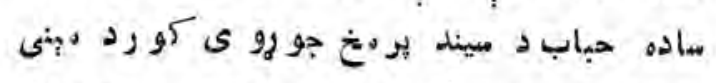

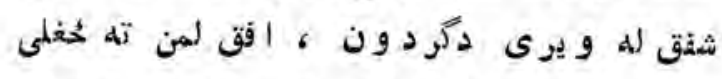

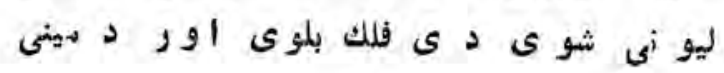
اتلس 
كو ى ير و أزديو بو كى، تو ر ى سيالى بهوز رو

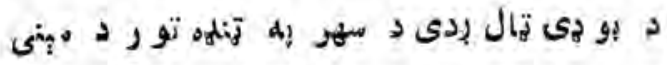
لغنم سلمى و هى خونى ، حيا إو إنهم شواله

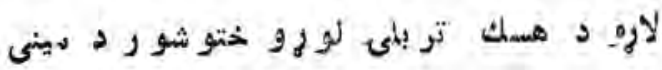

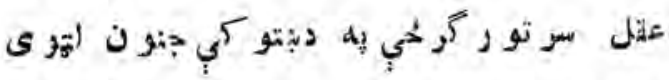

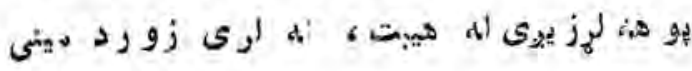

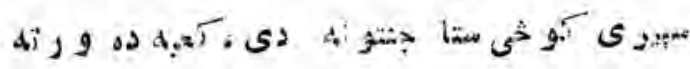

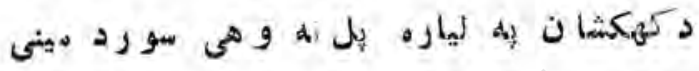

$$
\begin{aligned}
& \text { L }
\end{aligned}
$$

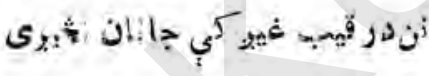

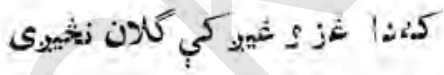

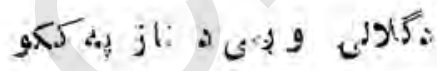

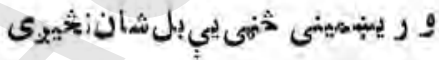

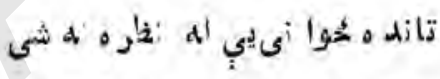

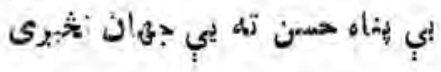

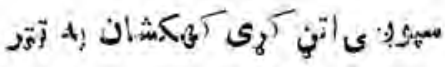

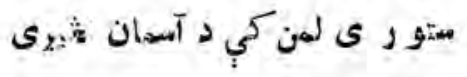

$$
\begin{aligned}
& \text { أولس }
\end{aligned}
$$





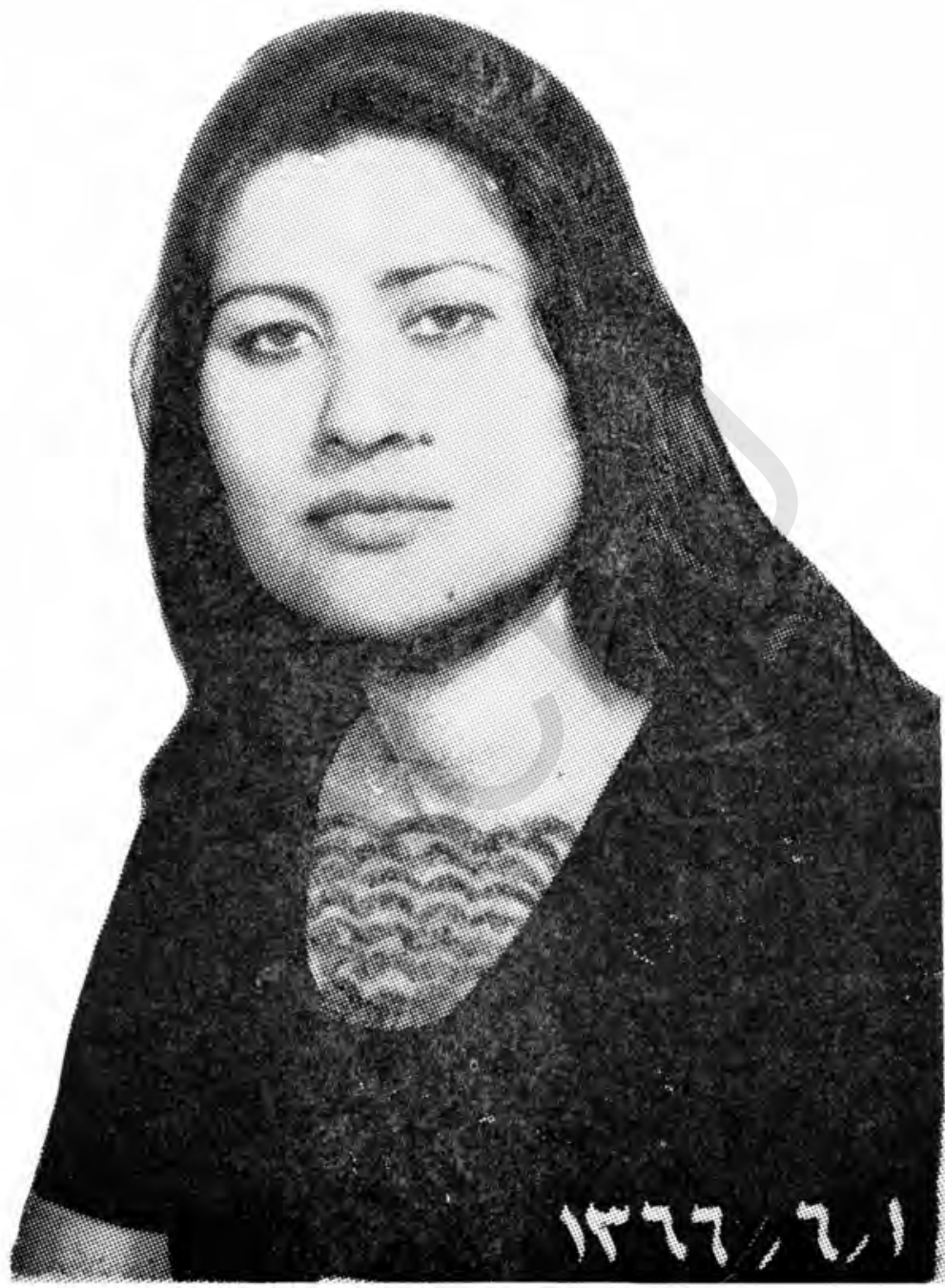

كبرا مظهر ى ملورو 


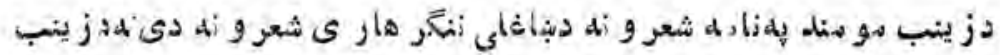
مو هند .

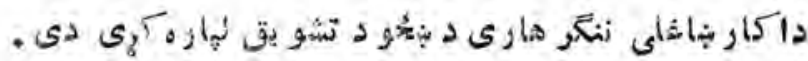

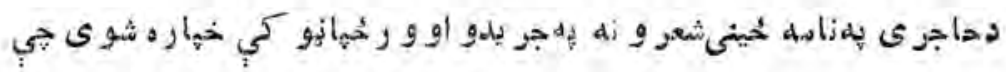

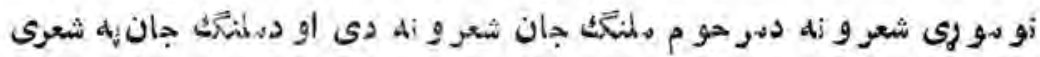

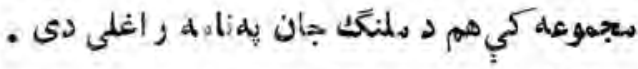

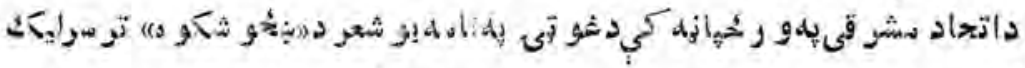

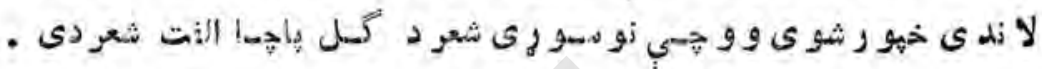

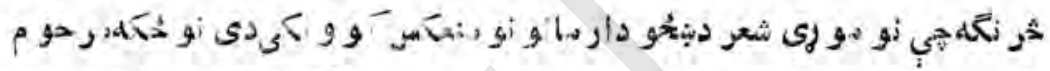

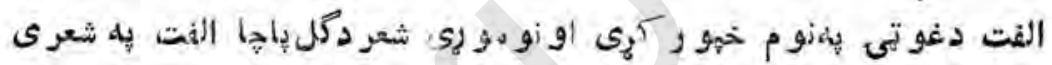

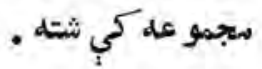

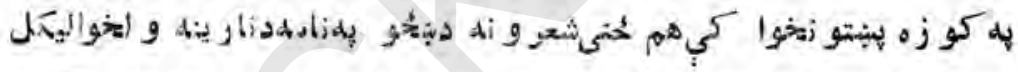

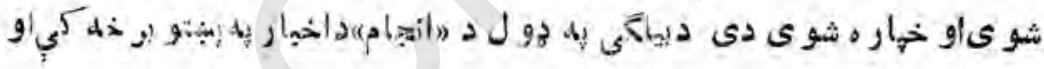

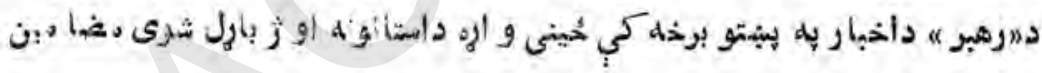

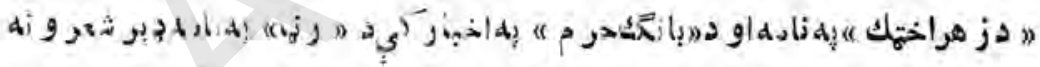

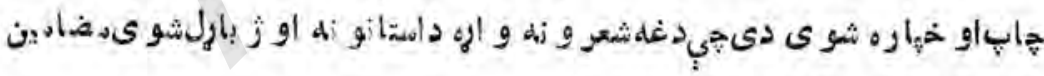
دبناغلى اجهل خهلهن

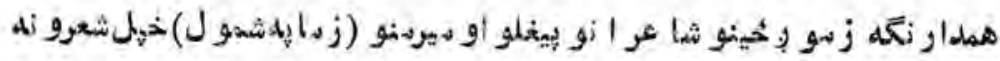

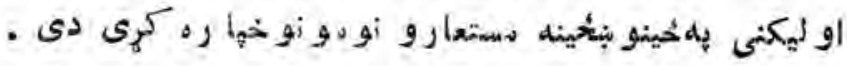

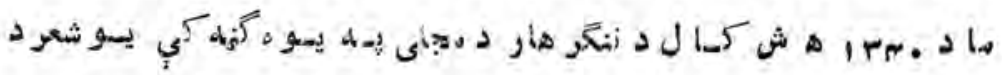

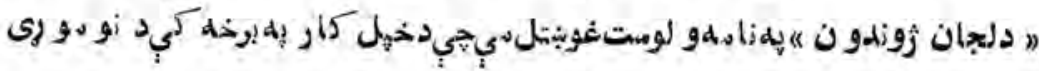




\section{ثو ضزورى خبرى}

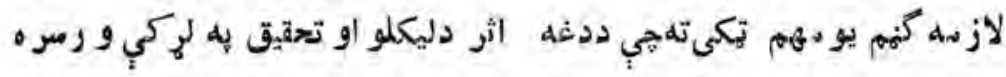

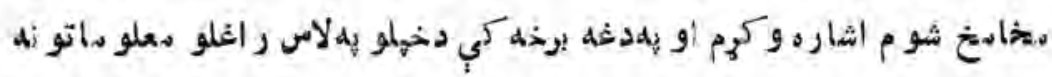

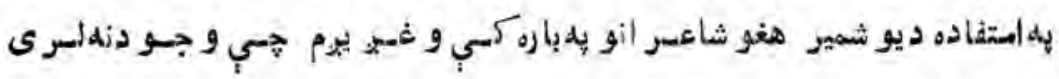

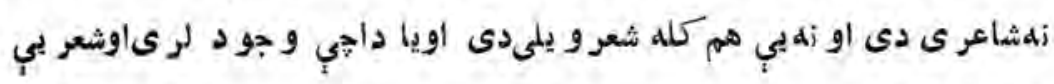
.

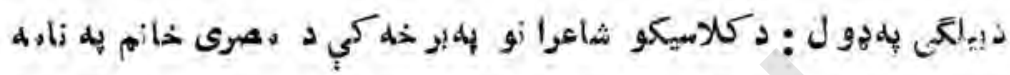

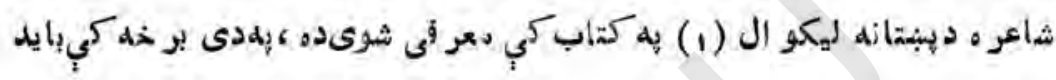

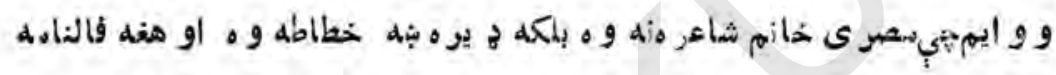

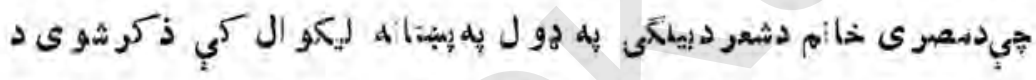

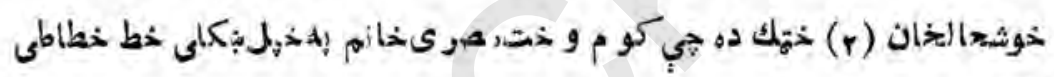
.095

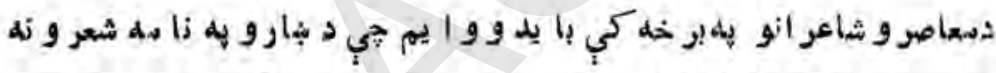

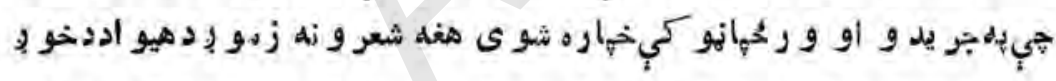

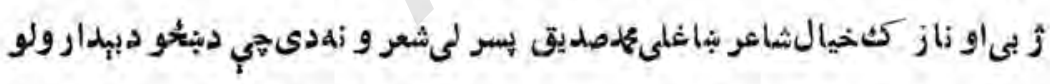

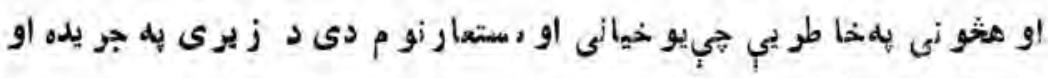

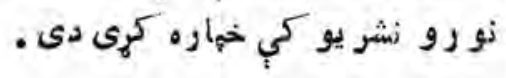

$$
\text { - }
$$

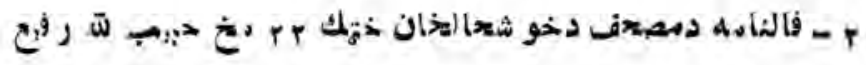




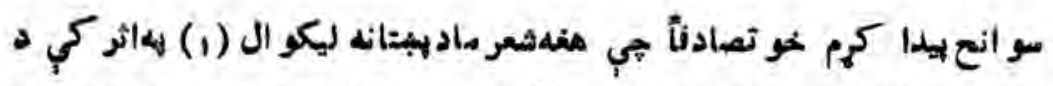

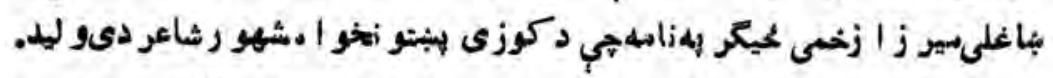

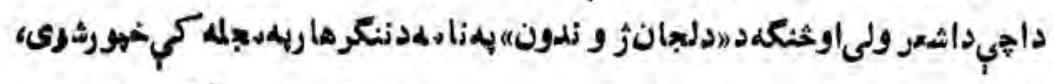

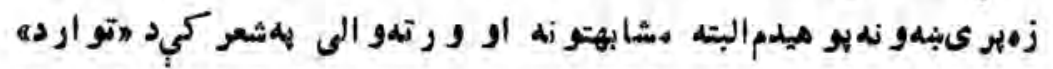

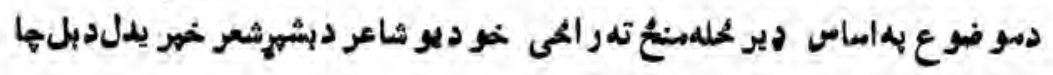

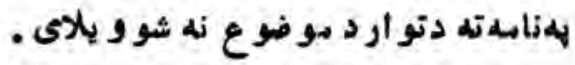

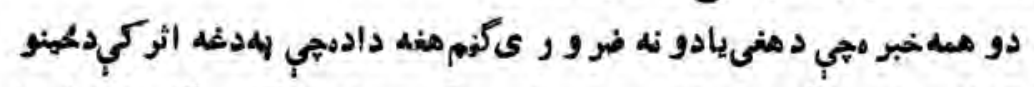

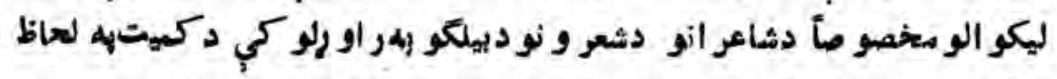

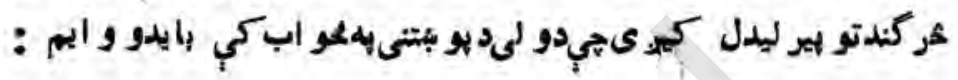

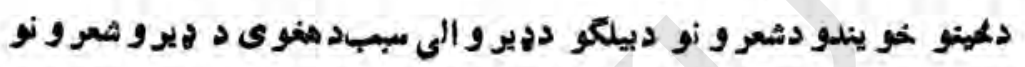

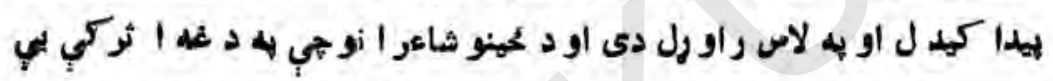

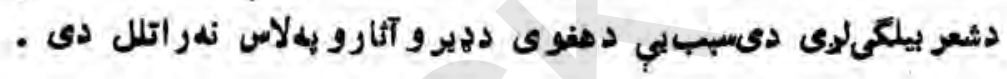

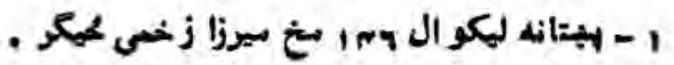




\section{هيله اومنته}

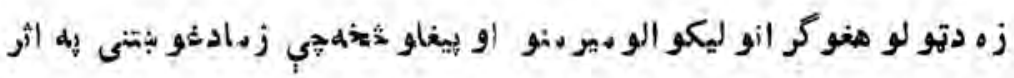

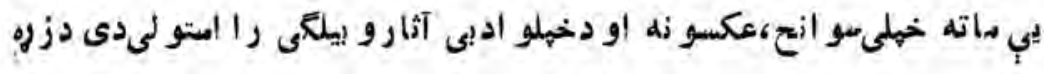
له كوبى هينه كو م او و ر تلككو رو دأنى و ايمم .

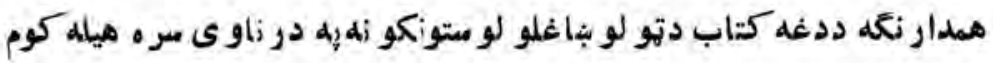

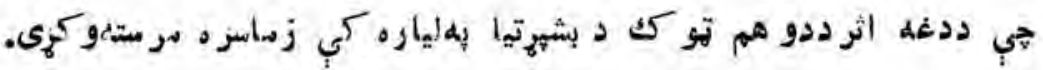

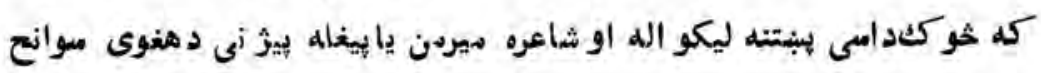

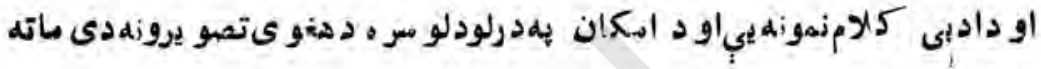
راو استوى .

به ثينه 


\section{ما خدونه}

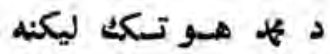

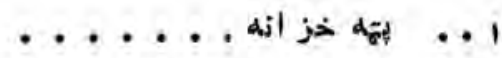

د هميث خهليل ليكنه

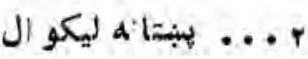

د عبد الحليم اثثر ليكنه

r.... تير هير شاعر ان.

دعبدالر وف بهنو اليكنه

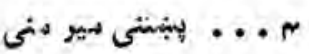

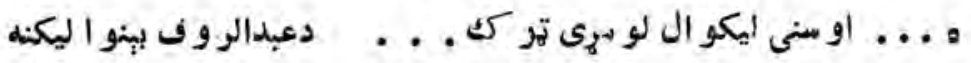

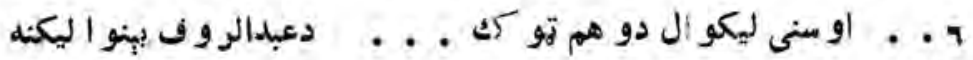

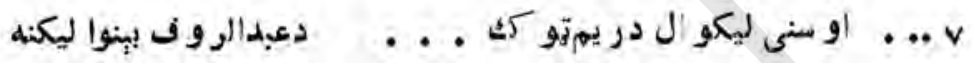

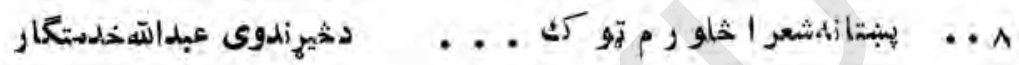

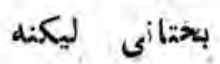

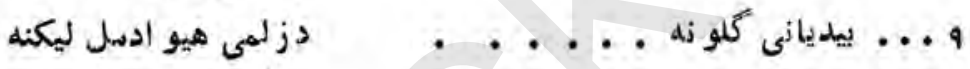

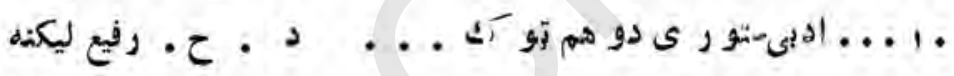

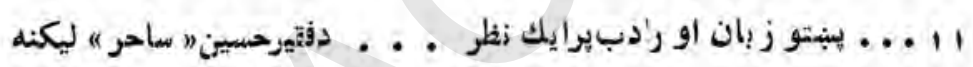

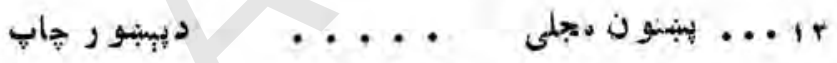

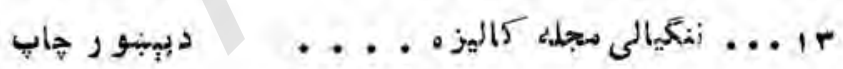

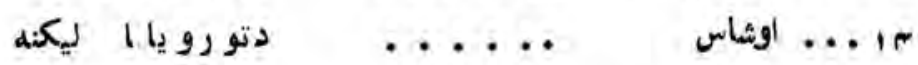

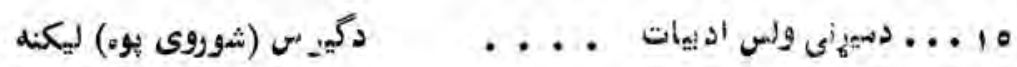

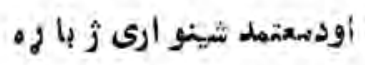




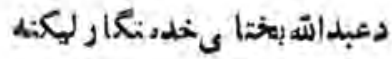

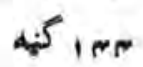

دلامبر

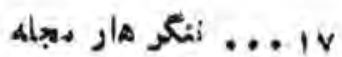

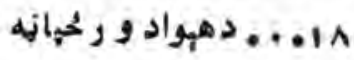

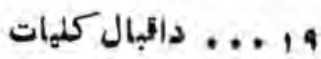

ز يثون نانو هبثورجاب

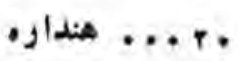

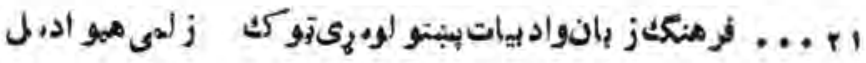
1901 r....... وركل خزانه دو هم توكت ... عميش خليل

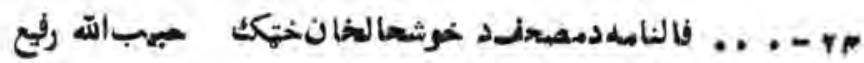
مرحوم هلفك جا ن

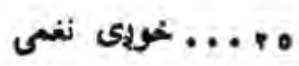

الفت

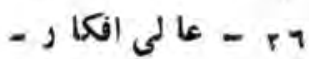

يتبنورجاب

$-g$ - rv

به

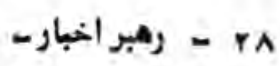

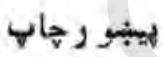

- 9

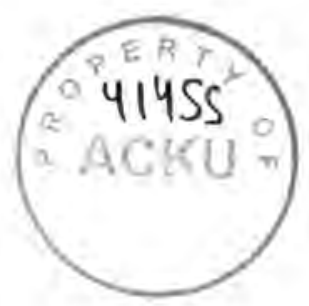




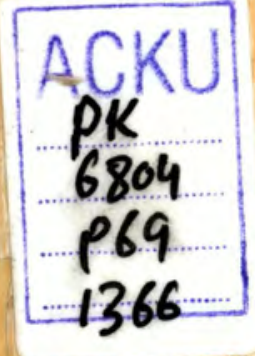

